\title{
Terecht, maar te laat: de werking in de tijd van verandering van bestuursrechtspraak
}

Citation for published version (APA):

Bakker, R. (2004). Terecht, maar te laat: de werking in de tijd van verandering van bestuursrechtspraak. [Doctoral Thesis, Maastricht University]. Datawyse / Universitaire Pers Maastricht. https://doi.org/10.26481/dis.20040930rb

Document status and date:

Published: 01/01/2004

DOI:

10.26481/dis.20040930rb

Document Version:

Publisher's PDF, also known as Version of record

\section{Please check the document version of this publication:}

- A submitted manuscript is the version of the article upon submission and before peer-review. There can be important differences between the submitted version and the official published version of record.

People interested in the research are advised to contact the author for the final version of the publication, or visit the DOI to the publisher's website.

- The final author version and the galley proof are versions of the publication after peer review.

- The final published version features the final layout of the paper including the volume, issue and page numbers.

Link to publication

\footnotetext{
General rights rights.

- You may freely distribute the URL identifying the publication in the public portal. please follow below link for the End User Agreement:

www.umlib.nl/taverne-license

Take down policy

If you believe that this document breaches copyright please contact us at:

repository@maastrichtuniversity.nl

providing details and we will investigate your claim.
}

Copyright and moral rights for the publications made accessible in the public portal are retained by the authors and/or other copyright owners and it is a condition of accessing publications that users recognise and abide by the legal requirements associated with these

- Users may download and print one copy of any publication from the public portal for the purpose of private study or research.

- You may not further distribute the material or use it for any profit-making activity or commercial gain

If the publication is distributed under the terms of Article $25 \mathrm{fa}$ of the Dutch Copyright Act, indicated by the "Taverne" license above, 
Terecht, maar te laat: de werking in de tijd van verandering van bestuursrechtspraak 



\section{Terecht, maar te laat: de werking in de tijd van verandering van bestuursrechtspraak}

\section{Proefschrift}

ter verkrijging van de graad van doctor aan de Universiteit Maastricht, op gezag van de Rector Magnificus, prof.mr. G.P.M.F. Mols, volgens het besluit van het College van Decanen, in het openbaar te verdedigen op donderdag 30 september 2004 om 16.00 uur

door

Robert Erik Bakker

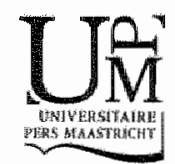




\section{Promotoren:}

Profmr. F.A.M. Stroink

Profmr. C. Flinterman (Universiteit Utrecht)

Beoordelingscommissie:

Profmr. A.W. Heringa (voorzitter)

Profmr. L.F.M. Verhey

Profmr. B.W.N. de Waard (Universiteit van Tilbung)

ISBN 9052784205

Druk: Datawyse boekproducties, Maastricht 


\section{Woord vooraf}

Dit boek heeft lang kunnen rijpen. Dat heeft zo z'n voordelen. Toen ik er aan begon, in 1993, stond ik vooral open voor de constitutionele aspecten die samenhangen met het onderwerp waarover ik schrijf. Voor de bestuurlijke complicaties van de door mij beschreven jurisprudentie had ik aanvankelijk minder oog. Dat veranderde toen ik later in mijn werk voor de rechtbank vooral met dit laatste aspect werd geconfronteerd. Ook kreeg ik daar veel meer inzicht in de weerbarstige sociale zekerheidswetgeving die in dit boek een belangrijke rol speelt.

Maar het had ook $z$ "n nadelen: mijn promotoren en alle anderen, aan de faculteit en in de rechtbank, die me uit pure hartelijkheid immer hebben aangespoord tot het voltooien van dit boek, moet ik soms tot wanhoop hebben gedreven. Jaren lang heeft het onderzoek stil gelegen, terwijl ik me concentreerde op al het andere dat het leven bimnen en buiten het werk te bieden heeft. Maar iets bleef knagen en voorzover ik dat zelf mocht vergeten werd ik daar ieder universitair feestje wel weer aan herinnerd.

Het is uiteindelijk bovenal aan Frits Stroink te danken dat het er toch nog van is gekomen. Het is dankzij zijn onvoorwaardelijke steun en vertrouwen dat ik de draad in 2001 weer heb opgepakt en met financiële ondersteuning van het faculteitsbestuur een drietal maanden aan de faculteit gedetacheerd ben geweest om voluit aan mijn boek te kunnen werken. Toen was het 'point of no return' bereikt, al heeft het ook sindsdien nog lang geduurd eer ik een punt onder het werk heb gezet.

En hier ligt het dan, met een door Caroline ontworpen omslag die in één beeld samenvat waarover het in dit boek gaat: om traagheid, van het besef dat mensen rechten hebben gekregen waarop ze niet meer verdacht waren, traagheid van gerechtelijke procedures on deze alsnog verkregen rechten geldend te kunnen maken, maar ook vastberadenheid van sommigen die van geen wijken wisten en procesrechtelijke barrières wisten te slechten. Het is aan zeer weinigen gegeven zowel in woord als beeld uiting te kunnen geven aan ideeën en gevoelens. Caroline, mijn vrouw, is éen van hen. Wat zal het heerlijk zijn met haar en onze kinderen Luke en Anouk de vakanties, zonder de last van een onaf werk, door te brengen!

Het boek zou evenmin gereed zijn gekomen zonder de al even onvoorwardelijke steun die ik door alle jaren heen heb gekregen van Nettie Litjens, die alan het einde van de rit ook nog eens de lay-out heeft verzorgd. Veel dank ben ook verschuldigd aan Cristina Tobias die, toen ik uitgeteld aan Britse stranden lag, met grote precisie de registers heeft samengesteld. Dank heb ik ook voor Appie Luermans die het aantrekken van Cristina als student-assistente mogelijk maakte, na zich eerder al garant te hebben gesteld voor mijn detachering aan de faculteit.

Ik draag het boek op aan mijn ouders. Het doet mij verdriet - en weet dat mijn moeder, mijn zus Renée en mijn broer Paul dit ook zo zullen voelen - dat mijn vader de plechtigheid niet meer kan mee beleven. Juist in de laatste maanden, toen zijn geest in 
opperste verwarring leek te verkeren, sprak hij met mij over het verglijden van de tijd, vergankelijkheid en voortleven op een wijze die peilloos dieper ging dan wat in dit boek ook maar wordt besproken. 


\section{Inhoud}

Lijst van gebruikte afkortingen

\section{Hoofdstuk 1 \\ Inleiding}

1. Schets wan de problematiek

2. Terminologie

3. Concreet versus abstmact

4. Hoger recht

5. Gemeenschapsrecht

6. Rechterlijke rechtsvorming

7. Daadwerkelijk rechtsherstel

8. Opzet van het boek

\section{Hoofdstuk 2}

\section{Aantastbaarheid van besluiten}

1. Inleiding

2. Rechtskracht algemeen

2.1 Formele rechtskracht 13

2.2 De strekking van de formele rechiskracht 15

$\begin{array}{ll}2.3 & \text { Doorbreking van de fornele rechtskracht }\end{array}$

$2.4 \quad$ Verschoonbare termijnoverschrijding 22

$\begin{array}{lll}2.5 & \text { Overige aspecten } & 23\end{array}$

3. Herziening van bestuurlijke besluiten 24

3.1. Inleiding $\quad 24$

$3.2 \quad H e r z i e n i n g$ wan besluiten 26

$3.2 .1 \quad$ Ontvankelijkheid van het verzoek om herzicning 27

3.3 Discretionaire bevoegdheid 30

$3.4 \quad$ Toepassing discretionaire bevoegdheid 32

$3.5 \quad$ Verandering van rechtspraak als grond voor herziening 37

3.6 Tussenbalans 40

3.7 Werking in de tijd 42

3.7.1 De dagloonzaak 42

3.7.2 Dekinderbijslagzaak 44

3.7.3 Vz. ARRS 26 oktober 1984

3.7 .4 CRvB 24 september 1987

$\begin{array}{lll}3.7 .5 & \text { CRvB 2l april } 1994 & 48\end{array}$

$\begin{array}{lll}3.7 .6 & \text { CRvB } 10 \text { april } 1991 & 49\end{array}$

4. Werking in de tijd van een rechterlijke onverbindendverklaring 50

$4.1 \quad$ Inleiding $\quad 50$

4.2 De uitwegvergunningszaken $\quad 50$

4.3 De aanvullende rol van de burgerlijke rechter $\quad 52$

5. Conclusies 58 


\section{Hoofdstuk 3 \\ Rechtsverkrijging door rechtstreekse toepassing van het internationale recht, Inleiding}

1

$1.1 \quad$ CRvB 26 november 1970

1.2 Opzet van behandeling

2. De doow werking van het internationale recht

2.1. Begrippen

2.2 Beginsel van gelijke behandeling

2.3 Het verbod van discriminatie

2.4 Artikel 26 IVBPR

2.5 Artikel 141 EEG

$2.6 \quad$ Richtlinn $79 / 7 \mathrm{EEG}$

2.6.1 De werking van richtlijnen in het algemeen

2.6.2 Richtign 79/7 EEG

2.6.3 Artikel 14 EVRM

\section{Hoofdistuk 4}

Rechtswerkrijging door rechtstreekse toepassing van het internationale recht, uitwerking

1.

De WWV en het kostwinnersbeginsel

$1.3 \quad$ CRVB 10 nei 1989

1.4 De Wet van 6 juni 1991 (Stb. 318)

2. De AAW en de uitshiting van gehuwde vrouwen

2.3.2.5 De materiele en formele werking in de tijd van CRvB 5 januar 1998: 
4. De AOW en de niet-verzekerde tijdvakken 144

4.1 Inleiding 144

4.2 Het arrest Verholen 145

$4.3 \quad$ CRvB versus Hoge Raad 147

4.4 Het arrest Wessels-Bergenoet 151

4.5 CRvB 5 maart $1997 \quad 152$

4.6 EHRM 4 juni 2002 (Wessels-Bergervoet) 154

4.7 Conclusie 155

5. De Bopa-affaire 156

$\begin{array}{lll}5.1 & 156\end{array}$

$\begin{array}{lll}5.2 & \text { Voorgeschiedenis } & 156\end{array}$

$5.3 \quad$ CRvB 22 mei $1990 \quad 157$

5.4 ARRS 5 september 1991 159

5.5 HR 29 november 1991 160

5.6 Conclusie A-G Koopmans bij HR 29 november 1991

\section{Hoofdstuk 5}

\section{Formele werking, nader beschouwd}

1. Inleiding 165

2. Verenigbaarheid formele rechtskracht met EG-recht 167

2.1 Het gemeenschapsrecht 167

$2.2 \quad$ HR 24 januari 2003 (Maple) 169

2.3 Breuken in het bastion 173

$\begin{array}{lll}2.3 .1 & 173\end{array}$

2.3.2 CBB 1 november 2000 (Kühne en Heitz) 174

2.3.3 EHRM 16 april 2002 (Dangeville) 186

$\begin{array}{lll}2.3 .4 & \text { HR } 27 \text { september } 2002 \text { (Pearl) } & 191\end{array}$

2.3.5 HR 11 oktober 1996 (Leenders) 194

Hoofdstuk 6

Conclusie

Summary

Jurisprudentie

Literatuurlijst

Curriculum vitae 



\section{Lijst van gebruikte afkortingen}

AAW

AB

ABP

ABRS

$A G$

AgvB

AOW

APV

ARB

ARAR

Arob

ARRS

a.w.

Awb

AWBZ

AWR

AWW

B\&W

BNB

$\mathrm{BR}$

BW

CBB

CRvB

DETAM

EEG

$\mathrm{EG}$

EHRM
Algemene Arbeidsongeschiktheidswet

Administratiefrechtelike Beslissingen

Algemene burgerlijke pensioenwet

Afdeling bestuursrechtspraak van de Read van State

Advocaat-General

Afdeling voor geschillen van bestuur van de Raad wan State

Algemene ouderdomswet

Algemene Plaatselijke Verordening

Administratieve en Rechterlijke Beslissingen

Algemeen Rijks Ambtenarenreglement

Administratieve rechtspraak overheidsbeschikkingen

Afdeling rechtspraak van de Raad van state

aangehaald werk

Algemene wet bestuursrecht

Algemene wet bijzondere ziektekosten

Algemene wet inzake rijksbelastingen.

Algemene Weduwen-en Wezenwet

Burgermeester en Wethouders

Beslissingen in belastingzaken Nederlandse belastingrechtspraak

Bouwrecht

Burgerligk Wetboek

College van Beroep voor het bedrijfsleven

Centrale Raad van Beroep

Bedrijfsvereniging voor Detailhandel, Ambachten er.

Huisvrouwen

Europese Economische Gemeenschap

Europese Gemeenschap

Europees Hof voor de rechten van de mens 
EVRM

Gst.

HBA

HR

HWJ EO

IVBR

NVESCR

$\mathrm{JB}$

Jut.

JSW

KB

Mv'T

NI

NJB

NJCM

NTB

NV

Rawb

RSV

RvdW

RWW

SCOSZ

SEW

SMA

SozaWe

$\mathrm{stb}$

Stcrt.

SVB
Europes Verdrag voor de bescheming van de rechten van de mens en de fundamentele vrijheden

Gemeentestem

Hoofobedrij fschap Ambachten

Hoge Raad der Nederlanden

Hof van Justitie van de Europese Gemeenschappen

Internationaal Verdrag inzake Burgerrechten en Politieke

Rechten

Intemationaa] Verdrag inzake Economische, Sociale en

Cullturele rechten

Jurisprudentie Bestuursrecht

Jurisprudentic van het HVJ EG

Jurisprudentie sociale voorzieningen

Koninklijk Besluit

Memorie van Toelichting

Nederlandse Jurispradentie

Nederlands Juristenblad

Nederlands Juristen Comité voor de Mensentechten

Nederlands Tijdschrift voor Bestmursrecht

Naamloze Vennootschap

Rechtspraak Algemene wet bestuursrecht

Rechtspraak Sociale Varzekeringen

Rechtspraak van de Week

Rijksgroepsregeling werkloze werknemers

Stichting Centrum voor Onderzoek van het Sociaal

Zekerheidsrecht

Social-economische wetgeving

Sociaal Maandblad Arbeid

Sociale Zaken en Werkgelegenheid

Statsblad

Staatscourant

Sociale verzekeringsbank 
TAR

$\mathrm{tB} / \mathrm{S}$

TK

USZ

$\mathrm{Vz}$.

WAO

WSW

WUBO

WUV

WW

WWV

ZW

ZFW
Tijdschrift voor ambtenarenrecht

ten Berge/Stroink, (Administratieve rechtspraak overheidsbeschikkingen)

Tweede Kamer der Staten-Generaal

Uitspraken sociale zekerheid

Voorzitter

Wet op de arbeidsongeschiktheidsverzekering

Wet sociale werkvoorziening

Wet Uitkering Burger Oorlogslachtoffers

Wet uitkering vervolgingsslachtoffers

Werkloosheidswet

Wet werkloosheidsvoorzieningen

Ziektewet

Ziekenfondswet 



\section{Hoofdstuk 1}

\section{Inleiding}

\section{Schets van de problematiek}

De afgelopen decennia thebben een ontwikkeling te zien gegeven, waarbij in toenemende mate het recht niet slechts gevormd is door de wetgever, maar tevens door de rechter." Vooral de witspraken van de hogere colleges zijn mede bepalend voor de rechtsontwikkeling. Met de toename van de rechtsvormende rol van de rechter wordt de bestudering van een aantal vraagstukken die voorheen slechts in verband met wetgeving aan de orde werden gesteld, ook voor rechispraak relevant. Een van die wraagstukken betreft het overgangsrecht: de rechtsregels die aangeven welke werking in de tijj moet worden gegeven aan nieuwe rechtsregels. Toegespitst op rechtsprak gaat het daarbij om de vraag in hoeverre het voor personen die geen partij waren bij een bepaalde rechtszaak mogelijk is om achteraf, dat wil zeggen nadat een rechterlijke uitsprak gewezen is, aan deze uitsprak rechten te ontlenen in verband met feitelijke omstandigheden die zich (soms lang) vóór de desbetreffende uitspraak hebben voorgedaan. Het betreft hier een soort 'precedentwerking naar het verleden", die in de literatuur ook wel wordt aangeduid als de "terugwerkende kracht." van rechterlijke uitspraken. ${ }^{2}$

Een voorbeelld moge een en ander verduidelyken. Op 5 januari 1988 deed de Centrale Raad van Beroep uitspraak over het recht op AAW-witkering voor gehuwde vrouwen. In deze uitspraak sprak de Centrale Raad wan Beroep uit dat aan artikel 26 van het Internationaal Verdrag inzake Burgerrechten en Politieke Rechten (IVBPR), voor wat de AAW betreft, direkte werking moest worden toegekend vanaf 1 jamuari 1980. De Raad sprak als zijn oordeel uit dat vanaf die datum de uitsluiting van de AAW-uitkering voor de genoemde groep vrouwen in strijd moest worden geacht met het in artikel 26 IVBPR gewaarborgde beginsel van gelijke behandeling. Zoals bekend is, was de uitspraak aanleiding tot opschudding bij de regering vanwege de vrees voor een stortvloed van aanvagen 'met terugwerkende kracht' van vrouwen, die in dezelfde positie verkeerclen als de eiseressen in deze zaak.

1 Zie o.a. T. Koopmans, De Polsstok van de rechter (1979), in: Juridisch Stippelwerk, Deventer 1991, p. 253 e.v.; zie voorts: M.V. Polak, Algemene beginselern wan rechterlijk overgangsrech, RM Themis $1984 / 3$, p. 228-260 volgens wie "de fictie van de rechter die in de wot het recht vindt en wiens oordeel altijd geacht wordt al in de wet besloten gelegen te hebben, achterhaald is an vervangen is door de idee (of, zo men wil, de fictie) dat de rechter recht vormt met de wet alls richtsnoer". Zie mei name ook J.B.M. Vranken, mr. C. Asser's thandleiding tot de beoefening wan het Nederlands burgerlijk recht, Zwolle 1995, p. 120-121. Zie voor rol van artikel 12 Wet algemene bepalingen in dit verband: J. Drion, Stare decisis, Het gexag wan precedenten, in: Verzamelde Geschriften van I. Drion, Deventer 1968 , p. 142-170 i.h.b. p. 155-157, Jessulinun d"Oliveira, De meenwaarde van rechterlijke uitspraken Arrêts de règlements en precedenten, Preadvies woor de Nederlandse Vereniging voor Rechtsvergelijking, geschrift nr. 10, Deventer 1973 en Heringa in zujn noot onder HR 12 oktober 1984, NJCM-Bulletin 10-1 (1985), 32 e.v.

2 Zie voor een wroeg voorbeeld: J. Drion, a.w. (nool. I1), p. 167. 
Met dit woorbeeld moge tevens aangegeven zijn dat een deel van de verklaring voor de vraag warom de in dit boek aan de orde gestelde problematiek zo actueel is geworden, is te vinden in de veranderde rol van de rechter in verband met de toenemende betekenis van het intemationale en het Europese recht. ${ }^{3}$ Wordt de rechter tot de toepassing hiervan geroepen, dan is hij gedwongen zijn tenghoudende opstelling jegens de wetgever te laten varen. In dit verband valt bij voorbeeld te wijzen op een opvallende overweging in, wat men zou kunnen noemen het 'Landbouwrliegers-arrest' van de Afdeling Rechtspraak. In deze uitspraak geeft deze rechter weliswaar blijk wan terughoudendheid ten aanzien van de rechterlijke toetsing van lagere wetgeving door te overwegen dat "de Afdeling niet kan treden in de vraag of zij zich een rechtvaardiger of billijker regeling kan voorstellen, doch zich ertoe dient te beperken te toetsen of verweerder, in aanmerking genomen de belangen die hem ten tijde van de totstandkoming van de aangevochten regeling bekend waren of behoorden te zijn, bij afweging van alle betrokken belangen in redelijkheid tot de Regelling is kunnen komen"; maar de Afdeling geeft tevens aan dat zij deze tenughoudendheid laat varen, indien de wetgever buiten de door het internationale recht gestelde marges treedt, door de zojuist geciteerde overweging te laten voorafgaan door de woorden "voorzover het geschreven hogere recht de nationale regelgever beleidsvrijheid laat'. ${ }^{4}$

Zo wijst Alkema erop dat de rechter de rechtstreeks werkende bepalingen van het EVRM op een voor de wetgever onaantastbare wijze kan uitleggen ${ }^{5}$ en merkt Van der Velde de rechter ter zake van de naleving van EVRM-verplichtingen aan als het 'voorsteven van staat'. "Toepassing door de rechter van internationalrechtelijke bepalingen leidt dus noodzakelijkerwijs tot een verschuiving in de rechtsvorming in de richting van de rechter.

Maar ook op pur nationaal vlak vinden we de problematiek van de terugwerkende kracht van rechtspraak terug. Toen de Hoge Raad zich in het arrest Heesch-Von de Akker ${ }^{7}$ aansloot bij de rechtspraak van de Afdeling Rechtspraak van de Raad van State door het "uitwegvergunningenstelsel' in strijd met de Wegenwet te verklaren, deed ook dát de vraag rijzen in hoeverre personen die eerder de met dit stelsel samenhangende heffing al hadden betaald en die hiertegen geen beroep bij de AROB-rechter hadden ingesteld, alsnog op grond van de uitspraak van de Hoge Raad op restitutie aanspraak konden maken.

Het voorgaande toont tevens aan dat de problematiek van de terugwerkende kracht van rechterlijke uitspraken nauw samenhangt met de desbetreffende procesrechtelijke regelingen. Zo was in de AAW-zaak van belang dat de aanvraag van de AAW-uitkering niet aan een ternijn gebonden wws. In Heesch-Van de Akker moest de Hoge Raad, om tot een uitspraak ten gronde te kunnen komen, allereerst de procesrechtelijke barrière gelegen in de

Vgl, in dit werband: $5 . K$. Martens, Do grenzen van de rechtswomende taak wan de rechter, NDB 2000 .
ant. $14,0,747-753$. ARRS 4 decmber 1990, AB 1991,687, n.n. Sewandono, zie levens ARRS 4 december 1990, AB
1991,597 , m.nt. H. Simon.

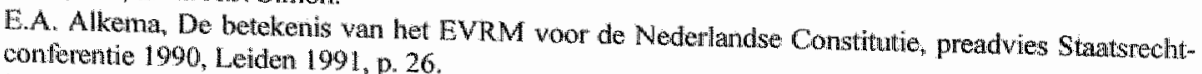
1. van den" Valde. Het "wrijo spel der rechtelijke krachten", Ower het tweetrapskarakter van de Europese mensenrechterbescherming en de beoordelingsmarges van artkel 5 en 6 EVRM, preadvies
Statsrechtconferentie 1990 Leiden 1991, p. 17 . HR 16 mei 1986, NJ 1986,723 m.nt. Scheltenta; AB 1986,573 mnt. FHwdB. 
formele rechtskracht van beschikkingen uit de weg ruimen; ook de lange verjaringstermijn van de vordering uit onverschuldigde betaling was in deze zaak niet zonder betekenis.

Het onderzoek waarop dit boek ziet zal geschieden aan de hand van de begrippen 'materiële en formele werking'. De materiële werking ziet op de vrag in hoeverre, op grond van verandering van rechtspraak, alsnog, met terugwerkende kracht, materiële rechten ontstaan; de formele werking op de vraag of en in hoeverre deze rechten ook daadwerkelijk geldend kunnen worden gemaakt. Het is met name deze laatste vraag die in dit boek centraal staat. Dit boek heeft dan ook een andere invalshoek dan de dissertatie van Haazen, ${ }^{8}$ die zich, op het terrein van het privaatrecht, toespitst op, wat in dit boek wordt aangemerkt als, de materiële werking van verandering van rechtspraak. Waar laatstgenoend onderzoek zich voorts kenmerkt door een sterk rechtstheoretische inslag, treden in mijn onderzoek de procedurele aspecten van de werking in de rijd van rechtspraak meer op de voorgrond."

2.

\section{Terminologie}

Men kan zich afvragen of de term 'tengwerkende kracht van rechterlijke uitspraken' wel zo gelukkig gekozen is. Afgaande op het 'Algemeen Deel' van Scholten hebben rechterlijke uitspraken immers altijd terugwerkende kracht: ${ }^{10}$ zij stellen vast wat rechtens was ten tijde van het voordoen van de feiten waarover de rechter moet oordelen. Deze rechtsvaststelling is bindend voor de desbetreffende partijen en - zeker als bet een uitspraak van een hoger college betreft - richtinggevend voor het oordeel in toekomstige gelijksoortige gevallen. Dit laatste aspect ziet op de precedentwerking van rechterlijke uitspraken. Het object van deze precedentwerking zijn de rechtsoverwegingen die tot het uiteindelijke dictum leiden.

Nu is het paradoxale gevolg van deze opvalting over rechtspraak, dat een eenmaal gegeven rechterlijke interpretatie de altijd gegolden hebbende heet te zijn. Voor wat de partijen in het geding betreft levert dit geen problemen op. Hierboven is echter gewezen op een aantal gevallen waarin het toeschrijven van de rechterlijke interpretatie aan het verleden, een precedent schept ten aanzien wan zich in het verleden voorgedaan hebbende feiten; een precedent dat de rechtsorde - en in de AAW-zaak de financiële huishouding van de staat voor problemen kan stellen. Voor sommige rechterlijke colleges is dit aanleiding geweest beperkingen aan te brengen op de terugwerkende kracht van hun uitspraak om de kring van gerechtigden te verengen. Verband hiermee houdt de techniek van het zogenaamde

O.A. Haazen, Algemeen Deel van het rechterlijk overgangsrecht, Een verhandeling over de terugwerkende kracht van rechtspraak, de rechtsdwaling en de democratische rechtsvindingslleer, diss. KUB, 2001.

9 Door Hazzen kort aan de orde gesteld onder het kopje 'Lites finiri oportet", zie a.w. (noot 8) p. 479. 480. Naar zijn oordeel gaat het bij gezag van gewijsde niet on een rechtsbeginsel, maar uiteindelijk om niet meer dan een beleidsmatige invulling var het gelijkheidsbeginsel. Ten gevolge van de korte beroepstermijnen in het bestuursrecht krijgt de bestuursstechtelijke tegenhanger van het gezag van gewijscle, de in hoofdstuk 2 te behandelen formele rechtskracht, echter een bijzondere lading en leidt deze bij verandering van rechtspraak voor betrokkenen waak tot vergaande consequenties.

10 Paul Scholten, Asser"s Handleiding tot de beoefening van het Nederlands burgerlijk recht. Algenieen Deel (met aanvullingen van mr G.J. Scholten), Zwolle 1974, p. 137. 
prospective overwiling," waarbij de rechter de voorliggende zaak nog volgens het "oude" recht beslist, maar daarbij tevens aankondigt dat hij in de nabije toekomst bij de interpretatie $^{12}$ van de desbetreffende rechtsregels 'om zal gaan'.

\section{3.}

\section{Concreet versus abstract}

De precedentwerking van rechterlijke uitspraken wint aan kracht naarmate de rechter zich meer in abstracto - dat wil zeggen los van de feiten in de voorliggende zaak - uitspreek.t over de gelding van een rechtsregel. Deze abstracte toetsing kan op twee manieren gestalte krijgen. Enerzijds kan het gaan om situaties waarin rechter 'omgaat' ten aanzien van de gevestigde interpretatie van de toe te passen rechtsregel; anderzijds om situaties waarin de rechter een algemeen verbindend woorschrift onverbindend verklaart. Van dit laatste gaat zelfs $z o$ " $n$ sterke precedentwerking uit dat een onverbindendverklaring in veel gevallen feitelijk tot gevolg heeft dat de desbetreffende bepaling in de toekomst niet meer wordt toegepast en de desbetreffende wetgever overgaat tot wijziging van de bepaling.

Dit (feitelijke) gevolg beperkt zich niet tot uitspraken van de mationale rechtelijke instanties. Zeer illustratief in dit verband is de jurisprudentie van het Europese Hof voor de Rechten van de Mens. Weliswaar gaat deze Europese rechter uit van de stelregel dat "the court's task is not to review the relevant law and practice in abstacto: ${ }^{13}$ Maar tevens achtte het Hof het in het Marckx-arrest 'inevitable that the Court's decision will have effects extending beyond the confines of this particular case, especially since the violations found stem directly from the contested provisions and not from individual measures of implementation'. ${ }^{4}$ En hoewel het Hof hieraan nog uitdrukkelijk toevoegt dat zijn 'decision cannot of itself annul or repeal these provisions', merkt Heringa op dat in de praktijk met de uitspraken van het Hof een resultaat kan worden bereikt dat vergelijkbaar is met het nietig-verklaren van wetgeving, indien de uitspraken van het Hof een verder reikende werking hebben dan de concreet voorgelegde zaak..$^{15}$

Vooral bij deze rechterlijke onverbindendverklaring treedt de vraag in hoeverre door derden rechten ontleend kunnen worden aan rechterlijk uitspraken, sterk op de voorgrond. Zoals zojuist werd aangegeven komt aan de precedentwerking in deze zaken een bijzondere betekenis toe. Aan dit precedent komt een vrij algemene gelding toe, juist vanwege het feit dat de onverbindendverklaring een oordeel in abstracto, dus los van de feiten in het
geding, inhoudt.

11 Zie onder meer P.B. Zwart, Enkele opmerkingen over rechterlijk overgangsrecht, NIB 1997, afl. 3, p. $108-114$ en de aldaar vernelde literatur. 12 Jie A-G Franx in zijin conclusie voor HR 16 mei 1986, NJ 1986, 723 (Heesch-Hon de Akker) en
Polak, aw (noot I) p. 228 e.v.

13 Zue EHRM 24 mei 1989. Howschild, Series A, vol. 154, par. 45; N 1990, $627 \mathrm{~m}$.nt PvD.

14 EIHRM 13 juni 1979 , Marckx, Series A, vol. 31 , par. 58 ; NJ 1986, 462 m.nt. E.A. Alkema. in: 40 jas Eliropees Verdrag tot bescherming vederlandse constitutie voot de Rechten van de Mens, 
Een onverbindendverklaring door de rechter impliceert tevens het oordeel dat de toepassing van de desbetreffende wettelijke bepaling onrechtmatig is geschied, omdat deze bepaling in strijd is met hoger recht. De precedentwerking die van een dergelijke uitspraak uitgaat wordt als het ware versterkt door de toepassing van regels van 'hoger' recht: waar het 'lagere' recht ondeugdelijk is moet aan het 'hogere' recht door de rechter voorrang worden gegeven. De mate waarin het precedent, dat is gelegen in de onverbindendverklaring, bindend is ten aanzien van feiten die eerder onder de gewraakte regeling hebben plaatsgevonden, staat dus niet geheel meer ter vrije beoordeling van de rechter; zij wordt mede beheerst door de "hogere' regel waaraan de rechter heeft getoetst.

Gaat het bij deze hogere regelingen om internationaal recht, meer in het bijzonder om de direkt werkende bepalingen van de mensenrechtenverdragen, dan wint de precedentwerking van rechterlijke uitspraken verder aan belang. Om het voorbeeld van de AAW-zaak nog eens aan te halen: aan de uiteindelijke beslissing van de Centrale Raad van Beroep dat eiseressen met terugwerkende kracht woor een AAW-uitkering in aanmerking kwamen, lag de algemene overweging ten grondslag dat op grond van de doorwerking in de Nederlandse rechtsorde van artikel 26 IVBPR het onderscheid dat in het AAW-overgangsrecht werd gemaakt naar het al dan niet kostwinner zijn van de gehuwde vrouw, vanaf 1 . januari 1980 alls verboden moest worden aangemerkt. Voor de desbetreffende vrouwen gold dus sinds 1 januari 1980 als (Nederlands) recht dat zij aanspraak konden maken op een uitkering. Deze algemene overweging laat geen ruimte voor latere rechterlijke beslissingen om in een soortgelijke casuspositie anders te beslissen.

\section{Gemeenschapsrecht}

De problematiek van deze terugwerkende kracht als 'precedentwerking naar het verleden' wint nog meer aan belang indien de (Nederlandse) rechter moet toetsen aan het EG-recht ${ }^{\text {to }}$ Voor het oordeel over de werking in de tijd van rechterlijke uitspraken is de rechter aangewezen op het oordeel wan het Hof van Justitie van de EG. Het Hof van Justitie EG stelt als hoofdregel dat aan de interpretatie die het aan de communautaire bepaling geeft, terugwerkende kracht toekomt. Slechts in zeer bijzondere gevallen blijkt het Hof bereid te zijn beperkingen op deze terugwerkende kracht te aanvaarden. ${ }^{17}$ Blijkt wit de interpretatie van het Hof dat geconstateerd moet worden dat aan Nederlandse wettelijke bepalingen een toepassing is gegeven die in strijd is met het gemeenschapsrecht, dan kan dit aanleiding zijn tot op het gemeenschapsrecht gebaseerde aanspraken met betrekking tot de periode gedurende welke aan de Nederlandse bepalingen een 'verkeerde' toepassing is gegeven. Een voorbeeld dat sterk de aandacht heeft getrokken was de toekenning, met terugwerkende kracht tot 23 december 1984, van een WWV-uitkering aan gehuwde vrouwen, die voorheen van het recht op uitkering uitgezonderd waren, ondat zij niet aan de door de wet gestelde kostwinnerseis voldeden. Toepassing van deze kostwinnerseis werd door het HuJ 
EG voor alle gehuwde vrouwen die vóór 23 december 1984 werkloos waren geworden geacht in strijd te zijn met artikel 4, lid 1 van Richtlijn $79 / 7$ (de derde EG-richtlijn, inzake gelijke behandeling in de sociale zekerheid). ${ }^{18}$

Beperking van de periode waarover de interpretatie van het Hof van Justitie terugwerkt, valt buiten de rechtsmacht van de Nederlandse rechter; ze ligt geheel in handen wan het Hof. Een mooi voorbeeld hiervan biedt de uitspraak van het Hof van Justitie in de zaak Barber." In deze zaak werd door het Hof, voor wat - kort gezegd - de bovenwettelijke pensioenstelsels betreft, bepaald dat de hantering van verschillende pensioengerechtigde leeftijden tussen mannen en wrouwen in strijd is met art.119 EEG-Verdrag. Deze uitspraak heeft aanleiding gegeven tot de veronderstelling dat vanaf 17 mei 1990 iedere werknemer onder dezelfde, niet-discriminatoire, voorwaarden een pensioen kan claimen, ongeacht de aanspraken die hij of zij voor die datum heeft opgebouwd. ${ }^{20}$ Uit vrees voor deze consequentie werd te elfder ure bij het 'Verdrag van Maastricht' een protocol opgenomen, krachtens hetwelk pas van gelijke behandeling in pensioenen sprake zal zijn, voor zover men deze na 17 mei 1990 (de datum van het Barber-arrest) is gaan opbouwen. ${ }^{21}$

\section{Rechterlijke rechtsworming}

Het bovenstaande strekt ertoe te onderzoeken hoe verstrekkend de werking wan rechterlijke uitspraken in de tijd is. Een andere vraag is hoe verstrekkend zij zou mogen zijin. Om deze vraag te beantwoorden moeten we nogmaals stilstaan bij de aard van de in dit boek aan de orde gestelde problematiek. Hiervoor is al aangegeven dat deze in belangrijke mate is ingegeven door de sterk toegenomen rechtsvormende rol wan de rechter. Voorts is aangegeven dat de problematiek zich vooral voordoet, wanneer de rechter 'omgaat' ten aanzien van de interpretatie van de toe te passen rechtsregel en wanneer hij een algemeen verbindend woorschrift onverbindend verklaart. In deze beide situaties heeft de rechterlijke uitspraak een belangrijke verandering in de rechtsorde, een rechtshervorming, tot gevolg.

In de 'klassieke' opvatting over de verhouding tussen wetgever en rechter ${ }^{22}$ kon een dergelijke verandering alleen worden teweeggebracht door de wetgever. ${ }^{23}$ De wetgever was

HwJ EO 5 maart 1988, zaak 80887, Dik, Jur. 1988, p. 1601. Zie voor de werking in de tijd wan ardresten var het HW EG voors: J. Wouters, Celijke behandeling van mannen en vrouwen inzake bep. $274-298$.

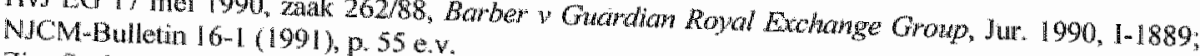

20 Zie: Sacha Prochat Ondeugdeloke com p. 1302 consequenties hiervan: Sach de gang van zaken rond het 'Barber-protocol' en de (constitutionele) NJB 199211 , p.352 $2 . \mathrm{y}^{\circ}$ Tie 7 . Koopm, $1991, \mathrm{p}, 211-214$.

aresent trends, in: Juridisch Stippelwerk, Deventer wan deze gedachte, zie: L. Strikwerd, Artak, a.w. (noot 1), p. 229. Voor een historische verklaring houden? Ars Aequi, XXII (1974), p. 1-17. 11 AB: middlel om de rechter in het rechte spoor te 
hierbij gehouden het rechtszekerheidsbeginsel in acht te nemen. Uit dit rechtszekerheidsbeginsel werd afgeleid dat een wet (strekkendle tot verandering van de rechtsorde) in beginsel niet eerder kon werken, dan na een behoorlijke bekendmaking, die een ieder in staat zou stellen van de wet, en dus van de verandering in de rechtsorde, kennis te nemen. Meer in het bijzonder werd uit dit beginsel een verbod van terugwerkende kracht van wetgeving afgeleid. Noch het beginsel van de rechtszekerheid, noch het verbod van terugwerkende kracht werden echter grondwettelijk vastgelegd. Wél is er de bepaling van artikel 4 van de Wet Algemene Bepalingen, die luidt: 'De wet verbindt alleen voor het toekomende, en heeft geene terugwerkende kracht ${ }^{2.4}$

In de literatuur is wrij veel aandacht besteed aan de toelaatbaarheid van terugwerkende kracht van wetgeving. Ten aanzien van 'lagere wetgeving' lijkt de heersende opvatting te zijn dat daaraan geen terugwerkende kracht mag worden toegekend, tenzij de formele wet hiertoe de mogelijkheid schept. Deze opvatting vindt steun in de jurisprudentie, in het bijzonder in de uitspraken van de Centrale Raad van Beroep. De Centrale Raad toetst in dergelijke gevallen aan het 'aan artikel 4 van de Wet Algemene Bepalingen ten grondslag liggende rechtszekerheidsbeginsel'. ${ }^{25}$ De Hoge Raad is evenwel geneigd in dit artikel alleen een tot de rechter gericht verbod te lezen (dus een werbod aan de rechter om de wet met terugwerkende kracht toe te passen). Niettemin is ook de Hoge Raad overgegaan tot een marginale toetsing van wetgeving waaraan terugwerkende kracht is toegekend. ${ }^{20}$

Ten aanzien van formele wetgeving ligt de zaak gecompliceerder. Niet alleen interpreteert de Hoge Raad artikel 4 van de Wet Algemene Bepalingen restrictief, maar bovendien kan elke formele wet derogeren aan dit artikel. De rechter staat hier machteloos tegenover. Een zeer belangwekkende ontwikkeling in dit verband vormde evenwel het Harmonisafiewetarrest, ${ }^{27}$ waarin de Hoge Raad zijn restrictieve opvatting leek te laten varen door te overwegen dat een aantal bepalingen uit de Harmonisatiewet, die met terugwerkende kracht bepaalde rechten aan studenten ontnam, strijdig waren met het rechtszekerheidsbeginsel. Het grondwettelijk toetsingswerbod stond er echter aan in de weg dat de rechter ook consequenties (in de vorm van een veroordeling van de Staat wegens onrechtmatige daad) kon trekken uit deze overweging.

Hierboven is erop gewezen dat aan rechterlijke uitspraken enerzijds een rechtsherwormend karakter toekomt dat in veel gevallen niet onderdoet voor dat wan wetgeving. Anderzijds wordt als regel uitgegaan van de terugwerkende kracht wan rechterlijke uitspraken, niet

24 Zie: M.V. Polak, a.w. (noot 1), p. 247-248 en I.C.M. Leijten, Overgangstecht I en II, NJB 1972, p. $364-373$ en p. $389-400$.

25 Zie in het bijzonder CRvB 3 april $\Perp 1963$, ARB 1964, p. 75, mnt. Boer; Ars Acqui XII (1963-1964), p. 69 m.nt. Prins (salariswizziging miverheidsondenwigs). Voor andere voorbeelden, zie: Van Wijk/ Konijnenbelt, Hoofdstukken van Administratief Recht, Culemborg 1988, p. 81.

Zie achtereenvolgens: HR 26 oktober 1951, NJ 1952, 756 mint. Veegens; HR 15 masurt 1974, NJ 1974, 348 m.nt. Prins, AB 1975, 85 m.nt. Stellinga, Ars Aequi XXIV (1975), p. 623 m.nt. Jeukens en HR 7 maart 1979, NJ1979, 319 m.nt. Schettema, AB 1979, 218 m.nt. Stellinga, BNB 1979, 125 m.nt. Horstra (onroerend-goedbelasting Rotterdam).

27 HR 14 april 1989, NJ 1989, 469 m.nt. MS; AB 1989, 207 m.nt. FHvdB; Ars Aequi 38 (1989), p. 578 m.nt Hirsch Ballin. Zie in dit verband ook: CRvB 6 juli 1989, TAR 1989, 201, waarin de CRvB zich bij de jurisprudentie van de Hoge Raad aarsilut. 
alleen ten aanzien van partijen (hetgeen voor de hand ligt), maar ook, door het scheppen van een precedent ten aanzien van feiten die zich in het verleden - dat wil zeggen vóór de uitspraak hebben afgespeeld - ten aanzien van derden. Dit roept de vraag op in hoeverre de uit het rechtszekerheidsbeginsel voortvloeiende restricties ten aanzien van de terugwerkende kracht van wetgeving (en van bestuualijke rechtshandelingen) niet van overeenkomstige toepassing zijn op de rechterlijke rechtshervorming.

\section{Daadwerkelijk rechtsherstel}

Bij beide hierboven aan de orde gestelde wijzen van abstracte rechterlijke toetsing - te weten het rechterlijk omgaan en de rechterlijke onverbindendverklaring van een wettelijke bepaling - kan de rechterlijke uitspraak impliceren dat aan de desbetreffende wetsbepaling gedurende kortere of langere tijd een onjuiste toepassing is gegeven. Aan een dergelijk oordeel zal in het algemeen zelfs niet te ontkomen zijn, indien de rechter constateert dat de toe te passen wetsbepaling in strijd is met een internationalrechtelijke bepaling, waaraan rechtstreekse werking is toegekend vanaf een tijdstip dat vóór de uitspraak ligt. Het voorbeeld van de AAW-zaak - dat in dit boek met vele andere zal worden uitgebreid - toont aan dat een dergelijk rechterlijk oordeel aanleiding kan zijn tot de conclusie dat naast partijen tevens "derden" rechten kunnen doen gelden met betrekking tot een periode die aan de rechterlijke uitspraak voorafgaat. Het gaat hier dan wel te verstaan om materiële rechten. Of dergelijke rechten ook daadwerkelijk geldend gemaakt kunnen worden, of er, met andere woorden daadwerkelijk rechtsherstel kan worden verleend, is echter weer afhankelijk van een aantal andere factoren. Deze betreffen alle de met de desbetreffende materiële rechten samenhangende procesrechtelijke bepalingen.

Zo zal in burgerlijke en strafzaken het heropenen van een zaak in verband met een wijziging van de jurisprudentie in de meeste gevallen afstuiten op verjaring respectievelijk het gezag van gewijsde van eerdere rechterlijke vonnissen: nadat over een zaak tot in hoogste nationale instantie is beslist of nadat de beroepstermijn tegen een vonnis ongebruikt is verstreken, wordt het vonnis geacht onherroepelijk te zijn. In bestuurlijke zaken doet zich een gelijksoortig verschijnsel voor in de vorm van de formele rechtskracht. Het nalaten tijdig tegen bestuurlijke beschikkingen bezwaar of beroep in te stellen leidt tot "onaantastbaarheid ${ }^{2 k}$ van de beschikking. Wordt bij de burgerlijke rechter de geldigheid van een bestuurlijke beschikking, waategen niet tijdig de desbetreffende administratieve rechtsgang is gevolgd, in twijfel getrokken, dan dient deze rechter ervan uit te gaan dat "[die] beschikking zowel wat haar wijze van tot stand komen als wat haar inhoud betreft in overeenstemming is met de desbetreffende wettelijke voorschriften en algemene rechtsbeginselen'. Indien achteraf blijkt dat van een dergelijke owereenstemming 'toch' geen
sprake is, indien op grond van latere rechtspraak mocht blijken dat de appellant 'toch'

Soms wordt een terminologie gebezigd die aen verband lijkt te leggen tussen de formele rechtskracht van besturilijke beslissingen en het gezag van gewijsde van vonnissen. Zo spreekt de Centrale Raad van Beroep soms van in "kracht van admministratief gewijsde" gegane bestisingen (CrvB 10 april 1991. RSV $1992 / 23$ ). Zie voots over dit verband: H.D. van Wijk/W. Konijnenbelt, Hoofdstukfuen
van Administratief rech van Administratief recht, "s-Gravenhage 1979 , p. 75 en A.M. Donner, Nederlands Besturarstecht,
Algemeen Deel, Alphen aan den Rijn 1987, p. 260 . 
recht op een vergunning of uitkering had, versperren de hier aangehaalde procesrechtelijke beginselen hem alsnog de weg zijn (materiële) recht ook daadwerkelijk te 'halen'.

\section{Opzet van het boek}

De vraag in hoeverre er, in het licht van veranderde rechtspraak, gelegenheid moet bestaan tot daadwerkelijk rechtsherstel maakt de kem van de probleemstelling van dit boek uit. Deze vraag zal beantwoord worden aan de hand van een studie van de jurisprudentie van de bestuursrechter. Vertaald naar de terminologie van het bestuurstecht ziet deze probleemstelling in het bijzonder op de vraag in hoeverre bestuursorganen op grond van een wijziging in de jurisprudentie gehouden kunnen zijn om terug te komen van, nog onder de oude jurisprudentie genomen en in rechte onaantastbaar geworden, besluiten. Hoofdstuk 2 behandelt deze vraag in algemene zin, voor louter nationale rechtsverlhoudingen. Daarbij zal mede worden ingegaan op het in de jurisprudentie van de burgerlijke rechter tot ontwikkeling gekomen begrip formele rechtskracht. In de hoofdstukken 3 en 4 komt in wezen dezelfde vraag aan de orde, maar dan toegespitst op die gevallen waarin het verlaten van de 'oude' jurisprudentie het gevolg is van de doorwerking van bepalingen van internationaal recht. In hoofdstuk 3 zal allereerst het juridisch kader worden geschetst waarbinnen deze doorwerking plaatswindt. Vervolgens komt in hoofdstuk 4 de kem van dit onderzoek aan de orde. Hierbij wordt aan de hand van een groot aantal, voornamelijk op de sociale zekerheid betrekking hebbende, uitspraken onderzocht in hoeverre rechterlijke uitspraken waarbij rechtstreeks toepassing is gegeven aan internationaalrechtelijke normen met terugwerkende kracht materiële rechten kumnen scheppen. Voorts wordt onderzocht in hoeverre deze rechten ook daadwerkelijk geldend kunnen worden gemaakt. In hoofdstuk 5 zullen de bevindingen uit de voorgaande hoofdstukken nogmaals kritisch worden bezien in het licht van recente ontwikkelingen in de jurisprudentie van her Hof van Justitie EG en van het Europese Hof voor de Rechten van de Mens. Daarbij komt tevens aan de orde welke rol de burgerlijke rechter, met voorbijgaan aan het beginsel van formele rechtskracht, zou kunnen spelen bij het verkrijgen van daadwerkelijk rechtsherstel. Meer in het bijzonder zal de intrigerende vraag aan de orde komen of de uit het nationale procesrecht voortvloeiende beperkingen op het met terugwerkende kracht geldend maken van alsnog verkregen rechten, op hun beurt de toetsing aan het internationale recht kunnen doorstaan. Hoofdstuk 6 sluit het boek af met een aantal conclusies. 
$*$ 


\section{Hoofdstuk 2}

\section{Aantastbaarheid van besluiten}

1. Inteiding

Zoals in het eerste hoofdstuk is uiteengezet staat in dit boek de vraag centraal in hoeverre aan (plotselinge) veranderingen in de rechtspraak van de bestuursrechter aanspraken kunnen worden ontleend ten aanzien van vóór de desbetreffende uitspraak liggende tijdvakken. Daarbij doet zich in de eerste plaats de vraag voor of op grond van de nieuwe rechtspraak kan worden "ingebroken" op onder de oude rechtspraak tot stand gekomen rechtsposities. Deze vraag heeft betrekking op het in de Nederlandse civiele- en bestuursrechtspraak ontwikkelde beginsel van de formele rechtskracht. Dit beginsel kont er, zeer kort gezegd op neer, dat een besluit in rechte onaantastbaar wordt, als een tegen dat besluit opengestaan hebbende administratieve rechtsgang niet is benut, dan wel dit besluit in rechte is gehandhafd. Het begrip rechtskracht heeft reeds vele pennen in beweging gebracht.' Ik zal mij dan ook beperken tot die aspecten die voor het onderwerp van dit boek van rechtstreeks belang zijn. Deze komen in paragraaf 2 aan de orde. Paragraaf 3 gaat in op de vraag of, en in hoeverre, bestuursorganen gehouden kunnen zijn op verzoek terug te komen van voór de veranderde rechtspraak genomen besluiten. Paragraaf 4 is gewijd aan de vraag welke mogelijkheden er bestaan om bij de burgerlijke rechter een vordering aanhangig te maken wegens, naar achteraf blijkt, onrechtmatige bestuurlijke besluitvorming. Het hoofdstuk wordt in paragraaf 5 afgesloten met een aantal conclusies.

\section{2.}

\section{Rechtskracht algeneen}

Een door alle rechterlijke instanties gehuldigd uitgangspunt is dat een besluit door verloop van de tijd onaantastbaar wordt. Deze onaantastbaarheid treedt in, indien van een tegen het besluit openstande administratieve rechtsgang niet binnen de daarvoor gestelde termijn gebruik is gemaakt, of indien op een ingesteld beroep definitief ten gronde is beslist. Zo geformuleerd is de onaantastbaarheid niet meer dan een uitdrukking varn het aloude adagium lites finiri oportet doelmatig overheidsbestuur en de rechtszekerheid vereisen dat besluiten op een bepaald moment "vast" komen te staan.

Naast de formele rechtskracht wordt de materiẻle rechtskracht onderscheiden., De formele rechtskracht is de werking die samenhangt met het bestaan van de beschikking. Zij ziet in

Zie ECH.J. van der Linden, Formele en materiete rechtskracht, De kleren van de keizer, diss. UM, Den Haag 1998.

2 Zie A.M. Donner, Nederlands Bestuursrecht, Algemeen deel, Alphen aan den Rijn 1987, p. 260. Vgl, tevens F.H. van der Burg, Formele rechtskracht, vertrouwensbeginselen en derde-beroep, in: Een stellig annotator (Stellinga-bundel, p. 8, die wijst op 'de grote verwarring [die zou] ontstaan, wanneer nog vele jaren na dato zou kunnen worden wastgesteld dat een beschikking nict rechtsgeldig is'.

3 Voor een vitgebreide uiteenzetting ower dit onderscheid, zie: E.C.H.J. van der Linden, a.w. (noot 1) hoofdstuk 3, par. 4.2 . 
het bijzonder op de mate waarin het voor administratieve rechters en andere beroepsinstanties mogelijk is de beschikking ongedaan te maken. Eveneens wordt zij geacht betrekking te hebben op de mate waarin het voor het beschikkend orgaan zelf mogelijk is de beschikking, met terugwerkende kracht tot het tijdstip waarop deze tot stand is gekomen, in te trekken. ${ }^{4}$ De materiële rechtskracht, daarentegen, ziet op de werking die met de inhoud van de beschikking samenhangt. Ze heeft betrekking op de gebondenheid van het bestuursorgaan aan de eigen beschikkingen; zij heeft, anders gezegd, betrekking op de vraag in hoeverre het bestuursorgaan bevoegd moet worden geacht de beschikking 'ex nunc', dus met ingang van het tijdstip waarop de nieuwe beschikking genomen wordt, in te trekken. ${ }^{5}$ De materiële rechtskracht wordt voorts geacht betrekking te hebben op de mate waarin de beschikking derden, in het bijzonder andere overheidsorganen (dan het beschikkend orgaan), bindt."

Positiefrechtelijk gezien heeft het begrip 'materiële rechtskracht' geen ingang gevonden. Normal gesproken wordt het met dit begrip samenhangende probleem "gewoon' aan de orde gesteld als dat van de intrekbaarheid van beschikkingen. Hantering van het begrip materiële rechtskracht in het kader van dit onderzoek heeft des te minder zin, omdat het, daar waar het betrekking heeft op de bevoegdheid woor bestuursorganen beschikkingen "ex nunc" in te trekken, aan de probleemstelling van dit boek voorbijschiet. Veeleer dan op de bevoegdheid met ingang van het heden terug te komen op 'oude' beschilkkingen, heeft dit onderzoek immers betrekking op het al dan niet bestaan van een plicht voor bestuursorganen om in het licht van 'mieuwe' jurisprudentie terug te komen van 'oude' beschikkingen, waarbij de herzieningsbeschikking werkt met ingang van een tijdstip dat voorafgaat aan de datum waarop de herzieningsbeschikking genomen wordt. ${ }^{8}$

In de rechtspraak komt dit probleem aan de orde als de vraag naar de rechtmatigheid van besluiten van bestuursorganen inhoudende een weigering om, in het licht van veranderde rechtspraak, terug te komen op rechtens onaantastbare besluiten. Het is dus niet in de

HR 8 december 1995, NJ 1997, 163 m.nt. MS.

A.M. Donner, De rechtskracht van administratieve beschikkingen, diss. VU Aunsterdam, Alphen aan den Rijn 1941, p. 17-19. Zhe voorts W.G. Vegting, Het Nederlands Administratief Recht, Eerste
Deel, Alphen asu den Rijn 1954, p. 278-280.

Zie woor deze opvatting zere expliciet: W $G$.

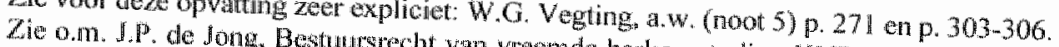

oorcleet is dat het begrip ingterisle van vreemde herkomst, diss. KUB, Zwolle 1988, p. 96, die van de rechtspraak over de intrekking of whacht van beschikkingen 'in het geheel geen rol [speelt]' in baarheld wan beschikkingen geheel beheerst doar de toepassingen. Zijns inziens wordt de intrekalgenene beginselen van behoorlijk bestuur ( $p .91$ )
Wel lijken op het ewrste gezicht de opvattinge vasselijke wettelijke voorschriften en de

in her Staats- en administratief recht, diss., Assen 1958 . Steenbeek (Rechtshandeling en rechtsgevolg onderscheid tussen formele en materièle rechts 1958 ) relevant met het oog op dit onderzoek. Het bestaan (gelding) van het besluit enerzijds, en de door koppelt hij atan het ondersoheid tussen het anderzijds. De materiële bechit enerzijds, en de door dat besluit tot stand gebracite rechtsgevolgen bestuursorgasn on in het licht van nieuwe onstandigheden betrekking op de bevoegdheid van het gevolgen van het eeder genomen besluit. Ook in dereden een wijziging aan te brengen in de nechtsgevolgein echter ex munc, dus met ingang van het opvatting werkt de verandering van de rechtsgenomen. En ook deze opvarting gaat woorbij aan de stip waarop de wijzigingsbeschikking wordi ring in de omstandigheden bestat in een veranderin situatie dat de tot wijziging nopende verandeeen wijziging van de beschikking met 'tengwarkende kracht'. 
eerste plaats de materiële rechtskracht of de intrekbaarheid van beschikkingen die in deze jurisprudentie centraal staat, maar het probleem van de onaantastbaarheid en de mogelijke relativeringen die hierop kunnen worden aangebracht. Om hiervan een beter beeld te verkrijgen is het van belang allereerst enige aandacht te besteden aan de ontwikkeling die het begrip formele rechtskracht in de jurisprudentie te zien heeft gegeven."

\section{$2.1 \quad$ Formele rechtskracht}

De inkt van de bijdrage van Donner aan de Special van thet blad Ars Aequi, waarin bekende schrijvers terugblikken op hun proefschrift en waarin Donner opmerkte dat het begrip rechtskracht als abstractie mislukt was, ${ }^{10}$ was bij wijze van spreken nog maar nauwelijks droog, of de Hoge Raad introduceerde het begrip formele rechtskracht in het arrest Heesch-Van de Akker. ${ }^{11}$ Het zou echter onjuist zijn te beweren dat het begrip zomaar uit de lucht is komen vallen. Reeds lang was vaste jurisprudentie van de burgerlijke rechter dat, indien van een tegen een beschikking openstaande administratieve rechtsgang niet binnen de daarvoor gestelde temijn gebruik wordt gemaakt, deze beschikking onaantastbaar wordt. ${ }^{12}$ Deze onaantastbaarheid houdt tevens in dat de rechter in volgende zaken in beginsel steeds van de rechtsgeldigheid van de beschikking dient uit te gaan, ook indien duidelijk is dat, zo tegen de beschikking aanstonds bezwaar of beroep zou zijn ingesteld, deze vernietigd zou zijn. Ook de burgerlijke rechter, die zich ziet geplaatst voor de vraag naar de rechtsgeldigheid wan een beschikking, placht zich aanvankelijk van de tem onaantastbaarheid te bedienen, zoals bijvoorbeeld blijkt uit het Hei- en Boeicoparrest: ${ }^{13}$

Bogerd stelt in kort geding een yordering uit onrechtmatige daad in tegen de gemeente Hei- en Boeicop. B\&W van deze gemeente hebben op 12 september 1979 aan de gemeente wergunning verleend tot de aanleg van een parkeerterrein grenzend aan het terrein van Bogerd. Bogerd laai na tegen deze vergumning AROB-beroep in te stellen. Hierbij speett een rol dat hij aanvankelijk niet op de hoogte was van de vergunningverlening. Vast staat evenwel dat zijn raadsman op 31 oktober 1979 van de desbetreffende vergunning kennis heeft gekregen vanwege een door de gemeente aan hem geschreven brief. Bogerd laat evenwel na alsnog, op grond van artikel 9 lid. 4 , Wet Arob beroep tegen de beschiklking in te stellen. ${ }^{14} \mathrm{Nu}$ Bogerd van deze rechtsgang geen ge.bruik heeft gemaakt, is de Hoge Raad van oordeel dat er in cassatie van uit moet worden gegaan dat genoemde beschikking onatutastbaur is geworden. Vervolgens geeft de Hoge Raad als zijn oordeel te kennen dat zulks betekent dat 'de burgerlijke lechter ervan [dient] wit te gaan dat de

9 Voor een thitvoerige uiteenzetting over het ontstaan van dit begrip in de rechtspraak van de burgerlijke rechier, zie: E. C.H.J. van der Linden, a.w. (noot ll) hoofdstuk 3.

10. A.M. Donner in zijn terugbllik, op zijn dissertatie (De rechiskrachi wan adminisuratieve beschikkingen, Amsterdam 1941) in A.rs Aequï 34 (1985), p. 679.

11 HR 16 mei 1986, NJ 1986,723 m.nt. MS; AB 1986, 573 m.nt FHwdB; Ars Adequi (35) 1986. 19.642 m.nt. H.Ph.L.A.M. Hennekens; BR 1986, p. 775 m.nt. N.S.F. Koeman.

12 Zie voor een wroeg woorbeeld wan het gebruik wan deze terminologie: HR 30 juni 1911, W 9197 , vermeld bij I.A.M. van Angeren, De gewone rechter en de administratieve rechtsgangen, diss, l.eiden 1968 , p.57 e.w. en bij F.H. van der Burg, aw (noot 2) p.8.

13. HR 4 febnuari $1983, \mathrm{NJ} 1983,21 \mathrm{mint}$ MS

14. Volgens dit artikellid bleef niet-ontvankeligkerklaring wegens te lat ingesteld beroep achierwege. indien de klager aantoont, dat hij het beroep heeft ingesteid zo spoedig als dit redelijkerwijs verwach kon worden. Zie artikel 6:1 I Awb voor de huidige regeling. 
[beschikking] zowell wat haar wijze van totstandkoming als wat haar inhoud betreft in overcenstemming is met de desbetreffende wettelike voorschriften". is

Te beginnen met het zojuist genoende arrest Heesch-Van de Akker hanteert de Hoge Raad echter en andere terminologie. Vanwege de centrale rol die deze uitspraak in dit onderzoek speelt ga ik hier wat witvoeriger op dit arrest in:

In 1977 voldoel Van de Akker aan de gemeente Heesch een som van $f 3.2$ l6 ter verkrijging van een wergurining tot het maken van een witweg van zijn percel naar de openbare weg. De gemeente achtte zich tot het bedingen van dexe geldsom bevoegd op grond van het Hoogeloonarrest van de Hoge Raad. ${ }^{16}$ Krachtens deze uitspraak kwam aan de gemeente als aigenares de bevoegdheid toe on woor het werlenen wan cen recht van uiweg naar haar eigendom (te weten de openbare weg) de betaling wan een geldsom te verlangen.

Op I september 1977 kent de Afdeling Rechitspraak van de Raad van State aan een soortgelijke heffing van de gemeente Maastricht het karakter van een beschikking toe; tevens oordeelt de Afdeling dat de gemeentelijke regeling watop deze beschikking berust - in grote linnen gelijk atan die van de gemeente Heesch - in strijd is met artikel 14 Wegenwet, op grond waarvan de Afdeling de gemeentelike regeling onverbindend verklaart (de Afdeling was van oordeel dat onder het gebnuik overeenkomstig de bestemming, dat de rechthebbende op en openbare weg krachtens artikel 14 Wegenwet moet dulden, mede moet worden verstaan het "gebruik van de weg ten behoeve van de ontshuting wan aan die weg grenzende terreinen, wartoe het uitwegen op die weg dient te worden gerekend".

Nadat hij van deze untspraak kennis heeft genomen wordert Van de Akker van de gemeente terugbetaling van het voomelde bedrag. De weigering van de gemeente aan deze eis te voldoen vormt het geschil in deze uitspraak. In de procedure probeert de gemeente wan twee juridische walletjes te eten: enerzijds beroept zij zich op het in goed vertrouwen afgaan op het Hoogeloonarrest en de daaruit voortvloejende privatrechtelijke grondslag voor haar heffingsbevoegdheid; anderzijds beroept zij zich op de niet-ontwankelijkheid van Van de Akker in zijn vordering voor de burgerlijke rechter, nu hij heeft nagelaten tegen de heffingsbeschikking AROB-beroep in te stellen. De Hoge Raad vat dit laasste betoog samen door dit "kort gezegd" an te merken als cen betoog van de gemeente als zou de betaling berusten op een beschikking met formele rechts-
hrach.

Het Hof had dit beroep op de formele rechtskracht verworpen. In zijn antwoord op de wrag of deze verwerping terecht was geschied, komt de Hoge Raad tot de beschrijving, die sindscien als de klassieke van het beginsel van de formele rechtskracht is gaan gelden:

Zie ook: HR 19 november 1976, NJ 1979,216; AB 1978, 243 m.nt. J.R. St (Semper Crescendo). Ook hiervan oordeelde de Hoge Ragd dot 'de administhatieve rechtsgang geen gebruik gewaakt. Op grond onderhavige geding niet aan de orde kan koming dat de [beschikking] ten onrechte is geweigerd in het [beschilkking] rechtmatig was'. Zie liveromtrent zodat er thans van dient te worden uitgegaan dat de Boman; AB 1984, 399, m.nt. EM. van Eijden; Oedewrode); HR 22 nowember 1985 , RwdW 1985 BR 1984, p. 508 m.nt. K. Van Rijckeworsel (St. zie woorts noot Brunner bij HR 2 februari 1979, N198, 218; N1 1986, 722 m.nt. MS (Fd D-Groninger); 1981, AB 1981, 516 ; noot Boman (sub \&) bij HR 11 97, 581; noot Bomman (sub 7) bij ARRS 25 mei 1984, p. 466; A. Walter de Bruin in BR 1984, HR II december 1981, NJ 1983, 320; Koeman in BR e. $v^{\prime \prime}$ Ars A Aqui (16) 1967, p. 137 m.nt. Prins. 
"Voorop moet worden gesteld dat wameer tegen een beschikking een met voldoende watrbotgen onklede administratiefrechtelike rechtsgang heeft opengestann (zoals die ingevolge de Wet Arob), de burgerlijke rechter, zo deze beropsgang niet is gebruikt, in geval de geldigheid varn de beschikking in het voor hem gevoerde geding in geschil is, ervan dient unt te gaan dat die beschikking zowel wat haar wijze van tot stand komen als wat haar inhoud betreft in overeenstemming is met de desbetreffende wettelijke voorschriften en algemene rechtsbeginselen. Dit beginsel geldt oók dan, indien dit de burgerlijke rechter ertoe zon nopen aan zijn uitspraak de rechtsgeldigheid ten grondslag te leggen van een beschikking waarvan als vaststaand mag worden aangenomen dat zij, àls daartegen tijdig administratiefrechtelijk beroep zou zijn ingesteld, zou ziln vernietigd."

Nieuw ten opzichte van het Hei- en Boeicoparrest - afgezien van de gehanteerde terminologie - is dat de Hoge Raad het uitgangspunt van de rechtsgeldigheid van de beschikking ten overstaan van de burgerlijke rechter tevens betrekt op allgemene rechtsbeginselen. In zoverre 'versterkt' deze uitspraak de onaantastbaarheid van beschikkingen waartegen geen tijdig beroep is ingesteld. Nieuw is echter ook de toevoeging van een uitzonderingsgrond: direct op de zojuist aangehaalde overwegingen warin de hoofdregel is vastgelegd laat de Hoge Raad volgen:

'De daaraan verbonden bezwaren kunnen evenwell door bijkonende omstandigheden zo klemmend worden dat op dat beginsel een tuitzondering moet worden aanvaard. Of voor zulk aen uitzondering plaats is, hangt bijgevolg af van de bijzonderheden van het gegeven geval."

Een in algemene bewoordingen gegoten anti-hardheidsclausule dus; een clausule die de Raad in dit geval bovendien van toepassing acht. De Hoge Raad sluit zich namelijk aan bij de opvatting van de rechtbank dat 'overduidelijk [blijkt] dat de gemeente (...) al het mogelijke heeft gedaan om aan haar handelen tegenover Van de Akker het karakter te geven van een overeenkomst naar burgerlijk recht". De Raad is van oordee dat Van de Akker door deze handewijze van de gemeente is 'misleid' en dat in zijn geval het onverkort vasthouden aan het beginsel van de formele rechtskracht zou leiden tot een vermindering van rechtsbescherming. Om deze reden trekt de Hoge Raad de zaak toch aan zich en komt hij tot het oordeel dat de beschikking in strijd met de wet is genomen en derhalwe niet als een rechtsgeldige titel tot de betaling kan worden aangemerkt.

\subsection{De strekking van de fow we le rechtskach}

In zijn aanvullende conclusie bij het zojuist besproken arrest ${ }^{17}$ merkt $\mathrm{A}-\mathrm{G}$ Franx op dat "de hier besproken onaantastbaarheid wan een beschikking in een civiele procedure het effect heeft van rechtsbescherming van de overheid tegen de burger". De rechtsbescherming tegen de overheid zou zijns inziens "in haar tegendeel [zijn] komen te verkeren". "Tevens legt hij een nauw verband tussen het beginsel wan de formele rechtskracht en thet rechtszekerheidsbeginsel:

Na het verstrijken wan de beroepstermijn kan geen Arob-beroep meer worden ingesteld. Alle betrokkenen hebben daardoor de zelkerheid verkegen dat de beschikking in stand blijh, allhans niet meer in Arob-beroep kan worden vernietigd. Dat is niet alleen voor de belanghebbende particulier maar ook voor de betrokken bestuursinistantie van grote betekenis, ook met het oog op 
het in de tokkonst voor geliksoortige gevallen te voren beleid en de financiele consequenties daarvan."

Dat neemt niet weg dat het beginsel der formele rechtskracht zich ook tegen de overheid kan keren. Zo is het een overheidsorgaan niet toegestaan zich tegenover degene die tegen zijn beschikking geen beroep heeft ingesteld op een achteraf gebleken onjuistheid van die beschikking te beroepen. Tegenover degenen die de beschikking in rechte hadden kunnen aanvechten is de overheid dus aan haar besluit gebonden. ${ }^{19}$

Ook Scheltema wijst in zijn noot bij Heesch/Van de Akker op het "belang van de rechtszekerheid dat er niet langdurig twijfel blijft bestaan omtrent de rechtsgeldigheid van een beschikking." ${ }^{21}$ Interessant is overigens dat hij dit rechtszekerheidsargument in verband brengt met het terugdringen in het bestuursrecht van de nietigheid van beschikkingen: 'bij het bestaan var een goede rechtsbeschermingsmogelijkheid is een gebrekkige beschikking niet meer nietig, maar slechts vernietigbaar'. Tak heeft in dit verband opgemerkt dat de leer der formele rechtskracht tot nauwelijks aanvaardbare consequenties leidt bij (onder meer) onbevoegdheid, schending van fundamentele rechten of (anderszins dwingende publiekrechielijke voorschriften. ${ }^{21}$

Het beginsel van de formele rechtskracht houdt niet alleen in dat beschikkingen waartegen niet tijdig in een administratieve rechtsgang is opgekomen door de burgerlijke rechter als rechtsgeldig moeten worden aangemerkt. Het beginsel ziet ook op de bindende werking die beslissingen in administratieve rechtsgangen toekomt jegens de burgerlijke rechter als de bestuursrechtelijke weg wél tijdig is gevolgd. Te denken valt hierbij bij voorbeeld aan situaties waarin de burgerlijke rechter wordt geconfronteerd met een schadevergoedingsactie gebaseerd op een "vernietigende" ${ }^{22}$ uitspraak in een administratieve rechtsgang. De rechtszekerheid die de formele rechtskracht beoogt te dienen vereist niet alleen dat beschikkingen waartegen niet in beroep wordt opgekomen na zekere tijd komen vast te staan, maar vereist eveneens een zekere coördinatie tussen de administratieve rechtsgangen en die voor de burgerlijke rechter. In het arrest Heesch/Van de Akker overweegt de Hoge Raad in dit verband dat de met de formele rechtskracht samenhangende regels "[er mede toe strekken] te voorkomen dat de burgerlijke rechter inzake vragen waarover ook de administratieve rechter tot oordelen is geroepen, tot een ander oordeel komt dan deze'. De formele rechtskracht ziet aldus enerzijds op de wraag naar de ontwankelijkheid van vor-
deringen bij de burgerlijke rechter in geschillen met de overheid; anderzijds op de vraag
naar de mate waarin de burgerlijke rechter wordt gebend naar de mate waarin de burgerlijke rechter wordt gebonden aan een eerdere, in een admini-
strat ieve rechtsgang tot stand gekomen beslissing ${ }^{2.3}$

19

Cécile M. Bitter, Formele rechtskraclut wan. MS (V d D-Groningen) Zia hiertoe tevens: EJ. Daalder,

20 N. 1986,723, p. 1695. Zie ook N. Verheij in punt 8 gijn noot Bestum, nr. 3/ maart 1990, p. 75.

AB. 2004, 75, waar loij in meer algemene zin opmerk taj noot bij EHRM 16 april 2002, Dangeville, rechwardigheid en rechtszekerheid. A.Q.C. Tak, noot onder HR 11 nove

De teminologie is ontleend aan A.Q.C. Tak,

Burgerlijke rechter, nr. 4 . 
Allereerst de ontvankelijkheidsvraag. Deze grijpt terug op de rechtspraak over de bevoegdheid van de burgerlijke rechter om kennis te nemen van rechtsvorderingen die voonvloeien uit publiekrechtelijke verhoudingen. Van algemene bekendheid is het arrest Guldemond/Noordwijkerhout, ${ }^{24}$ op grond waarvan voor de bevoegdheid van de burgerlijke rechter beslissend is de aard van het recht waarin de eiser vraagt te worden beschermd (de objectum litis-leer). Is dit recht van privaatrechtelijke aard, dan is de burgerlijke rechter bevoegd van het geschil kennis te nemen. De burgerlijke rechter zal een desbetreffende vordering evenwel niet-ontvankelijk verklaren, indien tegen de beschikking een bijzondere, beroep op de burgerlijke rechter uitsluitende, rechtsgang openstaat. Van een dergelijke uitsluiting is sprake indien naar het oordeel van de burgerlijke rechter de administratieve rechtsgang met voldoende waarborgen is omkleed. ${ }^{25}$ Zeer expliciet over de in de formele rechtskracht besloten bevoegdheidsverdeling is de Hoge Raad in het arrest Hot Air/Staat ${ }^{26}$, waarin hij overweegt dat "het beginsel van de formele rechtskracht erop berust dat het oordeel over de vraag of de betrokken beschikking zowel wat betreft haar wijze van tot stand komen als voor wat betreft haar inhoud in overeenstemming is met do wettelijke voorschriften en met algemene rechtsbeginselen, bij uitstek toekomt aan de administratieve rechter'?

Is eenmaal in een met voldoende waarborgen omklede administratieve rechtsgang een oordeel geveld over de rechtsgeldigheid van de beschikking, dan is de burgerlijke rechter ook aan dit oordeel gebonden. Dit betekent dat, in het geval de overheid een beschikking neemt die in een administratieve rechtsgang wordt vernietigd, de burgerlijke rechter bij een eventuele latere, op artikel 6:162 BW gebaseerde, schade-actie van de in de administratieve rechtsgang vastgestelde onrechtmatigheid heeft uit te gaan ${ }^{28}$ Daarbij acht de burgerlijke rechter in beginsel tevens de schuld van het overheidslichaam gegeven. Deze aanname van schuld is niet beperkt tot de situatie waarin de beschikking is vernietigd wegens strijd met

king een met voldoende waarborgen omkilede administratieve rechtsgang heef opengestaan en die rechtsgang door de belanghebbende niet, niet tot lat einde of zonder succes (dat wil zeggen zonder dat dit tot ventetiging van het bestreden beshit heef geleid) is benut. In dat geval moet de burgerlijke rechter uitgaan van de rechtsgeldigheid van de inhoud en de wijze van totstandkoming van de beschiklking.

Van oneigenlijke formele rechtskracht is volgens hen sprake indien de burger een openstalande administratieve rechtsgang heeft benut en dit tot vernietiging wan de beschikking heef geleid, In dat geval dient de burgerlijke rechter er van uit te gaan dat de beschikking van de atnvang af niet rechtsgeldig is wat betreft haar inhoud of totstandkoming (M.R. Mok en R.P.I.L. Tjittes, Formete rechtskracht en overheidsaansprakelikkneid, RM Themis $1995 / 9$, p. 383-404).

24 HR 31 december 1915, NJ 1916, 407.

25 Aldus het bekende Scheller- en deuropenersarrest (HR 22 februar 1957, AB 1957, p. 555. m.nt M. Troostwijk). Aanvankelijk placht de burgerlijke trechter zich onbewoegd te verklaren in ambtenarerizaken. Sinds het Changoe-arrest (HR 28 febmari 1992, AB 1992, 301 m.m. FHudB) volgt ook hier een niet-ontvankelijkwerklaring.

26 HR 26 februari 1988, N 1989, 528 m.nt. MS; AB 1989, 80 m.nt. F. A. van Bakelen; BR 1988, p. 674 m.nt. Koeman; Gst. 6856 , p. 231 m.nt. L. I.A. Damen.

27 Zie ook A.Q.C. Tak in zijn noot bij HR 11 nowember 1988, AB/S 1988, Burgerlijke rechter, nr. 3 , volgens wie de leer der formele rechtskracht. "in wezen een ontwankelijklieidsleet [is] woor die situaties waarin een bijzondere rechssgang heeft opengestaan (en al dan niet is gevolgd)"

28 Vgl. HR 24 februari 1984, NI 1984, 669 m.nt. JAB (St. Oedenrode). Voor L.J.A. Damen is dit aanleiding de fomele rechtskracht, ietwat verwarrend mijns inziens, aan te merken als aen materieal beginsel (L.J.A. Damen, noot bij HR 11 november 1988, Gst. 6875, nr 2). 
de wet, ${ }^{29}$ maar strekt zich tevens uit tot de situatie waarin de beschikking is vernietigd wegens strijd met ongeschreven recht. Het duidelijkst komt dit beginsel tot witing in het arrest Van Gog-Nederweert, ${ }^{31}$ warin de Hoge Raad oordeelt dat een overheidslichaam een onrechtmatige daad pleegt door een beschikking te nemen en te handhaven die naderhand wordt vemietigd wegens strijd met de wet of enige andere in artikel 8 lid I Wet Arob vermelde grond - dan wel een overeenkomstige grond vermeld in enige andere admintstratieve wer. Deze onrechtmatige daad komt in beginsel voor rekening van het overheidslichaam, zelfs indien dit laatste geen enkel verwijt treft. De uit de formele rechtskracht voortvloeiende binding van de burgerlijke rechter aan het oordeel van de administratieve rechter komt uitdrukkelijk naar woren in de yolgende overweging:

\begin{abstract}
"Zulk een oordeel (te weten het oordeel van de Afdeling dat B\&W niet in redelijkheid tot hun besluit hadden kunnen komen, RB) heeft in beginsel voor de burgerlijke rechter in een later geding tussen partijen bindende kracht, niet alleen bij zijn oordeel omtrent de onrechtmatigheid, maar ook daarbuiten, zoals bij zijn oordeel omtrent de toerekening van de onrechtmatige daad.."
\end{abstract}

De Hoge Raad is voorts van oordeel dat:

'dit moet worden aanvard, omdat aldus wordt voorkomen: (i) dat partijen - en met name de burger - opnicuw moeten strijden over een punt waaromtrent reeds is beslist in een met voldoende waarborgen omklede rechtsgang; (ii) dat de burgerlijke rechter in zaken waarover ook de administratieve rechter tot oordelen is geroepen, tot een ander oordeel komt dan deze; en (iii) dat de burgenlijke rechter zich moet begeven in wragen die typisch tot het werkterrein van da administraticve rechter behoren',

daarmee opnieuw de coördinerende functie van het beginsel van de formele rechtskracht benadrukkend.

Een relativering ten aanzien van de binding voor de burgerlijke rechter aan beslissingen in administratieve rechtsgangen lijkt de Hoge Raad aan te brengen in zijn arrest van 14 juni 1991. ${ }^{31}$ In deze uitspraak oordeelt de Hoge Raad dat de kring van belanghebbenden in de zin van artikel 7 Wet Arob niet behoeft samen te vallen met de kring van personen jegens wie de door de Afdeling Rechtspraak vemietigde beschikking een onrechtmatige daad oplevert. Dit arrest houdt in zoverre een relativering in van de met de formele rechtskracht samenhangende bindende werking van beslissingen in administratieve rechtsgangen, dat mét een vernietigingsbesluit weliswaar komt vast te staan dat de desbetreffende beschikking onrechtmatig is, maar dat daarmee nog niet komt vast te staan dat het overheidslichaam ook jegens een ieder die op grond van de Wet Arob als rechtstreeks belanghebbend kan worden aangemerkt schadeplichtig wordt. Verrassend is dit niet, omdat ook de overheid slechts aansprakelijk is indien aan alle vereisten van de onrechtmatige daad in de zin van artikel 6:162 BW is voldaan. Krachtens Van Gog/Nederweert zijn bij een vernietigingsbeshit in een administratieve rechtsgang in beginsel de eerste twee vereisten onrechtmatigheid en schuld - gegeven. Van schadeplichtigheid van de overheid is evenwel

Zoals wel werd angenomen op basis van HR 26 september 1986, AB 1987, 70 m.nt. FHvdB; NJ 1987,253 m.nt MS (Hoffinanm-La Roche); zie ook HR 30 januari 1987, NI 1988, 90 m.nt MS HR 31 mei 1991 , AB 1992, 291 m.nt. FHudB. 
pas sprake als eveneens aan de overige vereisten - schade, causaal verband en relativiteit is voldaan. Het arrest van 14 juni 1991 vormt een weerslag van dit laatste vereiste.

Samenyattend kan worden opgemerkt dat het beginsel van de formele rechtskracht nauw samenhangt met het ontvankelijkheidsvraagstuk bij de burgerlijke rechter inzake procedures tegen de overheid. Slechts indien geen met voldoende waarborgen omklede administratieve rechtsgang tegen een beschikking voorhanden is, bestat de mogelijkheid op grond van een vordering uit onrechtmatige daad de beschikking aan te vechten bij de burgerlijke rechter. Bij de formele rechtskracht gaat het echter om meer dan alleen het oplossen van de ontvankelijkheidsvraag. ${ }^{32}$ Het wraagstuk van de formele rechtskracht betreft de uit de wettelijke bevoegdheidsverdeling tussen administratieve beroepsinstanties en burgerlijke rechter te trekken consequenties omtrent de bindende werking van beschikkingen. Deze bindende werking berust enerzijds op een tot de burgerlijke rechter gericht voorschrift inhoudende dat, indien niet tijdig van de administratieve rechtsgang gebruik is gemaakt, de burgerlijke rechter dient uit te gaan van de rechtmatigheid van de beschikking. Anderzijds verplicht ze de burgerlijke rechter om, indien wèl van de administratieve rechtsgang gebruik is gemaakt, de beslissing van de administratieve beroepsinstantie omtrent de rechtmatigheid van de beschikking te aanvaarden. Voor beide gevallen geldt echter de juridische ontsnappingsformule: 'in beginsel'.

\subsection{Doorbreking van de formele rechtskracht}

Zoals hiervoor werd aangegeven overwoog de Hoge Raad in Heesch/Van de Akker dat de aan de formele rechtskracht verbonden bezwaren door bijkomende omstandigheden zo klemmend kunnen worden dat op dat beginsel een uitzondering moet worden aanvaard. Of voor zulk een uitzondering plaats is, hangt, naar het oordeel van de Raad, af wan de bijzonderheden van het gegeven geval. In Heesch/Van de Akker waren deze bijzondere omstandigheden gelegen in de jaren lang voortdurende discrepantie tussen de rechtspraak van de Afdeling Rechtspraak en de burgerlijke rechter op het gebied van de uitwegvergunningsstelsels, en meer in het bijzonder in de onzekere procesrechtelijke situatie die van deze discrepantie het gevolg was. Ook het misbruik dat het gemeentebestuur in deze zaak van de verwarring had pogen te maken droeg bij aan het oordeel van de Raad dat ten aanzien van Van de Akker een uitzondering moest worden gemaakt op het beginsel van de formele rechitskracht.

Een andere uitspraak die een voorbeeld biedt van de doorbreking van de formele rechtskracht is het arrest Ekro/Staat. ${ }^{3}$ In deze zaak acht de Hoge Raad een reden voor het maken wan een uitzondering op het beginsel van de formele rechtskracht gelegen in de 'ondoorzichtige situatie" met betrekking tot de mogelijkheden wan bezwaar en beroep in verband

32 Vgl. Koeman in zijn noot bij HR 12 december 1986, BR 1987, p.236 e.v. voor het geval dat sprake is van een besluit, waartegen Kroonberoep mogelijk zou zïn geweest, doch waarover da Kroon, wegens het niet instellen van beroep, geen oordeel heeft gegeven. In dat geval dienit zijns inziens de gewone rechter een wordering, gebaseerd op de stelling dat een dergelijk besiluit onrechtmatig is, nietontwankelijk te verklaren. Hij is evenwel wan oordeel datt dit niet betekent dat de rechter er steeds van zall moeten uitgaan dat een dergelijk bestuit rechmatig is en het dus in zoverne geen formele rechtskracht verkrijgt.

33 HR 11 nowember 1988, AB 1989,81 m. nt. FHvdB; Gst. 6875, nr. 2, m.nt. L.J.A. Damen. 
met keuringen op grond van de Vleeswet en de Vleeskeuringswet. In het bijzonder bestond onzekerheid of de krachtens deze wetten verschuldigde heffngen aan te merken waren als beschikkingen in de zin van de Wet Arob. Tot deze zaak had de Staat zich nimmer op het beschikkingskarakter van deze heffingen beroepen. De Hoge Raad spreekt in dit verband van een "vast beleid" en vindt de rechtvaardiging voor de uitzondering op de formele rechtskkracht in de overweging "dat de Staat niet zonder grond ten nadele van een burger van een bestendig beleid behoort af te wijken'.

Zowel in Heesch/Van de Akker als in Ekro/Staat ${ }^{34}$ maakt de Hoge Raad een uitzondering op het uitgangspunt dat de burgerlijke rechter, indien geen gebruik is gemaakt wan het Arob-beroep, van de rechtmatigheid van de beschikking dient uit te gaan.

Een voorbeeld van een uitzondering op het andere aspect van de formele rechtskracht - te weten dat, indlien de administratieve rechtsgang wèl doorlopen is, de burgerlijke rechter gebonden is aan de uitkomst hiervan - biedt het arrest 's-Gravenhage/Aral Nederland b.v. ${ }^{35}$ In deze uitspraak wijdt de Hoge Raad een overweging aan de formele rechtskracht van een uitspraak in Kroonberoep in verband met het Benthem-arrest van het Europese Hof voor de Rechten van de Mens:
"Dat beginsel (van de formele rechiskracht, RB) Iijdit, gezien de uitspraak van het Europese Hof voor de Rechten van de Mens van 23 oktober 1985, NJ 1986, 102 (de Benthem-zaak) uitzonde- ring indien "de houder van de verguning of degene die de inrichting drijft" zich erop beroept dat de Kroon niet kan worden beschouwd als een "rechterlijke instantie" die voldoet aan de eisen van art. 6 lid I EVRM: alsdan windt voomeld beginsel geen toepassing en heeft de burgerlijke rechter ook het door de Kroon reeds besliste punt wan geschil ten volle zelfstandig te beoor-
delen."

De Hoge Raad is voorts van oordeel dat door een dergelijk beroep aan de uitspraak van de Kroon de farmele rechtskracht komt te onkallen. Deze uitzondering op de formele rechtskracht geldt slechts de houder van de vergunning, niet het overheidsorgaan dat deze verleend heeft. Op het eerste gezicht doet dit denken aan het relatieve karakter dat Vegting ${ }^{36}$ aan het beginsel van de formele rechtskracht toekende. Bedacht moet echter worden dat deze 'relatieve werking' rechtstreeks samenhangt met het karakter van artikel 6 EVRM, de Hoge Raad 'niet zou stroken de overheid, wamneer in de administratiefrechtelijke
rechtsgang een voor haar ongunstige uitspraak is gevallen, bevoegd te achten de zaak ten
nadele van de burger weer op losse schroeven te nadele van de burger weer op losse schroeven te zetten door ter zake een nieuw, zelf-
standig oordeel van de burgerlijke rechter te verlangen'.

Tot welke conclusie leiden de hier besproken uitspraken? Bij de beoordeling van de vraag of in cen bepaald geval cen uitzondering moet worden gemaakt op her beginsel van de for-
mele rechtskracht, staat de rechter voor een afweging van twee met elkaar concurrerende
rechtsbeginselen. Enerzijds is er het rechtszekerheidsbeginsel: rechtsbeginselen. Enerzijds is er het rechtszekerheidsbeginsel: de rechtszekerheid werlangt
dat de beschikking na verloop van tijd voor alle betrokkenen vast komt te staan. Ander-

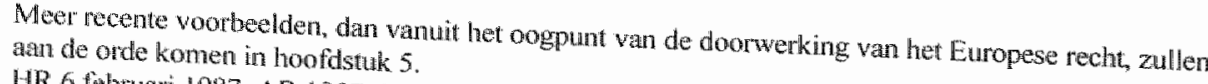

W. G Veruari $1987, A B 1987.272$ m.nt. FHVdB. 
zijds is er het beginsel van toegang tot de rechter: een ieder jegens wie onrechmatig wordt gehandeld heeft in beginsel recht op toegang tot een rechter, die door de wet bevoegd is verklaard deze onrechtmatigheid 'recht te zetten".

Omwille van het rechtszekerheidsbeginsel doet de formele rechtskracht afbreuk aan het recht op toegang tot de rechter. Men zou het zo kunnen formuleren dat voor wat de in dit boek aan de orde gestelde problematiek betreft het rechtszekerheidsbeginsel in beginsel "voorgaat" op het recht op toegang tot de rechter. De betekenis van de zojuist behandelde uitspraken is dat in die gevallen de Hoge Raad bereid blijkt van die voorrangsregel af te wijken. In Heesch/Van de Akker en Ekro/Staat, gevallen waarin door rechtsonzekerheid -nog aangewakkerd door het gedrag van de de desbetreffende bestuursorganen - het administratief beroepsrecht werd gefrustreerd, gaf de Hoge Raad vootrang aan het recht op toegang tot de rechter. Dit komt in het bijzonder duidelijk naar voren in Heesch/Van de Akker, waarin de Hoge Raad het recht op rechisbescherming uitdrukkelijk in zijn overwegingen betrekt: de Hoge Raad is immers van oordeel dat er bij vasthouden aan het beginsel van de formele rechtskracht sprake zou zijn van een vermindering van rechisbescherming voor degenen die de mogelijkheid van Arob-beroep niet tijdig hebben onderkend (en ook niet hebben behoeven te onderkennen), terwijl "uit [de Arob-ljurisprudentie onmiskenbaar voortvloeit dat betalingen als de onderhavige van hen in strijd met de wet zijn "geheven". De Hoge Raad stelt dus vast dat er "onmiskenbaar' sprake is van een schending van het recht, terwijl daar bij een strikte toepassing van de formele rechtskracht geen recht op toegang tot de rechter tegenover staat.

Onmiskenbare strijd met het recht kan ook optreden, indien (lange tijd) na het nemen van een beschikking komt vast te staan dat de beschikking berust op een onverbindende regeling in verband met strijd met het internationale of communautaire recht. Ook dan zal de vraag rijzen of aan degenen die, afgaande op de geldigheid van de wettelijke regeling, aanvankelijk in de mening verkeerden dat beroep tegen de beschikking kansloos zou zijn, de formele rechtskracht van de beschikkingen kan worden tegengeworpen. Anders gezegd: is er ook dan sprake van een "klemmend bezwaar" tegen de formele rechtskracht van beschikkingen, indien de betrokkenen bij het kiezen van het juiste rechtsmiddel (of het afzien van instellen van beroep) geen rekening hebben gehouden thet niet te voorziene ontwikkelingen in de jurisprudentie, een vragg die door Scheltema bevestigend werd beantwoord. ${ }^{37}$. Van der Burg lijkt nog een stapje verder te gaan, wanneer hij mede naar aanleiding van het beginsel van de formele rechtskracht zoals dat is geformulleerd in Heesch/Van de Akker opmerkt dat "deze onaantastbaarheidsopvatting [hem nict lijkt op te gaan] in de gevallen dat de regeling waarop de beschikking steunde, zelf - naar achteraf wordt wastgesteld - nimmer rechtsgeldig is geweest ${ }^{3 *}{ }^{3 *}$

Zoals hiervoor werd vastgesteld wordt in Heesch/Van de Akker en Ekro/Staat getoetst aam het recht op toegang tot de rechter: een ongeschreven ${ }^{30}$ recht dat direkt verband houdt met de idee van de rechtsstaat; een idee, die in de angelsaksische landen mijns inziens treffender wordt aangeduid als de rule of / $/ \mathrm{ow}$. In Aral/Nederland toetst de Hoge Raad de formele

Vgl. EHRM 21 fobruari 1975, Series A, vol. 17; W 1975,462 m.tn. E.A. Alkemal. 
rechtskracht van het Kroonberoep aan artikel 6 EVRM, het verdrag dat gezien kan worden als de belichaming van de rule of low in Europees verband. ${ }^{40}$ Volgens artikel 6 EVRM heeft een ieder, voorzover het de vaststelling van zijn cril rights and obligations betreft, recht op een fair and public hearing within a reasonable time by an independent and impartial tribunal established by law. In het Benthem-arrest was gebleken dat het Kroonberoep niet aan deze eisen voldeed. On deze reden komt, voorzover het geschil de vaststelling een civil right of obligation betreft, voor de belanghebbende burger de formele rechtskracht aan de beslissing wan de Kroon te ontvallen en krijgt hij recht op toegang tot de burgerlijke rechter. ${ }^{41}$

De formele rechtskracht moet hier overigens niet verward worden met de onherroepelijkheid van een besluit. Ook al wordt met een beroep op art. 6 EVRM een besluit van de Kroon aangevochten voor de burgerlijke rechter, dan nog blijft dit besluit onherroepelijk ${ }^{42}$. Dat de burgerlijke rechter het in hoogste beroepsinstantie (genomen besluit naar burgerlijk recht omrechtmatig kan achten (zoals het geval was in Dekker/Barneveld), deed aan de onherroepelijkheid (in bestuursrechtelijke zin) van het onderliggende besluit niet af.

\subsection{Verschoonbare termijnoverschrijding}

Door sommige schrijvers ${ }^{43}$ is wel verdedigd dat, in gevallen waarin een beroep wordt gedaan op de doorbreking van de onaantastbaarheid van beschikkingen waarvan op grond van latere jurisprudentie geoordeeld moet worden dat deze onrechtmatig zijn, aan het onverbiddelijke karakter van de formele rechtskracht kan worden ontkomen door een ruimere toepassing te geven aan de toepassing van artikel 6:11 van de $\mathrm{Awb}$, dat ziet op de verschoonbaarheid van termijnoverschrijding bij het instellen van beroep bij de bestuursrechter. Voorop moet echter worden gesteld dat van een doorbreking van de formele rechtskracht bij de toepassing van artikel 6:11 van de Awb geen sprake is. Als de rechter de overschrijding van de beroepstermijn immers verschoonbaar acht, is er immers juist geen sprake van een rechtens onaantastbaar besluit en heeft dit besluit dan ook geen formele rechtskracht. Belangrijker is echter dat artikel 6:11 van de Awb niet ziet op de gevallen die in dit onderzoek centraal staan. Dit artikel heeft betrekking op (op de persoon van) appellant betrekking hebbende feiten en omstandigheden die hem ervan hebben weerhouden tjjdig beroep in te stellen. Het ziet niet op de situatie waarin blijkt dat de juridische grondslag van het bestreden besluit achteraf, blijkens uitspraken in andere gedingen, op

402 meent Alkema dat het Verdrag de rule of law, gehandhaafd door de rechter, voorop stelt; zie: E.A. Alkema, De betekenis wan het EVRM voor de Nederlandse Grondwet, preadvies Statsrechitconferentie 1990, Leiden 1991 , p. 32

41 Adus het zich als een 'tweeling-uitspraak' tot Aral-Den Haag verhoudende arrest Dekker-Barneveld (HR 12 december 1986, NJ 1987,381 m.nt. MS; BR 1987, p.236 e.w. m.nt. Koeman).

42 Zie in dit verband: AGNB 20 december 1991, AB 1992, 294: van de onherroepelijkheid van een beschikking dient te worden uitgegaan wanneer de beroepstermijn ongebruikt is verstreken, dan wel wanneer de op de in de wet (de Hinderwet en de Wabm in dat geval, RB) voorziene wijze in hoogste instantie is beslist op het beroep. De ratio hiervan is dat het besluit alleen in een administratief-
rechtelijke beroepsprocedure kan worden vernietigd.

Zie bijvoorbeeld N.S. I. Koeman woor wat de Wet Arob betreft in zijn noot onder HR 16 mei 1986 ,
BR 1986, p. 782 (H. 
losse schroeven komt te staan. Artikel 6:11 van de $\mathrm{Aw}^{\text {t4 }}$ zal in de rest van dit boek dan ook slechts een ondergeschikte rol spelen.

\subsection{Overige aspecten}

Van doorbreking van de formele rechtskracht dient eveneens te worden onderscheiden de mogelijkheid om aan het bestuursorgaan te vragen terug te komen van eerdere, in verband met veranderde jurisprudentie 'onjuist' gebleken beschikkingen. Zoals in paragraaf 3 nader zal worden uitgewerkt kan een weigering van het bestuur om tot een dergelijke intrekking over te gaan worden aangemerkt als een weigering een beschikking te gever. Deze weigering kan vervolgens weer voorwerp zijn van een procedure bij de bestuursrechter. Deze procedure spitst zich dan toe op het herzieningsbesluit. Hoewel dit besluit uiteraard in naww verband staat tot het besluit waarvan heroverweging is verzocht, kan dit laatste besluit als zodanig niet opnieuw voor de rechter worden betwist. Van belang is voorts reeds op te merken dat de procedure waarin het herzieningsbesluit centraal staat, zich kenmerkt door een geheel eigen toetsingskader. Ook hierop wordt in paragraaf 3 nader ingegaan.

Tot slot moet er nog op gewezen worden dat met het aan de orde stellen van de doorbreking van de onaantastbaarheid in verband met veranderde jurisprudentie nog geenszins alle problemen die samenhangen met de terugwerkende kracht van nieuwe jurisprudentie zijn behandeld. De vooronderstelling in deze paragraaf was steeds dàt er een eerdere beschikking is die heroverweging verdient in het licht van nieuwe jurisprudentie. Maar in zeer veel van de in dit boek aan de orde te stellen gevallen is er helemaal geen eerdere beschikking, simpelweg ondat een aanvraag hiertoe onder de 'oude' jurisprudentie zinloos leek. Dit probleem doet zich in het bijzonder voor in de sociale zekerheid, waar verandering van rechtspraak in verband met de doorwerking van het internationale en communautaire recht er vaak de oorzaak van is geweest dat grote groepen 'plotseling" recht op een uitkering bleken te hebben; een recht, waarop ze in het licht van de 'oude' interpretatie van de desbetreffende wetsbepalingen niet konden rekenen, om welke reden ook van een aanvraag werd afgezien. In dit soort gevallen speelt de onaantastbaarheid van beschikkingen hooguit indirect, ${ }^{45}$ gewoonweg omdat er geen cerdere beschikking voor" handen is. De rechtspraak over dit soort gevallen heeft gewoonlijk betrekking op de vraag met ingang van welk tijdstip het alsnog verkregen uitkeringsrecht geacht moet worden in te gaan. Deze rechtspraak zal in hoofdlstuk 3 centraal staan.

44 En de hieraan woorgaande bepalingen. zoals artikel 9, Hid 4 Wet Arob, artikel 33, lid 3, Wet Arbo en artikel 84 , lid 2 Beroepswet.

45 Bij de interpretatie van wettelijke hardheidsclausules in werband net een te late alanvaag. 


\subsection{Inleiding}

Op 31 december $1984^{\text {st }}$ deed de Centrale Raad van Beroep uitspraak in de volgende casus.

Het bestuur van de voormalige Bedrijfsvereniging voor de Hout- en Meubelindustrie en Groothandel in hout (het uitvoeringsorgaan) kent aan een voormalig werknemer (W) een witkering toe op grond van de Wet op de arbeidsongeschiktheidswerzekering (WAO). Gedurende zijn werkzaamheden thad Ween aantall extra financiële voordelen genoten. Zo was hem door zijn werkgever een auto ter beschikking gesteld, die hij ook voor privế-doeleinden thad mogen gebruiken. Ook had de werkgever W's telefoonkosten gedragen. Bij de berekening van het WAO-dagloon. hield het uitwoeringsorgaan echter geen rekening met deze 'emolumenten'. Dit geheel in overeenstemming met de toen geldende jurisprudentie wolgens welke de desbetreffende financiële voordelen niet als loon in de zin van de WAO waren te beschouwen, en om die reden ook niet bij de berekening van het dagloon mochten worden betrokken. Tegen het aldus genomen besluit wendt $W$ geen rechtsiniddel aan.

Enige tijd later neemt $W$ kennis van een uitspraak van de Centrale Raad van Beroep van 22 september 1981, ${ }^{47}$ waarin deze omgaat met betrekking de berekening van het dagloon. De Raad beslist dat in het licht van de gewijzigde maatschappelijke omstandigheden het woordeel voortvloeiende uit het privé-gebruik van een dienstauto en uit het genot van het voor privé-doeleinden op kosten van de werkgever mogen gebruiken van een telefoon wel alls loon is te beschouwen en derhalve bij de berekening van het dagloon in aamerking moet worden genomen. Op grond van deze nieuwe rechtspraak verzoekt Whet bestuur van de BV terug te komen wan de aanvankelijke berekening van het dagloon.

In voornoemde uitspraak van 22 september 1981 had de Centrale Raad van Beroep bepaald dat ook de vergoedingen voor de kosten van het gebruik van de auto-van-de-zaak voor privé-doeleinden en voor de telefoonkosten dienden te worden meegenomen bij de bepaling van het WAO-dagloon. De Raad had in deze uitspraak als zijn oordeel te kennen gegeven dat deze nieuwe opvatting beter strookte met de gewijzigde maatschappelijke omstandigheden. In zijn uitspraak van 31 december 1984 waarin het naar aanleiding van de jurisprudentiewijziging ingediende herzieningsverzoek ter beoordeling stond, gaat de Centrale Raad uit van de volgende premisse omtrent de wijziging in de maatschappelijke omstandigheden waaraan hij in zijn uitspraak van 22 september 1981 had gerefereerd:

'Daargelaten wanneer die wijziging in de maatschappelijke omstandigheden zich is gaan wordoen, in ieder geval heef de Raad bij die uitspraak (van 22 september 1981, RB) implicite vasigesteld dat de bedoelde ontwikkeling zich reeds had voltrokken op de datum van aanvang van de periode waarover het betreffende geschil handelde, dit is de (eerste) datum, met ingang warvan destijds het toen betwist dagloon was berekend (17 oktober 1978).'

We zien hier de figuur verschijnen die typisch is voor de in deze paragraaf aan de orde te stellen problematiek. W tracht alsnog aanspraak te maken op een hoger dagloon, waarbij hij zich beroept op een na de onherroepelijke vaststelling van zijn dagloon jegens een ander gewezen rechterlijke uitspraak, waaruit kan worden afgeleid dat het uitvoeringsorgaan destijds bij de vaststelling van W's dagloon van een verkeerde rechtsopvatting is 
uitgegaan. W doet, met andere woorden, een beroep op de terugwerkende kracht van een precedent dat voortvloeit uit een uitspraak waarbij hij geen partij was.

Zo gesteld hangt deze figuur nauw samen met de vrang of van rechterlijke uitspraken ook een bindende werking kan uitgaan die verder strekt dan alleen tot de bij die vitspraak betrokken partijen; een vraag die verwantschap vertoont met het vraagstuk wan de "rechter als wetgever". Voorts, wordt eenmaal geconcludeerd tot een dergelijke algemenere werking van een rechterlijke uitspraak, dan speelt in nawwe samenhang hiermee de vraag naar de werking in de tijd van deze binding. Van een dergelijke algemene werking van rechtspraak biedt de dagloonzaak een goed voorbeeld. Op de zojuist geciteerde passage laat de Raad immers volgen:

'Een rechens juicre dagloonvaststeling over een na 117 oktober 19781 gelegen periode dient derhalve uit to gaan van medeberekening van de betreffende emolumenten.

Bij de beslissing d.d. 24 september 1980 warvan eiser in het onderhavige geding aan gedaagde on herziening heeft verzocht (...) is dit niet geschied.

Die beslissing is mitsdien in zoverre rechtews anjust te achten, zij het dat van die onjuistheid aan gedaagde, gezien de destijds geldende jurisprudentie van de raad, geenszins een verwijt kan worden gemaakt". (mijn cursivering, RB)

Aan de nieuwe jurisprudentie was door de Raad in zijn uitspraak van 22 september 1981 toepassing gegeven met ingang van 17 oktober 1978. Opvallend - en tevens typerend voor de in dit hoofdstuk aan te snijden problematiek - is dat deze datun nu ook voor de door W aangespannen zaak beslissend wordt, in die zin dat naar het oordeel van de Raad dagloonvaststellingen die geen rekening houden met voomoemde emolumenten in elk geval waraf 17 oktober 1978 als rechtens onjuist hebben te gelden. Aan de datum van 17 oktober 1978 , die geheel 'eigen' was aan de positie van de belanghebbende in de uitspraak van 22 september 1981 , komt aldus volgens de onderhavige uitspraak de algemene betekenis toe, dat vanaf dat tijdstip alle dagloonvaststellingen volgens de oude methode als 'rechtens onjuist' te boek staan. Dat geldt dus ook voor de vaststelling van het dagloon van W, ook al vond deze ruim vóor de verandering van de jurisprudentie plaats, en ook al kon het uitvoeringsorgaan om die reden nog stellen "van niets te hebben geweten".

De keuze van de datum van 17 oktober 1978 doet op het eerste gezicht willekeurig atur. De algemene strekking die de Raad, aldus redenerend, toekent aan zijn uitspraak van 22 september 1981 rechtvaardigt de Raad echter met zijn beroep op de wijziging in de maatschappelijke omstandigheden. Deze wijziging vomt de werkelijke grond woor het oordeell van de Raad dat vaststelling van het dagloon onder uitsluiting van de hier bedoelde emolumenten rechtens onjuist is. De keuze voor de datum van 17 oktober 1978 is in wezen slechts van praktische aard, zijnde een datum waarop, naar de Raad heeft vastgesteld, de bedoelde maatschappelijke ontwikkeling zich reeds had voltrokken.

Haverkamp plaatst de uitspraak uitdrukkelijk onder de noemer van het rechterlijk overgangsrecht. ${ }^{48}$ Hierover had de CRvB zich in zijn uitspraak van 22 september 1981 niet uitgelaten en hierin wordt in de uitspraak van 31 december 1984 alsnog voorzien. Naar het oordeel van Haverkamp past de keuze voor de datum van 17 oktober 1978 slecht in de 
conceptie van de rechtswomende werking van jurisprudentie. Naar zijn cordeel is het uitgangspunt woor die werking dat de rechter in een gegeven geval een beslissing geef, waarvan men mag verwachten dat hij die in toekomstige gevallen eveneens zal geven. Naar zijn oordeel zit het rechtswormende element in dia latatste verwachting, maar daar katn pas sprake van zijn vanaf het tijdstip warop de rechter zijn beslissing heeft gegeven en niets reeds vanaf het tijdstip waarop het geval zich voordoet dat bij de rechter, jaren later, tot die beslissing zal gaan leiden. Haverkamp meent echter dat voór het standpunt van de CRvB pleit dat het strekt tot een gelijke rechtsbedeling. Als de datum van 22 september 1981 tot uitgangspunt genomen zou worden, zou er binnen het geheel van de tussen 17 oktober 1978 en 22 september 1981 genomen beslissingen sprake zijn van éen beslissing die een, naar hij noemt, "willekeurige voorkeursbehandeling' zou bebben gekregen. Naal" zijn oondeel weegt dit echter niet op tegen de onzekerheid die door deze jurisprudentie wordt opgeroepen bij de individuele verzekerde omtrent actie die moet worden genomen om alsnog voor terugwerkende kracht in aanmerking te komen. Voorts acht hij het een bezwaar dat de uitvoeringsorganen door deze jurisprudentie worden overvallen en - naar hij veronderstelt - worden verplicht tot een herzieningsoperatie.

Dit laatste argument overtuigt mijns inziens niet, omdat de Raad zelf aangeeft dat herziening met terugwerkende kracht alleen kan plaatsvinden op verzoek en dat deze verzoeken moeten worden beoordeeld in het kader wan de discretionaire bevoegdheid van bestuursorganen om terug te komen van in rechte onaantastbaar geworden besluiten. $\mathrm{Bij}$ de uitoefening van deze bevoegdheid kan, zoals de Haverkamp ook beaamt, de vraag worden betrokken of de aanspraak alsnog aan de hand van de feiten kan worden vastgesteld, "lets wat met aanspraken die met tengwerkende kracht worden verleend vaak nog de meeste problemen oplewert.

\subsection{Herziening van beshiten}

Na deze inleiding is het zaak op meer sytematische wijze stil te staan bij het vraagstuk van de herziening van bestuurlijke besluiten in het licht van veranderde jurisprudentie. Daarbij dient te worden opgemerkt dat de praktijk zich bedient van een uiteenlopende terminologie die nogal wat verwarring kan oproepen. Afwisselend wordt er gesproken van verzoeken om herziening, verzoken om terug te komen van (of op) een eerder besluit en van herhalde anvragen. De herhalde aanvragg wordt thans geregeld in artikel $4: 6$ van de Awb. De verzoeken on herziening of om een "terug komen wan" worden doorgaans in verband gebracht met in rechte onaantastbaar geworden besluiten en zijn woor dit onderzoek dan ook het meest toepasselijk. Zij kunnen bovendien, anders dan artikel 4:6 van de Awb, tevens betrekking hebben op ambtshalve genomen beshuiten. Wit de jurisprudentie blijkt niettemin dat verzoeken om 'terug te komen wan' of om herziening vaak in rechtstreeks verband worden gebracht met artikel $4: 6$ van de Awb. Hiermee is echter voorzichtigheid geboden, omdat in de jurisprudentie van de CRvB is uitgemaakt dat artikel 4:6, lid 1, wan de Awb eveneens geldt met betrekking tot besluiten die, ten tijde van het verzoek om herziening, nog niet onherroepelijk zijn geworden." De termen herzieningsverzoek" en 'verzoek om terug te komen van' beschouw ik overigens als synoniem. 50 
Gelet op de MvT bij artikel 4:6 van de Awb kan een herzieningsverzoek niet worden aangemerkt als een herhaalde aanvraag in de zin wan deze bepaling. Ten aanzien van de situatie waarin het recht wordt gewijzigd in de periode gelegen tussen de oorspronkelijke beslissing en de nieuwe aanvraag (het herzieningsverzoek) is in de MvT aangegeven dat de nieuwe aanvraag in beginsel in haar volle omvang moet worden behandeld. ${ }^{\text {s1 }}$ Gelet op de strekking van de desbetreffende passage in de MvT moet het er naar mijn mening echter voor worden gehouden dat het vereiste wan 'volle behandeling' van de nieuwe aanvraag beperkt is tot de situatie van een tussentijdse verandering van de wettelijke regeling en niet ziet op de hier aan de orde zijnde situatie waarin sprake is van een tussentijdse jurisprudentiewijziging. ${ }^{52}$

In zijn annotatie onder in paragraaf 3.6.4 te behandelen uitspraak van de CRvB van 24 september $1987^{53}$ heeft Van Male zich overigens op het standpunt gesteld dat onwerbindendverklaring en gewijzigde jurisprudentie moeten worden aangemerkt als een wijziging van het recht, zulks omdat het creatieve element in de rechtsvinding als rechtsvorming kan worden aangemerkt. Van Male verbindt hieraan de conclusie dat een op gewijzigde jurisprudentie gegronde aanvraag om herziening van een in rechte onaantastbaar geworden besluit moet worden aangemerkt als een nieuwe aanvraag, die, gelet op voornoemde toelichting, 'vol' zou moeten worden behandeld. De ontwikkelingen in de jurisprudentie hebben mijns inziens echter uitgewezen dat ook dergelijke aanvragen moeten worden beschouwd als verzoeken om terug te komen van een in rechte onaantastbaar geworden besluit, met de daarbij behorende discretionaire bevoegdheid voor het bestuursorgaan en de terughoudende toetsing van de uitvoering hiervan door de rechter.

\subsubsection{Ontvankelijkheid van het verzoek om herziening}

Naar de huidige stand van de jurisprudentie moeten verzoeken om herziening door het bestuursorgaan in behandeling moeten worden genomen. Deze soepele houding van de administratieve rechters ten aanzien van de ontvankelijkheid van tot bestuursorganen gerichte herzieningsverzoeken heeft niet altijd bestaan. Aanvankelijk ging de jurisprudentie uit van een vrij strikte toepassing van het he bis in idem-beginsel: was een beschikking cenmaal in rechte onaantastbaar geworden, dan dienden verzoeken tot hernieuwde behan-

verwarrend is dat een anvraag ook het werzoek kan inhouden toepassing te geven asn een bevoegdheid ambtshalve een besluit te nemen.

50 Daar kan tegen worden ingebracht dat de tem "werzoek om terug te komen wan' zich als zodanig richt op het met terugwerkende kracht ontnemen wan de rechtsgevolgen aan een eerder besluit, terwijl de term herzieaing soms gereserveerd wordt woor een wijziging van de rechtsgewolgen met het oog op de toekornst. In de rechtsprazk wordt de term herziening echter ook gebruikt in die ge wallen waarin met terugwerkende kracht beoogd wordt rechtsgevolgen van rechtens onaantastbaar geworden besluiten te wijzigen. Bovendien ligt de term 'berzieningsverzoek' aangenamer in het oor dan de term "verzoek om terug te komen van".

51 TK 1988-1989,21221, nr. 3, blz. 94.

52 De passage luidt: "Het artikel ziet niet op de situatie dat het recht wordt gewijzigd. Indien hett woor de aanvraag relevante recht wordt gewijzigd, kan er vollgens de dan geldende bepalingen een (nieuwe) aanwraag worden gedaan. Daar zij betrekling heeft op nieuwe bepalingen is in zo"ngewal in begingel sprake van een niewwe aanvraag. Weit kunnen wit het owergangsreclit ter zake beperkingen woonwloeien.

53 TAR 1988, p. 1.01-103. 
deling te worden geweigerd. ${ }^{\text {s.4 }}$ Met name uit de Arob-jurisprudentie volgde dat dergelijke verzoeken niet-ontvankelijk dienden te worden verklaard. Herhaalde verzoeken waren immers niet gericht op een (nieuw) rechtsgevolg. Van een op (nieuwe) rechtsgevolgen gerichte rechtshandeling was wolgens de Afdeling Rechtspraak pas sprake wanneer er naar aanleiding van een verzoek om terug te komen van een eerder genomen besluit een inhoudelijke heroverweging van de beslissing had plaatsgevonden of, wanneer zo"n inhoudelijke heroverweging, vanwege gewijzigde feiten of omstandigheden, had behoren plaats te vinden. ${ }^{35}$

De Centrale Raad van Beroep volgde reeds lang een soepeler lijn op grond waarvan een weigering om terug te komen van een eerdere beslissing in beginsel een appellabel besluit oplevert en dus in beginsel een, zij het zeer terughoudende, inhoudelijke beoordeling vergt. ${ }^{56}$ Dit is sindsdien vaste jurisprudentie. Op de strekking van deze beperkte toetsing zal in paragraaf 3.3 nog nader worden ingegaan. In deze jurisprudentie lijkt de ontwankelijkheidswraag op te gaan in de wraag naar de gegrondheid van het verzoek om herziening, behoudens het geval dat het verzoek om herziening is op te vatten als een zuivere herhaling van een eerder, door het bestuursorgaan afgewezen, verzoek..$^{\text {? }}$

In de jurisprudentie van de Afdeling Rechtspraak heeft de ontvankelijkheidsdrempel langer stand gehouden. Dat gold niet alleen woor gevallen waarin het ging om zuivere herhalingen van eerdere verzoeken, ${ }^{5.8}$ maar ook voor gevallen die verwantschap vertonen met de in dit boek aan de orde gestelde problematiek. Een en ander laat zich illustreren aan de hand van een uitspraak van 13 december $1984^{5 y}$ die betrekking heeft op een zaak die zag op de beëindiging van het zogenaamde Terugkeerprojectenprogramma. Deze beëindiging. was bekendgemaakt in een op 15 september 1983 gepubliceerde Minderhedennota van het ministerie van Sociale Zaken en Werkgelegenheid (SoZaWe).

Op 9 mei 1984 dienen de Stichting Nederland Centrun Butenlanders (de Stichting) en een zekere A. Aksu, en samen met hem nog 537 anderen, bij de staatssecretaris van SoZaWe een verzoek in terug te komen van zijn beslissing van 4 oktober 1983, waarbij alle terugkeerprojecten waren stopgezet. De aanleiding tot het verzoek van de Stichting was een uitspraak van de Afdeling Rechtspraak van 30 maart 1984, waarin de Afdeling het besluit tot stopzetting had vernietigd voorzover dit tevens betrekking had op projecten ten aanzien waarvan de Stichting de statssecretaris reeds positief had geadviseerd. Het verzock van 9 mei 1984 strekt ertoe de staltsecretaris er, mede in het licht van deze uitspraak, toe te bewegen het besluit tot stopzetting, ook voor wat de overige projecten aangaat, te heroverwegen. De staatssecretaris wijgst het verzoek af.

De slaatssecretaris was van oordeel dat geen heroverweging van diens eerdere standpunt had plaatsgevonden en dat diens beslissing derhalve was aan te merken als een herhaling

54 A.M. Donner, Nederlands Bestuurstecht, Algemeen Deel, Alphen aan den Rijn 1987, p. 263.

55 ARRS 5 juli 1982, AB 1982, 56, m.nt v.d.V. Zie werder de noot van Voermans onder ABRS 13 jun [997, nr. 7 .

Voor wat de rechtspraak in ambtenarenzaken betref is deze lign al tot de dertiger jaren terug te voeren. Zie CRvB 18 maart 1937, ARB 1937, p. 408. Zie voorts CRvB 14 februari 1950, ARB 1950,
581 .

Zoals in ARRS 4 september 1981 , AB 1981,541 m.nt. J.R.St.

$\mathrm{AB} 1985,448$ m.nit. RF. 
van een eerdler genomen besluit en dus rechtsgevolg miste: de brief waarin de staatssecretaris zijm standpunt verwoordde zou sllechts van informatief karakter zijn. Daar tegenover staat de opvatting van appellanten die door de Afdeling als volgt wordt weergegeven:

"Het standpunt van appellanten houdt kort weergegeven in, dat indien aan het bestreden besluit geen heroverweging van het beslut van verweender van 4 oktober 1983 ten grondslag zou liggen, dit besluit niettemin als een beschikking in de zin van de Wet Arob dient te worden opgevat, aangezien zich sinds laatsigenoemde datum zodanige ontwikkelingen hebben voorgedaan dat verweerder er rechtens toe was gehouden om zijn beshit van 4 oktober 1983 in heroverweging te nemen."

De Afdeling was evenwel van oordeel dat noch in haar uitspraak van 30 maart 1984, noch in de overige door de appellanten aangevoerde argumenten sprake was van mieuwe feiten of omstandigheden. Het bestreden besluit zou niet meer behelzen dan 'een herhaling van een eerder gegeven besluit en derhalve geen beschikking [bevatten] als bedoeld in artikel 2 eerste lid Wet Arob', en verklaarde appellanten niet-ontvankelijk in hun beroep.

In 1.985 vindt de omslag in de jurisprudentie van de Afdeling plats." Van toen af aan mochten herhaalde verzoeken niet langer niet-ontwankelijk worden verklaard met een wisluitend beroep op het ne bis in iden-begunsel. Volgens de Afdeling

'betekent het enkele feit dat' aan het bestreden beshit (op een verzoek om herziening, RB) een onderzoek ten grondslag ligt naar het bestaan wan feiten of omstandigheden die aanleiding kunnen geven tot heroverweging van een beshit, dat een inhoudelijke toetsing van het verroek om herziening daarvan heeft plaatsgevonden" ${ }^{663}$

Is aan dit 'enkele feit' voldaan, dan is er naar het oordeel van de Afdeling sprake van een beschikking, en dus van een ontvankelijk beroep tegen een weigering tot herziening. Hiermee heeft de Afdeling zich, althans voor wat de ontwankelijkheidsvraag betref, atangesloten bij de jurisprudentie van de Centrale Raad van Beroep. Uitgangspunt in de huidige jurisprudentie van beide rechters is dat beslissingen op herzieningswerzoeken zijn aan te merken als beschikkingen waartegen (opnieuw) beroep openstaat. ${ }^{62}$ Dit moge tenslotte nog blijken wit een uitspraak van de Afdeling die in paragraaf 5.4 van hoofdstuk 4 nog uitvoeriger aan de orde zal komen in verband met de zogenaamde Bopa-affaire. ${ }^{63}$ In deze uitspraak overweegt de Afdeling zonder verdere omhal:

"vils het bestreden besluit de weigering wan verweerder behelst om tot heroverweging van deze eerder genomen beschikkingen over te gaan, dient ook dit beshit te worden aangemerki als een beschikking in vorengenoemde zin. ${ }^{64}$

In tegenstelling tot de vroegere jurisprudentie van de Afdeling blijft een niet-ontvankelijkverklaring ook dan achterwege, wanneer vaststaat dat het verzoek om therziening een

60 Resp. in VzAR 22 februari 1985, tB/S VII, wr. 88 en ARRS 4 julli 1985, tB/S VIII, nr. 97, Ost 1985, 6797,4 m.nt. JMK.

61 Zie voor dienovereenkomstige jurisprudentie tevens: ARRS 21 augustus 1986, AB 1987, 367; ARRS 30 januari 1987, AB 1987, 420 m.nt. JHwdV; ARRS 8 maart 1991, tB/S 1991, nr. 28a m.nt. B.W.N. de Waard en ARRS 26 november 1991, AB 1992, 378.

62. Zie zeer stellig: J.B.J.M. ten Berge in zijn noot bij AR 3 decenber 1990, tB/S 1990 , nr. 149.

63 ARRS 5 september 1991 , tB/S 1991, nr. 118.

64 Zie tenslotte de felle uthaal van de CRwB waarbiji deze rechtspraak nog eens wordt bevestigd in zijn uitspraak wan 21 april 1994, AB 1994, $476 \mathrm{~m}$.nt. HH. 
zuivere herhaling is wan een eerder verzoek. Zo corrigeerde de Afdeling het besturursorgaan in een geval dat betrekking had op een verzoek on herziening dat "voor de zekerheid' aan een te laat ingediend bezwaarschrift was gekoppeld. Het besturursorgaan had het tegen zijn weigering ingestelde bezwaarschrift niet-ontvankelijk verklaard. De Afdeling was echter van oordeel dat in dit geval een ongegrond verklaring had moeten worden uitgesproken, dit 'gelet op de vaste jurisprudentie van de Afdeling rechtspraak inzake het ne bis in idem-beginsel. ${ }^{65}$

In de Awb wordt over de niet-ontvankelijkheid van herzieningsverzoeken niet meer gerept. Voorzover herzieningsverzoeken worden beheerst door artikel 4:6 van deze wet, stelt deze bepaling voorop dat bij een beoordeling van de nieuwe aanvraag in de regel door het bestuursorgaan kan worden volstaan met een afwijzing onder verwijzing naar de eerder gegeven beschikking. Dit is slechts anders, indien bij de nieuwe aanvraag feiten en omstandigheden worden aangevoerd die bij de vorige beschikking niet bekend waren. ${ }^{66}$ Indien geen nieuwe omstandigheden zijn gesteld of indien de gestelde omstandigheden het bestuursorgaan niet tot een andere oordeel leiden, volgt afwijzing van de aanvraag. De MvT stelt buiten twijfel dat tegen deze afwijzing dezelfde rechtsbeschermingsmogelijkheden openstaan als tegen de oorspronkelijke beslissing op de aanvraag. ${ }^{67}$

Tenslotte dient nog te worden opgemerkt dat het doen van een verzoek om terug te komen van een rechtens onaantastbaar geworden beslissing om tot een gunstiger resultaat te komen op zichzelf niet aan tijd is gebonden. ${ }^{6 \%}$ De CRvB heeft voorts als zijn oordeel uitgesproken dat aard en strekking van de sociale-verzekeringswetgeving zich verzetten tegen het annemen van rechtsverwerking. ${ }^{\text {th }}$ Uit de jurisprudentie wan de CRvB komt echter well naar voren dat 'op rechtsverwerking duidende omstandigheden' een rol kumen spelen bij de bepaling van de mate van terugwerkende kracht van een beslissing naar aanleiding van een verzoek om herziening van een in rechte onaantastbaar geworden beslissing. ${ }^{70}$

\subsection{Discretionaire bevoegdheid}

In de dagloonzaak, waarmee dit hoofdstuk werd ingeleid, ${ }^{71}$ overweegt de CRvB ten aanzien van de bevoegdheid van het bestuursorgaan om terug te komen van een in rechte ontantastbaar geworden beslissing dat deze een discretionair karakter draagt, waarop de Raad laat volgen:

'De wijze wearop gedangde van die bevoegdheid gebruik maakt, en met name - zoals in casu de weigering on vath die bevoegdheid gebruik te maken, kan door de rechter slechts op beperkte wijze worden getoetst."

66 Zie de MWT bij eerste tranche: TK 1988-1989, 21221, ni. 3, blz. 94.

67 TK 1488-1989, 21221, mir. 3, blz, 94

68 CRvB 2 juli 1979 , RSV $1979 / 246$

69 CRvB 10 juni 1992, RSV $1993 / 176$.

70 CRVB 19 februari 1993, JSV 1993/175

7 CRvB 31 december 1984 , AB 1985,348, nunt J.H. Snits; RSV 1985/126, m.nt. N.J. Haverkamp. 
Deze beperkte toetsing berust op vaste jurisprudentie. 20 oordeelde de CRVB in 1976 over de bevoegdheid wan een bestursorgan te weigeren teng te komen op een in rechte onaantastbaar geworden besluit:

'Tot zodanig terugkomen is een orgaan als gedaagde bevoegd, doch niet verplicht, en de rechter komt daaromtrent slechts een beperkte toetsing toe [....]." (min cursivering, RB)

\section{Waarop de Raad laat volgen dat voor deze beperkte toetsing}

"slechts doorslaggevend is het antwoord op de waag, of het betrokken organ bij afweging van alle in aanmerking komende belangen niet in redelikheid tot zijn standpunt heeft kinnen geraken, dan wel anderszins in strijd heeft gehandeld met enig algemeen rechtsbeginsel of algerneen beginsel van behoorlijk bestuur. ${ }^{72}$

In een uitspraak wan 10 januari $1979^{73}$ heef de CRvB dit criterium aldus nader geconcretiseerd:

"Een administratief orgaan [...] is, indien daartoe deugdelijke gronden aanwezig zijn, bevoegd op cen wroegere beslissing tenug te komen, deze in te trekken en een nieuwe beslissing te gewen, indien zulks in het voordeel is van de daarbij betrokkene en mits daardoor geen verkregen rechten van derden worden aangetast en zulk een intrekking niet uitdrukkelijk of impliciet verboden is.

Deze bevoegdheid, die in beginsel evenzeer bestaat in het geval dat die wroegere beslissing in beroep is gehandhatd, is discretionair van aard. De rechter kan de wijze van hantering, of de niet-hantering, daarvan dan ook niet toetsen, tenzij zou blikken van feiten of omstandigheden op grond waarvan gezegd moet worden, dat het orgaan in redelijkheid net tot zijin besluit heeft kunnen geraken, of de desbetreffende beslissing anderszins in strijd is met een algemeen beginsel van behoorlijk bestuur.'

In de dagloonzaak overweegt de Raad dat tot de eisen die in het kader van de beperkte toetsing aan de weigeringsbeslissing kunnen worden gesteld

"in ieder geval [behoort] de eis dat deze gedragen wordt door de gronden warop zij berust, en dat de in anmerking te nemen belangen zijn affgewogen".

Interessant zijn vervolgens de overwegingen waanuit blijkt wanneer wolgens de Raad miet aan deze eisen wondt voldaan. Zo komt volgens de Raad geen betekenis toe an het verweer van het bestur van het uitwoeringsorgan dat de beslissing in owereenstemming mat de wettelijke bepalingen is genomen. De Raad acht dit verweer onjuist, omdat het rechtstreeks raakt aan de moreriële werkingssfeer van de vertnderde jurisprudentie. De Raad had immers vastgesteld dat aan de desbetreffende wettelijke bepalingen met terugwerkende kracht een betekenis conform de nieuwe jurisprudentie moest worden toegedacht.

Voorts is de Raad van oordeel dat aan het arguntent dat de wijziging van de jurisprudentie plaatswond nadat de oorspronkelijke beslissing in rechte onaantastbaar is geworden, geen doorslaggevende betekenis mag toekomen. Met een louter beroep op de onaantastbaarheid wan de eerdere beslissing neent de Raad dus geen genoegen: hij verlangt een uitdrukke-

72 CRvB 22 oktober 1976, AB 1977, 157. Zie ook A. M. Dorner, Nederlands Bestuurstecht, deel I (1974), die wijst op de uitspraken AB 1959,514; AB 1962, 198 en AB 1973, 86. Ziv voorts de noot van In "Veld bij CRvB 22 oktober 1976, AB 1977,157 , die tevens wijst op de witspraken CR 2 mei $1975, A B 1975,301$ en CRvB 15 oktober $1976, A B 1977,60 \mathrm{~m}$.nt. In "i $V$, 
lijke motivering waarin het uitwoeringsorgaan aangeeft waarom het niet alsnog betekenis toekent aan de verandering in rechtsopvattingen die zich naar het oordeel van de Raad ook al vóor de verandering van de jurisprudentie hadden geopenbaard. Met het in deze zaak door het uitvoeringsorgaan naar voren gebrachte argument dat dit laatste een 'enorme problematiek" met zich zou brengen, neemt de Raad, bij gebrek aan specificering, eveneens geen genoegen.

Tot slot geeft de uitspraak enig inzicht in de eis dat de in aanmerking komende belangen dienen te worden afgewogen. In deze zaak voerde het uitwoeringsorgaan het beleid dat niet op de enkele grond wan veranderde jurisprudentie ten gunste van belanghebbende zou worden teruggekomen van in rechte onaantastbaar geworden beslissingen; voorts stond vast dat dit beleid geen uitzonderingen kende. De CRvB is van oordeel dat zulk een "beleid' geen ruimte laat woor een belangenafweging. Uit deze overwegingen valt af te leiden dat de Raad zich in het kader van zijn beperkte toetsing weliswaar terughoudend opstelt ten aanzien van de door het bestuursorgaan gemaakte belangenafweging, maar dat de Raad reden ziet om in te grijpen indien belangenafweging geheel en al achterwege blifft.

Centraal staat aldus de discretionaire bevoegdheid van het bestuursorgaan: voert het orgaan daadwerkelijk een beleid ten aanzien de vraag of al dan niet in het licht van veranderde jurisprudentie moet worden teruggekomen op onaantastbare besluiten, dan zal de rechter zich bij de toetsing van dit beleid terughoudend opstellen. Van beleid is in dit verband slechts sprake als het bestuursorgaan een bewuste afweging heeft gemaakt tussen de gevallen waarin wel, en die waarin geen herziening op haar plaats is. Ontbreekt een dergelijke afweging, dan vindt het bestuur de rechter op zijn weg. De wijze waarop het bestuursorgaan uitvoering geeft aan de herzieningsbewoegdheid dient te beantwoorden aan de daaraan uit een oogpunt van zorgvuldigheid en motivering te stellen eisen. Zo overwoog de Raad terzake van een verzoek om terug te komen van eerdere inschalingsbesluiten, zulks nadat de CRvB soortgelijke besluiten in een andere procedure wegens strijd met de wet had vernietigd:

"Het spreekt voonts vanzelf dat de uitoefening van de discretionaire bevoegdheid van eiser om van zijn eerdere besluiten terug te komen met de nodige zorgvuldigheid dient te geschieden en dat het beshit waarin de uitoefening van die bevoegdheid witmondt van een deugdelijke motivering dient te zijn voorzien. ${ }^{7 * 4}$

\subsection{Toepassing discretionaire bevoegdheid}

Uit de in de vorige paragraaf angehaalde uitspraak van de CRvB van 10 januari $1979^{75}$ blijkt reeds dat voor rechterlijk ingrijpen ten aanzien van de uitoefening van voomoemde discretionaire bevoegdheid eerst plaats is als op grond van nieuwe feiten of omstandigheden moet worden geoordeeld dat de wijze waarop het bestuursorgaan van deze bevoegdheid gebruik heeft gemaakt de toetsing aan het verbod van willekeur niet kan doorstaan, of het clesbetreffende besluit anderszins in strijd is met een algemeen beginsel van behoorlijk bestuur. In het algemeen wordt ervan uitgegaan dat de rechter eerst dan bereid zal zijn een besluit dat berust op de uitoefening van deze discretionaire bevoegdheid te vernietigen 
indien er zich aantoonbaar nieuwe feiten of omstandigheden hebben voorgedaan, die in redelijkheid tot een andlersluidende beslissing aanleiding hadden moeten geven. Uit deze jurisprudentie blijkt tevens dat het bestuursorgaan ter motivering van een weigering om te herzien kan volstaan met een verwijzing naar het eerder genomen besluit. Dit laatste aspect ziet op de mogelijkheid wan vereenvoudigde afdoening, zoals deze is gecodificeerd in artikel 4:6, tweede lid, van de Awlo.

Voemans legt artikel 4:6 van de Awb aldus uit dat indieners van verzoeken om terug te komen van een rechtens onaantastbaar geworden besluit, willen ze een inhoudelijke behandeling van hun verzoek bewerkstelligen, nieuw gebleken feiten en omstandigheden dienen aan te woeren die, had het bestuursorgaan ze gekend bij het nemen van de aanvankelike beslissing, aanleiding zouden zijn geweest om tot een inhoudelijk ander besluit te komen. Worden dergelijke nieuwe feiten en omstandigheden niet aangevoerd dan kan het bestuutsorgaan zonder verdere plichtplegingen het verzoek on terug te komen op een eerdere beslissing afwijzen door een loutere verwijzing naar die eerdere beslissing. ${ }^{76}$

In de literatuur is onomstreden dat deze uitleg een juiste weergave is van de jurisprudentie van de Afdeling bestuursrechtspraak van de Raad van State (en voordien van de Afdeling Rechtspraak). In een uitspraak van 16 december $1996^{77}$ merkt de Afdeling bestuursrechtspraak een weigering van het college van $B \& W$ van Groningen om terug te komen van in rechte onaantastbaar geworden weigeringen van bouwvergunning aan als een besluit naar aanleiding wan een herhalde aanvraag als bedoeld in artikel 4:6 van de $A w b$ en overweegt dienaangaande:

\footnotetext{
"Niet kan worden aamaard dat degene die een beroepsmogelijkheid onberut heeft gellaten, langs de weg van indiening van een nieuw verzoek bij het bestuursorgaan, het verkrijgen van een beslissing daarop en het instellen van beroep tegen die beslissing, zou kumnen bereiken dat de bestuursrechter uitspraak doet als ware het beroep gericht tegen de oorspronkelijke beslissing. Indien er sprake is van een herhaald verzoek kan het door appellanten ingestelde beroep slechts de weg openen tot beantwoording van de vraag of na genoemde besluiten wan burgemeester en wethouders van 16 april 1992 en 30 november 1992 feiten en omstandigheden aan de dag zijn getreden, die burgemeester en wethouders noopten tot heroverweging. Dit ne bis in idembeginsel is - voor zover te dezen van belang - thans wervat in art. 4:6 Awb. ${ }^{\text {, }}$ "s
}

De Afdeling besturursrechtspraak grijpt hierbij terug op vaste jurisprudentie van de Afdeling rechtspraak ${ }^{7}$

Uit een uitspraak van de CRvB van 25 mei $1988^{80}$ zou afgeleid kunnen worden dat deze Raad van eenzelfde opvatting witgaat. Deze zaak betreft een werzoek om terug te komen

Zie zijn noot onder CRvB 14 mei 1996, Rabw 1997, nr. 3 en de in deze nool opgenomen verwijzingen naar ARRS 8 maart 1991, UB/S 1991, nr. 28a m.a. B.W.N. de Waard; ABRS 2 december 1994, AB 1995, 212 m.nt. B.I.P.G. Roozendaal, N.M. van Waterschoot an CRvB 21 apriil 1994, ABB $1994,476, \mathrm{~m}$.nt. HH.

77 AB 1998, 32 m.nt. B.J. Schueler.

78 Aldus de vaste jurisprudentie van de Afdeling: voor een recenter voorbeeld, zie: ABRS 4 april 2003, $\mathrm{AB} 2003,315 \mathrm{mnnt}$. BPV.

79 Zie bijv. ARRS 3 nowember 1989, AB 1990, 282 en ARRS 31 oktober 1990, AB 1991, 570, mint JHvdV.

$80 \quad$ RSV $1989 / 29$ 
van een weigering tot betaling van ziekengeld. Onder verwijzing naar het rechtsaekerheidsbegingel meent de Raad

"dat een herzieningsprocedure als de onderhavige niet de plats kan zijn on an de hand van dezelfde medische gegevens en argumenten de destjds gevoerde procedure (beter) over te doen, omdat anders een gevoerde rechisstrijd nimmer ten dienste van de rechtszekerheid een onherroepelik einde zou kunnen vinder. "

Tot voor kort viel uit de jurisprudentie van de CRVB echter tevens af te leiden dat de Raad ook dan aanleiding ziet woor herziening van een rechtens onaantastbaar geworden beshit als komt vast te staan dat dit besluit onmiskenbaar onjuist is. Een aanzet tot deze wijze van toetsen is te vinden in een uitspraak van 29 november $1989^{\circ}$, waarin de Raad ten aanzien wan een weigering van het uivoeringsorgaan om ten gunste van betrokkene terug te komen van een weigering van ziekengeld volgens het gebruikelijke toetsingskader overwoog dat

"hij nict verder kan gaan dan een oordeel [tel geven terzake van de wraag, of gedaagde bij afweging van de betrokken belangen in redelijkheid tot zijn beslissing heeft kunnen komen en daarbij ook overigens heeft gehandeld in overeenstemming met de algemene beginselen van behoorlijk bestuur'.

On vervolgens te oordelen dat de oude beslissing niet onmiskenboor onjust is en ook overigens de toetsing aan het zorgvuldigheidsbeginsel kan doorstaan. Dat deze laatste toetsing los zou moeten worden gezien van thet gebruikelijke, voor de terughoudende toetsing kenmerkende, toetsingscriterium wordt echter gelogenstraft door cen witspraak van 2 maart $1993^{82}$, waarin de CRvB overwoog dat

'[het] terugkomen wan een rechtens vaststaande beslissing [...] tot de discretionaire bevoegdheden varn gedaagde [behoort], hetgeen met zich brengt dat de raad niet verder kan gaan dan een oordeel geven terzake van de vaag, of gedaagde bij afweging van de betrokken belangen in redelijkheid niet tot zijn thans bestreden beslissing heeft kunnen komen dan wel anderszins heef gehandeld in strijd met enig algemeen beginsel van behoorlijk bestuur. Voor een oordeel in laatsbedoelde zin zal plaats kunnen zijn in het geval dat de nader aangedragen feiten en omstandigheden uitwijzen dat de oorsprorkelijke beslissing onmiskenbaar onjuist is geweest".

Dat de CRvB ook onder de Awb aan deze rechtspraak vasthoudt blijkt uit een uitspraak van 11 januari $1996^{\text {kat }}$ watarin de Raad overweegt dat:

"[volgens] vaste rechtspraak [...] een dergelijke weigering [dient] to worden geèrbiedigd, tenzij aan het eerder bestuit dusdanige gebreken kleven dan wel zich dusdanige omstandigheden hebben voorgedaan, dat het bestursorgatn in redelikheid niet had mogen weigeren dat eerdere besluit ongedaan te maken. Dakibij ligt het op de weg van de betrokkene die van het bestuursorgaan verlangt dat het terugkomt van een rechtens onaantastbaar geworden besluit feiten of omslandigheden am te dragen, die bij de eerdere besluitworming geen roll hebben gespeeld en evenmin destijds alls beroepsgrond naar voren hadden kumnen worden gebracht dan wel de
evidente onjuistheid van dat besluit aan te tonen.

Deze overweging was tot voor kort vaste rechtspraak. Recentellijk is de jurisprudentie van de $C R v B$ echter meer in de richting van die van de Afdeling bestuurstechtspraak opge-

81 RSV $1990 / 189$

82 AB $1993,421$.

83 JB $1996 / 37$. 
schoven. Op grond van de huidige jurispnudentie kan van de bevoegdheid wan het bestuursorgaan om van een eerder, in recthe onaantastbaar geworden besluit, terug te komen slechts sprake zijn indien bij het daartoe strekkende verzoek nieuw gebleken feiten of veranderde omstandigheden worden vermeld. Voorwerp van toetsing door de Raad blift everwel de wijze waarop het bestuursorgaan uitwoering geeft aan zijn discretionaire bevoegdheid. ${ }^{\text {st }}$

Gelet op de in het kader van dit onderzoek te bespreken jurisprudentie bliff het echter van belang nog wat nader in te gaan op de rumere toetsingsmarge die de jurisprudentie van de CRWB in vergeliking met die van de Afdeling bestumsrechtspraak wan de Raad van State heeft gekenmerkt. Schueler heeft erop gewezen dat de CRvB al bij de toepassing van het vóor de Awb geldende recht aamnam dat de omstandigheid dat een besluit rechtens onaantastbaar is geworden aan het bestuursorgaan niet de bevoegdheid ontneemt om op grond van latere inzichten of andere daartoe moverende redenen van dat besluit terug te komen. Hij begrijpt de toenmalige jurisprudentie van de CRvB aldus dat deze bevoegdheid ook kan worden aangenomen als niet is gebleken van nieuwe feiten of veranderde omstandigheden, tenzif belangen van derden daaraan in de weg staan." Naar het toenmalige recht kan men het naar het oordeel van Schueler zo formuleren dat het bestuursorgaan ervan mag afzien gebrukk te maken van de in artikel 4:6, tweede lid, van de Awb neergelegde bevoegdheid van vereenvoudigde afdoening. Naar zijn oordeel mag het besturisorgaan, als het eenmal heeft gekozen voor deze ruimere beoordeling, niet volstaan met een beoordeling van de vraag of er sprake is van nieuwe feiten of omstandigheden en moet het ook beoordelen of de verzoeker de evidente onjuistheid van het in rechte onaantastbaar geworden besluit heeft aangetoond. Schueler merkt voorts op dat een verplichting tot heroverweging als het rechtens onaantastbare besluit onmiskenbaar onjuist is, op gespannen voet staat met artikel 4:6 van de Awb, ondat dit artikel voor een dergelijke verplichting alleen numte laat indien de verzoeker nieuwe feiten of omstandigheden heeft aangevoerd. Als het belang van derden daarmee niet is gemoeid acht Schueler het onder omstandigheden evenwel toch wenselijk dat een bestuursorgaan tot heroverweging kan worden verplicht. Een dergelyje verplichting acht hij niet in strijd met artikel $4: 6$ van de $A w b$, omdat in dit artikel slechts sprake is van een bevoegdheid tot vereenvoudigd afwijzen en deze bevoegdheid slechts binnen de grenzen van het redelijke mag worden uitgeoefend."

84 CRVB 6 november 2003, JB 2004/29, mnt. ExdL.

85 Zie diens noot onder ABRS 16 december 1996, AB 1998, 32. Zie nok thennekens in zijn noot onder CRVB 27 aprit 1992, AB 1992, 688, die de wijze warop herzieningsverzoken doon de CRvB als ambtenarenrechter enerzijds en de voormalige Afdeling Rechtspraalk van de Rhad wan State anderzijds, als volgt naast elkaar zette: 'De Afdeling rechtspraak Raad van State catuvaardt dat in zulke gevallen volstaan wordt met verwijzing natr de eerdere motivering, tenzij nieuwe feiten of omstan digheden aanleiding zijn voor heroverweging. Er is derhalve verselyil tussen de ene en de andere benadering, waarbij de ambtenarenrechter zich rekenscluap geeft wan de inhoud van de onaantastbaar geworden beslissing, terwijl de Afdeling rechtspraak daar niet van wil weten en slechts wenst te bezien of nadien nieuwe feiten en omstandigheden grondslag bieden voor een herziening (...)."

86 Schueler verwijst in dit verband naar CRvB 21 april 1994, AB 1994, 476, m.nt HH; CRvB 28 november 1995, RAwb 1996, nr. 42, m.nt. De Waard en JB 1996/33.

87 Dat een dergelijke verplichting onder omstandigheden ook naar huidig recht nog actueel kan zijn, zal blijken uit het in paragraaf 2.3 .2 te bespreken witspraken van het College van Beroep voor het Bedrijfleven en het Hof van Justitie EG in de zaak Kuhme \& Heitz UB 2000/355, m.nt E. v.d Lindern, en IB 2004/42, m.nt. N. Verheij. 
Aanzienlijk. kritischer over de toenmalige jurisprudentie van de CRvB is Voermans volgens wie

'cen dergelijke lijn van redeneren [erop neerkomi] dat ieder rechtens onaantastbaar geworden besluit wegens nadere inzichten in de juistheid ervan vatbaar zou worden voor heroverweging. Hierdoor zou de bijl aan de wortel worden gelegd van de formele rechtskracht van besiuiten: een besluit blijft op die manier altijd inhoudelijk aantastbaar, ook buiten de strikte gevallen van artikel $4: 6 \mathrm{Awb}$. Ook de termijnstelling voor bezwaar- en beroep wordt daarmee in feite overbodig gemaakt"

De door Schueler gesuggereerde splitsing tussen het toepassen van artikel 4:6 van de $A$ wb enerzijds en de hantering van de, van vór de $A w b$ daterende, bevoegdheid om terug te komen van een in rechte onaantastbaar geworden besluit, vindt echter haar bevestiging in de ten aanzien van een verzoek om herziening van een malusoplegging gewezen uitspraak van 18 december $1997^{8 \%}$. In deze zaak kòn het uitvoeringsorgaan artikel 4:6, tweede lid, van de Awb niet toepassen, omdat het herzieningsverzoek zag op een ambtshalve opgelegd beshit; de Raad geeft evenwel tevens een oordeel voor de situatie dat het uitvoeringsorgaan deze bevoegdheid ook niet wil toepassen. Ook in dat geval acht de Raad het bestuursorgaan bevoegd

"om op aanvraag van een belanghebbende terug te komen van een eerder in rechte onaantastbaar geworden bestuit, indien daardoor geen rechten van derden worden geschonden, en zo een terugkomen miet expliciet is verboden. Het bestuursorgaan kan zulks echter ook weigeren. ${ }^{90}$

De conclusie uit het voorgaande kan dan ook geen andere zijn dan dat de Afdeling Bestuursrechtspraak van de Raad van State en de CRvB gedurende lange tijd uiteenlopende toetsingscriteria hanteerden ten aanzien van verzoeken om herziening van in rechte onaantastbaar geworden besluiten. Dit blijkt expliciet uit een uitspraak van de Afdeling van 24 januari $2000 .{ }^{\text {" }}$ Nadat de rechtbank in deze zaak het criterium van de CRvB had toegepast wordt zij door de Afdeling als volgt gecorrigeerd:

\footnotetext{
'indien het bestuursorgaan naar aanleiding van een verzoek om herziening van een in rechte onaantastbaar geworden besiuit tot de conclusie komt dat er geen termen zijn om op het oorspronkelijke besluit terug te komen, kan degene die de beroepsmogelijkheid onbenut heeft gellaten niet langs de weg van het instellen van bezwaar en beroep tegen het besluit dat op het verzoek om heroverweging is genomen kan bereiken dat de rechter de zaak beoordeelt, als was hei beroep gericht legen de oorspronkelijke beslissing. Anders zou aan het wettelijk voorschrift dat de mogetijkheid tot het instellen van beroep bindt aan een termijn zijn kracht worden ontnomen, welk voorschrift is te beschouwen als van openbare orde.

Het door appellant ingestelde beroep kon dan ook slechts de weg openen tot beantwoording van de vraag of ha her besluit van 8 september 1994 nieuwe feiten of veranderde omstandigheden aan de dag zijn getreden, die burgemeester en wethouders noopten dan wel aanleiding hadden moeien geven tot heroverweging van dat besluit.'
}

Met deze rechtspraak werd de hiervoor weergeven opvatting van Voermans, althans voor wat betreft de zaken die in hoogste instantie door de Afdeling worden beslist, bevestigd.

90 AB 1998, 124 , ni.nt. HBr en $\mathrm{dB} 1998 / 40, \mathrm{~m}, \mathrm{nt}$. Evill.

Welke bevogdheidsuitotening vervolgens weer word getoets volgens het hierwoor gecteerde 
De Waard heeft erop gewezen dat deze rechtspraak haar verklaring wind in het systeem van bezwaar- en beroepstermijnen en de voor de rechtspraak van de Afdeling kenmerkende betrokkenheid van belangen van derden. ${ }^{\text {y? }}$

\subsection{Verandering van rechtspraak als grond voor herziening}

Uit de vorige paragraaf kan de conclusie worden getrokken dat althans de CRvB tot voor kort ruimte liet voor een beoordeling van verzoeken om herziening buiten artikel 4:6 Awb on en dat hij in dat verband mede betekenis hechtte aan een eventuele onmiskenbare onjuistheid van het oorspronkelijke besluit. Gelet hierop doet zich enerzijds de vraag voor of de CRvB in gewijzigde jurisprudentie een feit of omstandigheid achtte gelegen die ananleiding kon zijn tot het met terugwerkende kracht herzien van een onder de oude jurisprudentie genomen besluit; anderzijds doet zich de vraag voor of de CRvB, indien hij tot het oordeel kwam dat het oorspronkelijke besluit was genomen met inachtneming van jurisprudentie die, achteraf bezien, onjuist is, een reden aanwezig achtte tot herziening met terugwerkende kracht op de grond dat het oorspronkelijke besluit onmiskenbaar onjuist was.

Een aanwijzing voor een bevestigende beantwoording van deze vragen is in elk geval te vinden in een uitspraak van de CRvB van 12 september $1978^{9.3}$ met betrekking tot een op een wijziging van jurisprudentie gegrond verzoek om herziening van een dagloon in het kader van de Werkloosheidswet. In deze zaak had het uitvoeringsorgaan gesteld alleen dan bereid te zijn van de desbetreffende rechtens onaantastbaar geworden beslissing terug te komen, indien zich nieuwe feiten hebben voorgedaan. De Raad acht een dergelijke opvatting echter te beperkt en overweegt:

'Met name is ook dan grond aanwezig een rechtens onaantastbaar geworden beslissing opnieuw in overweging te nemen, wanneer nietwe argumenten worden aangevoerd die twijfel doen rijzen aan de juistheid van de destijds genomen beslissing. ' (mijn cursivering, RB)

Deze uitspraak geeft weliswaar geen uitsluitsel over dle vraag of onder nieuwe feiten of omstandigheden ook een verandering in de jurisprudentie kan worden verstaan; geen twijfell lijkt echter mogelijk dat in veranderde jurisprudentie een argument voor herziening kan worden gevonden.

Ter verdere illustratie hiervan kan dienen een door de CRvB op 2 juli 1979 gewezen uitspraak, ${ }^{34}$ waarbij het ging om een verzoek om herziening dat was gebaseerd op een afwijkendle rechtsopvatting van een andere rechter, te weten de Hoge Raad.

De zaak heeft betrekking op een weigering van het utvoeringsorgaan terug te komen op een rechtens onaantastbaar geworden beslissing inzake kinderbijslag. Ten behoeve wan het kind Hendrik was over de tijdvakken vóór 1 oktober 1976 door het uilvoeringsorgaan overeenkomstig de destijds geldende richtlijnen enkelvoudige kinderbijslag toegekend. De toepassing van deze richtlijnen werd echter gestaakt ten gevolge van een op 18 december 1976 gepubliceerd arrest van de Hoge Raad wan 17 novernber 1976. Vast stat dat, ware de toekenining van de kinderbijslag ten behoeve van Hendrik geschied overeenkomstig de door het arresi van de 
Hoge Raad gestelde criteria, Hendrik in ammerking zou zijn gekomen voor dubbele kinderbijslag. Reden voor de wader wan Hendrik om in april 1977 bij het uitwoeringsorgan een verzoek in te dienen tot heriening van de kinderbijslag over de periode van 1 januari 1968 tot en met 30 september 1976. Het uitvoeringsorgaan wees dit werzoek af, onder ardere overwegende dat het om redenen van praktische en juridische azd onaanvalardbaar moet worden geacht terug te komen op reeds langere tijd woordien op zichzelf juiste vaststellingen var kinderbijslag". Voorts was het uitwoeringsorgaan van oordeel dat het verzoek om herziening niet binnen een redelike termijn was gedaan (in casta vier maanden na publicatie van het arresit van de Hoge Raad).

In het tegen de beslissing van het witwoeringsorgaan door de vader van Hendrik. ingestelde beroep vatte de Rad van Beroep het besluit van het uitwoeringsorgaan op als een besluit het recht op kinderbijsiag ten behoeve van klager's zoon Hendrik miet met ierugwerkende krach te herzien. De Raad van Beroxp was evenwel van oordeel dat "niet gesteld [kan] worden, klat verweerder bij alle te dezen in aanmerking komende belangen niet in redelijkheid tot zijn beslissing is kunnen komen. Met het bestuur van de Vereeniging van de Raden van Arbeid is de Raad dle meming toegedaan, dat van verweerder in redelijkheid miet kan worden verlangd telkens achteraf terug te komen op het bestand van genomen en onaantastbaar geworden beslissingen natat andeiding van latere rechtspraak".

In hoger beroep stelt de CRvB het discretionaire karakter van de bevoegdheid van het uitwoeringsorgaan om al dan niet terug te komen van in rechte onaantastbaar geworden beslissingen voorop. Hij relativeert echter het standpunt van het uitvoeringsorgaan dat de vader van Hendrik zijn verzoek om herziening van de kinderbijslag niet binnen een redelijke temiju zou hebben gedaan met de overweging dat

'het doen van een verzoek terug te komen op rechtens onaantastbaar geworden beslissingen, will dat tot een woor de verzocker gunstig resuitaat kumnen leiden, [...] op zichzelf nier aan een

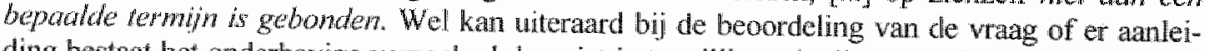
ding bestaat het onderhavige verzoek al dan niet in te willigen de tijd welke is verstreken tussen de latste uitbetaling van kinderbijskg en het betreffende verzoek mede als factor wan betekenis worden betrokken", (mijn cursivering, RB)

\section{Bovendien overwoog de Raad ar wel begrip woor te hebben dat}

'het (niet om financiè gevolgen maar) om redanen wan practische aard moeilijk kan zijn zeker m wansschinglijk het genal won eiser niet op zichzelf staat - terug te komen op reeds langere tijd vóndat eiser zich met bedoeld verzoek tot gedaagde wendde genomen beslissingen inzake kinderbijslag'. (mijn cursivering, RB)

Op grond van het bovenstaande vemietigt de CRvB de beslissing van het uitwoeringsorgatur en de uitspraak van de Raad van Beroep, omdat deze niet zouden steunen op een draagkrachtige motivering. De Raad beshit zijn uitspraak echter met een, over het hoofd van de eiser, tot degenen, die met een beroep op het arrest van de Hoge Raad een verzoek tot herziening van kinderbijslag willen indienen, gerichte waarschuwing tegen overspan-
nen verwachingen:

de Raad wil - ter voorkoning van ongegronde verwachtingen bij eiser - er nog op wijzen dat de omstandigheid dat een rechterlike uitspraak [...] indien deze eerder zou zijn gegeven [...], mogelijk tot andere, voor de aanwrager gunstiger beslissingen zou hebben geleid, op zichzelf onvoldoende grond oplevert om te oordelen dat van de bevoegdheid om van een rechtens on- 
aantastbaar geworden beslissing terug te komen gebruik zou behoren te worden gemaakt. wh (mijn cursivering, RB)

Uit de laatste overweging spreekt de nodige voorzichtigheid. Bij de bespreking van de dagloonzaak waarmee paragraf 3 van dit hoofdstuk werd geopend, bleek enerzjds dat de CRvB bij herzieningsverzoeken op grond van verandering van jurisprudentie geen genoegen neemt met het enkele argument dat de oorspronkelijke beslissing in rechte ondantastbaar is geworden. Anderzijds is thet niet zo dat de Raad in een verandering van jurisprudentie een grond ziet die in beginsel tot herziening zou moeten leiden. Zo oordeelde de Raad al in $1977^{97}$ dat het te ver woeren zou

"strijd met een algemeen beginsel van behoorlijk bestuu" aanwezig te achten, indien een organ in gevalten als dit's weigert aan werandering wan jurisprudentie die betekenis toe te kennen, dat daarin grond is gelegen eerder genomen beslissingen, welke onaantastbaar zijn geworden, alsnog in woor betrokkenen gunstige zin te herzien".

Op 16 februari 1984 stelt de CRvB, oordelende als ambtenarentechter, in het kader van zijn vaste jurisprudentie inzake de beperkte toetsing voorop:

"dat het enkele feit, dat door een rechterlijke uitsprak aan een wettelijk voorschrift een bepalde uitleg wordi gegeven, er niet toe kan leiden, dat alle voorafgande toepassingen van dat voorschrift in overeenstemming met die (nieuwe) uitleg moeten worden gebacht. Dergelijke verstrekkende gevolgen van rechterlijke uitspraken zouden thet ook ten behoeve wan de overheid geldende beginsel wan de rechtszekerheid te zeer aantasten'.

In zijn, eveneens op het ambtenarenrecht betrekking hebbende uitspraak van 24 september $1987^{100}$ achtte de CRvB deze jurisprudentie eveneens van toepassing op gevallen waarin achteraf wordt geoordeeld dat aan een wettelijk voorschrift een onjuiste toepassing is gegeven. Henmekens stelt naar aanleiding van deze uitspraak voorop dat, in het geval de rechter een bepaalde interpretatie aan een wettelik voorschrift geef, de rechtszekerheid gebiedt dat deze interpretatie niet onbeperkt terugwerkt. In een uitspraak van 10 april $1991^{101}$ past de CRvB deze rechtspraak ook in een socialle zekerheidszaak toe."

95 Uit de noot bij de uitspraak blikt evenwel dat de titspraak van de CRvB toch heefl gefeid tot toe kenning achteraf van kinderbijslag over de periode I aprill 1975 um 30 september 1976.

96 CRvB 31 december 1984, AB 1985,348 , m.nt. JH.Smits en RSV 1985/126, m.nt. N.J. Haverkanp.

97 CRvB 28 april 1977, RSV 1977, nr. 253.

98 Het ging in dit geval om en afwijzing van een verzoek om herziening van een waigening ben WW. titkering, terwijl na de weigeringsbeschikking een verandering in de jurisprudentie had plaatsgevonden op grond warvan de belanghebbende meende alsnog in aanmerking wor en uitkering te komen.

99 TAR $1984,82$.

100 AB 1988,149 , m.nt. HH: tevens geannoteerd door R.M. van Male in TAR $1988, p .101-103$.

101 RSV $1902 / 23$.

102 Van een wat ruimere opvatting lijkt een uitspraak van 31. december 1990 (TAR 1991/64) te gethigen waarin de Raad overwoog dat "[gedaagde], toen [...] definitief was vastgesteld dat het onthouden van een periodieke verhoging in onstandigheder als die van eiser strijdig was mot de loepasselijke regelgewing op de hem toekomende rechtszekerheid niet langer een 20 dwingend beroep [kon] doen dat hij zich op grond daarwan mocht blijven onttrekken aan zijn verantwoordelijkheid om vanaf ewengenoemd moment het sallaris in overeenstemming met die regelgeving valst te stellen. "Gelet op latere ontwikkelingen in de jurisprudentie van de CRvB mag worden aangenomen dat deze uilspraak niet meer betekenis toekornt dan de vitzondering die de regel bevestigt. 
In de reeds eerder genoemde uitspraak van 18 december $1997^{103}$ komt de Raad tot een principieler verwoording van zijn standpunt. Die zaak betrof het verzoek van een aantal bedrijven om een aan hen opgelegde malus, waarin zijn aanvankelijk hadden berust, ongedaan te maken nadat de CRvB in rijn uitspraak van 15 februari $1995^{104}$ wegens strijd met artikel 6 EVRM onverbindend had verklaard. Namens een van de bedrijven was aangevoerd dat de grond waarop het uitvoeringsorgaan diende terug te komen van de eerdere malusoplegging niet zozeer gelegen is in het feit dat de Raad eerder een principieel oordeel heeft gegeven over de malusoplegging als zodanig, doch dat uit die uitspraak blijkt dat er zodanige gebreken aan de malusbesluiten kleven dat de uitvoeringsinstellingen in redelijkheid niet kunnen weigeren terug te komen op die besluiten.

\title{
Naar aanleiding van dit betoog stelt de CRvB voorop dat
}

\begin{abstract}
"uitgangspunt is dat de inhoud van inmiddels tot stand gekomen jurisprudentie op zichzelf geen grond vornt van het doorbreken wan het rechens onaantastbaar zin van besluiten waartegen geen beroep bij de rechter is ingesteld, of die gezien thet resultatt van een wel bij de rechter gevolgde rechtsgang in rechte onaantastbaar zijn geworden. Naar het oordeel van de raad wordt dit niet anders indien in die jurisprudentie gewezen is op een mogelijke schending van fundamentele rechten. De reden woor deze beperking wan de mogelijkheid om alsnog het eerdere besluit door de rechter beoordeeld te krijgen, is gelegen in het uitgangspunt dat een belanghebbende binnen de daarwor geldende beroepstermijn bif de rechter in beroep kan komen tegen een besluit, doch dat na ommekomst van die termijn of nadat in die rechtsgang tot een eindresultaat is gekomen, het (potentiele) geschil geandigd is (lites finiri oportet)'.
\end{abstract}

In cen eveneens op een verzoek om herziening van een in rechte onaantastbaar geworden betrekking hebbende uitspraak van 16 juli $1998^{105}$ overweegt de Raad

"dat de omstandigheid dat het malusbeshuit zou zijn wemietigd indien daartegen tijdig beroep was ingesteld geen grond kan vormen woor het oordeel dat het bestuursorgalan niet in redelijkheid kan weigeren terug te komen wan een in rechte onaantastbaar geworden besluit.'

Volgens de Raad

[i...] moet daarbij in aanmerking worden genomen dat wolgens de jurisprudentie van de read de onstandigheid dat rechtspraak tot stand is gekomen die uitwijst dat bij een eventuele rechterlijke toetsing het intussen rechtens onatantastbaar geworden besluit niet in stand zou kumen blijven, geen grond kan opleweren voor het doorbreken wan de fornele rechtskrocht wan dat beshun"
(min cursivering, RB)

\section{Thssenbalans}

Naar aanleiding van deze jurisprudentie kan het volgende worden opgemerkt.

1. De inhoud van inmiddels tot stand gekomen jurisprudentie, op grond waarvan zou moeten worden geoordeeld dat het besluit waarvan herziening wordt verzocht, ware tegen dat besluit tijdig beroep ingesteld, niet in stand had kunnen blijven, vormt op zichzelf geen grond vormt voor de doorbreking van de formele rechiskracht van het oorspronkelijke besluit. De inhoud van de nieuwe jurisprudentie kan er dus niet toe leiden dat tegen het oorspronkelijke besiuit alsnog een rechtsmiddel kan worden aangewend. Uit de des-

105 AB 1998,439 m.nt. $\mathrm{HBr}$ 
betreffende overweging valt mijns inziens echter af te leiden dat in bijzondere gevallen, op grond van bijkomende omstandigheden, mogelijk wel een uitzondering kan worden gemaakt. Daarbij valt mijns inziens te denken aan een situatie waarin de betrokkene zich niet bewust heeft kùnnen zijn van zijn alsnog verkregen rechten, dan wel voor wat zijn mogelijkheden tot het aanwenden van rechtsmiddelen betreft, door het bestuursorgaan op het verkeerde been is gezet. ${ }^{106}$

2. Voor het doorbreken van de formele rechtskracht van het oorspronkelijke besluit is evenmin aanleiding als in de inmiddels tot stand gekomen jurisprudentie is gewezen op een mogelijke schending van fundamentele rechten. Deze formulering lijkt echter open te laten de vraag hoe de rechter zou oordelen als schending van fundamentele rechten in de inmiddels tot stand gekomen jurisprudentie zou konen vast te staan. ${ }^{40 ?}$

3. Het enkele feit dat (de toepassing die gegeven is aan) een wettelijk voorschrift, naar in latere jurisprudentie komt vast te staan, onrechtmatig is geweest, kan er op grond van het ook voor de overheid geldende rechtszekerheidsbeginsel niet toe leiden dat het desbetreffende bestuursorgaan verplicht is alle nog onder de 'oude jurisprudentie' genomen besluiten te herzien. Op grond van het feit dat de CRvB het in de burgerlijke rechtspraak ontwikkelde begrip van de formele rechtskracht hanteert, moet worden aangenomen dat ook de CRvB uitgaat van het beginsel, dat een besluit, waartegen een met voldoende waarborgen omklede rechtsgang heeft opengestaan, maar waarvan niet (met succes) gebruik is gemaakt, zowel wat haar inhoud als wijze van totstandkomen betreft geacht moet worden in overeenstemming te zijn met de desbetreffende wettelijke voorschriften en algemene rechtsbeginselen. Van deze 'materiele' gevolgtrekking uit de formele rechtskracht zou uiteraard weinig overblijven indien het bestuursorgaan zou worden verplicht tot een algehele herzieningsoperatie. De in paragraaf 3.1 aangehaalde vrees van Haverkamp blijkt dan ook ongegrond.

4. De conclusie moet dan ook zijn dat degene die op grond van veranderde rechtspraak 'rechtsherstel' vordert is aangewezen op het, in dit opzicht, buitenwettelijke en in de rechtspraak uitgewerkte, middel van een verzoek om herziening. ${ }^{108}$ Zoals Bröring in zijn noot

106 Vgl. par. 2.3 van dit hoofdstuk, waarin is aangegeven dat het recht op rechisbescherming onder omstandigheden reden kan zijn voor het doorbreken wan de formele rechtskracht. Vgl. voorts par. 2.3.2 van hoofdstuk 5 war het zelfde zal blijken, ditmaal in de context wan de doorwerking van het Europese recht.

107 Op deze vragg zal in meer algemene zin worden teruggekomen in hoofdstuk 5 .

108 Dat dit overigens niet vanzelfsprekend is moge bijken uit het feit dat in diverse buttenlandse rechtsstelsels is voorzien in een wettelijke regeling voor de herziening van besluiten die zijn genomen op grond van een wettelike bepaling die later is vernietigd dan wel onverbindend is verklaard. zo wijst Van Male in zijn noot bij CRvB 24 september 1987 (TAR 1987/257) op thet in het Belgische recht bestaande rechtsmiddel wan het recouss de retractatsom, waarin word woorzien door de Wet wan 10 mei 1985 op het Hof van Arbitrage. Dit rechtsmiddel, dat wordt ingesteld bij het gerecht dat de onherroepelijke uitsprak heeft gewezen, betreft een herziening met inachtneming wan het feit van de vernietiging var een algemeen woorschrift in een andere proceduru. Voots wijst hij op Par. 183 van de Duitse Verwaltungsgerichrsordnung op grond waarvan in dergelijke gevallen de kracht van gewijsde van de uitspraken van de bestuursrechter onaangetasi blijf, maar de desbetreffende uitspraken niet meer mogen wordèn uitgevoerd. 
onder de uitspraak van 18 december 1997 aangeeft: 'vragen staat vrij'. "wo Deze bevoegdheid bestaat, mits daxdoor geen rechten van derden worden geschonden en zo een herziening niet expliciet bij wethelijk voorschrith is verboden en is discretionair van aard. De wijze van hantering of niet-hantering van deze bevoegdheid kan door de rechter slechts terughoudend worden getoets. De rechter dient in elk geval na te gaan of de beslissing op het verzoek om herziening gedragen wordt door de gronden waarop zij berust en of de daarbij in aanmerking te nemen belangen zijn afgewogen. Deze afweging ziet enerzijds op het belang van betrokkene bij het alsnog verkrijgen vam rechtsherstel enerzijds en anderzijds op het op de rechtszekerheid terug te voeren belang van het bestuur ouder rechtsbetrekking niet opnieuw open te breken. "Daarbij komt blijkens de in paragraaf 4.3 besproken jurisprudentie geen doorslaggevende betekenis toe aan de omstandigheid dat het oorspronkelijke besluit in overeenstemming met de (toen geldende) wettelijke bepalingen is genomen en evenmin aan het argument dat de omslag in de jurisprudentie heft plaatsgevonden nadat de oorspronkelijke beslissing in rechter onaantastbaar is geworden. Uit paragraaf 4.4 is evenwel gebleken dat de rumte die de jurisprudentie van de CRVB tot voor kort bood om ook in de onmiskenbare onjuistheid van de oorspronkellike beslissing een mogelijke aanleiding tot herziening aan te nemen, geen doorbrak heeft betekend voor de in dit boek besproken gevallen. De onder punt 1 weergeven hoofdregel staat eraan in de weg dat een besturursorgaan, louter op de grond van het feit dat zijn oorspronkelijke beslissing in geval wan een tijdig instellen van beroep zou zijn vernietigd, tot herziening kan worden verplicht, zelfs als achteraf is komen vast te staan dat de oorspronkelijke beslissing in strijd is met fundarnentele rechten. De emst van de grief beinvloedt aldus op zichzelf niet de vrijheid van het besturursorgaan on al dan niet tegemoet te komen aan een verzoek om terug to komen van een rechtens onaantastbaar geworden besluit."

\section{7 \\ Werking in de tijd}

In deze paragraaf zal aan de hand van een antal voorbeelden uit de jurisprudentie met betrekking tot besluiten tot het al dan niet op grond van (nieuwe) rechtspraak uitoefenen van de herzieningsbevoegdheid worden onderzocht welke werking in de tijd aan deze (nieuwe) rechtspraak is gegeven. Dit onderzoek zal geschieden an de hand van een tweotal begrippen, te weten de materiele en de formele werking in de tijd van verandering van rechtspraak. Daarbij ziet de materièle werking op het tijdstip met ingang warvan (een bepaalde uitleg van een) wettelijk voorschrift onrechtmatig wordt geacht en de formele werking op het tijdstip met ingang waarvan op deze onrechtmatigheid gebaseerde vorderingen kumnen worden geteffechueerd.

\subsubsection{De dagloonzaak}

Enkele voorbeelden zijn de revme al gepasseerd. Zo bleek wit de in paragraat 3.1 behandelde dagloonzaak ${ }^{12}$ dat de CRvB voor wat betreft het tijdstip met ingang waarvan de nieuwe jurisprudentiele regel had te gelden, aansluiting zocht bij het tijdstip waarover het

110 Met alle dearbij komende administratieve lasten.

111 Zie ook punt 3 van de noot van Bröring onder CRvB 18 december 1997, AB 1998, 124

112 CRvB 31 december 1984, AB 1985,348, m.nt. J.H. Smits en RSV 1985/126, n.nt. N.J. Haverkamp. 
geschil in 'herzieningsuitspraak' van 22 september $1981^{113}$ handelde, en wel in die zin dat op dat tijdstip de wijziging in de matschappelike onstandigheden die de werkelike reden voor de onslag van de jurisprudentie vormde, zich reeds had voltrokken. Dagloonvaststellingen die na die datum (17 oktober 1978) nog werden vastgesteld golden als rechtens onju ist. Zoals in paragraaf 3.1 al bleek acht Haverkamp deze kevze voor ben tijdstip dat bijna drie jaar vóóm de datum van de herzieningsuitspraak ligt slecht passen in do conceptie van de rechtsvormende werking van jurisprudentie. Naar zijn oordeel is

"uitgangspunt voor die werking [...] dat de rechter in een gegeven geval een beslissing geeft, waarvan men mag verwachten dat hij die in de toekomstige gevallen eveneens zal geven. Het rechtsvormende element zit in die laatste verwachting, maar daar kan pas sprake van zijn vanaf het tijotip waarop de rechter zijn beslissing heeft gegeven en niet reeds vanaf het tijdstip waarop het geval zich voordoet dat bij de rechter, jaren later, tot die beslissing zal gaan leiden: Iilt

Dat laatste doet zich in deze zaak nu juist wel voor. Zich kennelijk baserend op een verondersteld primat van de wetgever in het overgangsrecht, had het uitvoeringsorgalan nog gesteld dat

"de beslissing waarvan herziening is gevaagd werd genonen in overenstemming met de wettelijke bepalingen",

Maar, naar reeds aan de orde kwam, kwalificeert de Raad dit verweer als

"onjuist [...] nt immers [....] die bepalingen tenminste ungaande de datun van de aanvang van de periode waarop het oordeel van de Raad blijkens voornoemde uitspraak d.d. 22 september 1981 betrekking had (17 oktober 1978) zodanig witgelegd dienden te worden dat de betreffende emolumenten wèl bij de dagloonvaststelling dienen te worden meeberekend".

Aldus laat de Raad er geen mïsverstand over bestaan dat de materièle werking van de in de uitspraak van 22 september 1981 neergelegde nieuwe rechtsregel op zijn laatst op 17 oktober 1978 is ingegaan.

Voor wat de effectuering van de nieuwe rechtspraak (de formele werking) betreft, overweegt de Raad dat onvoldoende door het uitwoeringsorgaan is gemotiveerd waarom nu juist de datum warop de nieuwe rechtspraak is gewezen doorslaggevend zou moeten zijn en niet de eerdere datum met ingang waarvan bligkens de vaststelling door de Raad de wijziging in de maatschappelijke omstandigheden die tot de nieuwe jurisprudentie had geleid, tot stand was gekomen. De Raad acht het zonder meer aanknopen bij de datum van de nieuwe rechtspraak, zonder de belangen af te wegen die met een effectuering met ingang van een eerder tijdip zouden zijn genoeid, niet rechumatig.

De formele werking van de uitspraak van 31 december 1984 krijgt vervolgens gestalte in een beleid van het uitvoeringsorgaan, waarin de algemene gedragslijn wordt gevolgd van een aanpassing van de daglonen met ingang van 17 oktober 1978. Dir beleid is op zijn beurt inzet geweest van een procedure, warin betrokkene die on een herziening van zijn dagloon verzocht met ingang van 24 mei 1977 (dus met ingang van een tijdstip gelegen vóór het in de uitspraak van 22 september 1981 in geding zijnde tijdstip, betoogde dat het 
ook in zijn geval vasthouden aan de datum van 17 oktober 1978 als willekeur te be schouwen zou zijn. De Raad was evenwel van oordeel dat

'Thet uitworingsorgan], door als datum van ingang van het neuwe beleid die datum te kiezen welke deze Raad in de vomoemde uitsprak d d. 31 december 1984 op de in die uitspraak aangegeven gronden heeft genoend, ex standpunt inneemi dat als beleidsregel binnen het raam van de hiek aan gedaagde toekomende beleidswimte zeker niet als onaanvartbaar te beschouwen is". "Is (min cursivering, RB)

Aldus is de danm van 17 oktober 1978 die geheel eigen was an de procedure die leidde tot de titspraak van 22 september 1981 , een geheel eigen leven gan leiden als tijdstip met ingang warvan in het algemeen, behoudens bijzondere omstandigheden, tot aanpassing wan het dagloon wordt overgegaan.

\subsubsection{De kinderbijslagzaak}

Ook de in paragraaf 3.5 behandelde kinderbijslagzaak, waarin de CRvB zich op grond van een uitspraak van de Hoge Raad van 17 november 1976 genoodzaakt zag zijn nog bij uitsprakk van 24 juni $1975^{1 / 1}$ onderschreven rechtspraak inzake de dubbeltelling van kinderbijslag te verlaten, kent de CRvB, althans voor wat de materiele werking betreft, terugwerkende kracht toe aan de nieuwe rechtspraak. De CRWB verwierp de opvatting van het uitvoewingsorgaan dat de in geding zijnde beslissingen, die zagen op het tijdvak van I januari 1968 tot en met 30 september 1976 , op zichzelf juist zouden zijn geweest. Voor wat de effectuering van de nieuwe rechtspraak betreft gaf de CRVB in feite aan zich te kunnen verenigen met het beleid van het uitvoeringsorgaan om de in de nieuwe rechtspraak neergelegde regel eerst ingaande de datum waarop het arrest van de Hoge Raad werd gewezen, toe te passen. Wel verwijt de CRvB het uitvoeringsorgaan dat dit beleid onvoldoende nimte liet voor bijzondere gevallen, waarin het recht op dubbele kinderbijslag ovar verder in het verleden gelegen perioden nog kon worden vastgesteld.

\subsubsection{VZ. ARRS 26 oktober $1984^{119}$}

Een ander woorbeeld waarbij het verzoek on herziening is gegrond op het omgaan van een andere rechter dan bevoegd is ten aanzien van het herzieningsbesiuit zelf, is te vinden in een uitsprak van de Voorzitter van de Afdeling Rechtspragk van de Raad van State van 26 oktober 1984.

Inzet wan thet geding was een geschil tussen cen bedrijf en het geneentebestuur van Steenwijk. Krachtens cen social plan, opgesteld in verband met een reorganisatie cq. beëindiging van de werkzantheden wan de het bedrijf we Stenwijk, was het bedrijf verplicht de WWV-uitkering wan hatr voomalige wetknemers an te vulfen tot 95 procent van het laatstelijk genoten netto

115 CRvB 13 mant $1985, \mathrm{AB} 1986,326$

116 Overigens blijkt unt de noot van Haverkamp dat de opname van het privé-gebruik van auto en telefoon in het dagloon later woor zowel de WAO, de WW, als de ZW weer ongedaan is gemakk bij besluten wan de Sociale Verzekeringsrazd wan 17 juni 1982 (Stch 186) eh 19 jantari 1984 (Stcrt. 60) en van de Stuatssecretaris van Sociale Zalken en Werkgelegenheid van 23 december 1982 (Strot. 254).

117 CRvB 2 juli 1979, AB 1980,502, m.nt. v. S en RSV 1979246.

$118 \quad S V 197520$.

119. VZARRS 26 oktober 1984, tB/S XIII, nr. 16, m.nt. De Waard. 
salaris, vermeerderd met enige toeslagen. Het geschil spitste zich toe op de weigering wath hat uitvoeringsorgaan om bij de vaststelling wan het dagloon in de zin wan de WWV tevens de $20-$ genoemde dertiende maanduitkering te betrekken, waardoor het bedrijf voor een hoger bedray moest "opdraiaien".

Het door het bedrijf tegen dit besluit van $B$ en $W$ ingesteide beroep wordt nede op grond cen witspraak van de CRvB van 27 mei 1983, waarin deze zijn vaste jurisprudentie dienaamgande nog eens bevestigde, door de Afdeling Rechtsprak verworpen

Op 29 november 1983 wordt echter door de CRVB een uitspraak geweren volgens welke de dertiende maanduitkering wèl moest worden betrokken bij de dagloonvaststelling in de zin van de WWV. De CRvB ging dus om. Met een beroep op deze uitsprask dien het bedrijt op 7 mei 1984 bij de Afdeling een verzoek om herziening in wan woomelde uitsprak.

De Voorzitter wijst dit verzoek af, "reeds ondat die witsprak (de uitspraak van de CRvB van 29 november $1983, \mathrm{RB}$ ) dateert van na het beshit van burgemeester en wethouders van Steenwijk van 5 maart 1982 en na de uitspraak van de CRvB 27 mei 1983 .'

Uit de uitspraak blijkt dat de Voorzitter pas bereid is betekenis toe te kennen am de omslag in de jurisprudentie van de CRvB vanaf het moment waarop deze verandering heeft platsgevonden. Aangezien de uitspraak van de CRvB dateent van ná de eerste uitsprak wan de $A$ fdeling kan zij geen aanleiding vormen tot herziening.

In zijn commentaar op deze uitspraak suggereert De Waard dat, ware de Afdeling ten tijde van de eerste uitspraak reeds geconfionteerd geweest met de opvatting van de CRvB, zij zich daaraan nar alle waarschijnlijkheid geconformeend zou hebben, omdat de WWVmaterie nomal gesproken tot de competentie van de CRvB behoort en de Afdeling hiermee slechts bij uitzondering te maken krijgt. De Waard wijst er bovendien op dat een dergelijke opvatting niet strookt met de theorie dat beide rechters ex tumc oordelen, mar verklaart het feit dat de Afdeling in dit geval het ex func-karakter aan de uitspraak van de CRvB ontzegt uit de omstandigheid dat zich hier twee verschillende rechters over dezelfde rechtsvraag hebben moeten uitspreken, terwijl tussen deze rechters een hiërarchisch verband ontbreekt. Hij merkt hiertoe op dat het rechtsoordeel wan de Afdeling Rechtspraak evenveel waard is als dat van de CRvB en dat het toekennen wan een ex tunc -karakter aan beide uitspraken zou leiden tot een simatie waarin tegengestelde witspraken zouden worden gedaan over de vraag hoe het "toen" rechtens was.

In deze uitspraak van de Voorzitter van de Afdeling Rechtspraak lijken de tijdstippen wan de materiele en de formele werking van de nieuwe jurisprudentiële regel santen te vallen. De nieuwe regel komt met ingang van de datum van omslag in rechtspraak van de CRvB te gelden, terwijl die nieuwe regel ook met ingang van diezelfde datum via een herzicningswerzoek kan worden geeffectueerd.

\subsubsection{CRvB 24 september $1987^{120}$}

In deze zaak wordt voor de werking in de tijd van de (nienwe) rechlspraak anngeknoopt bij het tijdstip waarop de zaak voor het eerst onder de aandacht van de rechter werd gebracht.

In geding was de toepassing door de minister van Verkeer en Waterstaat (drectoraat-generaal scheepvaart en maritieme zaken) van een correctiefactor bij de bepaling van het aantal vakantie- 
dagen woor loodsen. De in geding zijnde correcticfactor was bij brief wan 4 januari 1972 vastgesteld door de toenmalige directeu-generaal van hat loodswezen. Herower ontstond van meet af aan veel discussie. Dexe was aanleiding tot inter-departementaal overleg, hetgeen laidde tot eer standpuntbepaling van de minister van Binnenlandse Zaken bij bref van 16 oktober 1980 .

Eerst dit standpunt leidt tot een beroepszaak (naar ik aanneem tegen een met inachineming van dit standpunt opgestelde verlof-en vakantiekaart waarop de aanspraken voor het lopende jaar worden vermeld). Dit leidt uiteindelijk op 8 december 1983 tot een uitspraak wan de CRVB ${ }^{121}$, waatbij de toepassing van de gewraakte correctiefactor in strijd met het ARAR wordt varklaard. Deze laatste uitspratak is voor betrokkene in het onderhavige geding aanleiding om de minister te verzoeken de hem in thet verleden ten onrechte onthouden verlofdagen alsnog toe te kennen. Dit verzok, alsmede 700 gelijkluillende verzoeken, wordt ingewilligd over de jaren 1981, 1982 en 1983; de vakantic-aanspraken van vóo 1981 worden evenwel hiet herzien. Dit standpunt is erop gebascerd dat de zak niet eerder dan in 1981 onder de aandacht van de rechter werd gebracht.

De CRvB kan zich met dit standpunt verenigen. Dit oordeel berust allereerst op de in paragraf 3.5 reeds aangehaalde overweging dat het enkele feit dat door een rechterlijke uitspraak een bepaalde wijze van toepassen in strijd met het desbetreffende wettelijk woorschrift wordt geacht, er niet toe kan leiden dat alle aan de uitspraak voorafgegane toepassingen van dat voorschrift alsnog met die uitleg in overeenstemming zouden moeten worden gebracht. In het kader van de door de rechter toe te passen marginale toetsing acht de Raad verwolgens van doorslaggevend belang dat betrokkenen niet eerder beroep hadden ingesteld tegen de hum aan het begin van elk jaar verstrekte vakantie- en verlokkarten en er om hun moverende redenen de voorkeur aan hadden gegeven de resultaten van het overleg in de dienstcommissie en het ambtelijk overleg af te wachten. Het feit dat een van de betrokkenen de dienstleiding er reeds in een vroeg stadium schriftelijk op had gewezen dat de toepassing van de correctiefactor niet juist was, kon daaraan niet afdoen.

Uit de uitspraak blijkt niet expliciet met ingang van welk tijdstip sprake is van een onjuiste uitleg. Uit de manier waarop de uitspraak is opgebouwd maak ik echter op dat de Raad van oordeel is dat dit wan meet af aan het geval was. De Raad spreekt van de door betrokkenen ingestelde vorderingen als gericht op 'hun in het verleden ten onrechte onthouden verlofdagen" en werklaart zich vervolgens akkoord met het beleid van verweerder om op aanvraag slechts tot herziening over te gaan met betrekking tot de "ten onrechte onthouden" vakantie-aansprirken over de jaren 1981, 1982 en 1983. Deze laatste beperking ziet op de formele werking in de tijd van de uitspraak van 8 december 1983.

Hennekens ach de verwijzing wan de CRVB naar de discretionaire bevoegdheid van het bestuursorgaan in het kader van de beoordeling van de ingangsdatum van de nieuwe jurisprudentiele regel niet sterk. Aangezien de CRvB vooropstelt dat hei beginsel van de rechtszekerheid gebiedt dat de rechterlijke interpretatie niet onbeperkt terugwerkt, ligt het nat" zijn oordeel voor de hand ook het tijdstip met ingang waarvan de aanspraken volgens de (nieuwe) regel worden beoordeeld aan dit beginsel te relateren.

Van Male ${ }^{12 z}$ plaatst deze uitspraak in het kader van de strijd om voorrang tussen het algemene rechtsbeginsel van de rechtszekerheid - dat ook voor de overheid geldt en dat

122 Punt 6 van zijn noo bij CRvB 24 september 1987 , TAR 1987/257. 
gediend is bij een strikte hantering van de beroepstermijnen - en het beginsel van de rechtmatigheid van het bestuur. Voorts merkt hij op dat de CRvB weliswaar ontkent dat er een rechtsplicht is tot terugkomen van een onherroepelijk besluit dat in strijd met een algemeen verbindend voorschrift is genomen, maar dat bij de toetsing van de wijze waarop het bestuursorgaan uitvoering heeft gegeven aan zijn discretionaire bevoegdheid ook andere factoren dan deze strijd betrokken moeten worden, zoals de concrete betekenis van het rechtszekerheidsbeginsel, het belang van de ambtenaar, het (organisatorisch) belang van het administratief orgaan en eventuele rechtsverwerking. Naar zijn oordeel kan worden geconcludeerd dat het opnemen van alle vakantiedagen weliswaar ontwrichtend zou hebben gewerkt, maar dat een vergoeding in geld wel mogelijk ware geweest. Bij deze afweging acht hij het financiële belang van de overheid niet doorslaggevend: de overheid wist immers van stond af aan dat de gegrondheid van de korting door de loodsen werd bestreden en had voor het daaraan verbonden risico kunnen reserveren. Opmerkelijk is dat hij ook van oordeel is dat aan de formele rechtskracht van de jaarlijkse vaststellingen in de gegeven omstandigheden niet teveel betekenis worden kon gehecht, omdat de inbreuk daarop naar zijn oordeel eenvoudig is gegeven met het aanvaarcien van de mogelijkheid van het desverlangd terugkomen op eerdere besluiten.

Dit laatste lijkt me, ook gelet op de latere ontwikkelingen in de jurisprudentie niet goed verdedigbaar. Zoals in paragraaf 2 al is uiteengezet ziet het beginsel van de formele rechtskracht eerst en vooral op het in rechte vast staan van besluiten, in die zin dat deze als zodanig, indien zij niet in rechte zijn bestreden dan wel op een ingesteld beroep is beslist, niet opnieurw voor de rechter kunnen worden bestreden. Daarvan moet worden onderscheiden de mogelijkheid van het bestuursorgaan om op verzoek van zo'n besluit terug te komen. Het feit dat het herzieningsbesluit (of de weigering om hiertoe over te gaan) nauw gelieerd is aan het oorspronkelijke besluit, doet aan de formele rechtskracht hiervan niet af. In dit verband lijkt me juister de opmerking van Voermans ${ }^{123}$ volgens wie 'artikel 4:6 van de Awb als het ware een soort contectiemogelijkheid [vormt] op het strikte stelsell van de formele rechtskracht van besluit zoals dat in de Awb is neergelegd', zij het met die aantekening dat, zoals in par. 4.4 is uiteengezet, artikel $4: 6$ niet op de situatie van veranderde rechtspraak ziet.

Het valt op dat de Raad in deze uitspraak zeer de nadruk legt op het feit dat betrokkenen $\mathrm{er}$, zoals de Raad het uitdrukt, 'om hun moverende redenen, van af hebben gezien eerde" een procedure aan te spannen'. Men kan zich afwragen of dit wel zo redelijk was, aangezien de verlofaanspraken van meet af aan omstreden waren en voorwerp waren van ambtelijk overleg. De Raad overweegt in dit verband dat

"eiser X [welliswaar] bij brieven van 5 dec. 1977, 13 okt. 1978 en 20 febr. $1979 \mathrm{in}$ algemene termen de aandacht van de dienstleiding erop [heeft] gevestigd dat zijns inziens het toepassen van de eerdervermelde vermenigvuldigingsfactor niet juist was, maar hij heeft verder berust in de hem gedane mededelingen dat zijn brieven waren doorgezonden naar het directorat-generaal van het loodswezen en niet eerder gereageerd dan met het indlienen van zijn hierboven wermelde verzoek van januari 1984 naar aanleiding van 's Raads uitspraak van 8 dec. 1983'. 
Zoals ook in het volgende hoofdstuk aan de orde zal komen leidt een berustende houding, ook indien deze haar grondslag vindt in goed vertrouwen op de overheid, al gauw tot opschorting van de formele werking in de tijd van (nieuwe) rechtspraak. Voor deze werking is veelal doorslaggevend wanneer het geschil over de uitleg van een wettelijke bepaling voorwerp wordt van een rechterlijke procedure. Is dat eenmaal geschied, en is er sprake van een (nieuwe) jurisprudentiële regel, dan komt deze, zoals ook in de onderhavige zaak, gewoonlik algemene werking toe met een bepaalde mate van terugwerkende kracht.

\subsubsection{CRvB 21 april $1994^{124}$}

Deze zaak ziet op een verzoek om terug te komen van eerdere inschalingsbesluiten, zulks nadat de CRvB soortgelijke besluiten in cen andere procedure wegens strijd met de wet had vernietigd. Deze uitspraak is vooral van belang vanwege de eisen die de CRvB aan het besluit naar aanleiding van cen herzieningsverzoek stelt. Zo overweegt de Raad dat het

[Yvoorts] vanzelf [spreekt] dat de uitoefening van de discretionaire bevoegdheid wan [het bestuursorgatan] om van zijn eerdere besluiten terug te komen met de nodige zorgvuldigheid dient te geschieden en dat het besluit waarin de uitoefening van die bevoegdheid uitmondt van een deugdelijke motivering dient te zijn voorzien".

De Raad benadrukt in dit verband het belang van een belangenafweging en merkt tenslotte op dat

'hij voorbijgaat aan de cerst ter ziting naar voren gebrachte opvatting van eiser (het besturursorgann, RB), dat hij aan rechterlijke uitspraken slechts gevolgen behoeft te verbinden voor die gevallen waarin binnen de beroepstermijn tegen de oorspronkelijke besluiten is geopponeerd, aangezien eiser met die opvatting het bestaan van zijn hiervoor geschetste discretionaire bevoegdheid en de daarmee samenhangende verplichting om in elk afzonderlijk geval waarin om uitoefening van die bevoegdheid wordt gevraagd de nodige aandacht te besteden en de zich daarbij woordoende specifieke omstandigheden miskent".

Een zelfde indringende toetsing van de uitoefening van de discretionaire bevoegdheid blijkt uit cen uitspraak wan 31 december $1990,{ }^{125}$ die ziet op de situatie watarin achteraf, in een door cen derde tot de CRVB doorgevoerde procedure, is komen vast te staan dat ten aanzien van betrokkene, die zelf niet eerder had geprocedeerd, per 1 januari 1984 ten onrechte een bevriezing wan zijn salarisanciënniteit had platsgevonden. Mede gelet op het feit dat het hier om een duuraunsprak ging en de aanspraken van betrokkene rechtstreeks op de desbetreffende regelgeving waren terug te voeren, achtte de CRvB het bestuursorgaan gehouden met terugwenkende kracht tot de eerste dag van de maand nadat de CRvB in de zakk van de derde uitspraak had gewezen, ten behoeve van betrokkene terug te komen op de bevriezingsmaatregel. Naar het oordeel van de CRvB kon het bestuursorgaan

"toen [...] definitief was vastgesteld dat het onthouden van een periodieke verhoging in onstandigheden als die van eiser strijdg was met de toepasselijke regelgeving [...] op de hem toekomende rechtszekerheid niet langer een zo dwingend beroep doen dat hij zich op grond daarvan mocht blijven onttrekken kan zijn verantwoordelijkheid om vanaf evengenoemd moment het
salaris in overeenstemming met die regellgeving vast te stellen'. 
Deze zaak biedt weer een iets andere irvalshoek. Ze heeft betrekking op herzieningsverzoeken naar aanleiding van een eerdere uitspraak van de $\mathrm{CR} v \mathrm{~B}$ waarin de onderliggende regelgeving onverbindend werd verklaard. In deze uitspraak laat de CRvB de materiële werking van de uitspraak waarop de herzieningsverzoeken zijn gebaseerd weliswaar in het midden, maar wordt des te meer inzicht gegeven in de factoren die een rol kunnen spelen bij de bepaling van de formele werking in de tijd.

In geding is een weigering van het uitwoeringsorgaan om ten gunste wan betrokkenen terug te komen van in rechte onaantastbaar geworden beslissingen, waarbij betrokkenen was meegedeeld dat zij, gelet op het bepaalde in artikel 13, lid 1, aanhef en onder h, van de WWV niet woor uitkering in aanmerking kwamen wegens samenloop van inkomsten uit verzilverde cq. te verzilveren vakantiebonnen met hun uitkering krachtens de WWV. Ook na de inwerkingtreding wan het op 30 april 1983 krachtens lid 4 juncto lid I van artikel 17 WWV door de Staatssecretaris van Sociale Zaken en Werkgelegenheid gegeven Besluit van 28 april 1983, Stcrt. 1983, 83 bleef het uitvoeringsorgaan het bepaalde in artikel 13, lid 1, aanhef en sub h, WWV als weigeringsgrond hanteren. Dit Besluit werd evenwel bij uitspraak van 16 oktober $1985^{127}$ door de $\mathrm{CR} v \mathrm{~B}$ vernietigd.

Het uitvoeringsorgaan was van oordeel dat zijn op artikel 13 , Jid $\mathrm{l}$, aanhef en sulb $\mathrm{h}$, WWV gee baseerde wetstoepassing niet rechtstreeks door deze uitspraak werd geraakt, maar hield nietlemin rekening met de uitspraak bij de beoordeling van nadien ingekomen werzoeken om alsnog WWV-uitkering te verlenen over dagen waarover deze in het verleden in verband met vakantiebonnen was geweigerd. Op desbetreffende herzieningsverzoeken werd in beginsel positief beslist, waarbij het uitvoeringsorgaan het beleid voerde niet verder terug te gaan dan 28 april 1983, zijnde de datum van het bij de uitspraak van 16 oktober 1985 onverbindend verklaarde Besluit.

De CRvB kon zich met dit beleid verenigen. Uit de uitspraak blijkt niet met ingang van welk tijdstip de Raad de gewrakte wetstoepassing van het uitvoeringsorgaan in strijd met de wet achtte. Dit wordt vermoedelijk verklaard doordat de besluiten waarvan herziening werd verzocht niet rechtstreeks op het onverbindend verklaarde Besluit van 28 april. 1983 waren gebaseerd. De uitspraak bevat echter een tamelijk uitgebreide opsomming van de factoren die de Raad van belang acht bij de beantwoording van de vraag of de wijze waarop het uitvoeringsorgaan de onverbindendverklaring heeft geêffectueerd (de formele werking in de tijd) de rechterlijke toetsing kan doorstaan. Naast de op het rechtszekerheidsbeginsel gebaseerde overweging dat het enkele feit dat door een rechterlijke uitspraak aan een wettelijk voorschrift een bepaalde uitleg wordt gegeven of een bepaalde wijze van toepassen in strijd met dat wettelijk voorschrift wordt geacht, er niet toe kan leiden dat alle aan de uitspraak voorafgaande toepassingen van dat voorschrif alsnog in overeenstemming met die uitleg worden gebracht (zie hierwoor par. 4.5) acht de Raad de volgende factoren van belang:

a. dat betrokkenen geruime tijd hebben laten verstrijken alvorens hun betreffende verzoek aan het uitvoeringsorgaan te doen. Naar het oordeel van de Raad dient, wanneer sprake is van een in beginsel onaantastbaar geworden verhouding van betrokkenen tot 
het utvoeringsorgaan, in het algemeen een hogere toetsingsdrempel te worden overschreden naamate die rechtsverhouding langer onaangevochten heef voortbestaan;

b. dat betrokkenen bewust hebben berust in de toenmalige beshissingen;

c. dat van de "oude beslissingen" niet kon worden gezegd dat deze in alle opzichten onmiskenbaar onjuist waren:

d. dat het witvoeringsorgaan de wederzijdse belangen heeft afgewogen. In casu ging het om cenmalige kortingen, terwij] niet was aangevoerd/gebleken dat de financiele belangen wan betrokkenen zijn onderschat:

e. dat de ingangsdatum ook in die zin de beperkte toetsing kan doorstaan, dat het uitvoeringsorgaan hiermee mede de gelijkheid van behandeling met andere gemeenten heef beoogd.

4.

\section{Werking in de tijd wan ecen rechterlijke onverbindendverklaring}

\subsection{Inleiding}

De in paragraaf 3.6 besproken uitspraken zien alle op gevallen waarin het verzoek om herziening is gegrond op een rechterlijke uitsprask waarbij ofwel een werdere uitleg van een wettelijk voorschrift wordt verlaten, met andere woorden op een rechterlijk "omgaan", ofwell op een uitsprak waaruit kan worden afgeleid dat het desbetreffende bestuursorgaan gedurende soms lange tijd geen juiste uitwoering heeft gegeven aan het in geding zijnde wettelijk voorschrif. Uit de besproken uitspraken spreekt de nodige terughoudendheid met betrekking tot de toetsing van de werking in de tijd die door de desbetreffende bestuursorganen atan de (nieuwe) rechtspraak wordt toegekend. De vraag is of een zelfde terughoudendheid zich ook zal woordoen ten aanzien van uitspraken waarbij een wettelijk voorschrift onverbindend is verklaard. Er doet zich in dat geval immers een belangrijk verschil voor met een situatie waarin de rechter is omgegaan ten aanzien van de interpretatie van een wettelijk voorschrift. In hoofdstuk 1 is er al op gewezen dat wel is verdedigd dat bij een rechterlijk ongaan de nieuwe interpretatie als de altijd gegolden hebbende moet worden aangemerkt, maar dat het te ver zou voeren hieraan de conclusie te verbinden dat beslissingen die met inachtneming van de vroegere interpretatie zijn genomen 'dus' onrechmatig zijh. Dit laatste valt voor beshuten die zijn genomen op grond van later onverbindend verklaarde wettelijke bepalingen minder goed vol te houden. Bij de onverbindendverklaring constateert de rechter immers dat de wettelijke bepaling in strijd is met het recht (meestal cen 'hogere' bepaling van geschreven recht); met deze constatering komen andere besluiten die op zelfde regeling zijn gebaseerd op een wankele basis te berusten. Vaak zal vast staan dat, ware tegen deze andere besluiten tijdig in beroep gekomen, ook deze vernietigd zouden zijn.

\subsection{De winegverguningszaken}

Voor wat de nationale dimensie van deze problematiek betreft kunnen als voorbeelden bij uitstek dienen de uitwegvergunningszaken die zijn gevolgd op de bekende uitspraak van de Afdeling rechtspraak in de zaak Maastrich $L^{12}{ }^{28}$ In deze laatste zaak merkte de Afdeling CLR. 
het besluit van de gemeente Maastricht tot het heffen van een geldbedrag als voorwaarde voor het verkrijgen van een vergunning tot uitwegen van een particulier terrein op de openbare weg aan als een beschikking in de zin van de Wet Arob, om vervolgens - in afwijking van de toenmalige jurisprudentie van de Hoge Raad - deze beschikking in strijd te achten met de Wegenwet. Het gevolg van deze zaak was dat ook anderen, die meenden ten onrechte een soortgelijke heffing te hebben betaald juridische stappen ondernamen om het bedrag terug te krijgen. Een voorbeeld van een dergelijke terugvorderingszaak door een derde biedt de uitspraak van de Afdeling Rechtspraak in De Bilt $H^{129}$ Deze uitspraak is een vervolg op De Bilt I, ${ }^{130}$ waarin de 'Bijdrageregeling ontsluiting particulier bouwterrein' van de gemeente conform de uitspraak in Maastricht l onverbindend werd verklaard.

In De Bilt II is appellant van oordeel dat de onverbindendheid van de Bijdrageregeling geacht moet worden terug te werken tot de datum waarop de regeling in werking is getreden. Appellant stelt beroep in - niet opnieuw tegen de oorspronkelijke beslissing van B\&W om de heffing op te leggen - maar tegen "de weigering van het nemen van een besissing, inhoudende een herzieuning van voomoemde beslissing op grond van gewijzigde omstandigheden .

B\&W gaan evenwel uit van de formele rechtskracht van de oorspronkelijke beslissing, ook al ontbreekt, naar achteraf is gebleken, aan de heffing een rechtsgeldige grondslag. Nu appellant heeft nagelaten de beroepsgang te volgen waarin de Bijdrageregeling voorzag, is de beslissing waarbij de heffing werd vastgesteld onherroepelijk (art. 5 aanhef en onder d Wet Arob) geworden. B\&W hadden het bezwaarschrift van appellant dan ook niet-ontvankelijk verklaard; de weigering van het college om over te gaan tot herziening van de oorspronkelijke beslissing zou immers een (zelfstandig) rechtsgevolg ontberen.

De Afdeling gaat aan beide betogen voorbij. Appellant wordt weliswaar niet-ontvankelijk verklaard, maar om een andere reden dan door het gemeentebestuur was geopperd. De Afdeling merkt de beslissing waarbij $B \& W$ afwijzend hebben beschikt op het verzoek om terugbetaling aan als een rechtshandeling naar burgerlijk recht. Zij komt tot deze conclusie langs de volgende redenering. Allereerst refereert de Afdeling aan het betoog van appellant dat aan de vordering tot een financiële bijdrage een rechtsgeldige titel ontbrak (appellant had immers gesteld dat de onverbindendverklaring in De Bill I terug zou moeten werken tot de datum waarop de regeling in werking was getreden). Voorts overweegt de Afdeling echter dat haar niet is gebleken van een publiekrechtelijke regeling waarop het verzoek on terugbetaling kan worden gebaseerd. Op grond hiervan merkt zij de weigering van B\&W om tot terugbetaling over te gaan aan als een 'weigering een vordering op grond van art. 1395 BW te erkennen', en derhalve als een weigering tot het verrichten van een rechtshandeling naar burgerlijk recht. ${ }^{3 !}$

129 ARRS 25 mei 1981, AB 1981, 516 m.nt. J.A.B.; Gst. 6686; BR 1981, p. 780. De woordketize in cursief is afkomstig van annotator Borman. Zie verder ARRS 27 maart 1981, AB 1981, $323 \mathrm{mn} n \mathrm{nt}$. JA.B.; Gst. 6669 (Maastricht II).

130 ARRS 8 juni 1978 , Gst. nr. 6514.

131 Uit punt 8 van zijn noot onder HR 16 mei 1986, NI 1986,723 is op te maken dat Scheltema, gelet op de wijze waatop de vordering in De Bilt II was geformuleerd, van oordeel is dat de Afdeting het beroep wel ontwankelijk had moeten verklaren. Voorts dient erop te worden gewezen dat deze zaak naar huidig recht een ander werloop zou hebben gehad. Met de ekkenning varn de appellabiliteit van het zelfstandig schadebesluit in de procedure voor de bestuursrechter had woor betrokkene tegen de weigering van $B \& W$ de onverschuldigd betalde bijdrage terug te betalen rechtstreeks beroep bij de bestuursrechter opengestaan. De hier besproken rechtspraak blijft echter actueet waar het gaat on do vraag in hoeverre een dergelijke vordlering kans van slagen zou hebben. 
De uitspraak is interessant, omdat het dilemma waarvoor rechters zich in zaken als deze zien geplaatst er zo duidelijk uit spreekt. Immers, in materieelrechtelijk opzicht lijkt appellant gelijk te krijgen; de Afdeling ontkent immers niet dat aan de betaling een rechtsgeldige titel ontbrak. Anders gezegd: voor wat de materiele werking betreft komt aan de met de uitspraak in Macstricht I ingezette nieuwe jurisprudentie van de Afdeling terugwerkende kracht toe, al blijkt uit de uitspraken niet met ingang van welk tijdstip. Tegelijkertijd stuit het beroep echter af op procedurele gronden. De formele werking van de nieuwe jurisprudentie - de mogelijkheid om alsnog, met terugwerkende kracht, daadwerkelijk rechtsherstel te verkrijgen - kon niet in een procedure voor de Afdeling worden afgedwongen. Sommigen hebben daar vrede mee, zoals Borman die in zijn noot onder de uitspraak opmerkt dat 'het geven van terugwerkende effecten aan rechterlijke uitspraken onbegonnen werk [is]'. De vraag die restte was of de burgerlijke rechter daar ook zo over zou denken.

\subsection{De aanullende rol van de burgerlijke rechter}

In zijn noot onder de uitspraak van de Afdeling in De Bilt II liep Borman al enigszins vooruit op deze wraag, waar hij ten aanzien van een eventuele civiele procedure strekkende tot terugvordering van de onverschuldigd betaalde heffing opmerkte:

'Het zal wiet gaaln on een vordering tot vemietiging van de tweede beslissing maar om een vordering uit onverschuldigde betaling. Kern wan eisers betoog zal zijn dat de heffing ten onrechte is opgelegd. Dan zal de gewone rechter in aanmerking kunnen nemen dat die heffing niet is aangevochten met behulp van de daarvoor openstaande administratiefrechtelijke voorziening, bestaande in een beroepsgang bij de gemeenteraad gevolgd door een beroepsgang bij de Afd. rechtspraak. Hij zal, onder verwijzing naar dat feit, kunnen stellen dat de juistheid van de bewering dat de heffing ten onrechte is opgelegd bij hem niet aan de orde kan komen en dat van de rechtmatigheid van de heffing moet worden uitgegaan".

Deze opmerkingen brengen ons terug bij het leerstuk van de formele rechtskracht. Op deze zaak toegepast zou dit leerstuk hierop neerkomen dat de burgerlijke rechter zal hebben uit te gaan van de rechtmatigheid van de heffing van de bijdrage, nu de belanghebbende heeft nagelaten de administratiefrechtelijke beroepsgang tegen het besluit to heffing te volgen. De impliciete gevolgtrekking van deze redenering is dat aan de rechterlijke constatering van de onrechtmatigheid van de aan het beshit ten grondslag liggende algemene regeling iedere vorm van derdenwerking moet worden ontzegd. Van terugbetaling zou alleen sprake kunnen zijn, indien steeds weer in een afzonderlijke administratieve procedures de onrechtmatigheid van het heffingsbesluit zou zijn vastgesteld, gevolgd door een op grond van deze vaststelling gevolgde procedure bij de burgerlijke rechter. In alle andere gevallen zou de onverbindendheid van de bijdragestelsels voor reeds voldane heffingen zonder gevolg blijven.

De spanning tussen wat het materielle recht vereist en het procedurele recht belemmert wordt hier hoog opgewoerd. Té hoog, als de belanghebbende al te zeer door het bestuur het procedurele rad voor ogen is gedraaid, naar bleek uit het arrest Heesch/Van de Akker. ${ }^{132}$ Té hoog ook kennelijk voor een enkel gemeentebestuur, zoals dat van de gemeente Didam, dat aan de uitspraken van de Afdeling in Maastricht I en De Bilt I in volle omvang derden- 
werking toekende door te voorzien in een begrotingswijziging die het mogelijk maakte de inmiddels geheven bijdragen terug te betalen. Nadat GS van Gelderland aan deze begrotingswijziging hun goedkeuring onthouden hadden, omdat de uitspraken wan de Afdeling geen rechtsgevolgen voor het Didanse stelsel zouden hebben, ging de Kroon alsnog tot goedkeuring over. De Kroon gaf als zijn oordeel te kennen dat "gelet op evenbedoelde uitspraken wan de Afd. rechtspraak RvS, de gemeenteraad in redelijkheid tot restitutie van de na 1 sept. 1977 ontvangen bijdragen heeft kunnen besluiten". ${ }^{33}$ Van algemener betekenis is voorts de waarschuwende noot van Van der Net, wanneer hij opmerkt dat:

'Indien overheidsinstanties zich al te star gaan opstellen bij het volgen van een rechterlijke uitspraak in hoogste instantie, het wel zeer moeilijk [wordt] een verantwoorde, de burgers aansprekende rechtsstat en rechtstoepassing overeind te houden".

Toen de Hoge Raad in het voor de verdeling van de rechtsmacht tussen de burgerlijke en administratieve rechter cruciale arrest Heesch-Van de Akker uiteindelijk uitspraak deed over een terugvordering van een in het kader van het uitwegvergunningsstelsel van de gemeente Heesch onverschuldigd betaalde heffing, liep het bovendien anders af dan Borman had voorzien. De Hoge Raad stelde de door Borman genoemde rechtsregel weliswaar als uitgangspunt voorop, maar formuleerde hierop de in paragraag 2.1 behandelde uitzondering, die hij ten aanzien van het in de gemeente Heesch gehanteerde stelsel van toepassing achtte. Krachtens deze uitzondering kon Van de Akker de rechtmatigheid van de grondslag van de heffing, gelegen in een brief van 13 juni 1977, welke brief, gelet op de jurisprudentie van de Afdeling rechtspraak als een beschikking in de zin van de Wet Arob moest worden aangemerkt, alsnog voor de burgerlijke rechter in geding brengen. Met inachtneming van de jurisprudentie van de Afdeling rechtspraak oordeelde de Hoge Raad vervolgens dat de heffing een rechtmatige grondslag ontbeerde, zodat de gemeente allsnog verplicht werd de heffing aan Van de Akker terug te betalen.

Sommigen hebben dit arrest aldus opgevat dat hierdoor aan de uitspraak van de Afdeling bestuursrechtspraak in Maastricht I terugwerkende kracht werd toegekend. ${ }^{134}$ Deze opvatting berust echter op een misverstand. Allereerst zou het met de (grond)wettelijke verdeling van de rechtsmacht in strijd zijn als de burgerlijke rechter zou kunnen voorzien in overgangsrecht met betrekking tof uitspraken van de bestuursrechter. Voonts werd in de uitspraak van de Hoge Raad nu juist niet ingegaan op aspecten van rechterlijk overgangsrecht, ondanks het feit dat de eerste conclusie voor het arrest ${ }^{135}$ vrijwel geheel aan dit vraagstuk was gewijd. Juist omdat in dit arrest de formele rechtskracht en de uitzondering hierop centraal stonden, kon aan de overgangsrechtelijke aspecten van Masastricht I worden voorbijgegaan. Wat echter wèl van belang is, is dat Van de Akker, ondanks lhet feit dat hij geen beroep bij de bestuursrechter had ingesteld, een rechtsmiddel werd aangereikt waarmee hij alsnog daadwerkelijk rechtsherstel kon verkrijgen. Anders gezegd, in de in dit hoofdstuk gehanteerde terminologie komt de met de uitspraak van de Afdeling in Macs-

\section{$133 \mathrm{~KB} 8$ januari 1985, AB 1985, 266.}

134 Dat was bijw. de opvatting van de gemeente Madatricht toen zij in het kader van haar bes luitworming over een aantal op de uitspraak in Maastrich! I gebaseerde vorderingen uit onverschuld igte betaling met de uitspraak van de Hoge Raad werd geconfronteed; zie de aan mij in hel kader van dit onderzoek door de gemeente overgellegde Raddsstukken 1987, volgno. 485 inzuke de Afwikkeling Bijdrageregeling ontsluiting particulier bouwterrein.

135 Conclusie van $A \sim G$ Franx. 
trich I gevestigde rechtspraak. jegens Van de Akker niel alleen materiele werking toe. mar tevens formele.

Scheltema legt overigens een rechistreeks verband tussen de door de Hoge Raad op het begingel van de formele rechiskracht aangenomen wizondering en de hieruit voortvoetende uitbreiding van derechtsbescherming door de burgerlijke rechter enerzijds, en het ontbreken van voldoendeadministratiefrechtelijke voorzieningen tegen de besluiten warbij de heffingen werden opgelegd, anderzijds. Hij plaatst het vraagstuk aldus terug in het aloude kader van de aanwullende rechtsbescheming door de burgerlijke rechter. ${ }^{137}$ Naar zijn oordeel thadden twee bestuursrechtelijke voorzieningen mogelijk uitkomst kunnen bieden. Allereerst wijst hij op de krachtens artikel 9, lid 4, Wet Arob (thans artikel 6:11 Awb) bestande mogelijkheid om na verloop van de beroepstermijn zo spoedig als dit redelijkerwijs verlangd kon worden alsnog in beroep te komen (verschoonbaarheid van de overschrijding van de beroepstermijn). Daamaast wijst hij op de in dit hoofdstuk uitwoerig aan de orde gestelde mogelijkheid om het bestuursorgaan te verzoeken terug te komen van een eerdere onjuiste beschikking. Volgens Scheltema zal de Hoge Raad ook alleen dan een uitzondering op de formele rechtskracht willer aannemen als vast stat dat geen van deze beide bestuurstechtelijke mogelijkheden openstaat, ${ }^{138}$ hetgeen in het geval van Van de Akker het geval was. Een beroep op artikel 9, lid 4, Wet Arob kwam hem niet toe, ondat de termijn al lang was verlopen en het niet in het belang is van de rechtszekerheid de termijnoverschrijding te pardonneren. Voorts weigerde de Afdeling volgens vaste jurisprudentic te oordelen over een verzoek on terugbetaling van de heffing, ook, zoals bleek

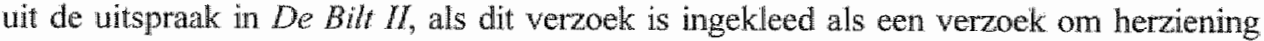
van het besluit waarbij de heffing was opgelegd. Volgens Scheltema moest de burgerlijke rechter, krachtens zijn aanwullende rol, dan ook wel een oplossing zoeken voor het geval het ontbreken van voomoemde voorzieningen tot klemmende bezwaren zou leiden.

136 Overigens bevatten de mij door de gemeente Maastricht overgelegde stukken enige interessante beschouwingen over het rechterlijk overgangsrecht. Uit Raadstukken 1978 , volgno, 561 blijkt dat de gemeente zich aanvankelijk op het standpunt stelde dat de in de uitspraak van de Afdeling in Moastrich $T$ uitgesproken onverbindendverklaring exclusiewe werking toekwam en dus niet kon raken aan vóór I september 1977 opgelegde heffingen. Naar het oordeel van de gemeente luidde tot deze datum het recht zoals dat door de Hoge Raad in het Hongeloon-arrest was uitgesproken.

Voorts bilikl vit de radsnotulen $(1978$, wolgno. 561, p. 3) dat de gemeente wel degelijk oog had woor de rechtsposilie wan degenen aan wie vón 1 juli 1976 (de datum wan inwerkingtreding van de Wet Anoby een heffing was opgetegd en die dus nimmer in de gelegenheid waren geweest de heffing ten principale aan de rechter voor te leggen. Zo bleak de gemente bereid besluiten die vóór 1 jull 1976 waren genomen in herowerweging te nemen, opdat de besluiten die naar aanleiding hiervan zouden worden genomen alsnog door de bestuursechter zouden kumnen worden getoetst. Zoals in deze paragraal al nader is aangegeven heet de Affeling rechtspraak deze mogelikkheid in, onder meer ${ }_{\text {De }}$ Bith II, afgeschoten.

Uiteindelijk heeft de radd van de geneente Maastrich besiloten de bijdrage in alle gevallen, ook als de civiellechtelijke verjaringstermijn al wass verlopen, terug te betalen, zij het zonder vergoeding vara rente (Handelingen 6 oktober 1987 , nr. 14 ).

137 Zie de putten 5 t/m 10 van zijn noot onder HR 16 mei 1986, NJ 1986, 723.

138 Voor wat het beroep de verschoonbaarheid van de termijnoverschrijding volgt dit uit rechtsoverweging 3.1 .3 van het arrest $H e e s c h-V a n$ de Akher zelf. Voor wat de mogelijke verschoonbasheid van de temijnoverschrijding blijkt dit volgens Scheltema wit het hiervoor, in par. 2.1 . besproken Hej- en Bocicop-arrest (HR 4 februari 1983 , NJ 1985,21 ); zie punt 9 van zijn NI-noot onder Heesch-
Was de Akke* 
Van de doot Scheltema genoemde omstandigheden die aanleiding zouden kwnen zijn tot het aannemen van klemmende bezwaren zijn er voor dit onderzoek met name twee van belang, te weten de situatie waarin de betrokkene niet eerder (bij de bestuursrechter) in beroep is gekomen, omdat hij niet wist en ook niet behoefde te weten dat dit kon, zoals in het arrest Heesch-Van de Akker zelf, waarin Van de Akker niet werd verweten dat hij bij het kiezen van het juiste rechtsmiddel geen rekening heeft kunnen houden met, naar het oordeel van de Hoge Raad, niet te voorziene ontwikkelingen in de jurisprudentie. Daarnaast wijst Scheltema op de situatie waarin de betrokkene niet zozeer vernietiging van de gebrekkige beschikking verlangt, maar uitsluitend schadevergoeding. Deze laatste optie is in het bijzonder voor dit onderzoek van belang. $Z \mathrm{ij}$ is, zoals Scheltema ook aangeeft, alleen denkbaar bij het aannemen van een uitzondering op het beginsel van de formele rechtskracht - dit beginsel vereist immers dat de onrechtmatigheid van een beschikking door de bestuursrechter wordt vastgesteld en dat de burgerlijke rechter aan dit oordeel is gebonden. Ze kan echter uitkomst bieden voor die gevallen, waarin de rechter tegemoet wil komen aan justitiabelen die zijn benadeeld door de toepassing van, achteraf onverbindend geoordeelde, wetgeving, zonder dat dit noodzakelijkerwijs moet leiden tot een vernietiging van eerder, op grond van die wetgeving genomen beschikkingen. Een dergelijke optie zou met name in een behoefte kunnen voorzien naarmate de door de desbetreffende wetgeving geschonden norm een fundamenteler karakter draagt. ${ }^{139}$

Benadrukt moet echter worden dat dergelijke oplossingen eerst dan kunnen worden over wogen als zich dusdanige omstandigheden voordoen dat er aanleiding is een uitzondering op de formele rechtskracht aan te nemen. Het is zeker niet zo dat de burgerlijke rechter in zijn algemeenheid kan voorzien in rechtsherstel ten aanzien van beschikkingen, waaronder het opleggen van heffingen, die op grond van, achteraf onverbindend verklaarde, regelgeving zijn genomen. Dit blijkt uit het arrest $V_{u}$ ihop ${ }^{100}$.

Vulhop is exploitant van een rondvaartbedrijf in Amsterdam. Van 1 januari 1979 tot en met 31 maart 1980 betaalt Vulhop aan de gemeente Amsterdan de door hem ingevolge de Verordening Watertoeristenbelasting verschuldigde bellasting op aangifte. In deze periode maakt hij geen gebruik van het hem toekomende beroepsrecht ingevolge de Algemene wet inzake rijksbelastingen (AWR). Dan gaat Vulhop echter in beroep bij het Gerechtshof te Amsterdam tegen de door them over de maand april 1980 voldane aanslag. Nadat zijn beroep door het Hof is verworpern, heeft hij vervolgens succes bij de belastingkamer van de Hoge Raad, dic de Verordening Watertoeristenbelasting onverbindend acht. In een nieuwe procedure, nu bij de burgerlijke rechter, vordert Vulhop terugbetaling van de door hem voor 1 april 1980 voldane belasting, primair op grond van een onrechtmatige daad van de gemeente, secundair op grond van onverschuldigde betaling. Rechtbank en Hof wijzen deze wordering af.

Conform het in Heesch-Van de Akker geformuleerde beginsel van de formele rechtskracht stelt de Hoge Raad voorop dat, nu tegen de vóor 1 april plaatsgevonden hebbende heffingen de met voldoende waarborgen omklede rechtsgang ingevolge de AWR heefi opengestaan en deze niet is gebruikt, de burgerlijke rechter ervan dient uit te gaan dat de aanslagen zowel wat hun wijze van tot stand komen als wat hun inhoud betreft in overeen-

139 Hoe voontitziend de blik van Scheltema was zal blijken in de in par. 2.3 .2 van hoofdstuk 5 te behan delen europeesrechtelijke jurispredentie.

140 HR 16 oktober 1992, NJ 1993, 638 m.nt MS; AB 1993, 40 m.nt FHvdB; Gst. 6962, nr. 5, p. 164 m.nt $\mathrm{HH}$. 
stemming zijn met de desbetreffende wettelijke voorschriften en algemene rechisbeginselen. Nu hij dit niet heeft gedaan kan Vulhop niet met vrucht bij de burgerlijke rechter aanvoeren dat de heffing ongeldig is en de geheven belasting hem om die reden als onverschuldigd betald zou moeten worden gerestitueerd. Evenmin kan hij met vrucht aanvoeren dat de heffing onrechtmatig is en dat de geheven belasting hem bij wege van sclradevergoeding zou moeten worden terugbetaald.

Het belang van de uitspraak voor dit onderzoek ligt echter in het bijzonder in de volgende overweging, die een categorische uitsluiting bevat van de derdenwerking van een onverbindendverklaring:

"Anders dan [het middel] aanvoent, doet aan hetgeen hiervoor [...] omtrent een beroep op onrechtmatigheid van de heffing is overwogen, niet af dat de Verordening Watertoeristenbelasting 1978 in de voormelde witspraak van de belastingkamer [...] onverbindend is geoordeeld. De bindende kracht van een zodanige uitspraak is - daargelaten de overtuigende werking die daturan in andere zaken mag worden verwach - naar haar aard beperkt tot her in de desbetreffende belastingzack aan de belastingrechter voorgelegde geschil. Dit brengt mee dat die uitspraak niet tot gevolg heeft dat de burgerlijke rechter [...] ter zake van de in de onderhavige zaak aan de orde gestelde heffingen over een eerdere periode wèl zelf mag beoordelen of zij onrechtmatig zijn of [...] die onrechtmatigheid op grond van voormelde uitspraak zonder meer zou moeten aannemen.' (mijn cursivering, RB)

Bovendien stelt de uitspraak buiten twijfel dat de onverbindendverklaring door de belastingrechter geen bijzondere omstandigheid oplevert die op het beginsel van Heesch/Van de Akker een uitzondering maakt. Zonder kritiek bleef deze uitspraak echter niet. Zo werd onder andere in twijfel trekken of de leer van de formele rechtskracht wel op gevallen als de Vulhop-Zaak van toepassing is. Zo betwijfeli Van der Burg ${ }^{141}$

'of het standpunt dat de Hoge Raad in dit arrest heeft ingenomen well zonder meer voortvloeit uit de 'leer" van de formele rechtskracht. Die leer dient immers om de competentie van administratieve rechters te beschermen. Wanneer de wetgever een administratieve rechtsgang heeft gecreeserd, dan moet de burgerlijke rechter die beroepsgang niet ondermijnen door ma afloop van de termijn toch nog wan de zaak kennis te nemen".

\section{Waarna hij opmerkt dat}

'in het onderhavige geval de toewijzing van de vordering de competentie van de administratieve rechter niet in gevaar gebracht [zou]] hebben. Integendeel de burgerlijke rechter zou niet anders gedaan hebben dan het oordeel dat de verordening onverbindend is, executeren. Door de uitspraak van de belastingkamer van de Hoge Raad is de burgerlijke rechter eclairé, Hij weet dat de verordening onverbindend is en derhalve de hefting van belasting op basis van die verordening onrechtmatig'. ${ }^{143}$

142 Zie voor een overeenkomstige, meer op proceseconomische overwegingen gebaseerde opvatting, maar dan in het kader van de anth ARRS I september 1977, AB 1977, 366 m.nt. v.d.V. (Maastrich I) te werbinden gevolgen: Ten Berge/Stroink. Administratieve Rechtspraak Overheidsbeschikkingen, $\mathrm{V}$, p. 875 en 878 , waar zij betogen dat de 'burgerlijke rechter sinds I september 1977 weet dat de Afd, rechtspraak hethingen als die bedoeld in Afd. rechtspraak 27 maart 1981 in strijd met de wet acht, en dat het daawom niet nodig is eerst de hele Arob-rechtsgang te gaan aworens de burgerlijke rechter te
adizren met een vordering wit art. 1395 lid $1 \mathrm{BW}$. 
Om daar meteen op te laten volgen:

"Ik neem aan dat de onverbindendverklaring door de administratieve rechter niet betekent dat de verordening door de rechterlijke uitspraak vernietigd wordt! De verordening was al onverbindend De uitspraak wan de belastingrechter constateert slechts de onverbindendheid en werkt ex twhc'. (mijn cursiwering, RB)

Hennekens ${ }^{143}$ acht de benadering van de Hoge Raad in de zaak $V_{u}$ thop onverenigbaar met 's-Raads overwegingen in het Pocketbooks II-arrest ${ }^{144}$ en het Van Gelder-arrest ${ }^{145}$. In dit laatste arrest had de Hoge Raad overwogen:

'De Staat handelt onrechtmatig en is, wamneer aan de overige vereisten van artikel $1401 \mathrm{BW}$ is voldaan, aansprakelijk wanneer hij een met een hogere regeling strijdig en mitsdien onverbindend voorschrift uitvaardigt en op grond wan dat voorschrift belasting heft".

Hij wijst erop dat uit de hierboven aangehaalde overwegingen uit het Vulhop-arrest zou blijken dat de Hoge Raad niet zonder meer de onrechtmatigheid van de verordening wenst te aanwaarden.

Mijns inziens moet de terughoudender positie van de Hoge Raad in de Vulhop-zaak verklaard worden uit een streven om de terugwerkende effecten die van de bestempeling van wetgeving als onrechtmatige daad uitgaan, te beperken. De wijze waarop de Hoge Raad dit tracht te bereiken overtuigt echter niet. In de eerste plats staat ze staat op gespannen voet met de "normale" rechtspraak van de burgerlijke rechter inzake onrechtmatige daad, volgens welke de schadevergoedingsplicht een aanvang neemt wanaf het moment waarop de schade die het gevolg is van de onrechtmatige daad intrad. Het zal duidelijk zijn dat in het geval van Vulhop dit moment vóór april $1980 \mathrm{lag}$, indien althans mag worden uitgegaan van de opvatting van de Hoge Raad in het Van Gelder-arrest dat het uitvaardigen van een onverbindend voorschrift en het op grond daarvan belasting heffen een onrechtmatige daad in de zin van artikel 6: $162 \mathrm{BW}$ inhoudr.

Voorts doet de hantering van de Heesch/Wan de Akker-formule in gevallen als deze wat merkwaardig aan. Volgens deze formulering moeten immers de vóór april 1980 plaatsgevonden hebbende heffingen geacht worden in overeenstemming te zijin met de desbetreffende wettelijke woorschriften, terwijl tegelijkertijd vast staat dat deze 'desbetreffende wettelijke voorschriften' zelf onverbindend zijn. Een dergelijke redenering overtuigt niet. ${ }^{146^{6}}$

143 H.Ph.J.A.M. Hennekens, De Hoge Raad en de formele rechtskracht, De Geneentestem 6962, p. 153.

144 HR 24 januari 1969, NJ 1969, 316; Ars Aequi (18) 1969, p. 266-269 m.nt. M.T. en G.

145 HR 9 mei 1986, AB 1986,429 m.nt. FHvdB; NJ 1987, 252.

146 Maar zal, naar in par. 2.2. van hoofdstuk 5 zal blijken, door de Hoge Raad ook in Europeesrechtelijke context worden gehandhaafd. 
Uit de in dit hoofdstuk besproken jurisprudentie kan worden geconcludeerd dat de terugwerkende effecten van verandering van rechtspraak gering zijn. Dit blijkt wit de volgende factoren:

1. Het beginsel van de formele rechtskracht staat erin beginsel aan in de weg dat besluiten, waarvan de onrechtmatigheid op grond van latere ontwikkelingen in de jurisprudentie komt vast te staan, opnieuw in een procedure voor de rechter kunnen worden aangevochten.

2. Het rechtsmiddel van de herziening van bestuursrechtelijke uitspraken (artikel 8:88 Awb) biedt nauwelijks mogelijkheden voor herziening op grond van wijzigingen in de jurisprudentie.

3. De meest gangbare weg om rechtsherstel op grond van veranderde rechtspraak te verkrijgen is het indienen van een herzieningsverzoek bij het orgaan dat de oorspronkelijke beslissing heeft genomen. Dit middel is te beschouwen als een buitenwettelijke voorziening, ondat artikel 4:6 van de Awb niet op deze situatie ziet.

4. Als de onder 3 genoemde voorziening feitelijk ontbreekt, doordat het bestuursorgaan stelselmatig weigert hiervan gebruik te maken en dit door de bestuursrechter wordt gesauveerd, kan dit voor de burgerlijke rechter in een voor hem aangespannen procedure aanleiding zijn door het aannemen van een uitzondering op de formele rechtskracht alsnog rechtsbescherming te bieden.

5. De naar aanleiding van een verzoek om herziening genomen besluiten worden door de bestuursrechter terughoudend getoetst. Daarbij nam de CRvB tot voor kort een iets ruimer standpunt in dan de Afdeling bestuursrechtspraak van de Raad van State (en voorheen de Afdeling rechtspraak van de Raad van State) en wel in die zin dat de

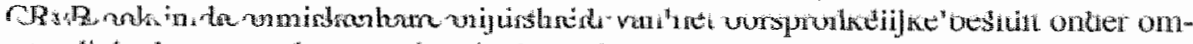
standigheden een reden voor herziening achtte gelegen.

6. Het ook woor de overheid geldende beginsel wan de rechtszekerheid belet in elk geval dat het bestuursorgaan bij verandering van rechtspraak verplicht zou zijn alle, nog onder de 'oude' rechtspraak genomen, besluiten te herzien.

7. Het niet gebruik maken van de bevoegdheid om oude besluiten in het licht van een nieuwe rechtsopvatting te herzien moet het resultaat zijn van een beleidskeuze. De $\mathrm{CRVB}$ toetst of dit beleid de resultante is van een redelijke belangenafweging. Een louter financieel argument om niet tot herziening over te gaan volstaat niet.

8. Uit de rechtspraak komt naar voren dat een onderscheid moet worden gemaakt tussen de vaststelling van een tijdstip met ingang waarvan een bepaalde wetstoepassing onrechtmatig moet worden geacht (in dit hoofdstuk aangeduid als de materiële werking van de veranderde rechtsopvatting) en het tijdstip met ingang waarvan door derden (zij die geen partij waren bij de uitspraak waarbij de veranderde rechtsopvatting werd gevestigd) aan de verandering van de rechtsopvatting daadwerkelijk rechten kunnen 
ontlenen (in dit hoofdstuk aangeduid als de formele werking van de veranderde rechtsopyatting). Deze laatste werking wordt geheel beheerst door het toepasselijke procesrecht.

9. De tijdstippen van aanvang van de materiële en de formele werking zullen minder ver uit elkaar liggen al naar gelang de verandering in de rechtspraak stoelt op een verandering in de rechtsopvattingen, die ook voor het desbetreffende bestuursorgaan reeds geruime tijd kenbaar was. ${ }^{47}$ In een dergelijke situatie boet het ook voor de overheid geldende rechtszekerheidsbeginsel aan kracht in.

10. Een bijzondere situatie ontstaat wanneer om herziening is verzocht naar aanleiding van een (gewijzigde) rechtsopvatting die haar grondslag vindt in rechtspraak van een andere (bestuurs)rechter. In de in dit hoofdstuk onderzochte gevallen treden zowel de materiële als de formele werking van de nieuwe rechtsopvatting in met ingang van de datum waarop de rechtspraak van de andere bestuursrechter werd gevestigd. ${ }^{4.8}$

147 Zie de in par. 3.6.1 behandelde dagloonzak (CRvB 31 december 1984, AB 1985, 348, m.nt. J.H. Smits; RSV $1985 / 126$ m.nt. H.J. Haverkamp).

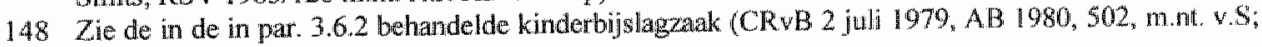
RSV 1979/246). 



\section{Hoofdstuk 3}

\section{Rechtsverkrijging door rechtstreekse toepassing van het internationale recht, inleiding}

1. Inleiding

Werd de in dit boek centraal staande vraag naar de terugwerkende kracht van verandering van rechtspraak in het tweede hoofdstuk besproken in een louter nationaalrechtelijke context, in de volgende hoofdstukken zal dezelfde vraag worden besproken in het kader van de doorwerking van het internationale recht. Zoals in de paragrafen 4 en 5 van hoofdstuk 1 al is vermeld wint de vraag naar de consequenties van de materiële terugwerking van verandering van rechtspraak aan belang indien deze berust op de constatering achteraf, dat aan nationale wetgeving vanaf een in (een soms ver verleden liggend tijdstip) in strijd is geweest met het internationale recht. Deze vraag is, gelet op het supra-nationale karakter hiervan met name pregnant, wanneer tot strijd met het EG-recht is geconstateerd. Zij wordt in de volgende paragraaf aan de hand van een aantal voorbeelden nader geillustreerd, waarna in paragraaf 1.3 de verdere opzet van de behandeling van dit vraagstuk uiteen zal worden gezet.

\section{1 $\quad C R V B 26$ november $1970^{\prime}$}

Deze zaak ziet op de volgende casus:

Met toepassing van artikel 28 van de Verordening nr. 3 van de Raad van de Europese Gemeenschappen inzake de saciale zekerheid van migrerende werknemers heeft het bestuur van de Sociale Verzekeringsbank (SVB) bij besluit van 20 decernber 1965 aan betrokkene met ingang wan 1 augustus 1.964 een ouderdomspensioen op grond van de AOW toegekend. Op dit pensioen heeft de SVB een aftrek toegepast ter hoogte van een aan betrokkene krachtens Duitse wetgeving toegekend Altersruhegeld. Tegen dit besturt heeft betrokkene geen rechtsmiddel aangewend, zodat het in rechte onaantastbaar is geworden.

Naar later, in een aantal "nieuwere principiele arresten van het $\mathrm{HvJ} \mathrm{EG}^{2}$ (de woorden zijn van de CRvB zelf, RB), blijkt, is in het geval van betrokkene deze aftrek ten onrechte toegepast. Voor betrokkene is dit aanleiding de SVB te verzoeken terug te komen wan haar eerdere beslissing. De SVB woldoet aan dit verzoek, maar laat het recht op de nieuwe wikering niet verder terugwerken dan tot $\rrbracket$ juli 1968 , zijnde de eerste dag van de kalendermaand volgende op de uitspraak van de CRvB waarin deze zich aansluit bij de nieuwe rechtspraak van het $\mathrm{HWJ}_{\mathrm{EG}}{ }^{3}$ Betrokkene is evenwel van mening dat de herziening van de uitkering dient terug te werken tot I augustus 1964, de datum waarop het hem ingevolge de AOW ioekonende pensioen was ingegaan.

2 Het gaat hier om een zestal arrester gewezen op 5 julli, 30 november en 12 an 13 december 1967. respectievelijk in de zaken $1-67$ (RSV 1969/1) 2-67 (RSV 1969/2), 9/67 (RSV 1969/4), 22/67 (RSV 1969/6), 111/67 (RSV 1969/9) en 12-67 (RSV 1969/10). 
Inzet van deze zaak is wisluitend de vraag tot welke datum de opheffing van de tevoren toegepaste korting geacht moet worden tenug te werken. Evenals in het vorige hoofustuk gaat thet in deze zaak on cen beroep dat gericht is tegen een beslissing inzake de herziening van een in rechte onaantastbaar geworden beslissing. Anders dan in het vorige hoofdstuk is het beroep gebaseerd op een vermeende strijdigheid tussen de Nederlandse uitworingspraktik van de AOW en regels wan gemeenschapsrecht. De CRvB overweegt.

"de op dit pensioen sinds deze datum toegepaste korting berustte op een beslissing van gedaagde; $[. .$.$] , welke in rechte onatntastbar was geworden;$

dat het bij dis beslissing len ook by zeer wele andere bestissingen wen anzien wan andere verzekerdon) ingenomen standpunt niet beruste op een administratieve vergissing, maar wel overwogen is ingenomen en ook door de Raad is onderschreven, $[\ldots]$;

dat de Raad geen enkel wettelijk voorschrift bekend is hetwelk in een geval als het onderhavige een administratief orgatan verplicht terug te komen op een eenmaal genomen bestissing welke in rechte onaantastbaar is geworden hetzij doordat de roor het instellen van beroep gegeven termijn ongebruikt is verstreken, hetzij doordat die beslissing in beroep of hoger beroep onaangetast is gebleven;

I....

dat eisers gemachtigde een beroep heeft gedaan op het communautaire recht der Europese Gemeenschappen, doch dit recht omtrent het onderhavige geschilpunt - de terugwerking van het terugkomen op een in rechte onaantastbaar geworden beslissing omtrent toepassing van communawtair recht - geen aan de Raad bekende regels bewat." (mijn cursivering, RB)

Van een rechtsplicht voor het bestutursorgaan om terug te komen van een besluit dat bij nader inzien in strijd met EG-recht blijkt te ziin genomen, wil de Raad in deze zaak dus niet weten. Net als in de gevallen die in het vorige hoofdstuk aan de orde zijn geweest neemt de Raad hier slechts een bevoggheid aan voor het besturursorgatan om terug te komen van eerdere bestuiten. En net als in het vorige hoofdstuk toetst de Raad de uitofening van deze bevoegdheid beperkt, zoals moge blijken uit "s Raads overweging dat

"het wel iswar mogelijk evenzeer redelijk zou zijn geweest indien gedaagde de bestreden beslissing had laten terugwerken tot 1 augustus 1964 of tot een andere vóón 1 juli 1968 gelegen datum, maar dat de Raad, oordelende binnen de beperkte kring zijner toetsingsbevoegdheid in deze, niet tot de slotsom is kunnen komen dat gedagde, door zijn beslissing zowel in het onderhavige geval als in zeer veel overeenkomstige gewallen niet verder te laten terugwerken dan wot juli 1968 , een beslissing heet genomen wartoe hij in redelijkheid niet heeft kunnen gerwker' (min cusivering, RB)

Mdus likt de Raad geen bijzonder gewicht toe te kennen aan het feit dat de grond voor de herziening van het $\mathrm{AOW}$-pensioen gelegen was in bepalingen wan gemeenschapsrecht volgens de interpretatie die hieraan doon het HvI EG was gegeven. En dit ondanks, wat je zou kumen noemen, het 'moderne' betoog van eisers raadsman, die het volle gewicht had gelegd op de autonome rechtssfeer van de Europese Gemeenschappen en op het beslissend karakter van de interpretatie van het gemeenschapsrecht zoals deze door het HW EG wordt gegeven. In dit verband had de raadsman tevens gewezen op het beslissend karakter van de rechtspraak van het HVJ EG waar het de werking in de tijd van bepaingen van gemeen-

De radsman thad zich onder andere op het standpunt gesteld dat de vraag war de onaantastbaarheid van openbare orde was en in dit geval niet beantwoord moest worden naar de matstaven en eisen van de onderwerpelijke nationale rechtsorde zonder meer, maar naar die van de eigen autonome, in het recht van de Lid-Staat Nedlerland geintegreerde orde van her gemeenschapsrecht. 
schapsrecht betreft. Op grond van de vaste rechtspraak van het HvJ EG, wolgens welke een door het Hof gegeven interpretatie van een bepaling van gemeenschapsrecht in beginsel terugwerkt tot het moment waarop de desbetreffende bepaling tot stand is gekomen, was de raadsman van oordeel dat de datum van 18 juni 1968 , de datum waarop de Centrale Raad van Beroep zich had aangesloten bij de nieuwe jurisprudentie van het $\mathrm{Hw} \mathrm{EG}$, niet rechtens relevant kón zijn.

Het betoog van zijn raadsman heeft betrokkene echter niet mogen baten. Voor wat de gevolgen van de doorwerking van het EG-recht aangaat, lijkt de rechter zich eerder aan te sluiten bij het oordeel van de toenmalige Wettencommissie, ${ }^{5}$ dat in thet licht van de latere ontwikkelingen bijna ontwapenend laconiek klinkt waar deze commissie opmerkt dat

\begin{abstract}
"er [tenslotte] nog de mogelijkheid [is] de oude gevallen te herzien vanaf da datum, warop het Hof (het HvJ EG, RB) voor de tweede maal uitspraak heeft gedaan, n.I. juli 1967. Als gronden hierwoor zouden kumnen worden aangevoerd dat wellicht gesteld zou kunnen worden, dat een uitspraak van een supra-nationaal orgaan praevaleert boven een van een nationaal orgain en dat, zelfs indien dit in twijfel getrokken zou kunnen worden, in ieder geval wanaf het moment watop het Internationale Hof zijn uitspraak deed reeds duidelijk was tot welke interpretatie de Centralle Raad en in navolging daarvan de uitkeringsorganen zouden moeten komen".
\end{abstract}

Ook deze redenering acht de Wettencommissie - althans in meerderheid - niet voldoende sterk om op grond daarvan ertoe te besluiten de reeds vastgestelde uitkeringen vanaf julli 1967 te herzien.

Naar aanleiding van deze uitspraak wan de CRvB kan het volgende worden opgemerkt. Op grond van de uitspraken van het HvJ EG kan niet anders worden geconcludeerd dan dat het aan eiser met ingang van I augustus 1964 toegekende ouderdomspensioen ten onrechte is gekort. Zoals ook door de raadsman in deze zaak was aangevoerd en in hoofdstuk 1 nader is uiteengezet, ${ }^{6}$ is het immers vaste jurisprudentie van het HvJ EG dat aan de door het Hof gegeven uitleg van communautaire woorschriften terugwerkende kracht toekomt, tenzij het Hof in de uitspraak waarin de uitleg is gegeven anders heeft bepaald. ${ }^{7}$ Dit laatste was in de hier aan de orde zijnde uitspraken van het Hof niet geschied. Gelet op de in het vorige hoofdstuk geïntroduceerde terminologie strekte de materiële werking in de tijd van de uitspraken van het HvJ EG zich in elk geval uit tot de datum met ingang waarvan de AOW-uitkering aan de betrokkene was toegekend, te weten 1 augustus 1964. Uit de aangehaalde overwegingen van de CRvB blijkt echter dat de formele werking in de tijd van de uitspraken van het Hof niet eerder een aanvang nan dan op 18 juni 1968, de datum waarop de CRvB zich had aangesloten bij de nieuwe jurisprudentie van het Hw EG.

Zie het kort verslag van dece aan de toenmalige Rijksverzekeringsbank vorbonden commissie wan 4 oktober 1968, opgenomen in de eveneens in RSV $1971 / 109$ gepubliceerde uitspraak wan de Raad van Beroep Zwolle van 31 maart 1970.

7 Deze jurisprudentie werd gevestigd bij Hv EG 8 april 1976, zalak 43-75, Defreme II, Jur. 1976, p. 471 . Zie in dit werband ook HvJ EG 10 juli 1980 , zaak 826/79, Mireco, Jur. 1980, p. 2559, ro. 7. waarin het Hof heeft verklaard dat "de uttegging die het Hof wan Justitie krachlens de hem bij artikel 177 (thans artikel 234 EG, $R B$ ) verleende bevoegdheid geeft van een voorscthrift wan gemeenschapsrecht, wanneer daaraan behoefte bestat, de betekenis en strekking van dat voorschrift verklaart en preciseert zoals het sedert het tijdstip wan zijn inwerkingtreding moet of had moeten worden verstaan en toegepast'. 
Ten aanzien van de door de Raad aldus aangebrachte beperkingen op de formele werking in de tijd van de uitspraken van het $\mathrm{HvJ} \mathrm{EG}$, verdienen de volgende punten de aandacht:

1. De CRvB benadrukt dat er geen wettelijk voorschrift is aan te wijzen dat het bestuursorgaan verplicht in een geval als het onderhavige terug te komen van een in rechte onaantastbaar geworden beslissing waarbij de toepassing van het communautaire recht aan de orde is.

2. Naar het oordeel van de Raad zijn er evenmin communautaire regels met betrekking tot het terugwerken van besluiten waarbij op grond van met het communautaire recht samenhangende overwegingen toepassing is gegeven aan de bevoegdheid om terug te komen wan een in rechte onaantastbaar geworden beslissing.

3. De beslissing van het bestuursorgaan om al dan niet gebruik te maken van de bevoegdheid om ten gunste van betrokkene terug te komen van een in rechte onaantastbaar geworden beslissing wordt, ook wanneer hierbij de doorwerking van het communautaire recht in geding is, op de in het vorige hoofdstuk beschreven terughoudende wijze getoetst.

4. De Raad laat in het midden of de nadere uitspraken wan het HvJ EG een verduidelijking en aanvulling dan wel een gedeeltelijke wijziging van eerdere rechtsopvattingen wan het Hof inhielden. Denkbaar is dat bij 'verduidelijking en aanvulling' eerder aanleiding is tot terugwerkende kracht dan bij een wijziging van rechtsopvatting.

5. Met het vorige punt hangt samen dat de Raad van oordeel is dat het oorspronkelijke toekenningsbesluit niet berust op een administratieve vergissing, maar, naar het oordeel van de Raad, weloverwogen is genomen volgens een nog bij uitspraken van 5 oktober 1966 door de Raad aanvaarde uitleg.

6. De formele werking in de tijd van de nieuwe rechtspraak is hier een andere dan in de in paragraaf 4.5 van hoofdstuk II aan de orde gestelde kinderbijslagzaak.. ${ }^{8}$ Evenals in de kinderbijslagzaak gaat het in de onderhavige zaak om de vraag welke werking in de tijd toekomt aan een uitspraak van cen andere rechter dan bevoegd is ten aanzien van het herzieningsverzoek. In de kinderbijslagzaak verklaarde de CRvB zich akkoord met een beleid waarbij door het desbetreffende bestuursorgaan aan de nieuwe jurisprudentie toepassing werd gegeven met ingang van het tijdstip waarop deze in de uitsprak wan de andere rechter gestalte heeft gekregen. In de onderhavige zaak aanvardi de CRvB echter dat aan de nieuwe jurisprudentie wan het HWJ EG eerst toepassing wordt gegeven met ingang van de datum van de uitspraak waarbij de CRvB zich canshuit bij de rechtspraak van het Hof. Aldus aanvaardt de Raad een beperking van de formele werking in de tijd van de uitspraken van het HivJ EG die zelfs in een overeenkomstige doorwerking van de rechtspraak van andere nationale rechter niet gebruikelijk was.

De Raad verklaart de klacht dat er sprake zou zijn van ongelijke behandeling met de verzekerde wiens uitkeringsrechten in de uitspraak van 18 juni 1968 in geding waren, ongegrond. De Raad volstaat hiertoe met de overweging dat de uitspraak van 18 juni 1968 zag op een eerste toekenning van een AOW-pensioen, terwijl de onderhavige uitspraak ziet op het terugkomen van een reeds in rechte onaantastbaar geworden beslissing. Hoewel 
zulks uit de overweging niet expliciet blijkt, mag worden aangenomen dat de Raad het relevante verschil tussen de zaak die leidde tot de uitspraak van 18 juni 1968 en de onderhavige zaak gelegen acht in het feit dat de betrokkene in eerstgenoemde de zaak partij was in een procedure waarbij de ingangsdatum van het pensioen rechtstreeks in geding was en waarin de nieuwe jurisprudentie van het HvJ EG bekend werd nog voordat de CRvB onherroepelijk op het tegen de toekenningsbeslissing instelde beroep had beslist.

Zeer terughoudend is ook de toetsing van de CRvB in de volgende uitspraak van 7 december $1988:^{9}$

Aan betrokkene is bij rechtens onaantastbaar geworden beshuit van 26 februari 1979 met ingang wan 14 november 1977 een geprorateerde WAO-uitkering toegekend. Het dagloon werd per toekenningsdatum wastgesteld op $f 150,63$. Dit dagloon was vastgesteld met toepassing van artikel 8 van het Bijzonder dagloonbesluit pro rata WAO-hitkeringen. "Op grond van deze bepaling vond een verlaging van het WAO-dagloon plaats naar evenredigheid van leemtes die in het verzekeringsverleden waren opgetreden. Deze uitwoeringspraktijk werd wervolgens door het $\mathrm{HvJ}$ EG bij uitspraak van 23 september $1982^{11}$ in de zaak Besem onverenigbaar geacht met het stelsel van berekening van uitkeringen ingevolge artikel 46 lid 2 van Verordening EEG n. $1408 / 71$. A Is gevolg van thet arrest kon artikel 8 van het Bijzonder dagloonbesluit geen toepassing meer winder.

Het uitwoeringsorgaan heef in het arrest van het Hof aanleiding gezien om in het geval van betrokkene gebruik te maken van zijn bevoegdheid on terug te komen van het beshit van 26 februari 1979 , en wel in die zin dat het dagloon wan betrokkene met ingang van 1 oktober 1982 (de eerste dag van de maand, volgend op de datum watrop het arrest van het HWl EG is gewezen) onder het buiten toepassing laten van artikel 8 van het Bijzonder dagloonbesluit, tot $f 213,34$ is verhoogd.

Betrokkene heeft zich op het standpunt gesteld dat het dagloon alsnog zou moeten worden herzien met ingang van de datum van toekenning en heeft zich hierbij beroepen op door de Federatie van Bedrijfsverenigingen naar aanleiding van een uitspraak van de CR $v B$ wan 8 maart $1983^{12}$ ontwikkeld beleid dat, voor de in die zaak aan de orde zijinde problematiek, woorzag in herziening van het dagloon met volledig terugwerkende kracht.

De grief treft echter geen doel. De CRvB ovenweegt korlaf:

'De enkele omstandigheid dat in andere situaties [....] warin sprake is van het categorisch ten woondele terugkomen van rechtens onaantastbaar geworden beslissingen gekozen is voor cen rumer uitgangspunt, brengt nar het oordeel van de Raad I...] niet met zich mee dat [het uitvoeringsorgaan] rechtens gehouden zou zijn zo'n uitgangspunt ook in het hier aan de orde zijinde beleid the hanteren."

Opvallend is dat de Raad het feit dat het herzien van de dagloonbeschikkingen rechtstreeks is terug te voeren op een onjuiste toepassing van het EG-recht niet uitdrukkelijk in zijn overwegingen betrekt. Wel is in deze zaak in die zin sprake van een iets ruimhartiger houding tegenover het gemeenschapsrecht dat, in tegenstelling tot het door de Raad in de uitspraak van 26 november 1970 (voornoemde AOW-zaak) beoordeelde beleid, aan de nieuwe uitleg toepassing is gegeven met ingang van de datum warop het Hof uitspraak

10. Deslunt van de Sociale Verzekeringsraad van 6 april 1978 , n. 7812154.

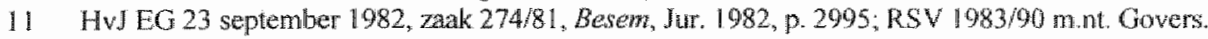

12 RSV 19831119 
heeft gedaan in de zaak Besem zelf (en dus niet met ingang van het latere tijdstip waarop de nationale rechter zich bij de uitleg van het HvJ EG heeft aangesloten).

Een ander voorbeeld waarbij de werking in de tijd van communautaire rechtspraak centraal staat is te winden in een tweetal uitspraken van het College van Beroep voor het Bedrijfsleven (CBB) van 23 december $1980 .{ }^{13}$ Beide uitspraken hebben betrekking op een terugvordering wan reeds betaalde heffingen op basis van een verordening die later onverbindend werd verklaard. De uitspraken zijn cen mooi voorbeeld van de gevolgen van het all dan niet ingetreden zijn van de formele rechtskracht van beschikkingen. De uitspraken zijn met name daarom interessant, omdat het $\mathrm{CBB}$ uitdrukkelijk motiveert waarom naar zijn oordeel het EGi-recht niet dwingt tot doorbreking hiervan.

Aan de betrokkenen in de eerste zaak wordt op 18 maart 1975 een heffing opgelegd op grond van de Verordening Vakheffing Bloembollen van het Produktschap voor Siergewassen. Betrokkene gaat over tot betaling van deze heffing, maar stelt tegen het onderliggende besluit op 7 april 1975 tevens beroep in bij het CBB en vordert dat het heffingsbesluit zal worden vernietigd en dat het Produktschap zal worden veroordeeld het inmiddels betaalde bedrag aan verzoeker terug te betalen.

Terwijl deze procedure aanhangig is verklaart het CBB op 24 februari 1976 de desbetreffende verordening onwerbindend wegens strijd met art. 40 , lid $3 \mathrm{EEG}{ }^{14}$ Deze uitspraak is op haar beurt een uitvloeisel van een eerdere prejudiciële beslissing van het HvI EG. ${ }^{15}$ Aangezien de heffing in de onderhavige zaak aldus blijkt te berusten op een onverbindende verordening wordt zij door het $C B B$ vernietigd. Voorts is het $\mathrm{CBB}$ van oordeel dat ter regeling van de gevolgen van die vernietiging behoort te worden bepaald dat het Produktschap het door verzoeker betaalde heffingsbedrag aan verzoeker zal terugbetalen.

De betrokkene in de tweede zaak heeft zich reeds op ॥ I februari 1975 schriftelijk tot het Produktschap gewend met het verzoek hem alle, sinds 1 januari 1943 betaalde, heffingen terug te betalen. Betrokkene is van mening dat de verordeningen waarop de heffingen waren gebaseerd, onverbindend waren. Voor een van de verordeningen kont dat inderdaad vast te staan in voornoemde uitspraak van het CBB van 24 februari 1976 .

Het CBB oordeelt echter dat, nu de verzoeker tegen geen der heffingen in beroep is gekomen en tevens niet is gebleken van omstandigheden die aanleiding zouden geven tot het oordeel dat verzocker terzake van de overschrijding van de beroepstermijn redelijkerwijze geen verwijt treft, deze noar Nederlands national recht, rechtens onaantastbaar zijn geworden.

Hei CBB merkt het bestreden besluit vervolgens aan als een weigering van het Produktschap om, ten gunste van betrokkene, op rechtens onaantastbare beshiten c.q. handelingen, terag te komen. Fen dergelijke weigering acht het CBB "niet in strijd met enig door een Nederlandse wetgevende instantic vastgesteld algemeen verbindend voorschrift' noch in strijd met een der algemene beginselen van behoorlijk bestuur.

Ten aanzien wan de vraag of deze onaantastbaarheid zich als zodanig verdraagt met het EGi-recht overweegt het CBB:

'Gelet op hetgeen door het Hof van Justitie van de Europese Gemeenschappen bij arrest van 16 dec. $1976^{16}[\ldots]$ woor recht is verklaard moet - nu de procesregels voor de onderhavige vorde-

16 Hwf EO 16 december 1976, zaken 33/76, Rewe, en 45/47, Comet, resp. Jur. 1976, p. 1989 en Jur. 
ring in rechte niet ongunstiger zijn dan die woor soortgelike nationale vorderingen, watop genoemde wet van toepassing is - ten aanzien van de onderhavige weigering on terug te komen moet worden gezegd, dat zij ook niet in strijd is met enig voorschritt of beginsel van com mumatair recht:

Deze rechtsoverweging berust op vaste rechtspraak van het $\mathrm{HvJ} \mathrm{EG}^{\text {i? }}$ op grond waarvan de wijze waarop de door gemeenschapsbepalingen aan particulieren toegekende rechten worden beschermo, zolang er geen geharmoniseerd stelsel van procesrecht bestat, door de nationale rechtsorde van de Lid-Staten wordt bepaald. Aan dit beginsel is evenwel de fundamentele voorwaarde verbonden dat de nationale modaliteiten en procedures niet ongunstiger mogen zijn dan gelden voor soortgelijke nationale beroepen ter bescherming wan rechten, en bovendien de uitoefening van rechten die de nationale rechter verplicht is te handhaven, niet onmogelijk maken. ${ }^{18}$ Deze op het vereiste van een effectieve rechterlijke bescherming gegronde voorwaarde had onder meer tot gevolg dat op het zojuist genoemde primaat van de nationale regels van procestecht ter bescherming van de naleving van communautaire bepalingen inbreuk werd genaakt in de arresten Factortome, ${ }^{19}$ Enmott ${ }^{2 n}$ en Francovich en Bonifaci. ${ }^{21}$. In het arrest Factortame oordeelde het Hof dat de verplichtingen die het gemeenschapsrecht aan de nationale rechter oplegt met betrekking tot de bescherming van rechtstreeks aan particulieren toegekende rechten, mede omvat de verplichting om bij wege van voorlopige maatregel de nationale wet waarvan gesteld wordt deze hij strijdig is met het gemeenschapsrecht, buiten toepassing te laten. Dat de Britse wetgeving destijds niet in een daartoe strekkende bevoegdheid voor de rechter voorzag, achtte het Hof niet werenigbaar met het gemeenschapsrecht. In Emmott oordeelde het Hof dat het de nationale autoriteiten verboden is processuele bepalingen en vervaltermijnen tegen te werpen aan degene die zijn uit een richtlijn voortvloeiende rechten geldend wil maken, wanneer de desbetreffende Lid-Staat die richtlijn zelf nog niet op correcte wijze heeft omgezet in nationale wetgeving. In Francovich en Bonifaci, tenslotte, introduceerde het Hof een rechtstreeks op het gemeenschapsrecht gebaseerde actie uit onrechtmatige daad in het geval wan een niet tijdige implementatie van een EEG-richtlijn.

\subsection{Opzet van de behandeling}

Het is mijn bedoeling in dit hoofdstuk uit de doeken te doen wat de werking in de tijd is van verandering van rechtspraak, wanneer deze verandering haar grondslag vindt in de doorwerking van bepalingen van het internationale recht. Evenals in het vorige hoofdstuk gaat het daarbij enerzijds om de vraag met ingang van welk tijdstip blijkens jurisprudentie

1976, p. 2043.

17 Zie onder neer: HvJ EG 16 december 1976, zaak 45/76, Comet, Jur. 1979, p. 2043; HwJ EO 10 juli 1980, zaak 811/79, Ariete, Junispr. 1980, p. 2545; Hwd EG 12 juni 1980, zaak 130/79, Express Darmy Foods, Jur. 1980, p. 1887; HvJ EG 27 matart 1980, zaak 61/79, Denkowi Itoliana, Jur. 1980, p. 1205; HwJ EG 27 februari 1980, zaak 68/79, Hans Just, Jur. 1980, p. 501 en Hw EG 9 november 1983. zaak 199/82, Son Giorgio, Jur. 1983, p. 3595 .

I8 Zie conclusie A-G Tesauro woon HvJ EG 19 juni 1990 , zaak C-21389, Fackortane, Jur. 1990, p. I. 2433.

19. HWJ EG 19 juni 1990, zaak C-213/89, Foctortame, Jurispr. 1990, p. $1-2433$ ).

20 Hw EG 25 juli 1991, zaak C-208/90, Emmott, Jut. p. I-4269; AB 1992, I m.nt. A.W.H. Meij; RSV $1992 / 189$ m.n. F.W.M. Keunen; SEW $10(1992)$, p. 783 e.v.

21 Hw EG 19 nowember 1991, zaken C-6/90 an C-9/90, Francowich en Bonifach, Jur. 1991, p. 1-5357; AB 1994, 482 m.nt. F.H. van der Burg; SEW (1993), p. 87 e.\%. 
waarbij rechtstrecks toepassing wordt gegeven aan het internationale recht (alsnog) rechten in het leven worden geroepen (de materiële werking in de tijd), en anderzijds om de vraag met ingang van welk tijdstip deze alsnog verkregen rechten daadwerkelijk geldend kumen worde gemaakt (de formele werking in de tijd). De formele werking zal, evenals in de in het vorige hoofdstuk besproken gevallen, vaak haar beslag krijgen in de vorm van herziening van inmiddels rechtens onaantastbaar geworden besluiten. Vanwege de nauwe samenhang zullen in dit hoofdstuk echter tevens de gevallen worden behandeld, waarin de nieuwe jurisprudentie aanleiding is geweest tot thet alsnog indienen van een aanvraag.

In plaats van geldend gemaakt zou vanwege de materie waartoe dit hoofdstuk zich zal beperken ook gesproken kunnen worden van te gelde gemaakt. De hoofdmoot van dit hoofdstuk zal bestaan uit een bespreking van jurisprudentie die betrekking heeft op de sociale zekerheid. Het is met name op dit gebied dat de rechterlijke constatering van strijd tussen de toepasselijke nationale bepalingen en de normen van het internationale recht tot verstrekkende gevolgen heeft geleid.

Is hiermee voor dit hoofdstuk een beperking gegeven die ziet het terrein waarop de te behandelen jurisprudentie betrekking heeft, een tweede beperking vloeit nog voort uit de aard van de internationale bepalingen die als toetsingsgrond zullen worden opgevoerd: het zal in dit hoofdstuk vooral gaan on de internationale bepalingen waarin het beginsel van gelijke behandeling belichaamd is. Om een vruchtbare analyse van de jurisprudentie mogelijk te maken zal in de volgende paragraaf allereerst een nadere uitleg worden gegeven over een aantal begrippen die bij deze analyse centraal zullen staan.

In hoofdstuk 4 zal aan de hand van een aantal concrete voorbeelden de werking in de tijd van rechterlijke uitspraken waarbij toepassing is gegeven aan het internationale en communautaire recht nader worden geillustreerd. Daarbij zal achtereenwolgens worden ingegaan op de WWV (paragraaf 1), de AAW (paragraaf 2), de - wat ik maar heb genoend - "wisselwerking" tussen de AAW en de AWW (paragraaf 3), de AOW (paragraaf 4) en tenslotte de zogenoemde Bopa-affaire (paragraaf 5).

\section{De doorwerking wan het internationale recht}

\subsection{Begrippen}

Bij de behandeling van het vraagstuk van de doorwerking van het internationale recht is het goed ons eerst voor ogen te houden wat precies werstaan moet worden onder 'internationaal recht'. In enge zin opgevat heeft het begrip international recht betrekking op de regels van het traditionele volkenrecht; in ruime zin heeft het tevens betrekking op het supranationale recht, waarbij het in dit boek in het bijzonder gaat om het recht van de Europese Gemeenschappen.

Van de rechtsbronnen van het volkenrecht komt in dit boek alleen het verdragsrecht ter sprake. Onder verdragsrecht zal worden verstaan het recht dat voortvloeit uit bi- of multilaterale verdragen. Rechtssubject bij deze verdragen zijn soevereine $\operatorname{staten}^{22}$ en internatio- 
nale organisaties. Met het soevereiniteitsbegrip hangt samen dat de mogelijkheid voor ingezetenen van een bij een verdrag aangesloten staat om zich voor een nationale rechter op verdragsbepalingen te beroepen, afhangt van de vraag of de constitutie van de desbetreffende staat zulks mogelijk maakt. De Nederlandse Grondwet voorziet in deze mogelijkheid in de artikelen 93 en 94 . Artikel 93 van de Grondwet schrijft voor dat bepalingen van verdragen en wan besluiten van volkenrechtelijke organisaties, die naar haar inhoud een ieder kunnen verbinden, verbindende kracht hebben nadat zij zijn bekend gemaakt. De betekenis van het begrip 'een ieder verbindend' en het daaraan verwante begrip 'rechtstreekse of directe werking" is omstreden. ${ }^{23}$ De meest relevante vraag voor het doel van dit onderzoek is echter steeds of een procespartij zich ten overstaan van een Nederlandse rechterlijke instantie op een internationalrechtelijke bepaling kan beroepen. De vraag of een bepaling van internationaal recht een ieder verbindend is, wordt beantwoord door de Nederlandse rechter. Het is ook de Nederlandse rechter die oordeelt over de vraag welke de rechtsgevolgen zijn van een door hem geconstateerde onverenigbaarheid tussen een Nederlands wettelijk voorschrift en een een ieder verbindende bepaling van internationaal recht. Weliswaar schrijft artikel 94 Grondwet voor dat de rechter een dergelijk wettelijk voorschrift dan buiten toepassing moet laten, maar uit de rechtspraak blijkt dat de doorwerking van het internationale recht een genuanceerder invulling kent dan artikel 94 Grondwet zou doen vermoeden. Deze nadere invulling zal voor een aantal internationaalrechtelijke bepalingen in de volgende paragrafen uit de doeken worden gedaan.

Voor het recht van de Europese Unie geldt echter een ander regime. Volgens vaste rechtspraak van het HwJ EG is met de Europese Gemeenschappen een afzonderlijke rechtsorde gecreëerd. ${ }^{24}$ In het kader van de EG-Verdragen is door de Lid-Staten een aantal belangrijke overheidsbevoegdheden overgedragen am de communautaire organen. De uitoefening van deze bevoegdheden vindt plaats door middel van een delicate wisselwerking tussen de communautaire en nationale overheidsorganen. Kenmerkend voor deze wisselwerking is dat enerzijds de uitvoering van communautaire regelgeving in de meeste gevallen wordt overgelaten aan de nationale overheidsorganen. Anderzijds wordt de vraag of deze aars de nationale organen overgelaten uitvoering in overeenstemming is met het gemeenschapsrecht in laatste en beslissende instantie beoordeeld door een communautair orgaan, te weten het HvJ EG. Daarmee wordt het beslissende oordeel over de vraag naar de mate van doorwerking van het communautaire recht in de nationale rechtsorde onttrokken aan de nationale rechterlijke instanties. Doel van hel communautaire recht is dat zijn doorwerking in de nationale rechtsstelsels (op termijin) gelijk is. Voorzover er tussen de Lid-Staten nog verschillen optreden in de doorwerking van het gemeenschapsrecht, moeten deze op het gemeenschapsrecht zelf zijn terug te voeren. Zij mogen geen gevolg zijn van verschillen in constitutionele bepalingen omtrent de doorwerking van het internationale recht in enge zin.

dragspartij op te treden; zie bijv. artikel 32 wan het Duise Grundgesetz.

23. Zie voor een overzicht van de opvattingen in de literatuir en jurisprudentie hierontrent: F.A.M. Stroink, Rechterlike organisatie en rechtspraak in beweging, Zwolle 1993, p. 43-44.

24 Aldus vaste jurisprudentie van het lHW EG sinds HvJ EG 5 februari 1963, Zaak 26/62 Wan Gend \& Loos, Jur. 1963, p. 23 . 


\subsection{Beginsel van gelike behandeling}

In paragraal 2.1 werd reeds angegeven dat de in dit hoofdstuk te behandelen jurispruden. the betrekking heeft op het beginsel van gelijke behandeling. Dit beginsel komt op diverse plaatsen in onze rechtsorde naar woren. Dat het beginsel een, in de letterlijke zin var het woord, vooraanstaande plats inneemt, blikt uit hef feit dat de Grondwet ermee opent: Op grond wan artikel 1 worden allen die zich in Nederland bevinden in gelijke gevallen geljjk behandeld. In zijn uitwerking kent het beginsel diverse verschijningsvormen. 20 is het allereerst de belichaming van het verbod van willekeur, in welke gedaante het zich vooral tot de wetgever richt. In die gedaante is het gelijkheidsbeginsel uitgewerkt in de uit het legaliteitsbeginsel wortvloeiende algemeenheid van de wet. De strekking van de algemeenheid van de wet is dat allen voor de wet gelijk zijn. De wet mag geen bevoordeling inhouden van bepalalde sociale groepen. Voorzover de wetgever beperkingen mag aanbrengen op de vijheidsrechten van de mens, mag hij dat alleen bij algemene, voor cen ieder zonder aanzien des persoons geldende, regeling ${ }^{26}$ Burkens is overigens van mening dat het gelijksbeginsel in deze gedaante nauwelijks nomatief is woor de wetgever en dat van overtreding pas sprake zal zijn 'indien de wetgever in redelijkheid een gelijke behandeling, en derhalve een onderling gelijk aanmerken van bepaalde gevallen niet kan. willen" ${ }^{27}$

Een tweede gedaante waarin het gelijheidsbeginsel zich voordoet is in die van het algemeen beginsel van behoorlijk bestuur dat gelijke gevallen gelijk behandeld dienen te worden. Op het eerste gezicht staat deze regel op gespannen voet met de eigen aard van Jet besturen, dat juist ziet op het vaststellen var bestuurlijke rechtsverhoudingen in concrete gevallen. ${ }^{2 x}$ Duk kent evenwel aan het gelijkheidsbeginsel in het bestuurstrecht een betekenis toe die nauwe verwantschap vertoont met hetzelfde verbod van willekeur dat zojuist in verband met het legaliteitsvereiste aan de orde kwam. De in het legaliteitsbeginsell gelegen garantie dat het bestuur niet willekeurig zal handelen, gaat immers alleen op als de nomen die het bestuur bij de uitoefening van zijn bevoegdheden in acht moet nemen concreet uit de wet voortvloeien; anders gezegd: bij gebonden bestuur. Waar de wet echter volstaat met het roekennen van niet nader genonneerde bevoegdheden, waar met andere woorden het bestur door de wet een discretionaire bevoegdheid krijgt toebedeeld, past miettemin de norm dat het desbetreffende bestuursorgaan deze bevoegdheid niet naar willekeur uitoefent. Dit verbod van willekeur dwingt het bestur tot het betrachten van stelselmatigheid bij zijn uitoefening van discretionaire bevoegdheden. Anders gezegd, het dwingt het bestuur tot een beleidsmatige uitvoering van de discretionaine bevoegdheid. Het voeren van beleid wordt gezien als een aweging wan belangen in abstacto, warbij dit beleid niet als ean onwrikbar gegeven mag worden beschouwd.

25 Ben diversiteit van een dergelijke omvang dat volgens Alkema gesproken kan worden van 'gelijkheid als een wat wol tegenstrijdigheden", zie: E.A. Akema, Het intemationale gelijkheidsbeginsel en de Nederlandsche staatsrechtelijke verhoudingen; wie leidt de wats van de gelijkheid; Preadvies Staatsrechlconterenthe 1986. Ars Aequi Libri, Serie staats- en bestuursrecht, Nigmegen 1987, p. 67.

Zie E.R. Böhtlingk, M.H.A. Logentan, Het wetshegrip in Nederland, Alphen aan den Rijn 1966, p. 8 en 24.

27 M.C. Burkens, Getijke bethandeling (art. 1.1) in: A.K. Koekkoek e.a., Grondrechten, commentaar op Hoofdstuk! wan de herziene grondwet. Nijmegen 1982, p. 59 .

Zie bijv. F.R. Bölut ingk, J.H.A. Logemann, a.w. (noot 26), p. 24 
Concrete gevallen kunnen verplichten tot afwijking van het beleid, maar waar deze afwijking onverplicht en ten nadele van een belanghebbende geschiedt, is sprake van schending van het gelijkheidsbeginsel. ${ }^{24}$

Ook Nicolai legt, in navolging van Duk, het verband tussen het gelijkheidsbeginsel en de uit het verbod van willekeur voortvloeiende eis van stelselmatigheid van bestuur. ${ }^{30}$ Ook hij is van oordeel dat het gelijkheidsbeginsel als beginsel van behoorlijk bestuur slechts de uitdrukking is van de eis dat daadwerkelijk stelselmatig dient te worden beslist. Met het oog op deze eis van stelselmatigheid moet het bestur beleidsregels vaststellen, waarin een afweging in abstracto plaatsvindt wan de bij de uitoefening van de desbetreffende bevoegdheid betrokken belangen. Op grond wan het gelijkheidsbeginsel is het bestuur vervolgens verplicht zijn bevoegdheid conform de in deze beleidsregels vervatte belangenafweging uit te oefenen. Afwijking van de beleidsregels is slechts op haar plaats indien bijzondere omstandigheden hiertoe nopen. In de opvatting van Nicolaï houdt het gelijkheidsbeginsel de eis in dat voor het beleid gelijke gevallen in principe gelijk dienen te worden behandeld. Daarbij vormen de beleidsregels het referentiepunt dat nodig is on te bepalen welke feitelijk ongelijke gevallen als rechtens 'gelijk' dienen te worden benaderd. Zo opgevat heeft het gelijkheidsbeginsel dus betrekking op een toetsing atan het beleid en vormt het slechts een formele maatstaf voor bestuurlik handelen. ${ }^{31}$

Naast deze toetsing aan het beleid onderscheidt Nicolaï een toetsing van het beleid aan het gelijkheidsbeginsel. Hierbij gaat het om een toetsing van materiêle aard die betrekking heeft op de beleidsregels zelf. Ging het bij de formele toetsing on de vraag of het bestuursorgaan al dan niet gerechtvaardigd van het beleid mocht afwijken, bij de materiêle toetsing gaat het om de vraag of het gevoerde beleid zelf in overeenstemming is met het fundamentele - met de idee van de rechtsstaat verbonden - gelijkheidsprincipe. ${ }^{32}$ Bij deze toetsing gaat het om de vraag welke ongelijke behandeling van categorieèn van burgers al dan niet rechtens aanvaardbaar is. ${ }^{33}$ Volgens Nicolaï lost deze vraag zich op in die naar de redelijkheid en billijkheid van de in de beleidsregels gestalte krijgende belangenafweging door het bestuur. Het gaat, met andere woorden, om de vraag naar de redelikkeid van door het bestuur aangevoerde rechtvaardigingsgronden voor ongelijke behandeling van verschillende groepen burgers. De rechter past hier slechts een marginale toetsing van het bestuursbeleid, tenzij de (Grond)wet en verdragen bepalde criteria als 'bij voorbaat' verdacht hebben aangewezen.

Het gelijkheidsbeginsel richt zich uiteraard ook tot de rechter. Het is dit beginsel dat ten grondslag ligt aan de vorming van jurisprudentie. Van jurisprudentie kan slechts sprake zijn als de rechtspraak een zekere stelselmatigheid en consistentie vertoont. Een van de belangrijkste taken van de rechter bestaat in de beoordeling van de vraag in hoeverre een aan hem voorgelegde zaak juridisch relevante overeenkomsten dan wel verschillen vertoont met zaken die eerder door een (hogere) rechter beoordeeld zijn. Het gelijkheids-

30 P. Nicolai, Beginselen van behoorlijk bestuur, Deventer 1990 , p. 303.

3 P. Nicolai, a.w. (noot 30), p. 308.

32 P. Nicolai, a.w. (noot 30$), p .311$.

P. Nicolaï, a.w. (noot 30$)$, p. 309. 
beginsel brengt mee dat dit eerdere oordeel de rechter in de nieuwe zaak tot leidraad strekt, voot zover de nieuwe zaak juridisch relevante overeenstemming vertoont met de oude. ${ }^{34}$

\subsection{Het verbod wan discriminatie}

In dit hoofdstuk komt vooral de meer specifieke vorm van het gelijkheidsbeginsel die is gelegen in het verbod wan discriminatie aan de orde. Dit beginsel wordt, onder andere, ${ }^{35}$ in de tweede volzin van artikel I van de Grondwet verwoord en daarnaast in de voor dit onderzoek van belang zijnde artikelen $141 \mathrm{EG},{ }^{36} 14 \mathrm{EVRM}$ en artikel 26 IVBPR. Het verbod van discriminatie is op het eerste gezicht iets tastbaarder dan het gelijkheidsbeginsel, maar ook hiervan is het niet zo eenvoudig de betekenis aan te geven. Discriminatie is het maken van ongerechtvaardigd onderscheid. Daarmee is in ieder geval aangegeven dat discriminatie geen neutraal begrip is, in die zin dat het een achterstellend, benadelend, terugplaatsend handelen veronderstelt ${ }^{37}$ Kenmerkend voor discriminatie is het stelselmatig achterstellen van mensen om de enkele reden dat zij tot een bepaalde groep ${ }^{38}$ behoren. Groepskenmerken die tot discriminatie kunnen leiden zijn te winden in de criteria van, bij voorbeeld, artikel 1 van de Grondwet: godsdienst, levensovertuiging, ras, geslacht en politieke gezindheid. Dat het hierbij slechts om voorbeelden wan discriminatiecriteria gaat, wordt duidelijk uit de grondwettelijke toevoeging van het verbod van discriminatie op welke grond dan ook. De betekenis van de opsomming van deze voorbeelden is volgens Drion evenwel dat zij de typische discriminatiecriteria betreffen:

'Men moet aannemen dat de voorbeelden door de opstellers van de verdragen als typische discriminatiecriteria zijn gezien, niet slechis als voorkomende vormen van juridisch onderscheid tussen personen, die in sommige gevallen wel eens discriminatie zouden kumnen opleveren. Het zijn, wat in de rechtspraak van de Verenigde Staten de 'werdachte' onderscheidingen worden genoemd. Verschillende behandeling van mensen op grond van deze criteria wordt als een te bestrijden misstand beschouwd, voor zover niet in een bepaald geval het maken van zo'n onderscheid gerechtvaardigd wordt door overwegingen die los staan van de vooroordelen, waarop het maken van het onderscheid is gebaseerd".39

Onderscheidend gedrag dat niet op vooroordelen berust zou aldus wel door de beugel kunnen. Om te kunnen oordelen of er sprake is van een wooroordeel is het echter nodig

Zic in dit verband levens: .. Drion, Stare decisis, in: Veramelde Geschrifen van I. Drion, Deventer 1968. p. 142 e. .

352 Zie voor een owerzicht van de belangrijkste intemationale teksten: E.A. Alkema, a.w. (noot 25) $75-77$.

36 Voothen: artikel $119 \mathrm{EEO}$.

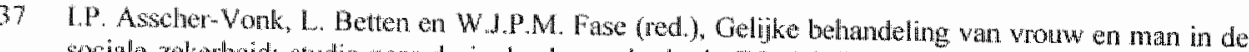
socialle zekertedi: studie naar de invloed van de derde liG-nithtin op de Nederlandse wetgeving Khluwer, Deventer 1986, p. 34. Of, in de woorden wan minister De Gaay Fortman tijdens het kamerdebnt in erste lezing van de voostellen tot wajging wan de Orondwet: "Discriminatie is een ander bethandelen op een zodange wijze, dat hij die ander duidelijk maakt, dat hij dere aspecten wan 2 jin

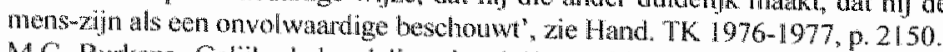

M.C. Burkens, Gelike behandeling, in: A.K. Koekkoek, W. Konijnenbelt, F.C.L.M. Crïns (red.) Grondredhen: commentas op Hoofdsth I van de herziene Grondwet. Aargeboden an mr. H.J.M. Jokens in verband met zijn afscheid als hoogleraar aan de Katholicke Universiteit Brabant (Jeukensbundel), Nijmegen 1982, p. 63 .

H. Drion, Nondiscrimintie, RM Themis-6 (1980), p. 491. 
enige distantie te betrachten tot hetgeen in de samenleving als "normaal" wordt beschouwd. Treffend is in dit verband de volgende waarschuwing van Drion:

"Het is goed daarbij te bedenken dat die vooroordelen door degenen die ze hebben, meestal beschowwd worden als realistische uitgangspunten en niet als rationalisaties van een emotionele behoefte aan het maken van onderscheid. Waar dan nog bij komt, dat mensen veelal de neiging hebben om zich min of meer aar te passen aan wat de samenleving van hen werwacht, zodat algemeen bestaande vooroordelen ten aanzien van een gediscrimineerde groep soms de realiteit in de richting van die vooroordelen beinvloedt.

Dat deze waarschuwing ook voor dit onderzok niet zonder betekenis is, moge blijken uit het volgende voorbeeld. In zijn noot bij het arrest van de Hoge Raad van 12 oktober 1984," waarin de Hoge Raad moest oordelen over de vraag of artikel 8 van de Wet op het nederlanderschap en het ingezetenschap al dan niet in strijd was met artikel 26 IVBPR, vat Van der Grinten artikel 26 IVBPR zo op dat het gelijke behandeling van man en vrouw gebiedt, indien er voor zover hum positie in de samenleving gelijk ix. Aldus op zoek gaande naar verschillen tussen de positie van mannen en vrouwen die een redelijke grond zouden bieden voor het uit de wet voortwloeiende verschil in rechtspositie tussen mamen en vrouwen voor zover het het optierecht op het Nederlanderschap betrof, merkt hij het volgende op: $:^{42}$

Gestell kan worden dat in onze samenleving tot dusverre de gehuwde vrouw een specilieke positie heeft of - om de woorden van de Hoge Raad te gebruiken - in een specifieke situatie werkeert. In het overgrote deel van de huwelijken is nog steeds de man de - voomaunste - kostwinner, wordt de woonplaats door de plaats van beroepsuitoefening van de man bepaald, hangt de maatschappelijke positie van de vrouw en het gezin goeddeels af van die van de man. Hiermede hangt samen dat de pensioenregelingen wel een weduwepensioen doch niet een weduwnatpensioen plegen te kemnen. De positie van de gehuwde vrouw is ook in onze huidige maatschappelijke constellatie niet gelijk aan die van de man.'

Dit voorbeeld is daarom zo interessant omdat de door de annotator ter staving van zijn oordeel in de zaak van het nederlanderschap naar voren gebrachte relevante verschillen tussen de (rechts)positie van mannen en vrouwen korte tijd daama stuk voor stuk in de jurisprudentie als discriminatoir zijn aangemerkt. Kostwinnerschap (bij voorbeeld in de WWV), de door de AOW verbonden gevolgen aan een buiteniands dienstverband van de man, en het geslacht (bij voorbeeld in de AWW): al deze criteria hebben het, vooral onder invloed van de jurisprudentie van het HvJ EG, korte tijd na 1984 moeten ontgelden."?

40 H. Drion, a.w. (noot 38), p. 491.

41 NII $1985,230$.

42 De wet voorzag in een optierecht op het nederlanderschap voor de met cen Nederlandse man gehuwde buitenlandse vrouw, terwijl de wet dit recht niet tockende aan de buitenlandse man die met een Nederlandse vrouw huwde.

43 Een woorbeeld van gelijke strekling biedt HR 8 oktober 1980, NJ 1981,63 , waarin da Hoge Raad de wettelijke onmogelijkheid voor de gehuwde vrouw, in tegenstelling tot de gehuwde man, on onder de eigen geslachtsnatm in het kiezerstegister te worden vermeld, niet in strijd met artikel 26 IVBPR achate en daartoe overwoog 'datt, naar algemeen bekend is, in Nederland een zeer grote meerderheid van gehuwde vrouwen in het matschappelijk verkeer de nam wan has man woen en daamee ook wordt aangeduid; dat duidelijk is dat een op deze werkelijkheid afgestende regitstratie van gehuwde vrouwen in let kiezersregister voor een goede gang van zaken bij verkiezingen eern betere wataborg biedt dan een registratie waarbij gehuwde vrouxwen niet anders worden vermeld dam met de naam die de zeer grote meenderheid van havar in het maatschappelijk werkeer niet woert.' (mijn cursivering RB) 
Zoals in paragraaf 2.1 is aangegeven is dit hoofdstuk gewijd aan een studie naar de werking in de tijd van rechtspraak waarbij toepassing is gegeven aan de intenationaal- en Europeesrechtelijke anti-discriminatiebepalingen. Het gaat hierbij meer in het bijzonder om de artikelen 26 IVBPR. 14 EVRM en Richtlijn $79 / 7$ van de Raad van de Europese Gemeenschappen van 19 december 1978 betreffende de geleidelijke tenuitvoerlegging van het beginsel van gelijke behandeling van mannen en vrouwen op het gebied van de sociale zekerheid. ${ }^{44}$ Aan deze regeling zal in het vervolg worden gerefereerd als Richtlijn 79/7 EEG.

Vanwege het belang van het artikel voor dit onderzoek wordt hier het eerste lid geciteerd:

'Allen ziin grelijk voor de wet en hebben zonder discriminatie aanspraak op gelijke bescherming door de wet. In dit verband verbiedt de wet discriminatie van welke aard ook en garandeert een ieder gelijke en doelmatige bescherming tegen discriminatie op welke grond ook, zoals ras, huidskleur, geslacht, taal, godsdienst, politieke of andere overtuiging, nationale of maatschappelijke afkomst, eigendom, geboorte of andere status.'

Het is niet overdreven te stellen dat artikel 26 IVBP in samenhang met artikel 4, lid 1 Richtlijn $79 / 7$ EEG heeft gefungeerd als een bom onder het Nederlandse sociale zekerheidsbestel. En dat, nadat het aanvankelijk toch toch wel mee leek te vallen, toen de CRvB in 1983 uitspraak deed in een aantal zaken waarin gehuwde vrouwen opkwamen tegen de zogenaande kostwinnerseis. Deze hield in dat het verkrijgen van recht op, bijvoorbeeld, een werkloosheidsuitkering afhankelijk werd gesteld van de vraag of de gehuwde vrouw was aan te merken als kostwinster. De desbetreffende vrouwen waren van oordeel dat deze eis discriminatoir was, aangezien de wet een dergelijke eis niet aan gehuwde mannen stelde. De CRvB oordeelde toen echter dat aan artikel 26 IVBPR met betrekking tot de in het geding zijncle sociale zekerheidsrechten betekenis moest worden ontzegd."

Dat het met artikel 26 IVBP wel niet zo'n vaart zou lopen als maatstaf voor de toetsing van wetgeving, leek ook te volgen uit de gezaghebbende studie van Tomuschat, volgens wie 'by virtue of article 26 , the $C C P R^{46}$ provides for equality before the law and equal protection in
the application of the law'

en: "The CCPR lacks a comprehensive guarantee of non-discrimination as meaning equality "of" or
"in" the law" "?

Zie in dit verband ook de warschuwing wan C.M. Sjerps in de noot onder RvB Roemond 12 maart 1991. N.CM-Bulleth 16-6 (1991), p. 554: "Het is vij natuurlijk dat degenen die zijn opgegroeid in een systeem geneigd zullen aijn om het bestaande snel gerechtyaardigd te vinden. Vandaar dat het mutting is on zoicts ook te laten beoordelen door rechters die door hum verschillende nationaliteit
eerder geneigd zullen zijn om bij nationale eigenaardigheden vagen te stellen."
Pb. 1979 , no. 624 . CRvB I noventber 1983, RSV $1984 / 147-150$ m.nt. W.M. Levelt-Overmars.
Het IVBPR.

46 Het IVBPR. Political Rights" Fs.H.Schlochauer, Berlin 1981. 
Artikel 26 zou dus slechts zien op de inachtneming van het beginsel van gelijke behandeling bij de toepassing van de wet en niet op wetgevend handelen zelf.

Dat het allemaal zo anders is gelopen dan de uitspraak van de CRvB uit 1983 leek te suggereren, valt te verklaren uit het feit dat de twee belangrijkste pijlers waarop de Raad zijn uitspraak had doen steunen al spoedig werden ondergraven.

De eerste betrof het ontzeggen van zelfstandige werking aan artikel 26 IVBPR voor het terrein van de sociale zekerheid. Daarbij was de Raad niet zo ver gegaan het uit artikel 26 IVBPR voortvloeiende recht op gelijke behandeling als een accessoir recht aan te merken. Een dergelijk accessoir karakter zou hebben betekend dat het artikel alleen een recht op gelijke behandeling zou geven ten aanzien van rechten die in het IVBPR zelf worden erkend. De Raad leidde uit de eerste twee artikelen van het Verdrag echter af dat

'artikel 26 niet slechts van toepassing is op de burgerrechten en de politieke rechten welke door het B.P.-Verdrag ${ }^{48}$ worden erkend?

Dat weerhield de Raad echter niet te overwegen dat uit het feit dat de sociale rechten in het tegelijkertijd met het IVBPR tot stand gekomen afzonderlijke Internationaal Verdrag inzake Economische, Sociale en Culturele Rechten (IVESCR) worden beschermi, moest worden afgeleid dat aan artikel 26 IVBPR ten aanzien van de sociale rechten geen rechtstreekse werking kon toekomen. Kenmerkend voor de door het IVESCR erkende rechten was immers, volgens de Raad, dat hierop door de burgers van de bij dit verdrag aangesloten staten geen rechtstreeks beroep kon worden gedaan; de sociale rechten zouden immers in het in het algemeen slechts geleidelijk, door middel van wetgeving en andere vitvoeringsmaatregelen, kunnen worden verwezenlijkt.

\section{Annotator Leveli-Overmars stelt hier echter tegenover dat}

'de reikwijdte wan deze bepaling' ${ }^{49}$ niet beperkt [is] tot de in het Verdrag toegekende burgerlijke en politieke rechten, maar alls zelfstandig recht in Hoofdstuk III - het hoofdstuk van de materizle rechten - [is] opgenomen. Concreet wil dat laatste zeggen dat art. 26 niet alleen discriminatie verbiedt ten aanzien van de in het Verdrag toegekende burgerlijke en politieke rechten $-[\ldots]-$ maar dat art. 26 inhoudende de gelijkheid van allen voor de wet en de aanspraak op gelijke bescheming door de wet zonder discriminatie-zelf een burgerlijk en politick recht inhoudt, dat voor alles geldt ${ }^{+50}$

Het is deze visie die niet lang daarna ten volle onderschreven wordt door het Comité voor de Rechten van de Mens, dat in de zaken Broeks" en Danning ${ }^{52}$ overwoog:

"12.1 The State party contends that there is a considerable overlapping of the provisions of article 26 with the provisions of article 2 of the Intemational Covenant on Civil and Political Rights. The Committee is of the view that the International Covenant on Econonic, Social and Cultural Rights would still apply even if a particular subject matter is referred to or covered in

48 Het IVBPR.

49 Artikel 26 IVBPR.

so RSV $1984 / 150$, p. 362 .

51 Comite voor de Rechten van de Mens 9 april 1987 Communication $180 / 1984$, RSV 1988/201.

52 Comité voor de Rechten van de Mens 9 april 1987 Communication nr. 172/1984, RSV 1987/245 m.tht W.M. Levelt-Overmars onder RSV 1987246 
other international documents, e.g [..] the Intemational Covenant on Economic, Social and Cultural Rights. Notwithstanding the interrelated drafting history of the two Cowenants, it remains necessary for the Committee to apply fully the tems of the Intemational Covenant on Civil and Political Rights. The Committee observes in this connection that the provisions of article 2 of the International Covenant on Econonic, Social and Cultural Rights do not detract from the full application of article 26 of the International Covenant on Civil and Political Rights.

$[\ldots]$

12.3 For the purpose of determining the scope of article 26 , the Committe has taken into account the 'ordinary meaning' of each element of the article in its context and in the light of its object and purpose. [...]. The Committe begins by noting that article 26 does not merely duplicate the guarantees already privided for in article 2 . Its basis stems from the principle of equal protection of the law without discrimination, as contained in article 7 of the Unversal Declaration of Human Rights, which prohibils discrimination in law or in practice in any field regulated and protected by public authorities. Article 26 is thus concerned with the obligation imposed on States in regard to their legislation and the application thereof.

12.4 Although article 26 requires that legislation should prohibit discrimination, it does not of itself contain any obligation with respect to the matters that may be provided for by legislation. Thus it does not, for example, require any State to enact legislation to provide for social security. However, when such legistation is adopted in the exercise of a State "s sovereign power, then stuch legislation must comply with articte 26 of the Covernant.

12.5 The Committee observes in this connection that what is at issue is not whether or not social security should be progressively established in the Netherlands but whether the legislation providing for social security violates the prohibition against discrimination contained in article 26 of the Intermational Covenant on Civil and Political Rights and the guowomuee given therein to all persows regatding egual and effective photection against discrimination." (mijn cursivering, RB)

Aldus liet het Comite er geen twijfel over bestaan (a) dat nationale wetgeving als zodanig aan het in artikel 26 IVBPR neergelegde discriminatieverbod kan worden getoetst, (b) dat aan artikel 26 IVBPR bij deze toetsing een zelfstandige betekenis toekomt, (c)dat artikel 26 IVBPR als zodanig niet verplicht to de invoering van sociale wetgeving, maar dat als hiertoe wordt overgegaan deze wetgeving de toets aan artikel 26 IVBPR moet kunnen doorstaan en (d) dat in artikel 26 IVBPR tevens de garantie van effectieve bescherming tegen discriminatie ligt besloten. Hoewel de beslissingen van het Comite niet bindend zin, zijn de punten a tot en met c sindsdien gemeengoed in de Nederlandse jurisprudentie geworden. De implementatie wan punt $d$ is echter moeizamer geweest, zoals in het vervolg van dit hoofdsuk nog zal blijken.

Met de uitspraak van het Comite in de zaken Broeks en Domming was de eerste pijler onder de uitsprak van de Centrale Raad van Beroep van 1 november 1983 geslecht.

De tweede pijler betrof's Raads overweging dat in sociale zekerheidsregelingen voorkomende, met bestaande maatschappelijke structuren samenhangende en mogelijk als discriminatoir an de merken onderscheidingscriteria als man/vrouw en gehuwd/ongehuwd doorgaans slechts door middel van geleidelyke maatregelen [kumen] worden opgeheven'. (mijn cursivering, RB) Ter nadere motivering van deze stellingname had de Raad gewezen op de periode van zes jaar die de EEG-Lidstaten is gegeven bij de implementatie van EEG-Richtijin $79 / 7$ van 19 december 1978 inzake de gelijhberechtiging van man en vrouw in de sociale zekerheid. Achteraf mag worden aangenomen dat in deze koppeling aan de implementatietermijn van de Richtlijn een zeer belangrijke adder onder het gras lag. Immers, na het verstrijken van de implementatietermijn en met het ruime toepassings- 
bereik dat het Comité voor de Mensenrechten voor artikel 26 IVBPR ziet weggelegd voor ogen, gaat de CRvB in zijn uitspraak van 14 mei $1987^{53} \mathrm{om}$. In deze uitspraak stond de vraag centralal of de in artikel 7 , lid 4 , van de Wet uitkering vervolgingsslachtoffers (WUV) opgenomen uitsluiting wan gehuwde vrouwen die geen kostwinner zijn, de toetsing aan het in artikel 26 IVBPR (door de Raad aangeduid als 'BP-Verdrag) kan doorstaan. Dienaangaande overweegt de Raad zonder enige omhaal:

'De Raad is van oordeel dat, mede gelet op art. 2 van het BP-Verdrag, artikel 26 daarvan ook van toepassing is op een regeling als is neergelegd in de wet. De raad moet darn ook constatteren dat het bepaalde in art. 7, vierde lid, en in art. 34, tweede lid, aanhef en onder a, van de wet strijgd oplevert met het bepaalde in art. 26 van het BP-Verdrag. ${ }^{5.4}$

De uitspraak van de CRwB van 14 mei 1987 kan, zeker achteraf, beschouwd worden als een doorbraak die de weg heeft geëffend voor andere belangrijke, in dit hoofdstuk nog aan de orde te stellen, uitspraken. ${ }^{5}$

Uit de uitspraken van het Comité voor de Mensenrechten in de zaken Broeks en Damning komt tenslotte naar voren dat het recht op gelijke behandeling niet betekent dat ieder onderscheid ontoelaatbaar is. Naar het oordeel van het Comité leveren onderscheidingen, berustend op redelijke en objectieve criteria geen door artikel 26 IVBPR verboden onderscheid op. Algemeen wordt aangenomen dat het Comité bij de beoordeling van de vraag of een bepaald onderscheid een verboden discriminatie in de zin van artikel 26 IVBPR oplevert, een marginaal-abstracte toetsing verricht. ${ }^{56}$ Beoordeeld wordt of de regeling zelf al dan niet met deze verdragsbepaling in overeenstemming is. Het Comité bespreekt slechts de vraag of de aangevochten regeling als zodanig juridisch aanvaardbaar is. Het Comité kent geen doorslaggevende betekenis toe aan de omstandigheid dat een betrokkene minder gunstig behandeld wordt dan anderen. Het Comité eist dus niet dat een regeling in zijn toepassing tot gelijke uitkomsten leidt. Tenslotte valt op dat, waar het Comité in de zaak Broeks voor zijn oordeel dat er sprake was van een ongeoorloofd onderscheid een extra argument achtte te zijn gelegen in het feit dat het gewraakte onderscheid inmiddels met terugwerkende kracht door de Nederlandse wetgever was ingetrokken, ${ }^{57}$ het in latere

53 CRvB 14 mei 1987, AB 1987.543 m.nt. HH; RSV 1987246 m.n. W.M. L.evelt-Ovemals.

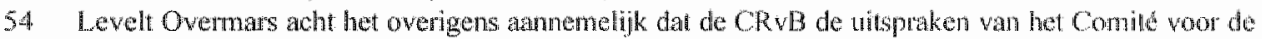
Rechten van de Mens in de zaken Broeks en Danning niet kende loen hij de witspratk in de WUVzaak deed; zie haar noot onder de uisprak in RSV 1987/246. Zie echter tevens de noot wan Aleidus

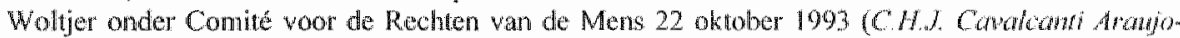
Jongen v. the Netherlands), NJCM-Bulletin 19-2 (1994), p. 185-186, volgens wie de uitspraken in de zaken Broeks (MC 9 april 1987, Comm. 172/1984, RSV 1987, 245) en MC 9 april 1987 (2wadn-do Vhies, Comn. 182/1984) aarleiding waren on terug te komen op het earder ingenomen standpunt, namelijk dat getijke behandeling op het terein van de sociale zekertieid geleidelijk mocst worden verwezenligkt hetgeen, althans aanwankelijk, vergezeld ging met de vastsielling dat artikel 26. IVBPR geen betekenis had voor het sociale zekertheidsrecht.

55 Zie de noot van J. RR iphagen onder CRvB 24 januari 1991, AB 1991, 338.

56 Zie bijv. de uitspraak wan het Comité voor de Rechten wan de Mens van 29 maar 1989. Vos, RSV $1990 / 172$ en NJCM-Bulletin, 14 (1989), mx. 7, blz. 879-888.

57 De zak Broeks had betrekking op de uitsluiting wan de gehuwde vroun, wiet kostwinner, van de uitkering ingevolge de Wet werkloosheidsvoorziening (WWV). Deze uitsluiting werd bij Wei van 29 april 1985 met terugwerkende kracht tot 23 december 1984 ingetrokken, zij het alleen ten behoeve wan gehuwde vouwen die op of na 23 december 1984 werkloos waren geworden. Zive hierover verder paragraaf 3 van dil hooldstuk. 
rechtsprak in het alsnog opheffen van de discriminatie eerder een reden voor afwijzing van de klacht ziet. ${ }^{58}$

\subsection{Artikel/4/EG}

Dit artikel warborgt de gelijke beloning van vrouwen en mannen. Deze was voorheen geregeld in artikel 119 EEG. Omdat alle in dit boek behandelde jurisprudentie over het beginsel van gelijke behandeling naar communattair recht nog onder het oude artikel heeft plaatsgevonden, zal hier worden volstaan met een korte inleiding op het 'oude' artikel. De geschetste ontwikkelingen in de jurisprudentie zijn echter evenzeer van toepassing op de nieuwe bepaling.

De eerste volzin van artikel arike $119 \mathrm{EEG}$ luidde:

Tedere Lid-Staat verzekert gedurende de eerste etappe en handhath vervolgens de toepassing van het beginsel wan gelijke beloning voor mannelijke en wrouwelijke werknemers voor gelijke arbeid."

Aan artikel 119 EEG-Verdrag kwam een zeer sterke werking toe. Het gold als een van de belangrijkste positiveringen van het beginsel van gelijke behandeling van mannen en vrouwen. In de communautaire rechtsorde heeft dit beginsel de status van grondrecht. Volgens het Hof van Justitie omvatten de algemene beginselen van het gemeenschapstecht de fundamentele rechten van de mens en lijdt het geen twijfel dat de opheffing van discriminaties naar geslacht deel uitmaakt van die fundamentele rechten. ${ }^{59}$

Artikel 119 EEG-Verdrag werkte rechtstreeks door in de nationale rechtsorde van de LidStaten, in die zin dat het aan de ingezetenen wan de Lid-Staten rechtstreeks een subjectief recht op gelijke behandeling toekende, zonder dat daartoe nog nadere tussenkomst van de communautaire of nationale autoriteiten nodig was. Eveneens werkte het direct, zonder tussenkomst van de nationale wetgever, door in de verhouding tussen particulieren. ${ }^{60}$

Blijkens de jurisprudentie van het HvJ EG hadden, naast de nationale wetgever, ook de nationale bestuurlike en rechterljke instanties een eigen verantwoordelijkheid ten aanzien van de uitwoering van artikel 119. Zo overwoog het Hof in Defrenne II:

"dat len slotte do verwizing nar de "Lid-Staten" in artikel 119 betrekking heeft op de witoefe-

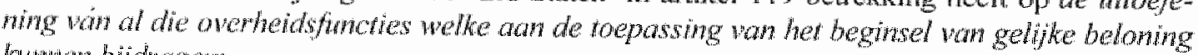
Hurwen biforagen:

dat derhalve, in legenstelling tot wat in de loop van het geding is betoogd, deze bepaling veel meer inhoudt dan oen verwizing naar de bevoegdheid van de nathonale wetgever;

58 Zie am. Comite woor de Rechen van de Mens van 5 mei 1993 J.W.H. Whe Netherlonds, W.CMBulletin 18-7 (1993), p. 858-862, Comifé voor de Rechten van de Mens van 22 oktober 1993 (C.H.J. Conalcant Arayo-Jongen w. The Nerherlands, NCM-Bulletin 19-2 (1994) m.nt. Aleidus Woltjer.

59 Zie: HvJ EG 15 juni 1978, zak 149/77. Defreme II, Jur. 1978, p. 1365. Zie in dit werband ook: P.J.G. Kapteyn en P. VerLoren van Themat, Inleiding tot het recht wan de Europese Gemeenschappen, Deventer 1995, p. 176-178; zie voorts: $\mathbb{E}$ A. Alkema, a.w. (noot 25), p. 90. 
dat wanneer artikel 119 wan de Lid-Staten spreek, dit mitsdien niet aldus kan worden uitgelegd, als zou rechtstreckse toepassing van het Verdrag door de rechuer daurdoor zijn uitgesloten ${ }^{\text {sol }}$ (mijn cursivering, RB)

Volgens het door het EEG-Verdrag voorziene tijdschema had de toepassing van artikel 119 ten wolle moeten zijn verzekerd op 1 januari 1962 en was het de bedoeling dat aan het artikel vanaf die datum rechtstreekse werking zou toekomen. Op de desbetreffende datum was echter, mede tengevolge van onzeker optreden van de kant van de Commissie, van een volledige implementatie van het artikel geenszins sprake. Een en ander was voor het Hof in Defrenne II aanleiding tot de vermanende woorden dat

\begin{abstract}
'aan de werkzamheid van deze bepaling ${ }^{62}$ nitet wordt afgedaan door de onstandigheid dat de Lid-Staten zich niet aan deze verphichting hebben gehouden en de gemeenschapsinstellingen onvoldoende tegen dit verzuim zijn opgetreden;

dat een andere opvatting erop zou uitlopen dat rechisverkochring vof interprelatieregel wordt verheven, welke opvatting het Hof niet tot de zijne kan maken zonder in strijd te komen met de hem in artikel 164 van het Verdrag gegeven opdracht". (mijn cursivering)
\end{abstract}

Waarna het Hof vervolgens toch de hand over het hart streek en de ingangsdatum wan de rechtstreekse werking stelde op de dag waarop dit arrest werd uitgesproken: 8 apri1 1976.

Voor wat de wettelijke stelsels inzake de sociale zekerheid betreft is an het in artike॥ $\| 19$ EEG gecodificeerde gelijkheidsbeginsel nader uitwerking gegeven in Richtlijn $79 / 7$ EEG. ${ }^{63}$ Op de werking van deze richtlijn, die een centrale rol zal vervullen in dit hoofdstuk, wordt thans in algemene zin ingegaan.

\title{
Richtijin $79 / 7$ EEG
}

2.6.1 De werking van richtlijnen in het algemeen

Krachtens artikel $249 \mathrm{EG}^{\text {it }}$ zijn richtlijnen van de Raad en de Commissie verbindend voor elke Lid-Staat waaryoor zij zijn bestemd. Deze verbindendheid heeft betrekking op het door middel van uitvoering van de richtlijn te bereiken resultaat. Voor wat de keuze van de vorm en middelen waarop dit resultaat kan worden bereikt laat artikel 249 EG de LidStaten vrij. Wel stellen de meeste richtlijnen een tormijn wasbinnen het door de richtijn beoogde resultat door de Lid-Staten dient te zijn verwezenlijkt.

De vrijheid wat de keuze van vorm en middelen aangaat heeft er echter niet aan in de weg gestaan dat ook aan bepalingen wan richtlijnen rechtstreekse werking kan toekomen. Reeds in 1974 bepaalde het Hof van Justitie dat na afloop van het werstrijken wan de implementatietermijn aan bepalingen van richtlijnen rechtstreekse werking loekomt, indien:

a. de bepaling een voldoende duidelijke verplichting bevat;

b. die niet afhankelijk is van een voorwaande of een termijn;

61 Hul EG 8 april 1976, zaak 43/75 (Defrenne ID), Jur. 1976, 1:0, 35-37.

62 Artikel $119 \mathbb{E E G}$.

63. Richtijn wan de Raad van 19 december 1978 betreffende de geleidelike tenuitworrlegging van het beginsel van gelijke behandeling van mannen en vroutuen op het gebied van de sociale zekerheid (PB $1979, \mathrm{~L} 6, \mathrm{p} .24)$. Voorhern: antikel 189 EEG. 
c. er geen nadere uitvoeringshandeling vereist is van de zijde van een Gemeenschapsinstelling of de Lid-Staten en

d. de betreffende bepaling strekt ter beperking van de discretionaire bevoegdheid wan de nationale autoritenten. ${ }^{65}$

Deze jurisprudentie baseert het Hof op de dwingende werking die door artikel 189 EEGVerdrag aan richtijnen wordt toegekend. Deze dwingende werking brengt blijkens het NO-arrest mee

"dat men name in gevallen warin het gemeenschapsgezag de Lid-Staten bij richtlin heeft werplicht een bepaalde gedragsling te volgen, het mutrig effect van zodunige handeling zou worden verzwakt, wanneer de justitiabelen zich datop in rechte niet zouden mogen beroepen en de mationale rechterlijke instanties daarop geen acht zouden mogen slaan als op een element van het gemeenschapstecht". (mijn cursivering, RB)

Volgens dit arrest is de strekking van de rechtstreekse werking van een richtlijnbepaling hierin gelegen dat de justitiabele zich voor de nationale rechter op de bepaling kan beroepen, teneinde door deze te doen nagaan of de bevoegde nationale autoriteiten bij de bun in het kader van de uitvoering van de richtlign gelaten vrijheid ten aanzien van vorm en middelen, binnen de door de richtlin aangegeven beoordelingsgrenzen zijn gebleven. ${ }^{6}$ Voorts bepaalt het Hof dat het zich van een oordeel dient te onthouden voorzover het gaat om uitvoering van bepalingen die "hetzij uitdrukkelijk hetzij vanwege de onbestemdheid der gebruikte begrippen aan de wetgevende of bestuursinstanties een beoordelingsruimte later ten aanzien wan de zakelijke inhoud der toegestane uitzonderingen en afwijkingen".

Dit is sindsdien vaste jurisprudentie wan het Hof. In 1986 wordt zij in de zaak Marshall als volgt verwoord:

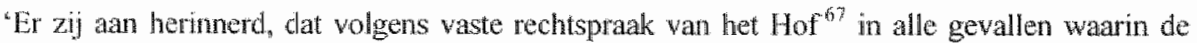
bepalingen van een richtlin inhoudelijk gezien onwoorwaardelijk en voldoende nauwkeurig zijn, particalieren gerechtigd zijn hierop een beroep te doen tegenover de staat, wanneer deze hetzij verzuimt de richtijn binnen de gestelde termijnen in thet nationale recht ten uitwoer te leggen, hetrij dit op onjuiste wijze doet.

Deze rechtspraak is gegrond op de overweging dat het onverenigbaar zou zijn meth de dwirgende werking die in antike 189 ELG-Verdrag aan de richtlijn wordt toegekend, om principieel wit te suiten dat de daarbij opgelegde verplichting door betroffen personen kan worden ingeroepen. Hicran beeft het Hof de gevolgtrekking verbonden, dat een Lid-Staat die de door de richthin voorgeschreven uitwoeringsmaatregelen niet tijdig heeft getroffen, het feit dat hij zijn uit de richtlin woortvloeiende verplichtingen niet is nagekonen, niet aan particulieren kan tegenwerpen.

65 Hw EG 4 december 1974, zak 4174, Fon Dwy v. Home Office, Jur. 1974, p. 1337; SEW 1976. 0. 67

66 HWJ EG I februari 1977,2 aak 51766 , WNO, Jur. 1977, p. 113, r.o. 23 en 24 .

67 Het Hof verwigst hierbij in het bijzonder naar HwI EG 19 januari 1982, zaak 8/B1, Becker, Jur. 1982 , p. 53.

68 HWI EG 26 februari 1986, zaak 152/84, Marshall, Jur. 1986, p. 723, 1.0, 46 en 47. Zse in dit verband ook de noot van F. W.M. Keunen onder Hw EG 8 maart 1988, zaak 80/87, Dik, RSV1988/183, die opnuerkt dat voor rechtstreekse werking van een richtihn is wereist dat deze voldoende naunkeurig, bepaald en onvoorwaardelijk is en voorts benadrukt dat dit wereiste ziet op de inhoud van de bepaling. dus op hel resultaat dat bereikt moet worden, en niet op de wijze waarop deze verplichting wordt 
Deze formulering brengt op twee punten een nadere verduidelijking aan. Allereerst wordt duidelijk dat een particulier niet slechts een beroep op de richtijn toekomt, indien deze door de staat niet tijdig wordt uitgevoerd, maar eveneens indien de uitvoering van de richtlijn wel tijdig, maar op onjuiste wijze heef plaatsgevonden. Uit eerdere jurispnudentie was reeds gebleken dat van onjuiste uitvoering gesproken kan worden, indien een staat zijn wetgeving gedurende de overgangstijd verder van het door de richtlijn voorziene einddoel afbrengt ${ }^{6 \%}$ Voorts is het, in het licht van de in dit hoofdstuk te behandelen jurisprudentie van het Hof, van belang erop te wijzen dat de overweging volgens welke een niet tjjdige uitvoering door de staat niet aan particulieren mag worden tegengeworpen, mede een procesrechtelijke betekenis heeft. Gezien haar ruime formulering houdt deze overweging immers ook aan de nationale rechterlijke instanties voor geen acht te slaan op van overheidswege aangevoerde argumenten die verband houden met de niet tijdige implementatie van de richtlijn. Naar uit dit hoofdstuk nog nader zal blijken kan dit onder omstandigheden betekenen dat uit de rechtstreekse werking wan richtlijnbepalingen een gebod aan de nationale rechter voortvloeit om geen acht te slaan op nationale wettelijke bepalingen die van de richtlijn afwijken.

In de literatuur wordt naast de rechtstreekse werking de richtlijnconforme interpretatie van richtlijnen onderscheiden. Bij richtlijnconforme interpretatie dient de nationale rechter een wettelijke bepaling die mogelijk in strijd is met een richtijnbepaling zo te interpreteren dat gevolg gegeven wordt aan de richtlijnbepaling. Voor richtlijnconforme interpretatie geldt niet de voorwaarde dat de richtlijnbepaling inhoudelijk gezien onvoorwaardelijk en voldoende nauwkeurig is en evenmin is vereist dat de aanpassingstermijn van de richtlijn is verstreken. Wel moet er sprake zijn van nationale wetgeving die richtlijnconform kan worden getoetst. Deze behoeft niet de in het kader van de richtlijn vereiste nationale wettelijke unitvoeringsregeling te zijn. ${ }^{70}$

In het arrest Dori ${ }^{71}$ heeft het $\mathrm{HvJ} \mathrm{EG}$ de richtlijnconforme interpretatie als volgt verwoord:

'Het is voorts vaste rechtspraak dat de uit een richtlijn woortvloeiende verplichting van de LidStaten om het daarmee beoogde doel te verwezenlijken, alsook de verplichting van de Lid-Sitaten krachens artikel 5 EEG-Verdrag, on alle algemene of bijzondere maatregelen te treffen die geschikt zijn om de nakoming vain die verplichting te verzekeren, voor alle met overheidsgezag beklede instanties in de Lid-Staten gelden, en dus, binnen het kader wan hun bevoegdheden, ook voor de rechterlijke instanties."

Daarbij heeft het Hof onder verwijzing naar de arresten Marleasing ${ }^{72}$ en Wagner Miret ${ }^{73}$ benadrukt dat de nationale rechter bij de toepassing van bepalingen van nationaal recht, ongeacht of zij wan eerdere of latere datum dan de richtlijn zijn, deze zoveel mogelijk moet

gerealiseerd.

69 HwJ EG 23 matart 1983, zaak 77/82, Anastasia Peskelogitow, Jur. 1983, p. 1085.

70 Deze wijze van interpreteren heef het Hof ontwikkeld in de arresten Won Colson ev Kamam, zatak 1483, Jur. 1984, p. 1891 en Harz, zaak 79/83, Jar. 1984, 1921 en SEW 1985, p. 216 m.nt. Leenen. Zie woorts Hv』EG 8 oktober 1987, zaak 8086, Kolpinghuis, Jur. 1987, p. 3969, Ars Aequi 37 (1988), p. 329 e. . m.nt. C.W.A. Timmermans.

71 HW EG 14 juli 1994, zaak C-91/92, Dori, Jur 1994, p. 1-3325; Ars Aequi 43(1994) 12, p. 845 e.r.

72 HWل EG 13 november 1990 , zaak C-106/89, Marleasing, Jur. 1990, p. 1-4135, r.o. 8.

73 HwJ EG 16 december 1993, zaak C-33492, Wagner Miret.Jur. 1993, p. $1-6911$, ro. 20. 
uitleggen in het licht van de bewoordingen en het doel van de richtijn, teneinde het hiermee beoogde resultaat te bereiken en aldus aan artikel $1.0 \mathrm{EG}^{74}$ te voldoen.

Uit deze overwegingen blijkt dat de op de nationale rechter rustende plicht tot richtlijnconforme interpretatie voortvloeit uit het in artikel $10 \mathrm{EG}$ neergelegde beginsel van gemeenschapstrouw, dat geldt voor alle met overheidsgezag beklede instanties in de Lid-Staten, en dus ook woor de rechterlijke instanties. ${ }^{\text {?5 }}$ Uit het arrest Marleasing vloeit voort dat deze plicht ook geldt ten aanzien van nationaal recht dat van voor de totstandkoming van de richuling dateert.

Mortelmans en Temmink onderscheiden in hun noot onder het arrest Dori ${ }^{76}$ nog een derde vorm van doorwerking van richtlijnen in de nationale rechtsorde, te weten de Francovichschadeplichtigheid. In het arrest Dori overweegt het HvJ EG onder meer:

\begin{abstract}
"Wanner het door de richtijin voorgeschreven resultaat niet via uitlegging kan worden bereikt, zijn de Lid-Staten volgens het arrest van 19 november $1991^{77}$ krachtens het gemeenschapsrecht gehouden tot vergoeding van de schade die aan particulieren is veroorzaakt doordat een richtlijn niet in nationaal recht is omgezet, mits aan drie voorwaarden is voldaan. In de eerste plaats moet de richuljin ertoe strekken rechten toe te kennen. In de tweede plats moet de inhoud van die rechten kunnen worden wastgesteld op basis van de bepalingen van de richtlijn. En ten slotte moet er een causaal verband bestaan tussen de schending van de op de staat rustende verplichting en de geleden schade.'
\end{abstract}

Mortelmans en Temming wijzen erop dat de categorie rechten vervat in deze formule ruimer is dan uitsluitend de rechten die in direct werkende richtlijnbepalingen zijn vastgelegd. Uit het arrest Dori blijkt huns inziens dat woor de staatsaansprakelijkheid geen voorafgaande veroordeling van het Hof waarbij een schending van het gemeenschapsrecht wordt vastgesteld, noodzakelijk is. Voorts valt er volgens hen in de rechtspraak van het Hvy EG een verschuiving waar te nemen van een verwijzing naar subjectieve 'rechten' die particulieren bezitten tegenover in gebreke zijnde Lid-Staten naar een concept van juridische remedies woor gedupeerde particulieren. ${ }^{7 .}$

Voothern. artikel $5 \mathrm{EBC}$.

75. Zie bu dit verband ook A-G Tesauro in zin conclusie wook HW EG 19 juni 1990, zak C-213/89,

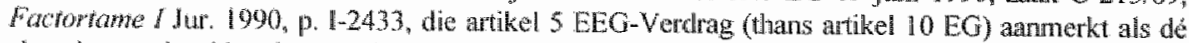
sleutel voor de vitheging wan her stelsel wan samenwerking thssen de communatuire en hationale organen. Feenstra heef de richlignconforme interpretate in verband gebrach met het zogenaande "estoppel" beginsel. Op grond van dit beginsel kan een Lid-Stat, die varzund heeft de richtijin tert uitvoer te leggen of dit niet op de juste wijze heef gedan, zich niet op deze nalatigheid negenover pathoulienen kan beroepen; zie de noot onder HWJ EG 11 juli 1991, zaken C8790, C38/90 en C89/90

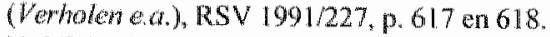

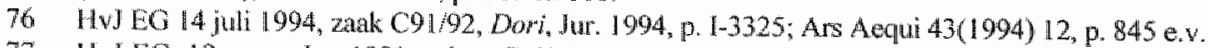

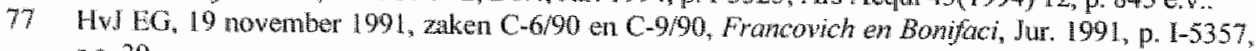
T.0. 39

78 De auturs verwizen in dit werband nar: W, wan Gerven, The horizontal effect of directive prowisions revisited: The neality of catchwords, in. Curtin en Heukels (eds), Liber amiconum Schemens, Dordrecht 1994 
Deze richtlijn, die de geleidelijke tenuitvoenlegging van het beginsel van gelijke behandeling van mannen en vrouwen op het gebied van de sociale zekerheid beoogt, speelt een centrale rol in dit hoofdstuk. Centraal staat het bepaalde in artikel 4 , lid 1 dat luidt:

'Het beginsel van gelijke behandeling houdt in dat iedere wom wan discriminatie op grond van geslacht, hetzij direct, hetzij indirect door verwijzing naar met name echtelijke staat of gezinssituatie, is uitgesloten."

Op grond van artikel 8 van de Richtlijn waren de Lid-Staten gehouden binnen een termijn van zes jaar volgende op de kemnisgeving van de richtlijn, dat wil zeggen te rekenen vanaf 23 december 1984, de nodige wettelijke en bestuurlijke bepalingen in werking te doen treden. Voorzover er nog twijfel bestond over de vraag of de richtlijn met ingang van 23 december 1984 rechtstreekse werking toe kwam, werd deze door het HVJ EG al snel weggenomen. In de hierna nog uitvoeriger te behandelen arresten Drake en FNV ${ }^{80}$ heeft het Hof deze vraag onomwonden in bevestigende zin beantwoord. Evenals de eerder vermelde uitspraak van het Comité voor de Rechten van de Mens in de zaak Broeks had het FNVarrest betrekking op de uitsluiting van de gehuwde, niet kostwinner zijnde, vrouw van een uitkering op grond van de WWV. Het Hof achite deze uitsluiting niet alleen in strijd met artikel 4, lid 1, van de Richtlijn, maar overwoog bovendien dat

'tot het tijdstip waarop de nationale regering de nodige uitwoeringsmatregelen treft, vrouwen derhalve recht op dezelfde behandeling en op toepassing wan dezelfde regeling [hebben] als mannen die in een gelijke situatie verkeren, warbij die regeling, zolang aan de richtlin geen witwoering is gegeven, het enig bruikbare referentiekader bliff . (mijn cursivering, $\mathrm{RB}$ )

In latere jurisprudentie gaat het Hof uit van de algemener geformuleerde regel volgens welke indien er sprake is van discriminatie en er geen uitvoeringswetgeving is, de minder begunstigde groep - hetzij mannen, hetzij vrouwen - recht heeft op toepassing van dezelfde regeling als de overige uitkeringsgerechtigden. Deze regel geldt ook voor gevallen van indirecte discriminatie. ${ }^{81}$ Het is in het bijzonder deze overweging die bepalend is geweest voor de terugwerkende effecten van de rechtspraak waarbij het sociale zekerheidsrecht in overeensternming is gebracht met de bepalingen van internationaal- en cornmunautair recht. Op deze jurisprudentie zal in de volgende paragrafen nader worden ingegaan.

Voor een beter begrip van de hiema te bespreken jurisprudentie is bovendien van belang op te merken dat de werkingssfeer van Richtlijn $79 / 7$ in twee opzichten is beperkt. In artikel 2 van de Richtlijn is aangegeven op welke groepen van personen de Richtlijn van toepassing is (de personele werkingssfeer). In artikel 3 van de Richtlijn is aangegeven tot welke soorten van sociale zekerheidswetgeving de werking van der Richtlijn zich uitstrekt (de materièle werkingssfeer).

79 HwJ EG 24 juni 1986, zaak 150/85, Drake, Jur. 1986, p. 1995; RSV $1987 / 240$.

80 HvJ EG 4 december 1986, zaak 71/85, FNV, Jur. 1986, p. 3855; NJ 1987, 846 m.nt Steyger; RSV $1987 / 95$ m.nt. Govers.

81 Zie Hw EG 13 december 1989, zaak C-102/88, Ruzius/Wibrink, Jur. 1989, p. 4311; Rechtspraak Nemesis 1990, nr. 85; NJCM-Bulletin, 16-1 (1991), p. 65. 
De in artikel 2 van de Richtlijn geregelde personele werkingssfeer ziet op de beroepsbevolking, op werkzoekenden en op werknemers en zelfstandigen wier arbeid is onderbroken door eén van de in artikel 3, lid 1 , sub a van de Richtlinn opgesonde risico's. ${ }^{82}$ De personele werkingssfeer heeft aldus betrekking op gepensioneerden, (invalide) werknemers, (invalide) zelfstandigen en personen wier arbeid is onderbroken door ziekte of een ongeval, of die onvrijwillig werkloos dan wel werkzoekende zijn. Blijkens het arrest Drake $e^{8 \not 3}$ onvat het begrip beroepsbevolking eveneens de gehuwde vrouw die haar werk heeft moeten opgeven ter verzorging van haar invalide moeder. Immers ook hier geldt dat de vrouw haar werk heeft moeten onderbreken ten gevolge van een van de in artikel 3 van de richtlijn genoemde risico's, te weten invaliditeit. Ook hier benadrukt het Hof de eis van het nuttig effect van het gemeenschapsrecht, waar het overweegt dat

"de onstandigheid dat een uitkering die wordt toegekend krachtens een wettelijke invaliditeitsregeling, wordt uitbetald aan een derde en niet rechtstreeks aan de gehandicapte, bijgevolg niet [meebrengt] dat de uitkering buiten de werkingssfeer van richtlijn $79 / 7$ valt. Anders zouden, gelijk de commissie in haar opmerkingen beklemtoont, onder de richtlijn vallende prestaties door het aanbrengen van formele wijzigingen aan de werkingssfeer daarvan kunnen worden onttrokken'.

Daarmee was wel de uiterste grens van de personele werkingssfeer bereikt. ${ }^{8.4}$ Blijkens het arrest Johnson ${ }^{4}$ is Richtlijn 79/7 EEG niet van toepassing op iemand die zijn of haar arbeid heeft onderbroken om zich met de opvoeding van zijn of haar kinderen bezig te houden en die door ziekte werhinderd is weer te gaan werken, tenzij de betrokkene werkzoekencle is en dat zoeken onderbroken is doordat zich een van de in artikel 3, lid 1 sub a, van de richtlijn genoemde risico's heeft voorgedaan. Voorts heeft het Hof in het arrest Wetten-Yan Uden ${ }^{\text {si }}$ bepaald dat de nationale rechter de personele werkingssfeer van de Richtlijn niet kan uitbreiden op de grond dat de justitiabelen zijn onderworpen aan een nationale regeling die onder de in artikel 3 van de Richtlijn omschreven materiële werkingssfeer valt.

Deze materiële werkingssfeer onvar blijkens artikel 3 van de Richtlijn de wettelijke regelingen inzake invaliditeit, ouderdom, arbeidsongevallen, beroepsziekten en werkloosheid, alsmede de sociale bijstandsregelingen die voor deze wettelijke regelingen in de plaats komen. In de praktijk betekent dit dat voor wat de Nederlandse wetgeving betreft de Richtlijn van toepassing is op de $Z W$, WAO, WW, $A O W, Z F W, A W B Z$, de ABP-wet, de wettelijke VUT-regelingen, alsmede de voormalige AAW, WWV en RWW. Voorts

HW EG 27 juni 1989, gevoegde raken 48, 106 en 107/88, Acherberg-Te Riele e.a., Jur. 1989, P. 1963: RSV 1990232 mint. Van Dalen-Van Bekkum.

83 Hu EG 24 jun 1986, zaak 150/85, Drake, Jur. 1986, p. 1995 ; RSW 1987240 m.nt. HH.

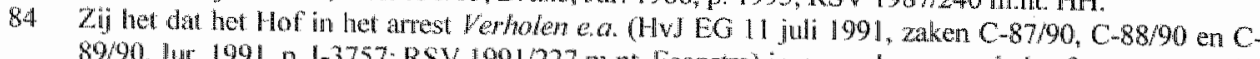

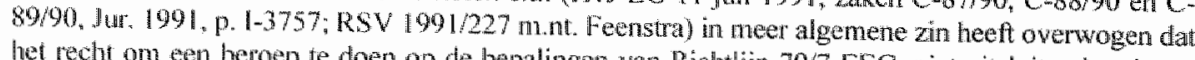
het recht om ten beroep te doen op de bepalingen van Richtijn $79 / 7$ EEG, niet uitslutend toekom aan justitiaben die onder de persone werkingssfeer van de richting vallen. Nawe het oordeal van thot Hof is immers nik wit to sluiten dat ook andere personen eq rechtstreeks belang bij kumen hebben dat het non-discrimunatiebeginsel jegens de beschemde personen in acht wordt genomen.

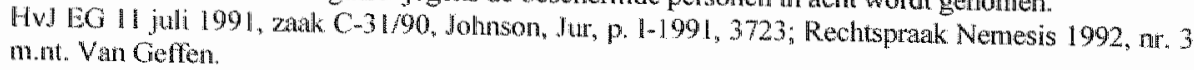

86 Hw LG 11 juli 1991, zank C-88/90, gevoegd behandeld met zaken C-87/90 an C-98/90, Ferholen e.4., Jur. 1991. P. 1-3757; RSV 1991/227 m.nt. Feenstra. 
zondert het tweede lid van artikel 3 de werking van de richtlijn nog uit voor de "eventualiteiten' weduwschap, moederschap en gezinslasten, tenzij het gaat om gezinsbijslagen die worden toegekend uit hoofde van verhogingen van de prestaties die worden toegekend als gevolg van de in het eerste lid genoemde eventualiteiten. Voor Nederland betekent dit in de praktijk dat de AWW en de kinderbijslagwetten buiten de werkingssfeer van de richtlijn vallen. ${ }^{87}$

In de Richtlijn 79/7 EEG wordt een uitdrukkelijk onderscheid gemaakt tussen directe en indirecte discriminatie. Dit onderscheid is afkomstig uit de jurisprudentie van het HvJ EG op artikel $119 \mathrm{EEG}$. Van directe discriminatie is sprake, indien een verschillende behandeling van mannen en vrouwen het gevolg is van het door bestuur of wetgever hanteren van criteria die direct aanknopen bij het geslacht, onverbrekelijk aan het geslacht verbonden eigenschappen of bij een exclusieve juridische status die aan een der geslachten is gegeven. Van indirecte discriminatie is sprake indien het verschil in behandeling voortvloeit wit het gebruik van criteria die weliswaar geslachtsneutraal zijn, maar niettemin een indirect middel vormen om mannen en vrouwen ongelijk te behandelen. Te denken valt hierbij aan criteria die associaties hebben met maatschappelijke rolpatronen of veronderstelde gedragingen, zoals het gehuwd zijn, het kostwinner zijn, het zijn van deeltijdwerker of het verzorgen van een huishouden. ${ }^{88}$

Er is sprake van een vermoeden van indirecte discriminatie wanneer uit bijwoorbeeld statistisch onderzoek blijkt dat een maatregel in haar effect in overwegende mate een onderscheid maakt tussen mannen en vrouwen. Deze statistische overweging kan zelfs beslissend blijken te zijn als er geen aanknopingspunten zijn voor de beoordeling van de vraag of het gemaakte onderscheid objectief gerechtvaardigd kan worden. Is er geen objectieve rechtvaardigingsgrond, dan kan het beoogde doel (discriminatie) uit het verkregen resultaat worden afgeleid en wordt op de ontkenning van een discriminerende bedoeling geen acht geslagen. De betekenis die in het EG-recht wordt toegekend aan het begrip 'onderscheid' is dan ook kleurloos: een discriminerende bedoeling behoeft niet te worden aangetoond. Bij een eenmaal bestaand vermoeden van indirecte discriminatie is het vervolgens aan degene die de maatregel heeft getroffen om te bewijzen dat aan de maatregel objectief gerechtvaardigde gronden ten grondslag hebben gelegen, waaraan elke gedachte van discriminatie vreend is. ${ }^{89}$

Samengevat stellen zowel het Hof als de Commissie de volgende eisen aan indirecte discriminatie:

het gebruik van een bepaald criterium moet, hoewel sexe-neutraal, een ongelijkheidseffect tussen mannen en vrouwen veroorzaken;

87 Zie hieromtrent: I.P. Asscher-Vonk. L. Betten en W.J.P.M. Fase (red.), a.w. (noot 36), p. 39-40.

88 i.P. Asscher-Vonk, L. Betten en W.J.P.M. Fase (red.), p. 48.49

89 Aldus naar de vrijwel letterljke bewoordingen van de Commissie in haar Tussentijds Verslag ower de toepassing wan de derde richtijn wan de Europese Commissie d d. 6 jusuari 1984 COM (83) 793 def., blz. 8, waarin de Commissie zich in belangrigke mate baseent op hef arrest Jenkins (HWW EG 31 maart 1981, zak 96/80, Jur. 1981, p. 911). 
- het ongelijkheidseffect moet de vrouwen of de mannen als groep tenminste in overwegende mate treffen; het gebruik moet dus in hoge mate hetzelfde effect als directe discriminatie opleveren en

- een objectieve rechtvaardigingsgrond is afwezig, althans kan niet worden bewezen door degene, die onderscheidend handelt.

Voor wat het toepassingsbereik var artikel 119 EEG en de ter nadere uitvoering van dit artikel uitgevaardigde richtlijnen geldt dat direct onderscheid naar geslacht altijd werboden is, tenzij het EEG-recht zelf uitdrukkelijk in een uitzondering op dit beginsel voorziet. ${ }^{\text {Sit }} \mathrm{De}$ vraag naar de objectieve rechtvaardigingsgrond komt alleen aan de orde bij indirecte discriminatie. Juist omdat het gemeenschapsrecht het begrip onderscheid 'kleurloos" opvat komt in gevallen waarin een vermoeden van indirecte discriminatie rijst het wolle gewicht te liggen op (1) wat dient te worden verstaan onder een objectieve rechtvaardigingsgrond en (2) weike instantie uiteindelijk bevoegd is vast te stellen of in een bepaald geval aan de desbetreffende criteria is voldaan. De laatste vraag is het eenvoudigst te beantwoorden. In de in dit hoofdstuk aan de orde te stellen gevallen komt de vraag naar de aanwezigheid van een objectieve rechtvaardigingsgrond gewoonlijk aan de orde in het kader van de in artikel 234 EG geregelde procedure van prejudiciële vraagstelling van de nationale rechterlijke instanties aan het HvJ EG. In het kader van deze procedure geeft het Hof weliswaar in algemene zin uitleg aan het begrip objectieve rechtvaardigingsgrond; het zijn evenwel de nationale rechterijke instanties aan wie de uiteindelijke beslissing toekomt over de vraag of in een bepaalde zaak an de criteria voor de aanwezigheid van een objectieve rechtvaardigingsgrond wordt voldaan. Een en ander neemt niet weg dat het Hof soms vrij gedetailleerde richtlijnen aan de nationale instantie kan geven. ${ }^{.1}$

Voor wat de eerste vraag betreft is het Hof van oordeel dat een eenmaal gebleken onderscheid in behandeling tussen mamnen en vrouwen slechts kan worden gerechtvaatdigd door objectieve factoren die niets van doen hebben met discriminatie op grond van geslacht. Uit de jurisprudentie van het Hof blijkt dat dergelijke factoren mede gelegen kunnen zijn in economische redenen. Zo kreeg het Hof in de zaak Jenkins ${ }^{92}$ te oordelen over een maatregel die tot gevolg had dat deeltijdwerkers naar verhouding minder verdienden dan 'full-time' werkers, wat een vermoeden van indirecte discriminatie deed rijzen, ondat vast stond dat aanzienlijk meer vrouwen dan mannen door deze maatregel werden getroffen. De staat gaf een economische reden voor het uitvaardigen van deze maatregel, namelijk het aanmoedigen van werken in voltijdarbeid, welke reden door het Hof als rechtvaardigingsgrond werd geaccepteerd. Ook het voeren van een 'sociaal beleid' kan volgens het Hof een rechtvaardigingsgrond opleveren. ${ }^{93}$ Aan dit sociaal beleid moet dan echter wel op consistente wijze uitvoering worden gegeven. Zo was het Hof van oordeel dat er wel sprake kon zijn van indirecte discriminatie toen het werd geroepen te oordelen over de bepaling in de AAW die arbeidsongeschikte deeltijdwerkers uitzonderde van de

90 Zue o.t.: I.P. Asscher Vonk, L. Betten en W. J.M. Fase (red.), a. w. (noot 36), p. 57, Zle voor wat het voormalige artikel 119 EEG-Verdrag betreft ook: Conchuste A-G Koopmans voor IHR 29 november 1991. NJ 1993, 150 en 151 (Bopa).

91 Zoals bijwoorbeeld in HVI EG 22 september 1988, zaak 236/87, Bergemam, Jur. 1988. p. 5125; RSV $1990 / 170$.

92 Hw EG 31 maart 1981, zadk 96/80, Jenkins, Jur. 1981, p. 911.

93 Zie bijw. HWJ $\mathbb{E G} 13$ juli 4989 , zaak 171/88, Ringer-Kihho, Jur. 1989, p. 2743. 


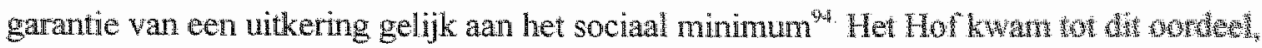

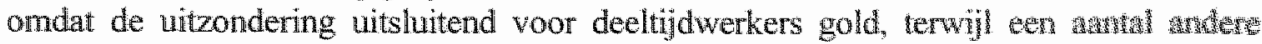
groepen die in het jaar voorafgaande am de arbeidsongeschiktheid in het gehoel yeen wa komen of slechts een zeer gering inkomen hadden, wel voor een volledige witurimy a.anmerking kwamen.

In de zaak Teuling-Worms ${ }^{96}$ acht het Hof mede een rechtvaardigingsgrond gelegen in do beheersing van de sociale uitgaven. In geding waren de verschllen die voorvloein uit de bantering van de respectievelijk hoge dan wel lage grondslag voor de berekering wan de witkeringsrechten in de WAO. ${ }^{97}$ Voor de hoge grondslag kwamen, kort gezegd, personew met gezinslasten in aanmerking. Vast stond dat aanmerkelijk meer (gehuwde) manwen dan (gehuwde) vrouwen aanspraak konden maken op de hoge grondslag, hetgeen exn vetmoeden van indirecte discriminatie opriep. Voor de beantwoording van de vaag of in dit geval een objectieve rechtvaardigingsgrond aanwezig is hanteert het Hof een evenredigheidstoets:

'Indien de nationale rechter, die bij witsluiting bevoegd is om de feiten te beoordelen en de: nationale wetgeving uit te leggen, vaststelt dat verhogingen als de hierbedoelde overenkomen met de zwaardere lasten die uitkeringsgerechtigden met een echtgenoot of kinderen ten laste in vergelijking met alleenstaanden hebben te dragen, en dat zij geschilk en ook noodzakelijk zijm om de uitkeringsgerechtigden een voor hen toereikend bestaansmimimum te garanderen, dan is de omstandigheid dat die verhogingen aan een veel groter aantal gehuwde mannen dan gehuwde wrouwen toekomen, niet voldoende om te concluderen dat de toekenning ervan in strigd is met de richtlijn. ${ }^{38}$ (mijn cursivering. RB)

94 Het 'sociaal beleid' dat hier in het geding was betrof de bezuiniging die van deze bepaling te verwachten was, waardoor de financièle garantie voor de gevallen die daar naar hel oordeel van de regering meer voor in aammerking kwamen kon blijven bestakn.

95 HwJ EG 13 december 1989, zaak C-102/88, Ruzius/Wilbrink, Jur. 1989, p. 4311; Reclaspraak Nemesis 1990, nr. 85; NICM-Bulletin 16-1 (1991), p. 65. Het Hof verwijst in dit verband naar de zogenaamde "vrijgestelden": zelfstandigen met cen volledige dagtaak en een inkomen minder dan $15 \%$ wan het minimumloon, studerenden, alsmede in de huishouding wan verwanten werkzame ongehuwden.

96 HvJ EG 11 juni 1987, zalak 30/85, Teuling-Worms, Jur. 1987, p. 2497, NJCM-Bulletin 13-2 (1988), p. 104; zie ook NICM-Bulletin 15-4(1990), p. 467.

97 Zoals deze was komen te hiden bij de wijziging wan 29 december 1982 , p.m. bron.

98 Aldus rechtsoverweging 18. Zie voor een uitdrukkelijke wermelding van het evernedigheidsbeginsel in een overweging die betrekking heeft op een rechtvalurdighingsgrond voor een inbreuk op het beginsel van de gelijke behandeling: HvJ EG 15 mei 1986, zalak 222/84, Johtnton, Jur. 1986, p. 1651, De zaak valt in zowerre buiten het bestek van deze paragraaf, dat ze betrekking heef op een geval vali: directe discriminatie onder richtlijn $76 / 207$ en het fllof moest oordelen over en in artikel 2 , lid 2 , van de richtlijn uitdrukkelijk vermelde uitzondering op het beginsel van de gelijke behandeling. Gezien de algemene bewoordingen warin ze gesteld is, is de bedoelde overweging echter ook van belang woor de hier behandelde problematiek van de rechtvaardigingsgrond in het kader van de indlirecte discriminatie. In ro. 38 stelt het Hof immers: "Voorts zij eran herinnerd, dat bij de vaststelling van de draagwijdte wan een afwijking van een individueel recht, zoals het in de richtijn neergelegde beginsel van gelijke behandeling van mannen en vrouwen, het evenredigheidsbeginsel, een wan de algemene rechtsbeginselen die ten grondslag liggen aan de communatuaire rechtsotde, noet worden geeterbiedigd. Op grond van dit beginsel mogen afwijkingen niet verder gaan dan passend on noodzakelijk is ter" verwezenlijking van het notgestreefde doel, en moet zoveel mogelijk een evenwicht worden tot stand gebracht tussen het beginsel van gel jjke behandeling en de eisen war openbare veiligheid die 
Ook in het op de gelijke behandeling van vrouw en man in de sociale zekerheid betrekking hebbende rapport van de Stichting Centrum voor Onderzoek van het Sociaal Zekerheidsrecht (SCOSZ wordt de toets naar de aanwezigheid van een objectieve rechtvaardigingsgrond mede in termen van evenredigheid gegoten. De werkgroep is van oordeel dat voor rechtvaardigingsgronden uitsluitend in aanmerking komen gronden, die binnen de context van het handelen functioneel zijn, terwijl de betrokken gronden in verhouding moeten staan tot het doel, waarvoor zij gezegd worden te zijn gehanteerd. Voorts moeten zij ook louter woor dat doel zijn gebruikt, terwijl het doel zelf vanuit het gelijke behandelingsbeginsel aanvaardbaar moet zijn. Dit laatste houdt in dat het doel van een zodanig gewicht moet zijn, dat daarvoor een feitelijke (maar bij een andere samenstelling van de betrokken groep personen niet noodzakelijke) ongelijke behandeling van mannen en vrouwen gerechtvaardigd wordt.

In het arrest Roks ${ }^{1 / 60}$ heeft het Hof evenwel geoordeeld dat louter budgettaire overwegingen niet kumen worden aangemerkt als een legitieme doelstelling van sociaal beleid. Hiertoe overwoog het Hof dat

"ofschoon budgettaire overwegingen aan de basis kunnen liggen van de sociale beleidskeuzen van een lid-staat en de aard of de omvang van de sociale beschermingsmaatregelen die de lidstaat wenst vast te stellen, kunnen beïrvloeden, zij op zichzelf evenwel niet een doelstelling van dat beleid wormen en ook niet een discriminatie ten nadele van een der geslachten kunnen rechtvaardigen'.

\subsubsection{Artikel 14 EVRM}

De anti-discriminatiebepaling die er in dit boek althans aanvankelijk wat bekaaid vanaf komt is artikel 14 EVRM. Dat is niet, omdat aan deze bepaling in verband met de sociale zekerheid geen betekenis zou toekomen. Op grond van vaste jurisprudentie kan op artikel 14 EVRM slechts een beroep worden gedaan in verband met schending van een der overige in het EVRM gegarandeerde rechten. Sinds het arrest Gaygusuz ${ }^{\text {i01 }}$ staat vast dat ook sociale zekerheidsuitkeringen onder de eigendonsbescherming van artikel 1 Eerste Protocol vallen, ${ }^{102}$ zodat ook terzake hiervan een beroep op artikel 14 EVRM mogelijk is. Daarbij kont dat het EHRM in het arrest Van Radte $e^{1037}$ heeft overwogen dat

beslissend zijn woor de voorwarden van utitoefening van de betrokken beroepsactiviteit.' Zie ook HWJ 19 novenber 1992, zak C-22691, Molenbroek, Jur. 1992, p. 1-5943, r.o. 13.

99 I.P. Asscher-Vork. L. Betten en W.I.P.M. Fase (red.), a.w. (noot 36). p. 57.

100 HuI EO 24 rebruant 1994, waak C-34392, Roks, Jur. p. 1-571: AB 1995, 53 m.nt. RH; RSV 1994214.

101 EHRM 16 september 1996, Goggusu, Reports 1996-IV; RSV 1997/234; JB 1997/20 m.nt. Heringa; NICM-Bulletin, $22(1997)$, p. $461-474$ m.nt. C.A. Groenendijk; SMA 1997, p. 253-259 m.nt. G.J.
Vonk.

102 Zie in dif verband ook puni 6 de noot van Nico Verheij bij EHRM 16 april 2002, AB 2004, 75 (Dangewille) waar hij concludeert dat het "eigendomsrecht" wan artikel I Eerste Protocol in feite alle vermogensbestanddelen onwat, zulks onder verwijzing naar T. Barkhuysen en M.L. van Emmerik, "De betekenis van artikel 1 van thet Eerste Protocol bij het EVRM woor het Nederlandse rechi inzake overheidsansprakelijkheid, O\& A, 2002, 4, p. 202 en IBPlus 2003, 1, p. 2; I.P. Loofe.a., The rights to propery. The infwence of article 1 Protocol no. I ECHR on several frelds of domestic lan, Maastricht 2002.

103 EHRM 21 februar 1997, Vam Raalk, Reports $1997-1$, JB 199764 m.nt. A.W. Heringa; AB 1997. 432 m.nu F I. L. Penuings. 
"wery weighty reasons would have to be put forward betore the Court could regard a difference in treatment based exclusively on the ground of sex compatible with the Convention".

Deze overweging heeft de vraag opgeroepen of in het kader van artikel 14 EVRM stretigere eisen worden gesteld aan de rechtvardiging van ongeljke behandeling van mannen en mouwen dan het geval is bij de artikelen 26 IVBPR en 1 Grondwet. ${ }^{104}$ Artikel 14 EVRM heeft dan ook op het terrein van de sociale zekerheid aanleiding gegeven tot een aantal interessante uitspraken, waarvan met nathe die op het terrein van de AOW woor dit onderzoek van belang zijn. Hierop zal worden teruggekomen in paragraaf 4.6 van hoofdstuk 4.

104 Zie in dit verband: A.W. Heringa en A. Woltjer, Gelijke behandeling in de sociale zekerheid: 'Straatsburg' scherpt de eisen aan, NJB 1997. afl. 37, p. 1710-1716. Voor een bevestigende beantwoording wan de hicr bedoelde wragg, zie: rechtbank Maastricht, 27 mei 1998, AB 1998, 337 m.nt $F$. Pennings. Zie evenwel de uitspraken van de CRvB van 11 anpril 1997 (RSV 1997/263), 2 juli 1997 (USZ 1997/196), 10 december 1997 (USZ 1998/58), waarin de Raad geen grond ziet on ten aanzien van de rechtvaardiging wan ongelijke behandeling in de xin van artikel 14 EVRM andere maatstaven aan te leggen dan in verband met artikel 26 IVBPR. Zle tenslotte de in paragraaf 4,4. van hoofdstuk 4 te behandelen arresten van het EHRM in de zaken Van Raalte (EHRM 21 februaril 1997 , Reports 1997-1; JB 1997/64) en Wessels-Bergervet (EHRM 4 juni 2002, Reports of hudgnents and Decisions 2002.IV; RSV 2002/181). 



\section{Hoofdstuk 4}

\section{Rechtsverkrijging door rechtstreekse toepassing van het internationale recht, uitwerking}

De WWV en het kostwinnersbeginsel

\subsection{Woorgeschiedenis}

De op 1 januari 1965 in werking getreden Wet werkloosheidsvoorzieningen (WWV) voorzag in een uit de algemene middelen te betalen voorziening in geval van werkloosheid, bestaande in een uitkering voor een maximum duur van twee jaar. Als uitvoeringsorgaam trad het College van Burgemeester en Wethouders (B\&W) op. Deze voorziening is voor nieuwe gevallen op grond van artikel 3 van de Invoeringswet stelselhezienimg sociale zekerheid ${ }^{2}$ met ingang van 1 januari 1987 ingetrokken. Deze wet voorzag echter in overgangsrecht op grond waarvan oude aanspraken op WWV-uitkering, die vóor 1 januari 1987 waren ontstaan, werden veiliggesteld. Op grond van artikel 13, lid 1, onder 1 , WWV was de gehuwde vrouw die niet als kostwinner kon worden aangemerkt, uitgesloten van het recht op uitkering. Het was deze bepaling die, naarmate de temijn voor omzetting van Richtlijn 79/7 EEG haar einde naderde, steeds meer onder vun kwam te liggen. Daarbij spitste de discussie zich niet zozeer toe op de vraag of de in artikel 13 , lid 1 , onder 1 , opgenomen uitsluiting van gehuwde vrouwen in strijd was met artikel I van Richtlijn $79 / 7$ EEG, maar veeleer op de wijze waarop de Nederlandse wet in overeenstemming met de Richtlijn zou moeten worden gebracht. Nadat op 13 december 1984 een voorstel tot aanpassung van de WWV aan Richtlijn 79/7 EEG in de Tweede Kaner schipbeuk had geleden en vervolgens de termijn voor omzetting van de Richtlijn op 22 december 1984 verliep, spande de FNV een kort geding tegen de Staat aan met als inzet de buitenwerkingstelling van de uitsluitingsbepaling. Deze vordering leidde tot een geruchtmakende uitspraak van de President van de rechtbank te 's -Gravenhage van 17 januari $1985{ }^{3}$ In deze uitspraak liet de President weliswaar in het midden of Richtijn $79 / 7$ EEG direkte werking heef, maar kwam op grond van het aan het Nederlandse recht als zodanig ten grondslag liggende beginsel van gelijke behandeling van mannen en wrouwen tot het voorlopig oordeel dat het niet intrekken van artikel 13, lid 1, onder 1, WWV onrechtmatig tegenover de betrokken wrouwen was te achten en beval de Staat de WWV vóór 1 maart 1985 te wijzigen. Deze uitspraak vond op constitutionele gronden geen genade in de ogen van het Hof "s-Gravenhages. Het. Hof was van oordeel dat artikel 120 van de Grondwet zich verzette tegen een toetsing van artikel 13 WWV - een bepaling uit een wet in formele zin - aan een algemeen rechtsbeginsel. Wel was het Hof van oordeel dat

"indien aan art. 4 Richtlijn vanaf' 23 december 1984 rechtstreekse werking wordt toegekend en zalks ten gevolge zou hebben dat voormelde bepaling wanaf die datum toepassing mist en dal de 
uitgezonderde vrouwen op grond daarwan een recht op uitkering zouden hebben verkegen de Staat in beginsel onrechtmatig [zoul halldelen door, terwi] hij aan zijn verplichting op grond van de Richtijn niet heef woldaan, nietemin door voomelde circulaire - waaraan gemeentebesturen gevolg plegen te geven en terwijl de Staat de uitkeringen aan de gemeentebesturen moet vergoeden - ie bewerkstelligen dat woormelde bepaling bliff worden toegepast in afwachting wan de tot standkoming van de aanhangige wetswijziging, waardoor de utkgezonderde vrouwen vooralsnog van en uitkering verstoken blijven.'

Het Hof zag dan ook aanleiding zich met prejudiciële vragen tot het HvJ EG te wenden. Daarbij werd het HVJ EG - kort gezegd - verzocht klaarheid te verschaffen over de vraag of artikel 4 van Richtlijn 79/7 EEG vanaf 23 december 1984 rechtstreekse werking heeft en welke gevolgen dit zou thebben voor de toepassing van artikel 13, lid 1, onder 1, van de WWV. Aldus kwam, langs deze wat ongebruikelijke weg, het HWJ EG voor de eerste keer in de gellegenheid zich uit te spreken over de verenigbaarheid van het Nederlandse sociale zekerheidsstelsel met de in Richtlijn 79/7 opgenomen anti-discriminatiebepaling. Het deed aldus bij de hiervoor reeds genoemde uitspraak van 4 december $1986{ }^{7}$

Het HvJ EG laat er in zijn uitspraak geen misverstand over bestaan dat ten aanzien van gehuwde vrouwem de in artikel 13, lid 1, onder 1 , WWV opgenomen kostwinnerseis met ingang van 23 december 1984 niet meer mag worden gesteld. Het Hof baseert dit oordeel op de rechtstreekse werking met ingang van deze datum van artikel 4, lid 1 van Richtlijn 79/7 EEG. Naar het oordeel van het Hof is deze bepaling voldoende nauwkeurig en onvoorwaardelijk om, ook zonder uitvoeringsmaatregelen, vanaf 23 december 1984 door particulieren voor de nationale rechter te kunnen worden ingeroepen teneinde de toepassing van iedere met dat artikel strijdende bepaling te beletten.

Inmiddels had de wetgever bij de Wet van 24 april 1985 (Stb. 230) artikel 13, lid 1, onder 1, WWV met terugwerkende kracht tot 23 december 1984 afgeschaft. Artikel II van deze Wet voorzag echter in een overgangsrechtelijke bepaling op grond waarvan de afschaffing van de kostwinnerbepaling niet van toepassing werd geacht op gehuwde vrouwen die vóór 23 december 1984 werkloos waren geworden. ${ }^{8}$ Aldus werden de 'oude gevallen' alsnog van het recht op uitkering ingevolge de WWV uitgesloten.

\section{2}

Het arrest Dik

Ook deze laatste bepaling kwam al spoedig onder vuur te liggen. Op 19 februari 1987 stelde de Raad van Beroep Amhem prejudiciële vragen aan het HvJ EG in een drietal zaken waarin an gehuwde vrouwen uitkering ingevolge de WWV was geweigerd op de grond dat de datun van ingang van hun werkloosheid en de datum waarop zij voor het eerste aangewezen raakten op een WWV-uitkering vóór 23 december 1984 was gelegen.

Bedoeld is de circulaire van de Staatssecretaris van Sociale Zaken en Werkgelegenheid van 21 decembel 1984 wartbij an de gemeentebesturen wend meegedeeld dat artikel 13, lid 1 onder 1 , wan de WWV vooralsnog moest worden toegepast.

Waar ook Van den Burg in zijn noot onder de uitspraak van het Hof heeft opgemerkt had het meer woor de hand gelegen indien deze vragen het HVJ EG zouden hebben bereikt via een bestumsrechtelijke procedure voor de (Centralle) Ratad van Beroep. HW EG 4 december 1986, zak 71/85, FNV, Jur. 1986, p. 3855; RSV 198795 m.nt. A.W. Govers; zie ook hoofdstuk 3, par. 2.6.2.

8 Tenzil zij op deze datum in het genot waren wan een WW-uitkering. 
Deze prejudiciële vragen hebben geleid tot het, de Nederlandse regering veel hoofdbrekens bezorgende, arrest $D i k^{9}$. In een combinatie van drie overwegingen haalt het Hof de bij voornoemd artikel II van de Wet van 24 april 1985 beoogde beperking van de terugwerkende effecten van het $F N V$-arresit ${ }^{10}$ onderuit. Onder verwijzing naar laatstgenoend arrest herhaalt het Hof allereerst zijn overweging dat artikel 4, lid 1, van de Richtlijn, zowel op zichzelf beschouwd als gezien in verband met het doel en de inhoud van Richtlijn $79 / 7 \mathrm{EEG}$, voldoende nauwkeurig is om door een justitiabele te kunnen worden ingeroepen en door de rechter te kunnen worden toegepast. Vervolgens verwijst het Hof naar de overweging in zijn kort tevoren gewezen arrest Borrie Clarke," waarin het Hof oordeelde dat Richtlijn 79/7 niet voorziet in uitzonderingen op het in artikel 4, lid 1, van de Richtlijn neergelegde beginsel op grond waarvan oudere nationale bepalingen hun discriminerende werking zouden mogen behouden. Naar het oordeel van het Hof

'[mag bijgevolg] een Lid-Staat na 23 december 1984 geen ongelijke behandelingen laten voortduren die te wijten zijn aan de omstandigheid, dat de aan het ontstaan wan het recht op uitkering verbonden woorwaarden reeds vóór die datum golden. De omstandigheid dat die ongelijke behandelingen uji overgangsbepalingen voortvloeien, leidt niet tot een andere benordeling."

Tenslotte overwoog het Hof dat uit de arresten FNV en Borric Clarke volgt dat

"Wrouwen op grond van art. 4, lid 1 , van de richtlifin, vanaf 23 december 1984 recht hebben op dezelfde behandeling en op toepassing van dezelfde regeling als mannen die in een gelijke situatie verkeren, waarbij die regeling, zolang aan de richtijin geen juiste uitwoering is gegeven, het enig bruikbare referentiekader blijh. In casu betekent dit dat, indien een man die vóor 23 december 1984 zijn betrelkking alsmede zijn recht op WWV-wilkering heeft verloren en woor die datum geen WWV-uitkering ontwing, na 23 december 1984 in aanmerking kwan voor een WWV-uitkering, een vrouw die zich in een gelijke situatie bevindt, eveneens recht heeft op die uitkering, zonder dat zij behoeft te voldoen aan een aanwullende voorwatrde die alleen voor gehuwde vrouwen gold".

Het Hof heeft hierbij angetekend dat te laat vastgestelde uitvoeringsmaatregelen ten volle rekening moeten houden met de rechten die art. 4 , lid 1, van de Richtlijn in een Lid-Staat ten gunste van particulieren heeft doen ontstaan vanaf het verstrijken van de uitvoeringstermijn.

Deze overwegingen hadden grote gevolgen voor het Nederlandse sociale zekerheidsstelsel. Met de arresten Borrie Clarke en Dik werd duidelijk dat op artikel 4, lid 1, van de Richtlijn ook een beroep kan worden gedaan, wanneer de aangevochten discriminatie haar oorzaak vond in een overgangsbepaling waardoor een oudere, immiddels buiten werking getreden, discriminatoire wettelijke bepaling toch nog bepalend kan zijn voor de vraag of iemand onder een nieuw, wèl met de Richtlijn in overeenstemming zijnde wettelijk stelsel, aanspraak op prestaties heeff. ${ }^{2}$ Voorts wordt duidelijk dat het Hof voor die gevallen waarin een richtlijn niet bimen de gestelde tijd in nationaal recht is omgezet en de rechtstreekse

12 Aldus Keunen in zijn noot onder het arrest Dik in RSV $1988 / 183$. 
werking van de richtlijn kan worden aangenomen, een soort "strafoptie ${ }^{1.33}$ heeft ontwikkeld die werkt als een sanctie voor de recalcitrante staat, op grond waarvan de gediscrimineerde personen, na het verstrijken van de omzettingstermijn, krijgen wat de meer bevoorrechte groep had gekregen vanaf deze datum.

In termen van de werking ratione temporis ${ }^{14}$ komt uit het arrest Dik naar voren dat aan Richtlin $79 / 7$ EEG met betrekking tot de Nederlandse WWV exclusieve werking toekomt: de rechtstreekse werking van artikel 4, lid 1, van de Richtlijn strekt zich mede uit tot in het licht van het toepassingsbereik van de WWV relevante feiten die zich vớr 23 december 1984 hebben voorgedaan. Vanuit het gezichtspunt van het nationale recht bezien heeft deze werking tot gevolg dat aan de jurisprudentie van het Hof terugwerkende kracht toekomt, in die zin dat gehuwde vrouwen wier werkloosheid vóór 23 december 1984 is ingetreden, alsnog recht blijken te hebben op WWV-uitkering. Het gaat hierbij om, wat in het vorige hoofdstuk is aangeduid als, de materielle werking in de tijd van de rechtspraak van het Hof. Voor de betrokken vrouwen was uiteraard interessanter de vraag of de uitspraken van het Hof tevens tot gevolg zouden hebben dat zij alsnog daadwerkelijk een uitkering zouden ontvangen.

Deze laatste vraag ziet op de formele werking in de tijd van de rechtspraak van het Hof. Ten aanzien hiervan kan allereerst worden opgemerkt dat de staatssecretaris van Sociale Zaken en Werkgelegenheid in de uitspraak wan het HvJ EG in de zaak Dik aanleiding heeft gezien bij circulaires van 5 mei en 27 juni 1988 aan de gemeentebesturen toe te staan om aan cen bepaalde groep wan vrouwen alsnog de vanaf 23 december 1984 resterende uitkeringscluur ingevolge de WWV toe te kennen.. ${ }^{15}$ Deze groep betrof vrouwen die, indien de kostwinnerseis wiet had bestaan, op 23 december 1984 nog in het genot zouden zijn geweest van de WWV-uitkering en had aldus in de regel betrekking op vrouwen die op of na 23 juni 1982 werkloos waren geworden ${ }^{16}$. De circulaire voorzag aldus in uitkering van het bedrag dat zou hebben geresteerd vanaf 23 december 1984, wanneer de WWVuitkering zou zijn verkregen direct aansluitend aan het einde van de WW-uitkering.

\subsection{CRVB 10 mei 1989}

Deze minimalistische uitleg van het arrest $D i k$ heeft niet lang stand gehouden. In zijn uitspraak van 10 mei $1989^{17}$ trekt de CRvB zijn conclusies uit de jurisprudentie van het Hof. De uitspraak toont fraai aan hoe de formele werking in de tijd wan rechtspraak waarbij toepassing is gegeven aan rechtstreeks werkende bepalingen van communautair recht wordt beinivloed door het desbetreffende stelsel van nationale wetgeving. Na de hiervoor

13 De term is ontleend aan de noot van D. Curtin onder HvJ EG 19 november 1991, zaken C-60 en C. 90, Frameowich en Bonifac, SEW 1 (1993) januari, p. 94-95.

14. De sandulding is wan A-G Mancini in zijn conclusie woor het arrest Dik (Hw EG 8 matar 1988, zaak 80/87, Jur. 1988, p. 1601.

15 Aldus blijkt uit de MVT bij het voorstel tot wijzing van de Wet van 24 april 1995, Stb. 230 , en de Inwoeringswet stelsetherziening sociale zekerheid, TK vergaderjaar $1989-1990,21543$, ne. 3, p. 34 .

16 Erwar uitgande dat in het algemeen eerst een half jaar WW-uitkering en daama gedurende twee jaar WWV-uitkering werd verstrekt.

17 RSV $1990231 ;$ JSV 1989139. 
weergegeven overwegingen van het Hw EG in de zaak Dik in herimering te hebben geroepen overweegt de Raad immers dat

blijkens vorenstaande owerwegingen wan het hof vouwen vanaf 23 december 1984 rech Thebben] op dezelfde behandeling en op toepassing van dezelfde regeling als mannen die in een gelijke situatio verkeren, waarbij die regeling, de WWV - zoals deze luidde zonder de vervallen kostwinnersbepaling het referentiekader blift zolang aan de vichtijn geen juiste uitworing is gegeven.

In werband met het bepaalde in artikel 13 wan de WWV kan het recht op uikering ontstaan op een tijustip gelegen geruime tijd na het intreden van de werkloosheid on onk na hel bereiken wan de maximum-duur van de WWV. De in de WWV neergelegde regeling brengt voorts mee dat een aanwraag om uitkering tot enig later, de betrokkene meer convenicirend, tijdstip ban worden uitgesteld, hetgeen met het oog op het bepaaide in de art. 9, eerste lid, aanhef en onder b, en 19 , eerste lid, van de wet geenszins meer ongebruikelijk is.

Dat ingevolge de in de WWV neergelegde regeling de werkloze niet verplicht is de witkering binnen een bepaalde termijn na het intreden van de werkloosheid aan te vragen ${ }^{18}$ is overigens een aspect dat in het kader wan de behandeling van bovengenoemde zaak $80 / 87^{19}$ nadrukkelijk onder de aandacht van het hof is gebracht. In dit verband is van bijzondere betekenis dat het hof in rechtsoverweging 10, tweede volzin, wan het in die zaak gewezen arrest de gehuwde wrouw vergelijkt met een man die voor 23 december 1984 zijn betrekking alsmede zijn recht op WWwitkering heeft verloren en voor 23 december 1984 niet in het genot was wan een WWV-uitkering maar die daar na die datum wel voor in aanmerking kwam. Een vrouw die zich in dezelfde situatie als die man bevindt heeft volgens het hof ingaande 23 december 1984 op dezelfide voet als die man recht op WWV-uitkering.

Uit de vorenuiteengezette samenhang tussen Richtijn $79 / 7$ en de ut het systeem van de WWV woortvloeiende figur waarbij de witkeringsperiode in de tijd opschwift, volgt dat in deze de vergelijking dient te worden gemaakt met de man die eerst ingaande of na 23 december 1984 yoor uitkering ingevolge de WWV in aanmerking wordt gebracht, hetzij ondat hij daarop nitet eerder wecht kon doen gelden hetzij ondat hij eerst op of na die datum een aanvraag on uitkering heeft gedaan'.(mijn cursivering, RB)

Uit deze overwegingen blijk dat de aan de aan de WWV eigen regeling van, enerzijds het moment met ingang warvan het recht op uitkering ontstaat en, anderzijds, van de termijn waarbinnen een aanvraag moet worden ingediend, een katalyserende werking uitgaat voor de onvang van de formele werking in de tijd van de jurisprudentie van hot Hof en van de met inachtneming hiervan gewezen rechtspraak van de nationale rechter. Deze katalyserende werking windt bij de WWV haar grondslag in het feit dat het ontstaan wan het recht niet is gekoppeld aan een op een bepaald moment intredend rechisfeit (werkloosheid) en in het feit dat de aanvraag niet aan een termijn is gebonden. Het waren vooral deze omstandigheden die de regering Kwetsbaar makkten in har pogingen de formele werking in de tijd van het arrest Dik en de hierop gebaseerde rechtspraak van de nationale rechter te beperken. ${ }^{20}$ Zo concludeerde de regering in de MvT bij de aanstonds te bespreken wet van

18. Uit het systeem van de WWV volgt dat de datum waanop de uitkering wordt aangevraagd witsitutend van belang is voor de datum van ingang van de uitkering, maar nimner woor bet recht daarop. De betrokkene had dan ook de wrijheid wan ketze ten aanzien van het tijdstip wan ingang van de witkering. Voorts kende de wet geen verjaringstermijn voor het recht op uitkering. Zie rechtbank Breda, 10 maart 1993, JSV 1993"107, onder verwijzing naar CRvB 30 jantuar: 1985, RSV $1985 / 190$.

19 Te weten de zaak Dik (HvJ EG 8 maart 1988, zaak 80/87, Jur. 1988, p. 1601).

20 Toen met het arrest Dik was gebleken dat artikel II van de Wet wan 24 april 1985 niet kon worder gehandhafd, heeft de regering eerst getracht de circulaires van 5 mei en 27 juni 1988 (met voornoemde minimalistische uitleg) en wetielijke status te geven. Het desbetreffende wetswoorstel werd 

brengen, met enige spijt:

'Er moet overigens op worden gewezen dat de datum wan 23 decernber 1984 - het tijdstip waarop de nationale wetgeving behoorde te zijn aangepast aan de Derde Richtlijn - bepalend blijft woor de werking van de eis tot gelijke behandeling van mannen en vrouwen in de sociale zekerheid. Dit valt mede af te leiden uit de CRvB-uitspraken van mei 1989. De bijzondere systematiek echter van de WWV, die geen bepaling bevat op grond waarvan de uitkering binnen een bepaalde termijn moet worden aangevraagd, heeft tot gevolg dat het recht op een uitkering op grond van deze wet kan worden ontleend aan werkloosheid die is ontstaan op een tjjdstip dat is gelegen woór het geldend worden van genoemd beginsel van gelijke behandeling. De consequentie hiervatn is ook, dat een WWV-uitkering kan worden ontleend aan werkloosheid in een periode lang voón de aanvaarding van de Derde Richtlijn. Gezien de ontwikkeling van de jurndische oordeelsvoming, die met name inhoudt dat vrouwen op grond van de derde EG-richtlijn dezelfde aanspraken hebben als mannen, valt aan de aanwaarding van dergelijke aanspraken niet te ontkomen. ${ }^{2 !}$

Voorts noet er de aandacht op worden gevestigd dat de WWV niet alleen in de vuurlinie lag van het communautaire recht, maar eveneens van artikel 26 IVBPR. Zo oordeelde het Comité voor de Rechten van de Mens in zijn reeds eerder, ${ }^{22}$ in verband met thet toepassingsbereik van artikel 26 IVBPR, genoemde uitspraak in de zaak Broeks ${ }^{23}$ de uit de toepassing van het kostwinnersbeginsel voortvloeiende uitsluiting van de gehuwde vrouw, onrechtmatig. Voor wat de materiële werking in de tijd van deze uitspraak betreft is opmerkelijk dat het Comité concludeert:

'The circumstances in which Mrs. Broeks found herself at the material time and the application of the then valid Durch law made her a victim of a violation, based on sex of article 26 of the International Covenant on Civil and Political Rights, because she was denied a social security benefit on equal footing with men. ${ }^{24}$

De material time in deze zaak was 1 juni 1980, de dag met ingang waarvan betrokkene geen aanspraak meer kon maken op een werkloosheidsuitkering. Uit een tegelijkertijd met voornoemde uitspraak van 10 mei 1989 gewezen uitspraak heeft de CRvB in een zaak waarin de toepassing van artikel 26 IVBPR op de WWV centraal stond, de materiële werking in de tijd van zijn rechtspraak waarbij de kostwinnerseis in strijd met artikel 26 IVBPR werd geoordeeld, beperkt tot 23 december 1984. ${ }^{26}$

ingetrokken naar ataleüding van de hier besproken uitsprak van de CRvB en mede naar aanleiding van een inmicldels door de Commissie van de Europese Gemeenschappen gestarte infractieprocedure. in welk kader de Commissic op 27 november 1989 aan de Nederlandse regering advies heeft unitgebracht.

21 TK 1989-1990,21543, nr. 3.

22 Zie hoofdstuk 3, par. 2.4

23 Comite voor de Rechten van de Mens 9 april 1987. Communication 180/1984; RSV 1987/245 m.nt. W.M. Levelt-Overmars.

24 Overweging 15 .

25 RSV $1990 / 230$.

26 Zulks onder verwijzing natar de in par. 3.1 nog nader te behandelen vaste jurisprudentie waarbij de Raad voor het tijdstip met ingang waarvan rechtstreekse werking van artikel 26 IVBPR wordt aangenomen aanknoopt bij de datum waarop de omzettingstermijn van Richtiin $79 / 7$ is verstreken. 
Met het voorgaande waren echter nog altijd niet alle formele beperkingen ten aanzien van de werking in de tijd van de zaak. Dik geslecht. Bjj de reeds eerder genoende wet wan 6 juni $1991^{27}$ kwam de wetgever materieel geheel aan het arrest Dik tegemoet door de kostwinnerseis ook vervallen te verklaren voor gehuwde vrouwen die op grond van artikel II van de Wet van 24 aprill 1985 van het recht op uitkering waren uitgesloten. Dit had tot. gevolg dat in beginsel alle gehuwde vrowwen die wóor 23 december 1984 werkloos waren geworden, alsnog een WWV-uitkering konden verkrijgen. Hieraan werd echter wel de eis verbonden dat de betrokken vrouwen overigens zouden voldoen aan de nomale nitkeringsvoorwaarden. Blijkens de MvT moest deze toetsing aan de normale uitkeringsvoorwaarden voor een deel plaatsvinden aan de hand van de situatie op de eerste werkloosheidsdag, ${ }^{28}$ en voor een ander deel naar de situatie op en vanaf de ingangsdatum van de uitkering. Daarbij werd in het bijzonder de eis gesteld dat de betrokken vrouwen nog werkloos waren op en vanaf 23 december 1984 dan wel, indien deze dag was gelegen na 23 december 1984, op en vanaf de dag waarop zij woor het eerst een WWV-aanyraag hadden ingediend. ${ }^{20}$ Deze voorwaarden vormden in tweeërlei opricht een belangrijke beperking van de mogelijkheden voor de desbetreffende vrowwen on de hun in het verleden ten onrechte onthouden uitkeringsrechten alsnog geldend te maken. Zij verkeerden enerzijds in een moeilijke bewijspositie ten aanzien van het vervullen van de aan de eerste werkloosheidsdag gekoppelde uitkeringsvoorwaarden. Anderzijds kon de koppeling van de werkloosheidseis aan de ingangsdatum van de uitkering tot gevolg hebben dat wrouwen die op grond van de Wet van 6 juni 1991 alsnog in verband met vó́r 23 december 1984 ingetreden werkloosheid zouden overgaan tot het indienen van een atuvraag (na hier eerder van te hebben afgezien ondat dit in verband met de kostwinnerseis zinloos leek) alsnog nul op het rekest zouden krijgen als zij inmiddels weer werk zouden hebben gevonden. Alsdan zouden zij nog altijd in een nadeliger positie verkeren dan mannen in een overeenkomstige situatie, omdat die hun uitkeringsrechten normal gesproken reeds eerder hadden genoten. Daarbij moet worden benadrukt dat de regering zich bij de parlementaire behandeling op het standpunt stelde dat de uitkering niet eerder zou kunnen ingaan dan op de datum van aamvaag. ${ }^{30}$ Ter ondersteuning van dit standpunt deed de staatssecretaris

Wet van 6 juni 1991 tot wijzging van de Wet wan 24 sprill 1985, Stb. 230 en de Invoeringswet stelselherziening sociale zeketheid, Stb. 318 .

28 De MVT vermeldt in dit verband de referte-eis su het werknemersehap in de zin wan we WWV.

29 TK, vergaderiaar $1989-1990,21543$, nr. 3, p. 5.

30 Tot wat voor merkwardige consequenties deze regeling kon leiden moge blijken uit de volgende, door de PvidA-fractie in het Eindverstag (TK vergaderjaar 1990-1991, 21 543, nr. 7, p. 3) aangedragen voorbeelden:

Medrouw A werd in 1980 werkloos. Zij vroeg geen WWV-uikkering aan ondat zij niet kon voldoen aan de kostwinnerseis. Zij liet zich ná de WW-periode uitschrijven bij het Arlbeidsburear. Als mevrouw A voorddurend getracht heeft werk te vinden en daar in 1989 in slaagde, hadden de leden dan goed begrepen dat zij nu geen recht op een WWV unitkering zou hebben?

Mevrouw 13 werd eveneens in 1980 werkloos. Zij voldeed niet aan de kostwinmersels naar vroeg toch een WWV-uitkering aan hoewel dat toen niet rationeel leck. Op het tijdstip van aranvalag voldeed zij wel aan de verdere voorwaarden vor een uilkering. dat wil zeggen zij schreef zich in bij het arbeidsbureatn en had geen andere dienstbetrekking. Inmiddels is mevrouw $B$ weer atin het werk. Hadden de leden goed begrepen dat in het geval van mevrouw $B$ haar situatie op het moment van aanvraag bepalend is voor het recht op uitkering en dat mevrouw $B$ daarom wel, in tegenstelling tot mevrouw $A$, in aanmerking komt voor een nabetaling wan haar WWV-uitkering? 
tijdens de mondelinge behandeling van het wetsvoorstel een beroep op de in het volgende hoofdstuk ${ }^{31}$ nog nader te bespreken uitspraak van de CRvB van 24 januari 1991, warin de Raad oordeelde dat de imperatief geformuleerde bepaling van artikel 34 wan de. Wet uitkering vervolgingsslachtoffers (WUV) in de weg stond aan toekenning van uitkering met ingang van cen datum voorafgaande aan de dag van aanvraag, ook dan als deze aanvraag is gegrond op de uitspraak van de CRvB van 14 mei 1987, waarbij de Raad had uitgesproken dat het in de WUV opgenomen kostwinnersvereiste in strijd was met artikel 26 IVBPR. ${ }^{32}$ Nadere jurisprudentie kon dan ook niet lang uitblijven. ${ }^{33}$

\subsection{Daadwerkelijk rechtsherstel}

\section{Op 30 april $1992^{34}$ deed de Raad van Beroep "s-Hertogenbosch een interessante uitspraak.}

Betrokkene, een gehuwde vrouw die niet aan de kostwinnerseis voldeed, had van 15 december 1976 tot en met 10 mei 1979 voor 20 uur per week als huishoudelijke hulp gewerkt, uit welke dienstbetrekking zij in maart 1979 na de geboorte van haar kind ontslag had genomen. Zij kwam niet in aanmerking voor een WW-uitkering, omdat ze vrijwillig ontslag had genomen. Ze diende evenmin een aanvwaag om een WWV-uitkering in, ondat, naar betrokkene letterlijk stelde, haar echtgenoot ervan op de hoogte was dat zij geen recht op deze uitkering kon doen gelden. Op 16 november 1990 diende betrokkene naar aanleiding van publiciteit over het voorstel tot intrekking van artikel II van de Wet van 24 april 1985 bij het gemeentebestuur alsnog een aanvraag in.

Bij besluit van 13 maart 1991 kent het gemeentebestuur aan betrokkene met ingang van de datum van aanvraag, 16 november 1990, een WWV-uitkering toe, waarop echter een korting wordt toegepast, omdlat betrokkene vanaf september 1990 voor 5 uren per week als alpha-hulp werkzaam was. Betrokkene acht zich door deze beslissing benadeeld en eist dat haar alsnog met ingang van een eerdere datum een niet gekorte WWV-uitkering wordt toegekend. Het gemeentebestuur verklaart het daartoe strekkende bezwaar ongegrond op grond van de overweging dat blijkens het wetsvoorstel de uitkering met toepassing van artikel 18 WWV in principe altijd dient in te gaan op de datum van aanvraag ${ }^{35}$ en de toetsing van de uitkeringsvoonwaarden, waar-

De statssecretaris beantwoord beide vragen bevestigend (Nota naar aanleiding van het eindverslag, TK vergaderjwar 1990-1991, 21543, wr. 8, p. 4) en volstaat ermee op te merken dat aanspraken op uitkering slechts binnen de wettelijke context kunnen worden toegekend, waarbij teleurstellingen niet altijd zijn te voorkomen. Zelf meen ik dat er tussen mevrouw A en B sprake is van een niet te rechtvaardigen verschil in behandeling, nu het (niet geringe) financiële voordeel wan mevrouw B louter berust op een handeling die naar de loenmalige stand van de wetgeving zinloos was. Zelfs is niet uit te slutien dat vrouwen die in een posibie als mewronw $B$ verkeerden, wit pure onwetendheid ontrent het geldenda recht in het verleden een aanvraag zouden hebben ingediend, welke 'domheid' later rijkelijk zou worden beloond. Zie in dit verband ook: Handelingen EK 4 jumi 1991, p. 31-1236 r.k.

31 Hoofdstuk 5 , par. I.

32 Zie, onder meer, Handelingen TK, 7 februari 1991, p. 50-2957 en 2958. Bij lezing van het kamer debat kan ik me overigens niet aan de indruk ontrekken dat de kamerleden zich door deze uitspraak. die, nair hierna nog zall blijken, strikt genomen voor de hier aan de orde gestelde problematiek niet relevant was, volledig hebben laten overrompelen.

33 Bij de Wet van 6 juni 1991 werd ook voorzien in een aanvaagperiode van zes maanden te rekenen van de inwerkingtreding, gedurende welke de 'oude rechten' nog geldend konden worden gemaakt. Deze bepaling is in de jurisprudertie op weinig problemen gestuit en wordt in deze paragraaf verder buiten beschouwing getaten.

34 ISV $1992 / 172$.

35. Dat is owerigens in die zin merkwaardig dat de regering zich in haar Memonie wan Antwoord bij het voorstel dat heef geleid tot de Wet van 24 april 1985 (Stb 230), bij welke wet het kostwinnersbeginsel met terugwerkende kracht per 23 december 1984 werd opgeheven, nog had overwogen 
onder het nog steeds werkloos zijn, dient plaats te vinden op en vanaf de ingangsdatum van de witkering. Daarbij heeft het gemeentebestur tevens gewezen op een circulaine van de statssecretaris van Sociale Zaken en Werkgelegentheid van 8 maart 1991, waarin dit standpunt, voorunitopend op - wat uiteindelijk de Wet van 6 juni 1991 zou worden-werd bevestigd.

De Raad van Beroep laat van deze argumentatie, die rechtstreeks is ontleend an de parlementaire geschiedenis van de Wet van 6 juni 1991, weing heel. De Raad overweegt als volgt:

'De raad merkt op dat uit de Kamerbehandeling van genoemd wetsontwerp en uit de Circulaire van 8 maart 1991 blijkt dat de staatssecretaris ter ondersteuning van haar standpunt heef verwezen naar de uitspraak van de CRvB van 24 januari 1991. WUV 1989/82 [...]. De raad is echter wan oordeel dat de Wet Uitkering Vervolgingsslachtoffers (WUV) - waarop evengenoemde uitspraak van de CRvB betrekking had - op het punt van de ingangsdatum van de uitkering niet vergelijkbaar is met de WWV. De WUV kent een imperatieve bepaling (ari. 34) ontrent de ingangsdatum, terwijl de WWV een systeem kent waarbij een recht op uitkering op een bepaald moment ontstaat en het verzoek om effecturing van dit recht kan worden uitgesteld tot een door betrokkene gewenst moment. Gelet op dit in de WWV neergelegde systeen en tevens gelet op het bepaalde in art. 18 WWV omtrent de mogelijkheid van uitzondering op de keuze van de datum van aanvrage als datum wan ingang wan de uitkering is de raad van oordeel dat beide wetten op het punt van ingangsdatum van de uitkering niet vergelijkbaar zijn.'

De Raad gaat echter in een overweging ten overvloede nog een flinke stap verder. Na te hebben overwogen dat ten aanzien van de rechtspositie van gehuwde vrouwen die niet kostwinner zijn en die vórór 23 december 1984 werkloos zijn geworden en op deze datum geen WW- of soortgelijke uitkering ontvingen, Richtlijn 79/7 EEG eersi bij de Wet van 6 juni 1991 op juiste wijze is omgezet, overweegt de Raad dat

'In deze situatie naar [zijn] oordeel aan de genoemde groep van gehuwde vrouwen niet [kan] worden tegengeworpen dat zij niet eerder een aanvrage om een WWV-uitkering hebben ingediend. De raad wijst in dit verband op het Arrest van het Hof van Justitie van 25 juli 1991 [in de zaak Emmott], waarin het Hof heeft overwogen dat eerst op het tijdstip van een juiste omzetting van een EEG-Richtlijn in national recht de rechtzoekenden in staat zijn hun rechten in volle omvang te kennen.

In het licht van het vorenoverwogene komt de raad tot het oordeel dat in de omstandigheden waarin de genoemde groep van gehuwde vrouwen [verkeert], het geneentebestur zich niet op het standpunt kan stellen dat er geen sprake is wan voldoende temen als bedoeld in art. 18 WWV op grond van het enkele feit dat de betreffende vrouw na het onistaan van thaar werkloosheid voor 23 december 1984 geen aanvrage on en WWW-uitkering heeft ingediend."

Een opmerkelijke overweging, die er in wezen op neerkomt dat aan betrokkene niet kan worden tegengeworpen dat zij destijds, bij het intreden van haar werkloosheid, is afgegaan op de tekst van de wet zoals die toen luidde. Opmerkelijk ook, omdat de Raad dit oordeel onderbouwt met een verwijzing naar het arrest Ewwot van het HwJ EG, waarbij het Hof in het niet (juist) omzetten van een richtlijn aanleiding zag tot het maken van een inbreuk op de procesautonomie van de betrokken Lid-Staat. ${ }^{36}$ De owerweging van de Raad raakt, met

het vanzelfsprekend te achten dat, waar het wetswoorstel terugwerkende kracht hat, de in artikel 18 WWV geformuleerde uitzonderingsmogelijkheid van toxpassing is, nu de betrokkenen niet te werwijten wiel dat zij niet eerder een aanvraag hadden ingediend.

36 Uit de uitspraak van de Raad wan Beroep blijkt impliciet dat de Raat wan oordeel was dat het arrest Emmott eveneens van toepassing was op aanvraagterminnen. Deze opvatting werd expliciet verwootd in de uitspraak van de rechtbank Utrecht van 26 januari 1993, RSV 1993/205, waarin de rechtbank, 
andere worden, rechtstreeks aan de formele werking in de tijd van het arrest Dik en geeft hieraan het volle pond. ${ }^{37}$

Opmerkelijk is tenslotte dat het tegen dexe uitspraak ingestelde hoger beroep door de CRwB ongegrond werd verklaard, ${ }_{5}^{3 *}$ ondanks het feit dat het HwI EG inmiddels in het arrest Steenhorst-Neerings ${ }^{39}$ had uitgesproken dat het gemeenschapsrecht zich niet verzet tegen de toepassing van artikel 25, lid 2, van de $\mathrm{AAW}^{40}$ en ondanks het feit dat de CRvB deze uitspraak van overeenkomstige toepassing achtte op artikel 18 WWV. De CRvB was echter om een andere reden van oordeel dat het vasthouden door het gemeentebestuur aan de datum van 23 december 1984 de rechterlijke toetsing niet kon doorstaan, waartoe hij overwoog dat

"de in de Circulaire van 8 mart 1991 aan de gemeentebesturen aanbevolen gedragslijn," welke $B$ en $W$ van $X$ als richtsnoer hebben overgenomen, [ertoe sirekt] dat woor het antwoord op de vraag of er al dan niet voldoende termen aanwezig zijn on een uitkering op een eerdere datum dan de datum van indiening van de aanvraag te doen ingaan uitsluitend bepalend is of betrokkene reeds voor 23 decermber 1984 een WWV-uitkering heeft aangevraagd.

Naar het oordeel van de raad wordt hiermee een criterium aangelegd dat ertoe leidt dat vrouwen, die voor 23 decernber 1984 ervan op de hoogte waren dat, uitsluitend in verband met het feit dat zij niet voldeden aan de kostwinnerseis, het indienen van een aanwraag om een WWV-uitkering geen enkele zin zou hebben en daarom van het doen van een dergelijke aanvraag hebben afgezien, anders worden behandeld dan wrouwen die - in verband met onbekendheid met die eis of om een andere reden - wel voor 23 december 1984 cen aanvraag om WWV-uitkering hebben ingediend, waarop uitsluitend in verband met het niet zijn van kostwinner afwijzend is beslist dan wel zou worden beslist.

Nu voor het maken van een clergelijk onderscheid naar het oordeel van de raad geen enkel redelijk motief bestaat, wordt aldus in de groep wan gehuwde vrouwen een rechtens niet relevant onderscheid gemaakt. Dit brengt met zich dat de bestreden beslissing, die is gebaseerd op de hiervoor tot richtsnoer gestrekt hebbende Circulaire van 8 maart 1991, en de daaraan voorafgaande, eveneens daarop gebaseerde, primaire beslissing genomen zijn in strijd met het algemeen beginsel van behoorlijk bestuur dat gelijke gevallen gelijk moeten worden behandeld.'

Ia te hebben owerwogen dat zij wit het Emmott-arrest affeidt dat tot het tijdstip van de juste onzetting wan een richtijn aan reottzoekenden niet kan worden tegengeworpen dat een beroep niet tijdig is ingesteld, overweegt dat zifj "van oordeel [is] dat het er a fortion woor moet worden gehouden dat, indien het beroep op uit een richtijin wootwloeiende rechten slechts geeffectneerd kan worden door het doen wan een aanvaag $[. .$.$] het tijdstip van anvraag niet tot gevolg kan hebben dat deze rechten$ gelneel of gedectielijk verloren gaan." De rechtbank is van oordeel dat Richilijn 79/7 EEG in elk geval rhict eerder dan bij Wet van 6 juni 1991 (Stb. 318) op juiste wijze is omgezet in het Nederlandse recht. Deze opvatting zou echter later door liet HWJ EG worden verworpen in het arrest Steevhorst-Neering: (Hw) EG 27 oktober 1993, zalk C-338/91; Jur. 1993, p. 1-5475; RSV 1994/211 m.nt. F.W.M. Keument).

37 Zic voor een uitsprak wan gelijke strekking rechtbank Rotterdam 13 oktober 1992, JSV $1992 / 319$ Ook in deze uitspraak wordt de ingangsdatum van de uitkering geheel losgekoppeld van de datum wan aameag, zowel in het geval da uitkering voor 23 decenber 1984 was aangevragd als wanneer dit na deze datuin was geschied.

38 CRVB 22 maart 1994, JSV 1994/133,

39 HWJ EO 27 oktober 1993, zaak C-33891, Jur. 1993, p. 1-5475; RSV 1994/21 1 m.nt. F.W.M. Keunen.

40 Zie hierover uitwoeriger par. 2.3.2.4.

41 Die, zoals hiervoor al blewk, geheel in overeenstemming was met het standpunt dat de regering tijdens de parlementaire behandeling van het woorstel van wet tot wijziging van de Wet van 24 april 1985 had ingenomen. 
Een ander voorbeeld van de "processuele doorwerking" van het EG-recht - nu op het gebied van het bewijsrecht - is te vinden in de uitspraak van de Raad van Beroep Groningen van 8 mei 1992." Deze uitspraak ziet op een aantal aanvragen om een WWV-uitkering in verband met in een relatief ver verleden ingetreden werkloosheid. De uitsprak heeft betrekking op de bewijspositie van de betrokken vrouwen met betrekking tot - wat in de parlementaire geschiedenis van de Wet van 6 juni 1991 werd aangeduid als - "de normale uitkeringsvoorwaarden'. Hierbij werd gedoeld op de ontstaansvoorwarden waarvan de verulling moest worden getoetst naar de situatie zoals die bestond op de eerste werkloosheidsdag. De uitspraak spitst zich toe op de problematische bewijspositie die de betrokken vouwen dienaangaande ondervinden. Aan de hand van de palementaire geschiedenis van de Wet van 6 juni 1991 stelt de Raad allereerst vast dat er bewust van is afgezien in deze wet een regeling van de verdeling van de bewijslast met betrekking tot de nomale witkeringswoorwaarden op te nemen. De Raad stelt vervolgens vast dat de desbetreffende gemeentebesturen in het kader van een intergemeentelik samenwerkingsverband alsnog in de nodige bewijsregels hebben voorien.

De Raad van Beroep stelt voorop dat het beginsel van gelijke behandeling, gelet op de in Richtlijn 79/7 EEG voorziene omzettingstermijn in ieder geval veel te laat in de WWV is doorgevoerd en tekent hierbij onder een kennelijke verwijzing naar het arrest Francovich en Bonifaci ${ }^{\text {t4 }}$ bil a an dat

"een te late omzetting van een EEG-richthijn inhoudt dat de nationale overheid de richtlijn miet is nagekomen en dat uit de jurisprudentie van het Hof van Justitie der EEG blijk dat, waar een richulijn rechten aan particulieren toekent en er een causaal verband bestaat tussen schending van deze rechten en schade van de particulier, de nationale overheid aansprakelijk mag worden gehouden."

Daartoe geïnspireerd door het door de staatssecretaris bij de parlementaire behandeling van de Wet van 6 juni 1991 ingenomen standpunt dienaangaande hadden de desbetreffende gemeentebesturen zich op het standpunt gesteld dat een aanvraagster ten bewijze van werknemerschap en het voldoen aan de dageneis moest aantonen dat zij uitkering ingevolge de WW had onvangen, en wel door middel van een geschrift. Aan dit criterium werd een zodanig gewicht toegekend dat, indien geen geschrift kon worden geproduceerd, de anvaag werd afgewezen, ook al waren bewijsmiddelen voorhanden met betrekking tot werknemerschap en dageneis, zoals verklaringen van derden, loonopgaven en ziekenfondsinschrijvingen. De Raad is van oordeel dat

Deze, niet in de (nationale) wet geregelde, verdeling van de bewijslast en de cisen aan het door klaagster bij te brengen bewijs, [zich] net verdragen met de toepasselijke EEG-regels. Het rechtstreeks werkende artikel 4 , eerste lid, van de Richtlijin 79/7, in samenhang met art. 5 EEC Verdrag, heeft in verband met de veel te late onzetting van het beginsel wan gelijke behandeling in de WWV, naar het oordeel van de raad tot gevolg dat klaagsters in de gelegentheid moeten worden gesteld om langs alle mogelijke wegen althans een begin van bewijs van werknemerschap en het voldoen aan de dageneis te leveren en dat, indien klaagsters daas in slagen:

43 De vroegste daum was in mei $\$ 971$.

44 Hw EG 19 november 1991, zaken C-6/90 en C-9/90, Jurispr. 1991, p. 1-5357; AB 1994, 482 m.nt. F.H. van der Burg. 
aangenomen dient te worden dat aan werknemerschap en dageneis is voldaan, tenzij verweerder er in slaagt te bewijzen dat dit niet het gewal is."

De Raad onderstreept zijn betoog tenslotte met een verwijzing naar het arrest van het HvJ EG in de zaak Danfoss. ${ }^{\text {t5 }}$ In deze zaak, die betrekking heeft op de toepassing wan de richtlijn inzake gelijke beloning ${ }^{46}$ heeft het Hof geoordeeld dat, gelet op de uit de richtlijn voortvloeiende eis dat het nationale recht dient te voorzien in doeltreffende middelen om op de naleving van het beginsel van gelijke beloning toe te zien, deze zo moet worden uitgelegd dat de nationale bewijslastregels moeten worden gewijzigd in de bijzondere situaties waarin dit voor een doeltreffende toepassing van het gelijkheidsbeginsel noodzakelijk is. ${ }^{47}$ Het bijzondere in de situatie van de betrokken vrouwen acht de Raad van Beroep te zijn gelegen in de veel te late omzetting van Richtlijn 79/7 EEG, in samenhang met het gegeven dat geen enkele overheidsinstantie, en met name niet de bedrijfsverenigingen, nog beschikte over gegevens met betrekking tot de tijd waarin de vrouwen stelden te hebben gewerkt, werkloos te zijn geworden en WW-uitkering te hebben genoten. De Raad aclht mede van belang dat de desbetreffende vrouwen evenmin meer beschikten over schriftelijke stukken waaruit (voldoende) duidelijk zou blijken dat zij WW-uitkering hadden genoten. ${ }^{48}$

Aldus komt het oordeel wan deze Raad van Beroep ${ }^{49} \mathrm{er}$ in wezen op neer dat de bewijslast met betrekking tot de wervulling van de normale uitkeringsvoorwaarden wordt omgedraaid. ${ }^{50}$ De Raad van Beroep koppelt aldus de materiële doorwerking van het EEG-recht uitdrukkelijk aan een, eveneens op het EEG-recht geïnspireerde, soepele houding ten aanzien van het te leveren bewijs.

\subsection{Conchusie}

De hiervoor besproken rechtspraak voorziet, ook voor wat de formele werking in de tijd betreft, in een ruime mate wan terugwerkende kracht van de uitspraak van het HvJ EG in de zaken FNV en Dik. Naast de opzet van de WWV heeft hierbij in belangrijke mate een rol gespeeld de in de rechtspraak soms uitdrukkelijk verwoorde opvatting dat de op of na 23 december 1984 op grond van de Europese rechtspraak ontstane rechten noch geheel noch gedeeltelijk verloren mochten gaan. ${ }^{51}$ Naar uit het vervolg van dit hoofdstuk zal blijken, biedt de rechtspraak over de WWV niet alleen het eerste, maar ook het enige voorbeeld waarbij de terugwerkende effecten van de rechtspraak waarbij een discriminerende bepaling van nationaal recht onverbindend wordt verklaard in zo'n ruime mate gepaard

45 HVI EG 17 ok tober 1989, zalk 10988, Danfos, Jur. 1989, p. 3199" RSV 19901176.

46 Richuijn $75 / 117$ wan de Rad van 10 tobruari 1975 betreffende het nader tot elkaar brengen van de wegevingen der Lid-Staten inzake de toepassing wan het beginsel van gelijke beloning voor mannelijke en vrouwelijke werknemers (PB 1975, 1. 45)

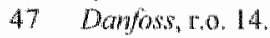

48 En, kan hieraan nog worden toegevocgd, ook geen enkete reden hadder om deze stukken te bewaren, zodat ook niet van verwijtbare nalatigheid kan worden gesproken.

49 Zie woor een overeenkomstige opvatting Rb Utrecht, 26 januari 1993, RSV 1993/205 an Rb Breda, 12 oktober 1993, JSV 1993/324.

50 Hetgeen in schril contrast staat tot de opwatting van de statssecretaris die tijdens de parlementaire behandeling van de Wet van 6 juni 1991 had aangegeven "nooit een bewijslast om te draaien" (Handelingen TK 7 rebruari 1991, p. $50-2962$ ).

51 Zie bijwoorbeeld Rb Utrecht, 6 jantant 1993, RSV $1993 / 205$. 
gat met de mogelijkheid de alsnog verkregen rechten daadwerkelijk geldend te maken; of, anders gezegd, waarbij de materiele werking in de tijd van deze rechtspraak grotendeels samenvalt met de formele werking hiervan.

\section{De AAW en de uitsiuiting van gehuwde vrouwen}

\subsection{Thleiding}

De oorspronkelijke AA ${ }^{52}$ voorzag in een recht op uitkening voor mannen en ongehuwde vrouwen die gedurende minimaal ean jaar arbeidsongeschikt waren geweest. Op grond van deze wet had een verzekerde ${ }^{53}$ recht op uitkering tot een door de mate van arbeidsongeschiktheid bepaald bedrag. Bij wolledige arbeidsongeschiktheid lag de uitkering op het niveau van het sociaal minimum. Voor het recht op uitkering speelde het arbeidsverleden in beginsel geen rol: nog uitgaande van de gedachte dat gedurende het luwelijk de man als kostwinner optrad, sloot de AAW de gehuwde vrouw van het recht op witkering uit. De Wet van 11 december 1975 voorzag voorts in overgangsrechtelijke bepalingen op grond waarvan ook een recht op uitkering in het leven geroepen werd voor degenen dic vór 1 oktober 1975 arbeidsongeschikt waren geworden; ook in dit geval echter met uitsluiting van gehuwde vrouwen.

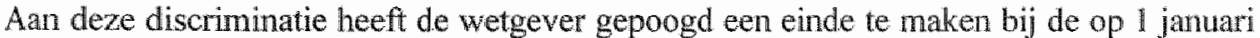
1980 ingevoerde Wet invoering gelijke uitkeringsrechten mannen en vrouwen." Met deze wet werd beoogd het recht op uitkering voor mannen en vrouwen gelijkelijk te regelen, maar dan met dien verstande dat zowel mannen als vrouwen voortaan moesten voldoen aan de zogenaamde inkomenseis: vereist werd dat de verzekerde in het jaar voorafgaande aan het intreden van de arbeidsongeschiktheid een bepaald bedrag ${ }^{5,5}$ an inkomen had verworven. Daamaast voorzag de gewijzigde wet in de introductie van de zogenoemde individuele grondslag: indien de aanvrager in het jaar woorafgaande aan het intreden van de arbeidsongeschiktheid minder had verdiend dan het minimumloon, werd de uitkering berekend naar het gemiddelde van de in dat jaar genoten verdiensten. In de praktijk betekende deze regeling een beperking van de uitkeringsrechten wan partimers. Door deze aanpassingen veranderde de AAW van karalkter: de wet kon niet langer worden beschouwd als een bodemvoorziening, aangezien door de inkomenseis een binding met het beroeps-en bedrijfsleven werd ingevoerd ${ }^{5 \%}$

De gew lizigde wet woorzag in een gelijke behandeling van mannen en (gehuwde) vrouwen die op of na 1 januari 1979 arbeidsongeschikt waren geworden, Voorzower de arbeidson

52 Wet wan 11 decenber 1975, Stb 674, latstelijk gewijzigd bij Wet van 24 december 1997, Stb. 1997 , 789 en ingetrokken per 1 januari 1998.

53 Verzekerd krachtens de A.AW zijn ingezetenen en niet ingezetenen die terzake van een in Nederland verrichte dienstbetrekking aan de loonbelasting zijn onderworpen (artikel 4 , lid 1 , onder a en b). Zte woorts de op artikel 4, lid 2, AAW gebaseende achterenvolgende Besluiten uitbreiding en beperking kring velzekerden volkswerzekeringen.

54 Wet van 20 december 1979 , Stb. 708 .

55 In eerste instantie vastgesteld op $f 3.423,81$ len nadien verhoogd.

56 Zie A.F.M. Brenninkmeijer, De ongelijke behandeling van mannen en wrouwen in de AAW, NJB 1981, afl. 24, p. 613-620. 
yeschiktheid vóor die daturn was ingetreden voorzag de Wet van 20 december 1979 in een aantal overgangsbepalingen (hierna: overgangsrecht AAW 1979) die hierop neerkwamen:

- de voór I oktober 1975 arbeidsongeschikt geworden gehuwde vrouw bleef van het recht op uitkering verstoken.

- de bij de Wet van 20 december 1979 ingevoerde inkomenseis was niet van toepassing op mannen en ongehuwde wrouwen, wier arbeidsongeschiktheid was ingetreden vóór 1 januari 1979. Dat had dus tot gevolg dat de vóór deze datum arbeidsongeschikt geworden gehuwde vrouwen wél, maar voor deze datum arbeidsongeschikt geworden mannen en ongehuwde vrouwen niet aan de inkomenseis behoefden te voldoen.

- tenslotte werd bepaald dat de ongehuwde vrouw die vóór 1 januari 1979 arbeidsongeschikt was geworden en die deswege recht had verkregen op uitkering, dat recht weer zou verliezen zodra zij in het huwelijk trad en zij ofwel vóór 1 jamuari 1975 arbeidsongeschikt was geworden, ofwel (bij tussen 1 oktober 1975 en 1 januari 1979 ingetreden arbeidsongeschiktheid) niet voldeed aan de inkomenseis.

Een en ander resulteerde - kort gezegd - in een specifieke regeling voor gehuwde vrouwen. Vrouwen wier arbeidsongeschiktheid was ingetreden vóór 1 oktober 1975 hadden geen recht op uitkering, zelfs indien zij aan de inkomenseis voldeden; vrouwen die tussen 1 oktober 1975 en 1 januari 1979 arbeidsongeschikt waren geworden, hadden alleen recht op uitkering indien zij aan de inkomenseis voldeden. Daarentegen hadden mannen en ongehuwde vrouwen in dezelfde situatie nog steeds automatisch recht op uitkering. ${ }^{57}$ Een en ander resulteerde in een ongelijke behandeling tussen vóór 1 januari 1979 arbeidsongeschikt geworden (gehuwde) mannen en gehuwde vrouwen. ${ }^{58}$ Op grond van de gewijzigde regeling herleefde het recht op titkering zelfs niet voor de van echt gescheiden, vóór 1 oktober 1975 arbeidsongeschikt geworden vrouw, die vór haar huwelijk op grond van de overgangsrechtelijke bepalingen in de oorspronkelijke wet van 11 december 1975 een uitkering had genoten. ${ }^{59}$

\section{$2.2 \quad$ CRvB 5 januari 1988}

Op 5 januari 1988 maakt de CRvB korte metten met het overgangsrecht, voorzover dit de gehuwde vrouw uitsloot van het recht op een AAW-uitkering. In een zestal zaken, ${ }^{6}$ waar-

57 Aldus A-G Darmon in zîn conclusie vón HWJ EG 24 februari 1994, zaak C-343/92, Roks, Jur. 1994, p. 1-571; RSV $1994 / 214$

58 Voon uitgebreidere beschouwingen over het overgangsrecht A.W, ze: A.F.M. Brenninkneijer, a.w. (noot 56), p. 613-620; W.M. Levelt-Ovemars, De uitspraken van de CRvB d d. 5-1-1988 over artikel 26 BuPO-Verdrag. NJB 1988, afl 18, p. 589-599 en rechbank 's-Hertogenbosch 8 juli 1992, RSW 1993/12. Zie voots noot onder CRvB 22 mei 1990 , Regelmat 544 (1990), p. $91-94$.

59 Het hier beschreven owergangsteclit AAW 1979 is overigens zelf een tweffend woorbeeld van formulering van overgangsiecht door de rechter ter opvulling van een wettelijke lacune; zie CRvB 17 wugustus 1983. AB 1984/150 m.nt. Smits; RSV $1983 / 209$ m.nt. Leveltovermars.

60 ANW 1982/S122; RSW 1988/104 en AB 1983, 252 (intrekking uitkering van vóór 1 oktober 1975 arbeidsongeschikt geworden en op 12 mei 1981 in het huwelijk getreden vrouw; AAW 1981/B126 (afwijzing van de aanratag om de uitkering wan een vroun die sinds 27 december 1979 gescheiden wan haar echtgenoot woonde te heropenen, aangezien de vtouw niet aan de inkomenseis voldeed: AAW 1983/S22; RSV 1988/199 en AB 1988, 254, munt. JHS: weigering AAW-uitkering te verstrekken aan een op 28 januari 1977 arbeidsongeschikt geworden gehuwde vrouw wegens het niet voldoen an de inkomense"s; AAW 1983/590; RSV $1988 / 200$ m.nt. S Feenstra (weigering uitkering A AW ann een vón 1 oktober 1975 arbeidsongeschikt geworden gehuwde wrouw). 
in alle zojuist aangehaalde vormen van ongelijke behandeling aan de orde komen, ${ }^{6}{ }^{6}$ verklaart de Raad de discriminatoire wettelijke bepalingen buiten toepassing op grond van strijd met artikel 26 IVBPR. ${ }^{2}$ Hiertoe overweegt de Raad dat artikel 26 NVPR een zelfstandig materieel recht bevat en dat dit artikel ook van betekenis is voor de hier in het ggeding zijnde rechten ingevolge de $A W^{6.3}$ Voorts overweegt de Raad noch in de bewoordingen van die wet, noch in de geschiedenis van de totstandkoming van de gewraakte wettelijke bepalingen een rechtvaardigingsgrond voor de gewraakte ongelikke behandeling te hebben gevonden. Om deze reden merkt de Raad het in het overgangsrecht gemaakt onderscheid tussen mannen en (gehuwde) vrouwen aan als een directe discriminatie op grond van geslacht in samenhang met de (echtelijke) status. Voor wat de vragg naar de rechtstreekse werking van artikel 26 NBPR betreft, herhaalt de Raad zijn overwegingen in de WUV-uitspraak van 1987, ${ }^{\text {t4 }}$ de Raad aanvaardt weliswaar dat do wetgever een termign moet worden gegund voor het in overeenstemming brengen van de wetgeving met artikel 26 IVBPR, maar is van oordeel dat deze termijn, woor wat de gelijkberechtiging var mannen en vrouwen in de sociale zekerheid betref, moet worden geacht te zijn verstreken op 24 december 1984, de datum waarop de implementatietermijn wan de derde EG-riehtlijn inzake de sociale zekerheid afliep.

Het verrassende is evenwel dat de Raad in de uitspraken van 5 januari 1988 de aanvang van de rechtstreekse werking van artikel 26 IVBPR niet op 23 december 1984 stelde, zoals hij in de WUV-zaak had gedaan, maar op een nog veel verder in het verleden gelegen tijdstip. Ook in de WUV-uitspraak had de Centrale Raad voor wat de bepaling van de ingangsdatum van de rechtstreekse werking van artikel 26 IVBPR aangaat al een zekere slag on de arm gehouden, waar hij overwoog dat de rechterlike keuze van de datum van 23 december 1984

"niet meebrengt dat een tot stand te brengen aanpassing van de Wuv geen vroegere ingangsdatum zou behoeven te kennen dan laatstgenoende datum,

In de uitspraken van 5 januari 1988 springt de Centrale Raad in de door de WUV-uitspraak gelaten ruimte waar hij overweegt dat

'in aansluiting op hetgeen in de laatste zin to uitdrukking is gebracht de Raad met betrekking tot de in het onderhavige geding ann de orde zinde bepalingen van sociale zekerheidswetgeving in het bijzonder van belang [acht] dat die bepalingen deel uitmaken van een wijzigingswer die -.. naar uit de wordingsgeschiedenis er van mag worden afgeleid - onder meer ten doel had de tot dan toe in de AAW voorkomende discriminatie van de (gehuwde) vrouw weg te nemen. Dat bij die wet - waarmee uiteraard is bedoeld de Wet inwoering gelyjke uitkeringsrechten voor mannen en vrouwen - een ongelijke behandeling op grond van geslacht als in dit geding aan de orde echter werd gehandhaafd achtte de wetgever kennelijk niet in strijd mot art. 26 van het BP-

61. Doch geen gevallen wan eventuele indirecie discrimimatie van de gehuwde wouw ten gevolge wan de toepassing van de individuete grondslag.

62 Voor een precieze weergave van deze bepalingen, zie noot S. Feenstra in RSV $1988 / 200$, p. 582 .

63 Een en ander in navolging van de jurisprudentie var het WN-Comite voor Rechten van de Mens; vgl. de in hoofdstuk 3, par. 2.4 behandelde zaken Danning en Broeks.

64 CRvB 14 mei 1987, WUV 1984/82; AB 1987, 543 m.nt. HH; RSV 1987/246 m.nt. W.M. LeveltOvemars; NJCM-Bulletin 12-6 (1987) m.nt. A.W. Heringa.

65 Zie RSV $1987 / 246$, p. 766, rechterkolom. 
Verdrag. Dal de wetgever die opvatting is toegedaan valt ook hienit op te maken dat bedoelde resterende ongelijke behandeling ook later niet door wetswijziging te niet is gedaan. Naar in het vootafgaunde besloten ligt, deelt de Raad die opvating echter niet, aangezien voor die ongelike behandeling, zoals reeds is overwogen, geen redelijke en objectieve rechtwaardigingsgrond bestalt.

De Raad houdt de wetgever vervolgens als het wate de spiegel voor: nu de wetgever kenrelijk zelf gewild en gepretendeerd heeft de AAW mel ingang van 1 januari 1980 , de datum van inwerkingtreding van de Wet invoering geljjke uitkeringsrechten voor mannen en vrouwen, in overeenstemming te brengen met artikel 26 IVBPR, wordt de wetgever vervolgens door de rechter ook aan deze datum gehoudlen. ${ }^{67}$ De Raad voegt hier nog aan toe dat

'art. 26 in gevallen als het onderhavige voldoende nauwkeurig is om door particulieren voor de nationale rechter te kunnen worden ingeroepen teneinde de toepassing van iedere met dat artikel strijdige bepaling te beletten in die zin, dat vrouwen recht hebben op dezelfde behandeling en op toepassing van dezelfde regeling als manthen die in een gelijke situatie verkeren'. ${ }^{8}$

Het was deze overweging, die aan de jurisprudentie van het Hof van Justitie EG lijkt te zijn ontleend, ${ }^{6}$ tezamen met de vroege ingangsdatum van de rechtstreekse werking van artikel 26 IVBPR, die aanleiding was tot de storn die naar aanleiding van deze uitspraken opstak. ${ }^{70}$ De commotie was een rechtstreeks gevolg van de omstandigheid dat de uitspraken voor een grote groep gehuwde wrouwen recht op AAW-uitkering met ingang van soms in een ver verleden gelegen tijdstippen aanspraken leken te vestigen.

\section{$2.3 \quad$ De werking in de tijd wan CRvB 5 jamuari 1988}

\subsubsection{Inleiding}

De mate waarin de doorwerking van het internationale recht alsnog rechten in het leven kan roepen is het resultaat van een wisselwerking tussen het nationaal en intemationaal recht. Deze bewering laat zich bijzonder fraai illustreren aan de hand van de hier aan de orde zijnde uitspraken. Afgezien van de keuze van de ingangsdlatum bevatten de uitspraken in wezen weinig nieuws over de juridische betekenis van artikel 26 IVBPR voor

66 Het IVBPR in de teminologie van dir boek.

67 Voor wat het dijdstip van de aanvang van de rechtstreekse werking varn artikel 26 IVBPR betreft hebben de uitspraken wan de CRWB van 5 januari 1988 echter slechts een beperkte strekking. Zo was. de CRvB in zijn uitsprakk van 23 mei 1991 (RSV 1991/255; NJCM-Bulletin $16-7$ (1991), p. 648 m.nt A.W. Heringal) wan oordeel dat aan artikel 26 IVBPR met betrekking tot artikel 32 , lid 1 , ananhef en onder $b_{4}$ AAW niet, zoals door de eerste rechter onder verwijzing naar de uitspraken van 5 januari 1988 was angenomen, met ingang van I januar 1980 rechtstreekse werking toekwam, maar eerst met ingang van 23 december 1984 , zulks onder de uitdrukkelijke overweging dat artikel 32 van de AAW geen deel uitmakkte van de Wel wan 20 december 1979 .

68 Feenstra spreekt in dit verband, onder aanhaling van nog andere voorbeelden, van "de door diverse rechterlijke instanties gevoerde wedstrijd wie het verst in het verleden kan duiken wanneer het de vraag naar de rechtstreekse werking van artikel. 26 [IVBPR] betreft; zie punt 8 van de noot onder CRWB 5 januari 1988 , RSV 1988/200.

69 Zie het in hoofdstuk 3 , par. 2.6 .2 behandelde $F N$-arrest en de aldaar vermelde verwijzingen.

70 Zie punt 1 van de noot van S. Feenstra in RSV 1988/200, aan wie deze beeldspraak is ontleend. Zie voonts noot onder CRvB 22 mei 1990 , Regelmaat $5 / 4$ (1990) p. 91-94, waarin nader wordt ingegaan op de paniekerige reacties van de regering die een miljardenstrop als gewolg van de uitspraken vreesde. 
de Nederlandse sociale zekerheid in vergelijking met de WUV-uitspraak van de Centrale Raad van Beroep in 1987. Toch deed deze laatste uitspraak heel wat minder stof opwaien dan de uitspraken van 5 januari 1988. De vergaande betekenis van deze uitspraken moet dan ook vooral worden gezocht worden in de katalyserende werking die van de opzet van de AAW zelf uitging op de toepassing van artikel 26 IVBPR als voorschrift uit een hogere dan de nationale rechtsorde. Deze beeldspraak verdient nadere toelichting.

In de opzet van de AAW zijn twee momenten van bijzonder belang. Enerzijds is er het moment waarnaar wordt beoordeeld of de belanghebbende aan de vereisten voor het recht op toekenning van de uitkering voldoet. ${ }^{31}$ Dit moment kan in een (ver) verleden liggen en duidt op een aan de AAW inherent element van terugwerkende kracht. Anderzijds is er het moment met ingang waarvan daadwerkelijk tot uitkering wordt overgegaan. Dit laatste moment wordt mede beheerst door het tijdstip waarop de uitkering wordt aangevraagd. Artikel 25, lid 2, AAW bepaalt dat niet vroeger tot daadwerkelijke uitkering wordt overgegaan dan één jaar voor de dag waarop de aanvraag wordt ingediend. Blijkens dezelfde bepaling kan van deze regel echter in bijzondere gevallen worden afgeweken. Evenals de hiervoor besproken WWV voorziet de AAW derhalve in een onderscheid tussen het moment waarop recht op uitkering ontstaat ${ }^{72}$ en het moment waarop dit recht op uitkering kan worden geeffectueerd.

De uitspraken van de CRvB van 5 januari 1988 brachten een spectaculair terugwerkend effect teweeg ten aanzien van de in die zaken in het geding zijnde uitkeringen. Dit moge onder andere hieruit blijken dat in vier van de zes zaken alsnog, met ingang van 1 januari 1980 , een arbeidsongeschiktheidsuitkering werd toegekend aan gehuwde vrouwen op grond van een vóór l oktober 1975 ingetreden arbeidsongeschiktheid. In al deze gevallen gebeurde dit doordat de Raad de bepaling die deze vrouwen van een uitkering uitsloot met ingang van 1 januari 1980 buiten toepassing liet. De grote vraag echter was evenwel wat de gevolgen van deze uitspraken zouden zijn voor andere gehuwde vrouwen die, met een beroep op de uitspraken van 5 januari 1988, alsnog een aanvraag zouden indienen naar aanleiding van een in een (ver) verleden gelegen tijdstip aangevangen arbeidsongeschiktheid.

Deze vraag was zeer actueel omdat de doorwerking van artikel 26 IVBPR waartoe de CRvB in zijn uitspraken van 5 januari 1988 concludeerde, rechtstreeks betrekking had op de voorwaarden voor het ontstaan van het recht op uitkering. Het gevolg van de uitspraken was dan ook dat voor vrouwen die uitsluitend op grond van het feit dat zij waren gehuwd van het recht op uitkering waren uitgesloten, alsnog met ingang van een datum, gelegen cen jaar na het intreden van hun arbeidsongeschiktheid, een recht ontstond op AAWuitkering. De opzet van de AAW brengt aldus mee dat aan de uitspraken van 5 januari 1988, voor wat hun materiële werking in de tijd aangaat, terugwerkende kracht toekomt. In dit verband is het interessant te verwijzen naar de discussie die zich ontspon tussen de staatssecretaris van Sociale Zaken en Werkgelegenheid en de Raad van State naar aan-

71 Zie voor een beschrijving wan de voonwaarden voor het recht op uitkering fo. M. Noordam, Inleiding sociale zekerheidsrecht ${ }^{\text {Deventer } 1992, \text { p. } 80 .}$

72 Zie ook W.M. Levelt-Overmars, a.w. (noot 58), p. 59, die in dir werband spreekt wan het tijdstip dat beslissend is voor de opening van het recht. 
leiding van wetswoorstel 20610 , waarin de regering trachtte de terugwerkende effecten van de uitspraken te beperken. Volgens de bewindsman ging de betekenis wan de uitspraken van 5 januari 1988 niet verder dan dat hieraan de verwachting kon worden ontleend dat na deze datum een weigering van een uitkering, die was gebaseerd op de wetsartikelen die in de uitspraken buiten toepassing waren verklaard, zou worden vernietigd. In dit verband zou er slechts sprake zijn van uitkeringsrechten naar analogie van de uitspraken van de $C R v B^{73}$. Blijkens zijn advies $s^{7 / 1}$ verbond de Raad van State evenwel verdere consequenties aan de uitspraken. De Raad van State stelde voorop dat door de wetgever toegekende rechten moeten worden geeerbiedigd, ook als dit verder gaat dan aanvankelijk werd gedacht. Met deze laatste woorden doelde de Raad van State op de verniming van de kring van $A A W$-uitkeringsgerechtigden die het gevolg was van de uitspraken van de $C R v B$. De Raad van State sprak in dit verband ook letterlijk van terugwerkende kracht van de uitspraken. Hij was van oordeel dat het in het kader van de AAW toekennen door de CRvB van rechtstreekse werking aan artikel 26 IVBPR met terugwerkende kracht rechten schiep voor de voonoemde groep vrouwen die voorheen van het recht op uitkering waren uitgesloten. Aldus kende de Raad van State aan de rechterlijke uitspraken een ruimere strekking toe dan de bewindsman.

Interessant is dat de zojuist aangehaalde passage van het advies van de Raad van State de terugwerkende kracht in zoverre ook nog in een nieuw daglicht stelt doordat daarin rechtstreeks wordt aangehaakt bij de werking van de wet, namelijk daar waar de Raad van State de terugwerkende kracht rechtstreeks in verband brengt met het beginsel dat door de wetgever toegekende rechten moeten worden geëerbiedigd. Door het zo te formuleren laat de Raad van State de werking van artikel 26 IVBPR delen in de algemene werking die inherent is aan wetgeving, aldus eens te meer het verschil benadrukkend met de casuïstische benadering van de staatssecretaris.

De AAW-casus is echter met name het bestuderen waard vanwege de pogingen die door de Nederlandse overheid zjjn gedlaan om de terugwerkende effecten van de uitspraken van 5 januari 1988 te beperken. Deze beperkingen hebben in de eerste plaats betrekking op de formele werking in de tijd, dus op de mogelijkheid voor gehuwde vrouwen om hun alsnog verkregen rechten daadwerkelijk geldend te maken. Wat de AAW-casus tamelijk uniek. maakt is dat de wetgever eveneens heeft getracht de materiêle werking in de tijd van de uitspraken van 5 januari 1988 te beperken door alsnog, met terugwerkende kracht, een voor mannen en vrouwen gelijkelijk overgangsregime in te voeren. Beide vormen van beperking hebben aanleiding gegeven tot principiële jurisprudentie van het HVJ EG.

\subsubsection{Formele werking in de tijd}

\subsubsection{Artikel 25, lid 2, AAW}

De formele werking in de tijd van de uitspraken van 5 januari 1988 wordt in de eerste plats bepaald door artikel $25 \mathrm{AAW}$. Op grond van de eerste volzin van het tweede lid van dit artikel gaat de uitkering niet eerder in dan een jaar woor de dag waarop de aanvraag werd ingediend. Op deze bepaling wordt in de tweede volzin van dit artikellid echter in die 
zin een uitzondering gemaakt dat daarin is bepaald dat het uitvoeringsorgaan in bijzondere gevallen bevoegd is van het in de eerste volzin verwoorde uitgangspunt af te wikken. In tegenstelling fot artikel 18 WWV houdt artikel 25 , lid 2, AAW een discretionaire bevoegdheid voor het uitvoeringsorgaan in warvan de uitvoering door de rechter slechws op terughoudende wijze kan worden getoetst. Deze bevoegdheid komt het witvocringsargaan echter alleen toe als er sprake is van een bijzonder geval. Aanwankelijk was het praktijk dat de CRvB een onverbrekelijk verband legde tussen de bijzonderheid var het geval en de verplichting om gebruik te maken van de bevoegdheid met verdergaande terugwerkende kracht dan een jaar uitkering te verlenen. Daarmee viel de vraag of sprake was van een bijzonder geval samen met de vraag of het uitvoeringsorgaan van zijn discretionaire bevoegdheid gebruk moest maken. ${ }^{75}$ In latere jurisprudentie heeft de Raad dit 'onverbrekelijke verband' bij de beoordeling van de vraag of de toepassing van de internationale gelijkheidsnormen aanleiding geven tot het met terugwerkende kracht toekennen van een uitkering, echter losgelaten. De Raad toetst 'vol' of er sprake is van een bijzonder geval. Hiervan acht de Raad sprake als de betrokkene terzake van een verlate aanvraag. redelijkerwijs niet geacht kan worden in verzuin te zijn geweest. ${ }^{76}$

De formele werking in de tijd van de uitspraken van 5 januari 1988 wordi verder bepaald door de mogelijkheid om met een beroep op deze uitspraken herziening te verkrijgen van een eerdere beschikking waarbij aan een vrouw, louter op grond van het feit dat zij gehuwd was, uitkering was geweigerd. Deze laatste mogelijkheid speelde in de praktijk echter slechts een ondergeschikte rol, omdat er, gelet op de toenmalige stand van de Nederlandse wetgeving, voor gehuwde vrouwen in het geheel geen aanleiding bestond om cen $A A W$-uitkering aan te vragen. ${ }^{77}$ De rest van deze paragraaf zal dan ook vooral betrekking hebben op de toepassing van artikel 25 , lid 2, AAW.

\subsubsection{CRvB 30 januari 1991}

Het interessante is nu dat bij de vraag naar de interpretatie van het in artikel 25 , lid 2 , AAW vermelde begrip bijzondere gevallen, artikel 26 IVBPR opnieuw, in een wat andere gedaante, om de hoek komt kijken. De vraag doet zich immers voor of de omstandigheid dat de genoemde groep gehuwde vrouwen in strijd met artikel 26 IVBPR cen AAWuitkering blijkt te zijn onthouden, hen niet en bloc bestempelt tot een bijzonder geval in de zin van artikei 25 lid 2, tweede volzin AAW. De consequentie van een bevestigencle beantwoording van deze vraag zou immers kunnen zijn dat de beperking die artikel 25 lid 2 , eerste volzin, aan het daadwerkelijk geldend maken van de witkeringsrechten stelt, voor deze vrouwen niet, of niet geheel, van toepassing zou blijken te zijn. Deze vraag kwam uitdrukkelijk aan de orde in een uitspraak van de Raad van Beroep te Amhem van 13 september $1990 .^{78}$

Zie de noot van W.M. Levelt-Overmars onder CRvB 26 november 1986, RSV 1988/22

Zie, onder meer, CRVB 30 januari 1991, AB 1991, 339 mmt. De Leede; RSV 1991/182 m.n. J.J.A. Kooijman en CRvB 11 december 1991. RSV 1992/46. Zie in dit verband tevens: F.M. Noordam. Weduwnaarspensioen met terugwerkende kracht, Tijdschrift vool" pensioenvragsstukken, meil 1991 , p. $33-35$.

77 Vgl. in dit verband: CRVB 22 maart 1994, JSV 1994/133

78 Rechtspraak Nemesis 1991, nr. 142. 
De uitspraak betref de toetsing van het beleid dat het witwoeringsorgatn voen bij de toepassing wan de haar op grond wan artikel 25, lid 2, AAW toekomende bevoegdheid om bij de toekenning van een AAW-unkering af te wijken van de in de eerste volzin wan het desbetreffende artikellid

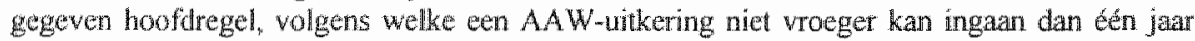
voor de dag waarop de aanvraag werd ingediend. Niet is geschil is dat betrokkene, gethwwe wrouw, in beginsel vanaf 1 januari 1980 recht op een uitkering heeft ingevolge de utspraken van de CRVB van 5 januari 1988. Het uitwoeringsorgaan is evenwel niet bereid betrokkene met terugwerkende kracht wan meer dam én jaar uitkering te verlenen. Hiertoe heeft het overwogen dat de omstandigheid dat betrokkene voón 5 jamuari 1988 niet heeft geweten dat zij voor een uitkering in aanmerking zou komen en om die reden van het doen van een aanvraag had afgezien, geen bijzonder, tot afwijking van de hoofidregel van art.25 lid 2 AAW nopend, geval oplewert:

\section{De Rad van Beroep overweegl dienaangaande:}

'Beslissend voor de beantwoording van de vraag of er in beginsel aanleiding kan zign een bijzonder geval als in dje bepaling bedoeld anwezig te achten, is naar het oordeel van de Raad het zich woordoen van een situatie waarin de uitkeringsgerechtigde het niet tijdig indienen van een anvraag niet kan worden toegerekend.

$[\ldots]$

Naar "s Raads oordeel heeft [het uirvoeringsorgaam] bij de beantwoording van de vraag of er in klaggsters situatie al dan niet een bijzonder geval als vorenbedoeld aanwezig moet worden geacht, ten onrechte geen gewicht toegekend aan de omstandigheid dat eerst op 5 januari 1988 door de Contrale Raad wan Beroep is geoordeeld dat - in weerwil van het per 1 januari 1980 door de wetgever in het leven geroepen overgangsrecht AAW - de gehuwde vrouw die vóór 1 januari 1979 arbeidsongeschikt is geworden, onder dezelfcte voorwaarden die voor de overige verzekerden gelden aausprak heeft op een uitkering ingevolge de AAW".

Wel houdt de Rad van Beroep nog een slag om de arm blijkens zijn overweging dat hij in dit verband voorop stelt
'dat de omstandigheid dat een verzekerde afziet van het doen van een aanvraag om een uitkering vanuit de veronderstelling daarop gezien de vigerende bepalingen geen recht te hebben, op zich geen reden behoeft te vormen een bijzonder geval als vorenbedoeld aan te nemen, indien nader- hand blikt dat de bepaling die de verzekerde uitshit van het recht op uitkering onverbindend is wegens strijd met en bepaling van hoger orde. Veelal zal moeten worden gezegd dat de ver. zekerde - met name ook door het inwinnen van inlichtingen bif deskundige instanties - op de hoogte had kunnen zijn wan de mogelijkheid dat een wettelije regeling door de beroepsrechter strijlig wordt bevonden met bepalingen wan internationaal en supranationaal recht. Onbekend- heid in vorenbedoeld opzicht zall naar hot oordeel van de Raad in het allgemeen dan ook voor rekening van de verzekerde kunnen worden gelaten. Dit geldt evenzeer voor een eventuele kewe die de verzekerde maakt op grond wan een bij hem of haar bestaande opvatting wat betreft de kans op het met succes adieren van de rechter".

Deze strenge nom past de Raad echter niet op dit geval toe, nu gezien de toentertijd geringe andacht voor artikel 26 IVBPR er niet van uitgegaan kon worden dat betrokkene had kunnen weten dat het indienen van een aanvraxg om een AAW-uitkering tòch zinvol had kumen zijn.

De overige overwegingen van de Raad van Beroep zijn interessant om enig inzicht te krijgen in het "beleid" dat het uitvoeringsorgaan tot dan toe had gevoerd met betrekking tot aanvragen van een uitkering gebaseerd op de uitspraken van de CRvB van 5 januari 1988 . Zo bleek het uitvoeringsorgaan wel bereid te zijn tot het verlenen wan een verder gaande terugwerkende kacht dan tot één jaar vór de datum van de aanvrage, indien de aanvraag 
vóór 5 januari 1988 was gedaan. Deze toekenning vond plaats ook indien de beslissing waarbiy dat verzoek was afgewezen rechtens inmiddels onaantastbaar was geworden. De Raad van Beroep constateert aldus een verschil in beleid tussen de ene groep, bestaande uit hen die weliswaar eerder een uitkering hadden aangevraagd, maar zich verder bij de afwijzing hadden neergelegd, en de andere groep, bestaande uit degenen die in het geheel geen aanvraag hadden ingediend, maar op een andere wijze hadden begrepen dat zij geen recht op verzekering hadden. Dit verschil in beleid acht de Raad onzorgvuldig.

Naar aanleiding van deze uitspraak kan in de eerste plaats worden opgemerkt dat de Raad van Beroep niet aanneemt dat de met artikel 26 IVBPR strijdige toepassing van de AAW voor het uitvoeringsorgaan 'automatisch' de rechtsplicht met zich brengt de desbetreffende groep vrouwen alsnog met terugwerkende kracht een uitkering toe te kemnen. Voorts zoekt de Raad de bijzonderheid van het geval niet in de onjuiste toepassing van de AAW als zodanig, maar acht hij voor de vraag of van een bijzonder geval in de zin van artikel 25 lid $2 \mathrm{AAW}$ sprake is beslissend of de aanvragsster het niet tijdig indienen van de aanvraag al dan niet kan worden toegerekend. Blijkens de zojuist aangeliaalde overwegingen wordt de aanvraagster een niet tijdige indiening in ieder geval toegerekend, indien zij in de gelegenheid heeft verkeerd inlichtingen te verkrijgen waaruit de mogelijkheid van een onverbindendverklaring van de toe te passen wetsbepaling zou blijken. Slechts ondat de Raad van Beroep van oordeel is dat vór de uitspraken van de CRvB van 5 januari 1988 voor aanvraagster onvoldoende informatie over artikel 26 IVBPR beschikbaar was geweest, meent de Raad dat het uitvoeringsorgaan bij de bepaling van haar beleid ten onrechte geen rekening heeft gehouden met de uitspraken van de CRvB van 5 januari 1988 .

Deze rechtspraak is in grote lijnen bevestigd door de CRvB. In dit verband dient in het bijzonder te worden gewezen op cle uitspraken van de CRvB van 30 januari $1991,{ }^{79}$ waarin de Raad zich heeft uitgesproken over de toepassing van het aan artikel 25 , lid 2, AAW gelijkluidende artikel 25 , lid 5, AWW, zulks in verband met een verzoek van een weduwnaar om op grond van de in paragraaf 5.1 nader aan de orde te stellen uitspraak wan de CRvB van 7 december $1988^{80}$ alsnog met terugwerkende kracht in aanmerking te worden gebracht voor een AWW-pensioen. De CRvB is van oordeel dat een bijzonder geval moet worden aangenomen ${ }^{81}$ gezien de grote onzekerheid die vóór 7 december 1988 bestond over de vraag of ook weduwnaars voor een uitkering ingevolge de $\mathrm{AWW}$ in aanmerking konden worden gebracht, welke onzekerheid voortvloeide uit onduidelijkheid over het bereik van de desbetreffende communataire en internationaalrechtelijke normen. De CRvB hecht in dit verband mede betekenis aan de ten tijde van de uitspraken van 30 januari 1991

79 AB 1991, 339 m.nt. De Leede; RSV $1991 / 182$ m.nt. JI. A. Kooijman en NICM-Bulletín 16-3 (1991), p. $217-221$ m.nt. A.W. Heringa.

80 RSV $1989 / 67$ m.n. F.W.M. Keunen. In deze uitspraak, waarop in paragraas 3.1 nog zal worden teruggekomen, oordeelde de CRvB dat artikel 26 IVBPR ten tijde tin geding meebracht dat ook wednwnats recht hadden op een uitkering ingevolge de AWW,

81 Kooijman heeft er in zijn noot bij deze uitspmakik (RSV 1991/182) op gewezen dat de CRvB in deze uitspraak blik geeft van een nieuwe benadering. In eerdere uitspraken (verwezen wordt naar: CRvB 20 maart 1978, RSV 1978/241) had de Raad immers geoordeeld dat ook het antwoord op de vratag of zich een bijzonder geval voordoet aan het oordeel van het uitvoeringsongaan moest worden overgellaten. In de nieuwe benaderingswijze loetst de rechter zelfstandig of er sprake is van een bijzonder geval. 
nog immer toegepaste circulaire van de toenmalige Vereniging van Raden van Arbeid van 15 december 1972, waarin onbekendheid met rechten die voortvloeien uit verdragsbepalingen een factor wordt genoend dic een rol kan spelen bij het aannemen van een bijzonder geval. ${ }^{32}$ Deze onbekendheid acht de Raad in de onderhavige gevallen onmiskenbaar aanwezig.

Uit de witspraken van de CRvB van 30 jamuari 1991 kan de conclusie worden getrokken dat weduwnaars die naar aanleiding van de uitspraak wan de CRvB alsnog een $A$ WW wikering indienen en bloc worden aangemerkt als bijzonder geval. De reden hiervoor is gelegen in de rechtsonzekerheid die was ontstaan doordat de Nederlandse wetgever nalatig was geweest bij de ampassing van de AWW aan de communautaire en internationatrechtelijke anti-discriminatiebepalingen. Blijkens zijn uitspraak van 8 augustus $1991^{83}$ acht de CRvB deze rechtspraak van overeenkomstige toepassing op gehuwde wrouwen die net een beroep op de uitspraken van de CRvB van 5 januari 1988 alsnog een verzoek indienen om met terugwerkende kracht in aanmerking te worden gebracht voor een AAW-uitkering.

Uit de jurisprudentie blijkt echter eveneens dat de groep van techthebbenden ten aanzien van wie een bijzondere geval wordt aangenomen is beperkt tot degenen van wie in redelijkheid kan worden aangenomen dat zij in onzekerheid verkeerden over het bereik van artike 26 IVBPR. Zo oordeelde de CRvB in een uitspraak van 29 april $1993^{8 *}$ dat

\footnotetext{
"van een bijzonder geval als bedoeld in antikel 25 , vijfde lid, varn de AWW blikens de uitspraak van de Raad van 30 januari 1991 [...] sprake is bij de - als nieuw en apart ve onderscheiden groep van weduwnats die in de periode voorafgaande aan de uitspraken van de Raad van $?$ december 1988 [...] betreffende de rechtstreekse werking van artikel 26 IVBPR ten aanzien wan de in de AWW vervatte discriminatoire bepalingen, in onzekerheid verkeerden over het bereik van onder meer grenoend artikel 26 IVBPR:
}

De Raad is woorts van oordeel dat

\begin{abstract}
'terecht [...] van de zijde van [het uitwoeringsorgaan] is opgemerkt dat uit genoemde uitspraak van de raad wan 30 januari 1991 niet kan worden afgeleid dat alle weduwnaars die een aanvraag om pensioen of uilkering ingevolge de. AWW hebben ingediend, als bijzondere gevallen moeten worden aangemerkt. Doorslaggevend in genoemde uitspraak was de evenvermelde, voón de uitspraak van 7 dec. 1988 bestaande onduidelijkheid over het bereik van de desbetrefende supraen internationaalrechtelijke normen. Van die onduidelijkeid was geen sprake meer nadat in de media cn ook in de woorlichting door [het uitvoeringsorgaan] rume aandacht was besteed aan de betekenis wan meergenoemde uitsprak van de raad van 1988. Naar het oordeel van de raad heef thet witvoeringsorgaan, dat] erop heeft gewezen dat in juli 1989 reeds 21.000 en in de tweede helf van dat jaar nog 7.000 weduwnaars een anvrang hebben ingediend, op goede gronden kumen oordelen dat van werschoonbare onbekendheid als grond om als bijzonder geval - behorend tot meebedoelde groep - te worden asngemerkt, niet meer gesproken kan worden vanaf 1 jan. 1990, dit ts rum é̉n jaar na de uitsprak wan 7 dec 1988.85
\end{abstract}

82 Door de Raad van Beroep te Roenmond in zijn uitspraak van 2 mei 1990, RSV $1991 / 40$ aangemerki als "wijs beleid".

83 AB 1991.657 m.nt. De Leede.

84 AB 1993,556 mint. De Leede; RSV $1994 / 9$.

85 Zie voorts CRvB 1 aptil 1998, PS Actua, 25 jumi 1998, nr. 79: "Voor wall betrett de stelling van 
Deze rechtspraak heeft de CRvB bij uitspraak van 14 februari $1995^{86}$ van overeenkomstige toepassing geacht op artikel 25, lid 2, AAW. Naar het oordeel van de Raad kon ten aanzien van na 1 januari 1990 ingediende aanvragen geen sprake meer zijn van een bijzonder geval als bedoeld in de tweede volzin van artikel 25 , lid 2, AAW, ondat aanvragen na die datum niet meer geacht worden te zijn gedaan naar aanleiding van de uitspraken van 5 januari 1988 die, naar het oordeel van de Raad, aan de onduidelijkheid ontrent het recht op AAW-uitkering van gehuwde vrouwen een einde makten.

Uit het voorgaande kan worden afgeleid dat de formele werking in de tijd van de uitspraken van de CRvB van 5 januari 1988 zich hierdoor kenmerkt dat terk aanzien wan de groep van gehuwde vrouwen die met een beroep op deze uitspraken een aanvraag indienen om met verder terugwerkende kracht dan een jaar vóór de datum van aanvraag voor een uitkering in aanmerking te worden gebracht, (collectief) een bijzonder geval wordt aangenomen, voorzover er sprake is van verschoonbaarheid op grond van onzekerheid over het bereik van artikel 26 IVBPR. Van een dergelijke verschoonbaarheid is geen sprake meer als voornoemde onzekerheid dankzij een actieve voorlichting van de zijde van de overheid geacht kan worden te zijn weggenomen.

Is aldus het aantal gevallen dat als bijzonder in de zin van artikel 25, lid 2, AAW kan worden aangemerkt (in de tijd) beperkt, ook het wel aannemen van bijzonder geval biedt geenszins de garantie dat aanspraak kan worden gemaakt op uitkering met verdergaande terugwerkende kracht dan een jaar vóór de indiening van de aanvraag. Zoals al eerder is opgemerkt roept de aanwezigheid van een bijzonder geval voor het uitvoeringsorgaan de bevoegdheid in het leven om met verdergaande terugwerkende kracht dan een jaar vóór de datum van aanvraag uitkering te verstrekken. Deze bevoegdheid is discretionair van aard. In zijn uitspraak van 30 januari 1991 overweegt de CRvB ten aanzien van deze bevoegdheid:

"Uitgaande van de aanwezigheid van een bijzonder geval, is voor het [uitvoeringsorgaan] de bevoegdheid anwezig om de uitkering op een eerder tijdstip te doen ingaan dan een jaar voor de aanvraagdatum. Gelet op de discretionaire aard van de bevoegdheid welke het [uitvoeringsorgaan] in deze toekomt, staat het het [witvoeringsorgaan] in het kader wan de (wijze van) hantering van die bevoegdheid vrij voor deze - naar de zienswijze van de Raad geredelijk als nieuw en apart te onderscheiden - groep van gevallen een beleid te ontwikkelen. [...]

De raad merkt terzake reeds thans op zich te kumnen verenigen met een beleid zijdens het [uitvoeringsorgaan], inhoudende dat slechts een eerdere (dan een jaar voor de aanvragdatum) ingangsdatum van de witkering vastgesteld wordt, indien er anders sprake zou zijn van bijzondere hardheid jegens de uitkeringsgerechtigde. In dat vlak liggende beleidscriteria zijn ook in andere situaties, eveneens in het kader van de toepassing van de corresponderende bepaling met betrekking tot de ingangsdatum van de AOW, door het [uitvoeringsorgaan] gehanteerd en door de Raad in constante jurisprudentie aanvaard. Uiteraard neemt de bevoegdheid van [het uitvoeringsorgaan] tot het stellen van een algemeen beleidskader niet weg dat na toetsing aan dat

betrokkene dat hij werkeend is voorgelicht door de SVB verwijst de CRvB naar exerdere jurisprudentive waarin overwogen is dat het niet indienen van een alanvag in werloand mot een mededeling die berustte op naderhand gewijzigde wetsinterpretatie niet zonder meer aan het bestuursorgaan kan worden tegengeworpen."

AB 1994, 391 m.nt. De Leede. 
beleid in geval van een negatieve urtkomst woor de belanghebbende de situatie nog op harar eigen merives dient te worden beoordeeld ter beantwoording van de wrag of zich in concreto voldoende bijzondere omstandigheden nopen tot afwijking van de beleidsregels ten gunste van de belanghebbende", (mijn cursivering, RB)

Aldus zet de CRVB zelf de toon voor een uitvoeringspraktijk, waarbij inmiddels verkiegen uitkeringsrechten alleen dan worden gehonoreerd als jegens de betrokkene sprake is van bijzondere hardhelid. Voor de invulling die door de uitwoeringsorganen aan dit begrip werd gegeven is, voor de wat de in deze paragraaf aan de orde gestelde AAW-problematiek betreft, het door de voomalige Bedrijfsvereniging woor Detailhandel, Ambachten en Huisvrouwen (DETAM) gevoerde beleid het meest illustratief. Volgens het beleid van de DETAM is er sprake van bijzondere hardheid indien éen van de navolgende situaties zich voordoet:

1. De betrokkene is om medische enfof psychische redenen kennelijk niet in staat geweest om eerder een aunvraag in te dienen, terwijl zij tevens geen beroep kon doen op persoonen in de directe omgeving. De terugwerkende kracht wordt mede bepaald door de mate van financięle hardheid.

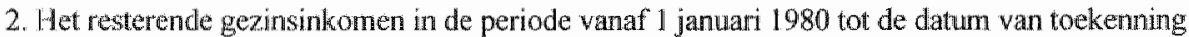
van de $\mathrm{AAW}$-uitkering lag gedurende een substantiele periode aantoonbaar beneden het sociale minhmum. Dit werd veroorzaakt door financiële schade, gelleden in de prive-sfeer die direct werd veroorzaakt door de arbeidsongeschiktheid.

Er wordt uitgegaan van het gezinsinkomen en niet van het inkomen van de betrokkene; aangezien betrokkene in weel gevallen gedurende de van belang ziljnde periode vanaf 1 januari $1980 \mathrm{in}$ liet geheel geen inkomen had. ${ }^{87}$

\subsubsection{Het TOTO-model}

Uit het voorgaande blijkt dat de wijze waarop de uitvoeringsorganen toepassing gaven aan artikel 25, lid 2, AAW tot gevolg had dat de formele werking in de tijd van de uitspraken van de CRvB van 5 oktober 1988 zich voor de betrokken groep gehuwde vrouwen in de meeste gevallen beperkte tot een terugwerkende kracht van een jaar vóór de aanvraagdatum. Deze beperking in het daadwerkelijk rechtsherstel voor de betrokken vrouwen was in wezen het gevolg van in het beleid wan de uitwoeringsorganen opgenomen voorwaarden, die destijds, an met de betrokken groep gehuwde vrouwen vergelijkbare (gehuwdej mannen, niet waren gesteld.

Dat het met terugwerkende kraciat verkrijgen van een $\mathrm{AAW}$-uitkering in sommige gevallen bijna letterlijk te vergelijken viel met het winnen wan een prijs in de woormalige voetbaltoto, moge blijken uit de door de Raad van Beroep Arnhem ${ }^{\text {B\& }}$ aangehaalde praktijk die ziet op gevallen waarin het uitvoeringsorgaan na 1 januari 1980 middels het zogenoemde meldingsformulier een aanvraag om een voorziening ingevolge de A.W had ontvangen. Indien de aanvrager op dat formulier tevens had aangegeven geheel of gedeeltelijk arbeidsongeschikt te zijn, werd die melding door het uitwoeringsorgaan alsnog alangemerkt als een aanvraag om uitkering. Naar het naar het oordeel van de Raad van Beroep 
"Wijt het geen twijfel dat althans in veruit de meeste van die gevallen door de verzekerde destijds met het aankruisen van de betreffende vragen op dat meldingsformulier alleminst is beoogd tevens een aanvraag om uitkering in te dienen. Zou dit anders zijn, dan zou thet uitwoeringsorgaan], naar mag worden verondersteld, in veel wan die gewallen na werloop van tijd met een verzoek om uitshitsel op die aanvraag zijn geconfronteerd, hetgeen bijkbaar niet het geval is geweest. Voorts zal het, nat de Raad wil voorkomen, aan lotter toevallige omstandigheden zijn toe te schrijven dat een aantal verzekerden destijds voor het indienen van een verzoek on een voorziening gebruk heeft gemaakt van bedoeld formulier". (mijn cursivering, RB)

Niettemin is het vaste jurisprudentie van de CRvB ${ }^{89}$ dat een dergelijke, op of na 1 januari 1980, gedane melding moet worden aangemerkt als een aanvraag om uitkering, zodat de in artikel 25, lid 2, AAW opgenomen discretionaire bevoegdheid niet aan de orde is en de uitkering, indien aan de overige voorwaarden is voldaan, met ingang van een jaar voor de meldingsdatum moet worden verstrekt. Deze rechtspraak van de CRvB moge als resultaat van pure wetsuitleg begrijpelijk zijn, vanuit het oogpunt wan de betrokken gehuwde viouwen noet zij als tamelijk willekeurig overkomen. Het louter aankruisen van het desbetreffende hokje op het meldingsformulier met daarnaast niet meer dan de bewering van betrokkene zelf met ingang van een bepaald tijdstip arbeidsongeschikt te zijn, zonder dat: het uitwoeringsorgaan destijds is overgegaan tot ook maar enig onderzoek naar de juistheid hiervan, wordt op deze wijze heel ruim beloond.

\subsubsection{Het arrest Steenhorst-Neerings}

Gelet op het voorgaande kan het nauwelijks verbazing wekken dat de wijze waarop de uitvoeringsorganen omgingen met verzoeken van gehuwde vrouwen on alsnog, met terugwerkende kracht, in aanmerking te worden gebiacht voor een AAW-uitkering to nadere jurisprudentie heeft geleid. Nadat de CRvB in voomoemde uitspraak van 8 augustus $1991^{90}$ als uitgangspunt voorop had gesteld dat

'de regeling van artikel 25 , tweede lid, voor" gevallen alls de onderhavige" op zichzelif niet in strijd is te achten met het IVBP, en met name niet met artikel 2 van dit verdrag, reeds ondat art. 25 tweede lid het honoreren van aanspraken als thans in het geding, ook met verdergaande terugwerkende kracht dan een jaar, op zichzelf niet onmogelijk maakt',

stelt de Raad van Beroep "s-Hertogenbosch in zijn bevel van 17 december 1991 in de zaak Steenhorst-Neerings ${ }^{92}$ de zaak pas werkelijk op scherp door de toepassing van artikel 25 , lid 2, AAW te betrekken op de rechtstreekse werking van artikel 4, lid 1, Richtlijn 79/7 EEG. De Raad van Beroep benadrukt dat vrouwen als betrokkene met ingang van 23 december 1984 door de werking van Richtlijn 79/7 EEG aanspraak konden maken op

89 Zie onder meer CRvB 9 mei 1994, RSV 1994/212; CRvB 31 oktober 1995, AB 1996,98 m.nt. F.J.L. Pernings.

90 AB 1991/657.

91 De zaak zag op een op 4 juli 1988 ingediende aanvraga naar aanleiding van in juni $1958(9)$ atangevangen volledige arbeidsongeschiktheid.

92 Rechtspraak Nemesis 1992, nr. 229.

93 Het gaat in deze zaak on een gehuwde wrouw die naar aanleiding van de uitspraken van de CRwB war 5 januari 1988 op 3 mei 1988 een aanvraag heeft ingediend naar aanleiding van in 1963 aangevangen arbeidsongesciniktheid. 
AAW-uitkering. De Raad stelt aldus de materiële werking in de tijd van de uitspraken wan 5 januari 1988 woorop. ${ }^{94}$

Vervolgens geeft de Raad de zaak een zeer interessante wending door ook de procedurele kant - het recht op toegang tot de procedure die alsnog tot het verstrekken van een uitkering kan leiden - aan een toetsing aan het gemeenschapsrecht te onderwerpen. De Raad maakt hierbij gebruik van het - toen recente - arrest van het HvJ EG in de zaak Emmott, waarin het Hof - in de woorden van de Raad van Beroep - heeft beslist dat

'pas vanaf het moment waarop de Lid-Staat een richtlijn correct heeft uitgevoerd aan justitiabelen termijnen kunnen worden gesteld waarbinnen zij hun desbetreffende rechten geldend kunnen maken'.

De Raad is van oordeel dat op 17 mei 1988 , de dag waarop klaagster de AAW-uitkering had aangevraagd, geen sprake was van een volledig correcte uitvoering van Richtlijn $79 / 7$ door de Nederlandse wetgever. Voorts ziet de Raad

"voorshands geen reden waarom het in het arrest Emmott neergelegde oordeel van het Hof van Justitie zich zou beperken tot (in dat arrest aan de orde zijnde) termijnen waarbinnen een rechterlijke procedure moet worden aangespannen en niet evenzeer zou gelden voor termijnen waarbinnen een uitkering bij een uitvoeringsorgaan moet worden aangevraagd'.

Een en ander leidt de Raad tot het stellen van de volgende prejudiciële vraag:

"Verlangt het Gemeenschapsrecht dat met terugwerkende kracht tot 23 december 1984 [...] aan vóór I oktober 1975 arbeidsongeschikt geworden gehuwde vrouwen uitkering krachtens de AAW wordt toegekend, indien die vrouwern om redenen welke in het verwijzingsbevel staan vermeld pas na 5 januari 1988 (de datum van op gelijke behandeling wan mannen en vrouwen betrekking hebbende uitspraken van de Centrale Raad van Beroep) een aanvraag om een dergelijke uitkering hebben ingediend?'

welke vraag door het HvJ EG in zijin naar aanleiding van het bevel van de Raad van Beroep gewezen arrest van 27 oktober $1993^{36}$ aldus werd verstaan

'of het gemeenschapsrecht zich verzet tegen de toepassing van een bepaling van nationaal recht, volgens welke een arbeidsongeschiktheidsuitkering niet vroeger dan een jaar yóór de daturn van aanvraag kan ingaan, wanneer een particulier zich beroept op de rechtsireeks door artikel 4 , lid 1. wan richtilijn $79 / 7$ met ingang van 23 december 1984 toegekende rechten en de betrokken Lid-

94 Dat in deze uitspiaken in het geheel niet gerept wordt van Richtlijn 79/7 EEG doet daarbij niet terake. Uit het feit dat de CR VB op grond van de werking wan artikel 26 IVBPR van oordeel was dat gehuwde wrouwern met ingang van 1 januari 1980 in beginsel in aanmerking kwamen voot" een AAW-uitkering kan, a fortiori, worden afgeleid dat dit tevens met ingang van een later tijdstip op grond van de sterkere werking van artikel 4, lid 1, Richtijn 797 EEG het geval moet zijn. In zijn noot onder de uitspraken (RSV 1988/200) merkt Feenstra op dat we naar de reden waarom de CRVB in zụju uitspraken van 5 januari 1988 niet aan Richtlijn $79 / 7$ EEG refereert "alleen maar kunnen gissen", warna hij opmerkt dat een gevolg daarvan is dat de ungangsdatum van de buiten toepassing verklaring van de desbetreffende overgangsbepalingen op een vroeger tijdstip kon worden wastgesteld dan het geval zou zijn geweest als de witspraken louter op de werking van Richtlijn 79/7 EEG gebaseend zouden zijn geweest.

95 HvI EO 25 juli 1991, zak C-208/90, AB 1992, 1, m.nt. Meij.

96. Hw EG 27 oktober 1993, zaak C-338/91, Sheenhorst-Neerings, Jur. 1993, p. 1-5475; RSV 1994/211 m.nt. F.W.M. Keunen. 
Stat deze bepaling op de datum van aanvraag nog niet naar behoren in nationatil recht heeft ongezet."

Deze vraag raakt het hart van dit onderzoek. Ze stelt aan de orde in hoeverre het de Nederlandse owerheid vrij staat rechten die gehuwde vrouwen met ingang van 23 december 1984 aan richtijin $79 / 7$ ontlenen te "blokkeren" door het toepassen van procedurele bepalingen. Een bevestigende beantwoording zou voor de uitvoering van de sociale zekerheidswetgeving grote gevolgen hebben gehad. ${ }^{97}$ De conchusie voor het arrest van Advocaat-Generail Darmon beloofde weing goeds voor de Nederlandse regering. Na te hebben overwogen dat, voor wat de bescherming van de rechten die justitiabelen aran de rechtsireekse werking van het gemeenschapsrecht ontlenen betreft, de procesautonomie van de Lid-Staten voorop staat, merkt de Darmon op dat, wil het nuttig effect van het gemeenschapsrecht niet worden gefrustreerd, de prerogatieven van de Lid-Staten inzake het procesrecht in die zin beperkt zijn dat

a. dient te worden vermeden dat procesrechtelijke vereisten en termijnen het un de pralktijk onmogelijk zouden maken rechten ${ }^{98}$ uit te oefenen die de nationale rechter verplicht is te handhaven en

b. justitiabelen die zich op aan het gemeenschapsrecht ontleende rechten beroepen, niet minder ginstig mogen worden behandeld dan degenen die soortgeijke, op het nationale recht gebaseerde, aanspraken doen gelden. ${ }^{100}$

Naar het oordeel van Darmon heeft het Hof in het arrest Emmott de procesautonomie nader beperkt voor het geval een Lid-Staat een richtlijn niet binnen de gestelde termijn natr behoren in nationaal recht heeft omgezet, zulks teneinde rekening te houden met de bjjzondere bescherming die woorfaan aan de richtlijn is verbonden. $\mathrm{Hij}$ is van mening dat de door het Hof in het arrest Emmott geformuleerde conclusie dat

'ot het moment waarop een richtlijn naar behoren is omgezet, en gebrekkige Lid-Staat zich niet kan beroepen op termijnoverschrijding door een particulier die een procedure tegen hem instelt [...], en dat cen in het nationale recht vastgestelde beroepstermijn niet wớr dat tijdstip kan gaan lopen'

niet kan worden beperkt tot een bepaalde categorie van procestermijnen en vat deze overweging aldus op dat zij eraan in de weg staat dat een Lid-Staat tot het moment waarop de richlijn naar behoren is omgezet, zich niet op interwe procedwreregels kan beroepen om aan een particulier een recht te weigeren dat deze aan een richtlijn ontleent. Hij is tonslotte van oordeel dat het

'nu het Hof het beginsel van gelijke belandeling wanaf 23 december 1984 heeft erkend, nogal kras [zon] zim indien een Lid-Staat de wolle werking van de richillin zou kumen aantasten door procedureregels, te meer nu de nationale rechter, indien alan de voorwaardien voor inroep-

9. Zie in dit verband de noot van F.W.M. Keunen in RSW 1994/211, die het arrest wan grote rechtspolitieke betekenis acht.

98 In casu dus het op grond wan de rechtstreekse werking van Richtijn $79 / 7$ EEG met ingang wan 23 december 1984 in het leven geroepen recht van de gehuwde vrouw op AAW-uikering onder gelijke voorwaarden als voor (gehuwde) mannen gelden.

99) HwJ EG 16 decenber 1976 , zaak 3376, Rewe, Jur. 1976 , p. 1989

100 HWJ EG 9 november 1983 , zaak 199/82, San Giorgio, Jutr. 1991, p. I-4269. 
baarheid is voldaan, de materiele bepalingen dhe in strid zijn wet dit beginsel buiten toepassing moet laten". "(mijn cursivering, RB)

Ik haal de opvatting van Advocaat-Generaal Damon zo uitvoerig aan om te illustreren hoe dicht de Nederlandse regering langs de (financiele) afgrond is gedaan. Eerst zeven maanden tha de conclusie wees het Hof zijn woor de Nederlandse regering en de uitvoeringsorganen bevrijdende arrest. $\mathrm{Na}$ zijn vaste rechtsprak over de vestiging van materiele rechten op grond van de directe werking van richtlijnen in herinnering te hebben geroepen, ${ }^{102}$ herinnert het Hof eraan dat

"de adnspraak op een arbeidsongeschiktheidsuntkering onder dezeifde voorwaarden als voor manrien gelden, welke aanspraak gehuwde wouwen ontlenen aan de rechtstreekse werking van atikel 4 , lid 1 , van trichtlijn $79 / 7$ moet worden uitgeoefend overeenkomstig de door de nationale bepalingen gestelde voorwarden. Gelijk uit vaste rechtsprak van het Hof blijkt, mogen deze woorwaturden echter nict ongunstiger zijn dan die welke woot soortgelijke vorderingen gelden, en mogen zij de uitoefening van de door de communautaire rechtsorde verleende rechten in de praktijk niet onmogelijk maken'.

Het Hof verwijst in dit verband uitsluitend naar het arrest Emmott, hetgeen in die zin wat curieus is dat het Hof in dat arrest de aan de Lid-Staten toekomende 'procesautonomie' juist anzienlijk had beperkt. ${ }^{\text {ins }}$

Naar het oordeel van het Hof voldoet artikel 25, lid 2, AAW, alls nationale bepaling die de lerugwerkende kracht van een aanvraag om een arbeidsongeschiktheidsuitkering beperkt, aan de in de zojuist geciteerde, uit de arresten Rewe en San Giorgio voortvloeiende, voorwaarden. Het Hof is voorts van oordeel dat de onderhavige zaak duidelijk verschilt van de zaak Emmot ${ }^{\text {th* }}$ en beklemtoont vervolgens in de eerste plats dat

'anders dan een nationale rechtsiegel waarbij een beroepstemijn wordt vastgesteld, de in de onderhavige vraag bedoelde regel het eigenlijke recht van de justitiabelen om zich voor een nationale rechterlijke instantie tegen een gebrekkige Lid-Stat op richtijn $79 / 7$ te beroepen niet

101 Dammon worwijst hiertoe nar HWJ EG 13 maart 1991 , zxak C-377/89, Cotter en MoDermof, Jur. 1991, p. $1-1155$.

102 Zie de in par. 1.2 behandelde arresten wan 4 decenber 1986 , zaak 71/85, FNV Jur. 1986, p. 3855 en van 8 makitt 1988, zaak 80/87, Dik, Jur.. 1988, p. 1601 .

103 Zonls natr mijn mening overtugend blijkt uit punt 19 van de conclusie van $\mathrm{A}$-O Darmon. Zie ook de nool wan F.W.M. Keunen (RSV 1994/211), die opmerkt dat het Hof met het arrest Emwot een belangrijke inbreuk heeft genaakt op het in vaste jurisprudentie neefgelegde uitgangspunt dat in beginsel de nationale procedurevoorschriften kunnen worden toegepast, zij het met inachtneming van de in de arresten Rewe en Son Giorgio opgenornen voorwaarden.

104 Het Hot merkt op dat verzoekster in de zaak Emmott naar aanleiding van het arrest van het Hof wan 24 maart 1987 (zank 286/5, MCDermott en Cotter", Jur. 1986, p. 1453) had gevorderd dat wanaf 23 december 1984 ingevolge artikel 4, lid 1, Richtlijn $79 / 7$ EEG op hat hetzelfde stelsel van invaliditeitsutkering zou worden toegepast als op mannen die in dezelfde situatie verkeerden. Vervolgens hadden de betrokken administratieve autoriteiten geweigerd op dit verzoek te beslissen onder de overweghng dat Richthijn $79 / 7$ EEG nog voorwerp van geschil voor een nationale rechterlijke instanthie was. Tenslotte werd Enmott, hoewel Richtlijn $79 / 7 \mathrm{EEG}$ nog niet naar behoren in nationaal recht was ongezet, het verval van haar rechtswordering tot vaststelling dat deze autoriteiten haar verzoek ladden moeten inwilligen, fegengeworpen. Aldus ontstond in Emmot een situatie waarin de ulitoefening van communautaire recht geheel onmogelijk werd gemaakt, terwijl in Steenhorst-Neerings de aanspraak alleen in de tijd wordt beperkt (zie ook de noot van F.W.M. Keunen in RSV 1994/211). 
aantast. Zij beperkt enkel de terugwerkende krach van aanvagen tot verkrigging van de in geding zijnde uitkering."

\section{Waana het Hof opmerkt dat}

thet verval van rech, voortvloeiend uit het verstrijken van beroepstermijnen, beantwoordt aan de noodzaak te voorkomen dat de wettigheid van administratieve beslissingen te allen tijde kan worden aangetast. Blijkens het arrest Emmott weegt deze noodzaak echter niet op tegen de noodzaak de rechten die een particulier ontleent aan de rechtstreekse werking van bepalingen van een richtijn, te beschermen, zolang de gebrekkige Lid-Staat van wie de beslissingen uilgaan, deze bepalingen niet naar behoren in nationaal recht heeft omgezet.'

\section{Waana het Hof overweegt dat}

"De bepaling die de terugwerkende kracht van amvragen on een arbeidsongeschiktheidsuitkering beperkt, evenwel eell geheel ander doel [dient] dan een regeling die een dwingende beroepstermijn vastlegt. Immers, zoals de Nederlandse regering en [het uitwoeringsorgaan] in het hoofidgeding in thun schriftelijke opmerkingen hebben uiteengezet, beantwoordt een dergelijke bepaling, die ook in andere Nederlandse sociale- zekerheidswetten is te vinden, aan de eisen van een goede administratie, met name de mogelijkheid om te kumnen controleren of de bellanghebbende voldeed aan de woorwaarden voor het recht op uitkering en om het arbeidsongeschiktheidspercentage te kunnen vaststellen, dat in de tijd kan varieren. Deze bepaling beantwoordt tevens aan de noodzaak het financieel evenwicht te bewaren van een stelsel watarin de door de verzekerden in een bepaald jaar ingediende aanvragen in beginsel moeten worden gedekt door de in dat jaar geinde premies.'

Het is de vraag of het Hof zich aldus niet al te gemakkelijk bij de door de regering en het uityoeringsorgaan naar voren gebrachte argumenten heeft aangesloten. Advocaat-Generaal Darmon was er in elk geval. niet van onder de indruk. Hij spreekt in de eerste plaats zijn twijfel uit over

'het met name ter terechtzitting naar voren gebrachte argument, dat een particulier bij gebreke van een procedurele termijn, verscheidene jaren na het ontstaan van zijn recht nog aanspraak zou kumen maken op een pensioen. Afgezien van het feit dat dit middel in de zaak Emmott reeds is opgeworpen en door het Hof verworpen, kan dit geval zich slechis voordoen indien de Lid-Staat gedurende lange tijd nalaat de richtlijn om te zetten in nationaal recht, en het zou onvechwaurdig zijn, deze nalatigheid door het verstrijken van de interne procediurele termijnen af te wentelen op degene die rechten ontleent aan een gemeenschapsnorm". (mijn cursivering, RB)

\section{In de tweede plaats merkt Darmon op dat}

'de kwalificatie van een dergelijke termijn in de rechtsorde van een Lid-Staat van weinig belang [is], aangezien uitshitend moet worden gelet op de gevolgen van de toepassing van die lemijn, in het licht van het beginsel wan gelijke behandeling. IK merk in dit verband op, dat de vaag die de lerse rechter het Hof in de zaak Emmott had gesteld, verder ging dan de verjaringstermijn. Die vragg had immers betrekking op de mogelijkheid wan een beroep op bepalingen wan nation naal procesrecht, "in het bijzonder bepalingen inzake terminen, ten einde een dergelijke vergoeding te beperken of te weigeren".

Darmon wijst er tenslotte op dat het dictum van het arrest Emmot in algenene bewoordingen is gesteld. ${ }^{105}$

1.05 Het dictum luidi: Het gemeenschapsrecht verzet zich ertegen, dat de bevoegde autoriteiten varn cen Lid-Staat de nationale procedurevoorschriften inzake beroepstemijnen invoepen in het kader van een 
Aan het voorgaande kan nog worden toegevoegd dat ook het beroep dat de Nederlandse regering en het uitwoeringsorgaan hebben gedaan op de eisen van een goede administratie niet overtuigend overkomt, omdat de door hen gevreesde administratieve lasten niet raken aan de toepassing van artikel 25 , lid 2 , AAW als zodanig. Immers ook bij de door de regering en het uitvoeringsorgaan voorgestane toepassing van artikel 25, lid 2, AAW is het praktijk dat allereerst wordt vastgesteld met ingang van welk (soms in een ver verleden liggend) tijdstip de betrokkene arbeidsongeschikt is geworden, zulks met inachtneming van de destijds, ten tijde van de aanvang van de arbeidsongeschiktheid, geldende normen. Het lijkt me clan ook aannemelijk dat de uitspraak van het Hof in het bijzonder haar verklaring vindt in de door de Nederlandse regering naar voren gebrachte bezwaren vanuit het oogpunt van het bewaren van het financieel evenwicht in het sociale zekerheidsstelsel.

In zijn uitspraak van 9 mei $1994^{106}$ trekt de CRvB zijn consequenties uit de rechtspraak van het Hof. Onder verwijzing naar het arrest Steenhorst-Neerings stelt de Raad voorop dat het bepaalde in artikel 25, lid 2, AAW niet in strijd is met Richtlijn $79 / 7 \mathrm{EEG}$ en evenmin met artikel 26 IVBPR. Evenmin in strijd met de discriminiatieverboden acht de Raad het door het uitvoeringsorgaan gevoerde beleid op grond waarvan alleen in gevallen van bijzondere hardheid tot toekenning van een uitkering met verdlergaande terugwerkende kracht dan een jaar voor de datum van aanvraag wordt overgegaan. Terwijl de betrokken uitkeringsgerechtigde het standpunt naar voren had gebracht dat de discriminatieverboden meebrachten dat

'[het uitwoeringsorgaan] zijn bevoegdheid ten volle op een zodanige manier dient te benutten dat gehuwde vrouwen vanaf [1 januari 1980] op dezelfde wijze moeten worden behandeld als gehuwde mannen ${ }^{307}$

overweegt de Raad deze zienswijze niet te onderschrijven ondat

'uit het [...] arrest Steenhorst-Neerings blijkt dat het Hof van Justitie artikel 25, tweede lid, eerste volzin, van de AAW [...] niet in strijd acht met de Richtilinn. Naar het oordeel van de Raad verdraagt eisers beleid on - behoudens in geval van bijzondere financiële hardheid -.. in gevallen als het onderhavige ${ }^{108}$ geen gebruik te maken van zijn bevoegdheid om meer dan een jaar terugwerkende kracht te verbinden aan de toekenning van een uitkering zich evenzeer met die Richtlijn alsmede met de overige discriminatieverboden".

In de hantering van het gezinsinkomen ter bepaling van de financiẻle hardheid acht de Raad evenmin cen discriminatoir element gelegen, ${ }^{14 \%}$ ondat

door een particulier voor de nationale rechter tegen hen ingestelde procedure ter bescherming van de rechen die them rechistreeks worden toegekend door artikel 4, lid 1 , van richtijn 79/7/EEG van de Raad wan 19 december 1978 betreffende de geleidelijke tenuirwoerlegging van het beginsel van gelijke belandeling wan mannen en vrowwen op het gebied van de sociale zekerheid, zolang die LidStaat deze richtlijn niet naa behoren in nationalal rech heefl omgezet.

106 RSV $1994 / 212$

107 Welk standpunt er op neerkomt dat de formele werking in de tijd van de uitspraken wan 5 januari 1988 dezelfde zou moeten zijn als de materiele werking in de tijd van deze uitspraken.

108 Het ging in deze zaak om een gehuwde vrouw die zich naar aanleiding van de uitspraken van 5 januari 1988 op 26 april 1989 met cen aanvraag tot het uitwoeringsorgaan had gewend in verband met op 8 september 1964 aangevangen arbeidsongeschiktheid.

109 Van de zijde van de uitkeringsgerechtigde was aangevoend dat deze eis indirect zou discrimineren omdat zij meer vrowwen dan mannen breft. 
[het uitwoeringsorgaan] met zijn beleid kennelijk heeft beoogd een inkomen ter hoogte van het bestaansminimum ook aan de betrokken gehuwde vrouwen te garanderen. Dit oogmetk heeft niets van doen met discriminatie op grond van geslacht, terwijl in de gegeven onstandigheden [het] beleid [van het uitvoeringsorgaan] inzake financiële hardheid als een geschikt en noodzakelijk middel moet worden beschouwd'.

De uitspraak is voorts van belang ondat de CRvB hierin afrekent met het bezwaar dat het beleid van het uitvoeringsorgaan een zekere willekeur in zich zou dragen, omdat aan gehuwde vrouwen die op of na 1 januari 1980 met gebruikmaking van een meldingsformulier een AAW-voorziening hebben aangevraagd en op dit formulier de vraag "sedert wanneer bent u arbeidsongeschikt' hebben beantwoord, wel met volledig terugwerkende kracht een uitkering wordt toegekend. Naar het oordeel van de Raad dient echter in het oog te worden gehouden dat

"in dergelijke gevallen de ingangsdatun wan de uitkering niet afhangt van [het] beleid [van het uitwoeringsorgaan] in het kader wan de witoefening van een discretionaire bevoegdheid, maar van de uitleg van het wettelijke begrip "aanvrag". De Raad aanvaardt [de] zienswijze [van het uitwoeringsorgaan] dat een op of na 1 januari 1980 ingediend 'meldingsformulier AAW' warbij cen verzoek van een voorziening ingevolge de AAW is gedaan en waarbij tevens is aangegeven sedert wanneer de betrokkene zich arbeidsongeschikt acht als een aanvrag om uitkering noet worden opgevat en dat dus [het uitwoeringsorgasan, dat] ter zake geen beleidswrijheid toekomt, een juiste uitleg heeft gegeven aan het wettelijke begrip 'aanvraag'.

\subsubsection{De materiele en formele werking in de tijd wan CRvB 5 januari 1998: tussenbalans}

Anders dan bij de WWV ten gevolge van de opzet van die wet het geval was en daartoe geholpen door de, in vergelijking met het arrest Emwort, terughoudender opstelling van het HWJ EG in de zak Steenhorst-Neerings, brengt de CRvB in zijn jurisprudentie over de AAW een scheiding aan de materiële werking in de tijd van zijn uitspraken van 5 januati 1988 (aanspraak op uitkering met ingang van 1 januari 1980) en hun formele werking in de tijd (uitbetaling van de uitkering met in beginsel niet meer dan één jaar terugwerkende kracht voor de datum van aanvraag). Dit latste uitgangspunt geldt niet als de uitkeringsgerechtigde (eerder, mits op of na 1 januari 1980) een aanvraag on een vooziening heef ingediend en op het desbetreffende formulier heeft aangegeven wanneer de arbeidsonge schiktheid is ingetreden. In een dergelijk geval is het mogelijk dat de materiele en formele werking in de tijd well samenwallen, namelijk als de voorziening op of vón 1 januari 1981 was aangevraagd.

\subsubsection{De wet wan 3 mei 1989}

De in paragraaf 2.3 .2 beschreven restrictieve toepassing van artikel 25 , lid $2, A A W$ is niet de enige dam die is opgeworpen tegen de terugwerkende kracht van de ultspraken van de CRvB van 5 januari 1988. Naast deze procedurele belemmering heeft de wetgever ook ingegrepen in de materiële rechten die wór $\mathbb{\|}$ januari 1979 arbeidsongeschikt geworden gehuwde vrouwen aan woomoemde uitspraak ontleenden. Dit is geschied bij Wek van 3

110 Immers ook dan zal op grond van artikel 25, lid 2, eerste volzin. AAW uitkering worden verstrekt met ingang van een jaar voor de datum van aanvraag. 
meil $1989^{\text {II }}$ houdende het recht op arbeidsongeschiktheidsuitkering op grond van de AAW van personen wier arbeidsongeschiktheid vóor 1 januari 1979 is ingetreden thierna aangeduid als Reparatiewet-AAW). Artikel III van deze wet bepaalt dat personen die voor I januari 1979 arbeidsongeschikt zijn geworden en op of na 3 mei 1989 een AAW-uitkering hebben aangevraagd, aan de inkomenseis van artikel $6 \mathrm{AAW}$ moeten voldoen. Artikel $\Gamma \mathrm{V}$ bepaalt dat de AAW-uitkering van personen die voor 1 januari 1979 arbeidsongeschikt zijn geworden wordt ingetrokken indien niet aan de inkomenseis is voldaan. De datum wan intrekking was aanvankelijk bepaald op 1 juni 1990 , maar is bij latere wet ${ }^{12}$ vastgesteld op 1 juli 1991.

Deze artikelen zijn weliswaar neutraal geformuleerd maar hebben desalniettemin een zeer verschillende uitwerking voor mannen enerzijds en gehuwde vrouwen anderzijds. Ten aanzien van arbeidsongeschikte mannen heeft artikel III van de Reparatiewet exclusieve werking: de inkomenseis is van toepassing met betrekking tot op of na 3 mei 1989 ingediende aanvragen om AAW-uitkering. Voor mannen ziet artikel III, met andere woorden, uitsluitend op nieuwe gevallen. Ten aanzien van gehuwde vrouwen heeft artikel III echter tot gevolg dat diegenen die op grond van de uitspraken van de CRvB van 5 januari 1988 alsnog aanspraak konden maken op een $A A W$-uitkering, deze aanspraak (opnieuw) geblokkeerd zien als zij zich op of na 3 mei 1989 met een aanvraag tot het uitvoeringsorgaan wenden. Artikel III bevat aldus een rechtstreekse beperking van de materièle werking in de tijd van de uitspraken van 5 januari 1988.

Of dit laatste ook geldt voor artikel IV is enigszins twijfelachtig. In tegenstelling tot artikel III kan van artikel IV niet worden gezegd dat het de materiële werking in de tijd wan de uitspraken van 5 januari 1988 voor een bepaalde categorie van gehuwden vrouwen geheel blokkeert - de bepaling ziet immers, behalve op mannen met een lopende uitkering, tevens op de gehuwde vrouwen die op grond van de uitspraken van 5 januari 1988 juist uitkering hebben verkregen. ${ }^{113}$ Anderzijds is het zo dat de bepaling tot gevolg heeft dat het materiële recht op uitkering woor de betrokken vrouwen na korte tijd weer komt te vervallen, terwijl arbeidsongeschikte mannen in een overigens gelijke positie vaak jaren lang aanspraak hebben kunnen maken op een uitkering.

Daarmee wil ik overigens de gevolgen die artikel IV voor (gehuwde) mannen meebracht allerminst bagatelliseren. Voor mannen die niet aan de inkomenseis voldeden heeft de Reparatiewet AAW het minstens zo dramatische gevolg dat zij werden geconfronteerd met een intrekking wan hun uitkering waarmee zij op grond van de tot voor kort geldende regelgeving in thet geheel geen rekening behoefden te houden. Waar het bij de hier te bespreken jurisprudentie echter steeds om gaat is dat (het alsnog moeten voldoen aany de inkomenseis tot gevolg heeft dat aanzienlijk meer gehuwde vrouwen dan mannen worden geconfronteerd met een weigering (artikel III) of een intrekking (artikel IV) van hun nitkering.

111 Stb. 126.

112 Met van 4 jull 1990, Stb. 386.

1132 ij het meestal met de hiernan in paragraaf 2.3 .2 .2 beschreven procedurele restricties. 
De inkomenseis was overigens al inzet geweest van enige procedures. Deze hebben gew resulteerd in een uitspraak wan de CRvB van 23 juni 1992 . $^{14}$ In deze uitspraak oordeelde de CRvB de inkomenseis als zodanig niet in strijd met artikel 4, lid 1, Richtlijn 79/7 an artikel 26 IVBPR, maar de bepaling waarbij de hoogte van deze eis was vastgesteld op $f 4,403,52$ wel, hetgeen de Raad deed beshiten het desbetreffende artikel 6, lid 2, AAW buiten toepassing te verklaren. Deze uitspraak is voorts een treffend voorbeeld van coördinatie tussen de gevolgen van de doonwerking van Richtlijn $79 / 7$ EEG en die van anikel 26 IVBPR die de CRVB in de loop der tijd steeds meer is gaan nastreven: warar het, gelet op het feit dat de inkomenseis rechtstreeks verband houdt met de Wet van 20 december 1984, voor de hand had gelegen dat aan artikel 26 IVBPR voor de toepassing van artikel 6, lid 2, AAW rechtstreekse werking met ingang van 1 januari 1980 zou zijn toegekend, stelt de Raad dit tijdstip in de onderhavige uitspraak vast op 23 december 1979 , de datum waarop de omzettingstermijn van de Richtlijn eindigde. Met ingang van deze datum zou aan de inkomenseis zijn voldaan als de betrokkene in het jaar voorafgaand aan de het intreden van de arbeidsongeschiktheid enig inkomen had verworven. ${ }^{15}$

In zijn uitspraak van 29 september 1992," ${ }^{116}$ die zag op een aamvraag van een gehuwde vroww in verband met op 1 augustus 1984 aangevangen arbeidsongeschiktheid, heeft de CRVB de werking in de tijd van zijn uitspraak van 23 juni 1992 nader bepaald. Onder verwijzing naar de arresten van het $\mathrm{HvJ} \mathrm{EG}$ in de zaken Borrie Clarke," ${ }^{11}$ Dik "is en Verholen ${ }^{119}$ is de CRVB van oordeel dat het feit dat betrokkene ten tijde van de aanvang van de arbeidsongeschiktheid niet voldeed aan de inkomenseis zoals deze destijds Iuidde, haar met ingang van 23 december 1984 niet meer mag worden tegengeworpen. ${ }^{120}$

I14 AB 1992/480 m.nt. De Leede; RSV 1992/317 en NJCM-Bulletin 18-3 (1993), p. 292-298 m.nt. G. Heerma van Voss. Zie woor een uitspraak van dezelfde strelking: CRvB 28 september 1993, AB 1994, 257; RSV 1994/93.

115 Wardoor deze eis in een nawwer verband komt te staan tot de in artikel 2 Richthin $79 / 7$ EEG voor de toepasselifkheid wan de richtlijn gestelde eis wh het behoren tot de beroepsbewolking. Van een gelijkstelling is overigens geen sprake. Zo heeft het $\mathrm{HvJ} \mathrm{EG}$ er in het arrest Posthuma Waw Domme en Oztäk (HvJ BG 1 februari 1996, zaak C-280/94, Jur. 1996, p. 1-179; AB 1996, 261 m.ni FP; RSV $1996 / 169 \mathrm{~m} . \mathrm{nt}$. F. W.M. Keunen) in verband met de rume strekking van het begrip beroepsbevolking op gewezen dat "iemand die in het jaar voorafgatwd aan het intreden van zijn arbeidsongeschiktheid, niet enig inkonien uit of in verband met arbeid heef verworven, niet noodzakelijkerwijs buiten de personele werkingssfeer van richtlijn $79 / 7$ valt'. (rechtsoverwegingen 20 en 21 )

116. RSV $1993 / 203$.

117 HvJ EG 24 juni 1987, zatk 384/85, Jur. 1987, p. 2865.; RSV 1988/182 m.nt. F.W.M. Keunen in RSV $1988 / 183$.

11 \% HvJ EG 8 maart 1988, zaak 80/87, Jur. 1988, p. 1601; RSV 1988/183 m.nt. F.W.M. Keunen.

119 HW EG 11 juli 1991 , zaken C 87/90, C $88 / 90$ en C 89/90, Verholen, Wetter-Vom Uden en Heiderijk, Jur. 1991, p. 1-3757; RSV 1991/227. In deze arresten heeft het Hof beslist dat in de dooi Richtilin $79 / 7$ EEG bestreken gevalten in hel algemeen de gevolgen van wetgeving die strigdig is met artikel 4 lid 1. van de richtlijn niet kumnen worden gehandhaafd na het einde van de in de richthijn opgenomen omzettingstermijn "De arresten Borrie Clarke en Dik zijn hierwoor behandeld in par. 1.2. Op het arrest Verholen $e . a$. wordt teruggekomen in par. 4.2

120 Zie in gelijke zin: CRvB 28 september 1993, AB 1994, 257; RSV $1994 / 93$. 
De Reparatiewet $A A W$ is heftig bekritiseerd ${ }^{121}$ en leidde al snell tot jurisprudentie met betrekking tot de verenigbaarheid van de artikelen III en IV met Richtlijn 79/7 EEG. Zo oordeelt de Raad van Beroep Arnhem op 6 februari 1992 in een fraal gemotiveerde uitspraak ${ }^{122}$ artikel IV van de Reparatiewet-AAW indirect discriminerend ten opzichte van vrouwen en deswege onverbindend wegens strijd met artikel 26 IVBPR. ${ }^{123}$ De uitspraak betreft een ongehuwde vrouw die op grond van de 'oude' AAW al sinds 27 maart 1979 een uitkering bad genoten. Nadat was komen vast te staan dat de betrokken vrouw in thet jaar voorafgaande aan het intreden van haar arbeidsongeschiktheid geen inkomen uit arbeid had genoten, ${ }^{124}$ had het uitwoeringsorgaan haar uitkering met toepassing van artikel IV van de Reparatiewet-AAW ingetrokken. De Raad van Beroep komt tot dit oordeel op grond van cijfermateriaal van de Sociale Verzekeringsraad, dat er op wijst dat aanzienlijk meer vrouwen dan mannen met een intrekking van de AAW-uitkering per 1 juli 1991 werden geconfronteerd. Het hieruit voortvloejende vermoeden van discriminatie is naar het oordeel van de Raad niet weerlegd door een rechtvaardigingsgrond. Interessant is dat de Raad, mede gezien het gestelde in de memorie van toelichting bij het woorstel tot de reparatiewetgeving, overweegt dat het doel van de Reparatiewet-AAW is geweest om een groot deel van de vrouwen, die op grond van de uitspraak van de CRvB van 5 januari 1988 alsnog in aanmerking kwamen voor een AAW-uitkering, na enige tijd het recht op deze uitkering weer te kunnen ontmemen.

Noch in het in 1979 door de wetgever aan de AAW ten grondslag gelegde inkomensdervingsbeginsel, noch in budgettaire overwegingen acht de Raad een rechtvaardigingsgrond gelegen. In het inkomensdervingsbeginsel niet, omdat ten aanzien van de uitkeringsgerechtigden die vóó 1 januari 1979 arbeidsongeschikt zijn geworden het inkomensdervingsbeginsel juist niet werd toegepast en zulks ook als juist werd aanvaard. De Raad overweegt hierbij dat de wens het inkomensbeginsel ook toe te passen op alle vóór 1 januari 1979 arbeidsongeschikt geworden personen immers pas is opgekomen toen als gevolg van de jurisprudentie van de $\mathrm{CR} v \mathrm{~B}$ een grote toestroom van gehuwde (voor 1 januari 1979 arbeidsongeschikt geworden) vrouwen werd gevreesd.

In het budgettaire aspect acht de Raad van Beroep alleen al om die reden geen rechtvaardigingsgrond gelegen, dat de werkelijk 'toestroom' van gehuwde vrouwen aanzienlijk kleiner bleek te zijn dan door de regering was gevreesd. Van meer principieel belang is echter dat de Raad bij zijn beoordeling of er sprake is van een rechtvaardigingsgrond voor thet uit artikel IV van de Reparatiewet-AAW woorvloeiende verschil in behandeling tussen mannen en wrouwen, mede belang hecht aan de gevolgen die deze regeling te weeg brengt voor dle groep in wier nadeel het verschil uitvalt. De Raad overweegt in dit verband dat

121 Comité Gelijke Rechten Nu, Gelijke behandeling in de AAW, Rechtshulp nr. 6/7, 1990, p. 2-10; H. van der Schar, $A$ AW, een getalsmétige toets, Nemesis nr, 4, juli/aug, 1990, p. 178-180; M. Steinmetz, De grondslagen in de AAW, Nemesis nr. 2, maartapril 1990, p. 67-76.

122 RSV $1992 / 166$.

123 De Rad wan Beroep toetste in casu niet aan Richtlijn 79/7 EEG, ondat de betrokken vrouw naar het oordleel van de Raad niet onder de personelle werkingssfeer van de richilijn viel, aangezien zij sinds 1960 geen inkomensvomende arbeid meer had verricht. In 1960 was de vrow in het huwelijk getreden. Ten tijde van haar arrvraag on een AAW-uitkering op 27 maart 1980 terzake wan met ingang van I oktober 1975 angrevangen arbeidsongeschiktheid was zij evenwel ongehuwd. In het geval van de betrokken vrouw betrof dit dus het jaar woorafgaande aan I okiober 1975! 
"vastgesteld moet worden dat toepassing van art. IV wan de Wet van 3 mei 1989 voor bedoelde groep tot zeer ingrijpende gevolgen leidt, nu de essentie van dit artikel niet is dat de wootwaarden om uitkering te verkrijgen woor komende gevallen worden aangescherpt, maar dat bestaande aumspraken warden aangetast.

Voor een gedeelte van deze groep betekent de toepassing van artikel IV van de Wet van 3 mei 1989 het ontnemen van een uitkering die, als gevolg van rechterlike uitspraken, in het kadern wan de gelijkberechtiging van mannen en vouwer werd verkegen. Voor een andere - en groter gedeelte van die groep leidt genoemd artikel tot intrekking wan een langdurig lopende witkering, waarvan de voortzetting op de tot nog toe geldende voorwaarden leek te zijn verzekerd". (mijn cursivering $\mathrm{RB}$ )

De verenigbaarheid van de Reparatiewet-AAW met de derde EG-richtlin komt vervolgens principieel aan de orde naar aanleiding van een verzok om een prejudiciate beslissing aan het HVJ EG van de rechtbank te 's-Hertogenbosch. ${ }^{125}$ In zijn naar aanleiding van dit werzoek gewezen uitspraak in de zaak Roks ${ }^{2}$ makt het HvJ EG korte metten met artikel III. Na te hebben overwogen dat gehuwde vrouwen op grond van de rechtstreekse werking van artikel 4 , lid 1, Richtlijn $79 / 7$ EEG met ingang van 23 december 1984 recht hadden op een AAW-uitkering onder dezelfde voorwaarden als mannen die in een gelijke situatie verkeerden, derhalve zonder aran de inkomenseis te behoeven te voldoen, en na voorts te hebben verwezen naar zijn vaste rechtspraak op grond waarvan te laat vastgestelde uitvoeringsmaatregelen ten volle rekening moeten houden met de rechten die artikel 4. lid 1, Richtlijn $79 / 7$ EEG ten gunste van particulieren heeft doen ontstaan vanaf 23 december 1984 , concludeert het Hof in bujna laconieke bewoordingen dat

'bijgevolg een Lid-Staat in de nationale wettelijke regeling die strekt tot uitwoering van artikel 4 , lid 1 van richtlijn $79 / 7$ en die na het verstrijken van de in die richtlijn bepaalde temijn is vastgesteld, geen voorwaarde [mag] opnemen waardoor gehuwde vrouwen rechten worden ontzegd die zij bij het verstrijken van die termijn aan de rechtstreekse werking van de bepaling van gemeenschapsrecht ontleenden'.

Voorzover door de uitvoeringsorganen was aangevoerd dat slechts aan gehuwde vrouwen die na de datum van inwerkingtreding van de Reparatiewet-AAW een uitkering hebben aangevraagd rechten werden ontzegd en dat deze uitsluiting gelijkelijk voor mannen gold, voegt het Hof nog aan het voorgaande toe dat

'mamen wier arbeidsongeschiktheid dateert van woor' 1 januari 1979 voól de vaststelling wan de Wet van 3 mei 1989 recht hadden op een AAW-uitkering zonder dat zij aan de inkomenseis behoefden te voldoen, zodat zij redelijkerwijs voor die datum een dergelijke witkering hebben kumnen aanvragen, terwijl gehuwde vrouwen die niet alan de inkomenseis voldeden, geen reden hadden eer aanwaag in te dienen, daar zij ingevolge de destijds toepasselijke nationale wattelijke regeling niet voor een. $\mathrm{AAW}$-witkering in aammerking kwamen.

In die omstandigheden leidt artikel III van de Wet van 3 mei 1989, door wan die vrowwen te verlangen dat zij hun uitkering voor de datum wan inwerkingtreding van de wet hebben angevraga, tot een bevestiging van de discriminatie zoals deze voor die tijd bestond, daat de vrouwen die als gevolg van de inkomenseis zijn gediscrimineerd, na genoemde daturn geen aansprak meer kunnen maken op de AAW-uithering waarop zij ingevolge de rechtstreskse werking wan artikel 4, lid 1, van richtijin $79 / 7$ sedert 23 december 1984 wel recht hadden'. (mijn cussivering, $\mathbb{R B}$ )

126 HWJ EG 24 februari 1994, zak C-343/92, Roks, Jur. p. 1-571; RSV 1994/214. 
In wezen komt de uitspraak van het Hof er simpelweg op neer dat artikel III van de Reparatiewet onverenigbad is met artikel 4, lid 1, Richtlin $79 / 7 \mathrm{EEG}$, ondat artikel II de gehuwde wrouwen een hun krachtens de rechtstreekse werking van de richtijnbepaling toekomend recht weer ontheemt. Van het nuttig effect van de richtlinin zou inderdaad weinig overgebleven zijn als het Hof in andere zin had beslist. Interessant is echter dat het Hof geen anleiding heeft gevonden om anders te oordelen in verband met de uitvoeringspraktijk waarbij aan gehuwde vrouwen die vöór 3 mei 1989 een aanvraag hadden ingediend, alsnog een uitkering werd verstrekt. Dat het blikkens de zojwist geciteerde overwegingen aan de desbetreffende gehuwde vrouwen niet kan worden tegengeworpen dat zij hun alsnog verkregen rechten door middel van een vót 3 mei 1989 ingediende aanvrag geldend hebben gemaakt, windt zijn verklaring in het aanvankelijk ook aan het arrest Emwott toegeschreven uitgangspunt dat aan degenen die aan de richtijn (materiële) rechten ontlenen, voordat een juiste omzetting van de richtljin heeft plaatsgevonden, niet kan worden tegengeworpen dat zij geen gebruik hebben gemaakt van de in het nationale recht woorziene procedure on hun rechten geldend te maken.

Het Hof komt aldus tot de conclusie dat artikel III van de Reparatiewet-AAW onverenigbaar is met richtlijn 79/7. Dat heeft tot gevolg dat aan vóor 1 januari 1979 arbeidsongeschikt geworden gehuwde vrouwen die na 3 mei 1989 een aanwrag indienen, de inkonienseis dus niet meer mag worden gesteld.

Ten aanzien van de verenigbaarheid van artikel IV van de Reparatiewet verschafte het arrest Roks geen definief uitshitsel. Enerzijds volgt uit het arrest

'dat het gemeenschapsrecht zich miet verzet tegen de invoering van een nationale wettelike regelling die, door bet behoud van het recht op een arbeidsongeschiktheidsuitkering afhankelijk te stellen van een voorwaarde die wortocm voor zowell mannen als vrouwen geldt, tot gevolg heelt, dat vrouwen voor de toekomst rechten worden ontnomen die zij ontlleendeth aan de rechtstreekse werking van artikel 4 , lid 1 , wan nichtijin $79 / 7^{\circ}$. (mijn cursivering, RB)

Anderzijds volgt uit het arrest dat de "voorwaarde die voortaan voor zowel mamen als vrouwen geldt" niet indirect discriminerend mag zijn. De desbetreffende, in artikel IV wan de Reparatiewet-AAW opgenomen voorwarde is de door de CRVB in zijn uitspraak van 23 juni 1992 geformuleerde inkomenseis dat in het jaar voorafgaande aan het intreden van de arbeidsongeschiktheid "enig" inkomen moet zijn verworven. Door de rechtbank ' $s$ Hertogenbosch was in de verwijzende uitspraak aan het $\mathrm{HvJ}$ EG de vraag voorgelegd of deze inkomenseis als indirect discriminerend voor vrouwen diende te worden beschouwd, "zelfs" als deze halr rechtvaardiging zou vinden in budgettaire overwegingen. Het Hof is categorisch in zijn antwoord dat

'artikel 4 , lid 1 , van richtlijn $79 / 7$ zich werzet tegen de toepassing van een nationale wettelijke regeling die de toekenning van een arbeidsongeschiktheidsuitkering afhankelijk stelt van de voorwatarde, dat de betrokkene in het jaar woordat de arbeidsongeschiktheid is ingetreden, enig inkomen heeft genoten, welke voorwaarde, ofschoon zij geen onderscheid maakt naar geslacht, een weel groter aantal vrouwen dan mannen treft, zelfs wanneer de vaststelling van deze wettelijke regeling haar rechtwaardiging vindt in budgettaire overwegingen*.

Onzeker bleef echter of andere rechtvaardigingsgronden dan van louter budgettaine aard wellicht wel een voldoende rechtvaardigingsgrond zouden bieden.

Definitieve duidelijkheid werd niet eerder verkregen dan bij het naar aanleiding van een verzoek om prejudicielle beslissing van de $\mathrm{CRvB}^{127}$ gewezen arrest Posthwma-Van Damme 
en Oxtür ${ }^{128}$ Met dit arrest heeft het HVJ EG een nadere uitleg gegeven wan het arrest Roks. In het verwijzingsbevel had de CRvB zowel de verenigbaarheid van de inkomenseis als zodanig ${ }^{129}$ met Richtlijn $79 / 7$ EEG aan de orde gesteld als die van artikel IV van de Reparatiewet. Het Hof is van oordeel dat de vragen van de CRvB aldus moeten worden verstaan dat

"zij ertoe strekken te vernemen of artikel 4 , lid 1, van de richtlijn $79 / 7$ zich verzet tegen de toepassing van een nationale wettelijke regeling die de toekenning van een arbeidsongeschiktheidsuitkering afhankelijk stelt van de voorwaarde, dat de betrokkenen in het jaar voordat de arbeidsongeschiktheid is ingetreden, enig inkomen uit of in verband met beroepswerkzaanheid theeft verworven, wanneer vaststaat dat die voorwaarde meer vrouwen dan mannen treft'.

Het Hof maakt allereerst duidelijk dat uit zijn ontkennende beantwoording van de hem in de zaak Roks voorgelegde vraag of een uit de toepassing van de inkomenseis voortvloeiende indirecte discriminatie gerechtvaardigd kan zijn met het oog op budgettaire belangen, geen conclusies kunnen worden verbonden met betrekking tot eventuele andere rechtvaardigingsgronden. In dit verband was door de Nederlandse regering en de desbetreffende uitvoeringsorganen aangevoerd dat de AAW ten gevolge van de introductie van de inkomenseis bij de Wet van 20 december 1979 van een zuivere volksverzekering in een inkomensdervingsverzekering die de verzekerden een minimuminkomen garandeert, was veranderd. Dit inkomensdervingsbeginsel zou met de Reparatiewet-AAW nog verder zijn aangescherpt. Aldus zou de Nederlandse wetgever een legitieme doelstelling van sociaal beleid hebben nagestreefd.

\section{Naar aanleiding van dit betoog overweegt het Hof dat}

"het garanderen van een minimuminkomen aan degenen die een inkomen genoten uit of in verband met een beroepswerkzaamheid waarvan zij de uitoefening wegens arbeidsongeschiikiheid hebben moeten staken, beantwoordt aan een legitieme doelstelling van sociaal beleid. De regel, dat dat minimuminkomen enkel wordt uitgekeerd indien de betrokkenen in het jaar voorafgaand aan het intreden van zijn arbeidsongeschiktheid, een dergelijk inkomen heeft verworven, is een geschikt en, naar de nationale wetgever in de uitoefening van zijn bevoegdileid in redelijkheid heeft kumnen oordelen, noodzakelijk middel om dat doel te bereiken'.

\section{Waarna het Hof opmerkt dat}

'aan deze vaststelling niet [wordt] afgedaan door de omstandigheid, dat een dergelijke regeling in de plats is gekomen van een zuivere volksverzekering en dat de groep van personen die voor een uitkering ingevolge die regeling in aanmerking komen, later is verkleind tot degenen die op het moment van het intreden van het risico daadwerkelijk inkomen uit of in verband met een beroepswerkzaamheid derfden'.

\section{Het Hof is voorts van oordeel dat}

'het gemeenschapsrecht zich er niet tegen verzet, dat een Lid-Staat maatregelen neemt als gevolg waarvan bepaalde categorieën van personen het recht op een uitkering van sociale zekerheid wordt ontnomen, op voorwaarde dat daarbij het in artikel. 4, lid I, van richtlijn $79 / 7$ geformuleerde beginsel van gelijke behandeling in acht wordt genomen. Onder dezelfde voorwaarde

127 CRVB 7 oktober 1994, RSV 1995, 121.

128 HWI EG I februari 1996, zaak C-280/94, Jur. p. I-179; RSV $1996 / 169$.

129 Zoals deze luidde met inachtneming van CRvB 23 juni 1992 , AB 1992,480 m.nt. De Leede; RSW 1992/317, N.JCM-Bulletin 18-3 (1993), 1. 292-298 m.nt. G. Heerma wan Voss. 
stat het een Lid-Staat eveneens vrij, in het kader van zin sociaal beleid niewwe modaliteten te bepalen, als gevolg waarvan het aandal personen dat wor een uitkering in aanmerking komt, kleiner wordt."

Het Hof komt mede tot dit oordeel tegen de achtergrond van vaste jurisprudentie op grond waarvan de Lid-Staten een nume beoordelingsmarge toekomt bij de uitoefenung van bevoegdheden die samenhangen met het voeren van een sociaal beleid. ${ }^{\text {so }}$

\section{Het Hof beantwoordt de vragen wan de CRvB dan ook aldus dat}

"artikel 4, lid 1, van richthin $79 / 7$ zich niet verzet tegen de toepassing van een nationale wettelijke regeling die de tockenning van een arbeidsongeschiktheidsuitkering alhankelijk stelt van de voorwatarde, dat de betrokkene in het jaar woordat de arbeidsongeschiktheid is ingetreden, enig inkomen uit of in verband met een beroepswerkzaamheid heeft verworven, zelf's indien vaststaat dat die voorwarde meer vrouwen dan mannen treft?

Ook aan deze uitspraak kan naar mijn mening een zeker rechtspolitiek karakter niet worden ontzegd. Evenals van het arrest Steenhorst-Neerings is her gevolg van deze witw spraak dat de Nederlandse Staat grote kosten zijn bespaard, maar blijft de vraag knagen of het Hof wel op een juridisch consistente wijze tot zijn uitspraak is gekomen. Meer in het bijzonder is het de vraag of het Hof zich met deze uitspraak wel voldoende rekenschap. heeft gegeven van de, in materieel opzicht, terugwerkende kracht van de uitspraken wan 5 jantari $1988 .^{131}$ In dit verband kan het volgende worden opgemerkt.

Bij uitspraak van 19 april 1990 in de zaak Tewing-Woms ${ }^{132}$ heeft de CRvB de doelstelling van de AAW, zoals deze wet met ingang van 1 januari 1980 luidt, omschreven als het fungeren wan een bodemverzekering binnen het geheel van verzekeringen tegen arbeidsongeschiktheid door het verstrekken wan een aan het sociaal minimum gerelateerde uitkering - warbij het niveau van het sociaal minimum als maximum dient - aan die verzekerden die inkomen uit of in verband net arbeid derven als gewolg van arbeidsongeschiktheid en die deswege niet in hun kosten wan levensonderhoud kunnen voorzien. Naar het oordeel van de CRvB valt de AAW aldus mede te kenschetsen als een inkomensdervingsverzekering tegen arbeidsongeschiktheid. Dit dervingsbeginsel is bij de Wet van 20 december 1979 voum gegeven door als woorwande voor het recht op uitkering de inkomenseis te

130 Zie onder meer de arresten van 9 juli 1987 , gewoegde zaken $281 / 85,283 / 85,284 / 85,285 / 85$ en 287/85, Duistand ea/Commissie, Jur. 1987, p. 3203, an 7 mei 1991, zaak C-229/89, Commissie Belgie, Jur. 199», p. 1-2205. Mede gelet op de conclusie war A-G Fennelly zou in de aanknoping bij deze, mede op de toenmalige artikell 177 en 188 van het EEG-Verdrag gebaseerde ruime marge tevens de verkluting zijn gelegen woor het feit dat het Hof artikel IV van de Reparatiewet-AAW. hoewel zulks door de CRvB in de wragstelling uitdrukkelijk aan de orde was gesteld, niet heeft getoetst aan het ook an het communatuaire recht ten grondslag liggende rechtszekerheidsbeginsel.

13. Zoals hiervor is witeengezet berust deze terugwerkende kracht op de rechtstreekse werking met ingang van \ jantari 1980 van ariikel 26 IVBPR (zie par. 23.1). Zoals hiervoor eveneens is aangegeven heeft dle toepassing van richtijin $79 / 7 \mathrm{EEO}$ voor de AAW dezelfde terugwerkende effecten tot gevolg, met dien verstande dat het wecht op uitkering woor de gehuwde vowwen eerst verkregen wordt met ingang van 23 december 1984 .

132 RSV $1990 / 323$ m.at. C.M. Sjerps. 
stellen. ${ }^{13.3}$ Nar de Raad van Beroep Arnhem in voomoende uitspraak van 6 februari $1992^{134}$ echter fijntjes heeft opgemerkt

'dient in aanmerking te worden genomen dat de wetgever wat betreft het stellen van een inkomenseis het omslagpunt aanvankelijk heeft willen leggen op 1 januari $1979^{\text {s5 }}$ en deze eis net alsnog heeft willen stellen aan degenen wier arbeidsongeschiktheid vón 1 januari 1979 was ingetreden, ook niet indien op 1 januari 1980 nog geen toekenning van uitkening had plaatsgevonden en evenmin als op die datum nog geen aanvraag om uitkering was ingediend".

\section{Naar het oordeel van de Raad van Beroep}

'[kan] tegen deze achtergrond bezien [...] in elk geval niet worden aangenomen, dat de wetgever voor het bekend worden wan de uitspraken van 5 jamuari 1988 van de Centrale Raad van Beroep nog argumenten had om ten aanzien van degenen die woor 1 jamuari 1979 arbeidsongeschikt zijn geworden, het inkomensbeginsel alsnog op dezelfde min of meer stringente wijze te realiseren als ten aanzien wan degenen wher arbeidsongeschiktheid na die datum is ingetreden.

Pas nadat was gebleken dat vón 1 januari 1979 arbeidsongeschikt geworden gehuwde vrouwen niet konden worden uitgesloten van de regeling die voor de overige woór die darum arbeidsongeschikt geworden personen reeds gold en ten aanzien van hen was gehandhaafd, kwann de wetgever tot de conclusie dat het inkomensdervingsbeginsel zoals dit vanaf 1 januari 1980 in de AAW gestalte heeft gekregen, alsnog ook zou moeten worden doorgevoerd in gevallen waarin de arbeidsongeschiktheid vóón 1 januari 1979 was ingetreden'.

De Raad van Beroep legt hiermee de vinger op de zere plek. Om het een beetje simpel uit te drukken: het blift wringen dat de door de CRvB aangenomen onrechtmathgheid bestaande in het toepassen van de inkomenseis op gehuwde vrouwen die vóór 1 januari 1979 arbeidsongeschikt zijn geworden, zou kumnen worden gerepareerd door het alsnog, maar dan voor marnen en vrouwen gelijkelijk, invoeren van diezelfde eis, terwijl dit tot gevolg heeft dat juist de aanvankelijk ten onrechte uitgesloten vrouwen na korte tijd weer met een intrekking worden geconfronteerd. Daaraan kan nog worden toegevoegd dat artikel IV van de Reparatiewet-A.AW in samenhang met artikel 25, lid 2, AAW meebrengt dat wóór 1 januari 1979 arbeidsongeschikt geworden vrouwen die op of na 1 juli 1992 een uitkering hebben aangevraagd, behoudens bijzondere gevallen, geheel van de uitkering worden uitgesloten. Dat zou gerechtvaardigd zijn te achten vanuit de gedachte dat een recht op uitkering tijdig door middel van een daartoe strekkende aanvraag geldig zou moeten worden gemaakt, maar de AAW vootziet nu juist niet in de regeling van een aanvragtermijn. Over de vraag of de voor de door de Reparatiewet-AAW teweeg gebrachte indirecte discriminatie een objectieve rechtvaardigingsgrond bestaat kan men wisten. De overwegingen van het Hof wijzen in de richting dat dit wel het geval is. De Raad van Beroep Arnhem beantwoordt deze vragg, mede gelet op die in die uitspraak weergegeven statistische gegevens - naar mijn mening terecht-ontkennend.

133 Zie in dit werband tevens Raad wan Beroep Rotterdam, 14 jantaari 1992 , RSV 1992/165.

134. RSV $1992 / 166$.

135. Daarbij maakt deze Raad onder verwijzing naar de parlementaire geschiedenis wan de Wet van 20 december 1979 ook nog aamemelijk dat bij de introductie var de inkomenseis per $₫$ januari 1980 itberhaupt de bedoeling heeft woorgezeten een in de AAW passend toelatingscriterium aan te leggen om een grote instroon van gehuwde vrouwen te voonkomen. 
Het laatste bedrij $\mathrm{f}^{16}$ van de juridische strijd rond de inkomenseis vormt de uiteindelijk uitspraak vant de CRvB in zaak. Posthuma-Van Damme. ${ }^{137}$ De Raad leest in het arrest wan het Hof een bindend oordeel dat het gemeenschapsrecht zich op generlei wijze verzet tegen de inhoud of de toepassing van artikel IV van de Reparatiewet-AAW. De Raad acht op grond van de door het Hof gegeven overwegingen evenmin strijd aanwezig met artikel 26 IVBPR $^{138}$ en acht, onder verwijzing naar het Harmonisatiewet-arrest evenmin aanleiding voor aantasting van de wet wegens strijd met ongeschreven rechtsbeginselen. ${ }^{139}$ De Ratad erkent echter het gewicht van de bezwaren van diegenen die zich geconfronteerd zien met de ontneming van een - in een aantal gevallen - reeds vele jaren geleden toegekende aanspraak, zonder dat zich in hun persoonlijke omstandigheden een wijziging heeft voorgedaan en besluit met de opmerkelijke overweging dat

\begin{abstract}
bij de Wet van 3 mei 1989 een juridische constructie is gevolgd welke op bedenkingen kan stuiten. Hier wordt immers, anders dan gebruikelijk, bij een ingreep in bestaande rechtsverhoudingen niet aangeknoopt bij een of meer elementen van de actuele positie van betrokkeneni.c. als gerechtigden tot een uitkering - imemen, maar wordt teruggegrepen op een niet meer door betrokkenen ingenomen, want vóór het intreden van het werzekerd risico gelegen, positie, waarvan de juridische status en de betekenis daarvan voor de actuele rechispositie achteraf worden gewijzigd. Dit strookt niet met de juridische notie dat voor een bepaalde rechtspositie geldende (zuivere) ontstaansvoorwaarden in het algemeen hun juridische relevantie, en daarmee hun aantastbaarheid, verliezen vanaf het tijdstip waarop de rechtstoestand intreedt tot het ontstaan warvan zij de voorwaarden vormden."
\end{abstract}

\title{
2.4 Conclusie
}

Waar bij de in de vorige paragraaf bespoken jurisprudentie met betrekking tot de WWV sprakke was van een vrijwel gelijk lopen van de materiële en de formele werking in de tijd van de jurisprudentie waarbij de ongelijke behandeling ongedaan werd gemaakt, laat de thans besproken rechtspraak over de AAW een ander beeld zien. Enerzijds is er, evenals bij de WWV, sprake van een zeer ruime materiële terugwerking van de desbetreffende jurisprudentie, anderzijds is er, anders dan bij de WWV, sprake van een veel beperktere formele terugwerking. Deze vindt haar verklaring in artikel 25 , tweede lid, van de AAW, in combinatie met de veel geringere bereidheid van de $C R \vee B$ om in de onbekendheid met het onrechtmatig karakter van het AAW-overgangsrecht aanleiding te zien daadwerkelijk rechtsherstel met verdergaande terugwerkende kracht dan een jaar voor de aanvraag mogelijk te maken, zulks in combinatie met de wat terughoudender opstelling van het HvJ EG in de zaken Steenhorst-Neerings en Posthuma-Van Damme.

136 Met nog eén toegit: in zijn uitspraken van 11 april 1997, RSV 1997/263, 16 januari 1998, JB $1998 / 60$ en van 22 december 1999 (RSV 2000/78) oordeelde de CRvB artikel IV van de Reparatiewet evenmin in strijd met artikel 4 EVRM in verbinding met artikel 1 wan het Eerste Protocol bij dit verdrag.

137 CRvB 15 meil 1996, AB 1996329 m.nt. F. Pennings; RSV 1996170.

138 HR 14 aprill 1989, N. 1989, 469 m.nt. MS; AB 1989, 207 m.nt. FHwdB; Ars Aequi 38 (1989), p. 578 m.nt Mirsch Ballin.

139 Annotator Pennings acht het overigens opmerkelijk dat het cordeel wan het Hof, zonder nadere welichting, door de CRvB word gehanterd om een bepaling van een geheel ander international orgaan te interpreteren, maar wijst erop dat dit oordeel goed past in de ontwikkeling dat de nationale rechter conform thet EUmrecht het nationale necht moet uitleggen, welke ontwikkeling werd ingezet met thet arrest Marleasing (Hw EG 13 november 1990, zaak 106/89, Jur. 1990, p. 4135). 


\subsection{CRVB 7 december 1988}

Uit de hierwoor behandelde uitspraken inzake de WUV en de AAW blikt dat de CRVB bij zijn toetsing aan artikel 26 IVBPR een onderscheid maakt tussen, enerzijds, het tijdstip met ingang waarkan de in geding zijnde wetgeving in strijd met artikel 26 IVBPR wordt geacht en, anderzijds, het tijdstip met ingang waarvan de rechter aan deze strijd consequenties mag verbinden. De vaststelling van het eerste tijdstip hangt samen met de voor de in geding zujnde wetgeving samenhangende maatschappelijke ontwikkelingen. Toegespitst op de hier behandelde sociale zekerheidswetgeving kan een onderscheid dat eens gerechtvaardigd was, door het optreden van veranderingen in de maatschappelijke rolpatronen tot discriminatoir (ver)worden. ${ }^{4} 10$ Wordt eenmaal aangenomen dat er sprake is van een door artikel 26 IVBPR verboden discriminatie dan ligt het, in de visie van de CRvB, allereerst op de weg van de wetgever om de discriminatie op te heffen. De Raad acht het, gelet op de aard wan de sociale zekerheidswetgeving, aanvaardbaar dat de wetgever enige tijd gegund wordt om de verboden discriminatie op te heffen. ${ }^{141}$

Het moment met ingang waarvan de wetgever geacht wordt nalatig te zijn ten aanzien van zijn plicht de discriminatie op te helfen is bepalend voor het tweede tijdstip, dat ziet op het moment met ingang waarvan door de rechter rechtstreekse werking van artikel 26 IVBPR. wordt aangenomen. De bepaling van dit moment is in die zin (enigszins) objectiever dan wan het eerste (het moment met ingang waarvan discriminatie wordt aangenomen) dat de rechter aanknopingspunten zoekt bij de omzettingstermijn van Richtlin $79 / 7 \mathrm{EEG}$ (in de WUV-zaak) of bij op het opheffen wan de discriminatie gericht handelen van de wetgever zelf (in de hiervoor behandelde AAW-zaken).

In de in deze paragraaf te behandelen uitspraak van 7 december $1988^{142}$ die ziet op de beperking in de AWW tot een weduwenpensioen, volgt de CRvB een overeenkomstige wijze van redeneren, met dien verstande dat de Raad voor het bepalen van het moment met ingang waarvan aan artikel 26 IVBPR rechtstreekse werking niet meer kon worden ontzegd van belang acht dat

"reeds omstreeks het moment van inwerkingtreding woor Nederland van het IVBPR, althans betrekkelijk kot daarna, de meerbedoelde beperking in de AWW ook aan tegeringszijde als een duidelijk knelpunt werd ervaren"

en verbond hieraan de conclusie dat de periode voor het geleidelijk opheffen van de discriminatie van de weduwnaar in elk geval ten tijde van het overlijden van de echtgenote op 6 april 1986 reeds ruimschoots was verstreken. Een in algemene termen wervatte overweging met betrekking tot het tijdstip met ingang waarvan rechtstreekse werking moest

140 Of, zoals Keunen het heef uitgedrukt in verband met de onstandigheid dat de A WW niet voorzag in een waduwharspensioen: "wat eens een geboden differentiatie was verword tot een verboden discriminatie' (noot onder CRvB 7 december 1988, RSV 1989/67).

141 Of, zoals de Raad het zelf formuleert, acht hij "grond aanwezig het rechtens voor niet onaanvardbaar te houden dat discriminatie in de nationale wetgeving in sommige situaties slechts geleidelijk [kan] worden opgeheven" (zie o.m. CRvB 7 december 1988, AB 1989, 10 m.n. J.H. Smits: RSV 198967 m.nt. F.W.M. Kexnen.

142 CRvB 7 december 1988, AB 1989, 10 m.nt. J.H. Smits; RSV 198967 m.nt. F.W.M. Keunen). 
worden aangenomen ontbrak, anders dan in de hiervoor behandelde uitspraken inzake de WUV, de WWV en de AAW, echter geheel. Niettemin is ook al in deze uitspraak een aanwijzing te vinden voor de bij latere rechtspraak ${ }^{343}$ plaatsgevonden hebbende vasistelling van dit tijdstip op 23 december 1984, nu de Raad immers overweegt dat de bepalingen van Richtlijn $79 / 7$ (van supranationale aard) en artikel 26 IVBPR (van internationaalrechtelijke aard) weliswaar geen onderling afhankelijke werking hebben, maar dat dit

'onverlet laat dat, waar enige speling kan worden aanwaard, synchronisatie alsdan op grond van vooral praktische overwegingen aanbeveling kan verdienen'.

De uitspraak van 7 december 1988 heeft sterk de aandacht getrokken. Allereerst maakt de CRVB korte metten met het - ook door het desbetreffende uitvoeringsorgaan naar voren gebrachte - argument dat er voor techterlijk ingrijpen ter opheffing van de discriminatie van de weduwnaar geen plats zou zijn, omdat de omstandigheid dat de weduwnaar niet voor een $A W W$-uitkering in aanmerking kwam was terug te voeren op de tot de weduwe beperkte werkingssfeer van de AWW en niet op een in een uitzonderingsbepaling van die wet wervatte beperking. In het laatste geval zou de discriminatie opgeheven kumnen worden door de uitzonderingsbepaling met toepassing van artikel 94 van de Grondwet buiten toepassing te laten; artikel 94 van de Grondwet zou evenwel niet voorzien in een bevoegdheid van de rechter om de werkingssfeer van de AWW 'op te rekken' tot weduwnaars. ${ }^{144}$ De Raad verwerpt dit standpunt en overweegt hiertoe dat

'het door [het uitvoeringsorgaan] ingenomen standpunt zou betekenen dat discriminatie welke haar grond vindt in een uitzonderingsbepaling, wel door een rechterlijke beslissing kan worden opgeheven door een buiten toepassing laten van die bepaling ingevolge artikel 94 van de Grondwet, doch dat discriminatie welke voortwloeit uit de rechtstreekse aanwijzing van de kring van rechthebbenden bij of krachtens de wet, bij rechterlijke toetsing in voorkomend geval in stand zou moeten worden gelaten.

De Raad is van oordeel dat het voor Nederland geldende $[\ldots]$ stelsel van het doorwerken van internationaal en supranationaal recht in het nationale recht met zich meebrengt dat bij de rechterlijke beslissing de discriminatie in het geval er strijd met art. 26 van het IVBPR bestaat en aan dit artikel rechtstreekse werking toekomt, moet worden opgeheven, ook wanneer de discriminatie niet aan een uitzonderingsbepaling is toe te schrijven. Dit stelsel laat derhalve wat de AWW betreft, maar het oordeel van de Raad niel toe dat hij zou volstann met het noemen van de wetgever als hebbende exclusief de taak om [.... bij strijd van de AWW met art. 26 IVBPR, welke is ontstaan alls gevolg van niet-tijdige opheffing van discriminatie door wetswijziging, een oplossing te zoeken voor de tijd dat die strijdigheid bestat en nog zal voortduren'. ${ }^{4.5}$

Opmerkelijk is voorts dat, waar de Raad eerder in de uitspraak benadrukt dat Richtlijn 79/7 EEG en artikel 26 IVBPR geen onderling onafhankelijke werking hebben, hij voor wat het verbinden van consequenties aan de geconstateerde strijdigheid met artikel 26

143 CRvB 30 januari 1991 , AB 1991, 339 m.nt. De Leede; RSV $1991 / 182$ m.nt. IJ A. Koojjnan.

144 Hiemee houdt werband her standpunt dat, hoewel sprake is van strijd met artikel 26 IVBPR, het de rechtswormende taxk van de rechter te buiten zou gatan de discriminatie door middel van oprekking van de AWW op te heffèn. Zie F.W.M. Keunen (RSV 1989/67) die in dit verband verwijst naar de jurisprudentie van de Hoge Raad, in het bijzonder HR 12 oktober 1984, NJ 1985, $230 \mathrm{~m}$.nt. W.CL. van der Grinten.

145 Zie ook de noot van A.W. Heringa in NJCM-Bulletin 14-1 (1989), p. 80, die opmerkt dat uit de tuitspraak blijkt dat 'artikel 94 Grondwet, hoewel dat slechts spreckt van 'buiten toepassing laten' ook ziet op de omstandigheid waar de strijdigheid met het internationale recht op positieve wijze (niet door schrapping maar door uitbreiding) dient te worden weggenonen". 
IVBPR betreft, aanshining lijkt te zoeken bij de hiervoor ${ }^{\text {th }}$ behandelde arresten van het HWJ EG in de zaken FNV ${ }^{\text {it? }}$ en Dik ${ }^{\text {1.4 }}$ waar hij overweegt dat

'de rechtstreekse werking [....] woor het ter toetsing van de rechter staande geval het effect [dient] te hebben dat bij het bestaan wan recht op uitkering en pensioen van weduwen op grond van de AWW aan de na het overlijden wan een der echtelieden achterblijvende de in deza wet voor een weduwe voorziene aanspraken toekomen, ongeacht of de achterblijvende de man dan wel de vrouw is".

Deze overweging kan niet anders worden verstaan dan dat de Rad op grond wan de rechtstreekse werking van artikel 26 IVBPR met terwgwerkende krocht een recht op nabestaandenuitkering voor weduwhars creeert, waarvoor het door de AWW geregelde weduwenpensioen het referentie kader vormt. Dit is mede af te leiden uit de volgende overweging warin de Raad aangeeft naar aanleiding van het door het uitwoeringsorgaan aangevoerde argument dat de wetgever bij het opheffen yan het in geding zijnde onderscheid tussen man en vrouw met het oog op artikel 26 IVBPR de keuze heef uit verschillende mogelijkheden en daarom de keuze aan de wetgever moet worden gelaten, opmerkt dat hij

[dit] in zoverre [beaarnt dat] het in casu gaat on de binnen hef raam van internationaal (en supranationadi) recht te maken keuzen voor de woekomst. Waar het - zoals in casu - evernwel gat on woor de ophefing der discriminatie gelegen tijd warin de justitiable art. 26 wan het IVPPR tev diewste staat, brengt het voor Nederland geldende stelsel van het doorwerken van internationaal en supranationaal recht in het nationale recht met zich mee dat de over laatstbedoelde tijd gemaakte aanspraken op een pensionen ingevolge de AWW door het bestuursorgaan en door de rechter dienen te worden beoordeeld naar de in de wet neergelegde criteria, doch los wan de vraag of de achtergeblevene van de echtelieden de man dan wel de vrouw is'. (mijn cursivering, RB)

Tenslotte is opvallend dat de Raad uitdrukkelijk aandacht besteedt aan rechterlijk overgangsrecht, zulks nadat het uitvoeringsorgaan 'uitgestelde werking' van de door de Rarad te geven uitspraak had bepleit onder verwijzing naarde uitspraak van de CRvB inzake de venplichte verzekering van directeuren/grootaandeelhouders. ${ }^{149}$ Het uitvoeringsorgaan beriep zich daarbij op het verschil in benadering tussen de hierwoor behandelde witspraken inzake de WUV en AAW, waarin de Raad wel zelfstandige betekenis van artikel 26 TVBPR yoor de sociale zekerheid aanvaardde, en de in het vorige hoofdstuk" ${ }^{\text {sit }}$ behandelde uitspraak van 1 november $1983^{151}$ waarin de Raad dit (nog) niet deed. De Rakd overweegt echter

"hier geen plaats [te zien] voor (extra) respijt langs de weg van uitgestelde werking bij wege van jurisprudentieel overgangsrecht. Het moge zo zin dat in uitspraken als de laatstbedoelde niet werd gerept over een eventuele rechtstreekse werking van art. 26 van het IVBPR op het terrein van de sociale zekerheid wanneer de geleidelike ophefling der discriminatie na verloop wan tijoll niet zou blijken haar beslag te hebben gekregen ats gevolg van cen niet totstandbrengen van

146 Par. 1.2

147 Hv/ EG 4 december 1986 , zaak 71/85, Jurispr. 1986, p. 3855; RSV 1987/956 m.nt. A. W. Govers.

148 HvIEG 8 maart 1988, zaak 8087, Jurispr. 1988, p. 1601. RSV 1988/183 m.nl. F. W.M. Keunen.

149 CRvB 4 oktober 1985, AB 1986, 38; RSV 1986/21; Ars Aequi 35(1986)3, p. 215 a.v. m.nt. E.P. de Jong.

150 Par. 2.4

151 RSV $1984 / 150$. 
daantoe nodige wetswizigingen, in het gewag maken van ean te aanvaarden geleidelikheid bij bedoelde opheffung kan eerder sen rechterlik markeren van een niet te lange nog voor die opheffing ten dienste starnde periode worden gezien dan een rechterlike geruststeling dat met die opheffing niet op afzienbare termijn emst zou behoeven te worden gemaakt".

Anders gezegd: nu het uitvoeringsorgaan er ten onrechte (mogelijk) gerust op is geweest dat artikel 26 geen rechtstreekse werking zou toekomen ten aanzien van de $\mathrm{AWW}$, komt het voor zijn risico dat weduwnaars alsnog op dezelfde wijze als weduwen aanspraken kumnen maken op een AWW-pensioen. Hoe zeer die duidelijkheid gewenst was moge blijken uit een bestuurspraktijk waarvan gewag gemaakt wordt in een uitspraak van de CRvB van 9 januari 1992, ${ }^{i 52}$ die betrekking had op een verzoek om nabestaandenuitkering krachtens de Spoorwegpensioenwet van een op 18 april 1983 weduwnaar geworden man. Artikel $\mathrm{G} 3$ van de Spoorwegpensioenwet voorzag slechts in een uitkering aan weduwnaars. wier echtgenote kostwinner was geweest. Het uitwoeringsorgaan was gelet op de uitspraak van de CRvB van 7 december 1988 weliswar van oordeel dat de man op deze grond geen uitkering kon worden geweigerd, maar was niet bereid tot uitkering over te gaan met ingang van een tijdstip gelegen wóór 6 april 1986, de datum waarop de eclatgenote van verzoeker in de zaak van 7 december 1988 was overleden. Aldus kwam in de visie van het uitwoeringsorgaan algemene betekenis toe aan een, aan de zaak van 7 december 1988 geheel eigen en voor de betrokkene in die zaak, droevig incident.

Duidelijkheid omtrent de werking in de tijd van de uitspraak van 7 december 1988 ontstond, zowel in materiële als formele zin, bij de reeds in paragraaf 2.3.2.2 aan de orde gekomen uitspraak van de CRvB van 30 januari 1991. ${ }^{153}$ Voor wat de materiële werking in de tijd betreft is de Raad, onder verwijzing naar - onder andere ${ }^{15-4}$ - zijn uitspraak van 14 mei 1987 inzake de WUV van oordeel dat op 23 december 1984 een tijdstip was bereikt waarop aan artikel 26 IVBPR rechtstreekse werking niet meer kan worden ontzegd. Daarbij dient echter te worden aangetekend dat uit de uitspraak tevens blijkt dat ook mannen die vóór 23 december 1984 weduwnaar zijn geworden, met ingang van 23 december 1984 recht hebben op een weduwnaarspensioen. Het feit dat deze weduwnaars vóór 23 december 1984 op grond van de toen geldende wetgeving geen recht hadden op een AWW-pensioen, kan hun dus na deze datum niet meer worden tegengeworpen. Ook in dit opzicht lijkt de Raad zich alan te sluiten bij de uitspraken van het HvJ EG die eraan in de weg staan dat oudere nationale bepalingen op en na 23 december 1984 hun discriminerende werking zouden mogen behouden. Dit is opmerkelijk ondat de AWW niet onder de materiële werkingssfeer van Richtlijn $79 / 7 \mathrm{EEG}$ valt en deze richtlijn mitsdien niet op de AWW van toepassing is.

Voor de fomele werking in de tijd volsta ik met te verwijzen naar paragraaf p.m. waarin nader is uiteengezet op welke wijze artikel 25, lid 5, AWW in de weg heeft gestaan aan

152 TAR 1992, 59; AB 1992, 225.

153 CRvB 30 januari 1991, AB 1991, 339 m.nt. De Leede; RSV 1991/182 m.nt. J.A. Kooijman en NICM-Bulletin 16-3 (1991), p. 217-221 m.nt. A.W. Heringa.

154 De Raad verwijst tevens naar zijn uitspraken van 17 maart 1988, WUBO 1986/38 en van 5 oktober 1989, RSV 1990/132. 
het, met terugwerkende kracht van meer dan een jaar voor de aanvragdatum, geldend maken van het alsnog verkregen recht op weduwnaarspensioen. ${ }^{55}$

[s, behoudens de in paragraaf 3.1 besproken punten, de werking in de tijd van de uitsprak van 7 december 1988 in grote lijnen vergelijkbaar met de in paragraf 4 besproken werking in de tijd van de uitspraken van 5 januan 1988 inzake de AAW, de uitspraak zou nog een merkwaardig vervolg krijgen door de wijze waarop ze is verweven in de rechtspraak van de CRvB met betrekking tot artiliel 32, lid 1, onder b, van de AAW.

Op grond van de uitspraken van de CRvB van 7 december 1988, in onderling verband gelezen met de uitspraak van de CRvB van 30 januari. 1991, hebben met ingang van 23 december 1984 ook weduwnaars recht op een AWW-uitkering. Gelet op de laatste uitspraak konden deze rechten in de praktijk evenwel eerst worden geäffectueerd met ingang van I december 1987 , behoudens - overigens zeldzame gevallen - waarbij de uitkering in verband met bijzondere hardheid met ingang van een eerdere datum werd toegekend.

Op grond van artikel 32 , lid 1, onder b, AAW wordt de AAW-uitkering van een vrouw ingetrokken wanneer zij recht krijgt op AWW-pensioen. Door allerlei complicaties in het bruto-netto traject heeft deze intrekking tot gevolg dat de desbetreffende weduwen in de meeste gevallen een financieel nadeel lijden. Dit nadeel werd in de praktijk niet geleden door de weduwnaar die op grond van de uitspraak van 7 december 1988 een AWWwitkering verkreeg. Met betrekking tot de periode tussen 23 december 1984 en 1 december 1987 leden weduwnaars geen schade, omdat aan hen over deze periode in de praktijk niet alsnog een AWW-uitkering werd verstrekt, terwijl zij voor wat de tussen 1 december 1987 en 7 december 1988 gelegen periode betreft evenmin financieel nadeel leden, omdat de AAW-uitkering blijkens een uitspraak van de CRvB van 23 mei $1991^{156}$ slechts kon worden teruggevorderd voorzover de AAW-uitkering werd betaald na de beslissing waarbij de AWW-uitkering was toegekend. Dit heeft in de praktijk tot het gevolg gehad dat weduwnaars in sommige gevallen over de periode van 1 december 1987 tot 7 december 1988 in het genot van beide uitkeringen waren.

Op 23 mei 1991 157 heeft de CRvB uitgesproken dat aan artikel 26 IVBPR in relatie tot artikel 32 , lid 1 en sub b. AAW rechtstreekse werking toekomt met ingang van 23 decenber 1984. ${ }^{158}$ Op dezelfde dag heeft de CRvB zich echter tevens, in wat wel de wonderlijkste uitspraak die in dit boek aan de orde zal komen kan worden genoend, op het standpunt gesteld dat artikel 32, eerste lid, onder b, AAW niet direct discriminerend is ten aanzien van vrowwen.

155 Het door de SVB in het kader van de toepassing wan artikel 25, lid 5. AWW gevoetde beleid inzake bijzondere hardheid is onder meer kenbaar uit: CRvB 29 april 1993, AB 1993, 557 m.nt. De Leede; RSV 199411.

156 RSV $1992 / 290$

157 CRvB 23 mei 1991, RSV 1991/257; NJCM-Bulletin 16-7 (1991), p. 648-651 m.nt. A.W. Heringa op p. 655-656; Rechtspraak Nemesis, $1991 / 198$ en 199.

158 CRvB23 meil 1991, RSV 1991/255. 
De uitspraak heeft betrekking op een vrouw aan wie met ingang van I oktober 1976 een AAWuitkering was toegekend. Deze uitkering is met toepassing van artikel 32 , lid 1, onder $b$, AAW ingetrokken, nadat aan de wroww in werband met het overlijden wan haar ectrgenoot met ingang van I maart 1985 een (pro rata) ${ }^{159}$ weduwenpensioen ingevolge de AWW was toegekend. Betrokkene had bezwatr tegen deze beslissing omdat ze resulteende in een uitkering die lager was darn haar vooheen genoten netto AAW-uitkering. De eerste rechter achtte de beslissing in striju met artikel 26 IVBPR en artikel 4, lid 1, Richtlijn $79 / 7$ EEG en was bowendien van oordeel dat het feit dat betrokkene vóor de omzettingstermijn van de richtlijn weduwe was geworden, er net aan in de weg kon staan dat aan haar bezwalr met ingang van 23 december 1984 tegemoet gekomen kan worden.

Deze opvatting word evenwel verworpen door de CRvB. Naar het oordeel van de Raad is artikel 32, lid 1 , onder $\mathrm{b}, \mathrm{A}$ AW een bepaling die slechts noar de letrer discriminatie natar geslacht in de zin wan artikel 4 van Richtlijn 79/7 EEG zou kunnen opleveren. De Raad Wijst er echter vervolgens op dat hij in zijn uitspraken van 7 december 1988 en 30 januari 1991 op aan artikel 26 IVBPR ontleende gronden heeft beslist dat weduwnaars met ingang van 23 december 1984 in beginsel aan de AWW aanspraken op uitkering kunnen ontlenen, overeenkomend met die van weduwen. De Raad is yan oordeel dat

"de rechtsgevolgen die aan het toekemen van een dergelijke uitkering zijn verbonden orverkort dienen te gelden waar de prestaties wit hoofde van een andere wet in het geding zijn. Art. 32, earste lid, aathef en sub b van de AAW heef derhalwe thans ook betekenis voor mannen en leidi ook voor hen tot intrekking van de AA W-uitkering indien zij recht verkrijgen op een weduwmaarspensioen of en tijdelijke wedumaarsuitkering. (mijn cursivering, RB)

Zo er ooit nog aan zou worden getwijfeld of uitspraken van een rechter ook een algemene, zich niet tot de procespartijen beperkende werking, kan toekomen, dan wordt deze twijfel hier toch wel definitief weggenomen. Dat de overweging van de Raad berust op de gedachte dat artikel 26 IVBPR meebrengt dat aan de AWW met ingang van 23 december 1984 een zodanige toepassing moet worden gegeven dat ook weduwnaars voor een uitkering in aanmerking komen, is op zichzelf niet opmerkelijk. Dit is immers aan te merken als een rechtstreeks gevolg van de, voor wat de materiële werking in de tijd betreft, terugwerkende kracht van de uitspraak van 7 december 1988. Dat deze werking in de visie van de Raad zo sterk is dat zij mede to gevolg heeft dat artikel 32, lid 1, onder b, AAW, dat naar de tekst uitsluitend ziet op de intrekking van de uitkering van vrouwen, ook op mannen van toepassing is, is echter wel opmerkelijk. Op grond van de op de AWW betrekking hebbende uitspraak van 7 december 1988 blijkt immers ook artikel 32, lid 1, sub b, AAW met ingang van 23 december 1984 anders te luiden dan wat er letterlijk staat. Dat de Raad aldus 'op de stoel wan de wetgever' zou zijn gaan zitten, heef de Raad bij uitsprak van 14 april $1992^{i \text { tan }}$ echter uitdrukkelijk verworpen. Hij heef hiertoe overwogen dat

"de wijze wan wetstoepassing als hiet in geding voortvloeit uit een een ieder verbindende verdragsbepaling, welke prevaleert boven een nationaal wettelijk voorschrift, hetgeen er onder meer toe kan leiden dat een dergelijk voorschift rumer dient te worden getezen dan overeenkont met zijn letterlijke tekst".

159 Zulks in verband met niet verzekerde tijdvakken die samenhingen met het door de echtgenoot verrichten wan anbeid in buitenlands dienstverband.

160 AB 1992, 492 m.nt. De Leede. 
In zijn nitspraak van 23 meil 1991 trekt de CRWB uit het voorgaande dan ook de conclusie dat

"artikel 32, eerste lid, aanhef en sub b wan de AAW sinds 23 december 1984 ital niet direet discriminerend werkt ten opzichte van vrouwen. Het elfect wan een lager uitkeringsbedrag als gevolg van de overgang van een AA W-untkering op een AWW-uitkering kan zich sindsdien bij marnen evenzeer voordoen'. (mijin cursivering, RB)

Deze overweging steunt louter op de, in materieel opzicht, terugwerkende kracht van de utspraak van 7 december 1988 en gaat volledig voorbij aan de aanzienlijk beperktere formele werking in de tijd van deze uitspraak. Zoals de Raad in zijn uitspraak van 30 januari 1991 heeft bevestigd, is er inmers slechts in gevallen van bijzondere hardheid aanleiding weduwnaars met terugwerkende kracht van meer dan een jaar voor uitkering in aanmerking te brengen. De door de uitspraak van 7 december 1988 alsnog met ingang van 23 december 1984 in het leven geroepen rechten zullen dixn ook slechts in hoogst uitzonderlijke gevallen hebben geleid tot het verstrekken van een witkering met ingang van een tijdstip gelegen vón 1 december 1987. Kortom, de door de CRvB aangenomen gelijke behandeling van weduwen en weduwnats waar het de toepassing van artikel 32, lid 1 , onder b AAW betreft, berust in ieder geval voor het tijdvak van 23 december 1984 tot 1 december 1987 op een fictie. De Raad is echter wan oordeel dat

"aarn het worenstaande niet [afdoet] dat tot de uitspraken van deze Raad van 7 december 1988 art.32, eerste lid, alanhef en sub b uitsluitend op vrouwen is toegepast, nu dit in verband moet worden gezien met de omstandigheid dat blijkbarr niet eerder dan in de door de Raad berechte gevallen door mannen aanspraken ingevolge de AWW in rechte geldend zijn gemaakt, waaraan echter voor de beantwoording van de vraag of er sprake is en was van discriminatie geen beslissend bellang kan worden gehecht". (mijn cursivering)

Het kan echter geen werbazing wekken dat er" tot de uitspraak van 7 december 1988 "blijkbaar" niet of nauwelijks een beroep op de AWW was gedaan door weduwnaars, omdat ze tot 7 december 1988 niet konden weten dat zij reeds vanaf 23 december 1984 recht hadden op een uitkering. Het geldend maken van rechten wordt pas mogelijk als deze rechten kenbaar zijn. Afgaande op het recht zoals dit uit de wet bleek konden weduwnaars tot 7 december 1988 juist geen aanspraak maken op een AWW-uitkering. Een en ander kan niet anders betekenen dat tussen 23 december 1984 en 7 december 1988 zeer aanzienlijk meer weduwen dan weduwnars wegens de overgang van AW naar AWW met een verlaging van inkomen geconfronteerd zijn.

De overwegingen op grond waarvan de CRvB tot het oordeel komt dat er evenmin sprake is van indirecte discriminatie, zijn, gelet op hun hypothetisch karakter, niet minder opmekkelijk. Naar het oordeel van de Raad kan niet worden gezegd dat de in artikel 32, lid 1, onder b, AAW opgenomen regeling een aanmerkelijk groter deel van hetzij de vrowwen hezij de mannen in vergelijking met de leden wan het andere geslacht nadelig treft, waartoe hij overweegt dat

'van de gehuwde wrowwen in Nederland, naar wan algemene bekendheid is, het merendeel een oudere mannelijke partner [heett]. Oudere personen sterven geniddeld eerder dan jongere, terwijl vrouwen bovendien gemiddeld langet leven dan mannen. Als gevolg hiervan zullen meer vrouwen dan mannen als gevolg van het verlies wan de huwelijkspartner recht werkrijgen op een

161 Maar daarvoor evenmin omdat artikel 4, lid 1, Richtlijn $79 / 7$ toen nog niet rechistreeks werkte. 
A WW-uitkering. Anderzids nemen, zoals eveneens van algemene bekendheid is, meer mannen dan wrouwen ada hat beroeps-en bedrifsleven deel en zal derhalve een groter aantal mannen dan trouwen in het genot wan een $A$ AW-uitkering zijn.

Deze gegevens bieden, in samenhang bezien, onwoldoende grond zowel om voor juist the houden dat aanmerkelik meer vrouwen dan mannen als gevolg van een recht op AWW-uitkering de AAW-uitkering verliezen, als om voor juist te houden dat dit voor aanmerkelijk meer mannen dan vrouwen zou gelden. Voor beide veronderstellingen geldt immers dat er gegevens bestaan welke eerder het tegendeel aannemelijk maken. Nu ten gedinge ook overigens niet is gebleken van gegevens watuit de juistheid van éen van beide veronderstellingen valt af te leiden wind de Raad reeds om deze reden geen grond het bestaan wan indirecte discriminatie aan te nemen'. ${ }^{162}$

Heringa heeft opgemerkt dat de CRvB aldus de stelling inneemt dat het waarschijnlijk grotere aandeel van vrowwen in de AWW als het ware gecompenseerd wordt door de omstandigheid dat meer mannen een A.W-uitkering hebben. Naar zijn oordeel is echter niet rellevant de verhouding man/vrouw in de $\mathrm{AAW}$, maar de mar/vrouw-verhouding ten aanzien van degenen die hun $A \mathrm{~A} W$-uitkering verliezen voor een $\mathrm{AWW}$-uitkering. ${ }^{63}$

\section{Het arrest Van Gemert-Derks"}

De uitspraak van de CRvB van 23 mei 1991 heeft geen stand gehouden. Bij bevel van 17 december $1991^{\mathrm{i} \text { in }}$ heeft de Raad van Beroep 's-Hertogenbosch aan het HwJ EG onder meer de volgende prejudicièle vrag voorgelegd:

Is cen bepaling van national recht als wervat in artikel 32 , lid 1 , aanhef en onder $b$, van de AAW - welke bepaling volgens de Centrale Raad van Beroep sedert 23 december 1984 niel meer ditect diseriminerend zou werken ten aanzien van vrouwen omdat "het effect van een lager uitkeringsbedrag als gevolg van de overgang van een AAW-uitkering op een AWW-uitkering zich sindsdien immers evenzeer bij mannen kan voordoen' - verenigbaar met art. 4, lid 1, van EEG-Richtlijn $79 / 7$ zolang die nationale bepaling feitelijk nog steeds cen inkomensachtenitgang teweeg brengt voor alle (volledig of in voorkomend geval ook gedeeltelijk) arbeidsongeschikte weduwen en slechts bij uitzondering (te weten: in gevallen waarin een 'bijzondlere hardheid" tot toekenning van weduwnaarspensioen met langdurige terugwerkende kracht zou nopen èn er de mogelijkheid bestat tot terugvordering van de $\mathrm{AAW}$-uitkering) voor vergelijkbare weduwnaars." (mijn cursivering, RB)

Het Hof ${ }^{365}$ formuleert deze vraag aldus dat ze er

162 Zis voor en soortgelijke redenering CRvB 25 juli 1991, NJCM-Bulletin 17-7 (1991), p .651 m.nt. A.W. Heringa. Deze uitsprakk betwef de korting op de AAW-uitkering voor degene wier echtgenoot aansprak heet op ouderdomspensioen ingevolge de AOW.

163 Noot bij, onder meer, CRvB 23 mei 1991, NJCM-Bulletin 16-7 (1991), p. 655. Zie ook de noot van F. W.M. Keunen onder HvJ EG 27 oktober 1993, zaak C-337/91, Fan Gemer-Derks, Jur. P. 1-5435; RSV 1994/213, de uitsprak waarbij het Hof de redenering van de CRvB onderuit haalt. Keunen merkt op dat het Hof de arbeidsongeschikte nweduwe aan wie tussen december 1984 en december 1987 AWW-pensioen is toegekend, niet vergelijkt met de bijzondere positie van een arbeidsongeschikte weduwnar wiens partner tussen 1984 en 1987 is overleden en atan wie op grond van bijzondere hatheid AWW-pensioen met terugwerkende kracht van meer dan een jaar is toegekend, maar met de "modale" weduwnaar op wie de hardheidsclausule niet is toegepast.

164 RSV $1992 / 190$

165 Hw EG 27 oktober 1993, zaak C-337/91, Van Gemeri-Derks, Jurt. p. 1-5435; RSV 1994/213 m.nt. F.W.M. Keunen. 
"in wezen [toe] strekt te vernemen, of artikel 4 , lid 1 , wan richulin $79 / 7$ eraan in de weg staat, dat op grond van een nationale bepaling de arbeidsongeschiktheidsuitkering van arbeidsongeschikte weduwer als gevolg van de toekenning van een wedwerpuensioen wordt ingetrokken. wanneer een dergelijke intrekking niet plaatsvindt in het geval van weduwnaas die in het genot zijn van een arbeidsongeschiktheidsuitkering".

Zo gesteld kan het naturlijk niet verbazen dat het Hof deze vraag bevestigend beantwoordt, zij het dat het Hof een uitzondering maakt voor de situatie waarin de betrokkene vrijwillig aftstand heeft gedaan van de AAW-uitkering. ${ }^{166}$ Het Hof reageert hiermee op het van de zijde van het uitvoeringsorgaan en de Nederlandse regering naar voren gebrachte betoog dat de toekenning van de AWW-uitkering (en dus de intrekking van de AAWuitkering) op aanwraag zou geschieden, welke prakrijk is neergelegd in een medio juli 1989 door de Sociale Verzekeringsbank uitgevaardigde richtlijn. Deze richtijin voorzag er tevens in betrokkenen te informeren over de funanciële consequenties van hun keuze.

Het is van belang op te merken dat het Hof bij zijn toetsing uitgaat van de feitelijke situatie en niet van de door de CRvB gevolgde abstracte redenering die erop neerkomt dat er vanaf 23 december 1984 (in theorie) geen sprake meer is van een verschil in rechtspositie tussen mannen en vrouwen. Het Hof overweegt voorts dat de nationale rechter vrij is in de keuze wan de procedure tot nakoming van de richtlijn, mits maar gekozen wordt voor een procedure waarbij voor vrouwen de toepassing van een identieke regeling wordt gewaarborgd als geldt woor mannen in dezelfde situatie.

De rechtbank 's-Hertogenbosch stelt in haar naar aanleiding van het arrest van het Hof gewezen uitspraak van 20 april $1994^{167}$ allereerst vast dat tot 7 december 1988 in het geval van weduwnaars, anders dan bij weduwen, geen intrekking heeft plaatsgevonden van AAW-uitkering. De rechtbank voegt hieraan toe dat

"de enkele vaststelling achteraf (door de CRvB op 23 mei 1991) dat artikel 32, lid l, aanhef en onder b van de AAW over de periode van 23 december $1984[\ldots]$ tot 7 december 1988 (en daarna) ook betekenis had voor mannen daaraan niet [kan] afdoen'.

\section{Waarna de rechtbank overweegt dat}

'[uit] de onvangrijke rechtspraak wan het Hof wan Justitie met betrekking tot de diverse terreinen van het gemeenschapsrecht [...] blijkt dat krachtens dat recht geldende geboden en verboden daadwerkelijk, feitilik en effectief moeten worden nageleefd en dat een uitsluitend formelle benadering (hier nog geaccentueerd door het gegeven dat terugvordering van voor december 1988 door weduwnaars genoten AAW-uitkering wegens met tenugwerkende kracht foegekend weduwnaarspensioen niet mogelijk is) daarbij niet volstaat', (mijn cursiwering, RB)

Nadat de rechtbank heeft vastgesteld dat er door het uitvoeringsorgaan aan de witkeringsgerechtigden pas van medio juli 1989 systematisch informatie is verschaft over de financiële consequenties van de vervanging van de AAW-uitkering door een AWW-pensioen, komt de rechtbank tot het oordeel dat artikel 32, lid 1, onder b, AAW in strijd is met artikel 4 , lid 1 , Richtlijn $79 / 7$ en verbindt hieraan de consequentie dat deze bepaling over de

166 Dit kan, onder omstandigheden, gunstiger zijn woor de betrokken weduwe, bijwoorbeeld wanneer de AWW-uithering (witbetaald natar het niveau wan het sociaal minimum) in de plats treedt wan cen uitkering die is gebaseerd op een nate van arbeidsongeschiktheid van minder dan $80-100 \%$.

167 Eveneens gepubliceerd in RSV 1994/213. 
periode van 23 december 1984 tot begin december 1988 in voorkomend geval geheel buiten toepassing moet worden gelaten.

Voor een goed begrip wan het vervolg is het bovendien van belang erop te wijzen dat wederom - de Raad van Beroep 's-Hertogenbosch in een afzondetlijk bevel van 17 december $1987^{16 \%}$ aan het HvJ EG de prejudiciële vraag had voorgelegd of

'een bepaling wan national recht als vervat in art. 32, lid II, anhef en onder b, van de AAW verenigbaar [is] met antikel 4, lid 1, van EEG-Richtlin $79 / 7$ indien die nationale bepaling (vanaf op zin vroegst 1 december 1987) weliswar feitelijk zowel op arbeidsongeschikte weduwen als op arbeidsongeschikte weduwnaars wordt toegepast, doch naar de tekst uitsluitend betrekking heeft op arbeidsongeschikte weduwen".

Het Hof vat deze vraag aldus op dat

'zij [er] in wezen [toe] strekt te vernemen, of artikel 4, lid 1, van richtlin $79 / 7$ zich verzet tegen de toepassing door de nationale rechter wan een wettelijke bepaling wolgens welke enkel in thet geval van vrouwen de arbeidsongeschiktheidsuitkering wordt ingetrokken als gevolg van da toekenning van een weduwenpensioen, wanneer deze bepaling ingevolge vaste nationale rechtsprak zowel op arbeidsongeschikte wedwwen als op arbeidsongeschikte weduwnars wordt tocgepast'.

In zijn antwoord stelt het Hof voorop dat

'volgens zijn vaste rechtspraak de Lid-Staten richtlijnen ten uitvoer moeten leggen op een wijze die volledig aan de eisen van rechtszekerheid voldoet, en bijgevolg de bepalingen van richtijnen moeten onzetten in dwingende bepalingen wan intem rechl'. ${ }^{169}$

Op grond hiervan is het Hof van oordeel dat een Lid-Staat geen bepaling mag laten voortbestaan die naar de letter tussen mannen en vrouwen discrimineert in de zin van artikel 4, lid 1, wan Richtlijn 79/7 EEG. Het Hof is echter tevens van oordeel dat

'indien een dergelijke bepaling evenwel ingevolge waste rechtspraak ondanks haar bewoordingen zonder onderscheid op mannen en vrowwen wordt toegepast, [er] niets op tegen [is], dat de nationale rechter in bij hem anhangige zalken deze bepaling blijft toepassen in het kader van een dergelijke rechtspraak, waardoor hij in stat is de wolledige werking van artikel 4, lid 1, wan richtijn $79 / 7$ te verzekeren, zolang de Lid-Staat de woor de volledige tenuitwoerlegging van deze bepaling noodzakelijke naatregelen nog niet heeft getroffen".

Uit de uitspraak van het Hof kan aldus de conclusie worden getrokken dat het (communautaire) rechtszekerheidsbeginsel zich niet werzet tegen een toepassing van artikel 32 , lid 1, onder $\mathrm{b}, \mathrm{AAW}$, waarbij deze bepaling op grond van vaste jurisprudentie, in afwachting van nieuwe, richtlijnconforme wetgeving, tevens geacht wordt van toepassing te zijn op. arbeidsongeschikte weduwnaars die voor een AWW-pensioen in aanmerking worden gebracht. Het oordeel van het Hof staat overigens haaks op de conclusie van AdvocaatGeneraal Darmon die, naar mijn mening terecht, benadrukt dat een vaste richtlijnconforme rechtspraak onvoldoende garantie inhoudt voor de bekendheid van de voor betrokkenen uit de richtlijn voortvloeiende rechten. Naar zijn oordeel wordt

168 Te weten in de in de reeds eerder in par. 2.3,2.4 behandelde zaak Steenhorst-Neerings.

169 Het Hof verwijst in dit verband naar zijn arrest wan 2 december 1986 , zaak 239/85, Commissiv? Belgiè, Jur. 1986, p. 3645, r.o. 7 ). 
'de rechtszekerheid niet gewaarborgd doordat zowel de rechispraak als de administratie an het beginsel van gelijke behandeling een correcte toepassing geven, zollang een nog van kracht zijnde wet in strijd is met dit beginsel doordat zij enkel aan vrouwen cen arbeidsongeschiktheidsuitkerng ontmeent wanneer zij wedwwe worden. Kortom, de toepassing contra legem, en zo nodig het buiten toepassing laten van een bepaling die in strijd is met het gemeenschapsrecht, zijn niet woldoende on deze bepaling wan een label van goedkeuring te voorzien.

De situatie van particulieren moet immers volkomen duidelijk zijn, zowel voor het heden als woor de toekomst, zodat kennis van de wet hun in stat moet stellen kermis te nemen van de rechten die zij aan de gelijke behandeling ontlenen. Voor conformiteit is een administratieve praktijk onvoldoende; hetzelfde geldt voor rechtspraak. Niet zelden doen zich immers wijzigingen voor in de praktijk en/of een onmekeer in de rechtsprak, zodat de eenwomige toepassing wan het gemeenschapsrecht en het beginsel wan rechtszekerheid in de Gemeenschap niet langer nomaal gegarandeerd zouden zinn".

Darmon heeft mijns inziens volkomen gelijk. Juist de in dit boek aan de orde gestelde problematiek toont aan hoe justitabelen, door - ik zou bijtia zeggen "zoals het hoort" - af te gaan op de wet zoals deze zich aan hen voordoet, voordelen kunnen mislopen die hun achteraf; op grond van gewijzigde rechtspraak, blijken toe te komen. De opvatting van Darmon zorgt er in elk geval voor dat er druk op de ketel blijft ten aanzien van de aanpassing van de wetgeving aan de richtijn. ${ }^{170}$

\section{$3.4 \quad$ CRvB 5 jul 1995}

Het sluitstuk van deze tussen de rechtbank "s-Hertogenbosch" en de CRvB gevoerde slag om artikel 32, lid 1, onder b, AAW wordt gevormd door de uitspraak van de CRvB van 5 juli 1995, ${ }^{172}$ een uilspraak die zich volgens annotator Feenstra kenmerkt door een "ingenieuze juridische constructie, die soms wat apodictisch overkomt, maar zeker creatief te woemen is en in elk geval getuigt wan rechterlijke moed". De uitspraak is een loepzuiver woobeeld van het optreden van de CRvB als "wetgever-plaatsvervanger" waarin de Raad, binnen de door de uitspraken van het HWJ EG gelaten marges, een definitieve oplossing tracht te geven voor de problematiek van de samenloop tussen de AAW- en de AWWuitkering. De uitsprak is enerzijds gebaseerd op de rumte die het $\mathrm{HvJ} \mathrm{EG}$ in het arrest Van Gemert-Derks laat voor de introductie van een keuzerecht ten aanzien van de verkrijging van de AWW-uitkering en de hiermee samenhangende intrekking van de AAW-utkering, en anderzijds op het oordeel van het Hof in de zaak Steenhorst-Necrings' dat de naleving van artikel 4, lid 1 , Richtlijn 79/7 EEG ook voldoende is verzekerd als de nationale rechter aan een wettelijke bepaling, die naar de letter discrimineert, op grond van waste jurisprudentie een richtlijnconforme uitleg geeft. De Raad stelt vervolgens vast dat de Sociale Verzekeringsbank op 10 juli 1989 , in samenspraak met de Federatie van de Bedriffsverenigingen een richtlijn heeft uitgevaardigd die ten behoeve van degenen die in het genot zijn van een AAW-uitkering en aanspraak krijgen op AWW-pensioen in een, op basis van door het uitwoeringsorgaan te verschaffen, keuzemogelijkheid tussen de twee uitkeringen voorziet. Daarbij is bepaald dat de AAW-uitkering niet wordt beèindigd als geen AWW-aanvraag wordt ingediend of deze, voordat toekenning heef plaatsgehad, wordt ingetrokken. De Raad is van oordeel dat

170 De Algemene nabestaandenwet is uiteindelijk in werking getweden op 10 jani $1996(5 \mathrm{tb} .305)$.

171 En vootheen de Raad wan Beroep 's-Hertogenbosch.

172 CRVB 5 juli 1995, RSV $1996 / 207$ m.nt. S. Feenstra. 
'deze maatregeler in toereikende mate voldoen alan de condities die het EG-hof in evenvermelde arresten heeft gesteld aan de toelaatbaarheid wan het bepaalde in artikel 32 , lid 1, sub b, wan de AAW. Nu in de nationale uitvoeringspraktijk het keuzerecht, in de hierboven weergegeven vorm, is ingevoerd en dit door het Hof als een maatregel welke de discriminatie kan wegnemen is anvaard, zal de Raad zich hicrbij aansluiten".

Ten aanzien wan de periode wazrin voomoemde maatregelen nog niet effectief waren, is de Raad echter van oordeel dat met betrekking tot artikel 32, Jid 1 , onder b, AAW niet van een met artikel 4, lid 1, Richthin $79 / 7$ conforme uitwoeringspraktijk kan worden gesproken. De Raad stelt zich in dit verband de vragg over welk tijdwak en ten aanzien van wie deze schending heeft plaatsgevonden, waaruit de schending bestaat, alsmede op welke wijze en tem aanzien van wie compensatie voor die schending moet worden geboden. De overwegingen wan de Raad żin interessant genoeg om hier integraal weer geven:

"1. Uitgaande van een met het communautaire recht verenigbare uitwoeringspraktijk met betrekking tot artikel 32, lid 1, sub b, van de A. AW op basis van de bovenvermelde documenten van de betrokken nitvoeringsorganen, neemt de Raad aan dat de daarin vervatte maatregelen tegen het cinde van 1989 wolledig effectief zijn geworden en dat vanaf I janwawi 1990 niet meer van een whet richtijin $79 / 7$ strijdige wetstoepossing kan worden gesproken. De Raad merkt daarbij op dai in algemene zin hiet is gebleken dat de informatieverstrekking door de betrokken uitvoeringsorganen met betrekking tot de keure tussen. AAW en AWW ontoereikend is in het licht van de overwegingen van het EG-hof. Dat betekent dat een intrekking tussen 23 december 1984 en I januari 1990 met toepassing van artike 32 , lid 1, sub $\mathrm{b}$, van de AAW in beginsel aantastbaar is, tenzij kan worden vastgesteld dat die intrekking is geschied. ma uitoefening van het keuzerecht overeenkomstig de bepalingen van de richtlijn van de SVB van 10 juli 1989.

2. Gelet op de twee hierboven vermelde arresten wan het EG-hof en op het worenoverwogene bestaat de schending wan het communataire recht hieruit, dat het thans in de nationale uitvoeringspraktijk gehanteerde keuzerecht tussen AAW en AWW in het hierboven afgebakende tijdvak niet bestond, hetgeen - onder omstandigheden - heeft geresulteerd in een inkomensachteruitgang ter grootte van het verschil tussen de, feitelijk ontvangen, netto AWW-uitkering en de netto AAW-uitkering welke zou zijn genoten indien deze niet was ingetrokken.

3. Binnen de onder (1), in fine, gestelde restrictie zal het keuzerecht overeenkomstig meervermelde SVB-richtlijn alsnog moeten worden geboden aan diegenen van wie de AAW-uitkering tussen 23 december 1984 en 1 jantuari 1990 op grond van artikel 32 , lid 1 , sulb b, wan de AAW is ingetrokken. On praktische redenen is het aangewezen deze keuze, indien deze uitvalt wor handhaving wan de AAW-aitkering, effectief le laten worden na de datum waorop zil is gredaan. Gelet op de mogelijke doorwerkingseffecten naar de toekomst van het - met het conmunautaire recht strijdige - onthouden van de keuzemogelijkheid in de hierboven aangegevern periode $e$ ziet de Raad voldoende grond om ook diegenen die hebben berust in de intrekking van hun $A A W$-uitkering voor dit keuzerecht in armmerking te laten komen in het geval zij de wens daartoe te kennen geven.

4. Behoudens het onder (3) gestelde, moet ervan worden uitgegaan dat de niet aangevochten AAW-intrekkingsbeslissingen over het tijdvak 23 december 1984 tot I januari 1990 in reche onadntastbacr ziln geworden. Overeenkomstig vaste rechtspraak van deze Raad leidt een wijziging in jurisprudentie, in casu op het punt van de verenigbaarheid van een nationale bepaling met een woorschrift van hogere orde, er niet toe dat alle voorafgaande toepassingen van dal vootschrift alsnog in overeenstemming met die wijziging moeten worden gebracht. Aan het recht van de $\mathrm{EO}$ vermag de Raad geen argumenten te ontlenen om hieromtrent een ander standpunt in te nemen, nu ook degenen die aanvankelijk hebben berust in de toepassing van artike. 32. lid 1, sub b, van de AAW in de gelegenheid worden gesteld het met richtlijn $79 / 7$ overeenstemmende resultaat te humen aanzien te verwezenlijken. Dit brengt mee, dat uitsiuitend aan degenen die in rechte zijn opgekomen tegen een ten aanzien van hen genomen beslissing ingevolge artikel 32. lid 1, sub b, van de AAW een compensatie zal moeten worden geboden 
woor de schade die zij hebben geleden als gevolg van het niet tijdig bieden wan de keuzemogelukheid woor het behoud van de AAW-uitkering, in het geval deze keuze, overeenkomstig. het onder (3) gestelde, aldus uitvalt.

5. Het bedrag van de compensatie dient te worden vastgesteld op het saldo - indien positief van het verschil tussen de voor de betrokkene geldende netto-bedragen van de AAW-, respectievelijk AWW-urkering, berekend over de uitkeringsperiode vanaf de datum van untrekking van de AAW-untkering tot de effectuering van de onder (3) bedoelde kewze." (mijn cursivering, $R B$ )

De Raad benadrukt dat het voorgaande uitsluitend van toepassing is op verzekerden die onder de personele werkingssfeer van Richtlijn $79 / 7$ vallen. ${ }^{173}$ De Raad overweegt echter dat

'een en ander onverlet [laat] dat het vanuit een oogpunt van eenheid van rechtstoepassing, en in het bijzonder gegewen het reit dat de in 1989 in de uitwoeringspraktijk ingevoerde keuzemogelijkheid ussen AAW- en AWW-uitkering zich niet beperkt tot belanghebbenden die bimen de personele werkingssfeer van de EG-Richtlijn vallen, de voorkeur zou verdienen dat ook diegenen wier AAW-uitkering tussen 23 dec. 1984 en 1 januari 1990 is ingetrokken mar die niet tot de beroepsbevolking in de zin van art. 2 Richtlijn $79 / 7$ behoren, alsnog de hierboven oinschreven keuzemogelijkheid zou worden geboden. Een rechtsplicht hiertoe kan de Raad echter niet anwezig achten".

\section{$35 \quad$ Conclusie}

Een aantal aspecten van de uitspraak verdient nadere aandacht. De CRvB overweegt dat een intrekking van AAW-uitkering die heeft plaatsgevonden tussen 23 december 1984 en 11 januari 1990 in beginsel aantastbaar is. Uit het vervolg van de uitspraak blijkt echter dat deze aantasibaarheid bestaat in het alsnog bieden van het door de SVB in juli 1.989 in het leven geroepen keuzerecht aan uitkeringsgerechtigden wier AAW-uitkering in genoemde periode is ingetrokken, ook als zij in de intrekking hebben berust. Van een alsnog in rechte aantastbaar worden van de intrekkingsbeschikking is, zoals ook uit de hiervoor geciteerde overwegingen blijkt, geen sprake.

De in deze uitspraak door de CRvB geïntroduceerde figuur kan evenmin op één lijn worden gesteld met de in hoofdstuk II behandelde figuur van de herziening. De herziening kenmerkt zich immers door een daartoe strekkende discretionaire bevoegdheid van het bestuursorgaan, terwij] in de onderhavige uttspraak van enige vrijblijvendheid voor het uitvoeringsorgaan om op annvaang, met terugwerkende kracht, het keuzerecht te effectueren, geen sprake is. Ook het resultat van de uitoefening van het keuzerecht wordt door de CRvB voorgeschreven. Als door de betrokken weduwe destijds geen rechtsmiddel tegen de intrekking werd aangewend, werkt de uitoefening van het keuzerecht om praktische redenen voor de toekomst; werd destijds wel een rechtsmiddel aangewend, dan voorziet de uitspraak in een vorm van compensatie van het geleden financiële nadeel. De hoogte van deze compensatie wordt door de CRvB vastgesteld op het netto, daadwerkelijk geleden, financiele nadeel.

173 De Raad verwijgt in dit verband nog naar de uitspraak van het Comite voor de Rechten vaiti de Mens 29 malar 1989, Fos, Communication n. 21896; RSV $1990 / 172$ m.nt. F. W.M. Keunen, warin artikel 32 lid 1 sub b AAW niet in strijd net artikel 26 IVBPR werd bevonden. 
Voorzover ik heb kunnen nagaan is het met deze uitspraak woor het eerst dat de CRvB in een zaak die betrekking heeft op de terugwerkende effecten van de doorwerking van het internationale en communataire recht de term 'compensatie' gebruikt en dat aan dit begrip een invulling geeft die in wezen neerkomt op een worm wan schadevergoeding zoals deze in het burgerlijk recht gebruikelijk is. De Raad 'beloont' op deze wijze de weduwen die wel cerder een rechtsmiddel hebben atangewend, maar hanteert hiervoor, anders dan bij de in de woorgaande paragrafen behandelde jurisprudentie het geval was, een middel dat los staat van de (toepassing van de) in geding zijnde wet. Dat blijkt ook hieruit, dat ook ten aanzien van degenen die eerder tevergeefs een rechtsmiddel hebben aangewend, de formele rechtskracht van de intrekkingsbeschikking als zodanig gehandhaafd blijft.

Naar de Raad uitdrukkelijk overweegt handhaaft hij met deze uitspraak zijn vaste rechtspraak volgens welke een wijziging in de jurisprudentie, ook indien deze het gewolg is van de toepassing van een voorschrift van hogere orde, er niet toe kan leiden dat het bestuursorgaan verplicht zou zijn alle voorafgaande toepassingen van de desbetreffende nationale wettelijke bepaling alsnog in overeenstemming met die wijziging te brengen. De uitspraak toont echter tevens aan dat de rechtstreekse werking van Richtlijn $79 / 7$ EEG meebrengt dat, niettegenstaande de formele rechtskracht van de intrekkingsbeschikking, wordt voorzien in een door de rechter voorgeschreven procedure die voorziet in een gedeeltelijke (voor hen die in de intrekkingsbeschikking hebben berust) dan wel volledige ${ }^{174}$ (voor hen die eerder een rechtsmiddel hebben aangewend) tegemoetkoming in het tengevolge van de intrekkingsbeslissing geleden financiële nadeel.

\section{De AOW en de niet-verzekerde tijdvakken}

\subsection{Inleiding}

Op grond van de oorspronkelijke $\mathrm{AOW}^{175}$ en de op deze wet gebaseerde, achtereenvolgende, Besluiten uitbreiding en beperking kring verzekerden volksverzekeringen waren in Nederland wonende gehuwde vrouwen, wier echtgenoot, hoewel Nederlands ingezetene, niet verzekerd was omdat hij in het buitenland arbeid verrichtte en aldaar verzekerd was, zelf niet verzekerd voor de betrokken tijdvakken. Een in Nederland wonende gehuwde man wiens echtgenote van de verzekering was uitgesloten, bleef daarentegen wel verzekerd. Op grond van de Wet van 28 maart 1985 en het hierop gebaseerde Koninklijk Besluit van 25 april $1985^{176}$ kon de gehuwde vrouw met ingang van 1 april 1985 niet langer op genoemde grond van de verzekering ingevolge de AOW worden uitgesloten, echter met dien verstande dat in de Wet van 28 maart 1985 een overgangsbepaling was opgenomen op grond waarvan de nieuwe regeling geen toepassing vond met betrekking tot het recht op ouderdomspensioen met betrekking tor vóór 1 april 1985 gelegen tijdvakken. De nieuwe regeling had aldus tot gevolg dat vrouwen die op of na 1 april 1985 recht op oudersomspensioen krachtens de AOW verkregen, nog immer werden gecon-

174 Daarbij moet echter opgement worden dat de CRvB in deze uitsprak in het geheel niet rept over vergosding van gederfde rente.

175 Wet van 31 mei 1956,5 tb. 281

176 Sth. 1985, 297. 
fronteerd met een korting vanwege het niet-verzekerd zijn van de echtgenoot over wớr I april 1985 liggende tijdvakken.

\subsection{Het arrest Verholen}

Bij bevell van 30 januari 1990 heef - alweer - de Raad wan Beroep 's-Hertogenbosch aan het Hw EG de prejudicięle vraag voorgelegd of

'verenigbaar [is] met artikel 4, lid 1 (en/of art. 5) van EEG-richilin $79 / 7$ dat het effect van een nationale bepaling, die uitsluitend gehuwde mouwen van de $\mathrm{AOW}$-verzekering uitsloot, zich uitstrekt tot na 22 december 1984 , en wel in deze zin dat ook na die daum het AOW-pensioen van die wrouwen nog steeds kan worden gekort wegens een verzekeringswoorwaarde die niet voor mamnen gold".

Het Hof heeft deze op de temporele werkingssfeer ${ }^{177}$ van Richtlijn $79 / 7$ betrekking hebbende waag aldus beantwoord dat

'het de Lid-Staten niet is toegestaan, na het verstrijken van de in artikel 8 [van Richtlijn $79 / 7$ EEG] vastgestelde omzettingstermijn de gevolgen te handhaven van een oudere nationale wehtelijke regeling die onder bepaalde onstandigheden gehuwde wrouwen wan het recht op ouderdomspensioen uitsloot'. $17 \%$

Dit antwoord kon nauwelijks verbazing wekken, omdat het geheel in de lijn ligt van de in paragraaf 1.2 reeds uitvoeriger besproken arresten Borrie Clarke ${ }^{\text {ty }}$ en Dik ${ }^{\text {180 }}$ die de belichaming vormen van vaste rechtspraak van het Hof dat Richtlijn 79/7 EEG zich verzet tegen het laten voortduren van ongelijke behandelingen die te wijten zijn aan de omstandigheid dat de aan het ontstaan van het recht op uitkering verbonden voorwarden reeds wót die datum golden.

Interessant is dat het Hof met dit antwoord tevens het door de Nederlandse regering gedaan beroep 'op het beginsel dat elke in het verleden gelegen situatie moet worden getoetst aan het destijds toepasselijke recht": "s: heeft verworpen. Bij het beroep op dit beginsel had Advocaat-Generaal Darmon overigens al de kanttekening gemaakt dat

"men zich trowwens emstig [kan afvagen], of het hier wel gat on witvoering wan op een situatie in het verleden toepasselijk recht. Sinds 23 december 1984 , dus thans, hebben vrouwan rechl op een pensioen bij de berekening waarvan niet meer van de discriminerende bepalingen wordt uitgegan. De situatie in het verleden betref pensioenen die zijn witgekeerd wór 23

177 De aanduiding is van hat Hof zelf.

178. De uitspraak van het Hof heeft aldus tot gevolg dat bij de toepassing van de kortingsbepaling van arikel 13 AOW aan de betrokken vrouw niet meer mag worden tegengeworpen dat zij van de verzekering was uitgesloten; zie punt 2 wan de noot wan F. W.M. Keunen onder HK 29 mei 1996. RSW 199777 .

179 Hw EG 24 juni 1987 , zak 384/85, Jur. 1987, p. 2865, RSV 1988/182.

180 HWI EG 8 matrt 1988, zalak 80/87, Jur. 1988, p. 1601; RSV 198\%/183.

181 Voor wat de AOW betreft kan in dit werband worden geweren op CRvB 28 december 1988, RSV 1989/175, waarin de Raad oordeelde dat "nu eisers atinspraken ingevolgde de AOW vastgesteld moeten worden met ingang van de datum waarop eiser opeisbare pensioenrechten kan ontlenen aan deze wet, diens aanspraken in beginsel beoordeeld dienen te worden naar de wet- en regelgeving zoals die ten tijde wan het ontstaan van die aanspraken tuiden, zij het dat voor het begrip verzekering op grond van of krachtens art. 6 van de AOW van betekenis is de regelgewing in het the beoordelen tijdvak zelve". 
december 1984, wardoor de rechthebbenden geen betaling kunnen verlangen van bedragen die zij als gevolg van discriminatie zijn misgelopen, ondat het beginsel van gelike behandeling destijds nog niet gold". (cursivering van A-G Damon)

Wellicht omdat op grond wan de arresten Borrie Clarke en Dik wel was te werwachten ${ }^{\text {iz }}$ dat het Hof niet zou instemmen met het na 22 december 1984 doorwerken van de kortingsbepaling is de Nederlandse regering nog voor een geheel ander anker gaan liggen om aan de terugwerkende effecten wan de door het Hof te geven uitspraak te ontkomen doot zich met een beroep op de arresten Defrenne $I^{183}$ en Barber ${ }^{184}$ op het standpunt te stellen dat het Hof de gevolgen in de tijd van zijn te wijzen uitspraak zou moeten beperken. Dit verzoek heeft geen gehoor gevonden bij het Hof, ongetwijfeld omdat, in veel sterkere mate dan het geval was in de zaken Defrenne II en Barber", woor de nationale wetgever en de sociale partners voorzienbaar was dat de hier bedoelde uitsluiting van de AOW-verzekering voor de gehuwde vrouw in strijd zou worden geacht met Richtlijn $79 / 7$ EEG. Anders gezegd, de nationale wetgever en de sociale partners hadden voldoende signalen gehad om te kumen anticiperen op de uitspraak van het Hof. Advocaat-Generaal Darmon $^{185}$ heeft in dit verband in het bijzonder gewezen op het reeds in 1982 gewezen arrest Koks. ${ }^{186}$ In deze zaak had de Commissie al overwogen dat
de Nederlandse regeling, waarbij de gehuwde vrouw behoudens uitzonderingen slechts ver-
zekerd is krachtens onder meer de AOW indien haar echtgenoot krachtens die wet werzekerd is,
in strijd is met [Richtlijn 79/7 EEG] en moet worden gewijzigd binnen een termijn die op 22
december 1984 werstrijkt, aangezien op 22 december 1978 van de richtlijn is kennisgegeven'. 187

Naar aanleiding van het arrest van het Hof heeft de Raad van Beroep 's-Hertogenbosch bij uitspraken van 15 november $199^{185}$ beslist dat het het uitvoeringsorgaan niet vrijstaat het recht op AOW-pensioen van betrokkene te beoordelen naar het recht dat gold tijdens de periode dat haar echtgenoot in het buitenland werkzaam was, maar dat - integendeel - het recht dat gold ten tijde van het bereiken van de 65 -jarige leeftijd van betrokkene als uitgangspunt heeft te gelden. Naar het oondeel van de Raad van Beroep brengt de recht=

182 De Nederlandse regering had kennelijk ook nog enige hoop geput uit het argument dat de uitspraken in de zaken Borrie Clarke en Dik niet onverkort op de AOW van toepassing zouden zijn, omdat deze rechtspraak betrekking heeft op risicostelselis en niet, zoals bij de AOW het geval is, op een bijdragestelgel. Ook met dit argument makt het Hof evenwel korte metten, onder de overweging dat "de tekst van richtlijn $79 / 7$ er [...] evenmin als woonoende anesten van 24 juni 1987 en 8 maart 1988 enige twijfel over [laat] bestaan dat, ongeacht de aard van het verzekeringsstelsel, na het verstrijken van de omzettingstemijn van de richtlijn iedere vorm van discriminatie verboden is'.

183 HvJ EO 8 april 1976, zaak 43/75, Jur. 1976, p. 455 en Hw EG 17 mei 1990, Barber, Jur. p. I-1889..

184 Hw EG 8 april 1976, zaak 43/75, Jur. 1976, p. 455 .

1852 Zie punt 52 van diens conclusie.

186. HWJ EO 23 december 1982, zak 275/81, Jurispr. 1982, blz. 3013

187 Opmerkelijk is overigens dat de Sociale Verzekeringsbank in beroep tegen de hierna te bespreken hitspratk ven de Raad wan Beroep 's-Hertogenbosch in de zaak Verholen e.a. (HvJ EG 11 juli 1991. zakon C 8790, C 88/90 en C 89/90, Verholen, Wetten-Van Uden en Heiderijk, Jur. 1991, p. 1-3757; RSV $1991 / 227$ m.nt. S. Feenstra) er bij de CRvB, onder werwijzing natr het arrest van het HwJ EG in de zak Ten Oever (HvJ EG 6 oktober 1993, zaak C-109/91, Jur. p. 1-4879) op heeft aangedrongen (alsnog) prejudiciele vragen te stellen aan het Hof met betrekking tot de werking in de tijd van 's Hofs arrest in de zaak. Verholen $e$ a. De CRvB heeft hier geen aanleiding toe gezien, daarbij onder mear verwijzende nar de conclusie van $A$ - $G$ Darmon en 's Hofs praktijk dat een beperking in de tijd slechts in de desbetreffende uitspraak kan worden gegeven.

188 RSV 1992/192-194. 
streekse werking van artikel 4, lid 1, Richtlijn 79/7 EEG mee dat een uitzondering moet worden gemaakt op het binnen het systeem van de $A O W$ geldende uitgangspunt dat het gedurende een bepaald tijdvak al of niet krachtens die wet verzekerd geweest zijin, moet worden beoordeeld naar het recht zoals dat in dat tijdvak gold.

Interessanter zijn echter de overwegingen die de Raad van Beroep wijdt aan de vraag of de toepassing van artikel 26 IVBPR en artikel 1 Grondwet tot eenzelfde resultaat zou moeten voeren. Met name ten aanzien van artikel 1 Grondwet was deze vraag actueel, omdat de CRvB bij uitspraak van 21 december $1990^{189}$ had geoordeeld dat artikel 2, lid 1, onder j van het Besluit uitbreiding en beperking kring verzekerden volksverzekeringen, voor wat de toepassing van de AAW betreft met ingang van 17 februari 1983 buiten toepassing moest worden gelaten wegens strijd met artikel 1 van de Grondwet. De Raad van Beroep is van oordeel dat noch artikel 26 IVBPR, noch artikel 1 Grondwet aanleiding geven tot het oordeel dat een inbreuk zou moeten worden gemaakt op het systeem dat de verzekeringsplicht wordt beoordeeld aan de hand wan het recht dat in de betrokken periode gold. Van de vraag of het systeem van de AOW zich als zodanig met deze anti-discriminatiebepalingen verdraagt onderscheidt de Raad van Beroep echter de vraag of artikel 1 Grondwet toestaat dat het maken van een dergelijke inbreuk voor de ene groep (bestaande uit tot de beroepsbevolking behorende, en dus onder de personele werkingssfeer wan Richtlijn 79/7 vallende, verzekerden) wèl, en voor de andere groep (zij die niet tot de beroepsbevolking behoren) niet wordt gemaakt. De Raad beantwoordt deze vraag ontkennend, omdat hij het criterium van het al of niet behoren tot de beroepsbevolking vanuit het oogpunt van de toepassing van de AOW niet redelijk en objectief gerechtvaardigd acht, waartoe hij overweegt dat

'hoewel dat criterium voor zover het gaat on de toepassing van het Gemeenschapsrecht volstrekt aanvaardbaar is, het dat miet [is] indien het gaat om de toepassing van de AOW. Die wet kent immers het ingezetenschap als voornaamste verzekeringsgrond en het al dan niet behoren tot de beroepsbevolking heeft woor de verzekering krachtens die wet - zeker als het gaat om ingezetenen [...] - geen enkele relevantie'.

Op grond hiervan komt de Raad van Beroep tot de conclusie dat

"krachtens artikel $\mid$ van de Grondwet ook indien het gaat om een niet tot de beroepsbevolking behorende persoon $[\ldots .$.$] de verzekeringsplicht over de hier aan de orde zijnde periode { }^{106}$ niet moet worden beoordeeld aan de hand van het recht dat in die perioden gold, doch volgens het recht dat gold op de dag waarop [betrokkene] de 65 -jarige leeftijd bereikte'.

\section{$4.3 \quad$ CRwB versus Hoge Raad}

Deze jurisprudentie over de ingevolge de AOW verzekerde tijdvakken zou een opmerkelijk vervolg krijgen in de in hoger beroep tegen de uitspraak van de Raad van Beroep 's Hertogenbosch gewezen uitspraken van 26 november $1993^{\mid 91}$ en, kort daama, een, in elk

189 RSV $1991 / 160$; NJCM-Bulletin 16-3 (1991), p. 208 m.nt. A.W. Heringa.

190 In casu ging het om de perioden van I oktober 1965 tot I april 1969 en wan I februari 1981 tot I april 1982.

191 CRvB 26 november 1993 , waarvan twee gepubliceerd in RSV $1994 / 125$ en 126 m.nt. F.W.M. Keunen in RSV 1994/127. 
geval ten aanzien van de werking wan artikel 1 Grondwet wan deze uitspraken afwijkende; uitspraak van de Hoge Raad van 1 december $1993^{192}$

In ziji uitspraken van 26 november 1993 maakt de CRvB ten aanzien van de aantasting van - wat hij noemt - 'de doorwerking van de destijds op zich rechtsgeldige uitsluiting van de gehuwde vrouw" een strikt onderscheid al naar gelang de betrokkene biy het bereiken van de 65-jarige leeftijd al dan niet tot de beroepsbevolking behoorde. Voorzover dit laatste wel het geval is leidt de CRvB uit het arrest Verholen af dat de rechtstreekse werking van artikel 4, lid 1, Richtlijn $79 / 7$ meebrengt dat de toenmalige uitsluiting van de verzekering op en na 23 december 1984 niet meer aan de betrokkene kan worden tegengeworpen. Voorzover de betrokkene bij het bereiken van de 65-jarige leeftijd niet tot de beroepsbevolking behoort ${ }^{\text {t2 }}$ komt de Raad, voor wat de werking van artikel 26 IVBPR en artikel I Grondwet betreft, tot een tegenovergestelde conclusie. Naar het oordeel van de Raad

"vermag een bepaling als artikel 26 IVBPR niet de rechisgeldigheid aan te tasten van een nationale regel waarbij de hoogte van een op een wettelijke verzekering berustende uitkering (als het AOW-pensioem, respectievelijk de toeslag) afhankelijk wordt gesteld van de mate waarin tijdvakken van verzekering zijn vervuld. Dit laatste wordi niet anders wanneer kan worden vastgesteld dat het niet-vervullen van tijdvakken van werzekering, athans woor wat betreft de tijd gelegen vór 23 , december 1984, was gebaseerd op een regel welke een onderscheid makte natar geslacht. Immers, de werking van die regel valt in een periode waarin justitiabelen nog geen rechtstreeks beroep op artikel 26 IVBPR konden doen en waarin derhalve door die bepaling de rechtsgeldigheid wan de eerder bedoelde, nationale, regel nog niet kon worden aangetast'. (mijn cursivering, RB)

De Raad komt aldus, naar hij uitdrukkelijk overweegt, tot een uiteenlopende interpretatie van het discriminatieverbod van Richtlijn $79 / 7$ EEG enerzijds, en artikel 26 IVBPR anderzijds, in wellk werband de Raad overweegt dat

"hij de eerstbedoelde uitleg met betrehking tor het ondewerp dat hier aan de orde is exclusief gebonden [acht] aan het specifieke, op aampassing van de bestaande wetgeving gerichte en binnen de bijzondere rechtsgemeenschap der EEG geldende gebod wan artikel 4, lid 1, van de richtlinin $79 / 7 / \mathrm{EEG}$.

Een zo vergaande werking als aan het beginsel van gellike behandeling van man en vrouw is toegekend in het arrest wan het Hof van Justitie der EG d.d. 11. juli 1991 [... kan naar het oordeel wan de Rand niet geacht worden voort te vloeien wit de meer algemene normstelling inzake het verbod van discriminatie als neergelegd in artikel 26 IVBPR". (mijn cursivering, RB)

Ten aanzien van het oordeel van de Raad van Beroep $s^{\prime}$-Hertogenbosch dat een aldus gemaakt onderscheid tussen het al dan niet behoren tot de beroepsbevolking in strijd met artikel 1 Grondwet moet worden geacht, overweegt de CRwB kortaf dat dit onderscheid wordt teweeggebracht door het EG-recht, en dat de werking hiervan niet terzijde kan worden gesteld door een bepaling van nationaal recht.

Op dit punt aangekomen is het goed te benadrukken dat er twee, blijkens de uitspraak van de CRvB van 26 november 1993 strikt van elkaar te onderscheiden, mogelijkheden zujn

192 Hoge Raad 1 december 1993. NJ 1996,230 m.nt. Scheltema; RSV 1994/127 m.nt. F. W.M. Keunen.

193 En dus ten tijde van het intreden van het verzekerde risico niet onder de personele werkingssfeer van Richtlijn 79/7 EEG viel. 
waarop de gehuwde vrouw alsnog aanspraak kan maken op AOW-pensioen met betrekking tot tijdvalken waarover zij aanvankelijk van de verzekering was uitgesloten. De eerste mogelijkheid betreft - wat wel is genoemd ${ }^{194}$ - de reflewerking van het arrest Ferholen dat ten aanzien van vrouwen die tot de beroepsbevolking behoren doorwerking wan de ingetrokken $\mathrm{KB}$-bepaling verbiedt. Daarbij is geheel onverschillig of betrokkene ten aanzien van tijdvakken gelegen vóór 23 december 1984 (alsnog) aanspraak kan maken op verzekering ingevolge de AOW. De andere mogelijkheid is gelegen in het betoog dat artikel 26 IVBPR en artikel 1 Grondwet meebrengen dat er in het verleden sprake was van 'gewone' verzekerde tijdvakken. ${ }^{195}$

De reflexwerking van het arrest Verholen wordt door de CRvB in zijn uitspraken van 26 novernber 1993 wolmondig erkend. Ten aanzien van de vraag met ingang van welk tijdstip de uitsluiting van de verzekering als zodanig onrechtmatig moet worden geacht laten de uiltspraken echter vragen open. Duidelijk is dat de Raad van oordeel is dat de uitsluiting van de verzekering voor de desbetreffende gehuwde vrouw niet op grond van artikel 26 [VBPR kon worden aangetast, omdat aan deze bepaling ten tijde in geding ${ }^{196}$ geen reclitstreekse werking toekwam. De Raad lijkt te suggereren dat hij het omslagpunt voor de rechtstreekse werking van artikel 26 IVBPR wil plaatsen op 23 december $₫ 984$, maar overweegt dit niet uitdrukkelijk. De uitspraak laat dus de mogelijkheid open dat dit omslagpunt op een eerder tijdstip geplaatst kon worden, waarbij als vroegste tijdstip 28 maart 1979 , de datum warop het IVBPR voor Nederland in werking is getreden, in aanmerking kwam. Voorts is uit de uitspraak niet af te leiden of de Raad, ewenals hij in zijn uitspraak van 21 december 1990 ten aanzien van de AAW had gedaan, in dit verband enige zelfstandige betekenis aan artikel 1 Grondwet zou willen toekennen.

Deze laatste vraag werd des te prangender toen de Hoge Raad in zijn uitspraak van 1 december $1993^{197}$ de uitspraak van de CRvB van 21 december 1990 casseerde en het tijdstip van de 'rechtstreekse werking' van artikel 1 Grondwet ten aanzien van de KBbepaling, voorzover deze is gebaseerd op de AAW, verder in de tijd terugschoof. ${ }^{19 \%}$ Het cassatieberoep was toegespitst op de vraag of het de CRvB vrijstond de in her KB opgenomen uitsluitingsbepaling voor wat de periode vóór 23 december $1984^{194}$ te toetsen aan

194 Zie, onder meer, de noot van F.W.M. Keunen onder HR I december 1993, RSV 1994/127.

195 Zie in dit verband ook punt 3 van de noot van F. W.M. Keunen onder Hoge Raad 29 mei 1996 , RSV 1997/77, waar hij opmerkt dal "naamate de loetsing van de betrokken KB-bepaling aan luel gelijkheidsbeginsel over een periode verder in het verleden magelikk is, de vragg of bij de loetsing atin art. 26 IVBPR al dan niet reflexwerking aan het arrest verholen moet worden toegekend, meer atan praktische betekenis [verliest]."

196 De witshiting van de verzekering zag op het tijdvak wan 1959-1965

197 N』1996.230 m.nt. Scheltema; AB 1994, 55 RSV 1994/127 m.nt F. W. M. Keunen. Beroep in cassatic kon worden ingesteld omdat de uitspraak van de CRvB zag op en loepassing van arlikel 4 varn de A AW, althans van het op dezen bepaling gebaseerde artikel 2 , arahef en onder $j$, van het Besiut uitbreiding en beperking kring verzekerden volkswerzekeringen van 19 oktober 1976, Stb. 557, zoals nadien gewijzigd. In artikel 80, lid 3 , zoals dat ten tijde van belang luidde, was bepaald dat ieder der parijen beroep in cassatie kom instellen terzake van schending of werkerde toepassing wan het bepaalde bij of krachtens artikel 4 AAW.

198 Zulks, naar mag worden alngenomen, tot onsteltenis war het witwoeringsorgaan, dat als eiseres in cassatie had aangevoerd dat dit tijdstip had moeten worden opgeschoven naar 23 december 1984

199 Dat betrokkene in verband met een op 1 november 1982 aangewanger arbeidsongeschiktheid vanaf 
het in artikel 1 Grondwet opgenomen discriminatieverbod. De Hoge Raad beantwoordt deze vraag bevestigend onder overweging dat

'geen rechtsregel eraan in de weg staat dat de rechter een, niet door de formele wetgever gegeven, algemeen verbindend voorschrift als de onderhavige bepaling van het besluit onverbinderd kan achten op de grond dat er sprake is van schending van algemene rechtsbeginselen, waaronder het gelijkheidsbeginsel, en dat voorts dit beginsel, zoals dat met ingang wan 17 februari 1983 in artikel 1 van de Grondwet is neergelegd, reeds geruime tijd woordien behoorde tot de ongeschreven beginselen vam het Nederlandse recht en in bedoeld Grondwetsartikel sllechts nader vorm heeft gekregen'. (mijn cursivering, RB)

\section{De Hoge Raad is voorts van oordeel dat}

'anders dan waarvan de Centrale Raad van Beroep kennelijk is uitgegaan, er geen reden [is] om aan te nemen dat vorenbedoelde toetsing niet kan platswinden voor wat betreft de periode gelegen tussen I november 1982 en 17 februari 1983. Dit brengt mee dat het bepaalde in artikel 2 , lid I, aanhef en letter $\mathrm{j}$, wan het Besluit, nu dit, zoals het [uitvoeringsorgaan] ook niet betwist, in strijd is met het verbod op discriminatie naar geslacht, voor wat betreft deze periode eveneens buiten toepassing dient te worden gelaten, ${ }^{200}$

Zowel Keunen ${ }^{201}$ als Scheltema ${ }^{202}$ wijden naar aanleiding wan dit arrest van de Hoge Raad een beschouwing aan het rechterlijk overgangsrecht. Keunen brengt het arrest in verband met de werking in de tijd van het Landbouwvliegers- en het Harmonisatiewet-arrest. ${ }^{2033} \mathrm{Hij}$ leidt uit het feit dat het arrest van 1 december 1993 betrekking heeft op feitelijke situaties die in de tijd ver voorafgaan aan de voor het Landboumwiegers- en Harmonisatiewetarrest relevante tijdvakken, af dat aan de in deze laatste arresten vastgelegde rechtspraak omtrent de toetsing van wettelijke voorschriften aan algemene rechtsbeginselen terugwerkende kracht toekomt. Hij acht dit ook gerechtvaardigd, omdat naar zijn oordeel noch het Landbouwvliegers-, noch het Harmonisatiewer-arrest een duidelijke cesuur vormden in de ontwikkeling van de jurisprudentie met betrekking tot de rechterlijke toetsing van algemeen verbindende voorschriften. ${ }^{204}$

23 december 1984 voor een uitkering in aanmerking zou komen stond niet ter discussie, ondat zulks voortwloeide uit de rechtstreekse werking wan artikel 4, lid 1, Richtlijn 79/7 EEG.

200 In de commentaren op deze uitspraak is wel gesuggereend dat de Hoge Raad, door zijn oordeel rechtstreks te baseren op thet gelijkheidsbeginsel als algemeen rechtsbeginsel en niet op artikel I Grondwet, de wotangel wan het in artikel 140 Grondwet opgenomen grondwettelik overgangsrech heeft willen omzeilen (zie bijw. punt 2 van de RSV-noot var Keunen; zie voorts punt 4 van de conclusie wan A-G Soest voor het onderhavige arrest en A.W. Heringa in zijn noot onder CRvB $2 \mathbb{1}$ december 1990, NCM-Bulletin 16-3 (1991), p. 208). Zie ook punt 6 van de NJanoot van Schelterna op het hiar behandelde arest die - mijns inziens nogal treflend - opmerkt dat het 'wel merkwaardig zou zijn indien de opneming van een ongeschreven rechtsheginsel in de Grondwet tot gevolg zou hebben dat een voordien mogelijke toetsing van regels daarna niet meer mogelijk zou zijn." "k laat deze, overigens zeer interessante, materie hier verder liggen.

201 In punt 3 van zijin RSV-noot.

202 In pund I van zijn NJ Jooot.

203 Respectievelijk Hoge Raad 16 mei 1986, NJ 1987 m.nt. MS; 251; AB 1986, 574 m.m. FHwdB en J.B.M.M. ten Berge, Heesch-Van de Akker, Hoge Raad 16 mei 1986, in: F.H. van der Burg, P.J.J. van Bumren en J.H. van der Veen (red), AB-klassiek, Zwolle 1994, p. 165-174 en Hoge Raad 14 april 1989, N.J 1989, 469 m.nt MS; AB 1989, 207 m.nt. FHvdB; Ars Aequi 38 (1989), p. 578 m.nt Hirsch Ballin.

204 Ter onderbouwing wan dir standpunt verwijst Keunen naar het overzicht van de jurisprudentie dienaangande in de conclusie van A-G Van Soest voor het arrest Bullenbadi (Hoge Raad 6 mei 
Mij komt voor dat het probleem aldus verkeerd is gesteld. Met het Landbouwvliegers-en het Harmonisatiewet-arrest is de bevoegdheid van de rechter tot het toetsen van lagere wetgeving, zoals het hier aan de orde zijnde Besluit uitbreiding en beperking kring verzekerden volksverzekeringen, buiten twijfel gesteld. In zijn arrest van I december 1993 past de Hoge Raad dus een reeds bestaande bevoegdheid toe ten aanzien van een op dat moment nog bestaand wettelijk voorschrift (en stelt buiten twijfel dat voor toepassing van deze bevoegdheid tevens aanleiding is bij strijd met het gelijkheidsbeginsel). Waar het echter in de uitspraak van $\mathbb{I}$ december 1993 wèl op aankomt - en die zin is er wel degelijk sprake van een overgangsrechtelijk aspect, zij het van andere orde - is de vraag of, gelet op de ten tijde in geding gangbare rechtsopvattingen, reeds sprake was van een verboden discriminatie.

Scheltema merkt op dat in deze zaak aan de orde was de vraag 'hoeveel terugwerkende kracht moest worden gegeven aan de onverbindendverklaring van een algemene maatregel van bestuur'. Naar zijn mening verdient het aanbeveling grenzen te stellen aan de terugwerkende kracht van de toetsing van regelingen. Hij merkt hiertoe op dat de interpretatie van vage of ongeschreven normen met de tijd kan veranderen, hetgeen de onzekerheid vergroot indien men een lang terugwerkende toetsing aanvaardt en waarschuwt

"dat velen bij een regeling betrokken kunnen zijn, terwijl het terugdraaien van de gevolgen van die regeling slechts voor een beperkte groep mogelijk is. Naarmate de terugwerking van de onverbindendwerklaring verder gaat, is de kans dat deze ongelijke effecten optreden groter'.

en raakt het hart van de in dit boek behandelde problematiek waar hij opmerkt dat

"het inherent [is] aan rechterlijke oordelen dat zij in beginsel terugwerken. De veronderstelling is immers dat [de rechter] het recht toepast zoals dat ook al woor zijn uitspratak gold. Maar naarmate de rechter duidelijker aan rechtsvorming doet, is het minder reèel aan die veronderstelling vast te houden. Integendeel, er gaat in het rechtssysteem iets wringen wanneer de rechter veranderingen in het recht door de (lagere) wetgever toetst aan het rechtszekerheidsbeginsel, maar geen rekening houdt met dat beginsel bij veranderingen in het recht die hij zelf aanbrengt? 2055

\subsection{Het arrest Wessels-Bergervoet}

Bij arrest van 29 mei 1996 heeft de Hoge Raad zich in het kader wan de AOW uitgesproken over de verenigbaarheid van de in artikel 2 van het Besluit uitbreiding en beperking kring verzekerden volksverzekeringen opgenomen uitsluiting van de verzekering voor gehuwde vrouwen. Daarbij heeft de Hoge Raad geen antwoord gegeven op de vraag met ingang van welk tijdstip de uitsluiting in strijd moet worden geacht met het gelijkheidsbeginsel, maar wel een criterium aangereikt aan de hand waarwan dit tijdstip moet worden bepaald. Hiertoe heeft de Raad overwogen dat

1983, AB 1984, 101 m.nt. F.H. van der Burg en H.K. Fernandes Mendes).

205 Zie in dit verband ook de werzuchting wan A-G Loeb in zinn conclusie voor thot hiema te bethandeten arrest wan de Hoge Raad wan 29 mei 1996 (NJ 1996, 556 ; RSV $1997 / 77$ m.nt F. W. M. Keunen; IB $1997 / 131 \mathrm{~m} . n t$. A.W. Heringa), waar hij opmerkt dat het hem 'overigens hachelijk [voorkomi] on thans anders dan met terughoudendheid te oordelen over de (on)redelijkheid van de destijds door de besluitgever gemaakte keuze. Een dergelijk oordeel wordi immers al snel beinvloed door contemporaine overwegingen, zeker met betrekking tot het hier aan de orde gestelde onderscheid". 
'blijkens de nota van toeliching op het [Koninklijk Besluit van 20 december 1956, Stb. 624], 306 was de uitshitung immers erop gericht een ongerechtwaardigd geachte cumulatie van uitkeringen te voorkomen. In dit verband wees de besluitgever erop dat in de in het besluit bedoelde gevallen het in het butenland door de man opgebouwde pensioen meda geacht kon worden voor zijn echtgenote bestend te zijn. Daarbij mocht de besluitgever, gelet op de iry de ondewhovige tijdvakken ${ }^{207}$ adrwezige hachschappelike verhowdingen, ervan uitgawn dat het in vrijwel alle gevallen de man was die de kostwinner was, zodat hij emnee kon volstaan de echtgenote uit te slutiten en niet gehouden was tevens een voorziening te treffen voor de gevallen warin de vrouw kostwinner was. Derhalve bestond woor het aan de uitsluiting ten grondslag liggende onderscheid naar geslacht destijds een redelijke en objecteve rechtvaardiging". (mijn cursivering, RB)

Het tijdstip met ingang waarvan betrokkenen met succes een beroep op het gelijkheidsbeginsel kumnen doen wordt aldus bepaald door het moment met ingang waarvan de wetgever, gelet op de wijzigingen in de rolverdeling tussen man en vrouw, er niet meer zonder meer vanuit mocht gaan dat in vrijwel alle gevallen de man als kostwinner optrad. Daarbij legt de Hoge Raad, in zorgvuldige bewoordingen, een zelfide criterium aan als kenmerkend is voor vrijwel alle in dit hoofdstuk aan de orde gestelde jurisprudentie. Met dit criterium wordt ook duidelijk dat de terugwerkende effecten van de hier behandelde uitspraken rechtstreeks zijn terug te voeren op het uitblijven van tijdige, voldoende op de maatschappelijke ontwikkelingen inspelende, wetgeving. Veel van de in dit hoofdstuk aan de orde gestelde uitspraken berusten immers op een - al dan niet uitgesproken - oordeel dat de wetgeving reeds gerume tijd niet beantwoord an de maatschappelijke ontwikkelingen, dus al in het verleden anders had moeten luiden dat zij zich op bet moment van toetsing aan de rechter voordoet. Een oordeel van dergelijke strekking verklaart mede de algemene, regelgevende, strekking wan de hier behandelde uitspraken. ${ }^{20 \%}$

Uiteindelijk heeft de CRvB bij uitspraak van 5 maart $1997^{209}$ de knoop doorgehakt door te bepalen dat de uitsluiting van de $\mathrm{AOW}$-verzekering van de gehuwde vrouw met ingang van 23 december 1984 niet meer verenigbaar kan worden geacht met, zowel artikel 4, lid 1, Richtijin 79/7 EEG als met artikel 26 IVBPR. ${ }^{230}$ Voor dit oordeel doet de Raad een beroep op - wat hij inmiddels aanduidt als --vaste jurisprudentie, ingevolge welke

206 Dit KB zag op het eerste Besluit inzake de uitbreiding en beperking van de kring van verzekerden en had nog slechls betrekking op de AOW. Naatmate er later meer volkswerzekeringen kwamen werd de werking van het KB tot deze verzekeringen uitgebouwd; zie in dit verband punt 4 van de RSV-noot van F.W.M. Keunen.

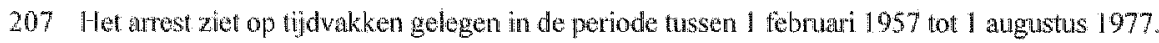

208 In cassatie was overigens ook angevoerd dat het in de jurisprudentie van de CRVB genaakte onderscheid tussen tot de beroepsbevolking behorende vrouwen op wie, ongeacht hun varzekeringsverleden de reflexwerking wan het arrest Verholen van toepassing is, en de niet tot de beroepsbevolking behorende wrouwen die van deze reflexwerking worden uitgesloten, een door artikel 26 IVBPR verboden discriminatie inhoudt. De Hoge Raad achtte het middel echter in zoverre nietontvankelijk, omdat dut zag op artikel 13 AOW ten amzien van de toepassing waarvan in cassatie niet kan worden gek laagd.

209 USZ 1997/131.

210 Hetgeen tevens tot gevolg had dat de witsluiting tot 1 april 1985, waarin nog werd voonzien in de We van 28 maart 1985, kwam te vervallen. 
"in het algemeen - behoudens zich hier niet woordoende uitzonderingen - de onverenigbaameid met artikel 26 IVBPR van nationale bepalingen niet eerder dan met ingang van 23 december 1984 kan worden ingeroepen:

Voor wat het in deze zaak in geding zijnde tjowak van augustus 1972 to januari 1984 ziet de Raad voorts

'geen grond om woor [dit tijdvak] betekenis toe te kennen aan de twee overige door de Hoge Raad besproken rechtsnomen, te weten artikel / Grondwet en het tot de algemene rechtsbeginselen behorende gelijkheidsbeginsel. Ten aanzien van beide - zo althans aan artikel 1 Grondwet over het zojuist aangegeven tijdvak op dit punt werking kan worden toegekend - stelt de Raad zich op het standpunt dat er onvoldoende redenen zijn on aan te nemen dat de in de zienswijze van de Hoge Raad binnen het stelsel van de AOW-verzekering geldende redelijke en objectieve rechtvaardiging van de uitshiting van de verzekering haar werking niet over het gehele bedoelde tijdvak zou hebben behouden".

Daarmee leek het pleit definitief beslecht. Op 27 mei 1998 heeft de rechtbank Maastricht de uitsluting van een gehuwde vrouw over de perioden van 1 januari 1957 tot 1 oktober 1978 en van 1 maart 1984 tot 23 december 1984, mede gelet op het arrest van het Europese Hof voor de Rechten van de Mens in de zaak Goggusuz ${ }^{211}$ getoetst aan artikel 14 EVRM in verbinding met artikel $\mathbb{I}$ van het Eerste Protocol bij dit Verdrag. ${ }^{212}$ Daarbij heeft de rechtbank zich onder meer op het standpunt gesteld dat uit het arrest van het EHRM van 21 februari 1997 in de zaak Van Raatte volgt dat artikel 14 EVRM zwaardere eisen stelt aan de rechtvaardiging van ongelijke behandeling op grond van geslacht dan artikel 26 IVBPR en artikel $\mathbb{1}$ Grondwet. In dit verband heeft de rechtbank onder meer overwogen dat:

'art. 14 EVRM in samenhang met art. I van het Eerste Protocol in die zin een nieuw licht werpt op de vraag naar de rechtvaardiging van het gemaakte onderscheid, dat het woor de beantwoording van de vraag of in casu sprake is van een onderscheid dat is ingegeven door een legiticme doelstelling, dat wil zeggen van een doelstelling die geen onevenredige inbreuk matkt op de gelijke bescherming wan de financiẻle belangen van de gehuwde vrouw ten opzichte van de gelhuwde man, niet voor de hand ligt een beroep te doen op het voorkomen van een financiële bewoordeling van gehuwde vrouwen. Vast moet immers komen te staan dat de gehuwde vrouw nict wordt benadeeld ten opzichte van gehuwde mannen die overigens in een zelfde positie verkeren. Van benadeling zal sprake zijn als, in werwil van de veronderstelling van de wetgever, de gehuwde vrouw niet in het buitenland blijkt te zijn meeverzekerd. De rechibank is dan ook wan oordeel dat de toetsing aan art. $\$ 4$ EVRM jo. At. 1 Eerste Protocol meebrengt dat niet volstaan mag worden met de veronderstelling in abstracto, dat de gehuwde vrouw heeft gededd in de buitenlandse wettelijke verzekering inzake ouderdomspensioen van haar echtgenoot, maa dat dit in concreto moet komen vast te staan'.

211 EHIRM 16 september 1996, AB 1997, 179; RSV 1997/234; NJCM-Bulletin 22 (1997), p. $461-474$ m.nt. C.A. Groenendijk; SMA 1997, p. 253-259 m.ni. G.J. Vonk.

212 AB 1998, 347 m.nt. FP.

213 Reports of Judgements andi Decions $1997-1 ; J B$ i $1997 / 64 \mathrm{~m} . \mathrm{ml}$. A.W. Heringa. 
De benadering van de rechtbank bleek uiteindelijk te voorzichtig. Nadat mevrouw Wessels-Bergervoet bij de voormalige Europese Commissie voor de Rechten van de Mens haar beklag had gedaan ower het in paragraaf 4.3 van dit hoofdstuk besproken arrest van de Hoge Raad, komt het EHRM op 4 juni 2002 met een uitspraak die alle bespiegelingen over het tijdstip waarop de wijziging in de relevante maatschappelijke verhoudingen zou hebben plaatsgewonden illusoir maakte. Na allereerst korte metten te hebben gemaakt met het argument van de Nederlandse regering dat artikel 1 van het eerste Protocol niet zou zien op de aanspraak op een AOW-uitkering, ${ }^{215}$ komt het in een aantal verstrekkende overwegingen tot het oordeel dat de uitsluiting van de gehuwde vrouw van de AOWverzekering in strijd is met artikel 14 EVRM. Terwijl de Nederlandse regering had betoogd dat de uitsluiting berustte op een objectieve en redelijke rechtvaardigingsgrond, gelet op de ten tijde van de in geding zijinde tijdvakken vigerende maatschappelijke verhoudingen, die zich daardoor kenmerkten dat in bijna alle gevallen de man de kostwimner was, alsmede in verband met het voorkomen van dubbele uitkeringen, stelt het Hof voorop dat

'the only reason for the applicant's exclusion from insurance under the AOW for a global period of nineteen years was the fact that sthe was married to a man who was not insured under the AOW on grounds of his employment abroad. It is undisputed that a married man in the same situation as the applicant would not have been excluded from the AOW insurance in this manner". 216

Het Hof concludeert dan ook dat de in geding zijnde korting op het AOW-pensioen uitsluitend gebaseerd was op het feit dat het hier een gehuwde vrouw betrof en dat deze ongelijke behandeling naar geslacht en burgerlijke status slechts dan kan worden gerechtvaardigd als hiervoor 'very strong reasons' zijn aangevoerd. Deze acht het Hof echter niet aanwezig. Nadat het ten aanzien van het door de regering aangevoerde argument van het voorkomen van dubbele pensioenuitkeringen droogjes heeft opgemerkt dat

'this legislation did not prevent a married man in the same situation as the applicant from accumulating pension rights. ${ }^{217}$

overweegt het ten anazien van het door de regering aangevoerde argument in verband met de ten tijde van de in geding zijnde verzekeringstijdvakken heersende tijdgeest het 'of some relevance" te achten dat het EVRM en het Eerste Protocol voor Nederland al op 31 augustus 1954 wan kracht zijn geworden, om vervolgens te overwegen:

"Furthermore, when examining whether a difference in treatment can be regarded as justified, the Court does not only have regard to its aim at the time the relevant provisions were enacted, but also to its effects in the concrete case concemed. In the present case, the applicant received an old age pension as from I March 1989 which was $38 \%$ less than that which a married man in the same situation would have received. In other words, the inequality in treatment embodied in

214 Reponts of Judgements and Decisions 2002-IV; RSV 2002/18H; NJCM-Bulletin, jrg. 28 (2003), nr. 1, p. 45-53, m.nt. Aart Hendriks.

215 De regering had betoogd dat voomoend arrest Goggusuz v. Austria toepassing zou missen, omdat de AOW zich door een onslagstelsel kenmerkt.

216 Wessels-Bergernoet, par. 47.

217 Wessels-Bergemoet, par. 50. 
the fomer legal rules materialised in 1989 when, given the prevailing social attitudes at the time, the aim pursued by the legal provisions could no longer be upheld. 218

Waaraan het Hof tenslotte nog toevoegt dat het bij zijn oordeel tevens heeft meegewogen dat

"When the relevant rules were changed in 1985 in order to bring them in conformity with more present-day standards of equality between men and women, no measures were taken to remove the discriminatory effect of the former legal rules' ${ }^{219}$

\subsection{Conclusie}

De benadering van het EHRM is aldus in tweeërlei opzicht fundamenteel verschillend van die van de Centrale Raad van Beroep en de Hoge Raad. Waar beide laatstgenoemde rechtscolleges in de eerste plaats, zij het met verschillende 'regressiviteit', van belang achtten met ingang van welk tijdstip de ongelijke behandeling van de gehuwde vrouw niet meer in overeenstemming kon worden geacht met de heersende maatschappelijke opvattingen, gaat het Hof uit van een, in wezen, positiefrechtelijke benadering, waarbij simpelweg aansluiting wordt gezocht bij het moment waarop het EVRM voor Nederland van kracht is geworden. En waar zowel de Centrale Raad van Beroep als de Hoge Raad in het verlengde van het voorgaande de doorwerking van de later als discriminatoir beschouwde uitsluitingsbepaling aanvaardden, houdt het Hof bij zijn beoordeling van de vraag of sprake is van een ongerechtvaardigd onderscheid rekening met de effecten die de gewraakte regeling heeft op het moment waarop de pensioenrechten geldend kunnen worden gemaakt en werpt het de Nederlandse wetgever zelfs tegen dat bij de aanpassingswetgeving geen werk is gemaakt van het wegnemen van discriminatoire effecten van de oude regelgeving. Aldus beschouwd is de praktische uitwerking van dit arrest te vergelijken met die van de reflexwerking van het arrest Verholen ${ }^{2211}$ en wordt ook een redelijker resultaat bereikt dan voortvloeide uit de in paragraaf 4.3 van dit hoofdstuk behandelde uitspraken van de Centrale Raad van Beroep van 26 november 1993. Deze laatste uitspraken kenmerkten zich immers door de onevenwichtigheid dat de reflexwerking van het arrest Verholem en dus het wegnemen van de discriminatoire effecten van de oude regeling afhankelijk werd gesteld, niet van de vraag of de vrouw over de in het (soms verre) verleden gelegen tijdvakken waarop de uitsluiting van haar echtgenoot betrekking had, zelf tot de beroepsbevolking behoorde en dus zelfstandig voor de AOW verzekerd was, maar of deze situatie zich kort voor het bereiken van de 65-jarige leeftijd had voorgedaan. ${ }^{221}$

218 Wessels-Bergervoet, par. 52.

219 Wessels-Bergernoet, par. 53 .

220 Vgl. par 4.2. van dit hoofdstuk.

221 Met het woorspelbare gevolg dat veel gehuwde vroumen kort woor het bereiken van de 65 marige leeftijd gingen solliciteren om als werkzoekende te kunmen worden aangemerkt en aldus onder de personele werkingssfeet wan Richtijn $79 / 7$ EEG te kamnen vallen. Dil heef op zijn beurt weer geleid tot beleid van de zijde van de uitwoeringsorganen, waarbij (alsnog) de eis werd gesteld dat de vrouw gedurende de twee aan het bereiken van de pensioengenechtigde leeftijd voorafgande jaren blijk moest hebben gegeven van serieuze sollicitatie activitieiten. Dit beleid is in de jurisprudentie gesauveerd. Wel heeft het uitvoeringsorgaan, blijkens onder meer de uitspraak van de CRwB 19 februari 1997 (RSV 1997/159) zijm beleid in die zin bijgesteld dat ook. gehuwde wrouwen die tot de leeftijd wan 57,5 jaar hebben gewerkt, dan wel daadwerkelijk ter beschikking van de arbeidsmarkt 
Wat echter vooral aan de uitspraak van het Hof opvalt is de vanzelfsprekendheid waarmee het concludeert tot de discriminatie van de desbetreffende gehuwde vrouwen, een benadering die verfrissend afsteekt tegen de 'subtiliteiten' waardoor de eerdere uitspraken van de nationale rechtscolleges zich kenmerkten.

\section{De Bopa-affaire}

\subsection{Inleiding}

Tot slot van dit hoofdstuk behandel ik een aantal uitspraken in - wat is bekend geworden als de - Bopa-affaire. Het bijzondere aan deze affaire is dat zij heeft geleid tot uitspraken van zowel de CRwB, als de Afdeling Rechtspraak van de Raad van State als de Hoge Raad met betrekking tot de werking in de tijd van een arrest van het HIJ EG. In deze uitspraken komen diverse wan de in dit en de vorige twee hoofdstukken besproken lijnen samen.

\subsection{Voorgeschiedenis ${ }^{222}$}

Tot 1 januari 1985 gold voor ambtenaren ten aanzien van de AOW/AWW-premieheffing de zogenaamde Bopa-regeling (Uitvoeringsbesluit beperking meervoudige overneming AOW/AWW-premie) ${ }^{223}$ Deze regeling strekte ertoe een einde te maken aan de zogenaamde overcompensatie. Van overcompensatie was sprake, indien de overheid namens de ambtenaar meer premie AOW/AWW aan de belastingdienst had afgedragen dan het door die wetten gestelde maximum-bedrag. Het door de overheid te veel betaalde werd vervolgens door de belastingdienst terugbetaald aan de ambtenaar. Deze situatie deed zich, gezien het feit dat voor de premieheffing echtparen als eenheid golden, in het bijzonder voor bij echtparen waarbij zowel de man als de vrouw als ambtenaar werkzaam waren. Op grond van de Bopa-regeling vond de premieheffing in eerste instantie plaats op basis van het inkomen van één der echtgenoten; het inkomen van de andere echtgenoot kwam woor de heffing in aanmerking tot het punt waarop het wettelijk maximum voor de premieheffing werd bereikt. Op grond van een circulaire van de Minister van Binnenlandse Zaken $^{224}$ werd voor de bepaling van de heffing eerst uitgegaan wan het inkomen van de man, daarna pas van dat van de vrouw. Een en ander leidde tot een situatie, waarbij in het geval van 'ambtenaren-huwelijken' door de werkgever in het algemeen meer premie werd afgedragen namens de man dan namens de vrouw. Het resultaat was een hoger brutoinkomen voor de man dan voor de vrouw, bij overigens gelijke werkzaamheden. Het resultaat was ook dat de vrouw in het vervolg een belastingvoordeel misliep.

Op 14 februari 1984 heeft de CRvB zich op grond van art. 177 EEG tot het Hof van Justitie van de Europese Gemeenschappen gewend met, kort gezegd, de vraag of de Boparegeling zich verdraagt met art. $119 \mathrm{EEG}$. Hierop heeft het Hof geantwoord dat

hebben gestaan, bij hat bereiken van de leetijd wan 65 jaar tot de beroepsbevolking in de zin van artikel 2 van Richtlijn $79 / 7$ kunnen worden gerekend.

222 Ze mijn noot onder CRvB 22 mei 1990 , Regeimat 1990 4, p. 92-93.

223 Vastgesteld op basis van de Wet gemeenschappelijke bepalingen overheidspensioenwetten (Stb. 1972, 650), bij Koninklijk Beshit wan 21 februari 1973 (Stb. 1973, 76) en gewijzigd bij Koninklijk Besluit van 26 september 1979 (Stb. 1979, 585).

224 Circulaire van 12 deember 1972, nr. AW72/3331. 
"een stelsel van sociale zekerheid waarin (1) de premie word berekend over het salaris wan de werknemer, maar een bepaald maximum niet kan overschrijden; (2) echtgenoten als een eenheid worden beschouwd en de premie - ook hier tot het wastgestelde maximum - over hun gezanenlijke salaris wordt berekend; (3) de ovatheidsorganen gehouden zün, woor rekening van hun werknemers, de door dezen verschuldigde premies af te dragen; (4) indien beide echtgenoten ambtenaar zijn, de ambtelike werkgever van de man als eerste premie moet afdragen en de ambtelijke werkgever van de vrouw daartoe slechts gehouden is, voor zover het maximum doon de voor rekening van de man afgedragen premie niet wordt bereikt, in strijd is net het in artikel 119 EEG-Verdrag wervatte beginsel wan gelijke beloning voor mannelijke en vrouwelike werknemers voor gelijke arbeid, voor zover de eruit voortvloeiende verschillen ussen het brutosalaris van de met een ambtenaar gehuwde vrouwelijke ambtenaar en dat van een mannelijke ambtenaar bepalend zinh woor de berekening van andere aan het salaris gekoppelde voordelen, zoals afwloeingsregelingen, werkloosheidsuitkeringen, gezinstoelagen en krediethaciliteiten". (mijin cursivering, RB)

De CRvB zag zich dus gesteld voor de vraag of de ten gevolge van de Bopa-regeling. ontstane verschillen in bruto-salaris tussen mannelijke en vrouwelijke gehuwde ambtenaren ook leidden tot verschillen tussen andere aan het salaris gekoppelde voordelen. In zijn uitspraak van 24 juni $1986^{223}$ oordeelde de CRvB dat dit inderdaad het geval was op grond van het feit dat voornoemde bruto bedragen onder andere bepalend zijn voor de (omvang van de) uitkeringsgerechtigdheid ingevolge de AAW. Op deze grond achte de CRvB de Bopa-regeling in strijd met art. 119 EEG en derhalve onverbindend.

De minister van Binnenlandse Zaken bleek niet van zins om aan de uitspraak van de CRvB ook ten aanzien van derden uitvoering te geven. Zo antwoordde hij op desbetreffende kamervragen dat

"uit de uitspraak van de Centrale Raad van Beroep van 24 juni j.l. blijkt dat de vrouwen waar het hier om gaat recht zouden hebben gehad op premiebetaling te hunner bate [...] dat beginselen van redelijkheid en billijkheid in verband met de rechtszekerheid de overheidsinstanties niet verplichten tot het alsnog ongedaan maken van eerdere besluiten. ${ }^{226}$

Op. 22 meil $1990^{227}$ heeft de CRvB uitspraak gedaan in een zaak waarin een vijftal vrouwen van het overheidsorgaan waarbij zij werkzaam waren alsnog uitkering van het niet afgedragen bedrag aan AOW/A WW-premie, dan wel afdracht van dit bedrag an de belastingdienst, hadden geëist. Zij beriepen zich hierbij op de onverbindendheid van de Boparegeling ${ }^{228}$. In alle gevallen is deze eis door de desbetreffende overheidsorganen afge-

225 TAR $1986 / 186$

226 Opwallend is overigens dat de minister hier een formulering gebrukt die doet denken aan de bewoordingen die de Hoge Raad in het arrest Boon-Van Loon (HR 27 nowember 1981, NJ 1982 , 503, m.nt E.E.A. Luyten en W.H. Heenskerk.) gebruikte om de terugwerkende effecten wan dit arrest te beperken.

227 Regelmaat 1990, afl. 4, blz. 91.

228 Twee van de betrokkenen hadden reeds eerder, te weten in 1980 resp. 1983 , tevergeefs een dergelijk werzoek gedaan; in een van deze gevallen was door betrokkene bewoep ingesteld bij het Ambtemarengerecht, dat het beroep had verworpen. Van het instellen van hoger beroep had betrokkene vervolgens afgezien. 
wezen en werden de tegen deze afwijzingen ingestelde beroepen door de respectievelike Ambtenarenrechters ongegrond verklaard.

\section{De CRvB is van oordeel dat}

a. de anngevochten besliuten het karakter dragen van een weigering om teng te komen van eerdere in rechte ondantastbaar geworden besluiten. Voor dit oordeel omtrent de aard wan de aangevochten besluiten acht de CRvB het onverschillig of het gemeenschapsrecht dan wel verdragsbepalingen an de orde zijn. De CRVB is van oordeel dat, ook in de gevallen waw whet gemeenschapswecht speelt, an overheidsorganen de bevoegdheid toekomt te weigeren terug te komen op besluiten die in rechte onaantastbaar zijn geworden.

b. ten atanzien van een dergeligke weigering de rechter slechts de in hoofdstuk II behandelde beperkte toetsingsmogelijkheid openstaat;

c. het niet of slechts ten dele voldoen van premie woor een met een ambtenaar gehuwde vrouwelijke ambtenaar, mede in het licht van de hierboven weergegeven overwegingen van het HWI $\mathbb{E G}$, alleen dan discriminatoir in de zin van art. $119 \mathbb{E E G}$ is, indien hiervan een nadelig. effect uitgaat op andere aan het (bruto)salaris gekoppelde voordelen. Het aldus door art 119 EEG beschermde belang betreft volgens de CRvB alleen die 'andere' aan het salaris gekoppelde voordlelen (zoals de AWW-uitkering wit de zaak van 24 juni 1986), niet echter het belang gelegen in het financiele voordeel dat voor eiseressen het gevolg zou zijn van het alsnog aan hen witkeren wan de niet algedragen premie.

d. [het uitwoeringsorgaan] in redelijkheid tot hun beslissing theef kunnen komen, De CRvB gaat zelfs nog een stap werder cloor te overwegen dat het belang van de eisers niet prevaleert boven dat van de gedaagden.

e. dal woor herziening evenmin aanleiding bestaat in die gevallen waarin de betrokkenen reeds eerder, nog ten tijde var de werking wan de Bopa-regeling, een soortgelijk verzoek hadden gedaan, omdat de besluiten waarbij die werzoeken werden afgewezen inmiddels in rechte onaantastbaar waren geworden.

f. er van strijd met art 26 Internationaal Verdrag inzake burgerrechten en politieke rechten (Bupo-Verdrag) en art. 7 Internationaal Verdirag inzake economische, sociale en culturele rechten (Esocul-Verdrag) evenmin sprake is. De Raad laat hierbj overigens in het midden in hoeverre aan deze verdragsbepalingen in deze materie rechtstreekse werking zou toekomen. (mijn. cursivering, RB)

"Een beslissing welke de staat in de honderden miljoenen bespaart, aldus een van de eerste reacties ${ }^{29}$ op deze uitspraak. Het gaat in deze zaak om de vraag of de uitspraak van de CRvB van 24 juni 1986 terugwerkt, in die zin dat voor tijdvakken gelegen in de periode van de gelding van de Bopa-regeling door vrouwelijke ambtenaren alsnog aanspraak kon worden gemaakt gemaakt op uitkering van het niet afgedragen bedrag aan $\mathrm{AOW} / \mathrm{AWW}$ premie met een beroep de achteraf gebleken onverbindendheid van de Bopa-regeling. Het in volle omvang toekennen van precedentwerking aan de door de Raad in zijn beslissing van 24 juni 1986 uitgesproken onverbindendverklaring zou betekenen dat ook derden overeenkomstig deze uitspraak rechten zouden kunnen ontlenen aan het feit dat de Boparegeling ten onrechte op hen is toegepast. Deze vraag krijgt extra gewicht omdat de onverbindendverklaring haar grondslag vindt in het communautaire recht. De uitspraak van het Hof wan 18 september 1984 houdt immers in dat de Bopa-regeling in strijd is met art. 119 EEG Verdrag, indien aan een nadere voorwarde, gelegen in de consequenties die 
de Bopa-regeling zou kunnen hebben voor, bijvoorbeeld, uitkeringsgerechtigdheid krachtens de sociale zekerheidswetten, zou zijn voldaan.

De wijze waarop de CRvB in de onderhavige zazk de eis van het vijtal vrouwen afwijst, vertoont enige bijzonderheden. In zijn uitspraak van 24 juni 1986 verrichtte de CRvB de "normale' incidentele toetsing: de artikelen uit de Bopa-regeling waaruit bovengenoemde verschillen in bruto-salaris voortvloeiden werden buiten toepassing verklaard. Dit had tot gevolg dat ten behoeve van betrokkene alsnog afdracht van premie AOW/AWW diende plaats te vinden. Dit geschiedde ondanks het feit dat het uitblijven van een financieel voordeel door het niet afdragen van premie op zichzelf niet door het Hof van Justitie als discriminatie in de zin van art. 119 EEG-Verdrag was aangemerkt. In de onderhavige uitspraak is deze laatste omstandigheid echter dé reden voor de CRvB om de eis al te wijzen: volgens de CRvB is het belang dat in de onderhavige zaak voor betrokkenen is gelegen in het verkrijgen van een financieel voordeel, niet het belang dat het Hof van Justitie beoogde te beschermen. De CRvB hanteert aldus een zeer concrete toetsing die de formele werking in de tijd van de uitspraak van 24 juni 1986 zeer beperkt.

Deze zaak betreft een tot de Minister van Justitie gericht verzoek van een rechter om haar rechtspositie over de periode 1973-1985 te herzien, in die zin dat alsnog premies AOW/ AWW worden afgedragen. Dit verzoek werd door de minister afgewezen. De Afdeling verwerpt het beroep, daartoe overwegende dat, aangezien betrokkene niet tijdig is opgekomen tegen de uit de jaaropgaven over de periode 1973-1985 blijkende beschikkingen, deze in rechte onaantastbaar moeten worden geacht. De Afdeling weigert in de in paragraaf 5.2 genoemde uitspraak van de CRvB van 24 juni $1986^{231}$ een omstandigheid te zien die tot een ander oordeel noopt, omdat
'deze uitspraak betrekking heeft en naar haar aard ook slechts kan hebben op het daarin aan de orde zijnde hoger beroep tegen een uitspraak van het Ambtenarengerecht te Amsterdam van 11 december 1980 en de daarin aan de orde zijnde rechtsbetrekking tussen partijen in dat geding, waartoe appellante niet behoorde'.

De Afdeling lat er overigens geen twijfel over bestaan dat in materieelrechtelijk opzicht de rechtspositie van appellante een andere is geweest dan uit de beschikkingen over de periode 1973-1985 blijkt. De Afdeling overweegt immers dat betrokkene

"artikel 119 van het EEG-Verdrag, waarin door de Centrale Raad wan Beroep in diens uitspraak witleg en toepassing is gegeven, [....] destijds, indien zij rechtsmiddelen had angewend tegen de jegens haar genomen besluiten waarvan zij thans heroverweging beoogt, ook reeds [had] kunnen inroepen; in haar rechtspositie is derhalve door de titspraak van de Centrale Raad van Beroep geen wijziging gebracht".

Dit komt wel heel dicht bij een erkenning dat betrokkene het recht aan haar zijde had (aangenomen dat de Afdeling de uitleg van de CRvB zou willen volgen), maar dit recht op formele gronden niet kon uitoefenen. Dat blijft onbewredigend, omdat ook hier geldt dat velen zich aanvankelijk in het geheel niet bewust waren van hun rechten. Geconcretiseerd 
werden deze rechten in elk geval pas in de uitspraak van CRvB van 24 juni 1986 , terwijl niet blijkt dat er van de kant van de regering stappen zijn ondemomen om aan deze uitspraak een ruime bekendheid te geven.

\section{$5.5 \quad H R 29$ november $199 I^{232}$}

Ook de Hoge Raad heeft een formele redenering gevolgd om onder de vergaande financiele consequenties, die het gevolg zouden zijn van het toekennen van een meer algemene betekenis aan de uitspraak van de CRvB, uit te komen.

De aan de Hoge Raad voorgelegde zaak betrof de semi-owerheid en had betrekking op een vordering jegens de in Amsterdaun gevestigde Stichting Montessori Onderwijs, ertoe strekkende dat de Stichting aan de betrokkene dan wel aan de belastingdienst de over de periode 1973-1984 te weinig afgedragen premies AOW/AWW zou voldoen. De Hoge Raad stelt voorop dat

"onder meer blijkens de in cassatie namens [betrokkene] gegeven toelichting [..] aan deze vordering tot nakoming de stelling ten grondslag [ligt] dat de Stichting door niet voor haar de premie AOW/AWW te voldoen jegens haar wanprestatie heeft gepleegd, immers tekort is geschoten in haar verpliclntingen ingevolge art. $\mathrm{N} 9 \mathrm{ABP}$, welke wanprestatie niet kan worden gerechtvaardigd met een beroep op de Bopa-regeling aangezien deze om voormelde redenen onverbindend is".

De Kantonrechter en de rechtbank hadden de vordering gedeeltelijk toegewezen. De Hoge Raad ging over tot vernietiging van beide vonnissen, waartoe hij een redenering volgde die de Bopa-spitsroeden zoveel mogelijk vermeed. Daartoe overwoog de Hoge Raad met een beroep op de parlementaire geschiedlenis ${ }^{233}$ van art. 5 lid 1 van de Wet pensioenmaatregelen $1963^{23.4}$ dat art. N9 ABPW

"niet anders [kan] worden werstaan dan dat deze bepaling het orgaan slechts verplicht tot het voldoen van premie voor zover deze door de ambtenaar (uiteindelijk) is verschuldigd'.

Op deze grond kan volgens de Hoge Raad niet worden gezegd dat de Stichting, door gedurende de periode 1973-1984 niet de AOW/AWW-premie te voldoen, jegens betrokkene wanprestatie zou hebben gepleegd.

\section{Conclusie A-G Koopmans bij HR 29 november $1991^{295}$}

Kenmerkien de voorgaande uitspraken zich door een vergaande beperking van de formele werking in de tijd van de uitspraak van de CRvB van 24 juni 1986 en van het artest van het HVJ EG van 18 september 1984, de conclusie van A-G Koopmans voor het in de vorige paragraaf aan de orde gestelde arrest van de Hoge Raad ademde een geheel ander sfeer. Ten aanzien wan de vraag of de door het HvJ EG in zijn uitspraak van 18 september 1984 bedoelde 'voordelen' zelf loonelementen in de zin van art. 119 EEG-Verdrag zouden moeten zijn en of die voordelen werkelijk genoten moeten worden dan wel of voldoende is

233 Bifl. Wand. II 1964-1965, 7980, nr. 4, p. 32, I.k.

234 Wet van 29 mei 1963, Stb. 210.

235 NJ 1993, 150 en 151 m.nt. J.H. van der Veen. 
clat daar, eventueel in de toekomst, aanspraak op kan worden gemaakt, stelt Koopmans voorop dat er in het licht van de strekking van art. $119 \mathrm{EEG}-$ Verdrag

"van uit moet worden gegaan dat art. 119 een woorschrift wan sociale aard is (het maakt ook deet uit van de 'sociale bepalingen' van het verdrag) dat tot doel theef mannelijke en vrouwelijke werknemers een gelijke positie in het arbeidsproces te verzekeren. [...] In de uitvoerige rechtspraak van het Hof staat dan ook centraal of de "voordelen" die man en vrouw wit hoofde van de dienstbetrekking genieten wel dezelfde zijn. [...] In dit perspectief gezien ligt het voor de hand dat het Hof verschil in brutosalariering dat nief tot onderscheid in nettosalaris leidt slechts van belang wond woor de toepassing van art. 119 voor zover "andere voordelen" dan het bedrag dat men maandelijks in de hand krijgt aan dit verschil gekoppeld zouden zijn. In dat geval zouden nl. man en wrouw, ondanks gelijk nettosalaris, toch in een verschillende positie verkeren ten aanzien van de voordelen die uit de dienstbetrekking voortvloeien'.

Op grond hiervan merkt Koopmans dan ook op dat hem

'geen gerede twijfel mogelijk [lijkt] dat het Hof met de uitdrukking 'andere voordelen' bedoeld heeft wat het heeft gezegd: aan het bruto-inkomen gekoppelde voordelen bepalen of het brutoinkomen relevant is voor de toepassing van art. 119. Die "voordelen' hoeven daarom zelf geen loonelementen te zijn in de zin van art. 119 , zoals blijkt uit het door het Hof gegeven voorbeeld van de kredietfaciliteiten; zij hoeven ook niet werkelijk genoten te worden, omdat anders de eveneens gegeven voorbeelden van afvloeimgsregelingen en werkloosheidsuitkeringen onbegrijpelijk zouden zijn".

\section{Op grond waarvan hij tot het oordeel komt dat}

"wamneer uitkeringen krachtens werkloosheidswerzekering of krachtens afvloeingsregelingen (bijv bij CAO) verschillend zijn voor man en wrouw ten gevolge wan verschillen in butosalaris, die laatste verschillen strijdig met art. 19 [zijn] ook al zijn de nettosalarissen van mannelijke en wrouwelijke werknemers gelijk".

Vervolgens refereert Koopmans aan de uitspraak van de CRvB van 1986, waarin deze rechter tot het oordeel kwam dat de gewraakte verschillen in brutosalaris inderdaad gevolgen hadden voor het recht op toekenning en de bepaling van de hoogte van AAWuitkeringen (en, naar wit een overweging ten overvloede blijkt, ook voor de WWVuitkering). Op grond van het woorgaande en op grond van de juridische constructie die de Bopa-regeling inhoudt komt Koopmans tot de conclusic dat er sprake is van directe discriminatie in de wirwoeringsprakfik ${ }^{230}$ en niet in de Bopa-beshiten zelf. In afwijking van de utspraak van de CRVB van 1986 oordeelt Koopmans dan ook dat het probleem van de onverbindendheid van wettelijke voorschriften zich hier niet voordoet, omdat er sprake is van een administratieve praktijk waarbij discriminetend is opgetreden. Zijns inziens zou onverbindendheid van de Bopa-besluiten alleen kumnen worden overwogen wanneer de daarin neergelegde voorschriften geen enkele andere dan een discriminerende praktijk zouden toelaten ${ }^{2}$. 37

Nu het Nederlandse recht naar het oordeel van Koopmans geen grondslag inhoudt voor een salarisverhoging voor de betrokkenen kan het discriminerende gedrag zijn inziens,

236 Belichaamd in de uirvoringsvoorschriften die de Minister van Binnenlandse Zaken bij briel en "instructie" heeft vastgesteld.

237 Aan de hand wan een aantal voorbeelden toont Koopmans aan dat dit laatste niet het geval is; zie N. 1993,150, p. $445 \mathrm{r} . \mathrm{k} \ldots$ 
that Nederlands rech, alleen door een actie uit schadevergaeding wonden bestreden, in welk verband hij zich de vragg stelt:
'Dwingt het Europese recht tot een andere slotsom? Volgens de rechtspraak van het Hof wan Justitie dient een dachwerkelike en doeltreffende rechisbescherming geboden te worden alan vrouwelijke werknemers die het slachtoffer zijn van discriminatie; een louter symbolische schadevergoeding woldoet niet an dic eis $[\ldots,]^{23 g}$ Die owerweging hoef niet te leiden tot toe- wijzing van een sallarisvordering, omdat daardoor immers een grotere ongelijkheid zou worden gecreterd dan de ongelijkheid waarwoor redres word gezocht; maar zij heeft wel tot gevolg dat de schadevergoeding een voldoende effectief middel moet zijn om de gelijkheidsregel van art. 119 EEG-Verdrag zijn volle werking te verzekeren. De werkgever moet worden ontmoedigd xijn discriminerend gedrag woort te zetten. ${ }^{, 239}$ (mijn cursivering, $R B$ )

De schadevergoeding betreft naar het oordeel van Koopmans niet gederfd inkomen, maar vloeit voort uit - wat hij noemt - de smood die de desbetreffende vrouwen is aangedaan door een discrimimerende behandeling. Het gaat dus om vergoeding van immaterïle schade." ${ }^{240}$ Daarbij ware volgens Koopmans te overwegen

'art. $1637 \mathrm{w} \mathrm{BW}$ in het licht van de rechtspraak van het Hof van Justitie dusolanig te interpreteren dat de naar billijkheid vast te stellen vergoeding ook een puritief karakter kan hebben'. (mijn cursivering)

Het voorgaande leidt Koopmans tot de slotsom dat betrokkenen met hun op wanprestatie gebaseerde loonvordering een verkeende weg hebben bewondeld ${ }^{241}$ Het belang van de conclusie is dan ook gelegen in de aanwijzing van een andere, tot compensatie van geleden nadeel lejdende weg, die los staat van de opzet van de in geding zijnde wetgeving. Hoewel Koopmans de door hem bepleite actie uit schadevergoeding lijkt te wilhen baseren op het Nederlandse recht, valt op dat de argumentatie die hij in dat verband gebruikt - met de nadruk op het bieden van daadwerkelijke en doeltreffende rechtsbescherming tegen door het EG-recht verboden discriminatie - op zijn minst verwant is met de argumentatie die het HvJ EG hanteerde in het arrest Francovich en Bonifaci, ${ }^{242}$ bij welke uitspraak het Hof een rechtstreeks op het EG-recht gebaseerde actie uit onrechtmatige daad introduceerde in een geval waarin het nationale recht niet in een dergelijke actie voorzag. Het Hof maakt hierbij ecn uitzondering op het uitgangspunt dat de Lid-Staten voor wat betreft het bieden van rechtsmiddelen ter handhaving van de toepassing in de interne reclitsorde betreft, aulonoom zijin. ${ }^{24 t 3}$

De conclusie van Koopmans roept ook in meer algemene zin de vraag op of met een louter beroep op de formele rechtskracht van eender afwijzende beslissingen, of door de toepassing van strikte aanvaagtermijnen, aan de gevolgen wan de materiele werking in de tijd

238 Warbij Koopmans verwijst nat IH.I EG 10 april 1984, zaak 79/83 Harz/Thadax, Wur. 1984, p. 1921.

239 Wanbij Koopmans verwijst naar HoJ EG 10 april 1984, zaak 14/83, Von Colson en Kawnon, Jur. 1984, p. 1891.

240 Zie art. 6: 106 BW en voor het oude recht: Asser-Hartkamp I (8e druk 1988, nr. 464), Zie voorts art. $1637 \mathrm{~W}$ BW dat naar de mening wan Koopmans ruimte laat voor de vergoeding van schade wegens een smadeligke behandeling van de werknemer.

24.1 On welke reden het cassatieberoep ook werd verworpen.

242. Hv EG 19 november 1991 , zaken C-690 en C-9/90, p. I-5357, AB 1994, $482 \mathrm{~m}$.nt. F. H. van der Burg; SEW (1993), p. 87 ev,

243 Zie ook hootdstuk 5 , par. 2.1 . 
van uitspraken waarbij toepassing is gegeven aan het internationale of communautaire recht, kan worden ontkomen. Op deze vraag zal in het volgende hoofdsiuk worden teruggekomen. 



\section{Hoofdstuk 5}

\section{Formele werking, nader beschouwd}

In de voorgaande twee hoofdstukken ging het steeds om de vaag in hoeverte verandering wan rechtspraak aanleiding kan zijn tot het wijzigen van onder de oude rechtspraak tot stand gekomen rechtsverhoudingen of tot het alsnog, met terugwerkende kracht, tot stand brengen van nieuwe rechtsverhoudingen. Voor wat de wijziging van bestaande rechts verhoudingen betreft zin twee relevante varianten besproken. De meeste aandacht is daarbij witgegaan naar het door het bestur op aamvaag dan wel ambtshalve met terigwerkende kracht herzien van onder de oude rechtspraak tot stand gekomen beslüten. Daamaast is al een antal keren de mogelijkheid ter sprake geweest om in het licht wan de veranderde jurisprudentie een procedure voor de burgerlijke rechter te voeren, ofwel om het besluit langs die weg alsnog aan te tasten, ofwel om, met instandlating van de rechtskracht van het besluit, schadevergoeding te vorderen. Van totstandkoming van nieuwe rechtsverhoudingen is sprake wamner naar aanleiding van nieuwe rechtsprak alsnog een aanvraag wordt ingediend ter verkrijging van een recht wartop de betrokkenen, afgaande op de oude rechtspraak, geen aanspraak leken te maken.

De mogelijkheid tot het veranderen van bestaande rechtsverhoudingen stuit blijkens het voorgaande meestal af op het beginsel van de formele rechtskracht, terwijl de vratg of met succes aanspraak kan worden gemaakt op krachtens veranderde rechtspraak alsnog verkregen materiële rechten in hoofdzaak afhankeljk blikt te zijn van de mate waarin nationaalrechtelijke procedurele bepalingen het mogelijk maken de alsnog, met terugwerkende kracht verkregen, materiële rechten geldend te maken.' Dat een en ander, voor wat het verkrijgen van daadwerkelijk rechtsherstel, een willekentig beeld kan opleveren, moge nog blijken uit de nevenstelling van de volgende twee uitspraken van de CRvB.

De eerste uitspraak ${ }^{2}$ heef betrekking op een anutal gehuwde vrouwen die net een beroep op de uitspraak var de CR.vB van 14 mei $1987^{\circ}$ inzake de WUV alsnog een aanviaag hadden ingediend om met ingang van 23 december 1984 voor een witkering in aramerking te komen. Deze aanvagen werden door het wivoeringsorgaan ingewilligd, maar net eerder dan met ingang van de eerste dag van de maand warin de desbetreffende aarvragen waren ingediend, zoals door artikel 34, lid 1 , aanhef en onder a, van de WUV werd voorgeschreven. Betrokkenen stelden zich echter op het standpunt dat zuiks in strijd met artikel 26 IVBPR was te achten en stelden bovendien dat aan hen ten gevolge van deze

I Vgl. in dit verband de verschillen tussen de fomele werking van de in par. I th 2 van hoofdstuk 4 besproken 'omgangsjurisprudentie" met beirekking tot, tespectievelijk, de WWV an de AAW' CRvB 24 jantari 1991, AB 1991, 338 m.nt. JR; RSV 1991268; NICM-Bultetin 16-3 (1991). p. 21.3 m.nt. Heringa.

AB 1987, 543 m.nt. HH; RSV 1987, 246 m.nt W.M. Levelt-Overmars; NJCM-Bulletin 12-6 (1987) p. 465. Zie voorts hoofdstuk 3 , par. 2.4 
handelwijze van het uitvoeringsorgaan geen daadwerkelijk rechtsherstel was geboden als bedoeld in artikel 2 , lid 3, aanhef en onder a, van dit verdrag. Beide argumenten worden door de Raad verworpen. ${ }^{4}$ Hiertoe overweegt de Raad dat

\begin{abstract}
"[hij] een formect-wettelijk voorschrift van die aard [heeft] te eerbiedigen. Dit is slechts anders indien in een concrete casus zodanige bijzondere ornstandigheden kunnen worden onderkend dat op grond van ongeschreven recht een strikte toepassing van het betreffende voorschrift geen rechtsplicht meer kan zijn. In dit katder kan worden geplaatst de stelling dat klaagsters in de tijd voor mei 1987 wel uiting hebben gegeven aan hun wens een periodieke uitkering te verkrijgen maar dat zij zich wen hebbern gericht naar en hebben berust in de informatie wanwege de begeleidende instelting dan wel de Uitkeringsraad dat zij als gehuwde vrouw geen aanspraak op een periodieke uitkering konden ontlenen. De Raad is van oordeel dat deze stelling geen bijzondere omstandigheden weergeeft als nodig is voor de slotsom, dat ten aanzien van klaagsters op grond wan ongeschreven recht een strikte toepassing wan art. 34 eerste lid aanhef en onder a wan de Wet geen rechtsplicht meer kan zijn. Hiertoe heeft de Raad laten wegen dat betrokken klaagsters zich met hun opstelling in wezen gericht hebben naar de wet. Met haar inhoud waren de toen bij de Uitkeringsraad vigerende uitvoeringspraktijk en de alstoen in het voetspoor van die praktijk aan de betrokken klaagsters aangereikte informatie in overeenstemming. In die situatie is eerst wijziging gekomen naar aanleiding van de voormelde uitspraak van de Raad d.d. 14 mei 1987, gegeven in een geding waarin geen van klaagsters (mede) partij was', (mijn cursivering, RB)
\end{abstract}

De tweede uitspraak ${ }^{5}$ ziet op op een op 26 april 1984 ingediende aanvraag om een vervoersvoorziening krachtens de Wet uitkering burger-oorlogsslachtoffers (WUBO). Nadat het uitvoeringsorgaan betrokkenen met ingang van 1 april 1984 (de datum van inwerkingtreding van de WUBO) voor de gevraagde voorziening in aanmerking had gebracht, maakte betrokkene bezwaar tegen de ingangsdatum. Hiertoe voerde hij aan dat hij zich al voor genoemde datum tot de Stichting Burger-aorlogsslachtoffers had gewend om te informeren of hij ingevolge de toen geldende Rijksgroepsregeling Oorlogsslachtoffers 1940-1945 aanspraak op een bijzondere uitkering terzake van vervoerskosten zou kunnen maken. Van die zijde is hem toen meegedeeld dat hij gezien de hoogte van zijn inkomen niet voor een dergelijke uitkering in aanmerking zou komen. In zijn uitspraak stelt de $\mathrm{CRvB}$ voorop dat, anders dan in de vorige uitspraak ten aanzien van artikel 34 van de WUV het geval was, het in deze zaak aan de orde zijnde artikel 40 , tweede lid, van de WUBO een bevoegdheid van discretionaire aarcl bevat om ten gunste van betrokkenen van een eerdere ingangsdatum uit te gaan. Daarmee is het juridisch kader van deze zaak weliswaar wezenlijk anders dan dat van de vorige, maar de overweging op grond waarvan de CRvB het uitvoeringsorgaan gehouden acht van deze bevoegdheid gebruik te maken is niettemin, gelet op zijn overwegingen in de WUV-zaak, interessant, waar hij overweegt van oordeel ve zijn dat

Het beroep op artikel 2, derde lid, onder c, IVBPR verwerpt de Raad overigens met de eigenaardige vverweging dat geen van de voorliggende gevallen beantwoordt aan het derde lid, onder $b$, van deze bepaling. Heringa heeft opgenterkt deze reden tot afwijzing onbegrijpelijk te vinden, daar het in artikel 2 . dercle lid, onder b, IVBPR bepalde de zeltstandige verplichting inhoudt dat er een bevoegde rechterlijke of bestuurlijke autoriteit is on over het ingestetde rechtsmiddel te beshissen. Wat betrokkenen echter hadden betoogd was dat die bevoegde autoriteit verplicht was daadwerkelijk fechtsherstel te verlenen als cen verdragsschending zou worden aangenomen (NJCM-Bulletin 16-3 (1991). p. 216 ). 
"aan [betrokkane] onder de zoẻven geschetste omstandigheden niet kan worden tegengeworpen dat hij ervan heeft afgezien zich daadwerkelik mef een aanwaag ingevolge de Rijksgroepsregeling Oorlogsslachtoffers 1940-1945 tot het geneentebestuur te wenden. Van [betrokkene] kan immers redelijkenwijs niet worden verlangd - ook niet vanuit het oogpunt wan toepassing van de WUBO - dat hij aanvragen indient waon an hij objecref besien mag aammemen wat die zanloos zim". (mijn cursivering, RB)

Kon dat laatste evenwel niet evenzeer worden gezegd van de vrouwen die in de zaak van 24 januari 1991 hadden verzocht met terugwerkende kracht in aanmerking te komen voor een WUV-uitkering? Kon aan hen in redelijkheid worden tegengeworpen dat zij zich richtten naar de wet. ${ }^{6}$ Is voorts niet aannemelijk dat de imperatieve bepaling van artikel 34 van de WUV in het geheel niet is geschreven voor gevallen waarin door de jurisprudentie met ingang van een bepaalde, in het verleden gelegen datum, de koers varn de wet wordt verlegd. ' Het beeld dat rijst is dat van betrekkelijke willekeur waar het gaat om de formele werking in de tijd van materieel terugwerkende uitspraken. Waar deze materiële werking steunt op de doorwerking van het internationale recht doet zich de vraag voor of aan het internationale recht geen gronden kunnen worden ontleend om aan deze betrekkelijke willekeur te ontkomen. Zo speelde in voomoemde WUV-zaak bijvoorbeeld de vraag of de betrokken vrouwen, gelet op de onmiskenbare materiële terugwerking van de WUV-uitspraak van 14 mei 1987, geen daadwerkelijk rechtsherstel als bedoeld in artikel 2, lid 3, onder a, IVBPR was onthouden. ${ }^{8}$ Een soortgelijke vraag kan worden gesteld bij de werking, in voorkomende gevallen, van de artikelen 6 en 13 EVRM. Alleteerst zal ik echter, om de draad van de in dit boek gehanteerde volgorde weer op te pakken, stilstaan bij de in hoofdstuk II nog opengelaten vraag in hoeverre het EG-recht mogelijk in de weg kan staan aan het beginsel van de formele rechtskracht.

\section{Verenigbaarheid formele rechtskracht met EG-recht}

\subsection{Her gemeenschapsrecht}

De verhouding van het Nederlandse beginsel van de formele rechtskracht met hel Europese gemeenschapsrecht houdt de gemoederen al lange tijd bezig. Zo oordeelde het College van Beroep woor het Bedrijfsleven in een uitspraak van 22 april $1975^{\circ}$ dat een besluit van cen Productschap tot oplegging van een heffing, door het verstrijken van de beroepstermijn rechtens onaantastbaar wordt. Dat de desbetreffende heffingen, naar uit cen latere uitspraak van het HvJ EG bleek, waren gebaseerd op een met het EG-recht strijdige verordening, kon het College niet tot een ander oordeel brengen.

Vgl Heringa, die in zijn noot kernachtig opmerkt dat 'af te gatan op de wet in dit geval leidt wot afgan in beroep'. (NJCM-Bulletin $16-3$ (1991), p. 217 ).

De beeldspraak is ontleend aan de noot wan Heringa (NJCM-Bulletin, 16-3 (1991), p. 217), die er bovendien op wist dat het Hormonisatiewet-arrest van de Hoge Raad (HR 14 april 1989, NJ 1989, 469 m.m. MS; AB 1989, 207 m.nt. FHvdB; Ars Aequi 38 (1989), p. 578 m.nt Hirsch Ballin) het bij het niet door de wetgever werdisconteerd zijn van bepalde onstandigheden mogelijk rnakkt een wetsbepaling buiten toepassing te taten.

Heringa is in elk geval van oordeel dat de CRvB bij de beantwoording van deze vratag in zijn WUVuitspraak wan 24 januari 1991 wel erg kort door de booht is gegaan (NJCM-Bulletin $16-3$ (1991). p. 216).

9 De zaak Van Haaster w. Productschap woor Siergewassen, SEW 1975, p. 449. 
In de reeds herhaaldelijk angehaalde zaak Comet heeft het CBB aanleiding gezien in een soortgelijke zaak prejudiciële vragen te stellen aan het $\mathrm{HV} \mathbb{} \mathrm{EG}$. Bij het in antwoord op deze vragen op 16 december 1976 gewezen arrest ${ }^{60}$ heeft het HwJ EG zijn sindsdien vaste jurisprudentie gevestigd met betrekking tot de mogelijkheid tot terugvordering van ten onrechte (in strijd met het gemeenschapsrecht) geheven nationale heffingen. Een illustratieve uiteenzetting over deze jurisprudentie is te vinden in het arrest Aprile $I I,{ }^{n}$ waarin het Hof overweegt herhaaldelijk te hebben opgemerkt dat

'bij vergelijking van de nationale stelsels blijkt, [dat] het vraagstuk van de betwisting van onwettig opgeëiste heffingen of de terugbetaling van onverschuldigd betaalde heffingen in de verschillende lidstaten en zelfs binnen eenzelfde lidstaat uiteenlopende oplossingen heeft gewonden, afhankelijk van de soort belasting of heffing waarom het gaat. In sommige gevallen stelt de wet zowel ten aanzien van tot de belastingdienst gerichte bezwaarschriften als van beroepen in rechte voorwaarden ten aanzien van de vorm waarin en de termijn waarbinnen dergelijke rechtsvorderingen of verzoeken kumen worden ingediend. In andere gevallen moeten beroepen tot terugbetaling van onverschuldigd betaalde heffingen voor de gewone rechter worden ingesteld, met name in de worm van een actie uit onverschuldigde betaling. Daarbij gelden voor deze beroepen meer of minder lange termijnen, in bepaalde gevallen de normale verjaringstermijn van het gemene recht.

[...]

Deze verscheidenlieid van de nationale sielsels is een gevolg van het onibreken van een gemeenschapsregeling inzake de terugbetaling van ten onrechte geheven nationale heffingen. In een dergelijke situatie is het immers een aangelegenheid van het interne recht van elke lidstaat om de bevoegde rechter aan te wijzen en de procesregels te geven voor rechtsvorderingen die ertoe strekken, de rechten te beschermen die de justitiabelen aan het gemeenschapsrecht ontlenen, mits die regels niet ongunstiger zijn dan die welke voor soortgelijke nationale vorderingen gelden (gelijkwaardigheidsbeginsel), en zij de uitoefening van de door het gemeenschapsrecht verleende rechten in de praktijk niet onmogelijk of uiterst moeilijk maken (doeltreffendheids. beginsel. ${ }^{12}$

$[\ldots]$

Wat laatstgenoemd beginsel betreft, is het volgens het Hof met het gemeenschapsrecht verenigbaar, dat in het belang van de rechtszekerheid, waarin zowel de contribuabele als de administratie bescherming vindt, redelijke beroepstermijnen worden vastgesteld die gelden op straffe van verval wan recht.

$[\ldots]$

Dergelijke termijnen maken immers de uitoefening van de door het gemeenschapsrecht verleende rechten in de praktijik niet onmogelijk of uiterst moeilijk".

Meer specifiek over termijnen voor bezwaar en beroep had het Hof in zijn arresten in de zaken Edis ${ }^{1.3}$ en Spac ${ }^{14}$ reeds overwogen dat

10 HvI EG 16 december 1976, zalken 33/76 (Rewe) en 45/76 (Comet), Jur, 1976, p. 1989; SEW 6 $(1977), \mathrm{p}, 466-473$

11 Amast wan 17 november 1998 zatak C-228/96, Jurispr. 1998, p. 1-714.

12 Nalast deze vereisten wijst het HWJ EG ook op het beginsel van effectieve rechtsbescherming: tegen de besluiten dia een inbreuk maken op communautaire rechten dient beroep bij de rechter open te staan en de desbetreffende alanspraken moeten in rechte kunnen worden afgedwongen; wgl. E.M. Vermeulen. Het geneenschapsrecht en de formele rechtskracht van Awb-beshiten, in: JBPlus 2002/1. p. 3848. Zie woonts HvJ EG 15 mei 1986, zak 222/84, Johnston. Jur. 1986 , p. 1651 en HvJ EG 15 oktober 1987, zaak 222/86 Heylens, Jur. 1987, p. 4097.

14 HvI EG 15 september 1998 , zak C-26096, Jur. 1998, p. I-4997. 
'het gemeenschaprecht [er] niet aan de de weg [staat], dat de wettelike regeling wan een lidstaat, naast en verjaringstermijn van gemeen recht die van toepassing is op vonderingen uit onverschuldigde betaling tussen particulieren, minder gunstige bijzondere regels kent voon bezwaar en beroep in rechte tegen heffingen en andere belastingen. Dit zou slechts anders zijn, indien die regels enkel gelden voor op het gemeenschapsrecht gebaseerde vorderingen to terug. betaling van die heffingen of belastingen."

In onder meer het arrest Fanfasks heeft het Hof bovendien overwogen dat, ook indien een richtlijn miet naar behoren is omgezet, het gemeenschapsrecht zich niet verzet tegen toepassing van een nationale verjaringstermijn die ingaat op de datum van opesbarhedid van de betrokken rechten. Hieruit blijkt dat de betekenis van het artest Emmot! in de loop der tijd enigszins is verbleekt. Zoals eerder in deze studie ter sprake is geweest, ${ }^{17} \mathrm{kwam}$ het HWJ EG in deze witspraak tot het oondeel dat beroepsteminnen niet aan een burger kumen worden tegengeworpen zolang een richtlin niet correct is omgeze. Blikens latere rechtspraak van het Hof moet deze regel worden verstaan in het licht van de specifiek omstandigheden die in deze zaak aan de orde waren, ${ }^{\text {is }}$ die tot gevolg hadden dat aan betrokkene elke mogelijkheid om haar aan het EG-recht ontleende rechten voor een nationale instantie geldend te maken was ontzegd. ${ }^{19}$ Widdershoven heeft in dit verband opgemerkt dat voor een succesvol beroep op dit arrest thans ook nodig is dat de overschrijding van de fatale termijn ${ }^{20}$ te wijten is aan misleidend gedrag van de overheid. Aldus treedt een frappante overeenkomst aan het licht met de grond die de Hoge Raad hanteerde voor het doorbreken van de formele rechtskracht in de arresten Heesch wam de Akker en Ekro-Staat. ${ }^{21}$

\subsection{HR 24 jannari 2003 (Maple)}

Op 24 januari $2003^{22}$ heeft de Hoge Raad een principiële uitsprak gedaun over de verenigbaarheid van het beginsel van de formele rechtskracht met het gemeenschapsrecht. De feiten vertonen het woor dit boek gebruikelijke beeld:

Maple en Game zijn exploitanten van speelgoedautomaten. Zij hebben over de jaren 1988 tot en mot 1990 , respectievelijk 1.988 tot en met 1992 op eigen aangifte onzetbelasting afgedragen. Deze belasting werd berekend aan de hand wan een op 6 januari 1988, bij mededeling van 18 juli 1988 aangevulde, resolutie van de Staatssecretaris van Financion. Deze resolutie strekte ter uitvoering van artikel 8 van de Wet op de omzetbelasting 1968 (Wet OB). Krachtens de reso-

16 HvJ EG 25 juli 1991 , zaak C-208/90, Jur. 1991, p. 1-4269; NJ 1994, 186; AB 1992, 1, w.ni. Meij; SEW 1992, p. 783 m.nt. Sewandono; TVVS 1993, p. 134 met comn. Mok

17 Zie hoofdstuk 4, par. 1.5 en 2.3.2.4.

18 Zie hoofdstuk 4, par. 2.3.2.4.

19 Zie in dil verband ook de conclusie van A-G Verkade voor HR 24 januari 2003, AB $2003,120 \mathrm{~m} . n \mathrm{C}$ Widdershoven.; JB 2003/44 m.nt E. v.d. Linden, die in dit verband verwijst naar de arresten Fantosk (HWJ EG 2 december 1997, Jurispr. 1997, p. \-6783; TVVS 1998, met comm. Mok) en de arresten Edis (Hvi EG 15 jull 1998, zaak C-231/96, Jur 1998, p. 1-4951), Spac (1-1vJ EG 15 september 1998, zaak C-260/96, Jur 1998, p. [-4997), Ansaldo (Hv] EG 15 septenter 1998, gevoegde zaken C$279 / 96, \mathrm{C}-280 / 96$ en C-281/96, Jur. 1998, p. 1-5025 en het arrest Roguente Freves (Hwl 28 november 2000 , zaak C-88\%9, Jur 2000, p. 1-10465).

20 Waardoor betrokkene in de onmogelijkheid verkeert zijn wit de te laat omgezette richtijn woortvloeiende rechten geldend to maken.

21 Zie hoofdstuk 2 , par. 2.3.

22 AB 2003,120 m.nt. Widdershoven.; JB 2003/44 mnt E. v. Linden. 
lutie werd de omzet bellasting op met de speclautomaten geleverde prestaties berekend aan de hand van de opbrengst van de automaten, berekend met een forfaitaire factor van 1,2 .

Op 5 mei 1994 heef het HvJ EG echter een arrist gewezen, ${ }^{23}$ warin lhet Hof, kort gezegd, heeft geoordeweld dat toepassing van voonoemde forfaitaire factor niet verenigbaar is met de Zesde BTW-richlin. ${ }^{24}$ Nar aanleiding van dit artest hebben zowel Maple als Game alsnog bezwar gemaakt tegen voomoemde heffingen. De besluiten waarbij deze bezwaarschriften vervolgens miet-ontwankelijk zijn werklaard, zijn in rechte onaantastbaar geworden. ${ }^{25}$

Maple en Game hebben zich vervolgens tot de burgerlije rechter gewend om alsnog terugave van de door hen ten onrechte afgedragen bellasting te bewerkstelligen. Daarbij zijn zij voor alle mogelijke ankers gaan liggen door hun vordering te baseren op, achtereenvolgens, onverschuldigde betaling, ongerechtvaardigde verrijking, onrechtmatige daad en strijd met de redelijkheid en billigheid.

Bij het voorgaande moet nog worden aangetekend dat de niet-ontvankelijkverklaring van de bezwaarschriften van Maple en Game was gebaseerd op een inmiddels door de Hoge Raad als belastingrechter gewezen witspraak. ${ }^{26}$ In deze procedure, die op dezelfde situatie zag als het hier besproken arrest, stond de wraag centraal of belanghebbenden, ondanks het overschrijden van de beroepstermijn, op grond van het arrest Emmott toch ontvankelijk moesten worden verklaard. De Hoge Raad was echter van oordeel dat het arrest Emmott niet op deze situatie wan toepassing is. Hij maakt daartoe een onderscheid tussen de omzetting van de Richtlijn in nationaal recht enerzijds, en de toepassing van de desbetreffende nationale bepaling anderzijds. Naar het oordeel van de Raad heeft de omzetting van de Richtlijn naar behoren plaatsgevonden in artikel 8 van de Wet OB. Dat de toepassing van de Richtlijn, die gestalte heeft gekregen in voomoemde, als een beleidsregel aan te merken, resolutie, niet met de Richtlijn verenigbaar was ook zou moeten leiden tot de conclusie dat nationale beroepsbepalingen niet aan belastingplichtigen zouden kunnen worden tegengeworpen, vindi naar het oordeel van de Hoge Raad geen steun in het nationale en communautaire recht. Anders gezegd: de hoogste belastingrechter acht in de achteraf gebleken onverenigbarheid van de Resolutie met het gemeenschapsrecht geen grond gelegen om een uitzondering te maken op het beginsel van de formele rechtskracht.

Als burgerlijke rechter ${ }^{27}$ komt de Hoge Raad in zijn uitspraak van 24 januari 2003 tot dezelfde conclusie. De Hoge Raad is allereerst van oordeel dat de in geding zijnde heffingen formele rechtskracht hebben verkregen, waartoe hij overweegt dat

"[...] in het kader van de in de Nederlandse rechtspraak ontwikkelde rechtsfiguur van de formele: rechskrach geen grond bestaat voor het maken wan een onderscheid tussen gevallen waarin de heffing achteraf in strijd blijkt te zijn met een hogete regeling van nationale herkomst ${ }^{28}$ enerzjis en gewallen waarin de heffing in strijd blijkt te zijn met een communautaire regeling anderzijods".

23 In zaak C-38/93, Glowte, Jur. 1994, p. I-1679.

24 Richtlign 77/388/EEG,PB 1977 , L 145.

25 Darbij noet worden aangetekend dat het beginsel van formele rechtskracht niet alleen bij de heffing van belasting bij wege van aanslag geldi,maar ook bij heffing van belasting bij wege van voldoening op eigen anginte; zie punt. 4.3 van de conclusie $A-G$ Verkade voor het hier besproken arrest.

26 HR 4 september 1996, BNB 1997, 43 m.nt. Finkenspier.

27 En restrechter!

28 Zie het in hoofdstuk. 2, par. 5.3 besproken arrest Vulhop (HR 16 oktober 1992, NJ 1993, 638 m.nt. Scheltema; AB 1993, 40m nt Van den Burg; Gst. 6962, 5, p. 165 m.nt. Hennekens). 
Onder verwijzing nat de hiervoor aangehaalde jurisprudentie van het HWJ EG is de Hoge Raad woonts van oordeel dat het gemeenschapsrecht er in deze zaak niet toe noopt een uitzondering te aanvaarden op het beginsel van de formele rechtsinach. De Hoge Raad concludeert

"dat het in het Nederlandse besturursecht geldende stelsel van algemene temijnen voor bezwaat" en beroep, dat zonder onderscheid naar de zuiver nationale of (mede)gemeenschapsrechtelijke aard van het geschil wordt toegepast, niet in strijd is met het gemeenschapsrecht, omdat het de witoefening van de door het gemeenschapsrecht verleende rechten in de praktijk niet onmogelijk of unterst moeilijk maakt. In overeenstemming hiemee heeft de Hoge Raad in zijn anest van 21 maart $2001, \mathrm{BNB} 2001 / 38$, geoordeeld dit redelijkerwijs niet voor twijel vatbaar is dat de voor het gehele bestuursrecht geldende unifome bezwartermijn wan zes weken een redelijke ternijn is, in die zin dat daardoor de uitoefening van (mede) op het gemeenschapsrech gebaseerde vorderingen niet praktisch onmogelijk wordt gemaakt.

[...] Evenmin voor redelijke twijfel vatbaar is dat de in Nederland ontwikkelde rechtsfigutur van de formele rechtskracht in een geval als het onderhavige niet in strijd is met het gemeenschapsrecht. Deze rechtsfiguur houdt, voorzover thans wan belang, immers in wezen niet meer in dan dat de burgerlijke rechter, indien in een woor hem aanhangig geding de geldigheid van heffing van omzetbetasting in geschill is, in de eerste plaats onderzockt of de belastingheffing wegens het niet of niet tijdig dan wel zonder succes aamwenden van de daartegen openstaande rechtsgang onherroepelijk vaststaat. Indien dat laatste het geval is, dient de burgerlijke rechter ervan uit te gaan dat de heffing zowel wat haar wijze van tot stand komen als wat haar inhoud betreft in overeenstemming is met de desbetreffende wettelijke voorschiften en algemene rechtsbeginselen. In zoverte bestaat geen verschil met de siluatie waarin de belastingrechter zelf bevoegd zou zijn te oordelen niet alleen over de rechtmatigheid van de heffing maar ook over een wordering tot terugbetaling van ten onfechte geheven belasting, in welke situatie, naar in het licht wan bet hiervoor [...] overwogene moet worden aangenomen, het handhaven van de termijn voor het aanwenden van een rechtsmiddel hiet in strijcl met het gemeenschapsrecht is. Ev is geen reden anders te oordelen woor de hier te lande bestaande situatie waarin de beoordeling vala de rechtmatigheid van de belastingheffing bij de belastingrechter en de beoordeling van de vordering tot terugbetaling van ten onrechte geheven belasting bij de burgerlijke rechter is ondergebracht, welke situatie aanleiding heeft gegeven tot de ontwikkeling van het stelsel. van de formele rechtskracht?

Opvallend is dat de Hoge Raad zich in geheel algemene zin uitspreekt over de verenigbaarheid van de in het Nederlands stelsel geldende termijnen voor bezwar en beroep net het gemeenschapsrecht. Naar het oordeel van de Hoge Raad kunnen deze door de communautaire beugel, ondat ze niet discrimineren nar louter nationale vorderingen en vorderingen die (mede) op het gemeenschapsrecht zijn gebaseend, terwijl de algemeen geldende bezwaartermijn van zes weken vanuit het oogpun van het doeltreffendheidsbeginsel voldoende wordt geacht.

Verder valt op dat de Hoge Raad, ter beoordeling van de vraag of het beginsel van de formele rechtskracht als zodanig verenigbaar is met het gemeenschapsrecht, een vergelijking maakt met de (naar Nederlands recht hypothetische) situatie waarin de belastingrechter zelf bevoegd zou zijn te oordelen over zowel de rechtmatigheid van de heffing als de vordering tot terugbetaling van de heffing. De redenering van de Hoge Raad is kemeljk dat, nu op grond van voomoemde jurispnidentie van het HvJ EG moet worden 
aangenomen dat het hanteren van de door de Awb voorgeschreven bezwaartemijn van zes. weken niet leidt tot schending van het gemeenschapsrecht, zulks evenmin het geval is woor de in Nederland geldende situatie waarin de beoordeling van de rechmatigheid van de heffing en wan de vordering tot terugbetaling in handen van verschillende rechters is gelegd.

In de laatste zinsnede van de geciteerde overweging wijst de Hoge Raad erop dat juist in deze verdeling van rechtsmacht over de bestuursrechter en de burgerlike rechter de ratio voor de ontwikkeling van de rechtsfigur van de formele rechtskracht is gelegen. Doel is te komen tot een goede takverdeling tussen de burgerlijke en de administratieve rechter. ${ }^{31}$ Tegen deze achtergrond is de conclusie wartoe de Hoge Raad komt wolkomen begrijpelijk. Toch roept de uitspraak nog wat vragen op. De Hoge Raad stelt bij de bespreking wan de cassatiemiddelen voorop dat het in deze zaak gaat om de vraag of de in geding zijnde heffing van omzetbelasting formele rechtskracht heeft gekregen en zo ja, of op het beginsel van de formele rechtskracht voor dit geding aen uitzondering moet worden gemaakt. Naar het mij voorkomt heef de Raad de eerste vraag in de hiervoor aangehaalde rechtsoverweging 3.4 .5 bevestigend beantwoord. De verwolgens in rechtsoverweging 3.6 .1 opgeworpen vraag of het gemeenschapsrecht voor het onderhavige geval dwingt tot een uitzondering op het beginsel van de formelle rechtskracht beantwoordt de Raad in de overwegingen 3.6 .4 en 3.6 .5 in geheel algemene zin, onder verwijzing naar de aanvaardbaarheid van de niet-discriminerende en in het licht van het gemeenschapsrecht redelijke lengte van de bezwaar-en beroepstermijnen en de ratio van het beginsel van de formele rechtskracht in verband met de voor Nederland kenmerkende verdeling van rechtsmacht over de bestuursrechter en de burgerlike rechter. Genoemde overwegingen kunnen mijns inziens dan ook moeilijk anders worden werstaan dan dat het gemeenschapsrecht in algemene zin geen aanknopingspunten biedt voor een andere dan de reeds uit rechtsoverweging 3.4 .5 voortvloeiende conchusie dat het beginsel van fomele rechtskracht eveneens geldt voor op het gemeenschapsrecht gebaseerde vorderingen. Uit het arrest valt echter niet af te leiden of ten aanzien van op het gemeenschapsrecht gebaseerde vorderingen ook dezelfde specifieke gronden gelden die in het Nederlandse recht zijn ontwikkeld voor het in een incidenteel geval aannemen van een uitzondering op het beginsel wan de formele rechtskracht. Zoals hiervoor al een aantal mallen ter sprake is gekomen, is naar Nederlands recht voor het aanmemen van een dergelijke specifieke uitzondering in het bijzonder aanleiding als het aan de overhaid is toe te rekenen dat betrokkene niet, dan wel niet tijdig, gebruk heeft gemakt van de voor hen aangewezen administratieve rechtsgang ${ }^{32}$. Hoewel dit niet met zoveel woorden uit het hier besproken artest van 24 januari 2003 is af te leiden, jijkt het me, gelet op de strekking van het arrest, onwaarschijnlijk dat voor op het gemeenschapstecht gebaseerde vorderingen een rumer regime voor het aannemen van specifieke uitzonderingen op het beginsel van de formele rechtskracht zal gelden dan voor louter op national recht gestoelde vorderingen. Een extra aanwijzing hierwoor is dat thans ook aan het arrest Emmot ${ }^{3 /}$ de betekenis wordt toegedacht dat voor doorbreking van de fomele rechtskracht van op onjuiste dan wel niet tijdige omzetting van EG-richtlijnen gebaseerde Liguor) en HR 27 mei 1994. N11997, 158 (Sprangers/Stat).

32 Zie in dit verband hoofdstuk 2, par. 2.3. Zie voots HR 14 mei 1993, NJ 1993, 641 m.nt. MS.

33 Dat, zoals is gebleken, op het onderhavige arrest net wan toepassing is. 
vorderingen alleen aanleiding is als de betrokkene door het desbetreffende overheidsorgaan voor wat de beschikbare rechtsmiddelen betreft op het verkeerde been is gezet. Van dit laatste was naar het oordeel van de Hoge Raad in deze casus geen sprake, nu hij, naar aanleiding van het betoog van Maple en Game dat er in hun geval aanleiding was om een uitzondering te maken op het beginsel van de formele rechtskracht, ondat zij aan de resolutie het vertrouwen hadden mogen ontlenen dat de heffing van belasting zou stroken met de terzake geldende (hogere) rechtsregels overweegt dat

"de omstandigheid dat aan de overheid is toe te rekenen dat de belastingplichtige niet tijdig gebruik heeft gemaakt van zijn recht op beroep op de belastingrechter, [grond kan] zijn voor het aannemen van een uitzondering [op het beginsel van de formele rechiskiracht]. Daarvan is echter geen sprake in het zich hier voordoende geval dat de belastingdienst op grond van een achteraf onjuist gebleken uitleg van het bepaalde in de Zesde Richtlijn meer belasting heft dan bij een juiste uitleg van de richlijin het geval zou zijn?"

waarna de Hoge Raad oordeelt dat het de belastingplichtige in een dergelijk geval vrijstaat gebruik te maken wan de openstaande mogelijkheid van bezwaar en beroep tegen de heffing en van hem mag worden verwacht dat hij, teneinde te voorkomen dat de onstreden heffing onherroepelijk wordt en formele rechtskracht verkrijgt, daarvan ook inderdaad gebruik maakt.

\subsection{Breuken in het bastion?}

\subsubsection{Inleiding}

In zijn conclusie woor het hier besproken anrest kwam A-G Verkate na een analyse van het beginsel van formele rechtskracht tegen de achtergrond van het nationale recht tot de kernachtig geformuleerde slotsom dat

"een uitzondering op de formele rechtskracht wegens een aan de overheid toe te rekenen mietgebruik maken door de belastingplichtige van administratieve procedures, in de rechtspraak van de Hoge Raad kan worden aangenomen indien door de overheid veroorzaakte onduidelijkheid bestond over de mogelijkheid van een administratieve procedure; maar dat het beroep op de uitzondering, als regel, niét opgaat ingeval van onduidelijkheid over het materiële recht oftewel over het succes van zo'n procedure'.

Blijkens de voorgaande paragraaf lijkt woor zaken met europeesrechtelijke aspecten een zelfde conclusie te mogen worden getrokken. Toch blijft enige voorzichtigheid geboden. Allereerst is het van belang nogmaals te benadrukken dat de uitspraak van de Hoge Raad alleen dan steun vindt in de Europese rechtspraak, als er sprake is van toepassing van algemene bezwaar-, beroeps- of verjaringstermijnen van cen redelijke duur. ${ }^{34}$ Is er echter sprake van specifieke wettelijke maatregelen waardoor de aan het gemeenscliapsrecht ontleende rechten in de praktijk weer ongedaan worden gemaakt, dan acht het Hof wel strijd

34 Aan de lengte van de temign lijkt het Hof, gelet op de voorgaande paragrat, geeld strenge eisen te stellen. Zie reeds het voornoemde arrest in de zaken Rewe en Comet (HVJ EG 16 december 1976, zaken $33 / 76$ en $45 / 76$, Jur. 1976, p. 1989; SEW 6 (1977), p. 466-473, m.nt. Van Dijk), warin het Hof akkoord ging met de termign van 30 dagen voor het aanhangig maken van hei beroep bij hei College van Beroep voor thet Bedrijfsleven en, voor een recent voorbeeld: HvJ 12 december 2002 zalak C-40/99, Unversale-Baw, Jur. 2002, p. I-11617, waarbij het Hot zelfs akkoond ging met een termijn van twee weken. 
met het $\mathrm{EG}$-recht aanwezig," zoals uit het in hoofdstuk 4 besproken arrest Roks voor wat de Nederlandse AAW-problematiek reeds bleek. Een zelfde lot treft nationale regels, die, hoewel niet specifiek gericht op het al dan niet gedeeltelijk ontnemen van aan het gemeenschapstecht ontleende rechten, de uitvoering hiervan onmogelijk of zeer moeilijk maken. $^{36}$

\subsubsection{CBB 1 november 2000 (Kihne en Heitz)}

Maar ook overigens blijkt het beginsel van de formele rechtskracht nog kwetsbare kanten te vertonen in het Jicht wan de doorwerking wan - in het bijzonder - europeesrechtelijke rechtsnormen. Zo bilikt wit de mu te bespreken uitspraak van het College van Beroep voor het Bedrijfsleven (CBB) van 1 november $2000^{37}$ dat het beginsel mogelijk aan erosie onderhevig is onder invloed van uit het EVRM voortwloeiende rechtstatelijkheidsvereisten en het in artikel $10 \mathrm{EG}$ opgenomen beginsel van gemeenschapstrouw.

Kulne \& Heitz NV (hierna: de NV) houdt zich onder meer bezig net de witwoer wan plumveeprodukten. In de periode wan december 1986 tot en met december 1987 heeft de NV bij het Productschap voor Pluimvee en Eieren (hierna: het Productschap) meerdere malen aangifte gedaan van uitvoer van hoeveelheden plumveedelen, met bestenming derde-landen. Bij deze aangiften heef de $N V$ tokenmale de uitgevoerde goederen aangeduid als vallende onder een bepaalde post van het Gemeenschappelijk Douane Tarief en verzocht om toekenning van de bij deze post belhorende restituties bij uitvoet.

Nadal het Productschap aanvankelijk overeenkomstig de verzoeken wan de NV tot uitkering van de restitutie was overgegalan, heef zij deze bij besluit van 1 maart 1990 teruggevorderd tot een bedrag van $f 970.950,98$, omdat van (een deel wan) de uitgevoxrde pluimvee-produkten was gebleken dat deze onder een onjuiste post waren ingedeeld. Bij besluit van 13 december 1990

$35 \mathrm{Vgl}$. in dit verband de door A-G Verkade in zijn conclusie voor HR 24 januan 2003 (Maple) aangehaalde zaken Bara (HvI EG 2 februari 1988, zaak 309/85, Jur. 1988, p. 355): strijd met het doeltreffendheidsbeginsel in geval van een nationale bepaling die specifiek betrekking had op betalingen die door het HWJ EG in strijd of onverenigbaar met het gemeenschapsrecht waren verkllaard en aan de tenggaaf daarvan voorwaarden verbond die ongunstiger waren dan die welke anders zouden zijn toegepast; Marks de Spencer (Hu EG 11 juli 2002, zaak C-62/00, Jur. 2002, p. I4483; SEW 12 (2002), p. $479-480 \mathrm{~m}$ nt. Swinkels): wettelijke regeling die met terugwerkende kracht de termijn verkort waabinnen kan worden verzocht on teruggaaf van BTW-betalingen die in strijd met EG-recht waren gënd, aangezien niet voorzien was in een, ook krachtens het rechtszekerheidsbeginsel, geboden overgangsregeling (vgl. in dit verband tevens de in hoofdstuk 4, par. 2.3.2.4 besproken arresten Roks (HvJ EG 24 februari 1994, zaak C-343/92, Jur p. 1-571; RSV 1994214) en Steenhorst-Neerings (HWJ EO 27 oktober 1993, zaak C-338/91, Jur. 1993, p. 1-5475; RSV 1994/211, m.nt F.W.M. Keunen.

36 In dil verband kan gewezen worden op de artesten FMC (Hv. EG \& februari 1996, Jurispr. 1996, p. I389): nationale regel volgens welke een ingevolge rechtsdwaling betaald bedrag slechts kan worden teruggevorderd indien die betaling onder voorbehoud van alle rechten is geschied in strijd met het doeltreffendheidsbeginsel; Fantask (HVJ EG 2 december 1997, Jurispr. 1997, p. 6783; TVVS 1998. met comm. Mok): algemeen rechtsbeginsel van nationaal recht op grond waarvan rechterlijke instanties van een lidstat vorderingen tol betaling wan in strijd met het gemeenschapsrecht geheven rechten moeten afwijzen wanneer die rechten lange tijd zijn geheven zonder dat de overheid van die lidstaten of de belastingplichtigen zich van die onrechtmatigheid bewust waren; Di-export (Hw) 9 februari 1999, zaak C-343/96. Jur. 1999, p. 1-579 (strijd met het doeltreffendheidsbeginsel in geval van strikte bewijswoorschriften die terugvordering van in strijd met het gemeenschapsrecht geheven douanerechten en heffingen in de praktijk uiterst, moeilijk maakten).

37 JB 2000935 m.nt E. van der Linden; AB 2001, 32, m.nt. J.H. van der Veen; NTER 200 1, p. $29-35$ m.nt. M. de Jong. 
heeft het Productschap het door de NV tegen voomoemd bestuit gemaakte bewwar ongegrond verklaard, waarna de NV bij het CBB beroep heef ingesteld.

Bij witspraak van 22 november 1991 heet het CBB het beroep ongegrond werklaard. Nam het oordeel van het CBB had het Productschap de restitutie destijds ten onrechte toegekend an konden in de jurisprudentie van het HVJ EG geen aanknopingspunten gevonden worden om tot een ander oordeel te kometn.

Op 5 oktober 1994 heeft het HwJ EG arrest gewezen in een soortgelijke zaak, "3a waanit alsnog bleek dat het Productschap van een onjuiste indeling was uitgegaan. De NV heef zich hierop bij brieven van 13 december 1994 en 3 januari 1995 tot het Productschap gewend met een weetal werzoeken. Deze betroffen: (a) de kosten terzake van de haars inziens ten onrechte teruggevorderde restitutie en (b) een bedrag terzake van het meedere dat zij zou hebben ontvangen indien de na december 1987 uitgevoerde pluirmvee-onderdelen onder de naar het oordeel van het Productschap uit het arrest Voogd volgende tariefpost zouden zijn ingedeeld.

Op het eerste gezicht lijken de feiten in essentie niet anders dan die in het hiervoor besproken arrest van de Hoge Raad in de zaak Mople, evenwel met dit verschil dat de bedrijven in de zaak die voor de Hoge Raad diende voordat de (nieuwe) rechtspraak van het HvJ EG bekend werd hadden berust in de hum opgelegde heffingen, terwijl de NV de in de CBB-zaak in geding zijnde terugvordering meteen had aangevochten, maar daarbij, naar achteraf blijkt ten onrechte, nul op het rekest had gekregen. Dit verschil zal, naar uit het hiema volgende zal blijken, gevolgen hebben.

Voor wat betreft de lotgevallen van het tweede verzoek, dat - kort gezegd - zag op vergoeding van de schade die de NV heeft geleden door ook in de perioden na december 1987 met een onjuiste tariefpost-indeling te zijn geconfronteerd, bevat de hier te bespreken uitspraak van het $\mathrm{CBB}$ weinig nieuws. Naar het oordeel van het $\mathrm{CBB}$ stat het beginsel van de formele rechtskracht eraan in de weg dat de rechtsgeldigheid van de aan de na december 1987 verleende restituties ten grondslag liggende besluiten alsnog, met een beroep op het arrest $V o o g d$, zouden kunnen worden aangetast, omdat de NV tegen deze besluiten geen rechtsmiddelen had ingediend, zodat deze in rechte waren komen vast te staan. Het CBB toont zich niet gevoelig voor het argument van de NV dat het instellen van beroep, gelet op voornoemde uitspraak van het CBB van 22 november 1991, volstrekt kansloos zou zijn geweest. Zo overweegt het CBB dat

'het enkele feit dat uit latere rechtspraak blijki dat een beroep succesvol zou zijn geweestwaarbij het college overigens uitdrukkelijk in het midden laat of dat in dit gewal daadwerkelijk zo zou zijn geweest - verweerder [uiteraard niet verplicht] on op zijn beslissingen terug to komen; zulks zou de bijl zijn aan de wortel van woormeld beginsel, ${ }^{30}$ warvan de functie immers is dat in een situatie als vooromschreven, beslissingen die niet aangevochten zijn, hun rechtskracht behouden, hoe onjust deze beslissingen achteraf gezien wellicht ook waren". (mijn cursivering, RB)

Van omstandigheden die zo klemmend zijn dat op het beginsel van formele rechtskracht een uitzondering zou moeten worden gemaakt, is volgens het CBB evenmin gebleken, waartoe het overweegt dat het naar zijn oordeel

38 HwI EG 5 oktober 1994, zark C-151/93, Voogd, Jur. 1994, p. I-4915.

39 Door hel CBB eerder onischrewen als 'het beginsel, dat beschikkingen die niet binnen de beroepstermijn zijn aarngewochten door degenen tot wie zij zich richten, to diens aanzien definitief worden". 
"net woor tot prejudiciele verwizing nopende twijfel vatbarar [is], dat ook het gemeenschapsrecht hiertoe niet dwingt. Het college overweegt in dit verband thet name nog dat de uitoefening vain rechten die voortwoeien wit het Europese recht, appellante geenszins onmogelijk is gemaakt. Dat heeft zij nagelaten en dient woor haar rekening en risico te bliven".

Het belang van de witspraak is in het bijzonder gelegen in het oordeel van het CBB over het eerste verzoek, het verzoek dat betrekking heeft op de terugbetaling van de in het licht van het arrest Voogd (mogelijk) ten onrechte teruggevorderde restitutie-bedragen. Het standpunt van de NV komt er - voorzover hier van belang - op neer dat het arrest Voogd. in het bijzonder gellet op het feit dat de hierin gelegen interpretatie van het Hof terugwerkende kracht toekomt, beschowwd moet worden als aen nieww feit of omstandigheid als bedoeld in artikel 4:6 van de Awb, op grond waarvan verweerder gehouden was de terugvordering ongedaan te maken. Het Productschap heeft hiertegen aangevoerd dat de in geding zijnde terugwordering met de uitsprak van het $\mathrm{CBB}$ van 22 november 1991 formele rechtskracht heeft gekregen en heeft voorts aangegeven evenmin op beleidsmatige gronden bereid te zijn tot terugbetaling over te gaan. Uit het betoog van het Productschap valt voorts af te leiden dat het van oordeel is dat de NV veeleer was angewezen op een mogelijke herziening van de uitspraak van het $\mathrm{CBB}$ van 22 november 1991 . Na voorop te hebben gesteld dat het eerste verzoek van het Productschap wordt aangemerkt als een verzoek om terug te komen van het besluit van 13 december 1990 tot instandlating van de terugwordering van de restitutie, welk besluit bij zijn uitspraak van 22 november 1991 in stand was gelaten, maakt het CBB als volgt korte metten met de argumentatie van het Productischap. Het CBB is van oordeel dat

"naar Nederlands recht [er] geen rechtsregel [aan] in de weg [staat] dat een bestuursorgaan uerugkont op door hem genomen beslutten, die naar finternationaal recht definitief zijn geworden, zelfs miet indien er geen miew gebleken feiren of weranderde onwandighedew (nova) zijn. In lijn hiemee biedt art. 4:6 Awb een bestuursorgaan de nogelijkheid een nieuwe aanvraag on een beschikking bij gebreke van nova op eenvoudige wijze af te doen, maar verplicht het hiertoe niet. Naar Nederlands recht heeft een bestuursorgaan derhalve in beginsel steeds de bevoegdheid on terug te komen op een beslissing die definitief is geworden; in beginsel, ondat uiteraard aan de belangen van derden niet tekort mag worden gedaan. Het bestaan wan een dergelijke bevoegdheid impliceent [...] dat onder omstandigheden ook een verplichting tor terugkomen kan bostran. Verweerder heefl een en ander niet onder ogen gezien bij de beslissing op het eerste verzock nu hij zich op het standpunt heef gesteld dat uitslutend herziening door het college van de uitspratk van 22 november 1991 eventueel aan de orde zou kumen zign. Dit standpunt van werweerder is evenwel onjuist ondat geen rechtsregel er aan in de weg staat on in plaats van herziening aan de rechter te verzoeken, aam het bestursorgaan dat het besluit heeft genonen dat de loets der rechtelijke kritiek heeft doorstan, te verzoeken daarop terug te komen". "(mijn cursivering, RB)

Op grond van deze overwegingen is het $\mathrm{CBB}$ van oordeel dat het Productschap bij de beoordeling van het eerste verzoek is uitgegaan van een onjuiste rechtsopvatting. Het CBB ziet vervolgens aanleiding te onderzoeken of het Productschap ook verplicht moet worden

40) In welk verband het CBB nog verwijst het arest wan het $\mathrm{HW}$ EG van 14 september 1999 , zaak C310/97, Commissie/Assi-Doman Krofl Products AB, Jur. 1999. p. 1-5363.

41 Waaman het CBB nog toevoegt dat in de memorie van toelichting bij de herzieningsparagraal van hoofdstuk 8 Awb als alternatief voor het vragen van herziening zelfs unddrukkelijk is gewezen op de mogelijkheid het bestuur te vragen terug ke komen op zijn besluit. 

volgende:

'Of een dergelijke verplichting bestaat, hangt af wan het gewicht dot in dit geval noer wordent roegekend aon niewwe ontwikkelingen in de rechtspraak Uitgangspunt is, [...], dat rechtsproal die van latere datum is dan een beshit dat definitief is geworden, op zichzell geen afbreuk kan doen aan het definitieve karakter van dat besluit; ook niet indien, zoals voor de prejudiciele uitspraak van het Hof geldt, deze rechtspraak een rechtswaststellend karakter draagt en het recht zoals dat door het Hof is vastgesteld derhalve moet worden geacht vanaf de inwerkingtreding wan het witgelegde voorschrift zo te hebben gegolden, tenzij het Hof witdrukkelijk anders heeft bepaald. Een opvatting, inhoudende dat besluiten die definitief zijn geworden, als regel wel in overeenstemming met latere - communautaire - rechtspraak zouden moeten worden gebracht, zou le den tot administratieve chaos en tot emstige aantasting wan de rechtszekerheid en kan derhalve niet worden aanvaard.' (mign cursivering, RB)

Tot zover niets nieuws. Het grote belang van de uitspraak voor dit onderzoek ligt echter in de volgende overwegingen warin het $\mathrm{CBB}$ uiteenzet dat in het wotionole recht niettemin wordt aanvaard dat latere rechtspraak onder omstandigheden wel consequenties behoort te hebben voor zaken die zijn uitgeprocedeerd. Het CBB wijst hierbij 'slechts bij wijze van illustratie' op het arrest van de Hoge Raad in de zaak Kostowk " dat betrekking heeft op de consequenties voor strafzaken van uitspraken van het EHRM. In dit arrest heeft de Hoge Raad onder meer overwogen:

'In het wettelijk stelsel ligt besloten dat een veroordelende beslissing van de strafrechter wartegen geen gewoon rechtsmiddel meer openstat, niet alleen mag maar ook moet worden ten uitvoer gelegd. Voorts is het onverenigbaar met het gesloten stelsel van rechtsmiddelen in strafzaken dat een veroordeelde de gellegenheid zou hebben langs de weg van een vordering tegen de Staat op grond van art. $1401 \mathrm{BW}^{43}$ de juistheid van de beslissing van de strafrechter of de atuvaardbaarheid van de procesgang die tot de beslissing heeft geleid, tot onderwerp van een nieuw geding te maken en door de burgerlijke rechter te doen toetsen.

In aanmerking genomen de uit de art. 1,5 en 13 EVRM voortwloeiende verplichtingen tot hat verzekeren van de in art. 6 EVRM neergelegde rechten en tot het voorzien in een recours effectif/effective remedy" in geval wan schending van die rechten, moet echter op voomelde regels een uitzondering worden aanwaard ingeval een uitspraak wan het Europese Hof, waarmee de strafrechter bi zijt beslissing geen rekening heeft kunnen houden, noopt tot de slotsom dat die beslissing tot stand is gekomen op een zodanige wijze dat niet meer kan worden gesproken van een eerlijke behandeling van de zaak in de zin van art. 6 lid I eerste zin EVRM. Wanneer zich en dergelijk uitzonderingsgewal voordoet, kan onverkorte tenuitvoerlegging van de beslissing niet meer krachens het wetrelijk stelsel begetaten worden beschourd en zal de veroordeelde zich kumnen wenden tot de president in kort geding met een vordering strekkende tol naar gelang de omstandigheden - het verbiedem, onderbreken, of beperken van de executie." (mijn cursivering, RB)

Waarna het $C B B$ de volgende parallel legt met deze overwegingen van de Hoge Raad:

'Zoals de Hoge Raad een later blijkende schending van hat fundamentele recht, vervat in art. 6 EVRM, een doorslaggevende reden acht om de tenuitvoerlegging van een onherroepelijke stralrechtelijke veroordeling aan te tasten en daarmee afwijkt van het uitgangspunt dat latero rechtspraak de (gevolgen wan) hieraan voorafgaande rechtspraak onvorlet laat, zo rijst de vraag of in een geval als het onderhavige, warin appellante een uitputtend gebruik heef gemaakt van 
de haar ten dienste statande rechtsmiddelen [...] en waarin het college op een bepaald punt een uitleg wan hot Europese recht heef gegeven, die vervolgens blikt af te wijken van de bij een later arrest van het Hof gegeven uitleg, niet het definiticve karakter van de beshitvorming moet worden doorbroken." (mijn cursivering, RB)

Het CBB acht thierbij tevens van belang dat het, naar achteraf moet worden wastgesteld, in 1991, bij zijn eerdere uitspraak, zijn uit artikel $234 \mathrm{EG}$ voortvloeiende rechtsplicht heeft geschonden door na te laten zich tot het HvI EG te wenden met een verzoek om uitleg van de in geding zijnde tariefbepalingen. Tenslotte acht het $C B B$ van belang dat de NV meteen na het bekend worden van het arrest Voogd actie heef ondemomen.

Het CBB beshit zijn uitspraak met de overweging dat de probleemstelling in deze zaak naast voonoemde nationaalrechtelijke $\mathrm{kant}^{4-4}$ tevens een belangrijk communautair aspect kent in welk verband het de vraag opwerpt of:

"de effectieve en volledige werking van het gemeenschapsrecht [vereist] dat in een geval als het onderhavige het definitieve karakter wan een besluit wordt gerelativeerd".

Waarna het $\mathrm{CBB}$ de zaak terugbrengt onder de noemer van artikel 4:6 van de Awb door te overwegen dat:

"toegespitst op de positie van verweerder, wiens besluit immers ter toetsing door het college voorligt, [...] de vraag [rijst] of het gemeenschapsrecht, waarbij met name valt te denken alan het in art. 10 EG vervatte beginsel van de gemeenschapstrouw, meebrengt dat een bestuursorgaan verplich is om in de omstandigheden wan dit geval, zoals hierwoor beschreven en gepreciseerd, terug te komen op een beslissing die definitief is geworden, teneinde de wolle werking van het gemeenselhapsrecht, zoals dit blijkens het antwoord op een latere prejudiciele werwijzing behoort te worden uitgelegd, te verzekeren'. (mijn cursivering, RB)

en besluit een daartoe strekkende prejudiciële vraag aan het HvJ EG voor te leggen. ${ }^{45}$ Dit is een in menig opzicht opmerkelijke uitsprak. Allereerst maakt het CBB, naar mijn mening terecht ${ }^{46}$ onderscheid tussen, enerzijds, de bevoegdheid om op een in rechte onaantastbaar geworden besluit ${ }^{47}$ terug te komen als zodanig, ${ }^{48}$ en, anderzijds de uit artikel 4:6 van de $A$ wb voortvloeiende bevoegdheid om een verzoek om terug te komen van een definitief besluit bij gebreke van nieuw gebleken feiten en omstandigheden (nova) vereenvoudigd af te doen. Verder doet de uitspraak op zijn minst het vermoeden rijzen dat het $\mathrm{CBB}$ bij de beoordeling van de vaag of het bestuursorgaan heeft mogen afzien gebruik te

44 Die blijkens de angehaulde overwegingen sterk is "ingekleurd' door de doorwerking van rechtstreeks werkende bepalingen wan het EVRM.

45 Vermeulen heeft er mijns inziens terecht op gewezen dat bij deze vraag in wezen aan de orde wordt gesteld of in de zaak Kahne \& Heitu de effectuering van de aan het gemeenschapsrecht ontleende rechten uiterst moeilijk of praktisch ommogelijk is gemaakt door het feit dat men tot in hoogste instantie vruchteloos heeft geprocedeerd tegen de terugvordering van de restitutie en het desbetreffende bestuursorgaan vervolgens heeft geweigerd terug te komen op het onalantastbaar geworden besluit, dus on een waag die betrekking heeft op het effectiviteitsvereiste; Zie EM. Vermeulen, a.w. $($ noot 12), p. 12

467 Zie hoofdstuk 2, par. 4.5. Voor een iets andere benadering zie Nico Verheij in zijn noot onder Hvl 13 januari 2004, JB 2004/42, die erop wijst dat een bestuursorgaan naar Nederlands recht altijd bevoegd is on een besluit ${ }_{0}$ onherroepelijk of niet, te heroverwegen, maar niet altijd om op dit besluit terug te komen.

47 Door her CBB aangemerkt als een "definitief besluit".

48 Hiem, evenals in hoofdstuk 2, ook wel aangeduid als "de therzieningsbevoegdheid". 
maken van zijn bevoegdheid om terug te komen van een definitief besluit een rumer toetsingskader ${ }^{49}$ hanteert dan de Afdeling bestuursrechtspraak van de Raad van State en mogelijk ook de Centrale Raad van Beroep. Het gaat daarbij niet om de vraag of het bestuursorgaan in het algemeen bevoegd kan worden geacht van een definitief beshuit terug te komen - dit beginsel vindt bij alle drie de rechtscolleges erkenning - maar veeleer om de vraag welke toetsingsruimte nog voor de rechter is weggelegd als het bestuursorgaan besloten heeft niet van zijn bevoegdheid gebruik te maken. ${ }^{5 i}$ Zoals in hoofdstuk 2 al ter sprake is gekomen ${ }^{51}$ is deze toetsingsruimte volgens de Afdeling zeer beperkt, nu de rechter zich naar haar oordeel heeft te beperken tot de vraag of het bestuursorgaan terecht heeft geoordeeld dat niet van nova is gebleken. Bovendien blijkt uit de jurisprudentie van de Afdeling dat een zich na een definitief besluit voltrokken verandering in jurisprudentie niet als novum kan worden aangemerkt. De jurisprudentie van de Centrale Raad van Beroep leek weliswaar een wat andere sfeer te adennen, in die zin dat de Raad het bestuursorgaan tot voor kort onder omstandigheden ook gehouden acht gebruik te maken van zijn bevoegdheid terug te komen op een definitief besluit, als dit als apert onjuist moest worden aangemerkt, ${ }^{52}$ maar, naar in hoofdstuk 2 is gebleken, ${ }^{5,3}$ heeft de Raad een dergelijke aperte onjuistheid niet aangenomen in gevallen waarin achteraf is gebleken dat het besluit waarvan herziening is verzocht onverenigbaar is met fundamentele rechtsbeginselen. Zoals eerder is aangegeven, ${ }^{54}$ hanteert de Centrale Raad van Beroep thans echter de lijn dat een bestuursorgaan alleen dan bevoegd kan worden geacht terug te komen van eerdere ambtshalve genomen besluiten als bij het daartoe strekkende verzoek nieuw gebleken feiten of veranderde omstandigheden worden vermeld die zulk een terugkomen rechtvaardigen. ${ }^{55}$ Daarmee is de Raad teruggekomen van zijn jurisprudentie dat een dergelijke bevoegdheid ook zou bestaan in geval van aperte onjuistheid van het eerdere besluit. Blijkens de hier besproken uitspraak ziet het CBB in een mogelijke strijd mer de gemeenschapstrouw nu juist wel aanleiding te onderzoeken of het bestuursorgaan verplicht ${ }^{56}$ is te achten gebruik te maken van zijn herzieningsbevoegdheid.

Volgens vaste jurisprudentie van het CBB dient in dit verband te worden beoordeeld of het bestuursorgaan bij afweging van alle in aanmerking komende belangen in redelijkheid heeft kunnen besluiten niet op het besluit terug te komen. Aan dat criterium is nier voldaan indien sprake is van een kennelijk misslag of van juist bevonden feitem die het bestunisorgaan bij het nemwn van het onherroepelijk besluit niet kende en die van dien aard zijn dat zij, zou het bestursorgaan deze toen wel hebben gekend, in redelijkheid tot een ander besiluit hadden behoren te leiden, Voorts wetst thet CBB in cen dergelijk geval of de weigering teng te konnen op een besluit anderszins in strijd komt met enig algemeen beginsel van behoorlijk bestum, zie CBB 6 augustus 1996, JB $1996 / 219$ m.nt. E. v.d.L. en woorts: E.M. Vermeulen, a.w. (noot 12), p. 11.

50 Verwijzen naar waste jp van ABRS en CRvB.

51 Hoofdstuk 2, par. 4.4 .

52 Zie hieromtrent tevens: E.M. Vermeulen, a.w. (noot 12), p. 9-19, die er voonts wijst op CRvB 16 augustus 2000, RSW $2000 / 243$ voor een (zeldzaani) geval waarin de CRvB het bestuursorgatui wegens het apert onjuist zijn van het eerdere, in rechte onaantastbaar geworden, beslut tot herziening verplicht achitte, omdat het niet ongedan maken van dat besluit in stijd zou komen met artikel $3: 4$, tweede lid, van de Awb.

53 Zie Hoofdstuk 2, par. 4.5 .

54 Hoofdstuk 2 , par. 4.4 .

55 Zie, onder meer, CRvB 6 nowember 2003 , RSV 2004/87; JB 2004/29, m. nt. E. van der Linden.

Zie voor een algemeen besturursechtelijke onderbouwing van een mogelijke plicht tot herziening de in hoofdstuk 2, par 4.4 besproken annotaties wan Schueler en Boxum onder, respectievelijk ABRS 16 december $1996, \mathrm{AB} 1998,32$ en ABRS 24 januari 2000, AB 2000, 199. 
In dit verband is ook interessant te bezien wat nu precies de onjuiste rechtsopvatting inhoudt waarvan het CBB het Productschap betich. Het likt erop dat het $C B B$ hiemee in de eerste plaats doelt op thet betoog van het Productschap dat het veeleer op de weg van de NV had gelegen on herziening van de CBB-uitspraak van 22 november 1991 te vragen, waarmee het de verantwoordelikheid wan de eerdere foute beslissing als het ware afwentelde op het rechtscollege. Het Productschap had in het bestreden besluit echter ook overwogen op beleidsmatige gronden geen aanleiding te zien zelf tot herziening van het beslluit van 13 december 1990 over te gaan. De onjuiste rechtsopvatting moet dus veeleer worden gezocht in het (impliciete) oordeel van het Productschap dat er geen sprake was van nova die tot herziening wan dit besluit zouden nopen. Dit neemt niet weg dat het CBB bij de beoordeling van de vraag of het Productschap tot herziening verplicht kan worden geacht lawat meewegen de omstandigheid dat het college zelf, naar achteraf moet worden vastgesteld, bij zijn eerdere uitspraak van 22 november 1991 , een onjuiste toepassing heeft gegeven aan de zogenoemde Cilfit-doctrine.

Wat de inhoudelijke beoordeling betreft valt natuurlijk allereerst op dat het CBB gevolgen werbindt aan de omstandigheid dat de weigering om tot herziening van het besluit van 13 december 1990 over te gaan mogelijk in strijd is met de fundamentele reclitsbeginselen. Veelzeggend is voorts dat het CBB de nadere onderbowwing van zijn uitspraak mede heeft doen steunen op de aangehaalde overwegingen van de Hoge Raad in de zaak Kostowski, waarin de Hoge Raad in afwijking wan het wettelijk stelsel cen woorziening heef getroffen voor de situatie dat een definitief geworden strafvonnis in strijd blijkt te zijn met een later gewezen arrest van het EHRM. Belangrijk is voorts dai de Hoge Raad deze voorziening rechtstreeks heeft gebaseerd op de uit de artikelen 1 en 13 wan het EVRM ${ }^{38}$ voor de Nederlandse Staat voortwloeiende verplichting tot het verzekeren van de in artikel 6 EVRM neergelegde rechten en tot het voorzien in een effective remedy in geval van schending van deze rechten. Er kan geen twijfel over bestaan ${ }^{59}$ dat het in geding zijnde verzoek van de NV ziet op de vaststelling van burgerlijke rechten en verplichtingen als bedoeld in artikel 6 EVRM. ${ }^{61}$ Aldus komt artikel $\mathbb{1 3}$ EVRM, als ondergeschoven kindje in de rechtspraak over de betekenis van het EVRM voor de nationale rechtsorde, ${ }^{61}$ als een duvelije uit een doosje in deze problematiek om de hoek kijken. Tenslotte valt op dat het CBB geen rechtstreeks werband legt tussen de schending van de genoemde fundamentele rechtsbeginselen en het

57 Op grond wan het artest Da Costa en Schouke (HvJ EO 27 maart 1963, gevoegde zaken 28-30/62, Jur. 1963, p. 63) is de hoogste nationale rechter niet verplicht het HwJ EG om een prejudiciéle beslissing te wragen, alss de desbetreffende vraag zakelijk gelijk is aan een vraag die reeds in een gelijksoortig geval voorwerp van een prejudiciẻle beslissing is geweest (acte eclauré). Het Cilfit-arrest (Hw EG 6 oktober 1982, zakk 283/81, Jur. 1982, p. 3415) heeft deze rechtspraak uitgebreid tot het geval wakin er al vaste rechtspraak van het Hof bestat op het punt waarop het geding betrekking heeft; zie Kapteyn-Verloren wan Themaat, Inleiding tot het recht van de Europese Gemeenschappen, Deventer 1995 , p. $314-315$.

58 Artikel 5 EVRM kan hier verder buiten beschouwing blijven.

59 Het CBB maakt er ook geen woord an vuil.

60 Vgl. on. EHRM. 16 september 1996, Gaggusu, AB 1997, 179; RSV 1997/234; NJCM-Bulletin 22 (1997), p. 461-474 m.nt. C.A. Groenendijk; SMA 1997 , p. $253-259$ m.nt. G.J. Vonk.

61 Vgl. S.K. Martens, De grenzen van de rechtsvornende taak van de rechter, NJB 2000, afl. 14, p. 752753. Voor een uitgebreide behandeling, zie Ton Barkhuysen, Art. 13 EVRM: effectieve nationale rechisbescherming bij schending van mensenrechten, diss. RUL 1998. 
unt artikel $10 \mathrm{EG}$ voortvloeiende beginsel wan gemeensclupstrouw, ${ }^{62}$ in welk latste beginsel het $\mathrm{CBB}$ aanleiding heeft gevonden prejudiciele vragen aan het HvJ EG we stellen. Gelet op de opzet en de strekking van de uitspraak van het CBB is echter alleszins aannemelijk dat, mocht het HvJ EG van oordeel zijn dat er sprake is van strijd met de gemeenschapstrouw, zulks voor het $\mathrm{CBB}$ onder het inroepen van de fundamentele rechtsbeginselen aanleiding zal zijn voor het treffen van een (butenwettelike) voorziening ter tegemoetkoming aan de NV.

Het HwJ EG heeft op 13 januari 2004 uitspraak gedaan. ${ }^{63}$ De uitspraak begint met de tweedeling die zo kenmerkend is voor de in dit boek behandelde rechtspraak. Na voorop te hebben gesteld dat uit vaste rechtspraak voortvloeit dat een bestuursorgaan gehouden is de door het Hof in een prejudiciële beslissing gegeven uitleg aan het gemeenschapstecht ook toe te passen op rechtshetrekkingen die zijn ontstaan vót het arrest van het Hof waarin de desbetreffende uitleg is gegeven (de materiële terugwerking), herimert het Hof er tevens aan dat

'de techtszekerheid tot de in het gemeenschapsrecht erkende algemene rechtsbeginselen behoort. Dat een besluit van een bestuursorgaan definitief wordi na het verstrijken van redelijke beroepstermijnen of na uitputting van alle rechtsmiddelen, draagt bij tot die zelkerheid. Bijgevolg vereist het gemeenschapsrecht niet dat een bestuursorgaan in beginsel moet terugkomen op een besluit dat aldus definitief is geworden'.

Lijkt, afgaande op deze overwegingen van algemene aard, het bestuurlijk pantser van de formele rechtskracht, ${ }^{65}$ nog ongeschonden te blijven, met het vervolg van de uitspraak loopt dit toch een klein deukje op, aangezien het Hof van oordeel is dat het gemeenschapsrecht in de concrete omstandigheden van de zaak Kühne \& Heitz meebrengt dat

'het bestursorgaan op grond van het in artikel $19 \mathrm{EG}$ vervalte samenwerkingsbeginsel desgevragd is gehouden zijn beshit opnieuw te onderzoeken, teneinde rekening te houden met de uitlegging die het Hof inmiddels aan de relevante bepaling van het gemeenschapsrecht heeft gegeven'. (mijn cursivering, RB)

Naar het oordeel van het Hof zal het bestuursorgaan aan de hand van de resultaten van dat heronderzoek moeten bepalen in hoeverre het, zonder de belangen van derden te schaden, op het betrokken besluit dient terug te komen. Van een dergelijke verplichting tot heronderzok is volgens het Hof sprake indien:

- het bestuursorgaan naar nationaal necht bevoegd is om op het definitief geworden besluit terng te komen;

dit besluit definitief is geworden ten gevolge van een uitspraak van een nationale rechterlijke instantie waarvan de beslissingen niet vatbaar zijn voor hoger beroep;

62 Inhoudende dat de LidwStaten verplicht zijn alle algenene en bijzondere maatregeten te treffen die geschikt zijn om de nakoming van de uit het EG-Verdrag of het secundaive genneenschapssecht voortvlloeiende verplichtingen te verzekeren.

63 HvJ EG 13 januari 2004, AB 2004, $58 \mathrm{~m} . \mathrm{nt}$. Widdershoven; $1932004 / 42, \mathrm{~m} . \mathrm{nt}$. N. Verheij.

64. In welk verband het Hof verwijst naar zijn uitspraken in de zaken Denkawit italiana (HvJ EG, 27 maart 1980, zhak 6179, Jur. 1980, p. 1205, par. 16 en Deutsche Telekom (HvJ 10 februari 2000 , zaak C-50/96, Jur. 2000, p. (-743, par. 43).

65. De beeldspraak, inclusief het bieropwolgende "deukje' is van Nico Verheij in zaak JB-noot onder" deze uitspraak. 
- deze uitspraak, gelet op latere rechtsprak van het Hof, benust op een onjuiste witlegging van het gemeenschapsrecht, gegeven zonder dat het Hof overeenkomstig artikel 234, lid 3, EG is verzocht om een prejudiciele beslissing, en

- de betrokkene zich tot het bestuursorgaan heeft gewend onmiddellik na van die rechtsprakk kennis te hebben genomen.

Aldus zet het Hof de deur voor formele terugwerking van zijn uitspraken op een kier. Dat zulks in overeenstemming zou zijn met het communautaire effectiviteitsbeginsel kwam ook al naar voren wit de conclusie van A-G Verkade voor het in paragraaf 2.2 . van dit hoofdstuk besproken arrest Maple, waarin hij in verband met de casuspositie van Kibhe o Heitz opmerkta dat het

"indien een belanghebbende, ondanks het aanwenden wan alle ten dienste staande rechtsmiddeIen in een eerste procedure uiteindelijk aan het kortste eind trekt, en vervolgens opnieuw zijn recht zoekt, nadat in een door derden geëntameerde procedure gebleken is dat het recht (mogelijk) toch in een voor hem gunstige zin dient te worden uitgelegd, moeilijk verteerbaar [lijkt] dat hij in de nieuwe procedure zijn neus stoot ondat inmiddels sprake zou zijn van termijnowerschrijding":

Het eerste dat naar aanleiding van de uitspraak van het Hof opvalt is dat ook hier een actieve processuele opstelling wordt beloond. Heef de betrokkene afgezien van de eerste procedure of heeft hij deze niet tot het (ongunstige) einde gevoerd, en dient hij voorts niet onmiddellijk na kennisname van de nieuwe jurisprudentie van het Hof een verzoek om herziening in bij het desbetreffende bestuursorgaan, dan staat de formele rechtskracht aan herziening in de weg. Bij de beoordeling van de processuele opstelling van degene die met een beroep op nieuwe rechtspraak van het Hof een verzoek om herziening indient doet zich voorts de vraag voor wat dient te worden verstaan onder onmiddellijk, almede de vraag wamneer iemand redelijkerwijs geacht kan worden kennis te hebben genomen van de nieuwe rechtspraak van het Hof.

Wat voorts opvalt is dat het Hof het antwoond op de vraag of het gemeenschapsrecht een verplichting tot heroverweging meebrengt, mede laat afhangen van het al dan niet in het nationale recht bestaan van de bevoegdheid voor het desbetreffende bestuursorgaan van een definitief besluit terug te komen. Dat is in die zin opmerkelijk dat het Hof de effectiviteit van zijn rechtsbescherming aldus mede laat afhangen van de eigenaardigheden van de desbetreffende nationale rechtsstelsels, voor wat Nederland betreft de in de jurisprudentie van de bestuursrechters aanwaarde bevoegdheid van bestuursorganen om terug te komen van onherroepelijk geworden besluiten. ${ }^{67}$ Aldus blijft de vraag onbeantwoord of, in geval van het ontbreken van deze mogelijkheid in het nationale rechtsstelsel, in een soortgelijke casus als die van Kuhne \& Heitz, strijd met het in paragraaf 2.1 van dit hoofdstuk besproken doeltreffendheidsbeginsel zou kunnen worden aangenomen. ook een 'absolute verjaringstermijn' zou moeten gelden, omdat heroverweging na al te lange tijd op praktische problemen kan gaan stuiten. 
Tenslotte dient te worden benadrukt dat het arrest voor het bestuursorgaan niet meer dan een verplichting tot heroverweging van het onherroepelijk geworden besluit inhoudt. Het arrest bevat als zodanig niet de verplichting voor het bestuursorgaan tot herziening of intrekking van het besluit. Wel verplicht het het bestuursorgaan 'zijn besluit opnieuw te onderzoeken teneinde rekening te houden met de uitlegging die het Hof inmiddels aan de relevante bepaling van gemeenschapsrecht heeft gegeven". Met Verheij ${ }^{\text {tis }}$ meen ik dat het bij pur financiële besluiten en bij gebreke van belangen van derden niet eenvoudig zal zijn om argumenten te bedenken die aan herziening op grond van de nieuwe jurisprudentie in de weg zouden staan.

Hoewel het voorgaande erop lijkt te wijzen dat de soep voor de Nederlandse Staat niet al te heet wordt gegeten, blijkt het arrest Kïhne \& Heitz in combinatie met de rechtspraak van het HvJ EG met betrekking tot vorderingen tot schadevergoeding wegens in strijd met het gemeenschapsrecht genomen besluiten toch verstrekkende gevolgen te kunnen hebben. Nico Verheij heeft in dit verband gewezen op het op 30 september 2003 door het Hof gewezen arrest in de zaak Köbler. ${ }^{69}$ In deze zaak heeft het Hof, zijn met het arrest in de zaken Francovich en Bonifaci ${ }^{70}$ ingezette lijn voortzettend, beslist dat de overheidsaansprakelijkheid voor de schending van het gemeenschapsrecht ook van toepassing is op schendingen toerekenbaar aan een in laatste aanleg rechtsprekende rechterlijke instantie." Waar het Hof op grond van laatstgenoemde jurisprudentie voor 'gewone' aansprakelijkheid wegens schending van het gemeenschapsrecht echter als voorwaarden stelt dat (1) de geschonden rechtsregel ertoe strekt particulieren rechten toe te kennen, (2) sprake is van een voldoende gekwalificeerde schending en (3) sprake is van een rechtstreeks causaal verband tussen deze schending van de op de staat rustende verplichting en de door de betrokkenen geleden schade, scherpt het arrest Köbler de tweede voorwaarde in die zin aan dat van aansprakelijkheid wegens onrechtmatige rechtspraak van een in laatste aanleg rechtsprekende nationale rechterlijke instantie eerst sprake is als deze het toepasselijke recht kennelijk heeft geschonden. ${ }^{72}$

Het arrest Köbler doet de vraag rijzen of deze verruimde maatstaf ${ }^{33}$ voor aansprakelijkheid wegens onrechtmatige rechtspraak ook soulaas had kunnen bieden aan Kühne \& Heitz. Dat lijkt weinig waarschijnlijk, gezien de zeer schappelijke houding waarvan het Hof jegens de betrokken Lid-Staat heeft blijkgegeven bij de toepassing van de kennelijkheidsvoor-

68 Verheij, ta.p. punt 3.

69 HvJ EG 30 september 2003, zaak C-224/01; JB 2004/41 m.nt. M. Claes; AB 2003, 429 m.nt. Widdershoven.

70 HWJ EG 19 nowember 1991, zaken C-6/90 en C-9/90, Jur. p. 1-5357.

71 Zie in dit verband voorts: $\mathrm{Hw}$ EG 9 december 2003 , zalk C.129/00, Commissie v. Itolie, JB 2004/72, m.nt. M. Claes, waarin het Hof zich heeft uitgesproken over de vraag welke gevolgen moeten worden verbonden aan nationale rechtspraak die zich niet conformeert aan bepalingen van primair en secundair gemeenschapsrecht, zoals deze wonden uitgelegd door thet Hof van Justitie.

72 Zie ook de noot wan Widdershoven bij dit arrest in $A B$ 2003, 429, die opmerkt dat niet erg duidelijk is wat het verschil is tussen het klassieke criterium van de gekwalificeerde schending en het aangescherpte criterium voor de in ladiste alanleg sprekende rechter.

73 Verheij (ta.p. punt 8) merkt op dat een vordering wegens onrechtmatige rechtspraak in Nedorland tot: voor kort zo goed als kansloos was; vgl laatstelijk HR 29 april 1994, NJ 1995,727 m.n. C.J.H.B. Brunner en E.A. Alkema. 
watrde. ${ }^{74}$ Verhej wijst er echter op dar in gevallen als die van Kihwe \& Heitz voor betrokkene ook de mogelijkheid openstalat van een wordering tot schadevergoeding gebaseerd op de onrechtmatigheid van het onherroepelijk geworden besluit zelf. Naar zijn mening stuit een dergelijke vordering niet af op de formele rechtskracht van het besluit, omdat uit het arrest Kuhne \& Heitz volgt dat de formele rechtskracht niet aan de benadeelde kan worden tegengeworpen alls aan de in dat arrest gestelde woorwaarden is voldaan. ${ }^{75}$ Verhej acht deze weg aantrekkelijker voor de benadeelde dan de actie uit onrechmatige rechtspraak, waartoe hil opmerkt dat

"[...] het Hof in het arrest-Kuhne, anders dan in het arrest-Kobler, niet de eis stelt dat de uit de latere Hof-uitspraak blijkende schending van het gemeenschapsrecht 'kemelijk' moet zijn. Als eenmal is voldaan aan de in het arrest Kuhne gestelde voorwaarden om de formele rechtskracht te doorbreken, moet de aansprakelijkheid van het bestuur vervolgens gewoon naar Nederlands recht worden beoordeeld."

Bij deze latste beoordeling behoeft niet voldaan te worden aan de door het HWJ EG gestelde gekwalificeerde voorwaarde: een 'gewone schending voldoet, terwijl bovendien op grond van waste jurisprudentie van de burgerlijke rechter de schuld van de overheid aan de rechtsschending in beginsel gegeven is. ${ }^{76}$

Dit laatste opent, althans voor de gevallen die beantwoorden aan de voorwaarden gesteld in het arrest Kihne Heitz, onvermoede perspectieven. Met de vordering uit onrechtmatige daad wegens een op schending wan het gemeenschapsrecht terug te voeren onrechtmatige besluitvorming wordt een mogelijkheid tot compensatie gecreéerd die los staat van de vraag of het desbetreffende beshuit formele rechtskracht heet verkregen. Zoals het Hof zelf in het arrest $K \ddot{b} b l e r$ heeft aangegeven, ${ }^{7}$

'[heeft] een procedure tot vaststelling van de aansprakelijkheid van de staat [...] niet hetzelfde voorwerp en niet noodzakelijkerwijs dezelfde partijen als de procedure die tot de in kracht van gewijsde gegane beslissing heeft geleid. In een schadevergoedingsactie tegen de staat verkrijgt de verzoeker namelijk, indien hij in het gelijk wordi gesteld, de veroordeling van de staat om de geleden schade te vergoeden, maar niet noodzakelikerwijs de opheffing van het gezag van gewijsde van de rechterlijke beslissing die de schade heeft veroorzaakt. In ieder geval vereist het beginsel van staatsansprakelijkheid, dat inherent is alan de communautaire rechtsorde, een dergelijke wergoeding, maar miet een herziening van de rechterlijke beslissing die de schade heeft veroorzaakt".

Het verdient nauwelijks betoog dat met het instandlaten van de kracht van gewijsde van de rechterlijke beslissingen tevens de instandlating van de formele rechtskracht van de

74. Naar het oordeel van Claes (ta.p. punt 4) was in de zaak Köbler sprake van een opeenstapeling van fouten en onnawkeurigheden, waaronder een fouticve lezing van het Oostenrijkse Verwallumgsgerichshof van een eerder arrest wan het HWJ EG en het foutief intrekken van een verzoek aan het Hof om een prejudiciële beslissing.

75 Verheij, ta.p. punt 9. Naar zijn oordeel "ligt [het] immers in de rede dat, als de door het hof voorgescheven heroverweging leidt tot de conclusie dat het besluit niet kan worden teruggedraaid, de "second best' optie van schadevergoeding in geld moet worden overwogen", waarbij hij bovendien verwijst na: het in de volgende paragrata te bespreken arrest van het EHRM in de zaak Domgewille (EHRM 16 april 2002, Reports of Judgments and Decisions 2002-IIT; EHRC 2002/45 m.nt Heringa: AB 2002, 75 m.nit. Verheij.

76 Vgl. HR 31 mei 1991, AB 1992,290 m.at. F.H. van der Burg (Van Gog/Nedenweert)

$77 \quad$ R.0. 39. 
beoordeelde, later in strijd met het gemeenschapsrecht bevonden, besluiten is gegeven. ${ }^{38}$ Verheij ${ }^{7 / 4}$ heeft hier echter de kantrekening bij gemaakt dat bij pur financielle geschillen, zoals hier aan de orde, schadevergoeding vaak op hetzelfde neerkomt als het terugdraaien van de bestreden beslissing. Naar zijn oordeel is het zuiverder te aanvaanden dat het gezag van gewijsde niet absoluut is. Hij leidt uit het arrest Kobler af dat het gezag van gewijsde op zichzelf overeind blijft, maar uitzondering lijdt als er sprake is van een kennelijke schending van het gemeenschapsrecht door de nationale rechter en is voorts van oordeel dat hetzelfde dient te gelden bij een ernstige schending van het EVRM of een ander mensenrechtenverdrag. Dit betekent naar zijn oordeel ook dat de burgerlijke rechter zich in het uiterste geval bevoegd zal moeten achten on een uitspraak van één van de hoogste bestuursrechters te corrigeren, waartoe hij opmerkt dat

'als iemand een vordering bij de burgerlijke rechter baseert op de stelling dat de ABRwS, de $\mathrm{CR} v \mathrm{~B}$ of het $\mathrm{CBB}$ het gemeenschapsrecht of een mensenrechtenverdrag kennelijk heeft geschonden, $[\ldots]$ deze vordering niet met een enkele verwijzing naar het leerstuk van de formele rechtskracht [kan] worden afgedaan. De burgerlijke rechter zal in zo'n geval zelfstandig moeten beoordelen of zich inderdaad zo"n schending heeft voorgedaan en of deze zodanig 'kennelijk' is, dat een uitzondering op de formele rechtskracht moet worden gemaakt". (mijn cursivering, RB)

Deze jurisprudentie werpt een nieuw licht op de in hoofdstuk 2 besproken mogelijkheid tot doorbreking wan de formele rechtskracht van besluiten uit het oogpunt van een effectieve rechtsbescherming. ${ }^{80}$ Ze biedt voorts ondersteuning voor het standpunt van Scheltema" dat de doorbreking van de formele rechtskracht meer aanleiding bestaat al naar gelang de door de in geding zijnde wetgeving geschonden norm een fundamenteler karakter draagt. Tenslotte doet de in deze paragraaf besproken jurisprudentie afbreuk aan de stelligheid van de rechtspraak van de CRvB volgens welke de inhoud van inmiddels tot stand gekomen jurisprudentie op zichzelf geen grond vormt voor het doorbreken van de formele rechtskracht van besluiten, zelfs indien in die jurisprudentie is gewezen op een mogelijke schending van fundamentele rechten. De in hoofdstuk 2 opgeworpen vraag of de CRvB mogelijk anders zou oordelen als schending van fundamentele rechten inmiddels zou zijn komen vast te staan, lijkt bevestigend te moeten worden beantwoord. ${ }^{82}$

Hoewel het voorgaande het beeld oproept van een ruime formele werking van uitspraken van het $\mathrm{HvJ} E G$, in die zin dat een vorm van daadwerkelijk rechtsherstel wordt geboden ten aanzien van alsnog in de jurisprudentie van het HvJ EG gebleken materielle rechten waarvan het bestaan eerder in inmiddels afgeronde nationale bestuurstechtelijke proce-

Verheij (ta.p. punt 9) wijst er in werband net het voorgaande op dat een benadeelde zich tot het bestuursorgaan kan wenden met het primaire werzoek het met het gemeenschapsrecht strijdige besluit terug te draaien, of met het subsidiaire verzoek de daardoor verooraakte schade te vergoeden. Als beide werzoken worden afgewezen heeft de benadeelde voorts de keuze over de schadevergoeding bij de besturstechter of bij de burgerinke rechter te procederen. Als het de benadeelde louter om schadewergoeding bestaat kan hij zich met een beroep op de jurisprudentie van het Hof uiteraard ook rechtstreeks tot de burgerlijke rechter wenden.

79 Zie de punten II t/m 13 van zinn noot bij EHRM 16 april 2002, Dangeville, AB 2004, 75.

80 Hoofdstuk 2, par. 2.3 en 5.3.

81 In zijn noot bij HR 16 mei 1986, NJ 1986,723 (Heesch- Han de Aker).

82 Zie hoofdstuk 2, par. 4.5. Daarbij moet nog worden opgemerkt dat (de strekking van) de bedoelde jurisprudentie van de CRvB in belangrijke mate mede ten grondslag lag atan de in hoofidstuk 4 besproken jurisprudentie op het gebied van de sociale zekerheid. 
dures was ontkend, mag niet uit het oog worden verloren dat deze ruime werking zich beperkt tot casusposities die beantwoorden aan de in het arrest Kühne \& Heitz gestelde voorwaarden. Het arrest biedt als zodianig dus geen soulaas aan benadeelden die hebben stilgezeten, hoezeer daar ook aanlleiding toe was gelet op de uitkomst van de nationale procedures. Dit laatste ging zelfs op voor Kühne \& Heitz waar het bedrijf met een beroep op het arrest Voogd tewens had verzocht om vergoeding van de schade in verband met de na december 1987 toegepaste onjuiste tariefindeling, aangezien het bedrijf tegen de restituities daterende van na december 1987 geen rechtsmiddel had aangewend. Zoals hiervoor al is aangegeven koesterde het CBB geen twijfel over de formele rechtskracht van deze restitutiebeschikkingen en zag af van het stellen van prejudiciële vragen dienaangaande. Het $\mathrm{CBB}$ heeft aldus een oordeel gegeven dat in het verlengde ligt van het de arresten van de Hoge Raad in de zaken Vulhop en Maple ${ }^{83}$ Zoals Verheij kernachtig aangeeft ${ }^{84}$

'[verlangen] al deze uitspraken van de belanghebbende dat hij alle beschikbare nationale rechtsmiddelen aanwendt. Dit geldt in beginsel ook, als een rechtsmiddel op hot tijdstip waarop het moest worden ingesteld, eigenlijk kansloos moest worden geacht".

Naar het oordeel van Verheij gaat deze regel op voor situaties waarin de belanghebbende vóor de nieuwe jurisprudentie van het Hof nooit enig rechtsmiddel heeft ingesteld en mogelijk ook nog voor de situatie waarin de belanghebbende niet tot in hoogste instantie heeft doorgeprocedeerd, maar voert deze regel te ver in gevallen als Küllhe \& Heitz waarin een besluit tot in hoogste instantie is aangevochten en de belanghebbende vervolgens wordt geconfronteerd met een reeks van besluiten die op dezelfde rechtsopvatting berusten. Verheij sluit niet uit dat het Hof ook in zo'n geval zou oordelen dat de niet eerder aangevochten besluiten dienen te worden heroverwogen. ${ }^{85}$

\subsubsection{EHRM 16 april 2002 (Dangeville ${ }^{86}$ )}

Ook deze zaak wijst op een mogelijke kwetsbaarheid van het beginsel van de formele rechtskracht ten gevolge van de rechtstreekse doorwerking van bepalingen van EG-recht. Daarbij is de invalshoek weer een wat andere dan in de vorige paragraaf. De uitspraak biedt een fraai voorbeeld van de wisselwerking tussen, enerzijds, de door het HvJ EG ontwikkelde doctrine van de rechtstreekse werking van richtlijnbepalingen waarvan de implementatietermijn is verstreken en, anderzijds, de procesrechtelijke gevolgen die door het EHRM worden afgeleid uit artikel 1 van het Eerste Protocol bij het EVRM ingeval een Lid-Staat deze rechtstreekse werking (tegen beter weten in) negeert. De zaak ziet op de volgende feiten. ${ }^{87}$

83 Resp. HR 16 oktober 1992, AB 1993, 40, m.nt. Van der Burg (zie hoofdstuk 2, par. 5.3) en HR 24 jaruari 2003, AB 2003, $120 \mathrm{~m}$.nt. Widdershoven.; JB $2003 / 44 \mathrm{~m}$.nt E. w.d. Linden (zie par, 2 van dit hoofdstuk).

84 T.t.p. punt 10.

85 Verheij verwijst in dit verband naar het antest van het Hw EG in de zaak Metallgesellschaf (HvJ EG 8 maart 2001, gevoegde zaken C-397/98 en C-410/98, Jur. 2001, p. I-1727; SEW 2002, p. 154, m.nt. Van den Hurk en Prinssen), wartin het Hof heeft overwogen dat van een belanghebbende niet kan worden verlangd dat llij een kansloze aanvragg indient, louter en alleen om vervolgens een vraag wan gemeenschapsrecht aan de rechter te kunnen voorleggen.

86 EHRM 16 april 2002, Reports of Judgments ans Decisions 2002-III; AB 2004, 75 m.nt. Venheij; EHRC 2002/45 m.nt Heringa.

87 Voor een belangrijk deel ontleend aan het overzicht in N.B, 2002, afl. 23. p. 1112. 
Dangeville is een Franse ondememing die van oudsher BTW-plichtig was. In 1978 droeg 2 ij een bedrag van bijna 300.000 Franse Francs an de fiscus af. In 1977 had de Rado van de Europese Giencenschappen inmiddels de Zesde BTW-Richthin aangenomen,. Deze richtlin, dis per jamuari 1978 in de nationale rechtsorde van de Lid-Staten diende te zjon gemmplementeen, zonderde bepaalde bedrijtstakken, waaronder die waartoe Dangeville behoorde, wit van de verplichting om BTW af te dragen. Frankrijk liet na de richlin te implementeren. Eind jum 1978 gaf voomoemde Rad Frankrijk weliswaar een extra termijn on de richtlijn om te zetien, wata deze toestemming had geen terugwerkende kracht, zodat het Franse recht in de periode van 1 jamuari 1978 tot 30 juni 1978 niet in overeenstemming met het EG-fecht was geweest.

Op grond hiervan vorderde Dangeville terugbetaling van haar BTW-afdracht voorzover deze betrekking had op de periode januari-juni 1978. Dit verzoek werd door de bestuturstechter afgewezen onder verwijzing naar de, destijds, vaste jurisprudentie van de Conseil d'Etat dat een individu zich niet op de inhoud wan een nog niet omgezette richtlin kan beroepen ten koste van een. regel van national recht. In 1986 had Dangeville in hoger beroep bij de Conseil d'Etal evenmin succes. De Conseil d'Etat was bovendien van oordeel dat het beroep niet-ontvankelijik was, ondat Dangeville had nagelaten zich mel een verzoek om teruggave tot de minister van financiên te wenden. Inmiddels had de belastingdienst kort voor de uitspraak van de Conseil d"Etat aangekondigd dat geen BTW meer zou worden gevorderd van onder de Richtijn vallende bedrijwen die nog geen BTW over de periode van jamuari tot juni 1978 hadden afgedragen.

Dangeville dient vervolgens alsnog een aanwaag in, ziet zich geconfionteerd met een afwizing en zijn beroep daartegen door de bestuursrechter opnieuw afgewezen. Vervolgens kont hij tegen deze uitspraak opnieuw in hoger beroep bij de Conseil d'Etat. Inmiddels had dit rechtscollege in zijn in 1989 gewezen witspraak Nicolo ${ }^{88}$ de voorrang van vechtstreeks werkendie richtijnbepalingen boven nationale wetgeving aanvaard. Dit laatste mocht Dangeville evenwel niet baten: zij ving in 1996 opnjeuw bot bij de Conseil d'Etat, nu ondat dit college van oordeel was dat zijn eerdere uitspraak uit 1986 kracht wan gewijsde had gekregen. Dangeville heeft zich verwolgens met een klacht tot de toenmalige Europese Conmissie in Strattsburg gewend, welke klacht na inwerkingtreding van het Elfde Protocoll werd owergenomen door het ETRM.

Ter beantwoording van de vraag of artikel 1 van het Eerste Protocol bij het EVRM in dit geval toepasselijk is, stelt het Hof voorop dat vast staat dat de desbetreffende Franse wetgeving voor wat de in geding zijnde periode betreft ${ }^{89}$ in strijd was met de Zesde BTWRichtlijn." Het Hof is voorts van oordeel dat de desbetreffende richtlijubepalingen 'parfaitement clair en précise" zijn en dat hieraan reeds vanaf de eerste door Dangeville aangespanneti procedure directe werking toekomt. De aan deze direkte werking ontleende aanspraak op tengbetaling van de betalde heffingen merkt het Hof aan als een 'goed' dat kan delen in de bescheming die door artikel I van het Eerste Protocol an het eigen domsrecht wordt gegeven. Veelzeggend is dat het Hof hier nog aan toevoegl dat de enkele, op de de richtlijn gebaseerde, legitieme verwachting dat de heffing zou worden terugbetzald, al voldoende is om de bescherming van artikel 1. van het Eersite Protocol in te kunien roven.

88 Conseil d'Etat, 20 oktober 1989, Nicolo, Recueil Lebon, p. 190.

891 januar 1978 tot 30 juni 1978 .

90 Ter onderbouwing van dit standpunt wijst het Hof natr de vaste jurispnudentie dienaangaande wain het HwJ EG en de (latere) erkenning wan deze strijdigheid dooor de Franse overtheid zelf blijkens voornoemde instructie van 2 januari 1986, een beslissing vain de Conseil d'Etat van 30 oktober 1986 en het befande arrest van de Conseil d'Etat in de zaak Nicolo (Conseil d"Etat, 20 oktober 1989 , Nicolo, Recueil Lebon, p. 190) waarin dit college heeft aanvaard dat de (bestuurs)rechter de bevoegdheid toekomt nationale wetten aart intemationaal rech te toetsen. 
Het Hof is voorts van oordcel dat er sprake is van een inmenging in het eigendomsrecht van Dangeville. Het acht hiertoe beslissend dat Dangeville door het arrest van de Conseil d'Etat van 30 oktober 1986 de mogelijkheid ontnomen is haar aanspraken in rechte te doen beoordelen, ondanks het feit dat vast staat dat de toenmalige heffingen onrechtmatig zijn.

Het Hof is vervolgens van oordeel dat de inbreuk op het eigendomsrecht van Dangeville geen rechtvaardiging kan vinden in gronden aan het algemeen belang ontleend. De Franse regering had zich ten betoge dat deze rechtvaardigingsgrond van toepassing is onder meer beroepen op het beginsel van de distinction des voies de recours, dat in haar uitwerking sterk doet denken aan het beginsel van de formele rechtskracht hier te lande." Het Hof stelt woorop dat de Conseil d'Etat voor zijn oordeel dat het eerdere arrest van $1986 \mathrm{kracht}$ van gewijisde" had gekregen met een simple verwijzing naar dit traditionele jurisprudentiële beginsel heeft volstaan. Het Hof aanvaardt het beroep op dit beginsel niet, waartoe het in de eerste plaats overweegt dat Dangeville haar recht ontleent aan rechtstreeks werkende communautaire bepalingen, om hier vervolgens droogjes aan toe te woegen dat dit recht niet door het arrest van de Conseil d'Etat van 1986 is verdwenen en ook gedurende de tweede procedure heeft gegolden. Dat, zoals de Franse regering had aangevoerd, het oordeel van de Conseil d'Etat berustte op een traditioneel beginsel van het Franse procesrecht, heeft het Hof evenmin kunnen vermurwen. Daarbij verwijst het naar naar vaste jurisprudentie dat het EVRM beschouwd moet worden als um instrument vivant, dat in het licht van de actuele maatschappelijke omstandigheden en de actueel heersende rechtsovertuigingen in de Lid-Staten geinterpreteerd dient te worden. Belangrijk is de volgende overweging waarin het Hof zich op het standpunt stelt dat

'l'interprétation particulièrement rigoureuse faite par le Conseil d'Etat de ce principe de procédure a a au vu des circonstances d'espèce, privé la requérante de sa seule procédure interne susceptible d'offrir un remède suffisant pour assurer le respect des dispositions de l'article ler du Protocol n. I'. (mijn cursivering, RB)

Met andere woorden: het Hof verwijt hier de Conseil d'Etat dat hij met gebruikmaking van een procedureel beginsel (voomoem beginsel van de distinction des voies de recours) Dangeville elke mogelijkheid heeft ontnomen om haar rechten geldend te maken, dus dat hij, in de terminologie van dit onderzoek, elke formele werking aan de rechten van Dangeville heeft ontzegd. Het door de Franse regering gedane beroep op het arrest van het HvJ EG in de zaak Fantask ${ }^{93}$ kon het Hof evenmin op andere gedachten brengen, ondat dit arrest ziet op de vraag of het hanteren van bepaaide beroepstermijnen de toetsing aan het EG-fecht kan doorstaan, en niet, zoals in de zaak Dangeville, op situatie waarin aan betrokkene elk recht om zijn uit het EG-recht voortvloeiende rechten geldend te maken is ontnomen. Het Hof is yan oordeel dat op Dangeville niet de lasten mogen rusten die het gevolg zijn van de moeilijkheden die de Franse regering heeft ondervonden bij de toepassing van het EC-recht. Niet zonder enig cynisme refereert het Hof nog aan de opmerking van de Franse regering dat voornoemde richtlijn van 2 januari 1986, waarbij

91. Blijkens het arrest verbied dit beginsel dat 'soit recherchee, sur le fondement d.une action en responsabilité de droit commun, une satisfaction refusée sur le tertain du recours spécialisé. Zie voor de overeenkomst met het Nederlandse beginsel van formele rechtkracht tevens punt 5 van de noot wan Vertheij bij thet hier besproken arrest in AB 2004, 75 .

93 Zie par. 2.1 van dit hoofdstuk. 
bedrijven die nog niet hadden betaald hiervan werden gevrijwaard; onverlet liet dat zij die deze wel reeds hadden betaald zich tor de rechter konden wenden, iets wat, in het licht van de uitspraak van de Conseil d'Etat van 1986 slechts een wassen neus bleek te zijn. Het Hof is tenslotte van oordeel dat de inbreuk op de rechten van Dangeville een disproportioneel karakter draagt. Bij dit oordeel neemt het Hof mede in aanmerking dat het Dangeville heeft ontbroken aan een remede sufissant ter verzekering van haar rechten. ${ }^{9}$ Het Hof concludeert tot schending van artikel I van het eerste Protocol bij het EVRM.

Aldus laat het Hof er geen twijfel over bestaan dat artikell 1 van het eerste Protocol bij het EVRM meebrengt dat in dit geval een uitzondering moet worden gemaakt op het procecurele beginsel van de distinction des voies de recours en de hieruit afgeleide autorité de chose jugée, nu toepassing van dit beginsel tot gevolg heeft dat betrokkene elke mogelijkheid om zijn uit het EG-recht voortvloeiende materiële rechten geldend te maken wordt ontzegd. Met het beginsel van de formele rechtskracht zoals wij dat in Nederland kennen zal het in vergelijkbare gevallen niet anders zijn. ${ }^{95}$ Opmerkelijk is voorts dat het Hof geen woord heeft vuil gemaakt aan het feit dat het eerste beroep van Dangeville in de uitspraak van de Conseil d'Etat van 1986 niet-ontvankelijk was verklaard. Aldus had ook het procedurele gebrek dat de Conseil d'Etat aan Dangeville toen had tegengeworpen ${ }^{9 / 6}$ geen gevolgen voor de uiteindelijke beoordeling warn de zaak. Het Hof schuift de procesrechtelijke beletselen juist opzij, omdat de desbetreffende bestuurlijke en bestuursrechtelijke instanties de materiële rechten die Dangeville van meet af aan aan de Zesde EGRichtlijn kon ontlenen had miskend. Bij dit oordeel heeft blijkens de overwegingen van het Hof wel de halsstarrige houding van de Conseil d'Etat meegespeeld, ${ }^{37}$ evenals de nalatig heid van de Franse wetgever bij het toepassing geven aan het EG-recht en, wat toch pikant mag heten, het feit dat de Franse Conseil d'Etat bij het vasthouden aan traditionele procedurele beginselen de tekenen des tijds verkeerd had verstaan. ${ }^{98}$

Heringa spreekt in zijn noot ${ }^{99}$ van een potentieel verstrekkende uitspraak. Volgens hem kan de uitspraak tot gevolg hebben dat het - althans waar het eigendomsrecht in geding is ${ }^{100}$ - niet aangaat een beroep op de kracht van gewijsde te doen als daarmee een uitspraak wordt gedaan die in strijd is met het geldende recht. Daarbij acht Heringa het waar-

94 De letterijke overweging van het Hof is: "En effet tant la mise on echee de la créance de lat requérante sur l'Etat que l'absence de procédures intemes offant un remède sulfisant pour asstuder lat protection du droit au respect de ses biens [...] ont rompu lo juste bquilibre entre les exigences de l'intéret général de la communauté et les impératifs de la sumvegarde des droils fondamentaux des individus."

95 Ook Heringa, in zijn noot onder dit arrest in EHRC 2002/45 en Vurkade in zijn conclusie voor HR 24 januari 2003 (AB 2003, $120 \mathrm{~m}$.nt. Widdershoven: JB 2003/44 m.ni. E. v.d. Linden) menen dat dit antest gevolgen kan hebben voor de werking van het beginsel van de formele rechtskracht.

96. Dat er, in Nederlandse teminologie op neerkwam, dat Dangeville had nagelaten een anuragg in le dienen.

97 Vgl. thet verwiji van de /"interpretation particulièrement migorezse van het procedurelle beginsel van de distinction des woies de recoups.

98. Nameligk waar het Hof de houding van de Conseil d"Etat tegen het licht houdt wan het Verdrag als wh instrament wivant.

99 EHCR $2002 / 45$

100 Maar dit is op grond wan de huidige rechisparak van het Hof bijna alligd het geval (zie hoofdstuk 3. par. 2.6.3). 
schijnlijk dat de uitspraak niet louter strekt tot ondersteuning van de suprematie die voortvloeit uit de rechtspraak van het HVJ EG, maar in meer algemene zin geplaatst moet worden in het perspectief van een correcte toepassing van het recht. Heringa wijst er voorts op dat de uitspraak wan het Hof tot gevolg heeft dat aan de uitspraak van de Conseil d'Etai in de zalk Nicolo tot op zekere hoogte een terugwerkende kracht wordt gegeven, namelijk met betrekking tot diegenen die door de pre-Nicolo rechtspraak in hun eigendomsrechten zijn geschaad en die wanwege die rechtspraak hun op het EG-recht gebaseerde vorderingen niet geldend konden maken. Heringa concludeett dan ook dat

"ingevolge art. I Eerste Protocol een rechtens bestaande vordering niet gefrustreerd mag worden doordat een procedureel leerstuk aan een klager de enige openstaande rechtsgang ontneemt waarmee hij zijn rechten geldend kan maken'.

A-G Verkade meent in zijin conclusie voor het in par. 2.2 van dit hoofdstuk besproken arrest van de Hoge Raad in de zaak Maple dat in de uitspraak van het EHRM in de zaak Dangeville geen reden is gelegen om te menen dat het beginsel van de formele rechtskrachi, zoals dat door de Hoge Raad wordt gehanteerd, herziening zou behoeven. ${ }^{101} \mathrm{Hij}$ is van oordeel dat uit de uitspraak niet kan worden afgeleid dat het EHRM strengere eisen zou stellen dan de door het HWJ EG gehanteerde gelijkwaardigsheids- en effectiviteitstoets $^{162}$ en meent dat de uitspraak vooral is terug te voeren op de bijzondere omstandigheden in het geval van Dangeville, waaronder met name de starre houding van de Conseil $d^{\prime}$ Etat. Tenslotte benadrukt hij dat het in de zaak Dangeville ${ }^{\text {it3 }}$ gaat om een geval waarin dezelfde belanghebbende, die eenmaal nul op het rekest kreeg in een eerste rechtsgang, in een tweede rechtsgang datzelfde dreigt te overkomen. De uitspraak wan het EHRM in de zaak Dangeville zou, met andere woorden, geen gevolgen hebben voor de in dit boek veel besproken situatie waarin iemand op grond van een uitspraak in een door een derde aangespannen procedure, in een latere procedure alsnog aanspraak maakt op blijkens die uitspraak over het verleden bestaande rechten.

Deze laatste opmerking lijkt mij terecht. Ik meen dat de uitspraak van het Hof gezien kan worden als een voorbeeld van rechtspraak waarbij het initiatief van degene die van meet af aan heeft geprocedeerd om een zijns inziens onrechtmatige rechtsregel van tafel te krijgen, wordt beloond, ook in die gevallen waarin eerdere afwijzende rechtelijke beslissingen kracht van gewijsde hebben gekregen. ${ }^{104}$ Zoals in paragraaf 2.3 .2 van dit hoofdstuk aan de

101 Zie in overeetnkonstige zin $N$. Verheij in punt 9 van zijn noot in $\mathrm{AB}, 2004,75$. Naar zijn oondeel heet het EHRM de ratio van de res juficata-regel in dit arrest miskend. Hoewel dat niet uit de uitspraak blijkt, gant Verheij ervan wit dat het EHRM slechts heeft willen zeggen dat het gezag van gewijsde niet aan en burger mag worden tegengeworpen als de onhertoepelijk geworden rechterlijke uitspraak evident onguist is, in welk geval het hien besproken arrest wonderwel zou sporen met het in de vorige paragraaf besproken arrest van het HvJ EG in de zaak Kobler (HvJ EG 30 september 2003 , zaak C-224/01; JB 2004/41 m.trt. M. Claes; AB 2003, 429 m.nt. Widdershoven).

102 Zie hiertoe par. 2 . I wan dit hoofdstuk.

103 Evenas in de in par. 23.2 besproken zaak Kühne \&Heit (HvH EO 13 januari 2004, JB 2004/42, m.nt. N. Verheij: AB 2004, 58 m.nt. Widdershover.

$104 \mathrm{Vgl}$. in dit verband de arresten Defreme // (HvJ EG 8 april 1976, zaak 4375, Jur. 1976, p. 455) en Barber (Hw) EG 17 mei 1990, zaak 262/88, Jur. 1990, 1-1889; NJCM-Bulletin 16-1 (1991), p. 55 e.v., waarin het $\mathrm{Hw} / \mathrm{EG}$ in een beperking wan de terugwerkende kracht wan deze uitspraken voorzag, behoudens voor degenen die al voó de uitspraak een procedure bij het Hof aanhangig hadden gemakt. Zie voon een vergelijkbaar oordeel van het EHRM het arrest Morx. EHRM 13 juni 1979 , 
orde kwam, deed zich dezelfde sinuatie voor in de zaak Kaihne \& Heitz. Verder is het op het eerste gezicht onwaarschijnlijk dat het EHRM met betrekking tot de mogelijkheid om aan het EG-recht ontleende aanspraken in rechte geldend te maken strengere eisen zou stellen dan het HwJ EG zelf. ${ }^{165}$ Hierbij past echter wel de kanttekening dat het EHRM blijkens de in het arrest gebezigde bewoordingen veel minder ontzag lijkt te koesteren voor de procesrechtelijke autonomie van de Lid-Staten en veel meer de nadruk lijkt de leggen op de mogelijkheid om bestaande materiële rechten ook datadwerkelijk geldend te kunnen maken. Dit laatste blijkt mijns inziens mede uit het betrekken van de aanwezigheid van een remède suffisant bij de toetsing aan het proportionaliteitsvereiste. Het Hof lijkt daarbij aan zijn oordeel dat het eigendomsrecht als bedoeld in artikel I van het Eerste Protocol in het geding is, ook los van een eventuele toepasselijkheid van de artikelen 6 en 13 EVRM, de gevolgtrekking te verbinden dat een mogelijkheid van daadwerkelijk rechtsherstel dient te worden gecreeerd, in dit geval bestaande uit het loslaten van een principe jurisprudentiel traditionnel, ${ }^{106}$ dat in een geval als dat van Dangeville niet meer aan de eisen van deze tijd beantwoordt. Kortom, net als de in paragraaf 4.6 van hoofdstuk 4 behandelde uitspraak van het EHRM in de zaak Wessels-Bergervoet, toont ook dit arrest aan clat het EHRM voor wat de formelle werking in de tijd van krachtens het internationale recht (alsnog) verkregen rechten betreft, voor verrassingen kan zorgen.

\subsubsection{HR 27 september $2002^{107}$ (Pearl)}

Lijkt het op grond van de vorige paragrafen steeds meer gerechtvardigd de conclusie te trekken dat voor doorbreking van het beginsel van de formele rechtskracht met het oog op het geldend maken van krachtens EGi-recht verkregen rechten alleen plaats is voor justitiabelen die rechtmatigheid van desbetreffende nationale wettelijke bepalingen van meet af aan hebben bestreden, de thans te bespreken beschikking van de Hoge Raad stelt deze veronderstelling weer op losse schroeven. Het gaat hierbij om het volgende. ${ }^{\text {ito }}$

Het Hoofdbedrijfschap Ambachten (HBA), een openbaar lichaam in de zin van de Wet op de bedrijfsorganisatie, heeft jaarlijks, voor de eerste keer over het jaar 1988, bij besluiten krachtens daantoe vastgestelde verordeningen een bestemmingsheffing opgelegd ten behoeve van de Commissie Optiekbedrift. De netto-opbrengst wan de bestemmingsheffing is door de Commissie Optiekbedrijf aangewend voor collectieve reclame voor de opticiänbanche. De heflingsverordeningen en de daannee gefinancierde collectieve reclame zijn niet op de voet van (thans) art. 88, lid 3, EG aangemeld bij de Europese Commissic. Een aantal opticithondernemingen, die op grond wan wettelijke bepalingen is aangestoren bij het $\mathrm{HBA}$, vordert in de onderhavige procedure onder meer nietig werklaring van de vorderingen wan het HBA en een verklaring voor recht dat de op grond van de verordening door then betalde bestemmingsheffingen onverschuldigd zijn betaald. Aan hum wordering hebben de opticiënondernemingen ten grondsilug gelegd dat de bij de verordeningen opgelegde bestemmingsheffingen (de Regeling) zijn aan te nerken als een

Series A, wol. 31 , par. 58; NJ 1986, 462 m.nt. E. A. Alkema, zie hoofdsttik 1, par. 3.

105 A-G Verkade nerkt in dit verband op dat de uitspraak in Dongewlle (EHRM 16 april 2002, Reports of Judgments ans Decisions 2002-II; AB 2004, 75 m.nt. Verheif; EHRC 2002/45 m.nt Heringa) als een steur in de rug van het HwJ EG kan worden aangemerkt; zie punt 4.43 vari de conclusie wan $A-G$ Verkade voor het arrest wan de Hoge Raad in de zaak Maple (TRR 24 januari 2003, AB 2003, 120 m.nt. Widdershoven; JB 2003 mint E. ... L. Linden).

106 R.o. 56.

$107 \mathrm{NJ} 2002,534$.

108 Het feitenrelaas is ontleend aan het overzicht gegeven in RvdW 2002, 149 . 
steunmatregel, zodal de Regeling bif de Commissie had moeten worden aangemeld en, nu dit. net gebeurd jw, nietig is en het op grond van die Regeling over de periode wan 1988 tot en met 1994 betaalde bedrag onwerschuldigd is betald. Tegen de beschikkingen waarbij de heffingen zijn opgelegd, heeft de mogelijkheid wan bezwaar en beroep bij het College van Beroep voor het Bedriffsleven opengestaan, waarvan door de opticiënondememingen evenwel geen gebruik is gemaakt.

De rechtbank heeft de Regeling bij tussenvonnis als een steunmaatregel in de zin van (thans) artikel 92, lid $\mathbb{E G}$ aangemerkt en aan het $\mathrm{H} W \mathrm{EG}$ prejudiciële vragen gesteld. Nadat het Hof dit vonnis vervolgens vernietigd had onder de kemachtige ${ }^{\text {mo }}$ overweging dat de Regeling beschouwd moest worden als "een sigaar uit eigen doos", heeft de Hoge Raad aanleiding gezien zich met een aantal prejudiciele vragen tot het HW EG te wenden. Deze betreffen niet alleen de vraag of de Regeling als een steummaatregel moet worden aangemerkt, maar tevens de vraag," wat, indien de Regeling inderdaad als zodanig moet worden aangemerkt, hiervan de gevolgen zijn in het licht wan het arrest van het $\mathrm{HvJ} E \mathrm{G}$ in zaak SFEI/La Poste. ${ }^{\text {II }}$ In dit arrest heeft het HvJ EG overwogen dat

'de nationale rechterlijke instanties de justitiabelen dienen te waarborgen, dat overeenkomstig hun nationale recht, wit een schending van artikel 93, lid 3, laatste volzin, van het Verdrag alle consequenties zullen worden getrokken, zowel wat betreft de geldigheid van de handelingen tot uitvoering wan de betrokken steumaatregelen, als wat de terugvordering betreft van de in strijd. met deze bepaling of met eventuele voorlopige maatregelen verleende steun".

Deze overweging roept de vraag op of het ten onrechte ontbreken van een aanmelding ertoe dient te leiden dat de verordeningen voor ongeldig dienen te worden gehouden en ook de rechtskracht van de op basis van die verordening genomen besluiten vervalt, dan wel of dit afstuit op de formele rechtskracht naar Nederlands recht van de beshiten. ${ }^{112} \mathrm{De}$ Hoge Raad verwoordt dit in zijn vragen aan het $\mathbb{H}$ I EG aldus:

\footnotetext{
"Volgt uit hetgeen is overwogen in de zaak [SFEI/Poste], met het oog op het ruttig effect van. artikel 93, lid 3 dat de nationale rechter zowel de verordeningen als de op grond van die verordeningen opgelegde heffingsbesluiten moet vernietigen en dat de rechter het overheidsorgaam. moet verootdelen tot terugbetaling van de heffingen, aok indien de in de Nederlandse rechtspraak ontwikkelde regel van de formele rechtskracht van de heffingshes/uiten daaraan in de weg zou statan?

[1....]

Kan een overheidslichaam, indien is verzuind een steummatregel op de voet wan art. 93 lid 3 aan te melden, ter afwering van een restitutieverplichting een beroep doen op de hiervoor vermelde regel wan formele rechtskracht van het heffingsbesluit, indien degene tot wie dat besluit was gericht ten thide van het nemen van dat besluit en gedurende de termijn waarbinnen deze in en bestutisrechtelike procedure had kunnen worden aangevochten, niet ervan op de hoogte was dat de steunmatregel waarvan de heffing deel uitmakt niet was aangemeld. Mag een fustitiabele in dit verband ervan uitgaan dat de overheid haar abnneldingsverplichtingen ingevolge art. 93 lid 3 heeft nageleefd?' (mijn cursivering; $R B$ )
}

109 De kwalificatie is van de Hoge Raad zelf (r.0. 3.6.2).

110 De Hoge Raad volgde thiemee de rechtbank, die in voomoemd tussenvonnis al eerder een soortgelijke vraag gan het HwJ EG had gesteld.

111 HuJ EG 11 juli 1996, zaak C-39/94, Jur. 1996, p. 1-3547.

112 Vgl. 1.0.3.3.3... 
Deze vragen zijn opmerkelijk in het licht van het korte tijd later gewezen en hiervoor, in par. 2.2 besproken arrest van de Hoge Raad in de zaak Maple, waarin de Raad heeft overwogen dat in dat geval niet woor redelijke twijfel watbaar is dat de in Nederland ontwikkelde rechtsfiguur van de formele rechtskracht niet in strijd is met het gemeenschapsrecht. Opvallend is verder dat de Hoge Raad, gelet op de tweede geciteerde vraag, de mogelijkheid van het aannemen van een uitzondering op het beginsel van de formele rechtskracht openhoudt op de grond dat betrokkenen verschoonbaar hebben afgezien van de gebruikmaking van bezwaar en beroep tegen de heffingsbesluiten. Dit lijkt op het eerste gezicht in schril contrast te staan met de overweging van de Raad in zijn arresi van 24 januari 2003 in de zaak Mople, ${ }^{113}$ waarin hij, ter weerlegging van de klacht dat de desbetreffende belastingplichtigen op het verkeerde been waren gezet doordat verweerder een met de Zesde BTW-Richtlijn strijdige uitvoering aan artikel 8 van de Wet op de omzetbelasting 1968 had gegeven, overwoog dat het de belastingplichtige wrij had gestan gebruik te maken van de mogelijkheid van indiening van een rechtsmiddel tegen de heffing en dat van hem mag worden verwacht dat hij, teneinde te voorkomen dat de omstreden heffing onherroepelijk wordt en formele rechtskracht verkrijgt, daarvan ook inderdaad gebruik maakt. ${ }^{1 / 4}$ De vraag dringt zich dan ook op welke redenen de Hoge Raad heeft gehad voor dit verschil in benadering.

De belangrijkste en meest voor de hand liggende reden is wellicht gelegen in de hiervoor geciteerde strenge bewoordingen van het arrest FFEI/la Poste zelf, waarin het HvJ EG de nationale rechterlijke instanties onvoorwaardelijk heeft voorgeschreven om een zodanige toepassing aan hum nationale recht te geven dat met artikel 93, lid 3 EG strijdige rechtshandelingen worden vernietigd en de in strijd met met deze bepaling verleende steun wordt teruggevorderd. Het (jurisprudentiële) beginsel van de formele rechtskracht zoals wij dat kennen zal al gauw aan het bereiken van dit resultaat in de weg staan.

Voorts is mijns inziens van belang dat de Hoge Raad in de zaak Maple, anders dan door de desbetreffende belastingplichtige was betoogd, van oordeel was dat geen onjuiste omzetting van de Zesde BTW-Richtlijn in de Nederlandse wetgeving had plaatsgevonden, ${ }^{15}$ terwijl de in de zaak Pearl de vraag voorligt of de in geding zijnde verordeningen rechtstreeks in strijd zijn met het EG-Verdrag.

Voor wat de mogelijke verschoonbaarheid van het niet (tijdig) instellen van een rechtsmiddel betreft is mijns inziens van belang dat de met de Zesde BTW-Richtlijn strijdige beleidsregel van meet af aan voor betrokkenen kenbaar was, zodat zij de rechtsgeldigheid hiervan konden aanvechten Voor de betrokkenen bij de in de zaak Pearl in geding zijnde Regeling was echter niet kenbaar of de Staat de steunmaatregel bij de Commissie had angemeld.

$113 \mathrm{AB} 2003,120 \mathrm{~m}$.nt. Widdershoven, $\mathrm{JB} 2003 / 44 \mathrm{~mm}$. E. v.d. Linden.

114 Owerweging 3.4 .3 van HR 24 januari 2003, AB 2003, 120 m.nt. Widdershowen; JB 2003/44 m.nt, E.v.d.Linden.

115 Zie HR 24 januari 2003 , JB $2003 / 44$, ro. 3.62 juncto 3.3 .3 . 
Hoe het ook zij, de zaak maakt duidelijk dat het voorbarig is te oordelen dat het beginsel van de formele rechtskrachit onder alle omstandigheden de toetsing aan het EG-recht kan doorstatan.

\subsubsection{HR II oktober 1996 (Leenders)}

Als we na de voorgaande paragrafen de balans opmaken, moeten we constateren dat het beginsel van de formele rechtskracht, zoals dat in hoofdstuk 2 is uitgewerkt, ook in het licht van het Europese recht, stand houdt, zij het met die kanttekening dat in de Europeesrechtelijke context in bepaalde gevallen een uitzondering op dit beginsel moet worden gemaakt. Deze gevallen zien op de situatie waarin een justitiabele met een beroep op een in een procedure van een derde gewezen uitspraak van het HvJ EG, zijn uit het EG-recht voontvloeiende rechten alsnog in rechte geldend wil maken, nadat een eerdere vordering met diezelfde strekking en van dezelfde justitiabele door de nationale rechter bij onherroepelijk geworden uitspraak is afgewezen. Uit de voorgaande paragrafen blijkt tevens dat de rechtspraak van het EHRM in dit verband van meer dynamiek lijkt te getuigen en mogelijk nog voor verrassingen kan zorgen.

Dat ecliter ook naar nationaal recht nog het een en ander op de 'blokkade' van het beginsel van de formele rechtskracht valt af te dingen blijkt uit het in deze paragraaf te bespreken uitspraak van de Hoge Raad in de zaak Leenders. ${ }^{160}$ In dit op het Pocketbook-arrest ${ }^{17}$ terug te voeren arrest lijkt de Hoge Raad langs de "omweg" van een procedure uit onrechtmatige wetgeving alsnog een ontsnappingsmogelijkheid aan de biokkade van de formele rechtskracht te bieden. De zaak heeft betrekking op de volgende, tamelijk bizarre, casus:

Leenders bedrijft detailhandel met een rijdende winkelwagen in de ongeving wan Nijmegen. Zij wil deze activiteiten ook tot de gemeente Ubbergen uitbreiden. Volgens de APV van deze gemeente heeft zij daarvoor een wergunning nodig. Leenders meent echinter van niet en start met haar activiteiten. Na korte tijd wordt tegen haar door de politie proces-verbaal opgemaakt en wordt haar meegedeeld dat bij herhaling haar inventaris in beslag zal worden genomen. Leenders staakt daarop de verkoop in Ubbergen en vraagt bij de gemeente een vergunning aan, echter met de aantekening dat deze naar haar mening niet vereist is. Zij dringt aan op een spoedige beslissing en geeft aan dat zij bij uitblijwen daarvan bezwaar zal maken tegen een fictieve weigerng. Na enige tijd wordt de desbetreffende APV-bepaling gewijzigd en wordt Leenders opnieuw in de gelegenheid gesteld een aanvraag in te dienen. Nadat zif de verkoop heeft hervat, verkriggt ze van de gemeente een - aan vergaande beperkingen gebonden - vergunning, waartegen zij bezwaar maakt, onder de uitdrukkelijke vermelding dat een vergunning niet vereist was, ondat desbetreffende bepaling van de APV onverbindend is. Leenders wordt vervolgens op haar bezwaar gehoord, maar op het bezwaar wordt nooit beslist. Een hangende het bezwaar ingediend verzoek on voorlopige voorziening wordt door de Voorzitter van de Aideling rechtispraak van de Raad van State afgewezen. Inmiddels is tegen Leenders opnieuw proces-verbaal opgemaakt met de aanzegging dat bij herhaling haar inventaris in beslag zal worden genomen. Ze staakt daarop opnieuw de verkoop in Ubbergen. Om toch een witspraak te verkrijgen over de verbindendheid van de APV-bepaling lokt Leenders, via de weg van artikel 12 van het Wetboek van Stratvordering, strafvervolging tegen zichzelf uit(!), hetgeen uitcindelijk resulteert in een uitspraak van de rechtbank waarbij de APV-bepaling wegens strijd met de Vestigingswet detailhandel onverbindend wordt verklaard. Met deze uitspraak in de hand

117 HR 24 januari 1969. NJ 1969, 316 m.nt HD. 
wendt zij zich vervalgens tot de burgerlijke rechter met een vordering tot schadevergoeding wegens onrechtmatig handelen van de gemeente.

\section{Leenders heeft aan haar vordering ten grondslag gelegd dat}

"de gemeente het [haar] onmogelijk gemaakt heeft haar bedrill in de gemeente Ubbergen wit te oefenen door haar te binden am een regeling, de art. 161 a en $161 \mathrm{~b}$ APV en de daarop gebaseerde Verordening op thet innemen wan standplatsen en venten [...]., die in strijd is met de Vestigingswet detailhandel en mitsdien onverbindend".

Nadat de rechtbank de vordering had toegewezen, heeft het Hof deze, met vernietiging van de uitspraak van de rechtbank, alsnog afgewezen onder de overweging dat het besluit van 29 april 1986, waarbij B\&W aan Leenders een ventvergunning onder beperkingen hadden verleend, formele rechtskracht heeft gekregen, aangezien Leenders had nagelaten op grond van artikel 3 van de toenmalige Wet Arob beroep in te stellen bij de Afdeling rechtspraak van de Raad van State tegen de fictieve weigering van $B \& W$ te beslissen op het bezwaarschrift van 29 mei $1986 .{ }^{118}$ In onderdeel 1 van het cassatiemiddel wordt namens Leenders echter benadrukt dat de grondslag van haar vordering is gelegen in het feit dat de gemeente het haar in de periode van april 1985 tot oktober 1989 feitelijk onmogelijk heeft gemaakt, op basis van het onjuiste standpunt dat daarvoor een door de gemeente te verlenen ventwergunning nodig zou zijin, om haar rijdende winkelwagens binnen de gemeentegrenzen te exploiteren. In verband hiermee wordt in het tweede onderdeel van het cassatiemiddel betoogd dat deze grondslag

'niet [behelst] dat enig besluit wan een orgaan wan de gemeente, waartegen een met voldoende waarborgen omklede administratiefrechtelijke rechtsgang heeft opengestaan of openstaat, ongeldig is".

\section{Dienaangaande stelt de Hoge Raad voorop dat}

'Leenders aan haar vordering niet ten grondslag heeft gelegd dat - an dus in het onderhavige geding niet in geschil is of - de beschikking van 29 april 1986 wegens haar inhoud of wijze van totstandkoming onrechtmatig is, maar dat de gemeente zich jegens haar onrechtmatig had gedragen door het uitvaardigen wan een onverbindende regeling en het handhaven daarvan door het standpunt te bljiven innemen dat op grond van deze regeling voor de door Leenders gewenste bedrijfsuitoefening een vergunning vereist was, en door haall dienovereenkonstig in die bedriffsuitvoering te belemmeren."

\section{En overweegt vervolgens dat}

"indien de overheid het standpunt inneernt dat een burger voor het verrichten van bepaalde handelingen, zoals het uitoefenen wan een bepaalde worm van bedriff of beroep, ingevolge een algemeen verbindend voorschrift een vergunning nodig heeft, maar die burger dit woorschrift onverbindend en daarop het inroepen en handhaven ervan jegens hem onrechtonatig acht, brengen de eisen wan een doeltreffende rechisbescherming tegen de overheid mee dat hij het geschil omtrent de werbindendheid van het woorschrift aan de rechter moet kunnen voorleggen. Zotang de beslechting van een dergelijk geschil niet aan de bestrupstechter is opgedragen [...] moet die

118 Vgl. HR 13 november 1992, NJ 1993,639 m. nt. MS (Lanser/Haarlemmermeer) waarin de Hoge Raad heeft geoordeeld dat er geen plats is voor een uitzondering op het beginsel van de formele rechtsklkacht, wanneer sprake is van een niet opkomen tegen een fictieve weigering om op een bezwaarschnift te beslissen. 
burger de vreag of het voorschrift verbindend is, in beginsel door middel wain een wordering gegrond op onrechtmatig overheidsoptreden kumen vorleggen atan de burgerlike rechter.

Dit laatste wordt niet anders doordat, indien de burger zonder de vereiste vergunning handelt en tegen hem [...] strafwervolging wordt ingesteld of bestursdiwang wordt toegepast, de verthindendheid wan de desberteftende regeing kan worden getoetst in een procedure woor de strafrechter resp. dle hestuurstechter. Niet kan immers van een burger worden werlangd dat hij, hoezeer er ook van overtuigd dat de regeling onverbindend is, het op een strafvervolging of toepassing van bestuursdwang latat aankomen om die onverbindendheid in rechte te doen waststellen". (mijn cursivering; $\mathbb{R B}$ )

Berusten deze owerwegingen nog op vaste rechtspraak inzake onrechmatige wetgeving, echt pikant voor het onderwerp dat ons bezighoudt is het verwolg, watr de Hoge Raad overweegt dat

'evenmin [...] in voormelde situatie van de burger [kan] worden gevergd dat hij, uitsinitend] teneinde de vragg of de regeling verbindend is, aan het oordeel van de rechter te kunnen onderwerpen, de vergunning voor zover nodig en onder aantekening van zijn zienswijze ontrent de verbindendheid van de regeling aanviaagt, vervolgens tegen de beschikking waarbij de vergumning wordt werleend, een bezwaarschrift indient en zonodig tegen de beslissing daarop beroep instelt bij de bestursrechter. Met het oog op een doeltreffende, waciporgen tegen misverstanden biedende regeling wan rechtsbescherming tegen de overheid moet worden aangenomen dat ook het openstaan van deze weing woor de hond liggende wieg blokkering van de toegang tot de burgerlijke rechter niet kan rechtvaardigen. Dit brengt mee dat deze toegang ook openblijf wanneer de burger - zoals hier - slechts de eerste stadia van voomelde weg heeft afgelegd, d.w.z desgevraggd een vergunning heeft gekregen en een bezwaarschrift heef ingediend, maar zich nadien, in stede van deze weg te vervolgen zich tot de burgerlijke rechter wendt teneinde deze voomelde waag te doen beslissen. Daarom kan in een dergelijk geval, bök indien ervan zou moeten worden uitgegaan dat de formele rechtskracht van de beschikking waarbij de vergunning is varleend, zich mede uitstrekt tot het oordeel van de vertenende instantie dat de desbetreffende regeling verbindend is, niet worden aarvaard dat de burgerlijke rechter in het in voege als voormeld door de burger tegen de overheid aangespannen geding op grond van die formele rechtskracht an dat oordeel van de overheid is gebonden'. (min cursivering; RB)

Bij dit arrest zou ik de volgende kanttekeningen willen plaatsen. Allereerst valt op dat de Hoge Raad zijn uitspraak heeft gedaan onder de noemer van de eisen van een doeltreffende rechtsbescherming tegen de overheid. Deze brengen, bij gebreke van de mogelijkheid van een rechtstreks beroep tegen algemeen verbindende voorschriften bij de bestuursrechter, mee dat de burger de vraag naar de verbindendheid van een algemeen voorschrift it beginsel rechtstreeks door middel van een wordering wit onrechtmatige daad aan de burgerlijke rechter moet kunnen voorleggen. ${ }^{120}$ Van de burger wordt niet verwacht dat hij het laat aankomen op een handhavingsmaatregel, van straf- of bestuursrechtelije aard, om

119 Vgl: HR 24 jamuari 1969, NJ 1969, 315 m.nt. MD: ARB 1969, p. 194; HR 16 mei 1986, N』1987. $251 \mathrm{~m} . n$. M. Schettema; AB 1986, 574 m.nt. P.J.J. van Butuen (Landbonwliegers); HR 18 januari 1991, N.I 1992, 638 m.nt. CI.H. Brunner; AB 1991,241 m.nt. F.H. van der Burg. (Varkenswester) Zie in dit verband ook punt 5 van de noot van Scheltema. Bij het hier besproken arrest in NJ1997, 165.

120 Hierbij dient nog te worden vermeld dat er ten tijde van het wijzen wan dit arrest nog van werd uitgegaan dat artikel $8: 2$ van de $\mathrm{Awb}$, waarin beroep tegen atgemeen werbindende voorschriften bij de besturstecher wordt tuigesloten, met ingang van I januari 1999 zou komen te vervallen. Bij wet wan 24 december 1998 , S1b 738 , is de desbetreffende overgangsbepaling zo gewijzigd dat het verval van artikel $8: 2$ is nitgesteld tot een bij wet te bepalen tijdstip. 
zich eerst dan, in een tegen die handhavingsmaatregel aan te spannen procedure, bij wijze van incidenteel beroep de rechtsgeldigheid van de desbetreffende regeling te kunnen aanvechten. De Hoge Raad acht een dergelijke omweg niet doeltreffend.

Gelet op voomoemd uitgangspunt van een doeltreffende rechtsbescherming tegen de owerheid is de Hoge Raad tevens van oordeel dat van een burger evenmin kan worden verwacht dat hij, ter verkrijging van een oordeel over de rechtmatigheid van een algemeen verbindend voorschrift, de omslachtige weg zou dienen te volgen van het op aanvraag verkrijgen van een besluit, het hiertegen maken van bezwaar om eerst dan, in de tegen het besluit op bezwaar aangespannen beroepsprocedure een oordeel van de bestuursrechter te verkrijgen over de rechtmatigheid van de in geding zijnde regeling. Veelzeggend is dat de Hoge Raad het volgen van deze laatste weg 'weinig voor de hand liggend vindt' en dat hij van oordeel is dat een regeling die voorziet in een rechtstreeks beroep tegen algemeen verbindende voorschriften bij de burgerlijke rechter, de beste "warborgen tegen misverstanden" ${ }^{421}$ biedt. Aldus geformuleerd kan de conclusie nauwelijks anders zijn dan dat de Hoge Raad de burgerlijke rechter als de eerst aangewezen instantie ziet om zich wit te spreken over de geldigheid van algemeen verbindende voorschriften.

De grote betekenis wan het arrest is echter gelegen in het schepje dat de Hoge Raad er vervolgens nog bovenop doet door te overwegen dat de toegang tot de burgerlijke rechter ook open blijft als de burger 'slechts de eerste stadia' van de besturursrechtelijke weg heeft afgelegd, zoals in het onderhavige geval het doen van een aanvraag, het verkrijgen van een besluit hierop en het hiertegen maken van bezwaar. ${ }^{1 / 22} \mathrm{Bij}$ het uitblijven van een procedure bij de bestuursrechter verkrijgt het op de aanvraag genomen besluit op een zeker moment immers formele rechtskracht. De vraag die dan nog rest is welke conclusies moeten worden werbonden aan het bestaan van deze formele rechtskracht. Daarover gaat de laatst geciteerde, wat mysterieus aandoende, overweging van de Hoge Raad. Bij het interpreteren daarvan lijkt mij allereerst van belang op te merken dat in de uitspraak niet wordt getornd aan de formele rechtskracht van het op aanvraag verleende besluit als zodanig. Die is verder ook niet in geding, omdat Leenders haar vordering op grond van onrechtmatige daad nu juist niet op de onrechtmatigheid van dat besluit had gebaseerd. ${ }^{123}$ Waar het in de

121 Denkbaur is dat deze overweging van de Hoge Raad mede ingegeven is door de well uiterst moeizame weg die Leenders heeft moeten bewandelen on cen oordeel over de rechtmatigheid van de verordening te krijgen, met als meest bizarre detail dat het uiteindelijk beslissende oordeel verkregen werd in een strafprocedure die ze tegen zichzelf had uitgetokt!

122 Vgl. in dit verband HR 17 december 1999, NJ 2000, 87, m, Mt. ARB (Groningen-Racrgever), warbij de Hoge Raad heeft bepaald dat een eenmal genomen zuiver schadebesluit niet in de weg staat atan een op dezelfde grondslag ingestelde vordering tot vergoeding van schade, tenzij de bestuurstechter in eerste of enige instantie het beroep tegen het schadebesluit ongegrond heef verktard.

123 In die zin is de onderthavige casus vergellikbaar met die van HIR 22 november. 1985, N』1986, 722 m.nt. MS; AB 1986, 245 m.nt. G.A.C.M. van Ballegooij.

( $V$ en DiGroningen (Superdoe) en HR 2 februari 1990, NJ 1993, 635 m.nt. MS; AB 1990, 223 m.nt. G.P. Kleijn. (Stalat/Bolsius). Z te ook de conclusie voor het anrest wan A-G Bloembergen, die uit deze aresten, en meer in het bijzonder het arrest StaotVan Benten (HR 7 oktober 1994, NJ 1997, 174 m.nt. MS; AB 1996, 125 m.nt. B.J.G.G. Roozendatal) in meer algemene zin afleidi dat de formelle rechtskracht van beschikkingen niet in de weg staat aan vorderingen uit onrechtmatige daad die hun grond vinden in gedragingen die onafhankelijk van de inhoud wan de beschijlking(en) onrechtmaltig zijn. 
latste overweging wel on gaat is wat het gevolg is van de formele rechtskrach van het bestuit waarbij de vergunning werd verleend voor de mogelijkheid van toetsing van de onderliggende regeling. De waag of de formele rechtskracht wan het besluit zich mede uitstrekt tot het oordeel van het bestuursorgan dat de desbetreffende regeling verbindend is, laat de Hoge Raad witrukkeljk in het midden, maar uitshiten doet hij het dat niet. Blijkens de laatste overweging is de Hoge Raad echter van oordeel dat, zelfs indien zou moeten worden aangenomen dat de formele reclitskracht wan het besluit 'doorwerkt' naar de onderliggende regeling, hij niet aanwaardt dat betrokkene de toegang tot de burgerlijke rechter terzake van een op onrechtmatige daad gebaseerde vordering tegen de onderliggende regeling wordt ontzegd. Scheltema leidt hieruit af dat de Hoge Raad hiemee een nicuwe uitzondering op het beginsel van de formele rechtskracht heeft geformuleerd. ${ }^{124}$

Naair het oordeel wan Scheltema ${ }^{125}$ strekken de consequenties van het arrest vrij ver. Hij leidt uit het arrest af dat al degenen die hun recht op vergunning hebben ontleend aan een wettelijk voorschrift dat onverbindend is, een procedure lijken te kunnen beginnen bij de burgerlijke rechter en schade kunnen claimen die thet gevolg is van de beperkingen die inherent zijn het vergunningensysteem. Uit het feit dat het arrest spreekt van 'de eerste stadia" van de bestursrechtelijke rechtsweg leidt hij echter af dat de weg naar de burgerlijke rechter niet meer openstat, indien de belanghebbende tegen de beschikking op zijn vergunningaanvraag in beroep bij de besturstechter zou zijn gekomen. Als de betrokkene aldaar zonder succes zou hebben betoogd dat de verordening onverbindend was, zou daarmee, volgens Scheltema, 'de kous af zijn', ondat er in zo'n geval sprake zou zijn van een rechterlijk gewijsde over de geldigheid wan de verordening. Scheltema neemt hierbij als uitgangspunt dat de formelle rechtskracht van een besluit waartegen een bestuursrechtelijke rechtsweg openstond maar niet is gebruikt, mede het oordeel omvat dat de verordening waarop de beschikking steunt verbindend is. Ik meen echter dat dit laatste oordeel niet kan worden tegengeworpen aan degenen die de bestuursrechtelijke weg nog niet hebben bewandeld. Als de formele rechtskracht van een besluit al zou "doorwerken", dan is deze werking louter relatief, namelijk beperkt tot degenen die een bestuursrechtelijk oordeel over een bestluit hebben verkregen. Zoals Scheltema ook zelf aangeeft zou het merkwaardig zajn indien een gemeente een onverbindende verordening zou kunnen maken die "in feite" verbindend wordt doordat tegen de daarop gebaseerde beschikkingen niet wordit opgekomen. ${ }^{12 k}$

Waar het mijns inziens op aankomt is dat de onrechmatigheid van algemeen verbindende voorschriften $^{12}$ altijd ter discussie staat, omdat de rechtopvattingen in de loop der tijd, door verandering in de maatschappelijke onstandigheden, al dan niet gepaard gaande met ontwikkelingen in het internationale recht, kunnen veranderen, zodat op een gegeven moment de geldigheid aran deze voorschuiften komt te ontvallen. Juist hierover gaat dit boek. De vraag is alleen altijd weer: wat zijn de consequenties van deze veranderde rechtsopvattingen voor besluiten die zijn genomen op grond van wetgeving waarvan de recht-

124 Dit is ook de mening van Schelterna; zie punt 1 van diens noot.

125 Noot in NJ 1997, 165, onder punt 10.

126 Noot in NJ 1997, 165 , onder purt 9.

127 Waarbij voor wat de formele wetgeving betreft uiteraard rekening moet worden gehouden met het toetsingswerbod van artikel 120 van de Grondwet. 
matigheid aanvankelijk in het geheel niet in geding was? ${ }^{28}$ En, meer toegespitst op het hier besproken arrest: kan een procedure uit onrechtmatige daad bij de burgerlijke rechter toch nog (enig) soulaas bieden, ondanks het feit dat eerdere, op later onrechtmatig bevonden regelgeving gebaseerde, besluiten formele rechtskracht hebben verkregen?

Het is mu zaak deze laatste vraag uitvoeriger te behandelen. Laat $\mathrm{k}$ vooropstellen dat ik in dit arrest niet kan lezen dat de Hoge Raad heeft beoogd terug te komen van zijn vaste, in hoofdstuk II, besproken jurisprudentie op grond waarvan heffingen waarvan later, in een door een derde aangespannen procedure, komt vast te staan dat ze berusten op een onrechtmatige regeling, niet alsnog als onverschuldigd betaald kunnen worden teruggevorderd. ${ }^{129}$ Deze conclusie wordt bevestigd door het in paragraaf 2.2 van dit hoofstuk besproken arrest Maple, ${ }^{130}$ waarin de Hoge Raad de lijn van het Vulhop-arrest heeft doorgetrokken naar de situatie waarin de wettelijke grondslag van de onaantastbaar geworden besluiten in strijd met het EG-recht werd geoordeeld.

Voorts kan ook in deze zaak de vraag worden opgeworpen of bij het oordeel van de Hoge Raad niet ook heeft meegespeeld dat Leenders zich van meet af aan op het standpunt heeft gesteld dat de verordening onverbindend was. De bewoordingen van het arrest wijzen hier niet op. Evenals Scheltema ${ }^{131}$ ben ik van mening dat het arrest er veeleer op wijst dat ook voor een - hypothetische - collega van Leenders, die braaf de beperkte vergunning heeft aanvaard, de door Leenders gevolgde rechtsweg openstaat.

Wat het toepassingsbereik van dit arrest voor de in deze studie besproken gevallen echter wel beperkt is dat het arrest mijns inziens alleen ziet op een situatie waarin de geleden schade rechtstreeks is terug te voeren op de onverbindendheid van de regeling en niet op een, ter uitvoering van die regeling, 'tussengevoegd' besluit van het bevoegde bestuursorgaan. Anders gezegd; Leenders leed door zich, althans tijdelijk, conform de verordening te gedragen schade en kan daarvan, nu de verordening onverbindend is gebleken, bij de burgerlijke rechter vergoeding vorderen. Zij kan dit doordat zij pas slechts de beginstadia van de bestuursrechtelijke weg heeft gevolgd en er dus nog geen oordeel van de bestuursrechter ligt. Ware dat wel het geval geweest, dan had het beginsel van de formele rechtskracht eraan in de weg gestaan dat de burgerlijke rechter zich in hour zaak nog had kunnen uitspreken over de rechtmatigheid van de verordening.

Voorts staat de vordering van Leenders geheel los van de vraag naar de rechtrnatigheid van de ter uitwoering van de verordening gegeven beschikking. Aldus is, in de woorden Bloembergen ${ }^{1 / 2}$ sprake van "een gedraging, die onafhankelijk van de inhoud van de

128 Het aspect van een mogelijke verjaring van deze vordering even daargelaten.

129 Zie i.h.b. het in thoofdstuk 2, par. 5.3, besproken arrest Vuhop (HR 16 oktober 1992, NJ 1993, 638 m.nt MS; AB 1993, 40 m.nt. FHwdB; ; Gst. 6962, nr. 5 , p. $165 \mathrm{~m} . n \mathrm{HH}$ H)

130 HR 24 januari $2003, \mathrm{AB} 2003,120 \mathrm{~m}$.nt. Widdershoven.; JB 2003/44 m.nt E. v.d. Linden.

131 Noot in N 1997, 165, onder punt 10.

132 Zie diens conclusie onder punt 2.3 .

133 Daarbij zij nog aangetekend dat Bloembergen de onrechtmatigheid van de gedraging van de gemeente niet rechtstreeks gelegen acht in de onverbindendheid van de APV-bepaling, matr in de ter uitvoering hiervan verrichte feitelijke gedragingen, te weten het feitelijk belemmeren van de handelsactiviteiten van Leenders. 
beschiking onrechtmatig is. Bloembergen heeft in dit verband gewezen op het door Mok en Tjittes gemaakte onderscheid tussen regelgeving die direkte en indirekte gevolgen heeft voor de betrokkenen. Daarbij is voor regelgeving die direkte werking heeft geen aparte beschikking nodig woor het intreden van rechtsgevolgen, terwijl bij regelgeving met indirekte werking nog wel een beschikking of andere uitwoeringshandeling nodig is om rechtsgevolgen te doen intreden. In het laatste gevall kan huns inziens pas sprake zijn van onrechtmatigheid als er een beschikking is gegeven die later is vernietigd. ${ }^{134}$ Het is deze situatie die aan de orde was in het arrest $V u$ uhop waarbij de schade niet rechtstreeks werd toegebracht door de belastingverordening als zodanig, maar eerst door de concrete toepassing die hieraan in de vorm van een heffingsbeschikking werd gegeven. Bloembergen verbindt aan een en ander de conclusie dat alleen bij indirekte werking de formele rechtskracht een rol kan_spelen.

De vraag is nu welke gevolgen uit het arrest Leenders getrokken kumnen worden voor de in hoofdstuk 3 behandelde sociale zekerheidszaken. Biedt het arrest, waar de bestuursrechtelijke weg, naar we hebben gezien, in de meeste gevallen weinig soullaas bood, betrokkenen alsnog de mogelijkheid om schadevergoeding te verkrijgen op grond van alsnog bij rechterlijke uitspraak gebleken onrechtmatigheid van de toepasselijke regelgeving? Op het eerste gezicht niet, ondat de regelgeving op het gebied van de sociale zekerheid bij uitstek is aan te merken als 'indirecte wetgeving' in de door Mok en Tjittes bedoelde zin. De gevolgen van onrechtmatige wetgeving op dit terrein ondervindt de burger pas door de met toepassing van deze wetgeving gegeven beschikking. En voor het indienen van een rechtsmidclel tegen deze beschikking is de burger aangewezen op het volgen van de bestuursrechtelijke weg.

Niettemin denk ik dat er in dit arrest toch nog wel een opening zit, die niet nieuw is, maar door het arrest wel weer in een nieuw daglicht is komen te staan. ${ }^{135}$ Zoals ik hiervoor al aangaf laat de Hoge Raad er in dit arrest geen gras over groeien dat hij de civiele procedure als de meest aangewezen weg beschouwt on een spoedige beslissing te verkrijgen over de rechtmatigheid van regelgeving. Krachtens vaste jurispmidentie ${ }^{136}$ is de toegang tot de burgerlijke rechter niet beperkt tot individuele burgers maar staat deze eveneens open voor belangenorganisaties, zoals, ik noem maar een voor de sociale zekerheid relevant voorbeeld, de IFNV. Niets staat er uiteraard aan in de weg dat een dergelijke organisatie ten behoeve van haar leden rechtstreeks een procedure bij de burgerlijke rechter aanspant ter verkrijging van een oordeel over de rechtmatigheid van regelgeving waartoe haar belangenbehartiging zich uitstrekt. Dat is niets nieuws, maar de rol die het volgen van deze weg kan vervullen bij het "preventief' ingrijpen ter bestrijding van onrechtmatige wetgeving wordt door dit arrest wel weer benadrukt, al besef ik wel dat ook de betckenis hiervan betrekkelijk is op het gebied van de sociale zekerheid. Het probleem is nu cenmaal dat de sociale zekerheidsrechten alleen op aanvraag kunnen worden ver-

1342 2ie Conclusie, puni 2.4 en M.R. Mok en R.P.M.L. Tjittes, Fomele rechtskracht en overheidsaansprakeligkheid, RM Themis $1995 / 9$, p. 383 e.v.

135 llk meen dan ook dat met dit arrest geen nietwe uitzondering op het beginsel van de formele wechtskracht is gegeven.

136 Zie hieromtrent: Van Wijk/Konijnenbelt \& Van Male, Hoofdstukken van Bestutusteoht, Den Hagg 1999, p. 110-113. 
kregen. Zolang de burgerlijke rechter geen onrechtmatigheidsoordeel ${ }^{137}$ heeft uitgesproken, zullen de desbetreffende bestuursorganen 'gewoon' de bestaande wetgeving uitvoeren en zullen de besluiten op aanvraag op een gegeven moment formele rechtskracht verkrijgen. Dit zal slechts anders zijn als de bestursorganen c.q bestuurstechter bereid is het oordeel van de burgerlijke rechter af te wachten. Het is niet te verwachten dat een dergelijke coördinatie in de praktijk tot grote problemen zall leiden, omdat de civielrechtelijke procedure gewoonlijk een kort geding zal betreffen. Maar dan nog biedt het volgen van deze weg geen oplossing voor de voor deze studie zo typerende gevallen, waarin een wettelijke regeling, waarvan de geldigheid aanvankelijk in het geheel niet werd betwist, op grond van latere ontwikkelingen 'toch' onrechtmatig blijkt te zijn. De 'oude' beschikkingen hebben dan reeds lang formele rechtskracht verkregen.

Het is tijd de ballans op te maken.

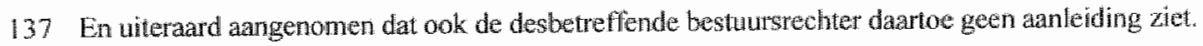





\section{Hoofdstuk 6}

\section{Conclusie}

In zijn rede die hij ter gelegenheid van zijn aftreden als president van de Hoge Raad heeft gehouden, heeft mr. S.K. Martens erop gewezen dat in de zestiger en zeventiger jaren van de vorige eeuw ook het taboe is neergehaald dat rechterlijke rechtsvinding niet meer of anders kan en mag zijn dan wetstoepassing. Hij wijst erop dat vanaf die tijd zowel doctrine, wetgever als rechter het 'kiekeboe spelen' hebben opgegeven en openlijk zijn gaan erkennen dat ook de rechter recht vormt.' Zoals in hoofdstuk 1 al ter sprake is gekomen, rezen met deze erkenning ook ten aanzien van de rechtspraak vragen van overgangsrecht. ${ }^{2}$

Bij zijn analyse van dit vraagstuk maakt Zwart een onderscheid tussen uitspraken met declaratoire werking en uitspraken die zien op een wijziging van het recht. In het eerste geval gaat het on uitspraken waarbij de rechter op louter juridische gronden blijk geeft van een andere visie op het bestaande recht. In dat geval wordt de nieuwe rechtsopvatting tevens geacht te gelden voor rechtsfeiten die zich vón de uitsprak hebben voorgedaan. In het tweede gewal gaat het om het optreden van de rechter die als regelgever nieuw recht schept. In de visie van Zwart vereist deze laatste activiteit een andere dan een zuivere juridische argumentatie en moet de rechter aangeven welke buiten het recht zelf gelegen maatschappelijke of andere factoren een rechtvaardiging voor de wijziging van de regel bieden. ${ }^{3}$ In beide gevallen gaat Zwart uit wan een situatie waarin de (Nederlandse) rechter zelf, autonoom, kan bepalen met ingang van welk tijdstip de nieuwe rechtsopvatting heeft te gelden.

De problematiek waar dit onderzoek betrekking op heeft ligt echter nog een graadje ingewikkelder en lijkt zich te kenmerken door een zekere mengvorm van de door Zwart beschreven situaties. Het gaat in dit boek immers enerzijds om situaties waarin een verandering van rechtspraak heeft plaatsgevonden op grond van een wijziging in thatschappelijke opvattingen, dus, in de woorden van Zwart, om rechterlijke regelgeving; anderzijds is het echter zo dat de in dit boek besproken verandering van rechtspraak ook een zuivere juridische component heeft op grond wan de doorwerking van het internationale recht. Voorts kenmerken de in dit boek besproken gevallen zich door een veelal grote divergentie tussen het moment waarop uitspraak wordt gedaan en het moment met ingang warvan het recht geacht wordt te zijn veranderd, waarbij dit laatste tijdstip de Nederlandse rechter niet zelden werd 'opgedrongen' door internationale rechtscolleges.

Dit onderzoek ziet op de waardering wan rechtsfeiten die zich tussen dexe twee tijdstippen hebben voorgedaan. Het gaat daarbij enerzijds om situaties waarin achteraf moet worden

1 S.K. Martens, De grenzen wan de rechts wormende taak van de rechter, NJB 2000 , p. 748.

2 Zie Martens, aw. 750 en voetwoot 49 en F.P. Zwart, Enkele opmerkingen over rechtertijk overgangsrecht, NJB 1997, af. 3, p. 108.114.

3 Zwart, a. W., p. 110. 
geconcludeerd dat op deze feiten lange tijd het "verkeerde recht" door het bestunirsorgaan en de bestuursrechter is toegepast, en, anderzijds, om situaties waarin de betrokkenen op het "oude" recht zijn afgegaan en hierin hebben berust. Om de vraag te analyseren welke aanspraken betrokkenen in deze situaties nog kumnen maken op de mieuwe rechtsopvatting, is in dit onderzoek het begrippenpaar van de materiële en formele werking van verandering van rechtspraak geintroduceerd. Daarbij ziet de materiële werking op het tijdstip met ingang waarvan een bepaalde uitleg wan een wettelijk voorschrift onrechtmatig wordt geacht. De formele werking ziet op het tijdstip met ingang waarvan op deze onrechtmatigheid gebaseerde vorderingen kunnen worden geëffectueerd. Bij de formele werking gaat het, met andere woorden, om de vraag of en in hoeverre daadwerkelijk rechtsherste! kan worden verkregen op grond wan veranderde jurisprudentie. Het doel van dit onderzoek is deze vraag te beantwoorden aan de hand van een aantal, veelal op de sociale zekerheid betrekking hebbende, casus. Dit levert het wolgende beeld op.

Uit het onderzoek komt in de eerste plaats naar voren dat de mogelijkheid onder de oude, later onjuist gebleken, rechtsopvatting tot stand gekomen besluiten aan te tasten in vrijwel alle gevallen afstuit op het beginsel van de formele rechtskracht. Dit is volgens de nationale rechtsopvatting ook het geval als de oude rechtsopvatting in strijd is met fundamentele rechtsbeginselen. Van betrokkenen wordt te allen tijde verwacht dat zij gebruik maken van de mogelijkheid rechtsmiddelen in te stellen, ook als dit, afgaande op de oude rechtsopvatting en rechtspraktijk, zinloos zou zijn geweest. Dit is slechts anders als zij voor wat de mogelijkheden van rechtsbescherming betreft op een aan het bestuursorgaan toe te rekenen wijze 'op het verkeerde been zijn gezet'. Dit laatste wordt echter niet aangenomen op de enkele grond dat het bestuursorgaan bij thet nemen van zijn besluiten is uitgegaan van een verkeerde rechtsopvatting c.q. deze heeft gebaseerd op een later onverbindend verklaarde regeling.

Recente rechtspraak van het EHRM en het HwJ EG heeft evenwel uitgewezen dat wel een uitzondering op het beginsel van de formele rechtskracht moet worden gemaakt ten behoeve van degenen die, na eerder een onherroepelijke uitspraak te hebben verkregen in een procedure waarin zij tevergeefs hadden betoogd dat het besluit in strijd was met het EG-recht, cen nieuwe procedure beginnen na in een door een derde aangespannen procedure alsnog hun gelijk te hebben zien bevestigd. Voor het overige is het beginsel van de formele rechtskracht naar de huidige stand van de jurisprudentie verenigbaar met het EGrecht geacht, tenzij de geboden rechtsbescherming niet beantwoordt aan thet gelijkheids- en doelmatigheidsbeginsel, zoals deze worden uitgelegd door het HvJ EG. De rechtspraak biedt voorts enige aanknopingspunten voor de veronderstelling dat een uitzondering op het beginsel van de formele rechtskracht eveneens is aangewezen bij gebreke van een effective remedy als bedoeld in thet EHRM on een, naar later blijkt, in strijd met het EG-recht onthouden aanspraak, te effectueren.

Zoals met name in hoofdstuk 2 is uiteengezet staat het beginsel van de formele rechtskracht er niet aan in de weg dat het besfuur op grond van de nieuwe jurisprudentie een onder de oude rechtsopvatting tot stand gekomen besluit ambtshalve of op verzoek met terugwerkende kracht heroverweegt. Tevens is gebleken dat de mate van daadwerkelijk rechtsherstel die langs deze weg kan worden verkregen een zeer wisselend beeld vertoont. Vaste jurisprudentie is in elk geval dat het enkele feit dat latere jurisprudentie leidt tot de conclusie dat door het bestuur bij eerdere besluitvorming op een onjuiste wijze toepassing 
is gegeven aan een wettelijk voorschrift, dan wel dit voorschrift onverbindend moet worden geacht, het bestuur niet verplicht alle nog onder de 'oude jurisprudentie' tot stand gekomen besluiten te herzien. Uit het discretionaire karakter van de bevoegdheid van het bestuur om terug te komen van in rechte onantastbaur geworden besluiten vloeit voorts voort dat door hei bestur ter uitvoering van deze bevoegdheid vastgesteld beleid door de rechter terughoudend wordt getoetst. Voorzover op grond van de nieuwe rechtsopvatting zou moeten worden geoordeeld dat een onder de oude rechtsopvatting genomen beshuit als onmiskenbaar onjuist zou moeten worden aangemerkt, is uit de besproken jurisprudentie niet af te leiden dat dit to een plicht van het bestuursorgaan zou leiden on "oude besluiten" te herzien. Uit de bespreking van de arresten Kuhne \& Heitz, Köbler en Dangeville is gebleken dat dit mogelijk anders is indien de "oude beshuten" alsnog in strijd blijken te zijin met EG-recht.

Ziet het voorgaande op een mogelijke gehoudenheid van het bestuur om in het licht van veranderde jurisprudentie bestaande rechtsverhoudingen te wijzigen, ten aanzien van de totstandkoming van nieuwe rechtsverhoudingen bleek in de eerste plaats dat de formele werking in de tijd (de mate waarin betrokkenen hun op grond van de nieuwe rechtspraak verkregen rechten alsnog geldend kunnen maken) in de eerste plaats afhangt van de wijze waarop de desbetreffende nationale wetgeving is ingericht. Zo bleek de ruime mate van terugwerkende kracht waarmee op grond van de rechtstreekse werking van EG-richtlijn $79 / 7$ alsnog WWV-rechten konden worden geclaimd eerst en vooral terug te voeren op het feit dat de WWV het recht op uitkering niet rechtstreeks koppelde aan het moment van intreden van de werkloosheid en bovendien niet vereiste dat de aanwagg binnen een bepaalde termijn na het intreden van de werkloosheid werd ingediend. Van een soortgelijke "katalyserende werking' bleek eveneens ten aanzien van de AAW, althans voor wat de materiële werking van EG-Richtlijn $79 / 7$ betreft (de mate warin op grond van de rechtstreekse werking van deze richtlijn alsnog met terugwerkende kwacht recht op uitkering ontstond). Terwijl een poging wan de Nederlandse regering om deze materiéle werking door middel van reparatiewetgeving te beperken bij het HVI EG schipbreuk leed, kon een wettelijke beperking wan de formele werking wel, zij het ternauwernood, genade winden in de ogen van her Hot.

De vraag naar welk tijdstip moet worden beoordeeld of iemand in verband met latere ontwikkelingen in de jurisprudentie rechten over het verleden kan doen gelden, kwam hot meest principieel aan de orde bij bespreking van de gevolgen van de doorwerking van intemational recht voor de verzekering krachtens de AOW. Doorslaggevend in deze kwestie leek lange tijd de vrag met ingang van welk tijdstip de matschappelijke ontwikkelingen zo ver waren woortgeschreden dat de bij algemene maatregel van bestur vonziene uitsluiting voor de AOW-verzekering van de gehuwde vrouw in strijd kon worden geacht met het gelijkheidsbeginsel, waarbij achtereenvolgens is getoetst aan EG-Richtlijn 79/7, artikel 26 van het IVBPR, artikel I wan de Grondwet en tenslotte artikel 14 van het EVRM. Het is ook hier dat de EHRM wan alle rechterlijke instanties die zich met deze vraag hebben beziggehouden de meeste dynamiek vertoont door geen verdere beperking in de tijd wan de doorwerking wan artikel 14 van het EVRM te aanvaarden dan is gelegen in het tijdstip van inwerkingtreding van dit verdrag voor Nederland.

Dat de bestum srechter ook de mogelijkheid openhoudt van het bieden wan daadwerkelijk rechtsherstel voor gemis aan uitkering op een wijze die los stat van de in geding zijnde 
wetgeving, blijkt uit de jurisprudentie van de Centrale Raad van Beroep met betrekking tot de problemen die ontstonden in verband met de samenloop van de AAW en AWW. In deze gevallen woorzag de Centrale Raad van Beroep voor de getroffen weduwen in een vorm van comperisatie van de financiële gevolgen van de op de toekenning van een AWW-uitkering volgende intrekking van de AAW-uitkering, die was geschied op een wijze die zich niet verdroeg met EG-Richtlijn 79/7. Deze compensatie bleef echter beperkt tot degenen die eerder in rechte tegen de intrekking van de AAW-uitkering waren opgekomen.

Dezelfde mogelijkheid werd, nu in meer principiële zin, geopperd door Koopmans in thet kader van de Bopa-affaire, dit keer in een situatie waarin betrokkenen, zonder eerder te hebben geprocedeerd, vergoeding vorderden van schade die het gevolg was van een bestuurlijke uitvoeringspraktijk die, naar in door een derde gevoerde procedure bij de bestuursrechter was komen vast te staan, is strijd was met het toenmalige artikel 119 EEGVerdrag. Uit het uit de rechtsprak van het HvJ EG volgende recht op een daadwerkelijke en doelireffende rechtsbescherming suggereerde Koopmans dat betrokkenen zich tot de burgerlijke rechter zouden kunnen wenden met een op onrechtmatige daad gebaseerde vordering van door hen geleden schade. Daarbij zoekt Koopmans de grondslag van de schadevergoeding in de immateriêle schade die de betrokkenen hebben geleden ten gevolge van de discriminatie die zij hebben ondervonden. Voorts is hij van mening dat de vergoeding voor de overheid ook een punitief karakter zou moeten dragen.

Mijn inziens is er ook in algemene zin wel wat voor deze oplossing te zeggen, vooral omdat zij een mogelijkheid biedt voorbij te gaan aan de vele in dit boek besproken procedurele en bewijstechnische voetangels die aan het bieden wan daadwerkelijk rechtsherstel in de weg staan. Het lijkt me bovendien een mogelijkheid die (eindelijk) recht doet aan het in artikel 13 van het EVRM opgenomen recht op een effective remedy. Gelet op de ruime interpretatie die het EHRM aan artikel 1 van het Eerste Protocol bij het EVRM heeft gegeven, kan er geen twijfel meer over bestaan dat artikel 13 van het EVRM op de in dit boek besproken gevallen van toepassing is. Dat een op gewijzigole jurisprudentie gebaseerde (financiële) aanspraak onder omstandigheden, zeker indien de betrokkene eerder tevergeefs heeft geprocedeerd, kan worden aangemerkt als een arguable claim lijkt me evenmin voor betwisting vatbaar. Mijns inziens wordt in de huidige rechtspraak op het in dit boek besproken terrein onvoldoende recht gedaan aan de door het EHRM uit artikel 13 van het EVRM afgeleide verplichting voor de Lid-Staten met betrekking tot deze arguable claim te voorzien in een domestic remedy strekkende tot het bieden appropriate relief." Dat het EHRM hecht aan de beschikbaarheid van een remède suffisant met voorbijgaan aan principess jurisprudentiels traditionnesl opdat an hoger recht ontleende, maar op grond wan oude nationale rechtspraak ontzegde, rechten alsnog geldend kunnen worden gemaakt, bleek uit de in hoofdstuk 5 besproken zaak Dangeville. 


\section{Summary}

This book deals with the consequences of (sudden) changes in the case law of Dutch administrative courts, particularly in the area of social security law. for legal positions established under earlier and meanwhile abandoned case law. The book is particularly concerned with changes in case law which are the result of the application by Dutch courts of international treaty provisions which are considered by the Dutch courts or the EC Court of Justice to be directly applicable in the Dutch legal order. What are the consequences of court decisions taken in, for example, 2001, holding that the national statutory provision applicable to the case is a violation of international law as from a moment in time - say, 1984 - often long preceding the moment of the court decision (in this example, 2001)? What is the position of third party (Mrs Smith) who, although having an identical legal problem to Mrs Jones, decided, on the basis of earlier case law to (justifiably) refrain from making a claim. When subsequently, Mrs Jones is vindicated in her decision to bring proceedings by a court holding that her rights have been violated, is it sufficient to say simply, that Mrs Smith has had a stroke of bad luck? Or do situations occur in which changes of case law have retrospective effect? It is this question which is central to the present book. When discussing the retrospective effect, through the whole book a distinction has been made between, on the one hand, the moment from which as a result of a change of case law a substantive right not earlier recognised has been theld to exist and, on the other hand, the moment from which this right can actually be enforced by third parties.

As is pointed out in chapter one the first moment, the moment from which the law is changed through new case law, has been given considerable attention in Dutch legal writing, most particularly in the dissertation of O.A. Haazen (Algemeen deel van her rechterlijk overgangsrecht, Tilburg 2001). His book concentrates on the effects of changes of case law in the field of private law. An important difference between the private and administrative law context is that, whereas the former is characterised by lengthy periods within which claims based on the new case law can be brought, the latter poses formidable limitations on the enforcement of new rights as a result of the very limited periods, generally six weeks, within which procedures have to be brought.

The latter aspect is further developed in chapter two. In this chapter I discuss the so-called formele rechtskocht, a rule that is central to Dutch administrative law. I will refer to this rule as the 'rule of finality' (broadly comparable with the rule known in the English system as Res judicaia). According to this rule a decision of a public authority which bas not been challenged in court within the required time limit is considered to be final. It also means that the Dutch civil courts are barred from giving judgement in tort proceedings regarding such a decision, and will apply the fiction that the administrative decision satisfies the requirements of the law. An exception to this rule is only applied if the civil court considers that the claimant had earlier been misled by the public authority concerned regarding his possibilities to challenge the administrative decision in the administrative courts. 
Ass a result two questions arise: (1) does a change of case law which, with retrospective effect, establishes substantive rights which third parties have not earlier pursued because they acquiesced in earlier case law denying them those rights, present a special circumstance giving rise to an exception to the rule of finality? (2) If the rule of finality still applies in these situations, are there other ways in which the newly acquired rights can be enforced? On the basis of research of the relevant case law it is concluded in chapter two that, according to national law, no exception to the principle of finality is accepted if third parties seek the enforcement of substantive rights which have been realised with retrospective effect in another procedure. The second question is much more difficult to answer. Traditionally Dutch public authorities have always had the power to reconsider decisions that have become final. According to well-established case law the way public authorities apply this power, including the decision not to apply it at all, can only be subjected to very marginal scrutiny by the courts. Nonetheless several examples are given in this chapter showing that public authorities have made it possible for third parties to enforce rights with retrospective effect, whilst the administrative courts have given judgements with regard to the moment in time from which the possibility of enforcement should apply. The picture that arises is varied: the relevant moments vary from the date of the judgement which established the change of the case law, the date at which the facts relevant to the earlier judgement took place and several other dates set in so-called 'policy rules'. Sometimes, more significantly, the moment at which the relevant social changes have taken place are considered decisive.

In chapter four the same two questions are discussed, but this time with respect to changes in case law that stem from the direct applicability of international law. Most of the case law treated in this chapter is concerned with the application of the principle of equal treatment of men and women in social security. By way of introduction and in order to explain the aspects of direct applicability relevant for my research I discuss in chapter three the international provisions, which play a central part in

chapter four. These are: Article 26 of the International Convention on Civil and Political Rights, Article 141 of the EC-Treaty, Article 4 of EC-Directive $79 / 7$ on the equal treatment of then and women in social security and Article 14 of the European Convention on Human Rights and Fundamental Freedoms (ECHR).

Chapter four forms the kemel of my research. Through a study of the case law regarding the effects of earlier case law in which Dutch courts have declared long standing practices of excluding groups of married women from social security rights unlawful under international law, I have analysed the factors that have been decisive for the measure of retrospectivity with which women relying on these judgements have been able to enforce their rights. Again, a varied picture arises, with the common factor that the measure of retrospectivity is first of all dependent on the structure of the relevant social security Act.

In paragraph 1, in the case of the former Wet werkloosheidsvoorziening (WWV), an Act providing for a financial allowance from the municipal authorities in case of unemployment, it appears that the (substantive) right to the allowance is directly dependent on the status of unemployment and that the Act has very lenient rules as to when an application should be made to acquire those rights. Through a series of judgements, both from the EC 
Court of Justice and the national courts, this results, in the end, to almost complete retrom spectivity of the enforcement of the newly acquired rights.

A different picture arises from the case law considering the retrospectivity of a number of very important cases decided by the Centrale Raad vam Beroep (the court of appeal in social security matters) on January 5 th 1988 . In these judgements - that were my main inspiration for carrying out this research - the Centrale Raad van Beroep held that the provision in the former Algemene Arbeidsongeschiktheidswet (General Disability Act) excluding married women whose disability to work dated from before lanuary Ith 1980 violated Article 26 of the International Convention on Civil and Political Rights. Because, as in the $W W W$, the substantive right to the allowance was dependent on the status of disability (regardless of the moment at which the actual claim was made), the Government feared immensely expensive retrospective effects of the judgements, taking account of the number of women involved and the long duration of the discriminatory treatment. The Government tried to curb the consequences of the judgements in two different ways: first, by removing, through legislation with retrospective effect, the newly-acquired rights; and second, by relying on the procedural provision in the General Disability Act which states that, even in cases in which it is established that the disability materialised a long time ago, the right to disability benefit can, in principle, only be enforced with retrospective effect of one year. In the relevant provision the public authority concerned was, however, given the power in special cases to grant the allowance with retrospective effect of more than one year. Discussion arose as to whether the cases of the married women fell within this category and whether the public authority could be held to be obliged to use its power to grant the allowance with retrospective effect of more than one year. Both attempts of the Dutch Government resulted in fundamental case law of the EC Court of Justice discussed in paragraph 2 of chapter four, with the end result that the statutory provision removing the substantive rights was held to be a violation of EC Law, whilst the procedural limitation of the enforcement of the rights only narrowly escaped the disapproval of the EC Court of Justice.

The case law discussed in paragraph 4 of chapter four concerning the provision excluding married women from the accumulation of pension rights under the Algemene ouderdomswet (the Act providing for an old age state pension) with respect to the periods up to April Ist 1985 during which their spouses had been employed (and insured) abroad, shows yet another set of features regarding the retrospective effect of case law. After the Dutch Government had tried to argue that, as far as the accumulation of pension rights is concemed, the relevant group of married women could only claim equal rights to those of married man from the date of December 24th 1984 onwards (a date vital to this research at which the period of implementation of EC Directive 79/7 had ended), the EC Court of Justice soon made it clear that women, from the 24 th of December 1984 onwards, were not to suffer the discriminatory effects of their former exclusion. This judgement put the women who, on attaining 65 belonged to the workforce and who therefore fell under the realm of EC Directive 79/7, in a strong position. The Dutch courts, particularly the Centrale Raad van Beroep, took a completely different stand, however, regarding married women who, upon reaching pensionable age, were considered to be unemployed. Through a quirk in Dutch administrative law in these cases, not only the Centrale Raad van Beroep-nontmal- 
ly the highest court in social security matters -, had jurisdiction, but also the Hoge Raad (usually referred to as the Dutch Supreme Court). The remarkable result was a series of cases in which the date as from which the unequal accumulation of pension rights for married women was considered unlawful, was pushed back from 24th December 1984 (Centrale Raad van Beroep 1996) to the moment in time when the social circumstances in the Netherlands could be considered such that the unequal treatment complained of was to be considered a violation of the general (unwritten) principle of equal treatment (Hoge Raad (996). Most important, in the end, was the role played by the European Court of Human Rights, which in 2002 effectively decided that the exclusion of married women amounted to discrimination contrary to article 14 of the ECHR from the very day that the ECHR came into effect.

Paragraphs 3 and 5 of chapter four signal a tentative development in the case law towards compensation for discriminatory treatment in social security, not through, from a particular moment in time, granting the formerly denied rights, but through damages in a tort procedure before the civil courts, thus by-passing the rule of finality.

Chapter five opens with a short evaluation of the case law discussed in the earlier chapters. It is concluded that the possibilities of retrospectively enforcing substantive rights acquired on the basis of changes of case law are, for practical purposes, inconsistent and to some extent even arbitrary. It is also pointed out that this inconsistency is due to a large extent to the fact that the procedural requirements for the enforcement of substantive rights, whether they stem from changes of case law at a purely national level or from directly applicable provisions of international law, are, in principle, always governed by national law. The question is therefore raised whether EC-law, considering its special, supra-national character can, in its own right, override the national principle of finality in order to create more balanced provision for the enforcement of rights, earlier wrongfully denied at the national level and later recognised to be truly founded on EC-law. It is shown that recent decisions of the EC Court of Justice have not only made little dents in the national bastion of the rule of finality but, in cases relevant to this research, also seem to have opened the door to actions for damages directly based on EC-Law. Furthermore it is shown that these developments are supported by recent case law of the European Court of Human Rights. 


\section{Jurisprudentie}

\section{Comité voor de Rechtem van de Mens}

9 april 1987, Danning, Communication nr. $172 / 1984$, RSV 1987245 m.nt. W. M. LeveltOvermars onder RSV $1987 / 246,75,77,105$

9 april 1987, Broeks, Communication 180/1984, RSV 1988/201; RSV 1987/245 m.nt. W.M. Levelt-Owermars 75, 96,105

29 maart 1989, Vos, RSV $1990 / 172$ en N.JCM-Bulletin, 14 (1989), mr. 7, p. $879-88877$. 143

5 mei 1993 J.W.H. v. The Netherlands, NJCM-Bulletin 18-7 (1993), p. 858-862 78

22 oktober 1993, C.H.J. Cavalcami Arawjo-Jongen w. the Netherlands, NJCM-Bulletin 19-2 (1994), p. 185-186, m.nt. Aleidus Woltjer 77,78

\section{FHRM}

EHIRM 21 februari 1975, Series A, vol. 17; NJ1975,462 m.nt. E.A. Alkema 2I

EHRM 13 juni 1979, Marckx, Series A, vol. 31, par. 58; NJ1986, 462 m.nt. E.A. Alkema 4,190

EHRM 4 mei 1989, Hauschildt, Series A, vol. 154, par. 45; NJ 1990.627 m.nt PvD 4

EHRM 16 september 1996, Gaygusuz, Reports 1996-IV; RSV 1997/234; JB 1997/20 m.nt. Heringa; NJCM-Bulletin, 22 (1997), p. 461-474 m.nt. C.A. Groenendijk; SMA 1997, p. 253-259 m.nt. G.J. Vonk $88,153,180$

EHRM 21 februari 1997, Van Raalte, Reports 1997-I; JB 1997/64 m.nt. A.W. Heringa; AB 1997, 432 m.nt F.J.L. Pennings 88,89153

EHRM 8 juli 1999, Tanrikulu w. Turkey, Reports of Judgements and Decisions 1999-IV 206

EHRM 16 april 2002, Dangeville, AB 2004, 75, m.nt. Verheij EHRC 2002/45 m.nt. Heringa $16,88,184,185,186,188,189,191$

EHRM 4 juni 2002, Wessels-Bergervoet, Reports of Judgments and Decisions 2002-IV; RSV 2002/181; NJCM-Bulletin, jrg. 28 (2003), nr. 1, p. 45-53, m. nt. Aart Hendriks 89 , 154 


\section{HWJ EG}

HvJ EG 5 februari 1963, Zaak 26/62 Van Gend \& Loos, Jur. 1963, p. 2369

HvJ EG 27 maart 1963, gewoegde zaken 28-30/62, Da Costa en Schaake, Jur. 1963, p. 63 180

HvJ EG 4 december 1974, zaak 41/74, Van Danyn v. Home Office, Jur. 1974, p. 1337; SEW 1976, p. 6780

HvJ EG 23 januari 1975, zaak 51/74, Van der Hulst, Jur. 1975, p. 7966

HvJ EG 8 april 1976, zaak 43/75, Defrenne II, Jur. 1976, p. 455 5, 63, 78, 79, 146, 190

HvJ EG 16 december 1976, zaak 33/76, Rewe, Jur. 1976, p. 1989 66, 117, 168, 173

Hv. EG 16 december 1976, zaak 45/47, Comet, Jur. 1976, p. $2043 \quad 66,67,168,173$

Hv.l EG I februari 1977, Zaak 51/76, VNO, Jur. 1977, p. 113, r.o. 23 en 2480

HvJ EG 15 juni 1978, zaak 149/77, Defrenne III, Jur. 1978, p. 136578

HvJ EG 27 februari 1980, zaak 68/79, Hans Just, Jur. 1980, p. 5067

HvJ EG 27 maart 1980, zaak 61/79, Denkavit Ilaliana, Jur. 1980, p. 1205 67, 181

Hv. EG 12 juni 1980, zaak 130/79, Express Dairy Foods, Jur. 1980, p. 188767

HvJ EG 10 juli 1980, zaak 811/79, Ariete, Jurispr. 1980, p. 254567

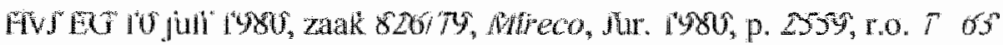

HvJ EG 31 maart 1981, zaak 96/80, Jenkins, Jur. 1981, p. 91185,86

HvJ EG 19 januari 1982, zaak 8/81, Becker, Jur. 1982, p. 5380

HvJ EG 23 september 1982, zaak 274/81, Besen, Jur. 1982, p. 2995; RSV $1983 / 90$ m.nt. Govers 65

HvJ EG 6 oktober 1982, zaak 283/81, Cilfit, Jur. 1982, p. 3415180

HvJ EG 23 december 1982, zaak 275/81, Jurispr. 1982, p. $3013 \quad 146$

HvJ EG 23 maart 1983, zaak 77/82, Anastasia Peskeloglou, Jur. 1983, p. 108581

HvJ EG 9 november 1983, zaak 199/82, San Giorgio, Jur. 1983, p. 3595 67, 117

HvJ EG 10 april 1984, zaak 14/83, Von Colson en Kamann, Jur. 1984, p. 1891162 
HvJ EG 10 april 1984, zaak 79/83 Harz/Tradax, Jur. 1984, p. 1921162

HvJ EG 26 februari 1986, zaak 152/84, Marshall, Jur. 1986, p. 723, r.o. 46 en 4780

HvJ EG 15 mei 1986, zaak. 222/84, Johnston, Jur. $\llbracket 986$, p. $165 \rrbracket$ 87. 168

HwJ EG 24 juni 1986, zaak 150/85, Drake, Jur. 1986, p. 1995; RSV $1987 / 240 \quad 83,84$

HvJ EG 2 december 1986, zaak 239/85, Commissie/België, Jur. 1986, p. 3645140

HvJ EG 4 december 1986, zaak 71/85, FNV, Jur. 1986, p. 3855; NJ 1987, 846 m.nt. Steyger; RSV $1987 / 95$ m.nt. Govers $83,92,93,118,133$

HvJ EG 11 juni 1987, zaak 30/85, Teuling-Worms, Jur. 1987, p. 2497; NJCM-Bulletin 13-2 (1988), p. 104; zie ook NJCM-Bulletin 15-4 (1990), p. 46787

HwJ EG 24 juni 1987, zaak 384/85, Borrie Clarke, Jur. 1987, p. 2865; RSV 1988/182 m.nt. F.W.M. Keunen 93, 123,145

HvJ EG 9 juli 1987, gevoegde zaken 281/85, 283/85, 284/85, 285/85 en 287/85, Duitsland e.a./Commissie, Jur. 1987 , p. $3203 \quad 128$

HvJ EG 8 oktober 1987, zaak 80/86, Kolpinghuis, Jur. 1987, p. 3969; Ars Aequi 37 (1988), p. 329 e.v. m.nt. C.W.A. Timmermans 81

HvJ EG 15 oktober 1987, zaak 222/86 Heylens, Jur. 1987, p. $4097 \quad 168$

HvJ EG 2 februari 1988, zaak 309/85, (Barra) Jur. 1988, p. 355174

HvJ EG 5 maart 1988, zaak 80/87, Dik, Jur. 1988, p. 16016

HvJ EG 8 maart 1988, zaak 80/87, Dik, RSV 1988/183, m.nt. F.W.M. Keunen 80.93, 94 , $95,118,123,133,145$

HvJ EG 22 september 1988, zaak 236/87, Bergemanm, Jur. 1988. p. 5125; RSV 1990/170 86

HvJ EG 27 juni 1989, gevoegde zaken 48, 106 en 107/88, Achterberg-Te Riele e.a., Jur. 1989 , p. 1963; RSV 1990/232 m.nt. Van Dalen-Van Bekkum 84

HvJ EG 13 juli 1989, zaak 171/88, Ringer-Kühm, Jur. 1989, p. 274386

HvJ EG 17 oktober 1989, zaak 109/88, Danfoss, Jur. 1989, p. 3199; RSV 1990/176 102

HvJ EG 13 december 1989, zaak C-102/88, Ruzins/Wilbrink, Jur. 1989, p. 4311; Rechtspraak Nemesis 1990, nr. 85; N.JCM-Bulletin, 16-1 (1991), p. 65 83,87 
HvJ EG 17 mei 1990, zaak 262/88, Barber v Guardian Royal Exchange Group, Jur. 1990, [-1889; NJCM-Bulletin 16-1 (1991), p. 55 e.y. 6, 146, 190

HvJ EG 19 juni 1990, zaak C-213/89, Fucrortame, Jurispr. 1990, p. I-2433 67,82

HvJ EO 13 november 1990, zaak C-106/89, Marleasing, Jur. 1990, p. I-4135, r.o. 8 82, 130

Hv EO 13 maart 1991, zaak C-377/89, Cotter en McDermott, Jur. 1991, p. 1-1155 118

HuJ EO 7 mei 1991, zaak C-229/89, Commissie/Belgie, Jur. 1991, p. 1-2205 128

HvJ EG 11 juli 1991, zaak C-31/90, Johnson, Jur, p. 1-1991, 3723; Rechtspraak Nemesis 1992, nr. 3 m.nt. Van Geffen 84

HvJ EO 11 juli 1991, zaken C87/90, C88/90 en C89/90, Verholen e.a., RSV 1991/227, p. 617 en 618, mnt. Feenstra $82,84,123,146$

HvJ EG 25 juli 1991, zaak C-208/90, Emmott, Jur, p. 1-4269; AB 1992,1 m.nt. A.W.H. Mej; RSV $1992 / 189$ m.nt. F.W.M. Kewnen; SEW 10 (1992), p. 783 e.v. 67, 116, 118, 169

HvJ EG 19 november 1991, zaken C-6/90 en C-9/90, Francowich en Bonifaci, Jur. 1991, p. I-5357; AB 1994, 482 m.nt. F.H. van der Burg; SEW (1993), p. 87 e.v. 67, 82, 94, 101, 162,183

HvI EG 19 november 1992, zaak C-226/91, Molenbroek, Jur. 1992, p. I-5943, r.o. 1387

HvI EG 6 oktober 1993, zaak C-109/91, Ten Oever, Jur. p. I-4879 146

HvJ EG 27 oktober 1993, zaak C-337/91, Van Genert-Derks, Jur. P. I-5435; RSV $1994 / 213$, m.nt. F.W.M. Keunen 138

HVI EG 27 oktober 1993, zaak C-338/91; Steenhorst-Neerings, Jur. 1993, p. 1-5475; RSV 1994211 m.nt. F.W.M. Kaunen 99,100,116,118,140,174

HvJ EG 16 december 1993, zaak C-334/92, Wogner Miret, Jur. 1993, p. I-69l1, r.o. 20 81

HvJ EG 24 februari 1994, zaak C-343/92, Roks, Jur. p. I-571; AB 1995, 53 m.nt. RH; RSV $1994 / 21488,104,125,174$

HVJ EG 20 april 1994, RSV $1994 / 213 \quad 139$

HvJ EG 5 mei 1994, zaak C-38/93, Glowe, Jur. 1994, p. I-1679 170

HvJ EG 14 juli 1994, zaak C-91/92, Dori, Jur. 1994, p. 1-3325; Ars Aequi 43(1994) 12, p. 845 e.v. $8 I_{n} 82$ 
HwJ EG 5 oktober 1994, zaak C-151/93, Woogd, Jur. 1994, p. $1-4915 \quad 175$

HWJ EG I februari 1996, zaak C-280/94, Poshmong-Von Dowme en Oztük Juir. 1996, p. I179; AB 1996, 261 m.nt. FP; RSV 1996/169 m.nt. F.W.M. Keunen 123, 127

HwJ EG 8 februani $1996, F M C$, Jur. 1996, p. $1-389 \quad 174$

HvJ EG 11 juli 1996, zaak C-39/94, SFELLa Poste, Jur. 1996, p. 1-3547 192

HWJ EG 2 december 1997, Fantask, Jur. 1997, p. 6783; TVVS 1998, met comm. Mok 169. 174

HvJ EG 15 juli 1998, zaak C-231/96, Edis, Jur. 1998, p. I-4951 168, 169

HwJ EG 15 september 1998 , zaak C-260/96, Spac, Jur. 1998, p. $1-4997 \quad 168$. 169

HWI EG 15 september 1998, gevoegde zaken C-279/96, C-280/96 en C-281/96, Ansaldo, Jur. 1998, p. 1-5025 169

HWJ EG 17 november 1998 zaak C-228/96, Aprile II, Jurispr. 1998, p. I-714 168

HwJ EG HvJ 9 februari 1999, zaak C-343/96, Di-eaport, Jur. 1999, p. I-579 174

HvJ EG 14 september 1999, zaak C-310,97, Commissie/Assi-Domön Kraft Prodncts AB, Jur. 1999, p. $\llbracket-5363 \quad 176$

IHv EG 10 februari 2000, zaak C-50/96, Deutsche Telekom, Jur. 2000, p. 1-743, par. 43 181

HvI EG 28 november 2000, zaak C-88/99, Roquette Frènes, Jur. 2000, p. L-10465 169

Hw EG 8 mart 2001, gevoegde zaken $\mathrm{C}-397 / 98$ en $\mathrm{C}-410 / 98$, Metalgeselschoft, Jur. 2001, p. 1-1727; SEW 2002, p. 154, m.nt. Van den Hurk en Prinssen 166

HwJ EG 1 ; juli 2002, zaak C-62/00, Marks \& Spencer, Jur, 2002, p. I-4483; SEW 12 (2002), p. 479-480 m.nt. Swinkels 174

HwJ EG 9 deember 2003, zaak C-129/00, Commissie v. Thalie, JB 2004/72, m.nt. M. Claes 183

Hv EG 12 december 2002, zaak C $470 / 99$, Universale-Baw, Jur. 2002, p. 1-11617 /73

HwJ EG 30 september 2003, zaak C-22401, Köbler, JB 2004/41 m.nt. M. Claes; AB 2003 , $429 \mathrm{~m} . \mathrm{nt}$. Widdershoven $183,184,190$

Hw EG 13 januari 2004, Kuhne of Heitz, JB 2004/42 m.nt. N. Vertheij $178,181,190$ 


\section{Conseil d"ettat}

20 oktober 1989, Nicolo, Recueil Lebon, p. 190187

\section{HR}

HR 30 juni 1911: W 9197 I3

HR 31 december 1915, NJ 1916,407 17

HR 26 oktober 1951 , NJ 1952, 756 m.nt. Veegens 7

HR 22 lebruari 1957, AB 1957, p. 555, m.nt M. Troostwijk (Schellen-en deuropenersarresn) 17

HR 2 februari 1966, NJ 1966, 415 m.nt. NJP; ARB 1966, 579 m.nt. J.R. Stellinga; BR 1966, p. 266; Ars Aequi (16) 1967, p. 137 m.nt. Prins 14

HR 24 januari 1969, NJ 1969, 316; Ars Aequi (18) 1969, p. 266-269 m.nt. M.T. en G. (Packetboek-arrest) 57, 194, 196

HR 15 maart 1974, NJ 1974, 348 m.nt. Prins, AB 1975, 85 m.nt. Stellinga, Ars Aequi XXIV(1975), p. 623 m.nt. Jeukens 7

HR 19 november 1976, NJ 1979,216; AB 1978, 243 m.nt. J.R.St (Semper Crescendo) I4 HR 2 februari 1979, NJ 1979, $581 \mathrm{~m}$. nt. Brunner 14

HR 7 maart 1979, NJ 1979, 319 m.nt. Scheltema, AB 1979, 218 m.nt. Stellinga, BNB 1979, $125 \mathrm{~m} . \mathrm{nt}$. Hofstra (anroerend-goedbelasting Rotterdam) 7

HR 8 oktober 1980 , NJ 1981,63 73

HR 27 november 1981, NJ 1982, 503, m.nt E.E.A. Luyten en W.H. Heemskerk.(Boon$\operatorname{Van} \operatorname{LoOn}) \quad 157$

HR 11 december 1981, NJ 1983, 320, m.nt. Borman I4

HR 4 februari 1983, NJ 1985, 21 m.nt. MS (Hei-Boeikop-arrest) 13,54

HR 6 mei 1983, AB 1984, 101 m.nt. F.H. van der Burg en H.K. Fernandes Mendes (Bullenbaai) 150

HR 24 februari 1984, NJ 1984, 669, m.nt. Borman; AB 1984, 399, m.nt. E.M. van Eijden; BR 1984, p. 508 m.nt. K. Van Rijckevorsel (St. Oedenrode) I4

HR 12 oktober 1984, NJCM-Bulletin 10-1 (1985), 32 e.v. m. nt. Heringa 1, 73, 132 
HR 22 november 1985, RvdW 1985, 218; NJ 1986, 722 m.nt. MS (/\& D/Groningen). I4. 16.17.197

HR 9 mei 1986, AB 1986, 429, m.nt. FHvdB; NJ 1987, 252 (Van Gelder-papier) 21, 57

HR 16 mei 1986, NJ 1986, 723 m.nt. Scheltema; AB 1986, 573 m.nt. FHvdB; Ars Aequi (35) 1986, p. 642 m.nt. H.Ph.I.A.M. Hennekens; BR 1986, p. 775 m.nt. N.S.F. Koeman (Heesch-Van den Akker) $2,8,13,15,21,22,51,54,185$

HR 16 mei 1986, NJ 1987/251 m.nt. MS; 251;AB 1986, 574 m.nt FHlvdB (Landboumwiegers-arrest) 150,196

HR 26 september 1986, AB 1987, 70 m.nt.. FHvdB; NJ 1987, 253 m.nt MS (Hoffmann-La Roche) 18

HR 12 december 1986, NJ 1987, 381 m.nt. MS; BR 1987, m.nt. Koeman 19, 22

HR 30 januari 1987, NJ 1988, 90 m.nt MS (Nibourg/Zuidwolde) I8

HR 6 februari 1987, AB 1987, 272 m.nt. FHvdB 20

HR 26 februari 1988, NJ 1989, 528 m.nt. MS; AB 1989, 80 m.nt. F.A. van Bakelen; BR 1988 , p. 674 m.nt. Koeman; Gst. 6856, p. 231 m.nt. L.J.A. Damen 17

HR 11 november 1988, tB/S 1988, m.nt. Tak, Burgerlijke rechter, nr. 3; Gst. 6875, ar 2, m.nt. L.J.A. Damen; AB 1989, 81 m. nt. FHvdB $16,17,19$

HR 14 april 1989, NJ 1989, 469 m.nt. MS; AB 1989, 207 m.nt. FHvdB; Ars Aequi 38 (1989), p. $578 \mathrm{~mm}$.nt Hirsch Ballin (Harmonisatiewet-amest) 7, 130, 150,167

HR 17 november 1989, NJ 1990, 746 m.nt. JBMV (Velzen-De Waard) 18

HR 2 februari 1990, NJ 1993, 635 m.nt. MS; AB 1990, 223 m.nt. G.P. Kleijn. (StactiBolsius) 197

HR 18 januari 1991, NJ 1992, 638 m.nt. C.J.H. Brunner; AB 1991, 241 m.nt. F.H. van der Burg. (Varkensmester) 196

HR 1 februari 1991, NJ 1991, 413 m.nt. ThWVV 177

HR 31 mei 1991, AB 1992, 291 m.nt. FHvdB (Van Gog/Nederweert) 18,184

HR 14 juni 1991, $1 \mathrm{~B} / \mathrm{S} 1991$, m.nt. Tak, Burgerlijke rechter, nr. 4; NJ 1991, 693; AB 1992, 291 m.nt. FHvdB 16,18

HR 29 november 1991, NJ 1993, 150 en 151; TAR 1992/22 (Bopa) 86, 160,161

HR 28 februari 1992, AB 1992, 301 m.nt. FHvdB (Changoe-arrest) 17 
HR 16 oktober 1992, NJ 1993, 638 m.nt MS; AB 1993, 40 m.nt FHvdB; Gst. 6962, nr. 5 , p. $164 \mathrm{~m} . \mathrm{nt}$ HH. (Vulhop) $55,56,170,186,199$

HR 13 november 1992, NJ 1993, 639 m.nt. MS (Lanser/Haarlemmermeer) 195

HR 14 mei 1993, NJ 1993, 641 (AnubalPlora Liquor) 172

HR 1 december 1993, NJ 1996, 230 m.nt. Scheltema; RSV 1994/127 m.nt. F.W.M. Keunen 148,149

HR 29 april 1994, NJ 1995, 727 m.nt. C.J.H.B. Brunner en E.A. Alkema 183

HR 27 mei 1994, NJ 1997, 158 (Sprangers/Staat) 172

HR 7 oktober 1994, NJ 1997, 174 m.nt. MS; AB 1996, 125 m.nt. B.J.P.G. Roozendaal (StanlYan Benten) 197

HR 8 december 1995, NJ 1997, 163 m.nt. MS 12

HR 29 mei 1996, RSV $1997 / 77$, m.nt. F.W.M. Keunen 145, 149, 151, 152

HR. 4 september 1996, BNB 1997, 43 m.nt. Finkenspier 170

HR 11 oktober 1996, NJ 1997, 165 m.nt. M. Scheltema (Leenders) 194

HR 17 december 1999, NJ 2000,87, m.nt. ARB (Groningen-Raatgever) 197

HR 27 september 2002 (Pearl) NJ 2002/534 192

HR 24 januari 2003, (Maple)AB 2003, 120 m.nt. Widdershoven.; JB 2003/44 m.nt E. v.d. Linden $169,174,186,189,191,193,199$

\section{CRvB}

CRvB 18 maart 1937, ARB $1937,408 \quad 28$

CRvB 1.4 februari 1950, ARB 1950, 581. 28

CRvB 3 april 1963 (salariswijziging nijkerheidsonderwijs), ARB 1964, p. 75, m.nt. Boer; Ars Aequi XIII (1963-1964), p. 69 m.nt. Prins 7

CRvB 18 juni 1968, RSV 1969/12 6I

CRvB 26 november 1970, RSV 1971/10961

CRvB 2 mei 1975, AB 1975, 30131 
CRvB 24 juni 1975, SV 1975/20 44

CRvB 15 oktober 1976, AB 1977, 60 m.nt. In 't Veld 31

CRvB 22 oktober 1976, AB 1977, 157, m.nt. In 'I Veld 31

CRvB 28 april 1977, RSV 1977, nr. 25339

CRvB 12 september $1978, A B 1980,61$, m.nt. v.S. 37

CRvB 10 januari 1979, RSV 1979/9431 32

CRvB 2 juli 1979, RSV 1979/246; AB 1980, 502, m.nt. v.S. 30, 44, 59, 64

CRvB 2 juli 1980, AB 1980, 502, m.nt. v.S.; RSV 1979/246 37

CRvB 22 september 1981, RSV 1982/72 m.nt. N.J. Haverkamp onder RSV 1982/7324 43

CRvB 31 maart 1982, AB 1983, 264 m.nt. JHS 28

CRvB 8 maart 1983, RSV 1983/119 65

CRvB 17 augustus 1983, AB 1984/150 m.nt. Smits; RSV 1983/209 m.nt. LeveltOvermars 104

CRvB 1 november 1983, RSV 1984/147-150 m.nt. W.M. Levelt-Overmars 74, 75 133

CRvB 8 december 1983, AW 1982/B83 46

CRvB 16 februari 1984, TAR 1984,8239

CRvB 13 december 1984, AB 1985, 448 m.nt. RF 28

CRvB 31 december 1984, AB 1985; 348 m.nt. J.H. Smits; RSV $1985 / 126$ m.nt. N.J. Haverkamp $24,25,30,39,42,43,59$

CRvB 30 januari 1985 , RSV $1985 / 190 \quad 95$

CRvB 13 maart 1985, AB 1986,32644

CRvB 4 oktober 1985, AB 1986, 38; RSV 1986/21; Ars Aequi 35(1986)3, p. 215 e.v. m.nt. E.P. de Jong 133

CRvB 16 oktober 1985, WWV/WSW 1985/170 49

CRvB 24 juni 1986, TAR 1986/186 157, 159 
CRvB 26 november $1986, \mathrm{RSV} 1988 / 22, \mathrm{~m} . \mathrm{nt}$. W.M. Levelt-Overnars 109

CRvB 14 mei 1987, AB 1987, 543 m.nt. HH; RSV $1987 / 246$ m.nt. W.M. LeveltOvemars, NJCM-Bulletin 12-6 (1987), p. 465 77, 105, 165

CRvB 24 september 1987, TAR 1988, p. 101-103; TAR 1987/257, m.nt. Van Male; AB 1988,149, m.nt. HH $27,39,41,45,46$

CRvB 5 januani 1988, AAW 1982/S122; RSV 1988/104 104, /16

CRvB 5 januari 1988, AB $1988,252 \quad 104,116$

CRvB 5 januari 1988, A.AW 1981/B126 104, 116

CRvB 5 januari 1988, AAW 1983/S22; RSV 1988/199 104, 116

CRvB 5 januari 1988, AB 1988,254, m.nt. JHS 104, 116

CRvB 5 januari 1988, AAW 1983/S90; RSV 1988/200 m.nt. S Feenstra 104, 106, 116

CRvB 17 maart 1988, WUBO $1986 / 38 \quad 134$

CRvB 25 mei $1988, \operatorname{RSV} 1989 / 29 \quad 33$

CRvB 7 december 1988, RSV $1989 / 15765$

CRvB 7 december 1988, AB 1989, 10 m.nt. I.H. Smits; RSV 1989/67 m.nt. F.W.M. Keunien $111,131,132$

CRVB 28 december 1988, RSV $1989 / 175 \quad 145$

CRvB 10 mei 1989 RSV $1990 / 23096$

CRvB 10 mei 1989 RSV 1990/231; JSV $1989 / 139 \quad 94$

CRvB 6 juli 1989, TAR 1989, 2017

CRvB 5 oktober 1989, RSV $1990 / 132 \quad 134$

CRvB 29 november 1989, RSV 1990/189 34

CRvB 19 april 1990, RSV 1990/323, Teuling-Worms, m.nt. C.M. Sjerps 128

CRvB 22 mei 1990, Regelmaat 5/4 (1990), p. $91-94 \quad 104,106,156,157$

CRvB 21 december 1990, RSV 1991/160; NICM-Bulletin 16-3 (1991), p. 208 m.nt. A.W. Heringa 147,150 
CRvB 31 december 1990, TAR 1991/64 39,48

CRvB 24 januari 1991, AB 1991, 338, m.nt. J. Riphagen; RSV 1991/268; NJCM-Bulletin 16-3 (1991), p.213 m.nt. Heringa 77, 165

CRvB 30 januari 1991, AB 1991, 339 m.nt. De Leede; RSV 1991/182 m.nt. JJ.A. Kooijman $109,111,132,134$

CRvB L0 april 1991, RSV 1992/23 8,42,49

CRvB 23 mei 1991 RSV 1991/255; 16-7 (1991), p. 648 m.nt A.W. Heringa; ISV 1992/43 $106,135,138,166$

CRvB 25 juli 1991, NICM-Bulletin 17-7 (1991), p.651 m.nt. A.W. Heringa 138

CRvB 8 angustus 1991, AB 1991, 657 m.nt. De Leede 112,115

CRvB 11 december 1991, RSV 1992/146 109

CRvB 9 januari 1992, TAR 1992, 59; AB 1992, 225134

CRvB 14 april 1992 AB 1992, 492 m.nt. De Leede 136

CRvB 27 april 1992, AB 1992, 688, m.nt. Hennekens 35

CRvB 10 juni 1992, RSV 1993/176 30

CRvB 23 juni 1992, AB 1992/480 m.nt. De Leede; RSV 1992/317 en NJCM-Bulletin 18-3 (1993), p. 292-298 m.nt. G. Heerma van Voss 123,127

CRvB 29 november 1992, RSV 1993/203 123

CRvB 19 februari 1993, JSV $1993 / 175 \quad 30$

CRvB 2 maart 1993, AB 1993,421 34

CRvB 29 april 1993, AB 1993, 556 m.nt. De Leede; RSV 1994/9 //2, 135

CRvB 28 september 1993, AB 1994, 257; RSV $1994 / 93123$

CRvB 26 november 1993, RSV 1994/125 en 126 m.nt. F.W.M. Keunen in RSV 1994/127 147

CRvB 22 maart 1994, JSV 1994/133 100, 109

CRvB 21 april 1994, AB 1994, 476 m.nt. HH; TAR 1994, 132 29, 32, 33, 35, 48

CRvB 9 mei 1994, RSV 1994/212 117,120 
CRvB 20 mei 1994, AB 1994/694 m.nt. De Leede in AB 1994, 696114

CRvB 23 juni 1992, AB 1992, 480 m.nt. De Leede; RSV 1992/317; NJCM-Bulletin 18-3 (1993), p. 292-298 m.nt. G. Heerma wan Voss 127

CRvB 14 februari 1995, AB 1994, 391 m.nt. De Leede $1 / 3$

CRvB 15 februari 1995, RSV $1996 / 21440$

CRvB 5 juli 1995, RSV 1996/207 m.nt. S. Feenstra $14 I$

CRvB 31 oktober 1995, AB 1996,98 m.nt. F.J.L. Pennings 115

CRvB 28 november 1995, RAbw 1996?, nr. 42, m.nt De Waard; IB 1996/33 35

CRvB 11 januari 1996, JB 1996/37 34, 36

CRvB 14 mei 1996, Rabw 1997, nr. 3 m.nt. Voermans 33,47

CRvB 15 mei 1996, AB 1996 329 m.nt. F. Pennings; RSV 1996/170 /30

CRvB 19 februari 1997, RSV 1997/159 155

CRvB 5 maart 1997, USZ 1997/131 152

CRvB 11 april 1997, RSV 1997/263 89.130

CRvB 2 juli 1997, USZ 1997/196 /18

CRvB 10 december 1997, USZ $1998 / 5889$

CRvB 18 december 1997 , AB 1998, 124, m.nt. HBr; JB 1998/40, m.nt. EvdL 36.40, 42

CRvB 16 januari 1998, JB 1998/60 130

CRvB 1 april 1998, PS Actua, 25 juni 1998, nr. $79 / 12$

CRvB 16 juli 1998, AB 1998,439, m.nt. HBr. 40

CRvB 21 december 1999, RSV 1982/72 m.nt. N.J. Haverkamp; AB 2000, 121 m.nt. $\mathrm{HBr}$ 26

CRvB 22 december 1999, RSV 2000/78 130

CRvB 16 augustus 2000, RSV 2000/243 179

CRvB 6 november 2003, JB 2004/29, m.nt. EvdL 35,179 


\section{ARRS}

ARRS I september 1977, AB 1977, 366 m. nt. VdV; Gst 6472 m.nt JMK; BR 1977. p. 914 m.nt. CLR (Maastricht I) 50,56

ARRS 8 juni 1978 , Gst. nr. 651451

ARRS 27 maart 1981, AB 1981, 323 m.nt. J.A.B.; Gst. 6669 (Moastrich h) 51

ARRS 25 mei 1981, AB 1981, 516, m.nt. Borman; Gst. 6686; BR 1981, p.780 /4,51

ARRS 4 september 1981, AB 1981, 541. m.nt. J.R.St. 28

ARRS 5 juli 1982, AB 1982,56, m.nt. w.d.V. 28

ARRS 4 juli 1985, tB/S VII, nr. 97, Gst 1985, 6797, 4 m.nt JMK 29

A.RRS 21 augustus 1986, AB 1987, 36729

ARRS 30 januari 1987, AB $1987,420 \mathrm{~m} . n t$. JHvdV 29

ARRS 3 november 1989, AB 1990,28233

ARRS 31 oktober 1990, AB 1991, 570, m.nt JHwdV 33

ARRS 3 december 1990, tB/S 1990, nr. 149, m.nt. J.B.J.M. ten Berge 29

ARRS 4 december 1990, AB 1991, 687, m.nt. Sewandono 2

ARRS 4 december 1990, AB 1991, 597, m.nt. H.J. Simon 2

ARRS 8 maart 1991, tB/S 1991, nr. 28a m.nt. B.W.N. de Waard 29,33

ARRS 5 september 1991, tB/S 1991, ar. 118 29,159

ARRS 26 november 1991, AB 1992,378 29

\section{ABRS}

ABRS 2 december 1994, AB 1995, 212 m.nt. B.J.P.G. Roozendaal, N.M. van Waterschoor 33

ABRS 13 juni 1996, Rabw 1997, nr, 7, m.nt. Voemans 28, 36

ABRS 16 december 1996, AB 1998, 32 m.nt. B.J. Schueler 33, 35, 179 
ABRS 24 januari 2000, AB 2000, 199, m.nt. J.L. Boxum; JB 2000, 66, m.nt. R.J.N.S. 36 , 179

ABRS 4 april 2003, AB 2003, 315 m.nt. BPV 33

\section{Vu. ARRS}

V2ARRS 26 oktober 1984, $1 \mathrm{~B} / \mathrm{S}$ XIII, nr. 16, m.nt. De Waard 44

VZARRS 22 februari 1985, tB/S VII, nr. 8829

Vz ARRS 8 maart 1991, tB/S 1991, nr. 28a, m.nt. deWaard 37

VZARRS 3 maart 1992, AB 1992, 356 m.nt. PvB 30

$\mathbf{K B}$

KB 8 januari $1985, A B 1985,266 \quad 53$

\section{AGvB}

AGvB 20 december 1991, AB 1992, 29422

\section{CBB}

CBB 22 april 1975 (Van Haaster v. Productschap voor Siergewassen), SEW 1975, p.449 167

CBB 24 februari 1976, SEW 1977, p. $577-58366$

CBB 23 december 1980, AB 1981, 32 . en 322 m.nt. Van der Wielen 66

CBB 6 augustus 1996, JB $1996 / 219$ m.nt. E.v.d.L 179

CBB 1 noyember 2000, (Kühne en Heitz), JB 2000/355 m.nt E..van der Linden; AB 2001, 32, m.nt. J.H. van der Veen; NTER 2001,p. 29-35 m.nt M. de Jong 35.174

\section{RvB}

RvB Arnhem 13 september 1990, Rechtspraak Nemesis 1991, nr. 142109

RvB Arnhem, 6 februari 1992, RSV 1992/166 114, 124, 129

RvB Groningen 8 mei 1992, JSV 1992/265 101 
RvB 's-Hertogenbosch 17 december 1991, Rechtspraak Nemesis 1992, nr. 229 115, 138 RvB 's-Hertogenbosch 15 november 1992, RSV $1992 / 192 \quad 146$

RvB 's-Hertogenbosch 30 april 1992, JSV $1992 / 17298$

RvB Roermond 2 mei 1990, RSV 1991/40 112

RvB Roermond 12 maart 1991, NJCM-Bulletin 16-6 (1991), p. 554, m.nt. C.M. Sjerps 73 RvB Rotterdam, 14 januari 1992, RSV 1992/165 129

\section{Rechtbank}

Rb. Breda 10 maart 1993, JSV 1993/107 95

Rb. Breda, 12 oktober 1993, JSV 1993/324 102

Rb 's-Hertogenbosch 8 juli 1992, RSV 1993/12 104, 125

Rb. Maastricht 27 mei 1998, AB 1998, 337 m.nt. Pennings 153

Rb. Utrecht 26 januari 1993, RSV 1993/205 99, 102

Rb. Utrecht, 6 januari 1993, RSV 1993/205 102

Rb. Rotterdam 13 oktober 1992, JSV 1992/319 100

Pres.Rb.'s-Gravenhage 17 januari 1985, AB 1985, 15491

\section{Hof}

Hof 's-Gravenhage 13 maart 1985, AB 1985, 253 m.nt. F.H. van der Burg $9 /$ 



\section{Literatuurlijst}

W. Alexander

Beperking van de terugwerkende kracht van rechterlijke uitspraken, RM Themis 5/6 (1986), p. 492-502

E.A. Alkema

De betekenis wan het EVRM voor de Nederlandse Constitutie, preadvies Statatsrechtconferentie 1990 , Leiden 1.991

E.A. Alkema

Het internationale gelijkheidsbeginsel en de Nederlandsche staatsrechtelijke verhoudingen; wie leidt de wals van de gelijkheid; Preadwies Staatsrechtconferentie 1986, Ars Aequi Libri, Serie staats- en bestuursrecht, Nijmegen 1987

J.A.M. van Angeren

De gewone rechter en de administratieve rechtsgangen, diss. Leiden 1968

L.P. Asscher-Vonk, L. Betten en W.J.P.M. Fase (red.)

Gelijke behandeling van vrouw en man in de sociale zekerheid; studie naar de invloed van de derde EG-richtlijn op de Nederlandse wetgeving, Kluwer, Deventer 1986

Tom Barkhuysen

Art. 13 EVRM: effectieve mationale rechtsbescherming bij schending van mensenrechten, diss. RLL 1998

T. Barkhuysen en M.L. van Emmerik, "De betekenis van artikel I van het Eerste Protocol bij het EVRM voor het Nederlandse recht inzake overheidsaansprakelijkheid, O\& A, 2002, 4, p. 102-116

J.B.J.M. ten Berge

Heesch-Van de Akker, Hoge Raad 16 mei 1986, in: F.H. van der Burg, P.JJ. van Buuren en J.H. van der Veen (red.), AB-klassiek, Zwolle 1994, p. 165-174

F.R. Böhtlingk, J.H.A. Logeman

Het wetsbegrip in Nederland, Alphen aan den Rijn 1966

A.F.M. Brenninkmeijer

De ongelijke behandeling van mannen en vrouwen in de AAW, NJB 1981, afl. 24, p. $613-620$

F.H. wan der Burg

Formele rechtskracht, vertrouwensbeginselen en dende-beroep, in: Een stellig annotator, Opstellen aangeboden aan Dr. J.R. Stellinga ter gelegenheid van zijn aftredien als woorzitter van de redactie van het tijdschrift Nederlandse Jurisprudentie/Administratiefrechtelijke Beslissingen (Stellinga-bundel), Zwolle 1982, p. I-20

M.C. Burkens

Gelijke behandeling (art. 1.1) in: A.K. Koekkoek e.a., Grondrechten, commentaar op Hoofdstuk I van de herziene grondwet, Nijmegen 1982

Comité Gelijke Rechten Nu

Gelijke behandeling in de AAW, Rechtshulp nt. 6/7, 1990, p. 2-10

E.J. Daalder, Cécile M. Bitter

Formele rechtskracht wan overheidsbesluiten, Bestuur, nr. 3, maart 1990, p. 74-77

A.M. Donner

Nederlands Bestuursrecht, Algemeen Deel, Alphen aan den Rijn 1987 
A.M. Donner

De rechtskracht van administratieve beschikkingen, diss. VU Amsterdam, Alphen aan den Rujn 1941

A.M. Donner

Terugblik op zijn dissertatie in Ars Aequi 34 (1985), p. 679

H. Drion

Nondiscriminatie, RM Themis-6 (1980), p. 489-492

I. Drion

Stare decisis, Het gezag van precedenten, in: Verzamelde Geschriften van J. Drion, Dewenter 1968, p. 142-170

W. Duk

De zachte kern van het bestuursrecht, RM Themis (1978), p. 576-577

W. wan Gerven

The horizontal effect of directive provisions revisited: The reality of catchwords, in:

Curtin en Heukels (eds.), Liben amiconm Schermers, Dordrecht 1994

O.A. Hazen

Algemeen Deel van het rechterijk overgangsrecht, Een verhandeling over de terugwerkende kracht van rechtspraak, de rechtsdwaling en de democratische rechtswindingsleer, diss. KUB, 2001

H.Ph.J.A.M. Hennekens

De Hoge Raad en de formele rechtskracht, De Gemeentestem 6962, p. 149-153

A.W. Heringa

Van Europese Conventie tot Nederlandse constitutie woor de Rechten van de Mens, in: 40 jaar Europees Verdrag tot bescherming van de rechten van de Mens, Leiden 1990, p. 3.7-335

A.W. Heringa en A. Woltjer

Gelijke behandeling in de sociale zekerheid: "Straatsburg" scherpt de eisen aan, NJB 1997, afl. 37, p. 171.0-1716

I.P. de Jong

Bestuursrecht van vreemde herkomst, diss. KUB, Zwolle 1988

P.U.G. Rapteyn en P. Verloren van Themaat

Tinleiding tot het recht van de Europese Gemeensehappen, Deventer 1995

T. Koopmans

Legislature and Judiciary - Present trends, in: Juridisch Stippelwerk, Deventer 1991 , p. $2\lfloor 1-2 ! 4$

T. Koopmans

De Polsstok van de rechter (1979), in: Juridisch Stippelwerk, Deventer 1991, p. 253-264

B.H. Ter Kuile

De imyloed van Francovich op Nederlandse wetgeving en bestuur, NTB 92/4, p. $1 \llbracket 3-120$

J.C.M. Lenjten

Overgangsrecht I en II, NJB $\| 972$, p. $364-373$ en p. $389-400$

W.M. Leveli-Ovemars

De uitspraken wan de CRvB d.d. 5-1-1988 over artikel 26 BuPo-Verdrag, NJB 1988, afl. 18, p. 589-599

E.C.H.J. van der Linden

Fiomele en materiele rechtskracht, De kleren wan de keizer, diss. UM, Den Haag 1.998 


\section{J.P. Loofe.a.}

The rights to property. The influence of article 1 Protocol no. 1 ECHR on several fields of domestic law, Maastricht 2002

\section{S.K. Martens}

De grenzen van de rechtsvormende taak van de rechter, NJB 2000, af1. 14, p. 747-758

M.R. Mok en R.P.J.L. Tjittes

Formele rechtskracht en overheidsaansprakelijkheid, RM Themis $1995 / 9$, p. 383-404

P. Nicolaĩ

Beginselen van behoorlijk besturr, Deventer 1990

F.M. Noordam

Inleiding sociale zekerheidsrecht, Deventer 1992

F.M. Noordam

Weduwnaarspensioen met terugwerkende kracht, Tijdschrift voor pensioenwraagstukken, mei 1991, p. 33-35

Jessurun d'Oliveira

De meerwaarde van rechterlijke uitspraken Arrềts de règlements en precedenten, Preadvies voor de Nederlandse Vereniging voor Rechtsvergelijking, geschrift nr. 10 , Deventer 1973

M.V. Polak

Algemene beginselen van rechterlijk overgangsrecht, RM Themis-3 (1984), p. 228-260

Sacha Prechal

Bommen ruimen in Maastricht: wijziging van art.119 EEG, NJB 1992/11, p. 349-354

Sacha Prechal

Ondeugdelijke communautaire wetgeving: de pensioenrichtlijn, NJB 1990/33, p. 12991303

H. van der Schaar

AAW, een getalsmatige toets, Nemesis nr. 4 , juli/aug. 1990, p. 178-180

Paul Schoiten

Asser's Handleiding tot de beoefening van het Nederlands burgerlijk reclyt, Algemeen Deel (met aanvullingen van mr G.J. Scholten), Zwolle 1974

J.G. Steenbeek

Rechtshandeling en rechtsgevolg in het Staats- en administratief recht, diss., Assen 1958

M. Steinmetz

De grondslagen in de AAW, Nemesis nr. 2, maartapril 1990, p. 67-76

L. Strikwerda

Art. $11 \mathrm{AB}$ : middel om de rechter in het rechte spoor te houden? Ars Aequi, XXIII (1974), p. 1-17.

F.A.M. Stroink

Rechterljke organisatic en rechtspraak in beweging, Zwolle 1993

C. Tomuschat

Equality and Non-discrimination under the International Convention on Civil and Political Rights, Fs.H.Schlochauer, Berlin 1981

W.G. Vegting

Het Nederlands Administratief Recht, Eerste Deel, Alphen aan den Rijn 1954

J. van der Veide

Het 'vrije spel der rechtelijke krachten', Over het tweetrapskarakter van de Europese mensenrechtenbescherming en de beoordelingsmarges van artikel 5 en 6 EVRM, preadvies Staatsrechtconferentie 1990, Leiden 1991 


\section{E.M. Vermeulen}

Het gemeenschapsrecht en de formele rechtskracht wan Awb-besluiten, in: JBPlus $2002 / 1$, p. $38-48$

J.B.M. Vranken, mr. C. Asser's Handleiding tot de beoefening van het Nederlands burgerlijk recht, Zwolle 1995

H.D. van Wijk/W. Konijnenbelt

Hoofdstikken van Administratief recht, "s-Gravenhage 1979

Van Wijk/Konijnenbelt

Hoofdstukken van Administratief Recht, Culemborg 1988

Van Wijk/Koninnenbelt \& Van Male

Hoofdstukken van Bestuurstecht, Den Haag 1999

J. Wouters

Gelijke behandeling van mannen en vrowwen inzake bedrijfspensioenen: de "PostBarber'-arresten van het Hof van Justitie, NJCM-Bulletin 20-3 (1995), p. 274-298

F.P. Zwart

Enkele opmerkingen over rechterlijk overgangstecht, NJB 1997, af1. 3, p. 108-114 


\section{Curriculum vitae}

Rob Bakker is op 16 mei 1956 geboren te Dordrecht. In 1974 behaalde hij aan het Gemeentelijk Lyceum in deze stad zijn diploma gymnasium- $\beta$. Na een aanvankelijk begonnen studie wiskunde aan de toenmalige Technische Hogeschool Delft heeft hij in Leiden de studie Nederlands recht gevolgd en deze in 1983 afgerond. Inmiddels was hij al enige tijd werkzaam voor het Parlementair Documentatiecentrum verbonden aan de Tweede Kamer der Staten-Generaal. Tussen 1984 tot 1995 was hij werkzaam als universitair docent aan de juridische faculteit van (toen nog) de Rijksuniversiteit Limburg. Sinds 1995 is hij werkzaam in de rechtbank Maastricht, eerst als gerechtsauditeur, sinds begin 1997 als rechter en sinds begin 2003 alls vice-president. 